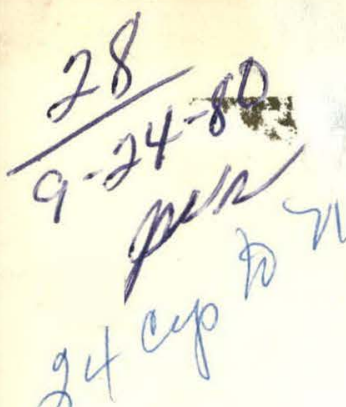

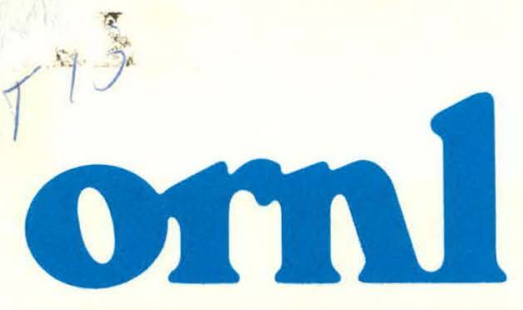

OAK RIDGE

NATIONAL LABORATORY

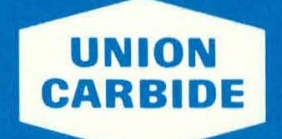

\title{
GEOECOLOGY: A County-Level Environmental Data Base for the Conterminous United States
}

\author{
R. J. Olson \\ C. J. Emerson \\ M. K. Nungesser \\ ENVIRONMENTAL SCIENCES DIVISION \\ Publication No. 1537
}

OPERATED BY

UNION CARBIDE CORPORATION

FOR THE UNITED STATES

DEPARTMENT OF ENERGY

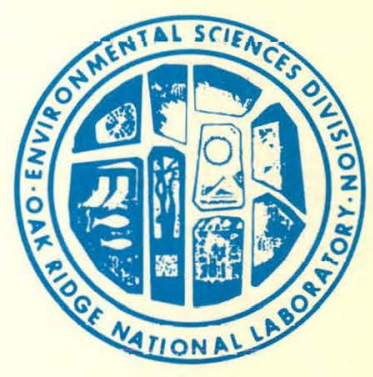




\section{DISCLAIMER}

This report was prepared as an account of work sponsored by an agency of the United States Government. Neither the United States Government nor any agency Thereof, nor any of their employees, makes any warranty, express or implied, or assumes any legal liability or responsibility for the accuracy, completeness, or usefulness of any information, apparatus, product, or process disclosed, or represents that its use would not infringe privately owned rights. Reference herein to any specific commercial product, process, or service by trade name, trademark, manufacturer, or otherwise does not necessarily constitute or imply its endorsement, recommendation, or favoring by the United States Government or any agency thereof. The views and opinions of authors expressed herein do not necessarily state or reflect those of the United States Government or any agency thereof. 


\section{DISCLAIMER}

Portions of this document may be illegible in electronic image products. Images are produced from the best available original document. 
Contract No. w-7405-eng-26

\begin{abstract}
GEOECOLOGY: A COUNTY-LEVEL ENVIRONMENTAL DATA. BASE FOR THE CONTERMINOUS UNITED STATES ${ }^{1}$
\end{abstract}

R. J. Olson, C. J, Emerson ${ }^{2}$, and M. K. Nungesser

ENVIRONMENTAL SCIENCES DIVISION

Publication No. 1537

${ }^{1}$ Work sponsored by the Department of Energy, Assistant Secretary for Environment, Office of Environmental Assessments, Regional Impacts. Division.

\title{
${ }^{2}$ Computer Sciences Division, Union Carbide Corporation Nuclear Division.
}

Date Published: September 1980

\section{OAK RIDGE NATIONAL LABORATORY \\ Oak Ridge, Tennessee 37830 operated by \\ UNION CARBIDE CORPORATION \\ for the \\ DEPARTMENT OF ENERGY}




\section{Printed in the United States of America. Available from National Technical Information Service \\ U.S. Department of Commerce \\ 5285 Port Royal Road, Springfield, Virginia 22161 \\ NTIS price codes-Printed Copy: A18 Microfiche A01}

This report was prepared as an account of work sponsored by an agency of the United States Government. Neither the United States Government nor any agency thereof, nor any of their employees, makes any warranty, express or implied, or assumes any legal liability or responsibility for the accuracy, completeness, or veofulnoes of any information, apparatue; product; or procoes dicolocod; or represents that its use would not infringe privately owned rights. Reference herein to any specific commercial product, process, or service by trade name, trademark, manufacturer, or otherwlse, does not necessarily constitute or imply its endorsement, recommendation. or favoring by the United States Government or any agency thereof. The views and opinions of authors expressed herein do not necessarily state or reflect those of the United States Government or any agency thereof. 
ACKNOWLEDGEMENTS

The Geoecology Data Base has benefitted from the contributions of many people. Dr. F. Glenn Goff, as the initial project leader, laid the groundwork for the Data Base, obtained initial funding, and coined the name Geoecology. As current project leader, the senior author gratefully acknowledges the concepts and foundation provided by Glenn Goff.

Appendix A describes each data set including "Compilers" - those individuals associated with digitizing, compiling, editing, or other aspects of data set creation. The authors acknowledge these contributions and the willingness of investigators to share data files through the Geoecology Data Base. Users have helped to ensure quality control and have provided useful suggestions for improving and expanding the Data Base. These individuals are credited for their contributions. Thus, the Geoecology Data Base, as reflected by this document, is the product of numerous named and unnamed individuals over the past six years. However, the Geoecology Project staff assumes responsibility for errors, omissions, or inconsistencies in the report. We also thank Natalie Millemann for her editorial assistance in the preparation of this document. Individuals associated with the contents and development of the Geoecology Data Base include, but are not limited to, the following:

Environmental Sciences Division, ORNL

R. M: Anderson

T. J. Blasing

R. L. Burgess

H. R. Delcourt

F. G. Guff*

S. D. Hicks*

J. L. Joness*

C. T. Kelsey*

J. T. Kitchings

J. M. Klopatek
L. K. Mann

V. G. Myers

J. S. Olson

W. M. Post

R. K. Schreiber *

R. A. Strand

C. S. Tucker

J. A. Watts

D. C. West

Computer Sciences Division, UCCND

B. D. Murphy

D. L. Wilson
R. L. Stephenson

Energy Division, ORNL
A. S. Loebl
A. H. Voelker 


\section{Other Contributors}

C. E. Calef, Brookhaven National Laboratory

P. A. Delcourt, University of Tennessee

E. Kaplan, Brookhaven National Labroratory

D. Merrill, Lawrence Berleley Laboratory

J. Nagy, Brookhaven National Laboratory

C. A. Roswell, University of Maryland

T. Webb, III, Brown University

ऋ. Not currently affiliated with ORNL. 


\section{ABSTRACT}

OLSON, R. J., C. J. EMERSON, and M. K. NUNGESSER. 1980 . GEOECOLOGY: A County-level Environmental Data Base for the Conterminous United States. ORNL/TM-7351. Oak Ridge National Laboratory, Oak Ridge, Tennessee. 350 pp.

The Geoecology Data Base represents a unique compilation of computerized environmental data for research and development needs. Environmental assessment and planning for energy development require rapid access to data at appropriate spatial and temporal scales. In the Environmental Sciences Division (ESD) at Oak Ridge National Laboratory (ORNL), we have developed an integrated data base of diverse environmental resource information from extant sources. Data are stored at the county level of resolution for the conterminous United States with some data available for subcounty units within larger, more diverse eastern counties. The Geoecology Data Base contains selected data on terrain and soils, water resources, forestry, vegetation, agriculture, land use, wildlife, air quality, climate, natural areas, and endangered species. Basic files on human population are also included to complement the environmental files. Data are stored in metric-SI units. The Geoecology Data Base is currently fulfilling diverse ongoing research needs while it is being expanded and updated as needs and new data are identified.

This report is both a documentation and a "user's guide" to the Geoecology Data Base. It describes the Data Base design, illustrates applications, provides examples of accessing the Data Base, and gives general information on the data set contents. Appendix A documents each of the over 100 data sets including source of the data, spatial and temporal characteristics, variable names and labels, and, for many data sets, sample graphic or tabular materials generated from the data. An index of the 1000 variable names and labels is given in Appendix B. Appendix C lists FIPS codes, names, sizes, and centroids of the states, counties, and subcounty units used in the Data Base.

The Geoecology Data Base can be accessed in either batch or interactive modes utilizing the ORNL/IBM computer system. The Geoecology Project uses the statistical Analysis System (SAS) for data storage, retrieval, and analysis. If the user knows SAS, the Data Base can be accessed with the information provided by this report. Maps and graphics are generated. from the Data Base by using independent computer programs. 


\section{THIS PAGE}

\section{WAS INTENTIONALLY \\ LEFT BLANK}


TABLE OF. CONTENTS

Page

ACKNOWLEDGEMENTS .......................... ii

ABSTRACT .......................... v v

TABLE OF CONTENTS . . . . . ............ . vii

LIST OF TABLES .................... . . . . . .

LIST OF FIGURES ...................... xiii

I. INTRODUCTION AND SCOPE ............. 1

A. Geoecology Data Base ......... 1

B. Scope of the User's Guide. ....... 5

C. Data Availability ......... 6

II. APPLICATIONS . . . . . . . . . . . . . . . 8

A. Sulfur Dioxide Environmental Impacts.: 8

B. Natural Vegetation and Land Use..... 8

C. Wilderness Area Evaluation:....... 12

D. Biomass Fuels ............. 12

III. DATA BASE MANAGEMENT .............. 15

A. SAS ............... 15

B. Display Programs:.......... 17

C. Data Base Conventions ........ 17

1. Units of Measure ....... 17

2. Variable Names ........ . 17

3. Data Sets.......... 18

4. Special Output Formats ..... 18

5. SAS Files.......... 19 
Page

IV. SPATIAL AND TEMPORAL ASPECTS ........ 20

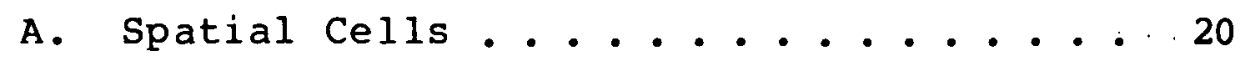

B. Geographic Coverage.......... 21

C. Temporal Coverage........... 22

v. DAta base compilation $\ldots \ldots \ldots$

9 A. Data Sources ........... 23

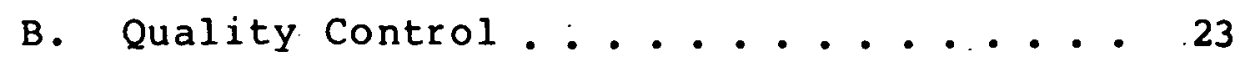

C. Compilers ............. 25

vi. data base contents ............. 26

A. Agriculture (A) .......... 26

B. Base Data (B) ............ 29

C. Climate (C) .............. 29

D. Vegetation (D) ........... 29

E. Forestry (F) ............. 29

F. General $(G) \ldots \ldots 29$

G. Air Quality $(K) \ldots . \ldots 30$

H. tand $\left(T_{1}\right) \ldots \ldots \ldots$

I. Natural Areas (N) ......... 30

J. Human Population (P) ......... 30

K. Water $(0) \ldots \ldots 31$

L. Terrain (T) ............... 31

M. wildlife $($ w) ............... 31

viI. ACCESS Ing the data base ........... 32

A. Data Set Contents ........ 32

B. Merging Data Sets ......... 32 
VIII. REFERENCES (INCLUDING THOSE FOR APPENDIX A) . . 43 AP PENDICES

A. Data Set Documentation ....... A-3

B. Index of Data Set Variables. ..... B-3

C. Spatial Units ........... B-3

1. States ................

2. County Units .......... C-4

3. Subcounty Units ......... C-24 


\section{THIS PAGE}

\section{WAS INTENTIONALLY \\ LEFT BLANK}




\section{LIST OF TABLES}

Table

Page

I.1: Spatial Hierarchies of Regions Illustrated

by Typical Geopolitical Units and

Rectangular Celi Sizes ............ 3

IV.1. Counties Containing Aggregated Data from

Associated Independent Cities within the

Geoecology Data Base ............ 21

IV.2. County Units Providing Confusion Resulting

From Historic Changes............... 22

VI.1. Number of Data Sets, Variables (items), and Records in the Geoecology Data Base Thematic sectors ............... 26

VI.2. Reference Year(s), Geographic Coverage, Spatial Units, and Status of Data

Sets within the Geoecology Data Base...... 27 


\section{THIS PAGE \\ WAS INTENTIONALLY \\ LEFT BLANK}


LIST OF FIGURES

Figure

Page

I.1. Geoecology Data Base Concept (Burgess and Kern 1973). ............... 2

I.2. Data Resources for Energy-Related Assessment and Planning. ............ 5

II.1. Southeastern Areas Where White Pine is at Risk from Impacts of High Sulfur Dioxide Levels (Nungesser and Olson 1980).

II.2. Acid Sensitive Soils in the Eastern United States (klopatek et al.'1980a). ...... 10

I. 3. Percent Floodplain Forest. (Kuchler Type 103)

(a) Not Adjusted for Current Land Use, and

(b) Adjusted for Current Land Use (Wilson 1979).

II.4. Overall Ecological Ranks for RARE II

Wilderness Areas in the Douglas-Fir Ecoregion (M3112) Represented by Circles Proportional to Area Sizes and Symbols Indicating 20 Percentile Classes (Klopatek

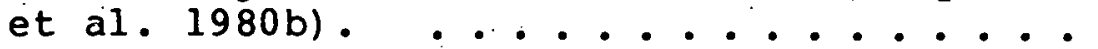

II.5. Wood Energy Conversion Unit Support Capability using Woody Biomass Farms as the Only Feedstock Source Assuming 25 percent of Suitable Land Being Available and a Maximum $64 \mathrm{~km}$ Haul ing Distance. (Ranney and Cushman 1980). .............

III.1. The Use of SAS with the Geoecology Data Base (Nungesser and Olson 1980). ........ 15

V.1. Sample Map used for Editing the Lithology Data Set. .................

VII.1. Example A Output: Displaying the Directory of the Online Data Base ...........

VII.2. Example A Output: Displaying the Contents of Individual Data Sets ...........

VII.3. Example B/C Output: Integrating Three Data Sets and Generating a County-level Report 
Page

VII.4. Example D Output: Calculating a Summary

Table using a sAS Statistical Procedure . . . 39

VII.5. Example E Output: Producing an X-Y Plot using Procedure DISPLAl. ......... 40

VII.6. Example F Output: A Map Produced by EZMAP

Utilizing a sAS Output File from the

Geoecology Data Base. 


\section{INTRODUCTION AND SCOPE}

\section{A. Geoecology Data Base}

The Geoecology Data Base represents a unique compilation of computerized environmental data for research and development needs. Environmental assessment and planning for energy development require rapid access to data at appropriate spatial and temporal scales. In the Environmental Sciences Division (ESD) at Oak Ridge National Laboratory (ORNL), we have developed an integrated data base of diverse environmental resource information from extant sources. Data are stored at the county level of resolution for the conterminous United States with some data available for subcounty units within larger, more diverse eastern counties. The Geoecology Data Base contains selected data on terrain and soils, water resources, forestry; vegetation, agriculture, land use, wildlife, air quality, climate, natural areas, and endangered species. Basic files on human population are also included to complement the environmental files. Data are stored in metric-SI units. The Geoecology Data Base is currently fulfilling diverse ongoing research needs while it is being expanded and updated as needs and. new data are identified (Olson et al. 1980).

The Geoecology Data Base was designed to meet the needs of regional environmental studies (Olson and Goff 1977). The prime consideration was to create a flexible; user oriented system which could be developed, utilized, and upgraded with minimal costs. The need to easily overlay thematic data stored for common spatial units for use in regional models was established during the National science Foundation-funded International Biological Program (Fig. I.1) (Burgess and. Kern 1973). The UPGRADE system, which has been developed by the Council on Environmental Quality (1980), includes a county-level Integrated Data Base designed similar to the Geoecology Data Base. The data base design considered anticipated applications, available data management systems, spatial and temporal requirements, and data availability. Factors which influenced the design are discussed below while subsequent sections in the report present details on aspects of the current system.

Research applications of the Geoecology Data Base most often involve large geographic areas and are concerned with assessing long-term changes. in ecosystems related to aggregated effects of man's activities. Such studies require the capability to (1) investigate single parameters over broad geographic areas, (2) integrate data on various aspects of the environment, or (3) examine in detail all environmental resources of a specific area. By storing data 


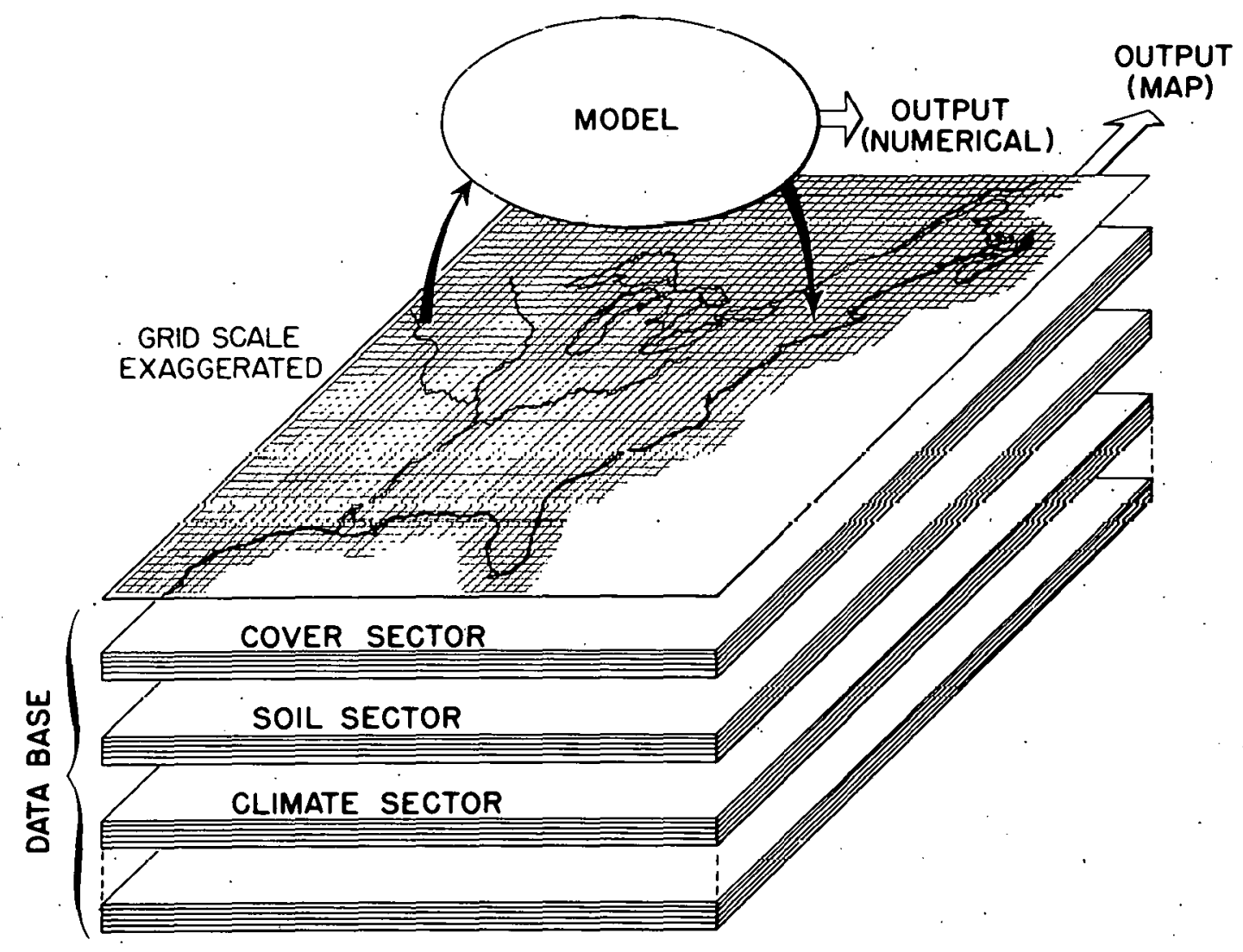

Figure I.1. Geoecology Data Base.Concept (Burgess and Kern 1973).

in a standardized computer format for common spatial cells. and temporal periods, the Geoecology Data Base permits quick response to these varied requirements.

The computer storage, analysis, and display aspects of the Ceoecology Data Dase were determined primarily by whal was both readily available and user-oriented. Data considered initially included: arrays of county statistics, rectangular qridded data, polygonal thematic maps, and isoline thematic maps. Considering these data types, available software, and spatial resolution requirements, a "county cell" file structure was selected. The statistical Analysis System - SAS (Barr et al. 1979) was selected to provide file management and statistical analysis (Olson and strand 1978), with separaie programs providing graphical display capabilities. Computerized geographic information systems have undergone significant evolution during the past decade. Integrated systems are currently available to 
accommodate analysis and display of mixed cell and polygonal data structures. A potential enhancement to the Geoecology Data Base would be the transition to a geographic information system to provide more efficient and flexible cartographic display and analysis capabilities.

The selection of an appropriate spatial scale was a major concern of the initial data base design. A spatial hierarchy was defined to serve as a framework in organizing and analyzing data at various scales. Table I.l shows the levels within the hierarchy in terms of metric, geodetic, and geopolitical units (Olson. et al. 1977). In general, the appropriate spatial cell size for studying regions at one level in the hierarchy is the next lower level. Most anticipated studies were "macro-region" in size so counties were an appropriate cell size for storage and analysis.

Table I.1. Spatial Hierarchies of Regions Illustrated by Typical Geopolitical Units and Rectangular Cell sizes

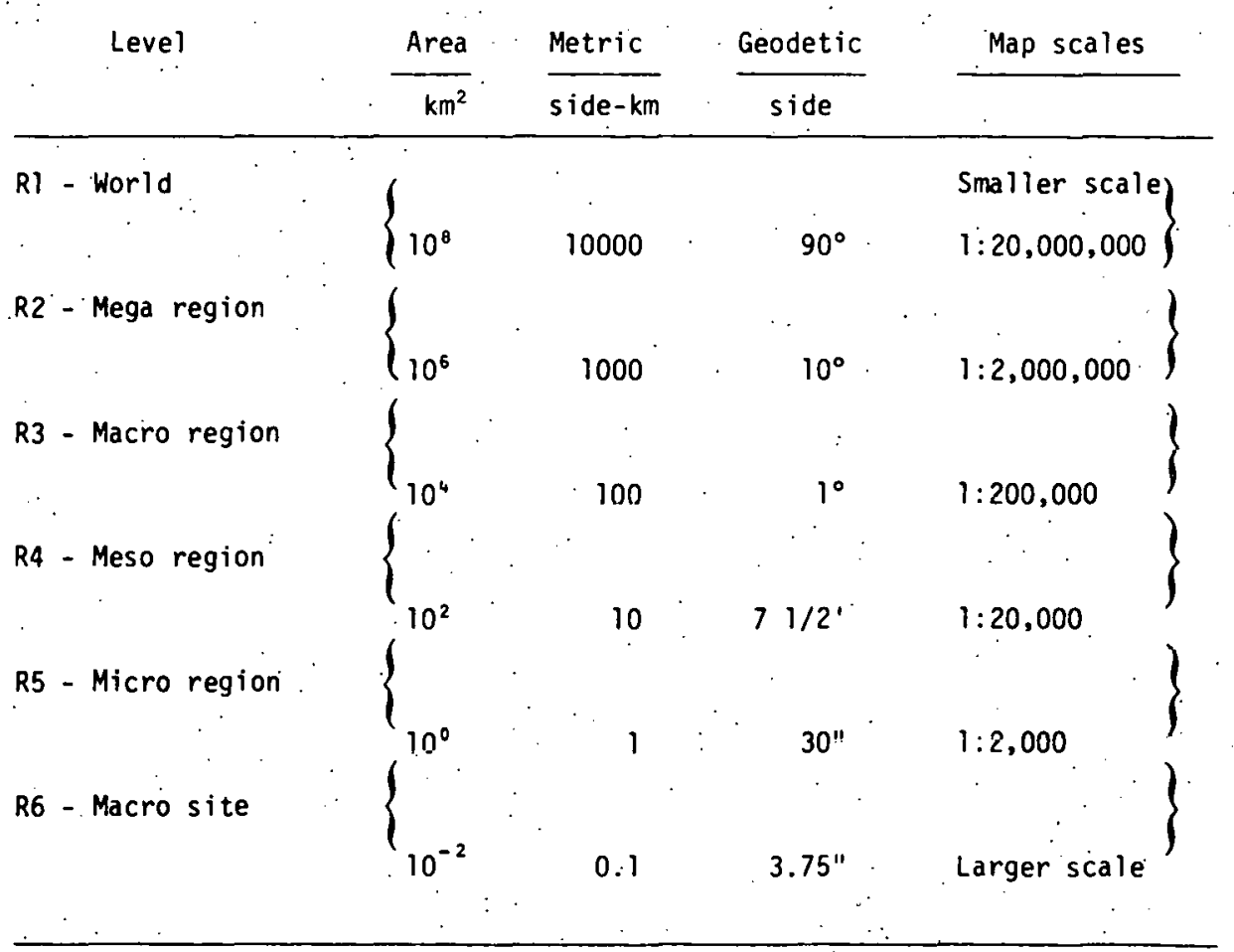


Counties can serve as building blocks to aggregate data into larger cells for "mega-region" studies. They can be used to access more detailed information by serving as pointers to data files not stored in the Geoecology Data Base. For example, county-level forestry data within the Data Base can be used to point to counties with white pine; this county list can then be used to more efficiently extract subcounty location data. of white pine from the detailed Continuous Forest Inventory plot tapes. In addition, spatial filters can be used to disaggregate county data to more detailed levels. If one parameter is available at a subcounty level (e.g.. soils) then statistical relationships can be estabilished to allocate other parameters to that subcounty level (e.g., vegetation-coil associations).

Some advantages of county units are: (1) they are we 1l-established and quite permanent geopolitical units; (2) large amounts of environmental data are readily available as county statistics; (3) counties are relatively uniform in size in the east; (4) county cells are an appropriate level of resolution for regional studies; (5) county governments are often responsible for implementing policy; and (6) county boundaries are available in computerized form for mapping. Disadvantages include: (1) occasionally names or boundaries change; (2) large and heterogeneous counties occur (primarily in the west); (3) independent cities, such as in Virginia, present special problems; and (4) some environmental models use input data in the form of rectangular grids of uniform cell size. We addressed some of the disadvantages by establishing a standard set of 3071 county units for the conterminous united states and hy subdividing larger eastern counties into subcounty units based on physiographic conditions.

The relationship between the Geoecology Data Base and extant data sources is shown in Fig. I.2. "Dispersed data" are those files which are routinely collected by various agencies to carry out their particular mission. Inventories of these data sets have been compiled by information centers (Kemp 1977, Shriner and. Peck 1978, Huber et al. 1978). These data bases are individually and collectively extremely valuable; however, they are often not readily available, have incomplete documentation, or were not designed to be compatible with other related studies: Accumulating these files into a single standardized data base would be costly and scientifically undesirable because of the uniqueness of each data set. For the Geoecology Data Base we have selected "preferred data sets" from these diverse sources based on geographic coverage, subject content, sampling time period, and avallability. 


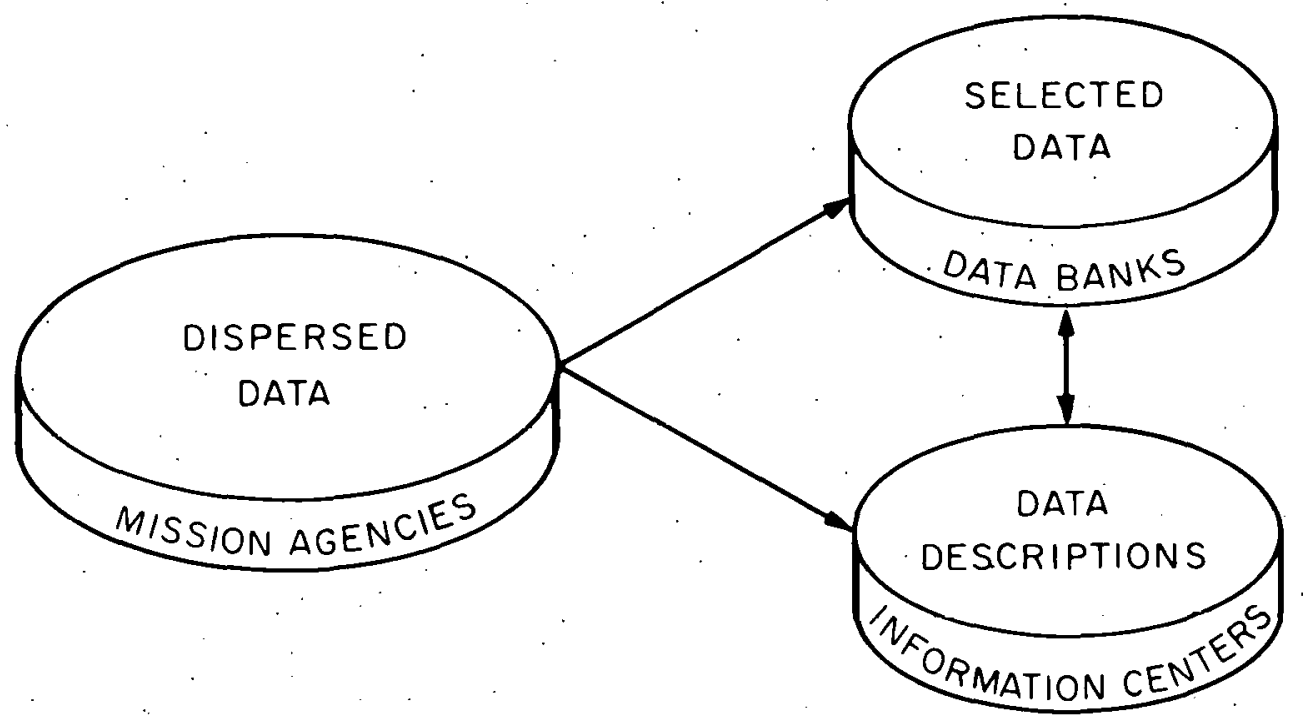

Figure I.2. Data Resources for Energy-Related Assessment. and Planning.

The Geoecology Data Base became operational in 1975 with applications and development continuing since that time. Less than a full-time-equivalent (person-year) per year has been devoted directly to Data Base development and management. The Office of Environmental Assessment, Department of Energy (DOE), is the principal funding agency.

B. Scupe of the User's Guide

This report is both a documentation and a "user's guide" to the Geoecology Data Base. It describes the Data Base design, illustrates applications, provides examples of accessing the Data Base, and gives general information on the data set contents. Appendix $A$ documents each of the over 100 data sets including source of the data, spatial and temporal characteristics, variable names and labels, and, for many data sets, sample graphic or tabular materials generated from the data. An index of the 1000 variable names and labels is given in Appendix B. Appendix C lists FIPS codes, names, sizes, and centroids of the states, counties, and subcounty units used in the Data Base. 
The Geoecology Data Base uses SAS for data storage, retrieval, and analysis. The report assumes the user is already familiar with SAS or will refer to SAS documents to obtain details of the programming language. The report provides names of online disk files on the ORNL system, but it does not give specific (and ever changing).Job Control Language (JCL) to access the disk file and execute the SAS programs.

\section{Data Availability}

The Geoecology Data Base is funded to support DOE research projects. Although it is compiled from existing data sources with federal funds, a mechanism does not currently exist to provide data and associated support as a service function to other agencies. Access to the Data Base is encouraged for individuals working on DOE-funded projects and may be arranged on a cost-recovery basis for others. In light of the dynamic nature of the Geoecology Data Base, it is required that users will assume certain responsibiliti.es. The conditions listed below were patterned directly after those contained in documentation of the Population at Risk to Air Poliution (PARAP) Data Base developed by Deane Merrill, Lawrence Berkeley Laboratory (LBL). These responsibilities apply equally to individuals obtaining copies of, accessing directly, or accessing indirectly all or parts of the Geoecology Data Base. Users of the Geoecology Data Base are asked to:

1. Inform the Geoecology Project when access to the Data Base is obtained, and keep.us informed of anticlpated uses of the data.

2. Agree to share in further distribution of data and related documentation which again includes informing the Geoecology Project of such distribution.

3. Include an appropriate citation in any published or unpublished reports which make use of the Geoecology Data Base and provide a copy of such materials to the Geoecology Project.

4. Obtain and consider all available documentation in order to understand limitations of the data. 
5. Contact the Geoecology Project regarding any errors or inconsistencies that are discovered in the data.

6. Agree that no portion of the Geoecology Data Base may be sold or incorporated into an information system which is offered to the public on a fee basis. 


\section{I. APPLICATIONS}

Applications of the Geoecology Data Base include site-specific environmental assessments (providing data), regional characterizations (Davis 1978, Copenhaver et al. 1979), regional analyses (Kitchings et al. 1976, Haynes et al. 1979, Ranney and Cushman 1980, Klopatek et al. 1980a, Nungesser and Olson 1980), and national analyses (Klopatek et al. 1980b, Klopatek et al. 1979). Selected examples are described below to demonstrate the versatility of county-level digital files in conducting regional environmental studies.

\section{A. Sulfur Dioxide Environmental Impacts}

An example of several applications of the Geoecology Data Base is the determination of potential regions where crops, natural vegetation types, or tree species are at $r$ isk to damage from sulfur dioxide (SO2) and other pollutants. The impact of air pollution on plants is complex. However, the data files on air quality, agriculture, veqetation, and forestry have been combined to identify areas at the greatest risk from so2 damage. The National Coal Utilization Assessment study (Davis 1978) dealt with potential soybean yield reductions. Fig. II.l shows areas where chronic so2 levels are currently high enough to cause damage to white pine (Nungesser and Olson 1980).

Average chemical characteristics of soils within counties were calculated to determine the potential capacity of soils to buffer the effects of acid rain and therefore reduce potential impacts of this so2-related factor (Klopatek et al. 1980a). Maps of soil pH, cation exchange capacity, base saturation, and base content were displayed for the eastern United States. These maps were overlaid with hydrogen-ion-loading levels calculated froil ratnfall amounts and rainfall pH. Fig. II.2 shows the 117 counties $\therefore$ in which solls were classified as most sensitive to acid rain.

\section{B. Natural Vegetation and Lana Use}

The need to incorporate information on natural vegetation (Küchler 1964) into regional studies prompted the estimation of the areal extent of vegetation types within countles using Küchler's map (USDI 1970). To allow the estimates to more nearly reflect current conditions, each vegetation type within a county was adjusted for land-use changes (Klopatek et al. 1979). Probabilities for land-use change were assigned to each vegetation type. An algorithm 


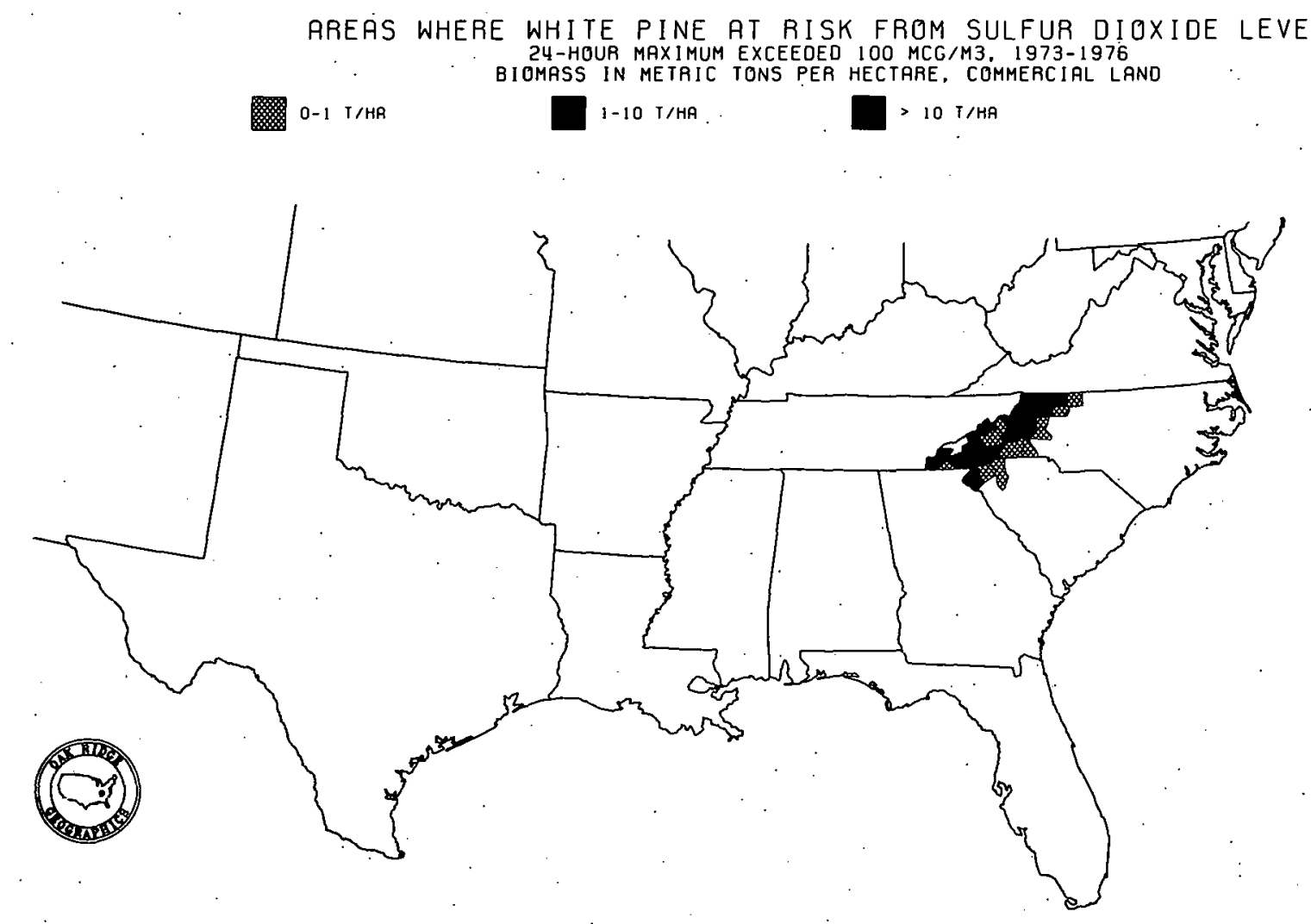

Figure II.1. Southeastern Areas Where White Pine is at Risk from Impacts of High Sulfur Dioxide Levels (Nungesser and olson 1980).

was devised to proportionally reduce natural vegetation types within a county by combining estimates of current land-use and the probabilities of changc.

The study of the declining distribution of the red wolf (Canis lupus) used the potential and land-use-adjusted natural vegetation data. Fig. II.3a shows the presettlement distribution of floodplain forest while Fig. II.3b shows the current extent of this type. This loss of habitat was one of the factors used to explain the endangered species status of the red wolf (Wilson 1979). The study used discriminant analysis of county-level. vegetation and land-use data to classify counties as probable or improbable habitat locations for the red wolf. 


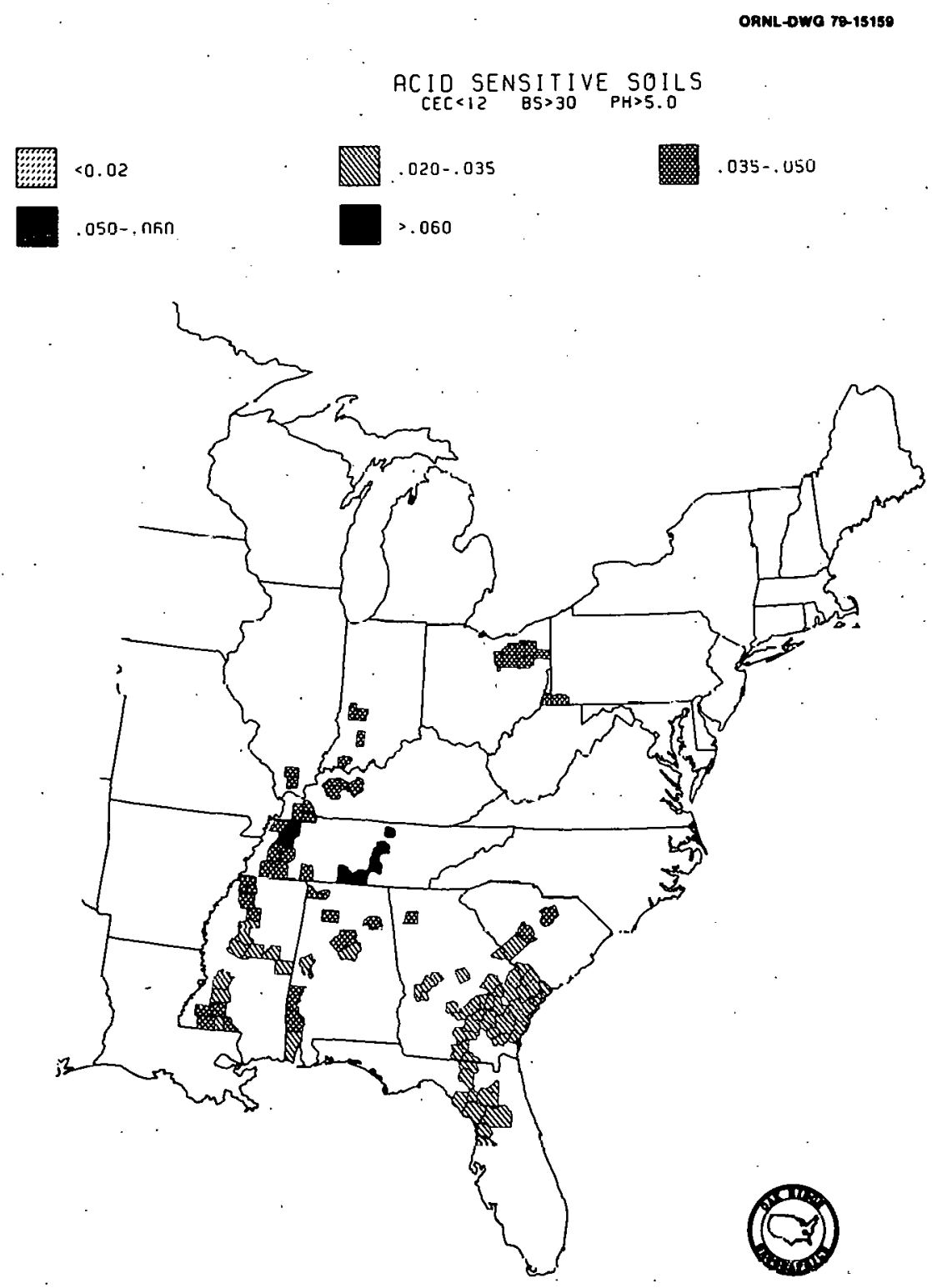

Figure II.2. Acid Sensitive Soils in the Eastern United states (Klopatek et al. 1980a). 


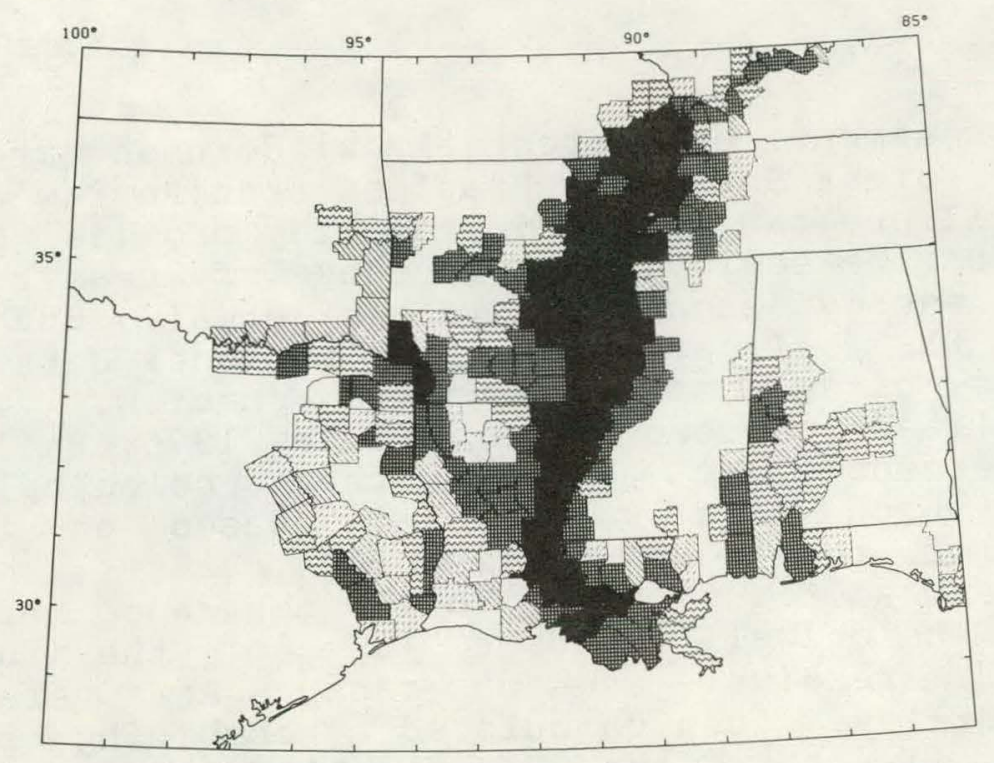

$\square<1 \%$

씼 $10-20 \%$

$1-5 \%$

$20-50 \%$

MV $5-10 \%$

$50-100 \%$

(a.)
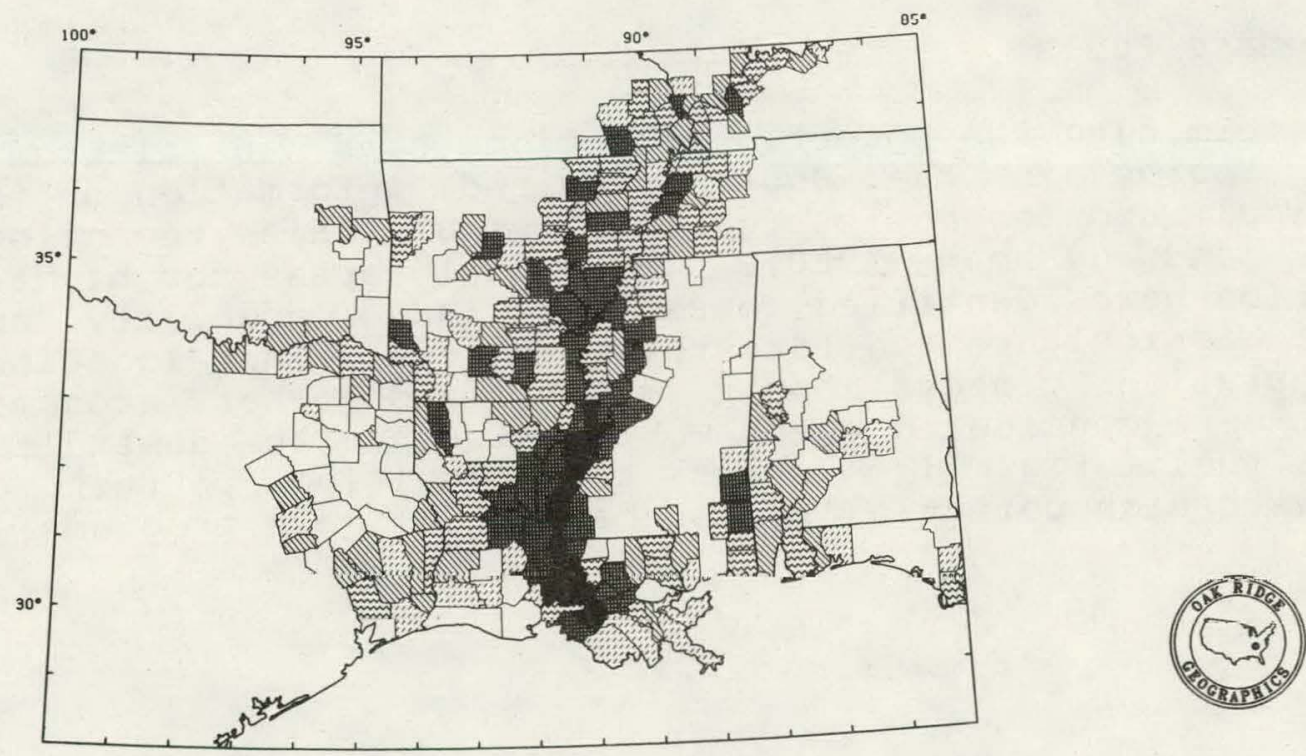

(b.)

Figure II.3. Percent Floodplain Forest (Klichler Type 103) (a.) Not Adjusted for Current Land Use, and (b.) Adjusted for Current Land Use (Wilson 1979). 


\section{Wilderness Areas Evaluation}

A national assessment of potential wilderness areas within the U. S. Forest Service's Roadless Area Review and Evaluation (RARE) II program was conducted to provide DOE with information on the ecological uniqueness of areas that also had potential energy resources (Klopatek et al. 1980b). The analysis of RARE II areas utilized national data on vegetation, mammals, birds, and endangered species. The country was stratified into ecoregions (Bailey 1976, Bailey 1978) to rank wilderness areas against other ecologically similar areas. Each area was ranked, based on the uniqueness of each of the four parameters, Values wcre cilculated so that a tract will local abundance of a nationally scarce ecological resource (one of the four parameters) would receive a high rank. An Overall Ecological Index (OEI) was then calculated by combining the four ranks. Fig. II.4 shows the OEIs for RARE II areas in the Douglas-fir ecoregion (M3112). RARE II areas are represented by circles drawn proportional lu the size of each area.

\section{Biomass Fuels}

Determining the potential for biomass as an alternate energy source in the south required information on the ecoloqical and economis feasibility of this technology (Ranney and Cushman 1980). Potential areas for biomass production were identified, based on land capability and current agriculture and forestry practices. Then locations of population centers, pulp mills, and other economic factors were considered which would influence the demand for biomass fuel. Fig. II.5 shows the resulting patteril of areas with high potential for successful biomass programs. 


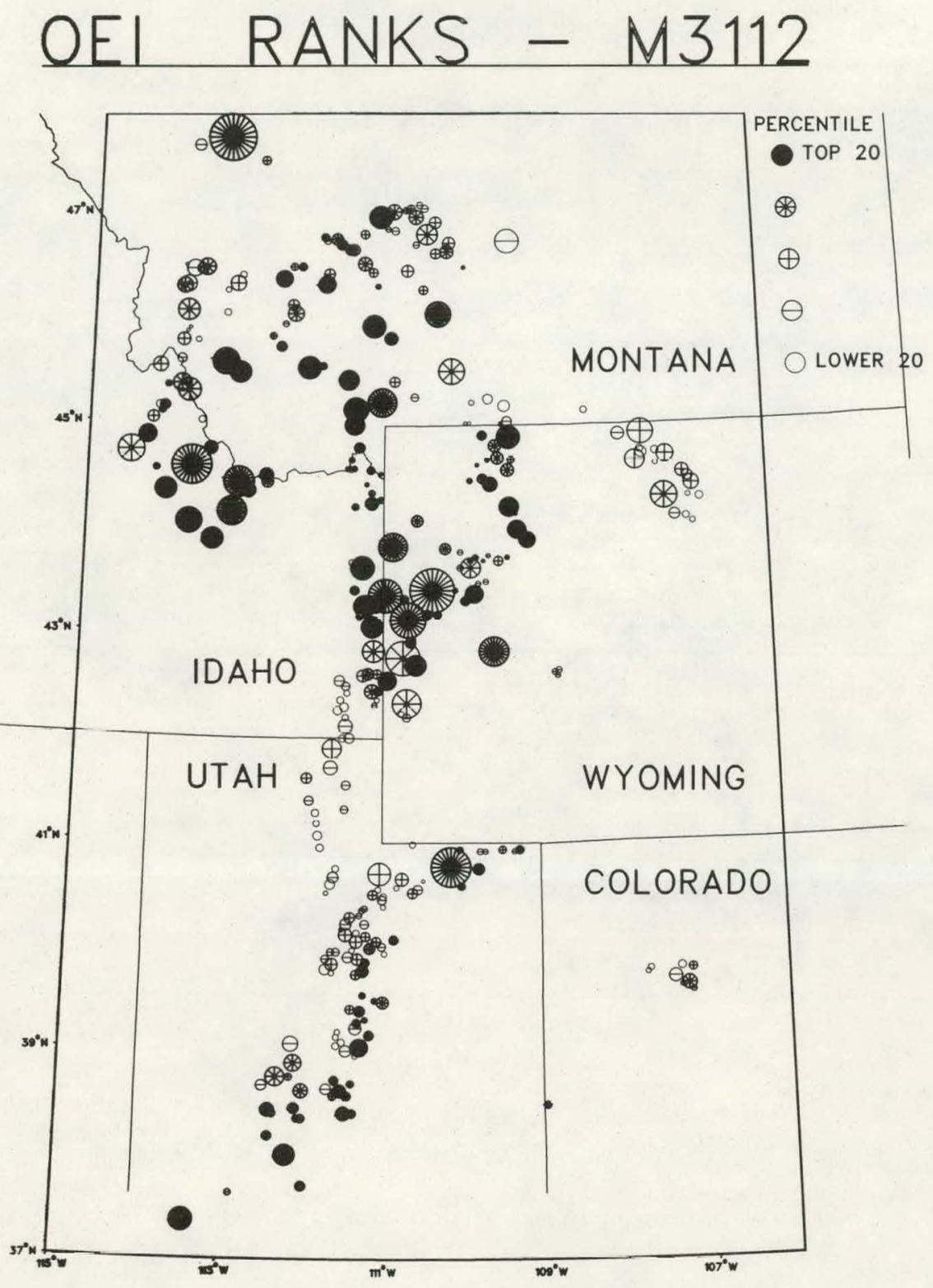

Figure II. 4 Overall Ecological Ranks for RARE II Wilderness Areas in the Douglas-Fir Ecoregion (M3112) Represented by Circles Proportional to Area Sizes and Symbols Indicating 20 Percentile Classes (Klopatek et al. 1980b). 
WOOD ENERGY CONVERSION IJNIT SUPPORT CAPABILITY USING WOODY BIOMASS FARMS AS ONLY FEEDSTOCK SOURCF $25 \%$ OF LAND CONSIDERED AVAILABLE

(HAUL DISTANCE MAXIMUM $=40$ MI.)

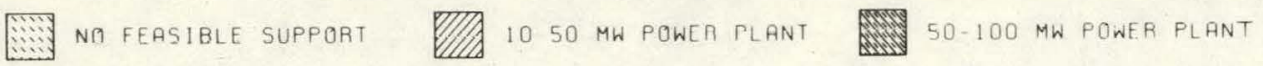

100-150 MW POWER PLANT 150* MW POWER PLANT

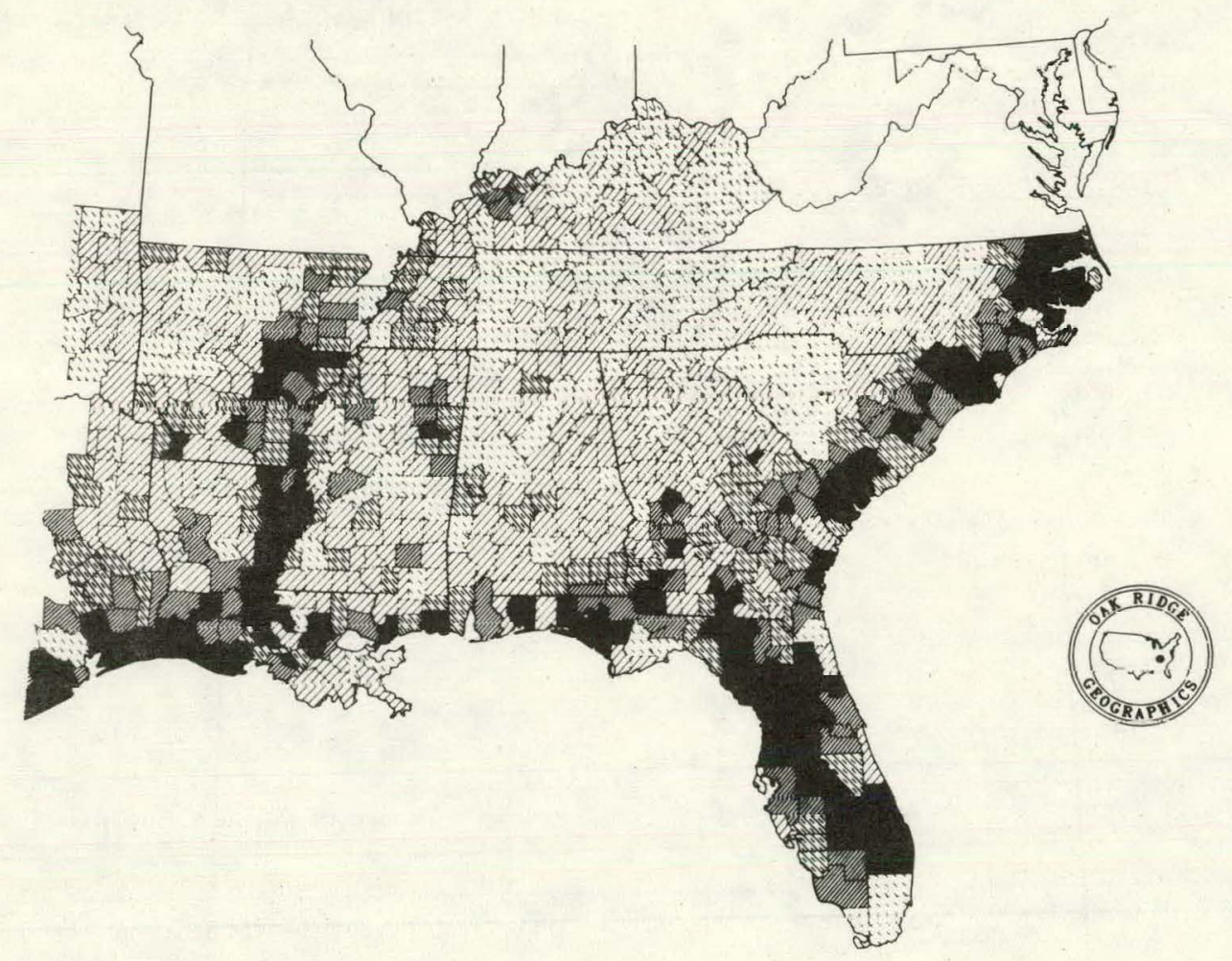

Figurc II.5 wood Energy Cunversion Unit Support Capability using Woody Biomass Farms as the Only Feedstock Source Assuming 25 percent of Suitable Land Being Available and a Maximum $64 \mathrm{~km}$ Hauling Distance (Ranney and Cushman 1980). 


\section{DATA BASE MANAGEMENT}

A. SAS

The statistical Analysis system - SAS (Barr et al. 1979) is used for data editing, data base management, and analysis (Fig. III.l). SAS provides a user-oriented file management system with extensive statistical capabilities. The system also allows user-written programs (FORTRAN, PL/I, etc.) to interface directly with the Data Base and other SAS programs. SAS operates exclusively on IBM computers in both batch and interactive modes. Analysis functions include tabular report generation, data retrieval, statistical analysis, and graphical display. Formatted files from SAS are used as input to other computer programs for graphic and cartographic display. Currently over 90 SAS data sets are stored on a single online disk file occupying 12 million bytes of storage. In addition; several larger files are stored offline as SAS tape files.

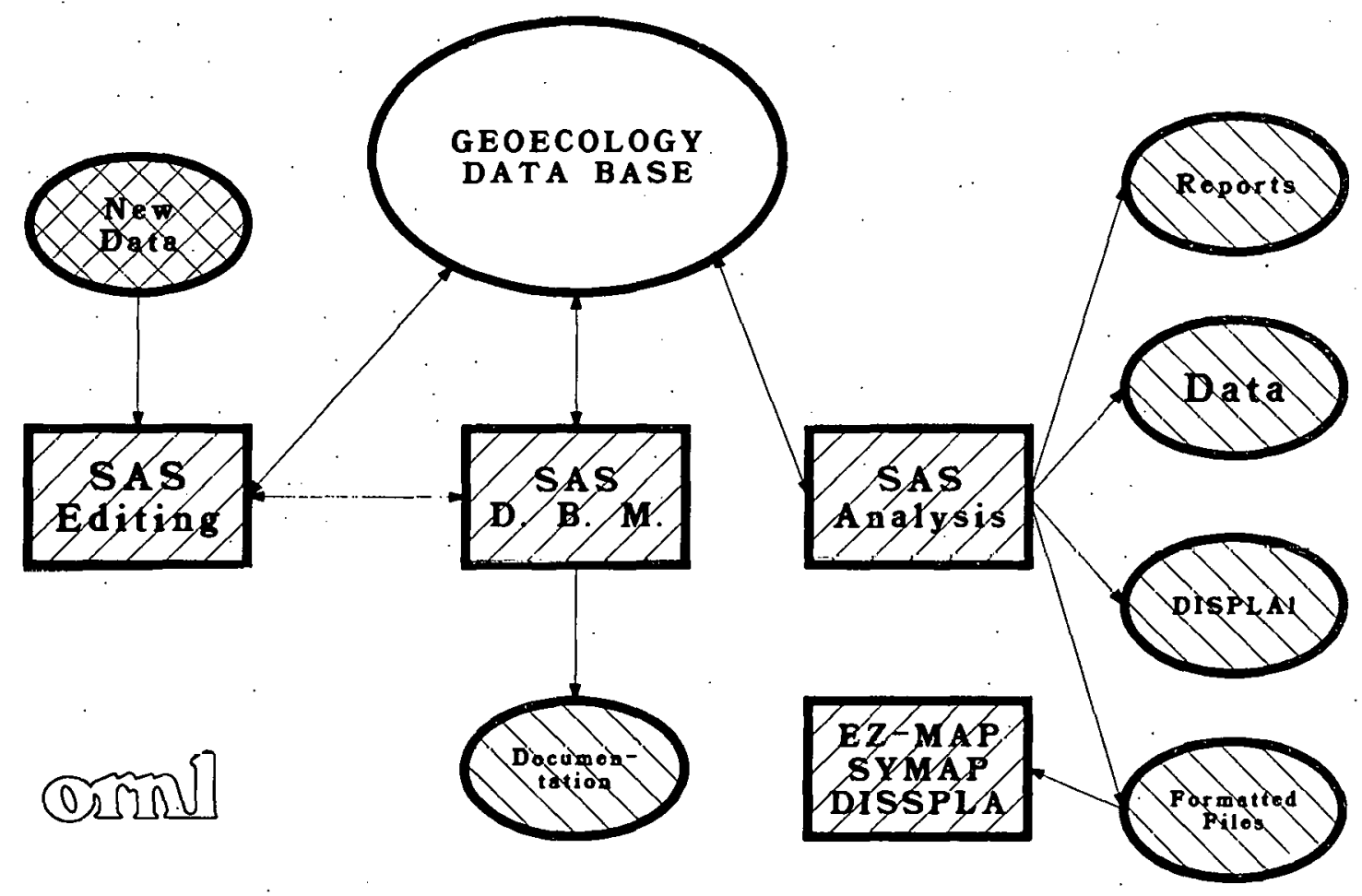

Figure III.1. The Use of SAS with the Geoecology Data Base (Nungesser and Olson 1980). 
Each data set contains a set of variables such as state and county identifiers, reference year, and data items. Data sets are assigned a permanent three-character name used as the second-level data set name within the SAS data base. The name consists of a letter representing thematic sectors within the data base (e.g., A-Agriculture, C-Climate, etc.) and a two-digit number assigned sequentially to new data sets within a sector. States and counties are consistently identified by Federal Information processing standards (FIPS) codes (USDC 1973a) to facilitate merging files for analysis and display. The FIPS code consists of a two-digit state code $(01$. to 56) and a three-digit county code, primarily odd numbers, assigned to counties in an alphabetic sequence 1001, 003, 005, etc.). Reterence years, abbreviated as the last two digits, are stored. when observations from several years are included in a data set.

Data sets may have single or multiple observations for each county unit. With single observations, each computer record contains all the variables for a county. As an example, within the forest resource data set, each county has an observation containing estimates for each of the 12 major forest types in the East, even though not all forest types occur in each county. Data sets with multiple observations per spatial unit include mammal, bird, and tree species data. In these cases, there is an observation per county unit for each species that occurs within a county. Therefore, computer storage is not used for species that do not occur in the county. In addition, the Data Base Includes dictionaries to provide English translations of codes used in the system and index files to define regions in which individual county units are located. The index files allow county data to be easily aggregated into regions as described under IV.A-Spatial Celis.

A significant facet of the project is maintaining up-to-date and adequate documentation. Meaningful mnemonic variable names and 40-character labels are used throughout the Geoecology Data Base. Thus, minimal online documentation is available for the casual user via the SAS CONTENTS procedure. In addition, a separate dictionary data set, G02, contains SAS variable names and labele extracted from the Data Base: Another data set, G01, contains the title, temporal and spatial characteristics, date compiled, compilers, and other relevant information for existing and planned data sets. Data sets G01 and G02 were used to provide most of the information on each data set presented in Appendix A. These dictionary data sets will be updated as new data are added so that users can list them to obtain the most up-to-date descriptions. 


\section{B. Display Programs}

SAS is used in connection with display programs to provide needed graphics. Procedure DISPLAl. (Olson and Kumar 1980) provides a direct interface between SAS and DISSPLA (ISSCO. 1978) to produce high quality line plots. Cartographic display is used both for editing and for displaying analytical results. Input to the mapping programs is usually a system tape or disk file that is created as a formatted output file by SAS. An in-house mapping program called. "EZMAP" was developed by the Geographic Systems Group at ORNL (Coleman 1978): It produces state and county outlines with shading or labels within the polygons. SYMAP (Dougenik and Sheehan 1975) is also used with the Data Base to produce shaded contour maps.

\section{Data Base Conventions}

\section{1.. Units of Measure}

The Geoecology Data Base is "metric-sI" (ASTM 1976). Land area measurements are expressed in hectares (ha), weights in kilograms ( $\mathrm{kg}$ ), and volumes as cubic meters (cu $\mathrm{m})$. Centimeters (cm) and degrees Celsius (C) are used in the climatic sector. Other units of measure are defined with individual data set descriptions in Appendix. A. Data were converted to metric-SI and rounded to the appropriate number of significant digits.

\section{Variable Names}

SAS variable names were assigned to be meaningful and unique within the Geoecology Data Base. Many names contain an underscore ("-) to improve the readability of the name. often names end $\bar{w} i$ th a single letter indicating the variable type. Soine standard varlable type detinitions are: A area (ha), C - code, D - descriptive name, F - Eraction of the total, N - number of unit occurrences, $\mathrm{P}$ - proportion of unit, and $T$ - general type code. Thus, the names VEG. $C$, VEG_D, and VEG $A$ indicate the: vegetation code, the desc̄riptive name, and the areal extent in hectares, respectively. Several standard SAS names that occur in many data sets are: FIPS_ST - FIPS state code, FIPS_CO - FIPS county code, SCU - subcōunty unit letter designatiōn, ST two-letter state abbreviation, and YEAR - reference year indicated by last two digits, e.g., $1980=80$. Appendix $B$ contains a combined list of the 1000 variable names, labels, and data set associations currently in the Geoecology Data Base. 


\section{Data Sets}

Data sets are assigned a permanent three-character data set name except for data sets containing subcounty unit (SCU) data. Data sets containing data for subcounty units have a data set name with an 'SCU' suffix. There are data sets in the Data Base (primarily climate and terrain data) which contain identical parameters but at different spatial scale than the primary county-level data set. An example is that $\mathrm{C} 07$ and $\mathrm{C} 07 \mathrm{SCU}$ both contain monthly temperature data. The main data set. (C.07) contains observations for all counties including those which have been subdivided. The data set with the SCU suffix (C07SCU) contains observations for the $239 \mathrm{SCU}$ 's which occur in the eastern 79 subdivided counties. Such data sets also contain the variable "SCu" identifying the subcounty unit.

Files with county identifiers are stored sorted by FIPS_ST and FIPS_CO codes, Dictionary files are sorted by the code variable. Identifier variables, including FIPS ST, FIPSCO, and "numeric" code variables, are stored as SAS charāter variables. Character variables are not used in numerical analysis and usually are defined with leading zeroes (e.g.," "001"). Therefore, when using SAS to select county or other codes, the user must use a statement such as "IF FIPS_CO='003';" in a SAS program.

To conserve space on the disk file, most variables are stored with a length of four or fewer bytes. Lengths were selected to accommodate the largest value occurring in the data and should not influence calculation accuracy since SAS performs statistical manipulations with double precision arithmetic.

\section{Special Output Formats}

The SAS procedure FORMAT allows the user to define output formats, giving label values to variable values (Barr et al. 1979). In relation to the Geoecology Data Base, we have created a library of stored labels for FIPS codes, ecoregion codes, and vegetation codes. To substitute English labels for codes, the user program must include JCL for the catalogued format load module library, construct a variable from the code variable to be used for the label, and include an appropriate FORMAT statement. An alternative slower method would be to merge files with dictionaries. The catalogued data set containing the library is ENVSCI.RJXI2891.GEOLIB. Statements that could be used to print state names for FIPS codes are given below: 
// EXEC SAS

$/ /$ SASLIB DD DSN=ENVSCI. RJXI2891. GEOLIB, DISP $=S H R$

//GEODAT DD DSN=ENVSCI. RJX12891. GEODAT, DIS P=SHR

DATA ONE; SET GEODAT.BOI; STATE=FIPS_ST;

PROC PRINT; BY FIPS ST STATE;

FORMAT STATE \$STATES.; VAR FIPS_CO CO_AREA;

The second JCL statement refers to the data set containing format load modules created and catalogued by procedure FORMAT. The STATE=FIPS_ST defines a variable which will temporarily contain state names. The FORMAT statement uses the \$STATES. load module to associate state names based on the FIPS code with the variable STATE for the duration of the program step. The output report will contain state FIPS codes (FIPS_ST), state names (STATE), county FIPS codes (FIPS_CO), and county areas (CO_AREA).

Names of the available format load modules within the Geoecology Data. Base are listed below. The SAS variables within the Data Base (e.g., FIPS ST, ECO CODE, VEG CODE) to be used with FORMAT statements are given. To obtain county names, the state and county FIPS codes must be concatenated to provide a unique code. If several of the format load modules are referenced by the same FORMAT statement, that program step may require more than $270 \mathrm{~K}$ of memory.

\$STATES. \$COUNTIES. \$ECOCODES. \$VEGCODES .
State and region names (FIPS_ST)

County names (FIPS_ST and FI $\overline{P S}$ _CO)

Ecoregion names (E $\bar{C} O$ CODE)

Vegetation names (VE $\bar{G}$ _CODE)

5. SAS Files

In addition to the Geoecology Data Base, there are two libraries available in connection with the Data Base. One contains the procedure DISPLAl program for producing line plots, and the second contains format load modules equivalents for use by the sAS FORMAT statement. The second library currently contains load modules for FIPS codes. ecoregion codes, and vegetation codes with, plans to add other codes as time permits. The names of the catalogued files on the ORNL computer system are:

ENVSCI.RJX12891.GEODAT. - Geoecology Data Base ENVSCI. RJX12891.GEOLIB - Procedure FORMAT Library ENVSCI.RJX12891.SASDSPLY - Procedure DISPLAl module 
IV. SPATIAL AND TEMPORAL ASPECTS

A. Spatial Cells

We have selected counties as our primary: geographic unit for analysis and display as discussed in the INTRODUCTION AND SCOPE. A standard set of 3071 county units for the conterminous United states was defined using the 1972 County and City Data Book (USDC 1973b) and the FIPS Codes book (USDC 1973a). Most independent cities were combined with appropriate county units because environmental data are normally not available for these smaller urban areas such as Baltimore City, st Louis City, and 34 of the 39 Virginia independent cities. The Interlaboratory Working Group for Data Exchange (Benkovitz 1979) has also endorsed FIPS codes and standardized county units to facilitate exchange of county-level thematic data files. Counties containing aggregated data from associated independent cities are listed in Table IV.1. Table IV.2 lists counties that we have found may be treated differently in the various "county-level" source files. We have estimated or aggregated data in creating our "standard" data sets to obtain observations for all county units. The 3071 county units are listed as Appendix C along with the 239 subcounty units and a summary by state.

County units can be easily aggregated by various regional designations stored in the Geoecology Data Base. Crop Reporting Districts, state Climatic Divisions, Land Resource Regions, Air Quality Control Regions (AQCR's), Aggregated Sub-Areas, Standard Metropolitan statistical Areas (SMSA's), Bureau of Economic Analysis areas (BEA's), and states all represent areas defined in terms of aggregates of county cells.

There is a distinct overall difference between county sizes in the eastern states and western states. Because of our interest in the Eastern Deciduous Forest Biome which covers parts of all the eastern states, we have concentrated efforts in this area. There are 2660 county units in the eastern 37 states ranging in size from 60 to $17,700 \mathrm{sq} \mathrm{km}$ with an average size of $1750 \mathrm{sq} \mathrm{km}$. By. subdividing 79 counties based on size and geographic heterogeneity, the largest county unit was reduced to $6,900 \mathrm{sq} \mathrm{km}$ and the average to $1660 \mathrm{sq} \mathrm{km}$. We have entered terrain and climatic data at the subcounty-level of resolution in the east. The ecologically heterogeneous large western counties still need to be subdivided. 
Table IV.1. Counties Containing Aggregated Data from Associated Independent Cities within the Geoecology Data Base

\begin{tabular}{|c|c|c|c|c|c|c|c|c|c|}
\hline \multirow{2}{*}{\multicolumn{2}{|c|}{ State }} & \multirow{2}{*}{ County } & \multicolumn{4}{|c|}{ FIPS code } & & \multirow{2}{*}{$\begin{array}{c}\text { Associated } \\
\text { Independent city }\end{array}$} & \multirow{2}{*}{$\begin{array}{l}\text { FIPS } \\
\text { code }\end{array}$} \\
\hline & & & State & & County & & & & \\
\hline MD & & Baltimore & 24 & & 005 & & & Baltimore City & 510 \\
\hline MO & & St. Louls & 29 & & 189 & & & St. Louls City & 510 \\
\hline MT & & Park . & 30 & & 067 & & & $\begin{array}{l}\text { Yellowstone National } \\
\text { Park - Part }\end{array}$ & 113 \\
\hline VA & & Albermarle & 51 & & 003 & & & Charlottesville & 540 \\
\hline VA & & Alleghany & 51 & & 005 & & & Clifton Forge & 560 \\
\hline VA & & Alleghany & 51 & & 005 & & & Covington & 580 \\
\hline VA & & Arlington & 51 & & 013 & & & Alexandria & 510 \\
\hline VA & & Augusta & 51 & & 015 & & & Staunton & 790 \\
\hline VA & & Augusta & 51 & & 015 & & & Waynesboro & 820 \\
\hline VA & & Bedford & 51 & & 019 & & & Bed ford & 515 \\
\hline VA & & Campbel1 & 51 & & 031 & & & Lynchburg & 680 \\
\hline VA & & Carroll & 51 & & 035 & & & Galax & 640 \\
\hline VA & $\cdot$ & Dinwiddle & 51 & & 053 & & . & Colonlal Helghts & 570 \\
\hline VA & & Dinwiddle & 51 & & 053 & & & Petersburg & 730 \\
\hline VA & & Falrfax & 51 & & 059 & & & Falrfax & 600 \\
\hline VA & & Fairfax & 51 & & 059 & & & Falls Chuch & 610 \\
\hline VA. & & Fredr1ck & 51 & & 069 & & & Winchester & 840 \\
\hline VA & & Greensville & 51 & & 081 & & & Empor1a & 595 \\
\hline VA & & Halifax & 51 & $\cdot$ & .083 & & & South Boston & 780 \\
\hline VA & & Henrtico & 51 & & 087 & & & Rlchmond & 760 \\
\hline VA & & Henry & 51 & & 089 & & & Martinsville & 690 \\
\hline VA. & & James City & 51 & $\therefore$ & 095 & & & W1111amburg & 830 \\
\hline VA & & Montgomery & 51 & & 121 & & R & Radford & 7.50 \\
\hline VA & & P1ttsylvania & 51 & & $14 \overline{3}$ & & & Danville & 590 \\
\hline VA & & Prince George & 51 & & 149 & & & Hopewell & 670 \\
\hline VA & & Roanoke & 51 & & 161 & & & Roanoke & 770 \\
\hline VA & & Roanoke & 51 & & 161 & & & Salem & 775 \\
\hline VA & & Rockbridge & 51 & & 163 & . & & Buena Vista & 530 \\
\hline VA & & Rockbridge & 51 & & 163 & & & Lexington & 678 \\
\hline VA & & Rockingham & 51 & & 165 & & & Harrisonburg & 660 \\
\hline VA & & Súlliamptun & 51 & & 173 & & & Frank I In & 620 \\
\hline VA & & Spotaylvania & 51 & & 177 & & & Freder lcks burg & 630 \\
\hline VA & & Washington & 51 & & 191 & & B & Bristol & 520 \\
\hline VA & & W1 se & 51. & & 195 & & $\mathbf{N}$ & Norton & 720 \\
\hline VA & & Chesa peake & 51 & & 550 & & & Chesapeake & 550 \\
\hline VA & & Chesapeake & 51 & & 550 & & & Norfolk & 7.10 \\
\hline VA & & Che sapeake & 51 & & 550 & & & Port smouth & 740 \\
\hline VA & & Hampton* & 51 & & 650 & & $\cdot$ & Hampton & 650 \\
\hline VA & & Newport News & 31 & & 700 & & & Newport News & 700 \\
\hline VA & & Suffolk & 51 & & 800 & & & Suffolk & 800 \\
\hline VA & & Suffolk & 51 & & 800 & & $\mathbf{N}$ & Name smond & 695 \\
\hline VA & & Virginia Beach* & 51 & & 810 & & & V1rginla Beach & 810 \\
\hline
\end{tabular}


Table IV.2. County Units Providing Confusion Resulting From Historic Changes

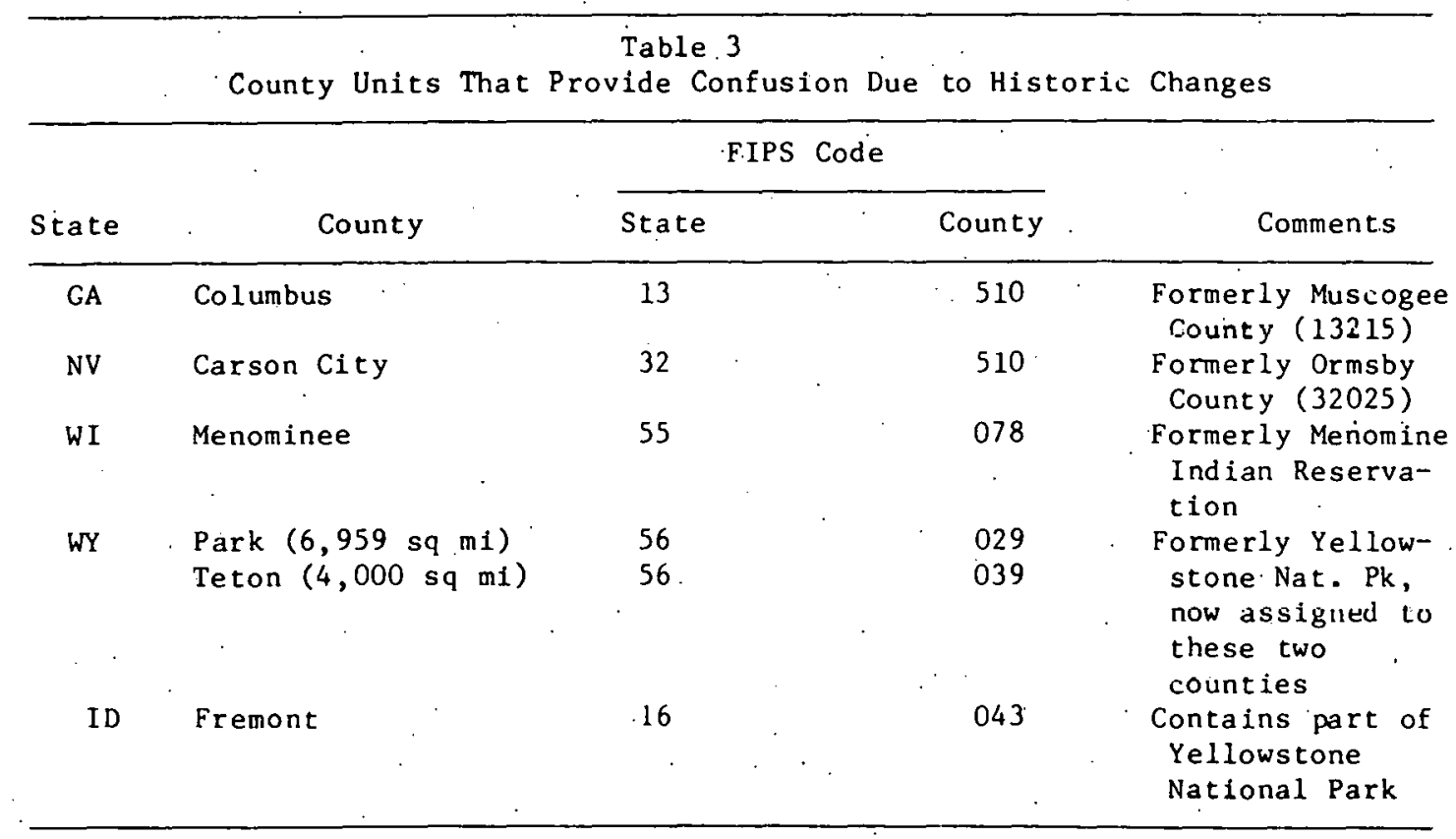

B. Geographic Coverage

Our goal is to have national coverage for all data sets. Historically, we have had three levels of coverage: the southern 16 states, the eastern 37 states, and the 48 conterminous states. The South is associated with ORNL's regtonal studies program tor DOE. States included in the South are Maryland, West Virqinia, Kentucky, Mississippi., Oklahoma, Texas, and all states to the south (the District of Columbia is considered a state unit). The East includes the eastern Deciduous Forest Biome with the more uniform county units. States in the East inciude North Dakota, South Dakota, Nebraska, Kạnsạs, Oklahoma, Texas, and al 1 states to the east.

\section{Temporal Coverage}

The temporal aspect of each data set was selected to reflect the most current conditions. In the case of rapidly changing resources, data sets may contain observations for a series of years. The reference year for most files lies between 1965 and 1978. Agricultural productivity, bird populations, air quality, and human population are examples of files with several years of data. Land-use changes occur very rapidly for certain areas, but current data are not available at the county-level to define these changes. 


\section{DATA BASE COMPILATION}

\section{A. Data Sources}

Extensive efforts are required to find appropriate data sources and to reformat them into data sets for the Geoecology Data Base. New data files are normally restricted to those files with U. S. coverage that contain the most recently available data and are available from a single source in a consistent, documented form. Such files are usually created, maintained, and not widely documented by mission-oriented agencies to fulfill their specific needs. Diligent searching and personal contacts are required to find these unique and very useful data sets.

The Geoecology Project has a collection of magnetic tapes which were used to create Geoecology data sets, provide additional environmental data, or provide complementary data such as health, population, energy, etc. The tape files exist in a variety of formats and usually do not have FIPS county identifiers. When the need arises, the flexible inputting capabilities of SAS are used to read and merge such files with the Geoecology Data Base. The file G0 3 provides an inventory with titles of the tapes; however, formats and associated information must be obtained from the Geoecology Project. Inventories of these and other spatial data files at ORNL have been published periodically since 1975 (Copenhaver and Barker 1980).

\section{B. Quality Control}

Our experience with extant data has emphasized the need for extensive data checking. Data problems encountered include erroneous data, missing data, wrong county identifiers, and inconsistent county identifiers for independent cities and other areas (e.g., Yellowstone National Park). The most fruitful ways to determine errors are (1) using the data, (2) generating thematic maps, (3) searching sorted lists, (4) calculating univariate statistics, and (5) associating two or more independent files. Although users of a data set may eventually discover errors, we have found that a preliminary thematic map of a variable will quickly display possible inconsistencies through irregularities in the spatial pattern. Fig. V.l is a typical map generated to edit the lithology data set. By comparing this map with the original source map, missing data and data errors were corrected.

One of the most thorough methods to ensure quality control is to combine two independent files by county and check for inconsistencies. Based on ecological 


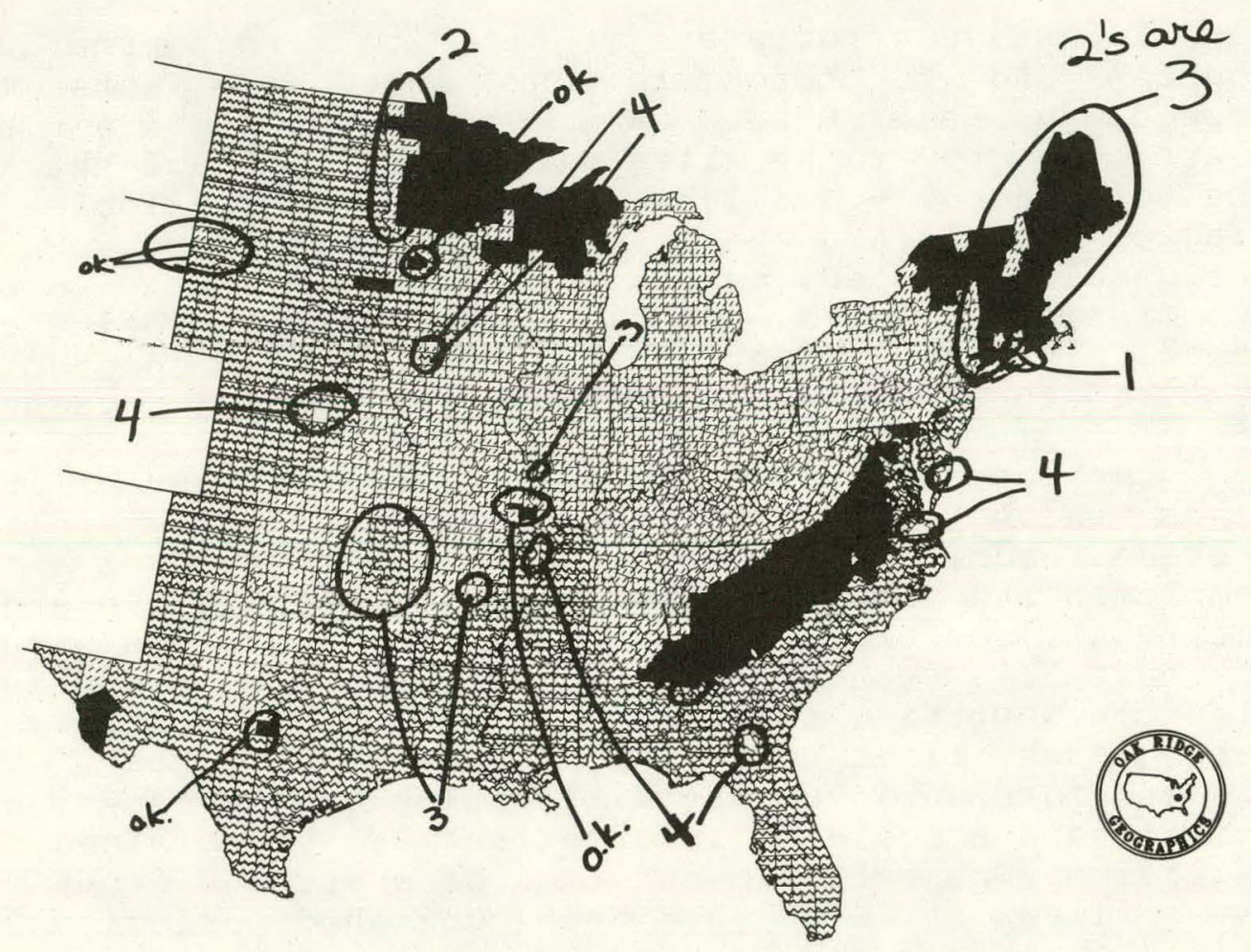

Figure V.1. Sample Map used for Editing the Lithology Data Set.

relationships, tree species occurrences are checked against potential vegetation types within a county; for example, many tree species do not normally occur in areas classified as prairie. If a county is found with such an inconsistency, both source maps are checked. If an error has occurred, cach filc is checked for crrors in digitizing, transcribing, keypunching, and entering data. Appropriate corrections are made using the SAS EDITOR procedure. Another example of cross-file checking compares county areas. Most files which contain an estimate of total county area do not agree with the 1970 Census values used as our base county statistic. Some of these differences stem from the classification of small and large water bodies in an inventory or from real changes in county boundaries. However, in other cases it has been exceedingly difficult to resolve differences in the elementary statistic of county size. 
Despite our continuing efforts toward quality control in the Data Base, it would be presumptuous to imply that the Geoecology Data Base is free of errors. Errors will be corrected when found. Individuals obtaining copies of the Data Base must share the responsibility of informing us of potential errors discovered in the data. Users should also periodically request information on updates or request an updated copy of the file.

\section{Compilers}

The Geoecology Data Base has involved the efforts of many individuals in the compilation of data sets. These individuals are listed in Appendix $A$ with the data. sets to which they contributed through digitizing, analytical methodologies, or editing. By utilizing the expertise of these contributors, we have achieved additional quality control and a broader spectrum of data sets. 


\section{DATA BASE CONTENTS}

There are thirteen thematic sectors in the Geoecology Data Base representing groupings of data sets into similar subject areas. Table VI.l lists the sector designation letter, title, and number of data sets in the sector. The Items column represents the number of SAS variables while the Records column gives the number of observations in the Data Base, Titles, temporal and spatial characteristics, and status of data sets within each sector are given in Table VI.2. Although individual data sets within a sector may he replaced by updated files, each sector represents an aspect of the environment often needing to be characterized within regional studies. Each sector, identified by its letter, is described below.

Table VI. I Geoecology Data Base Sectors

\begin{tabular}{llrrr}
\hline \multirow{2}{*}{ Eector } & Theme & Number & Ttems & Records \\
& & & & \\
\hline A & Agriculture & 5 & 89 & 22,179 \\
B & Base Data & 5 & 35 & 10,686 \\
C & Climate & 14 & 171 & 20,765 \\
D & Vegetation & 12 & 89 & 120,678 \\
F & Forestry & 7 & 67 & 38,794 \\
G & General & 2 & 18 & 1,968 \\
K & Air Quality & 3 & 21 & 4,081 \\
L & Land & 8 & 136 & 57,600 \\
P & Natural areas & 8 & 62 & 15,122 \\
Q & Population & 2 & 50 & 4,459 \\
T & Water Resources & 1 & 60 & 0 \\
W & Terrain & 12 & 78 & 28,765 \\
& Wilalife & 14 & 104 & 297,788 \\
& Totals & -- & --- & ---1 \\
\hline
\end{tabular}

A. Agriculture (A)

The Agriculture Sector contains both crop and livestock statistics selected from national inventories. Data for more crops and crops grown under irrigation are available on tapes. 
Table VI.2. Reference Year(s), Geographic Coverage,
Spatial Units, and Status of Data
Sets within the Geoecology Data Base

SECTOR CODE LETTER=A

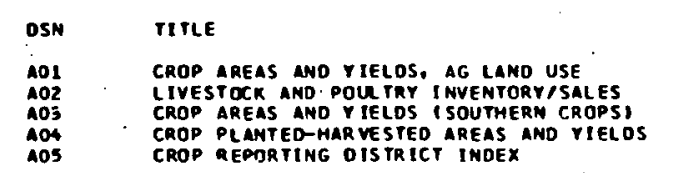

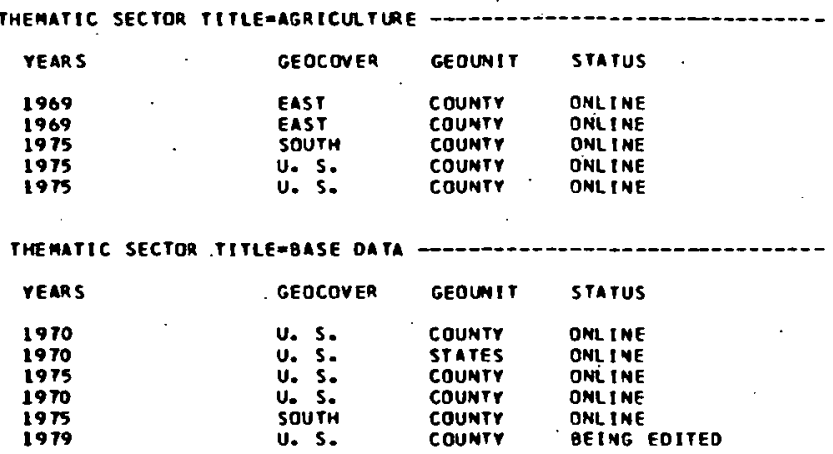

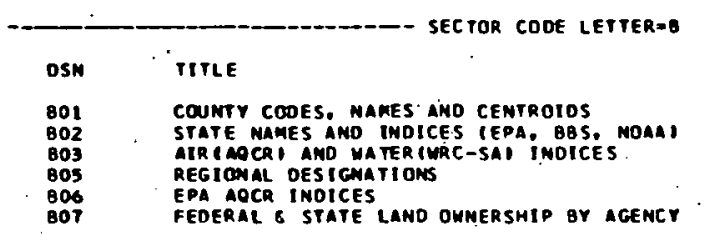

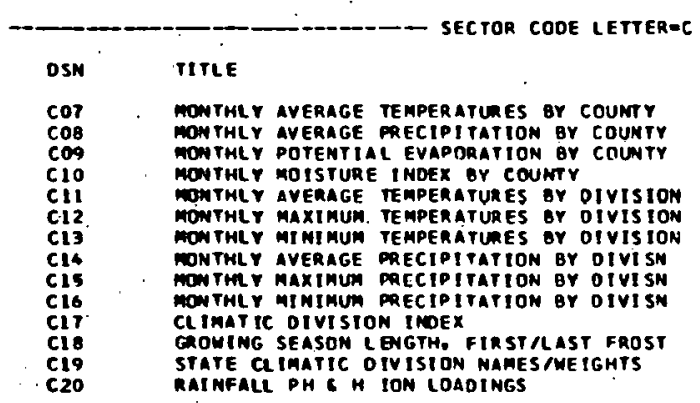

THEMATIC SECTOR TITLE-CLIMATE -

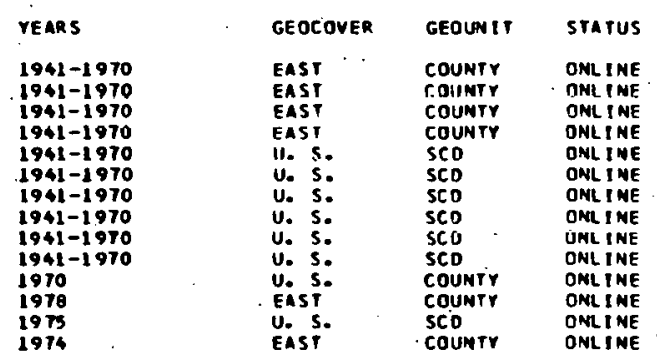

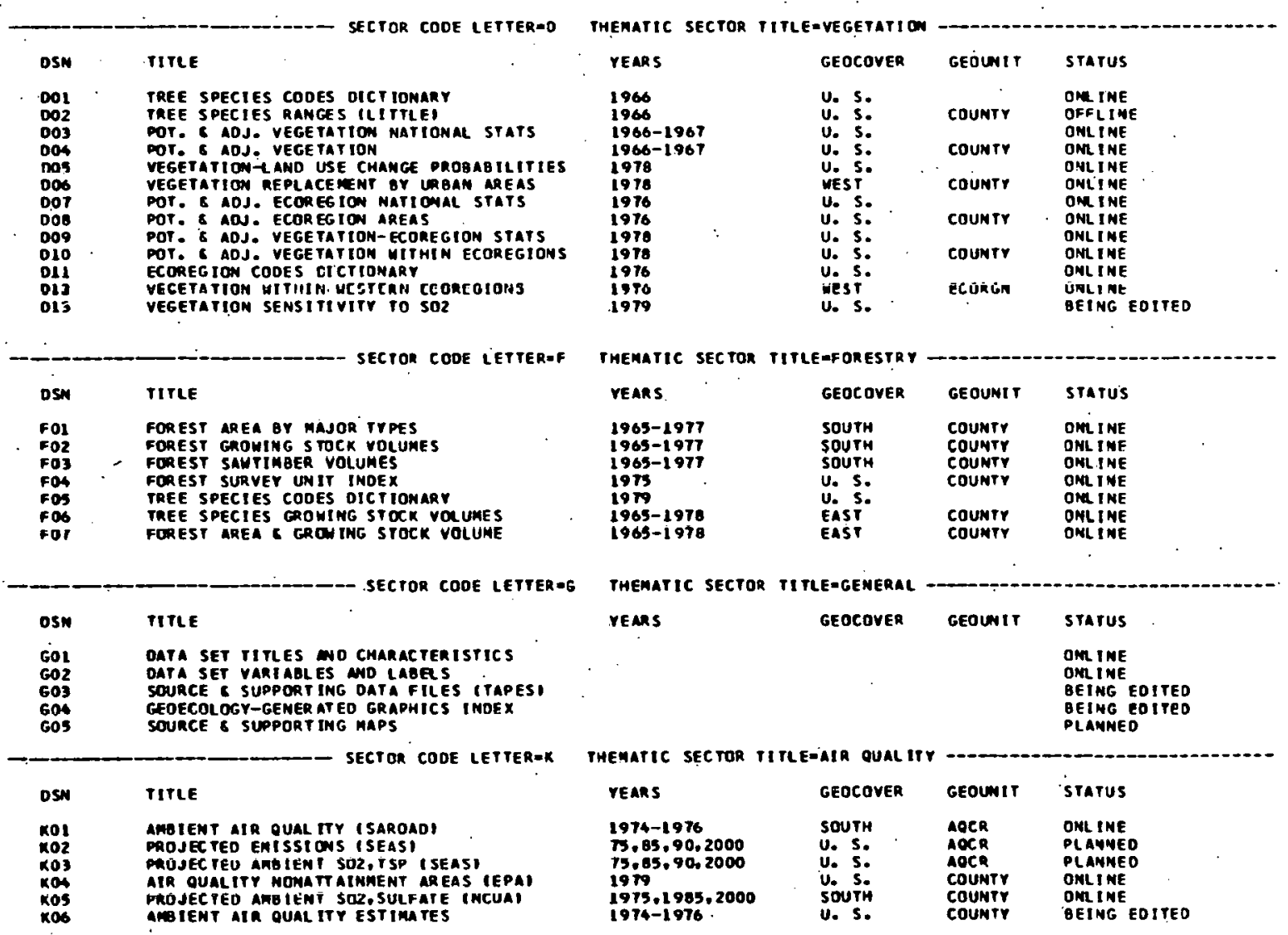


Table VI.2(cont.). Reference Year(s), Geographic Coverage, Spatial Units, and Status of Data Sets within the Geoecology Data Base

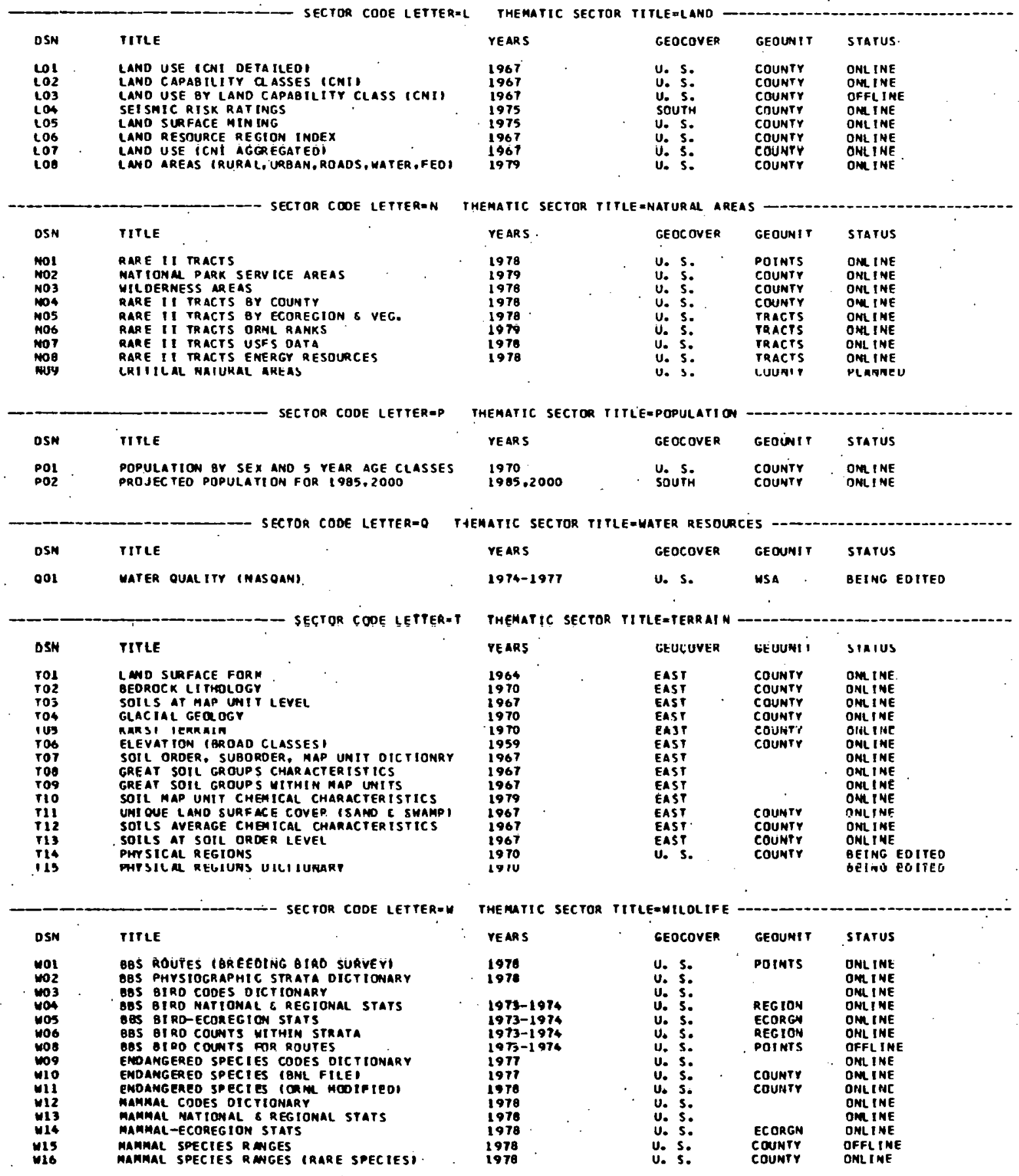


B. Base Data (B)

Basic data about the size and location of counties plus various index files are contained in the $B$ Sector. Data set B0l defines the 3071 county units used as the primary spatial cells in the Geoecology Data Base. The index files can be merged with other data sets to aggregate counties into various regions for analysis. Data set BO1SCU defines the 79 eastern counties that have been divided into 239 subcounty units.

C. Climate (C)

Climatic data in Sector $C$ consist of temperature, precipitation, potential evapotranspiration, moisture index, and length of growing season. Monthly and annual norms are included for State Climatic Divisions and for counties in the East. County values were estimated by T. Webb, III, (1976) using irregularly spaced weather station data and assuming that estimates for the county centroid would be representative for the county. Additional data tapes containing monthly observations for weather stations are available to provide records over long time periods.

D. Vegetation

(D)

The Vegetation Sector contains estimates of areas of potential natural vegetation (Küchler 1964) as digitized from Küchler's (USDI 1970) map and as adjusted for current land-use practices (Klopatek et al. 1979). In addition, the ecoregion classification map (Bailey 1976, Bailey 1978) has been digitized and combined with the vegetation data (see the Vegetation Overview in Appendix $A$ for additional information).

\section{E. Foreetry (F)}

The Forestry Sector represents a significant effort in compiling, editing, and reformatting county-level tree species growing-stock volume data involving a variety of data sources (Delcourt et al. 1980). Data include volumes and biomass estimates for major forest species and forest arca by major forest types.

F. General (G)

The General sector includes information on the contents of the other data sets and on a library of analysis and display materials that have been generated from the data sets. G01 provides characteristics of data sets and G02 contains variables and labels extracted from the individual 
data set directories. Data set G03 is an inventory of tape files associated with the Geoecology Project and data set G04 is an inventory of graphic materials that have been generated from the Geoecology Data Base.

G. Air Quality (K)

Ambient air quality statistics have been compiled by Lawrence Berkeley Laboratory as part of the Population At Risk to Air Pollution (PARAP) project (Merrill 1980). County-level statistics were estimated from available monitoring data which were screened before being used. These data are currently being added to the Geoecology Data Base. Air emission levels are projected by the strategic Environmental Assessment System (SEAS) model which is being developed by DOE. We plan to incorporate these data into the Data Base when available. The SEAS data are provided for Air Quality Control Regions. Existing data on air quality in the Data Base have geographic coverage limited to the south.

H. Land (L)

The Land Sector includes several data sets related to land-use, land capability, and land-use restrictions. County-level land-use statistics are available from the 1967 Conservation Needs Inventory (USDA 1971) which are both out-of-date and subject to relatively high statistical sampling errors for individual counties. The inventory is also restricted to nonfederal land. Land Resource Regions are defined in terins of the agriculture practices and capabilities of an area.

I. Natural Areas (N)

Natural areas are defined as areas administered and protected to maintain natural ecologlcal conditions. Included are parks, wilderness areas, national forests, wildife refuges, ecological preserves, and others. We anticipate expanding this sector to include a comprehensive inventory of these areas.

J. Population (P)

Human population statistics are stored for 1970 along with projections for 1985 and 2000 . 
K. Water Quality (Q)

The National stream Quality Accounting Network (NASQAN) provides a comprehensive system of monitoring stations for 328 water basins covering the United States. We are developing water quality statistics from these data for inclusion in the Geoecology Data Base.

L. Terrain (T)

Various aspects of the terrain are characterized as part of the Terrain Sector. A set of National Atlas maps including land form, elevation, soils, lithology, karst terrain, and glacial areas was digitized for the East by C. A. Roswell, Jr (1976). These files have been edited and several are being expanded to cover the West. In addition, a map on physical regions has been digitized. Characterization data are being developed for the chemical, physical, and land-use properties of the soils file.

M. Wildlife (W)

The wildlife sector includes information on birds from the annual Breeding Bird Survey (BBS), data on federally designated endangered and threatened species; and mammal species ranges. Information on the potential presence or absence of 280 mammal species by county was digitized from a variety of sources. Plans exist to incorporate information defining wildlife habitat requirements. 
VII. ACCESSING THE DATA BASE

As described earlier, files in the Geoecology Data Base are stored as SAS data sets with SAS used for data retrieval and analysis. The following examples demonstrate a typical analysis involving the SAS operations of: (A) checking the contents, (B) merging files, (C) generating reports, (D) statistical analysis, and (E) producing displays. Specifically, a file of crop production (A03) is combined with ambient air quality (K05) to portray potential areas of so2-soybean impacts. A third file (B01) is used to provide statistics on the size of countles.

A. Vata set contents

In the first stap, PRor CONTENTS is used to list the data set names of the files currently stored onitine (Fig. VII.1). The disk file is designated as GEODAT which must be correctly referenced by Job Control Language (JCL). PROC CONTENTS is also used to list the variables and labels within B01, A03, and K05 (Fig. VII.2).

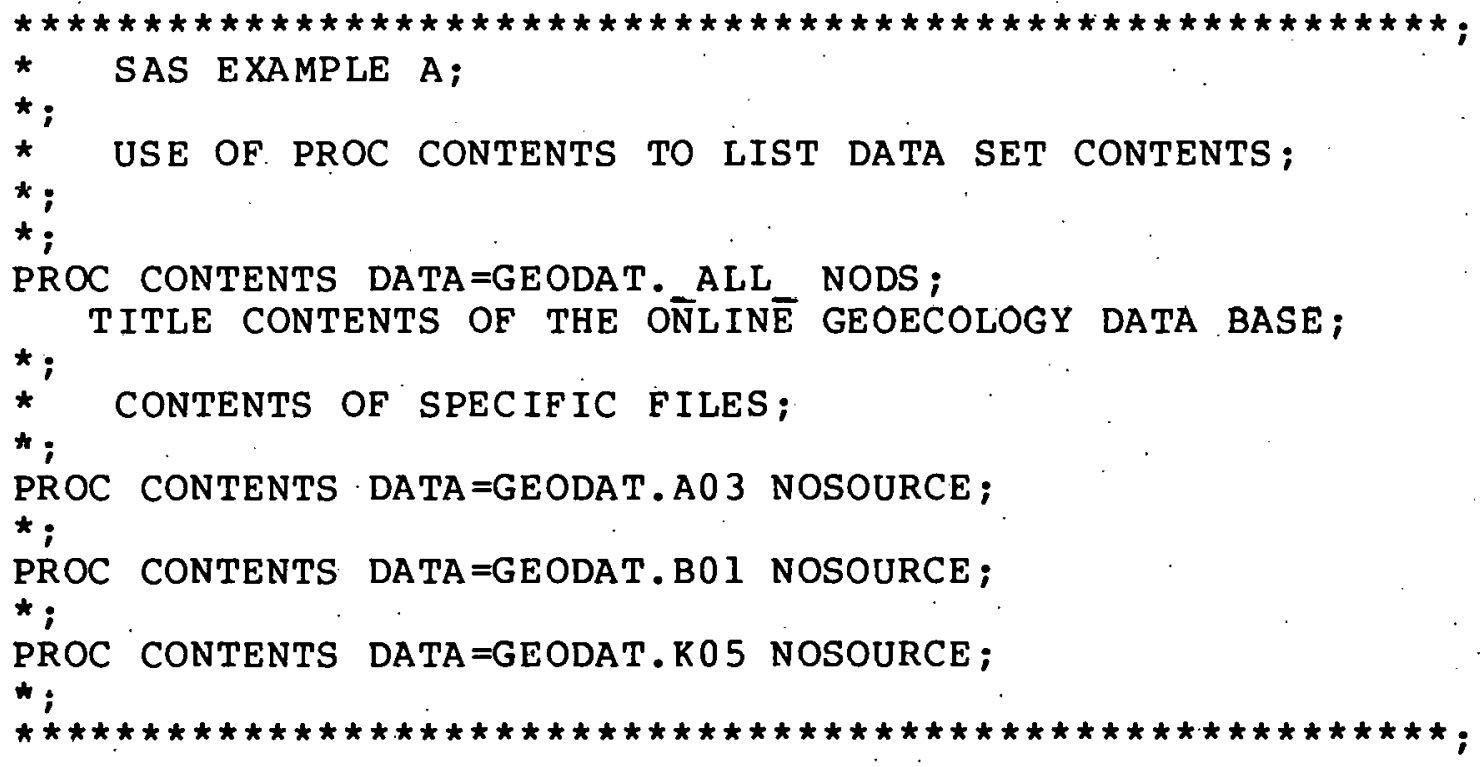

\section{B. Merging Data Sets}

The second step involves merging the data sets and calculating a crop yield value. The resulting data set is used to print a report, perform a statistical analysis, produce an X-Y graph, and generate a map. The combined data set, called FIVE, could be stored on a user's disk area. for subsequent access. In this series of examples, it is assumed that all steps will be run as one job and data set FIVE 


\section{COMTEATS OP THE OHLIME GBOBCOLOG DATA BASE \\ CORTEHTS PROCBDORE

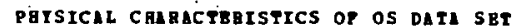

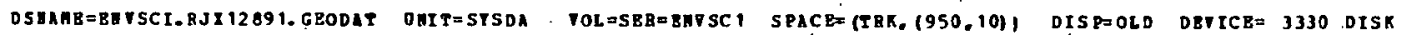
TRICRSIZE= 13030 BTIES CREATED SONOAT, DECBABER 27, 1976 950 TRACRS ALLOCATED I 1 BYTEETS

SAS DATA SET DIBECTOBT

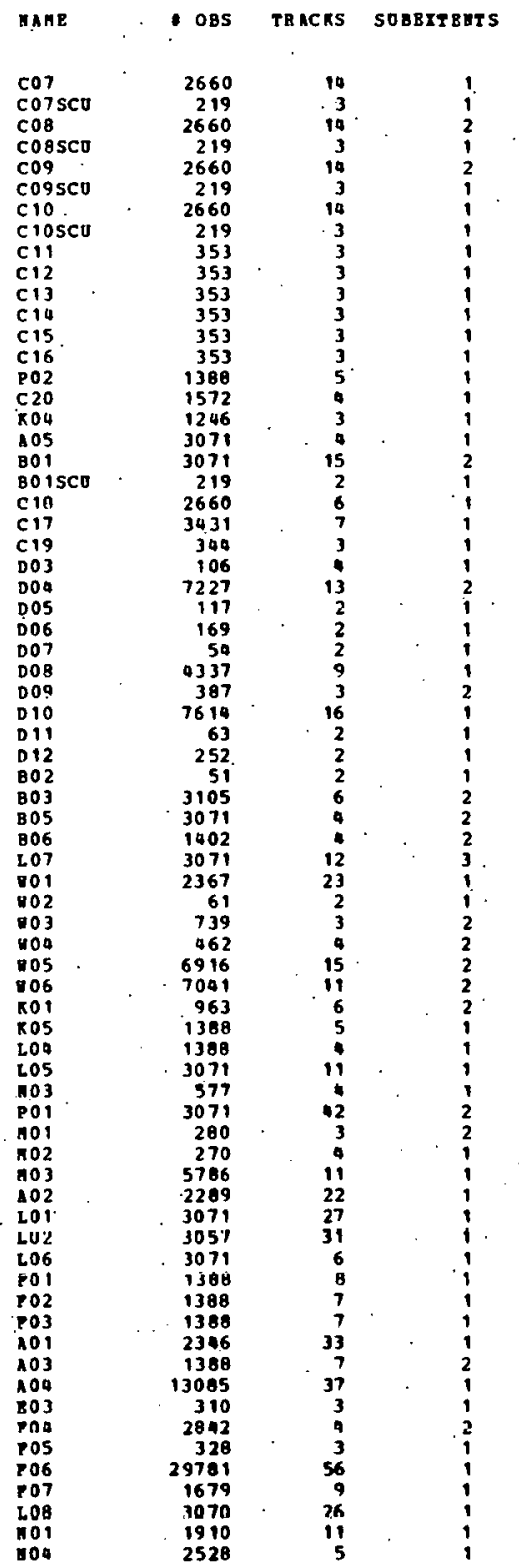
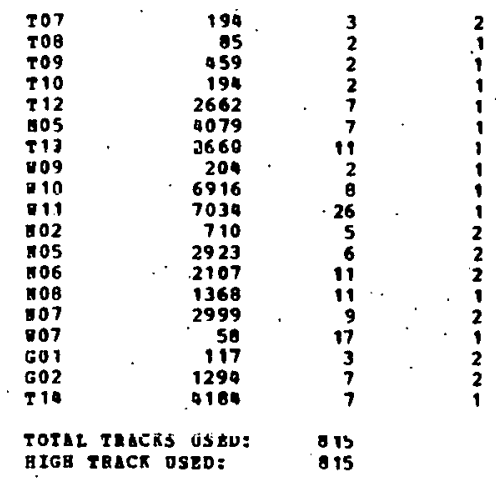

15

Figure VII.1. Example A Output: Displaying the Directory of the Online Data Base 
COMTEHTS OP THE OALIES GBOBCOLOGT DATA BASE

CONTEMTS OP SAS OATA SET GBODAT. 103

TEACKS OSED=7 SOBETBETS= CBSBRTTIOES=1388 CBEATBD B JOB CJBABT AT 11:16 TBIDAT. TBBEOARY 29, 1980

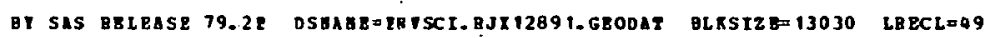

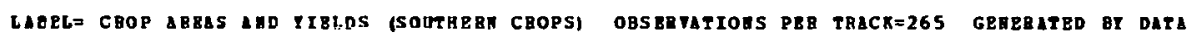

ALPABEETC LIST OP TARIAGLS

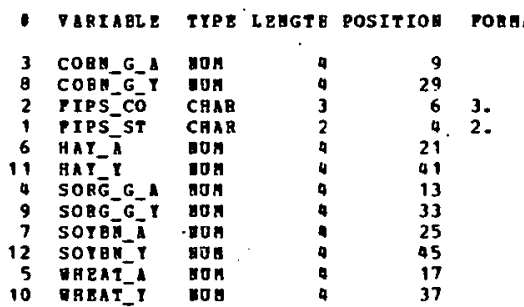

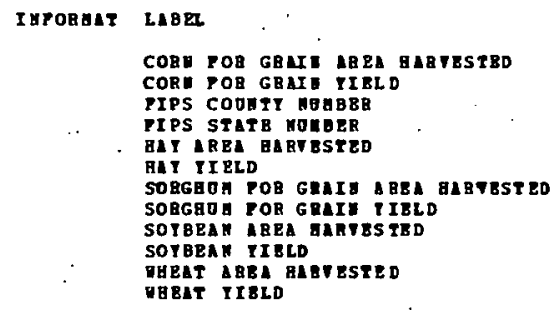

B.

COR POB GBMI TIBL

.

HIT IIELD

COMTELS Di SAS DATA SET GEOAT. ROS

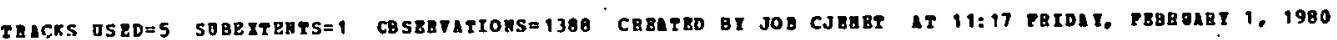

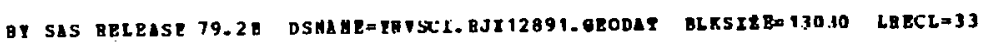

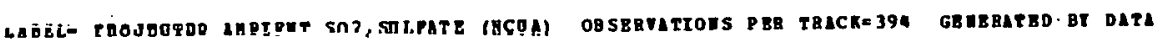

ALPABERTC LIST OP VAEIABES

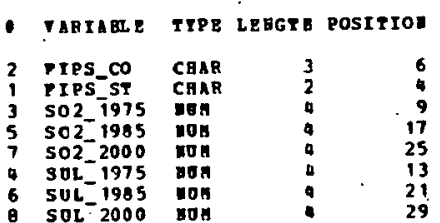

IMPOAHA LABgI.

TIPS COBzT1 Mongen

TTPS STLF TOHBB

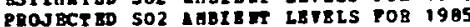

PRONECTED SO2 ABBIET LEVELS POR 2000

BSTIATED SULPATE IAIBET LBVBLS, 1975

PBOJ BCT BD SOLPATE A ITIETT LETELS, 1985

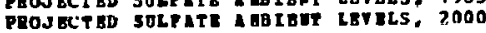

COMTEBTS OP SAS DATL SET GBODAT. BOS

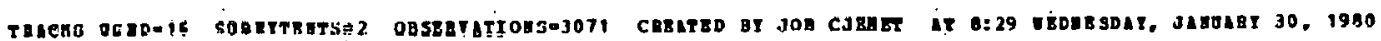

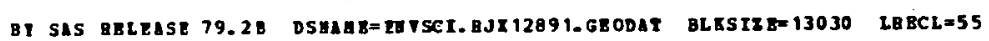

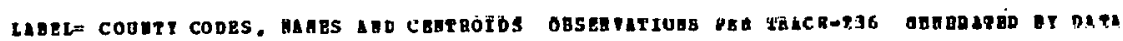
ALPEABEIC LIS T OP VABTMELES

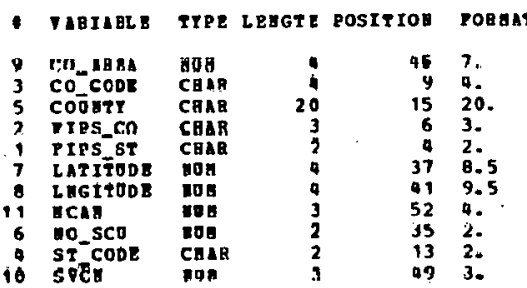

IETORALT LABI

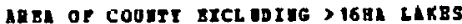

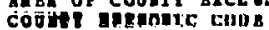

coutr ung

TIPS CoOATY HogBs

PIPS GTAT IIMBB

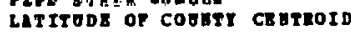

LOAGTrODs of COUET CBEROID

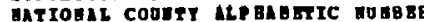

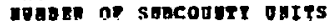

STITE CODE LETTER

STATE VISOAL COATIUOTTY WOABER

Figure VII.2. Example A Output: Displaying the Contents of Individual Data Sets 
will be held as a temporary data set by sAs. Files B0l and A0 3 are merged by FIPS ST and FIPS_CO. YIELD is calculated as the amount of soybeans produced within the county divided by the county area (kg/ha). This resulting data set is merged with K05 by FIPS_ST and FIPS_CO: Because data sets are stored sorted by FIPS ST and FIPS CO; they do not need to be sorted prior to the merging. Codes for mapping (MAPCODE) are assigned to each observation (county) based on the levels of 502 and soybean production. Criteria for the codes were based on prior knowledge of SO2 impacts on soybeans. A variable, called CounTY, is also created by concatenating FIPS ST and FIPS $C O$ which can be used with a FORMAT statement to be translated into the county name.

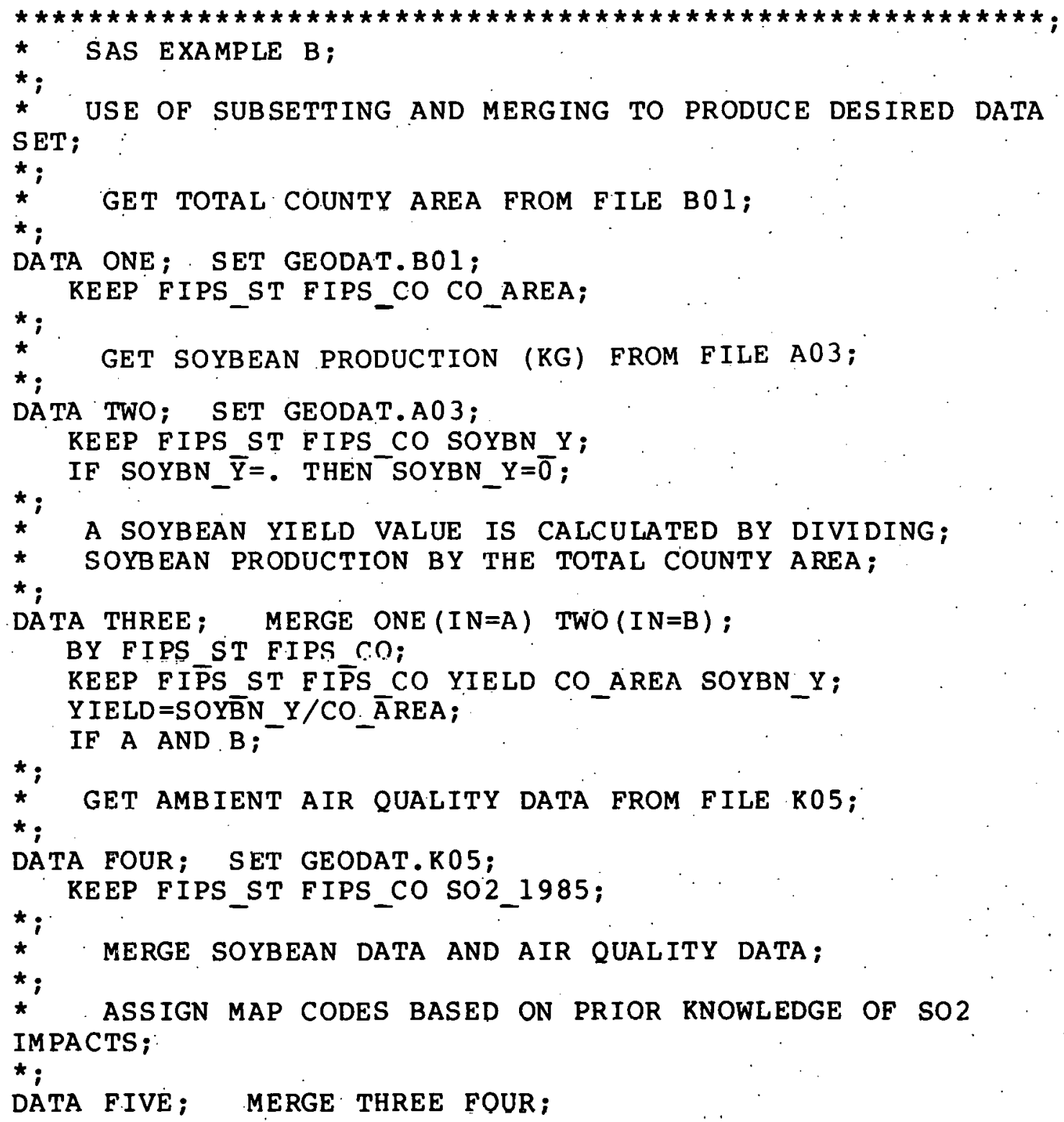




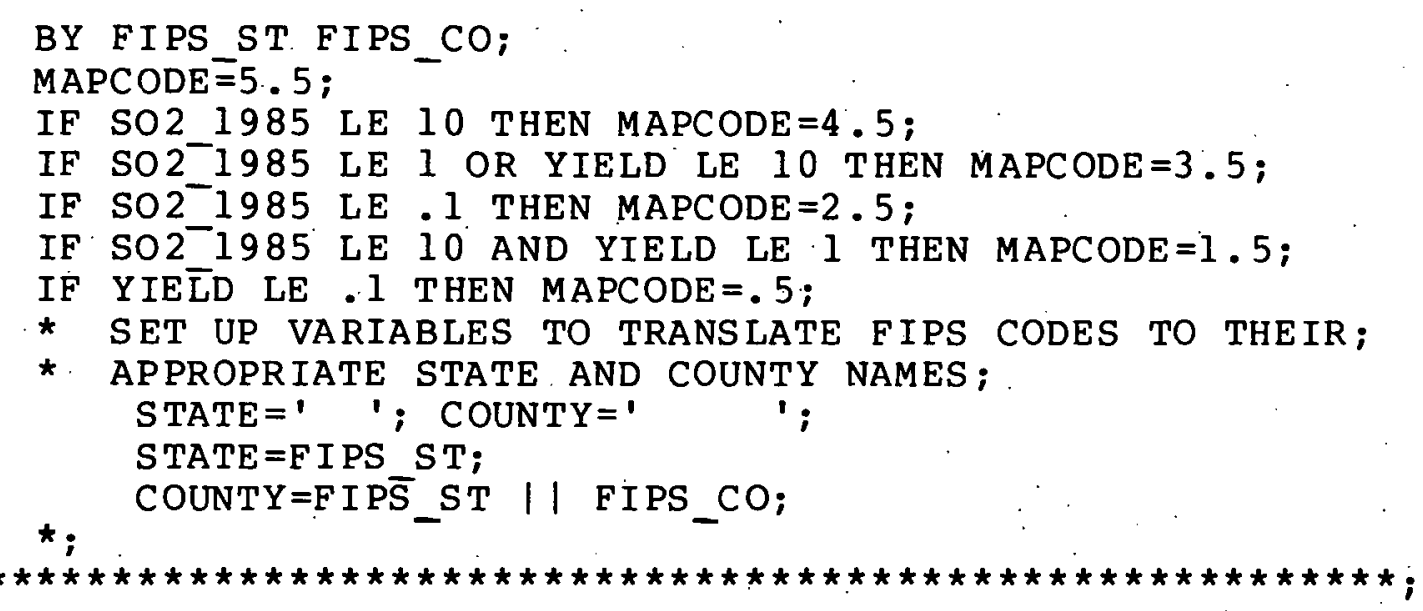

C. Report Generation

Frequently only a segment of a data file is of interest, so the capability to subset a file prior to generating a report is important. In this step, county values for Alabama are obtained by a simple subsetting "IF" statement. The data set is sorted by MAPCODE prior to printing to allow easy identification of counties with potential so2 impacts. The resulting report is given as Fig. VII. 3 .

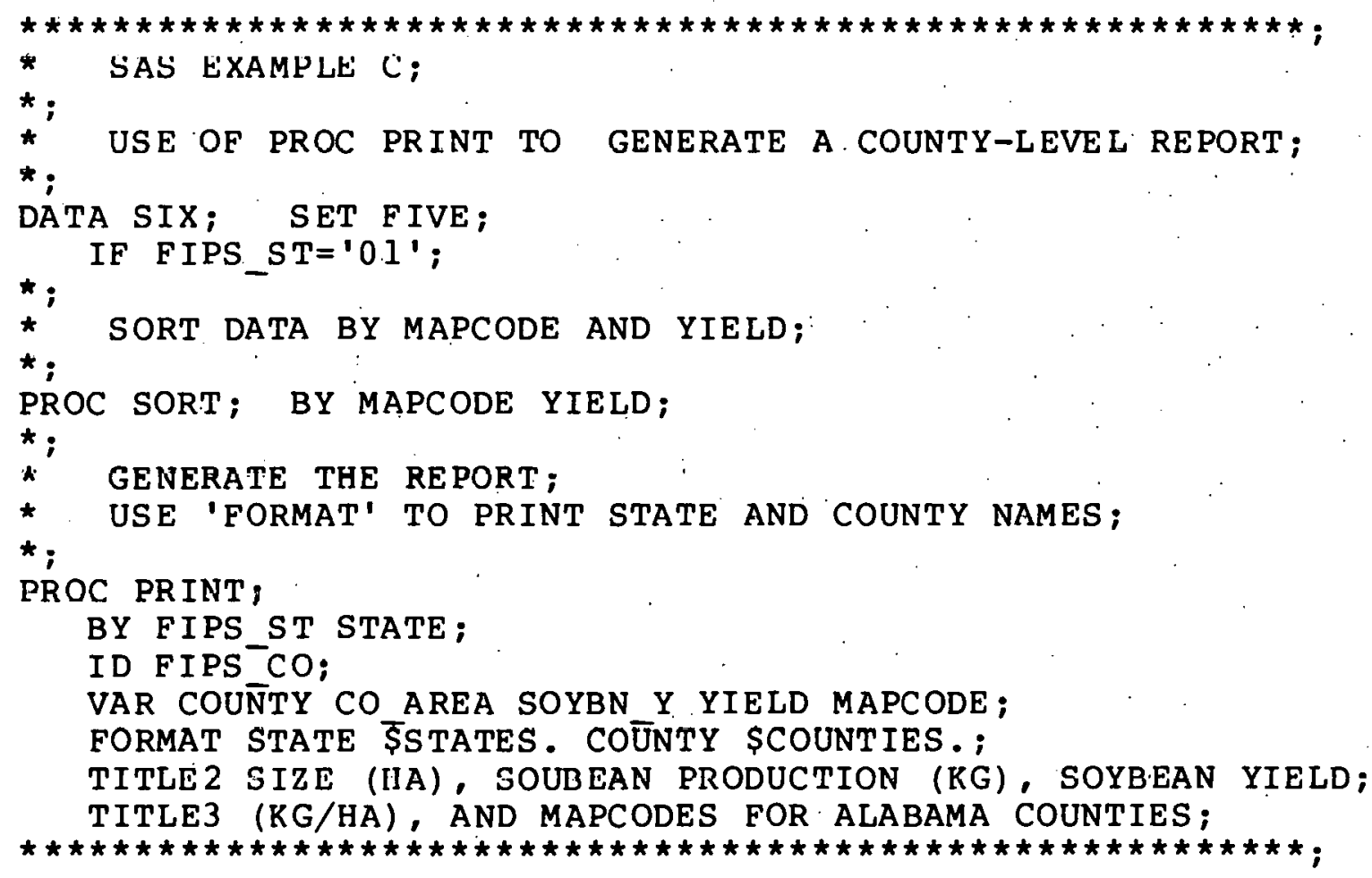


SIzBS (HA) , SOTBEA PRODBCYTOA (RG), SOTBBA TIBLD

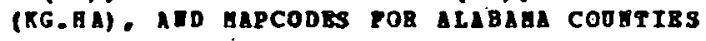

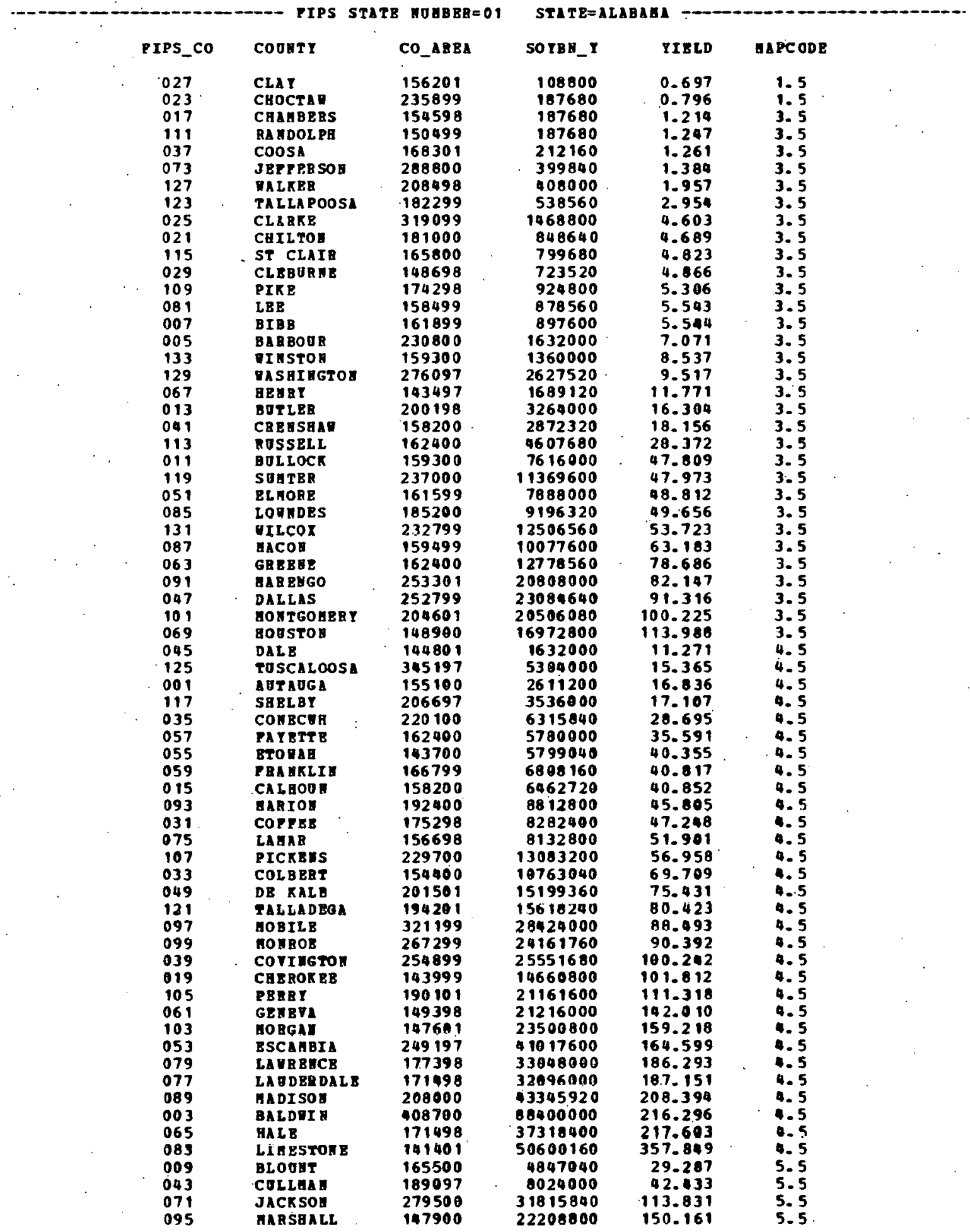

Figure VII.3. Example B/C Output: Integrating Three

Data Sets and Generating a County-level Report 
D. Statistical Analysis

The generation of summary statistics is also an important aspect of data analysis. Although this example uses PROC MEANS, the Geoecology data sets can be used easily in connection with any of the other SAS statistical procedures. This example demonstrates the creation of a table of state totals for soybean production with PROC MEANS. The OUTPUT option is used to allow reformatting the printed table. The variable STATE, created above; is used to print state names using the FORMAT statement. The final table is printed as Fig. VII.4.

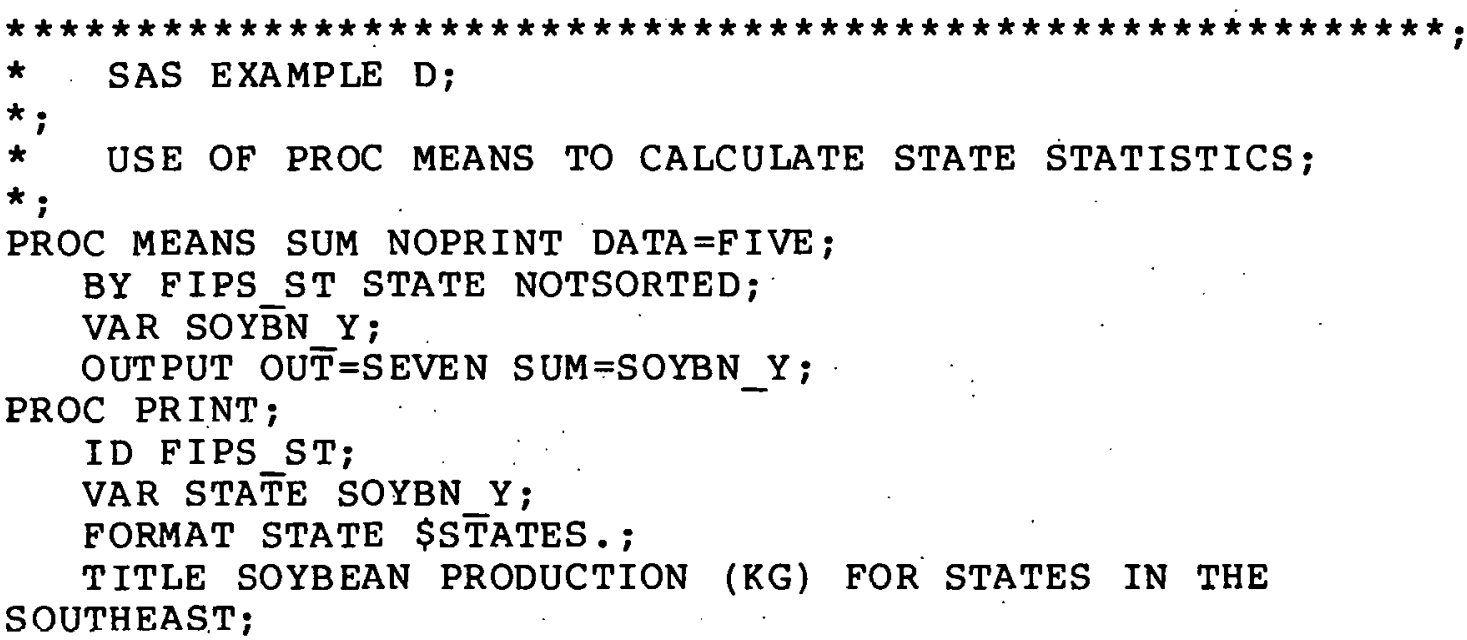

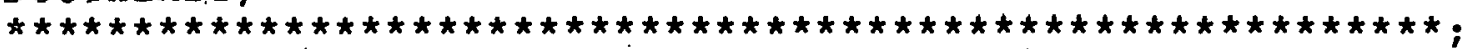

E. Graphics

An X-Y graph of soybeans and so2. levels was produced (Fig. VII.5) using the PROC DISPLAl (Olson and Kumar 1980). This procedure was written at ORNL to interface SAS and DISSPLA (ISSCO 1970) to produce report quality graphs from SAS data sets.

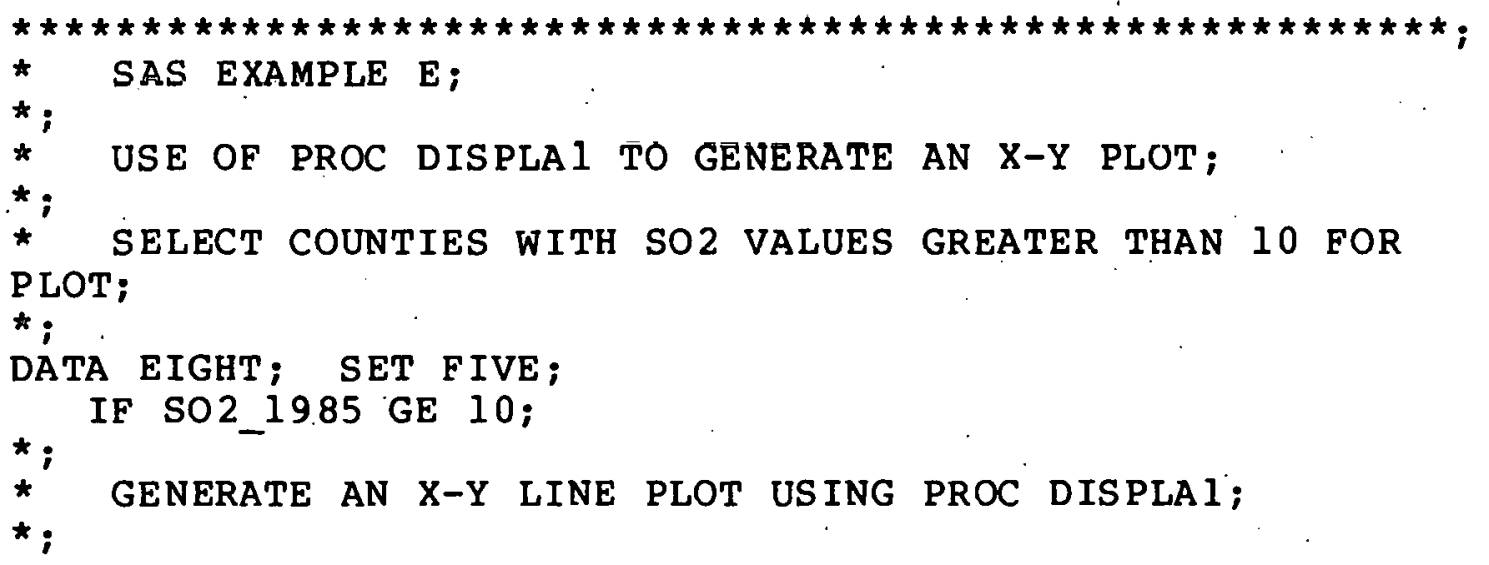




\section{SOPBEA PRODOCTION (KG) FOR STATES IA TAB SOETAEAST}

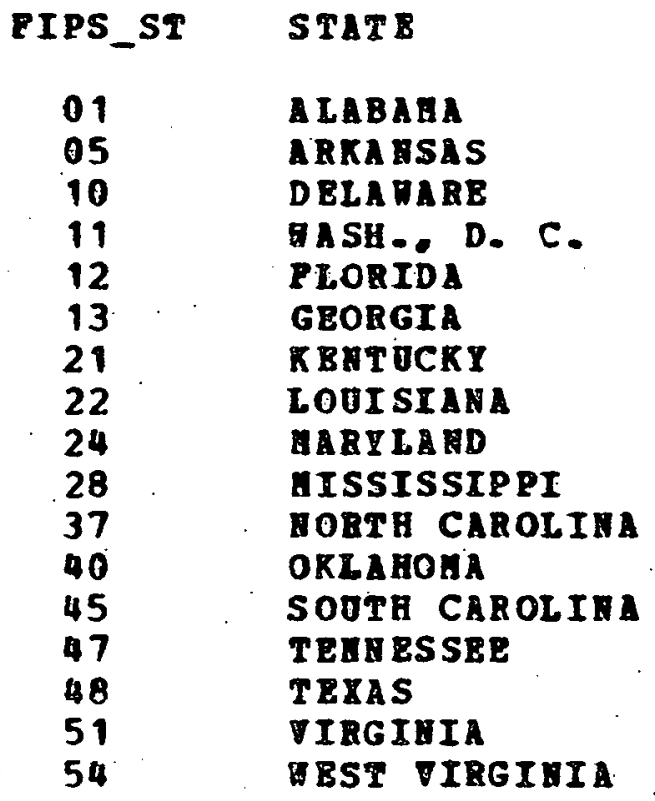

SOIBE_T
855168000
3068012960
138720000
0
142353920
856721820
863651680
1888996000
242188.800
1867908000
888352000
145443024
825248000
1228515200
243567840
293855200
0

Figure. VII.4. Example D Output: Calculating a Summary Table using a SAS statistical Procedure

PROC DISPLAI DATA $=$ FIVE

XINTAX YINTAX

$X O R I G=10 . \quad X S T E P=5 . X M A X=25$.

YORIG $=0$. YSTEP $=80$. $Y M A X=400$. ;

VAR SO2 1985 VALUE;

PARMCARD̄ ;

LTITLE 11985 SO2 IMPACT ON SOYBEANS \$

LTITLE2 COUNTIES WITH MORE THAN 10 KG SOYBEANS \$

LTITLE3 PER UNIT COUNTY AREA \$

LXNAME SO 2 - MICROGRAMS PER CUBIC METER\$

LYNAME SOYBEANS - KG/HAS

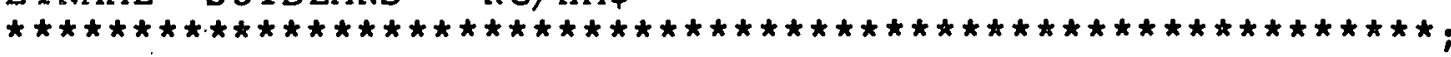

F. Cartographics

In many of the applications of the Geoecology Data Base, maps are used to show regional patterns and to generally aid in editing and interpreting large amounts of spatial data. SAS is used to assemble the data to be mapped and to create a formatted output file. The PUT statement is used to create the file which is stored on a temporary disk 


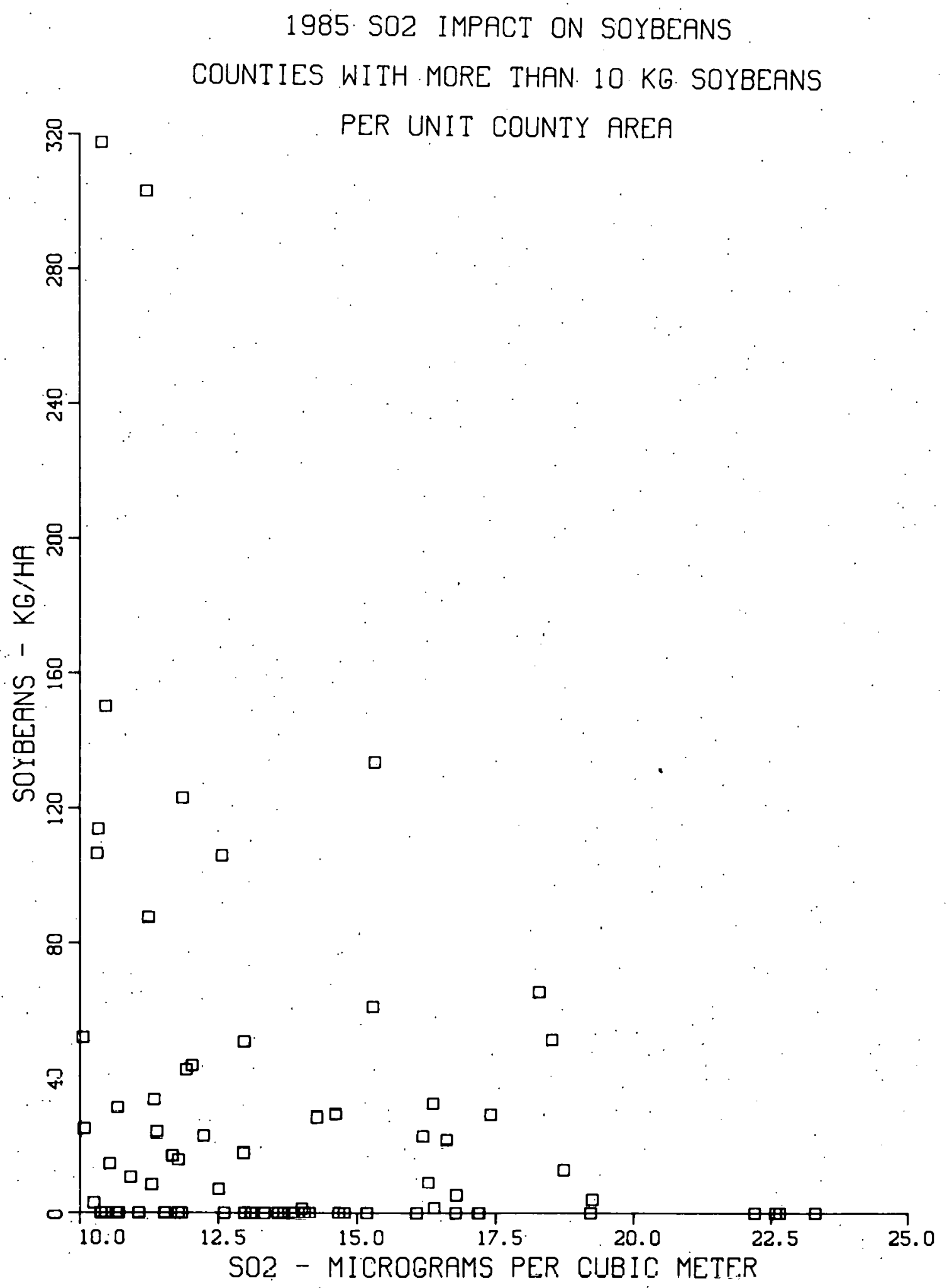

Figure VII.5. Example E Output: Producing an X-Y Plot using Procedure DISPLAl. 
file to be accessed by mapping programs. The mapping program used to produce Fig. VII. 6 was developed locally by the Geographic Systems Group and is called EZMAP (Coleman 1978). Alternately, map files can be created for the Harvard SYMAP and CALFORM programs or the DISSPLA system.

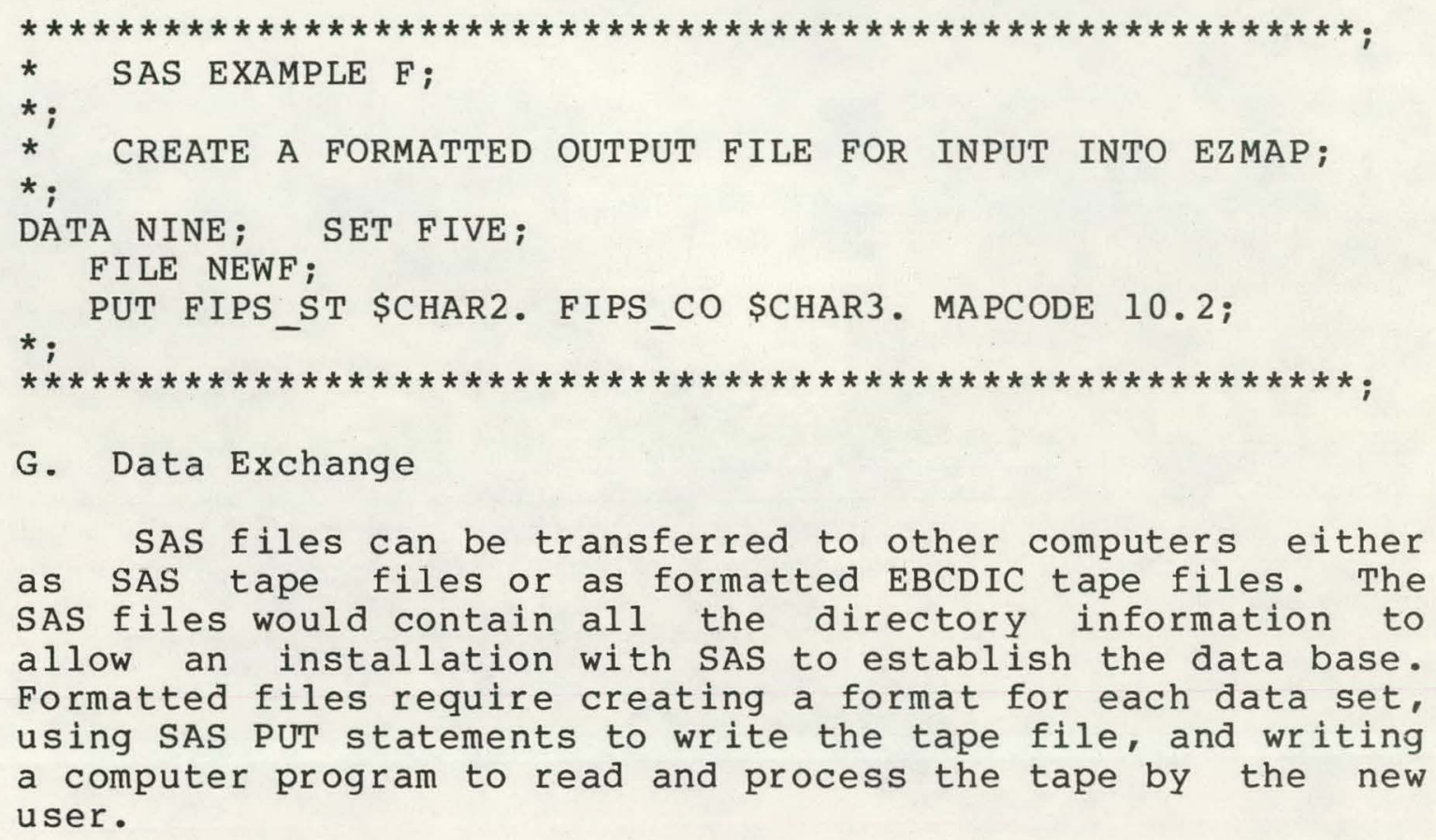

SAS files can be transferred to other computers either as SAS tape files or as formatted EBCDIC tape files. The SAS files would contain all the directory information to allow an installation with SAS to establish the data base. Formatted files require creating a format for each data set, using SAS PUT statements to write the tape file, and writing a computer program to read and process the tape by the new user.

This sequence of examples was selected to demonstrate the elementary operations of accessing, merging, subsetting, printing, analyzing, and displaying data from the Geoecology Data Base. If the Geoecology Data Base contains data applicable to a project, then the capability of using the Data Base is limited only by users' knowledge of SAS, understanding of the data, and imagination. 


\section{PROJECTED 1985 SO2 IMPACT ON SOYBEANS}

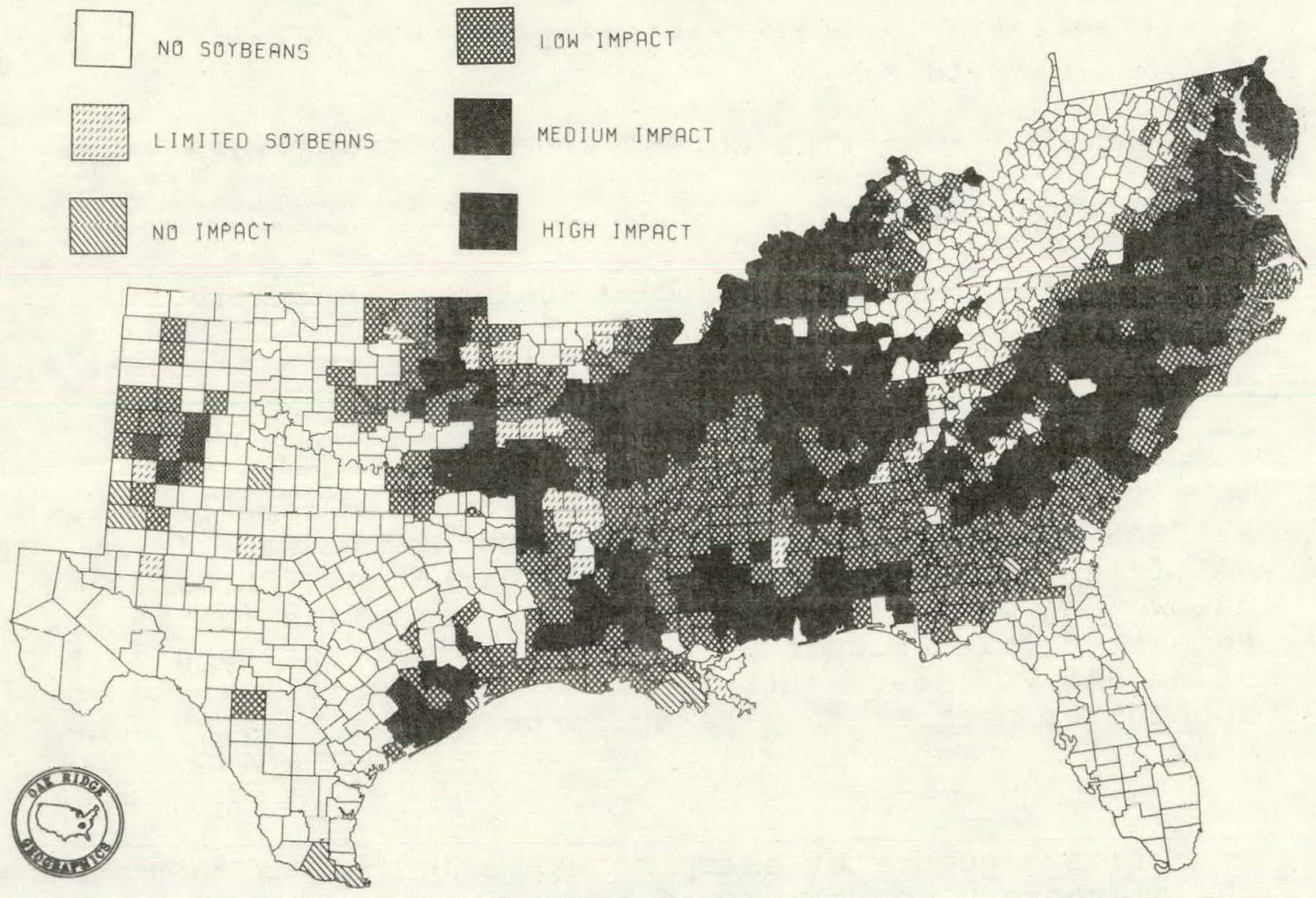

Figure VII.6. Example F Output: A Map Produced by EZMAP Utilizing a SAS Output File from the Geoecology Data Base. 
VIII. REFERENCES (INCLUDING THOSE FOR APPENDIX A)

American Ornithologists' Union. 1957, 5th ed. Check-1ist of North American Birds. American Ornithologists' Union, Baltimore, MD. 691 pp.

American Society for Testing and Materials (ASTM). 1976. Standard for metric practice. ASTM E 380-76. American Society for Testing and Materials, Philadelphia, PA.

Austin, M. E. 1965. Land resources regions and major land resource areas of the United States. Agriculture Handbook 296. U. S. Departmert of Agriculture, Soil Conservation Service, Washington, DC. $82 \mathrm{pp}$.

Bailey, R. G. 1976. Ecoregions of the United States. U. S. Department of Agriculture, Forest Service, Washington, DC. (map).

Bailey, R. G. 1978. Descriptions of Ecoregions of the United States. U. S. Forest Service, Ogden, UT. 77 pp.

Ballou, S. W., P. M. Irving, M. H. Gabriel, and K. E. Robeck. 1979. Identifying the potential for so2-induced vegetation damage in the evaluation of energy policy scenarios. Presented at the International Conference on Energy Use Management, 22-26 October 1979, Los Angeles, CA.

Barbour, R. W., and W. A. Davis. 1974. Mammals of Kentucky. The University of Kentucky, Lexington, KY. $322 \mathrm{pp}$.

Barr, A. J., J. H. Goodnight, J. P. Sall, W. H. Blair, and D. M. Chilko. 1979. SAS User's Guide. SAS Institute, Inc., Raleigh, NC. 329 pp.

Begovich, C. L., B. D. Murphy, and C. J. Nappo. 1978 . RETADD: A regional trajectory and diffusion-deposition model. ORNL/TM-5859. Oak Ridge National Laboratory, Oak Ridge, TN.

Bellamy, T. R., and H. A. Knight. 1970. Forest statistics for south Florida. Forest Service Resource. Bullet in SE-16. U. S. Department of Agriculture, Forest Service, Southeastern Forest Experimental Station, Asheville, NC. $35 \mathrm{pp}$. 
Benkovitz;C. M. 1979. DOE Interlaboratory Working Group for Data Exchange (IWGDE) progress report - October 1978. BNL-51071. Brookhaven National Laboratory, Upton, NY. 20 pp.

Brown, L. N. 1970. Unique mammals found in the Florida Keys. Fl. Nat. $43(4): 146-147$.

Buol, S. W., F. D. Hole, and R. J. McCracken. 1973. Soil genesis and classification. Iowa State University Press, Ames, IA. 360 pp.

Burgess, R. L., and L. H. Kern (eds.). 1973. Progress roport 1971-72, Eastern Deciduous Forest Biome, US-IBP. EDFB/IBP-73/5. Oak Ridge National Laboratory, Oak Ridge, TN. $326 \mathrm{pp}$.

Bystrak, D. 1979. The Breeding Bird Survey. Sialia I(2). 7 pp.

Calef, C., and J. Nagy. 1979. Assessment of endangered species - energy development conflicts: Methods development. Unpublished Project Report. Brookhaven National Laboratory, Upton, NY. 37 pp.

Cogbil1, C. V., and G. E. Likens. 1974. Acid precipitation in the northeastern United States. Water Resour. Res. $10: 1133-1137$.

Coleman, P. R. 1978. Input for EZ-MAP. Unpublished Memo. Geographic Systems Group, Computer Sciences Division, Union Carbide Nuclear Division, Oak Ridge, TN.

Copenhaver, E. M., and J. F. Barker (eds.). 1980. Spatial data on energy, environmental, health, and socloeconomic themes at Oak Ridge National Laboratory: $1979^{\circ}$ inventory. ORNL-5636. Oak Ridge National Laboratorory, Qak Ridge, TN.

Copenhaver, E. M., R. J. Olson, and P. L. Rice. 1979. Regional Environmental-Energy Data Book: Southern Regiun. DOE/TIC-10114/4. Uepartment of Energy, office of Technology Impacts. U. S. Government Printing office, Washington, DC. $823 \mathrm{pp}$.

Cost, N. D. 1968. Forest statistics for the southern coastal plain of South Carolina, 1968. Forest Service Resource Bulletin SE-12. U. S. Department of Agriculture, Forest Service, Southeastern Forest Experimental Station, Asheville, NC. 35 pp. 
Cost, N. D. 1975a. Forest statistics for the mountain region of North Carolina, 1974. Forest Service Resource Bulletin SE-31. U. S. Department of Agriculture, Forest Service, Southeastern Forest Experimental Station, Asheville, NC. 33 pp.

Cost, N. D. 1975b. Forest statistics for the southern coastal plain of North Carolina, 1973. Forest Service Resource Bulletin SE-26. U. S. Department of Agriculture, Forest Service, Southeastern Forest Experimental Station, Asheville, NC. $34 \mathrm{pp}$.

Council on Environmental Quality. 1980. UPGRADE user's manual. Council on Environmental Quality, washington,

Davis, R. M. (project manager). 1978. National Coal Utilization Assessment (NCUA): A preliminary assessment of the impact of coal utilization in the South (draft). Oak Ridge National Laboratory, Oak Ridge, TN.

Delcourt, H. R., D. C. West, and L. J. Allison. 1980. Guide to use of the Continuous Forest Inventory Data Base for eastern North America. Oak Ridge National Laboratory, Oak Ridge, TN. (In preparation).

Dougenik, J. A., and D. E. Sheehan. 1975. SYMAP User's Reference Manual. Laboratory for Computer Graphics and Spatial Analysis, Harvard University, Cambridge, MA. 196 pp.

Earles, J. M. 1967. Forest statistics for east Texas pineywoods counties. Forest Service Resource Bulletin SO-60. U. S. Department of Agriculture, Forest Service, Southern Forest Experimental Station, New Orleans, LA. 40 pp.

Earles, J.M. 1975. Forest statistics for Louisiana parishes. Forest Service Resource Bulletin So-52. U. S. Department of Agriculture, Forest Service, Southern Forest Experimental Station, New Orleans, LA. $85 \mathrm{pp}$.

Federal Register. 1977. Vol. 42, No. 35, July 14. (While this is the principal citation, numerous other volumes of the Register published prior to and subsequent to the July 14, 1977, issue have contributed information which has been factored into our data system.) 
Fenneman, N. M. 1931. Physiography of the Western United States. McGraw-Hill, NY. 534 pp.

Fenneman, N. M. 1938. Physiography of the Eastern United States. McGraw-Hill, NY. 714 pp.

Ferguson, R. H. 1964. The timber resources of West Virginia. Forest Service Resource Bulletin NE-2. U. S. Department of Agriculture, Forest Service, Northeastern Forest Experimental Station, Upper Darby, PA.

Finaley, J. S., A. H. Harris, D. E. Wilson, and C. Jones. 1975. Mammals of New Mexico. University of New Mexico Press, Albuquerque, NM. $360 \mathrm{pp}$.

Gansner, D. A. 1968. The timber resources of Kentucky. Forest Service Resource Bulletin NE-9. U. S. Department of Agriculture, Forest Service, Northeastern Forest Experimental Station, Upper Darby, PA. 96 Pp.

Geological Society of America. 1959. Glacial Map of the United States East of the Rocky. Mountains. The Geological Society of America, New York; NY.

Goff, F. G., R. K. Schreiber, and J. R. Thurman. 1974 . GST: A mnemonic technique for coding species names to facilitate field and computer processing. IBP/EDFB Memo Report 73-95. Environmental Sciences Division, Oak Ridge National Laboratory, Oak Ridge, TN. 7 pp.

Golley, F. B. 1962. Mammals of Georgia. University of Georgia Press, Athens, GA. 218 pp.

Golley, F. B. 1966. South Carolina mammals. The Charleston Museum, Charleston, SC: 181 pp.

Haince, W. H. B. 1067. Foresl slalislics fur the pledmont of South Carolina, 1967. Forest Service Resource Bulletin SE-9: U. S. Department of Agriculture, Forest Service, Southeastern Forest Experimental. Station, Asheville, NC. 35 pp.

Hall, E. R., and K. R. Kelson. 1959. The Mammals of North America, Vols. 1 and 2. The Ronald Press, New York, NY. 1079 pP.

Hamilton, w. J. 1943. The Mammals of the Eastern United States. Comstock Publishing Co., Ithaca, NY. 431 pp. 
Hammond, E. H. 1963. Classes of land-surface form in the forty-eight states, USA. Map Supplement No. 4. Annals, The Association of American Geographers, Vol. 54.

Haynes, R. J., J. F. McBrayer, R. M. Cushman, and R. D. Roop. 1979. Environmental impacts of coal extraction in Alabama: 1978-1985. ORNL/TM-6793. Oak Ridge National Laboratory, Oak Ridge, TN.

Hedlund, A., and J. M. Earles. 1969. Forest statistics for Mississippi counties. Forest Service Resource Bulletin So-15. U. S. Department of Agriculture, Forest Service, Southern Forest Experimental station, New Orleans, LA. 24 pp.

Hedlund, A., and J. M. Earles. 1970a. Forest statistics for Al abama counties. Forest Service Resource Bulletin so-39. U. S. Department of Agriculture, Forest Service, Southern Forest Experimental Station, New Orleans, LA. $65 \mathrm{pp}$.

Hedlund, A., and J. M. Earles. 1970b. Forest statistics for Arkansas counties. Forest Service Resource Bulletin SO-22. U. S. Department of Agriculture, Forest Service, Southern Forest Experimental station, New Or leans, LA. 52 .pp.

Hedlund, A., and J. M. Earles. 1971. Forest statistics for Tennessee counties. Forest Service Resource Bulletin SO-32. U. S. Department of Agriculture, Forest Service, Southern Forest Experimental station, New Orleans, LA. $58 \mathrm{pp}$.

Hole, F. D. 1976. Soils of Wisconsin. University of wisconsin Press, Madison, WI. 223 pp plus map.

Holmberg, G. V. 1977. Basic statistics: Status of 1 and disturbed by surface mining in the United States as of July 1, 1977, by states (draft). U. S. Department of Agriculture, Soil Conservation Service, Washington, DC.

Hoyle, M. C. 1973. Nature and properties of some forest soils in the White Mountains of New Hampshire. U. S. Department of Agrlculture, Northeast forest Experiment Station, Forest Service Research Paper NE-260. Upper Darby, PA. $18 \mathrm{pp}$.

Huber, E. E., C. S. Tucker, and G. A. Dailey. 1978. Inventory of sources of computerized ecological information. ORNL-5441. Oak Ridge National 
Laboratory, Oak Ridge, TN. $70 \mathrm{pp}$.

Integrated Software Systems Corporation (ISSCO). 1978. DISSPLA Pocket Manual. Integrated Software systems Corp., San Diego, CA. 151 pp.

Kemp, H. T. 1977. The national inventory of selected biological monitoring programs. Summary report of current or recently completed projects, 1976. ORNL/TM-5792. Oak Ridge National Laboratory, Oak Ridge, TN. 706 pp.

Kitchings, J. T., R. S. Anderson, and R. J. Olson. 1976, Blogeographic informatinn system for animal cpccico in the southeastern United States. The Association of Southern Biologists Bulletin 23(3):149-154.

Klopatek, J. M., W. F. Harris, and R. J. Olson. 1980a. A regional ecological assessment approach to atmospheric deposition: Effects on soil systems. pp 539-553. IN Shriner, D. S., C. R. Richmond, and S. E, Lindberg. Atmospheric Sulfur Deposition.. Ann Arbor Science, Ann Arbor, MI.

Klopatek, J. M., J. T. Kitchings, K. D. Kumar, and R. J. Olson. 1980b. An ecological analysis of the U. S. Forest Service's RARE-II sites. ORNL/TM-6813. Oak Ridge National Laboratory, Oak Ridge, TN. (in preparation).

Klopatek, J. M., R. J. Olsun, C. J. Emerson, and J. L. Joness. 1979. Land use conflicts with natural vegetation in the United States. Environ. Conserv. 6:191-199.

Knight, H. A., and J. P. McClure. 1967. Virginia's timber, 1966. Forest Service Resource Bulletin SE-8. U. S. Department of Agriculture, Forest Service, Southeastern Forest Experimental Station, Ashevilie, NC. 47 pp.

Knight, H. A., and J. F. McClure. 1974. Georgia's timber, 1972. Forest Service Resource Bulletin SE-27. U. S. Department of Agriculture, Forest Service, Southeastern Forest Experimental Station, Asheville, NC. $48 \mathrm{pp}$.

Klichler, A. W. 1964. Potential natural vegetation of the conterminous United States (map and manual). Special Pub. 36. American Geographical Society. 
Little, E. L., Jr. 1971. Atlas of United States trees, Vol. 1. conifers and important hardwoods. Misc. Pub. No. 1146. U. S. Department of Agriculture, Forest Service, Washington, DC. 9 pp, illus. (313 maps, folio).

Lowery, G. H., Jr. 1974. The mammals of Louisiana and its adjacent waters. Louisiana State University Press, Baton Rouge, LA. 565 pp.

McClure; J. P. 1969. Forest statistics for northwest Florida. Forest Service Resource Bulletin SE-14. U. S. Department of Agriculture, Forest Service, Southeastern Forest Experimental Station, Asheville, NC. $35 \mathrm{pp}$.

McClure, J. P. 1970. Forest statistics for northeast Florida. Forest Service Resource Bulletin SE-15. U. S. Department of Agriculture, Forest Service, Southeastern Forest Experimental Station, Asheville, NC. 35 pp.

Merrill, D. 1980. County-level estimates of air quality (draft). LBID-185. Lawrence Berkeley Laboratory, Berkeley, CA. 11 pp plus appendices.

Merrill, D. W. Jr, S. T. Sacks, S. Selvin, C. D. Hollowell, and W. Winkelstein, Jr. 1978. Populations at Risk to Air. Pollution (PARAP): Data Base Description and Prototype Analysis. UCID-8039. Lawrence Berkeley Laboratory, Berkeley, CA.

Nagy, J., and C. E. Calef. 1978. ESUSA: U. S. endangered species distribution file. BNL-24488. Brookhaven National Laboratory, Biomedical and Environmental Assessment Division, National Center for Analysis of Energy Systems, Upton, NY.

Nungesser, M. K., and R. J. Olson. 1980. Regional ecological analysis and data base applications. pp. 45-50. IN Proceedings, Fifth Annual SAS User's Group International Conference, SAS Institute, Inc., Raleigh, NC.

Olson, R. J., and F. G. Goff, 1977. Development and applications of a regional environmental data base for southeastern United States. pp. 289-293. IN B. Dreyfus (ed.), Proceedings, Fifth Biennial International CODATA Conference. Pergamon Press, NY. 
.Olson, R. J., F. G. Goff, and J. S. Olson. 1977. Development and applications of regional data resources in energy-related assessments. pp. 12.1-12.7. AGARD-CPP-207. Advancements in retrieval technology as related to information systems. North Atlantic Treaty Orangization, Advisory Group for Aerospace Research and Development.

Olson, R. J., J. M. Klopatek, and C. J. Emerson. 1980. Regional environmental analysis and assessment utilizing the Geoecology Data Base. Chapter 4 IN Computer Graphics in Policy Analysis and Planning. Prentice Hall, NJ (in press).

Olson, R. J., and K. D. Kumar. 1980. A SAS graphics procedure: DISPLA1. ORNL/TM-6993. Oak Ridge National Laboratory, Oak Ridge, TN. $35 \mathrm{pp}$.

Dlson, R. J., and R. H. Strand. 1978. Management of diverse environmental data with SAS. pp. 200-206. IN Proceedings, Third Annual Conference, SAS User's Group International. SAS Institute, Inc., Raleigh, NC. 320 pp.

Ranney, J. W., and J. H. Cushman. 1980. Regional evaluation of woody biomass production for fuels in the Southeast. Biotechnol. Bioeng. (in press).

Roswe11, C. A., Jr. 1976. Geoecology information system: Compilation of terrain data. Final Report Subcontract No. 4342. University of Maryland, College Park, MD. 74 pp.

Schreiber, R. K., R. L. Stephenson, F. G. Goff, D. C. West, and G. Muse. 1974. Geoecology information system, part 1. Biogeographic mapping of species $r$ anges: Documentation of input and data checking procedure for computer storage and retrieval of information. IBP/EDFB-74/5. Oak Ridge National Laboratory, Oak Ridge, TN. $44 \mathrm{pp}$.

Shreeve, D., C. Calef, and J. Nagy. 1978. The Endangered Species Act and energy facility planning: Compliance and conflict. BNL-50841. Brookhaven National Laboratory, Biomedical and Environmental Assessment Division, National Center for Analysis of Energy Systems, Upton, NY.

Shriner, C. R., and L. J. Peck. 1978. Inventory of data bases, graphics, packages, and models in Department of Energy Laboratories. ORNL/EIS-144. Oak Ridge National 
Laboratory, Oak Ridge, TN, $281 \mathrm{pp}$.

Snyder, N. L., and H. A. Knight. 1970. Forest statistics for central Florida. Forest Service Resource Bulletin SE-17. U. S. Department of Agriculture, Forest Service, Southeastern Forest. Experimental Station, Asheville, NC. $35 \mathrm{pp}$.

Sternitzke, H. S., and C. C. Van Sickle. 1968. East Oklahoma forests. Forest Service Resource Bulletin SO-14. U. S. Department of Agriculture, . Forest Service, Southern Forest Experimental station, New Orleans, LA. 32 pp.

Strand, R. H. 1979. Air quality and point source emissions data for the southern United States. ORNL/TM-6742. Oak Ridge National Laboratory, Oak Ridge, TN. 42 pp.

Thornthwaite, C. W. 1948. An approach toward a national classification of climate. Geogr. Rev. 38:55-94.

U. S. Department of Agriculture (USDA): 1960. Soil classification - A comprehensive system: 7 th approximation. U. S. Department of Agriculture, Soil Conservation Service, Washington, DC. 265 pp.

U. S. Department of Agriculture (USDA). 1967. Forest Survey Handbook, FSH 4813.1. U. S. Department of Agriculture, Forest Service, Washington, DC.

U. S. Department of Agriculture (USDA). 1971. Basic statistics - National inventory of soil and 'water conservation needs, 1967. Statistical Bulletin No. 461 . U. S. Department of Agriculture, Washington, DC. 211 pp.

U. S. Department of Agriculture (USDA). 1975. Soil taxonomy - A basic system for making and interpreting soil surveys. Agriculture Handbook No. 436. U. S. Department of Agriculture, Washington, DC. 754 pp.

U. S. Department of Agriculture (USDA). 1979. RARE-II Final Environmental Statement. Roadless area review and evaluation. FS-325. U. S. Department of Agriculture, Forest Service, Washington, DC. 113 pp. plus appendices.

U. S. Department of Commerce (USDC). 1968. Climatic atlas of the United States. U. S. Department of Commerce, National Oceanic and Atmospheric Administration, 
Environmental Data Service, Washington, DC. 80 pp.

U. S. Department of Commerce (USDC). 1969. Census of agriculture, parts 1-48. U. S. Department of Commerce, Bureau of the Census, Social and Economics Statistics Administration, U. S. Government Printing office, Washington, DC.

U. S. Department of Commerce (USDC). 1972. 1970 census of population and housing. $U$. S. Department of Commerce. Bureau of the Census, Washington, DC.

U. S. Department of Commerce (USDC). 1973a. Counties and county equivalents of the States of the United States. FIPS pub 6-2. U. S. Department of Commerce, Bureau of standards, Washington, DC. 35 pp.

U. S. Department of Commerce (USDC). 1973b. County and city data book, 1972 (A statistical abstract supplement). U. S. Department of Commerce, Bureau of the Census, U. S. Government Printing Office, Washington, DC.

U. S. Department of Commerce. (USDC). 1973c. Monthly averages of temperature and precipitation for state climatic divisions, 1941-70. Climatography of the United States No. 85 (by state). U. S. Department of Commerce, National Oceanic and Atmospheric

Administration, Environmental Data Service, Asheville, NC.

U. S. Department of Commerce (USDC). 1973d. Monthly normals of temperature, precipitation, and heating and cooling degree days, 1941-70. Climatography, of the United States No. 81 (by state). U. S. Department of Commerce, National Oceanic and Atmospheric Administration, Environmental Data Service, Asheville, NC.

U. S. Department of Commerce (USDC). 1977. State, regional and national monthly and seasonal heating degree days weighted by population (July 1931-June 1976). Job No. 14624. U. S. Department of Commerce, National Oceanic and Atmospheric Administration Environmental Data Service, National Climatic Center, Asheville, NC. 67 pp.

U. S. Department of Energy (USDOE). 1978. Department of Energy Classification of RARE-II Tracts According to Energy Development Potential, Part III. U. S. Department of Energy, Washington, DC. 
U. S. Department of Interior (USDI). 1964. USA national parks and monuments, national forests, Indian reservations, wildlife reserves, public lands, and historical boundaries. U. S. Department of Interior, Geological Survey, and Bureau of Land Management, Washington, DC.

U. S. Department of Interior (USDI). 1970. The national atlas of the United States of America. U. S. Department of Interior, Geological Survey, Washington, DC.

U. S. Department of Interior (USDI). 1975. Index of the national park system and affiliated areas as of January. 1, 1975. National Park Service, U. S. Department of Interior, Washington; DC. $136 \mathrm{pp}$.

U. S. Department of Interior (USDI). 1976. Endangered Species Technical Bulletin, Vol. I, Nos. 1-12. U. S. Department of Interior, Fish and Wildlife Service, Washington, DC:

U. S. Department of Interior (USDI) . 1977. Endangered Species Technical Bulletin, Vol. II, Nos. 1-12. U. S. Department of Interior, Fish and Wildlife Service, Washington, DC.

U. S. Department of Interior (USDI). 1978. Endangered Species Technical Bulletin, Vol. III, Nos. 1-8. U. S. Department of Interior, Fish and Wildlife Service, Washington, DC.

U. S. Department of Interior (USDI). 1979. Endangered Species Technical Bulletin, Vol. IV, Nos. 1-lo. U. S. Department of Interior, Fish and Wildlife Service, Washington, DC.

U. S. Environmental Protection Agency (USEPA). 1975. National summary of state implementation plan reviews. Vol. II. Technical Support Document. EPA-450/3-75-053-b. U. S. Environmental Protection Agency, Washington, DC.

U. S. Environmental Protection Agency (USEPA). 1976. A directory of air quality monitoring sites active in 1974. EPA-450/2-76-008. Office of Air and Waste Management, office of Air Quality Planning and Standards, U. S. Environmental Protection Agency, Washington, DC. 
U. S. Nuclear Regulatory Commission (USNRC). 1976. Nuclear energy center site survey - 1975. NUREG-0001, 5 parts. U. S. Nuclear Regulatory Commission, Washington, DC.

Water Resources Council. 1970. Water resource regions and. subregions for the national assessment of water and related land resources. Water Resources Council, Washington, DC.

Watts, J. A., V. G. Myers, and T. J. Blasing. 1980. Documentation of climate data for global carbon studies: I. U. S. state climatic division data (1931-1976). ORNL/TM-7366. Oak Ridge National Laboratory, Oak Ridge, TN. (in preparation).

Webb, T. 1976. A final report on the climatological data added to the ORNL geological data base. Brown University Memorandum, Brown University, Providence, RI. 3 pP.

Welch, R. L. 1968. Forest statistics for the northern coastal plain of South Carolina, 1968. Forest Service Resource Bulletin SE-10. U. S. Department of Agriculture, Forest Service, Southeastern Forest Experimental Station, Asheville, NC. 35 pp.

Welch, R. L. 1975. Forest statistics for the piedmont of North Cárolina, 1975. Forest Service Resource Bulletin SE-32, U. S. Department of Agriculture, Forest Service, Southeastern Forest Experimental Station, Asheville. NC. 33 pP.

Welch, R. L., and H. A. Knight. 1974. Forest statistics for the northern coastal plain of North Carolina, 1974. Forest Service Resource Bulletin SE-30, U. S. Department of Agriculture, Forest Service, Southeastern Forest Experimental Station, Ashevilie, NC. 33 pp.

Wilson, R. L. 1979. Discriminant analysis as a descriptive and predictive tool for red wolf (Canis rufus) populations. Unpublished report. Fnvironmental Sciences Division, Oak Ridge National Laboratory, Oak Ridge, TN. $11 \mathrm{pp}$.

Wyoming Game and Fish Department. 1977. Current status and inventory of wildlife in Wyoming. Wyoming Game and Fish Department, Cheyenne, WY. 133 pp. 
APPENDIX A. DATA SET DOCUMENTATION 
THIS PAGE

\section{WAS INTENTIONALLY LEFT BLANK}




\section{APPENDIX A. DATA SET DOCUMENTATION}

Appendix A documents the individual data sets in the Geoecology Data Base that are listed in Table A.1. The Appendix is subdivided into 13 thematic sectors. Sectors contain an initial overview section that describes relationships between the data sets within the sector, such as common data sources. Each data set documentation includes standard information as listed and defined below. In addition, many data set descriptions include illustrative maps, graphs, or tables selected to demonstrate applications of the data and display techniques (Table A.2). Dictionary tables are included to provide reference lists of codes and associated names used within data sets. The three-character data set name (DSN) is used in numbering pages, tables, and figures to easily associate all materials with a data set. This numbering scheme will also accommodate updates and additions.

The descriptive fields used in Appendix A include:

TITLE: The data set name (DSN) and title are given as they are stored in the Geoecology Data Base. Because SAS restricts the title to 40 characters, the title printed in the Appendix may include abbreviations used to accommodate this limit.

DESCRIPTION: Information is included about the creation of the data set, calculations of variables, expanded definitions of variables, units of measure, known limitations of the data, and potential applications of the data.

SOURCE(s): Possible sources are surveys, inventories, maps, other data bases, or other data sets within the Geoecology Data Base. Complete citations are listed in the REFERENCES section of the report.

COMMENTS: Specific items to be considered in using the data are highlighted, such as missing data, special data conventions, limited geographic coverage, etc.

REFERENCE(S): Citations are listed of published reports that specifically used this data set and provide additional descriptive material. See the REFERENCES section for complete citations.

YEAR(S): The date refers to the year or years in which the data were collected or the data source was published. 
TEMPORAL RESOLUTION: The temporal unit is defined as: Hist. (e.g., historic species ranges); Currnt (e.g., current conditions); Norms (e.g., 30-year averages); Annual (e.g., yearly crop yields); Months (e.g., climatic data); or Varies (different times within the data set). This field is blank for index and dictionary data sets and for data sets which reflect contemporary environmental conditions, such as soils or bedrock geology.

GEOCOVERAGE: Geographic coverage of the data set is defined as: U. S. (48 conterminous states), East ( 37 eastern states), West (11 western states), or South (16 southern states).

SPATIAL RESOLUTION: Smallest geographic units are defined as: States, Counties, SCU (subcounty units in larger counties), SCD (State Climatic Divisions), or Points (weather station locations).

STATUS: Possible conditions are: Online (edited and readily available); Offline (stored on magnetic tape in edited form as SAS data set); Being Edited (may be available in preliminary form); Unedited (source file may exist, but FIPS codes, metric conversion, or county aggregations have not been completed); Not Digitized (map or hard copy may exist but not as a computer flle); or Planned (needs and data have been identified but not yet compiled).

DATA SET TYPE: This field provides information about how the data set is structured: Single (one record per county unit); Multiple (several records per county, e.g., a record for each species occurring in a county); Index (pointers usually associating counties with various regions, e.g. State Climatic Division index); or Dictionary (names and characteristics associated with codes, e.g., species code names).

NUMBER OF RECORDE: Total number of recuids in the data set: data sets having single records per county should have 3071 records for the U. S.,'2660 for the East, 1338 for the South, and 411 for the west.

VARIABLES PER RECORD: Number of SAS variables in the data set.

CREATED/UPDATED: Gives the date the data set was originally added to the Data Base or that significant changes were incorporated. Most files have a March 1980 date when units of measure were changed to metric-sI units. 
NEW DATA: Interval at which new data may become available for addition to or replacement of the current data set.

COMPILER: Individuals involved in compiling, digitizing, editing, or other aspects of creating the data set for the Geoecology Data Base.

VARIABLE: Names 1 isted correspond exactly to the spelling of SAS variables within the Data Base.

LABEL AND UNITS OF MEASURE: Brief informative description of the variable corresponding to the sAs labels stored within the Data Base. Because SAS restricts the label to 40 characters, the label printed in the Appendix may include abbreviations used to accommodate this limit. 


\section{Table A.1. Geoecology Data Sets included in Appendix A.}

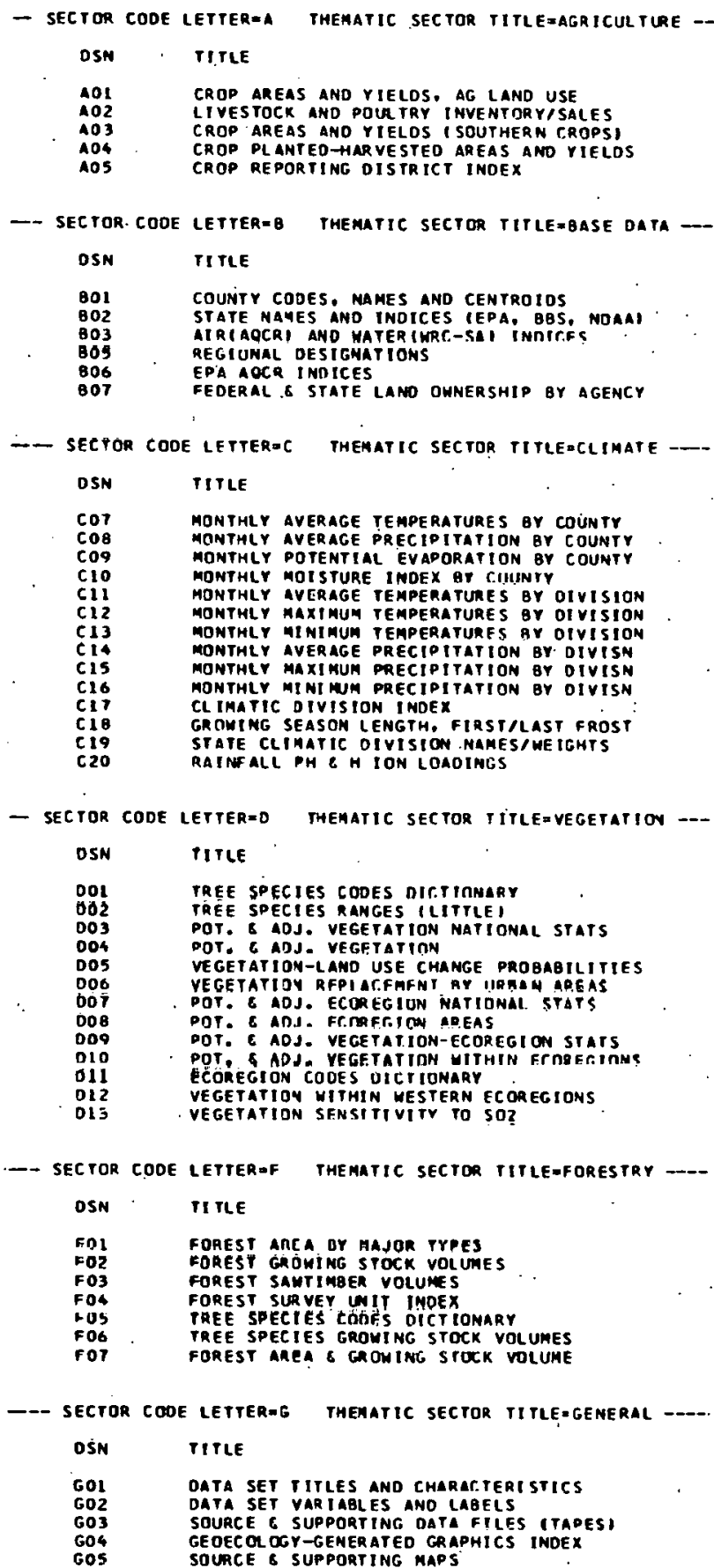

-D SECTOR COOE LETTER F THEMATIC SECTOR TITLEAFORESTRY --

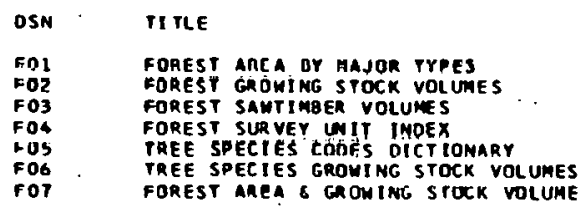

--- SECTOR COOE LETTERIG THEMATIC SECTOR TITLE=GENERAL ---DSN TITLE

GO1 DATA SET TITLES AND CHARACTERISTICS

G02 DATA SET VARIABLES ANO LABELS

ILES (TADESI GO4 GEOECOL OCY-GENERATED GRAPHICS INDEX
GOS SOURCE S SUPPORTING MAPS

- SECTOR CODE LEITER=R THEMATIC SECTOR TITLE=AIR OUALITY --

OSN TITLE

KOL AMBIENT AIR QUALITY. (SAROAD)

PAOJECTEO ENISSIONS ISEASI

KO3 PROJECTED AMBIENT SOZ,TSP ISEAS

AIR OUALITY NDMATTAIHMENT AREAS IEPA

PMO JECTED AMBIENT SO2, SULFATE (NCUA)

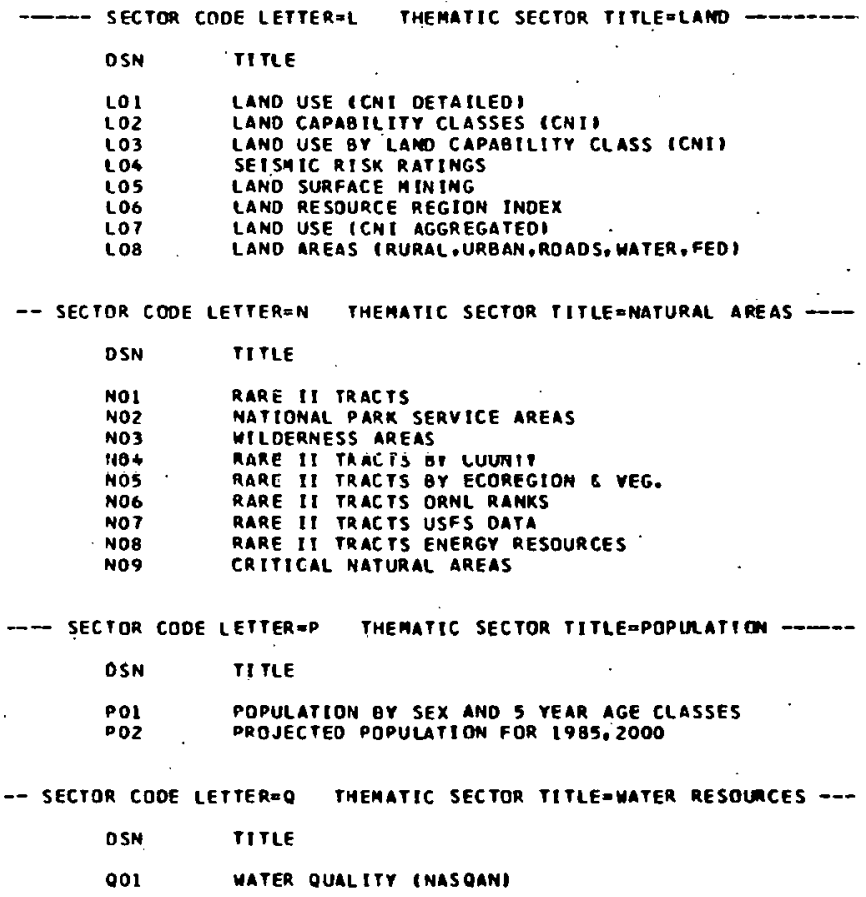

MAMMAL SPECIES RAMGES
MAMMAL SPECIIES RAMGES IRARE SPECIESI 
Table A.2. Illustrations included in Appendix A.

A03.1 Soybean Yield from the 1975 State Summaries Expressed as Total production for Total County Area. Interval limits in Bushels per acre: (1) $<0.001$, (2) $0.001-0.01$,
(3) $0.01-0.1$,
(4) $0.1-1.0$,
(5) $1.0-10.0$, (6) $>10.0$.

A04.1 1975 Corn Production in Bushels.

B01.1 Counties of the United States with FIPS County Numbers.

C07.1 Average Annual Temperatures Based on 30-Year Monthly Norms for the Period 19.41-1970. Interval limits in degrees Fahrenheit: (1) <54.5, (2) 54.5-59.0, (3) $59.0-63.5$, (4) $63.5-68.0$, (5) $68.0-72.5$, (6) $>72.5$.

C08.1 Total Annual Rainfall Based on 30-Year Monthly Norms for the Period 1941-1970. Interval limits in inches: (1) $<24.0$, (2) $25.0-32.0$, (3) $35.0-45.0$, (4) $45.0-55.0$, (5) $>55: 0$.

C09.1 Annual Potential Evapotranspiration Calculated from the 30-Year Monthly Temperature and Precipitation Norms for the Period 1941-1970 using the Thornthwaite Formulas. Interval limits in inches: (1) $<30.0$, (2) $30.0-35.0$, (3) $35.0-40.0$, (4) $4.0 .0-45.0$, (5) $>45.0$.

Cl0.1 Annual Moisture Index Calculated from 30-Year Monthly Temperature and Precipitation Norms. Interval 1 imits: (1) <-40.0, (2) $-40.0-0.0$, (3) $0.0-20.0$, (4) $20.0-40.0$, (5) $40.0-60.0$, (6) $>60.0$.

Cl1.l Monthly Temperature Ranges (Maximum; Average, Minimum) for East Tennessee.

Cl4.1 Monthly Precipitation Ranges (Maximum, Average, Minimum) for East Tennessee.

C18.1 Growing Season Length (days) for the Eastern United States.

C20.1 1974 Rainfali. pH for the Eastern United States.

D03.1 Potential Vegetation Percentages for the United States. 
D04.1 Percent Potential Vegetation Types Remaining in the United states.

D07.1 Ecoregion Percentages for the United States.

D08.1 Ecoregions. in the South.

D09.1 Percent of Potential Vegetation Types within Ecoregions.

D13.1 Potential Vegetation Types with Low Tolerance to Sulfur Dioxide (Relative Sensitivity).

F02.1 Forest Stand Volumes based on 1963-1975 Inventories. Growing-stock volumes are expressed as net volume of trees greater than 5.0 in. dbh per total county area. Interval limits in cubic feet per acre: $<100$, (2) $100-250$, (3) $250-500$, (4) $500-750$, (5) $>750$.

F05.1 Tree Species Codes Dictionary.

F06.1 Sensitive Tree Biomass in the South at Risk to High Levels of Sulfur Dioxide. High-level Areas are Air Quality Control Regions in which the 1974-1976 Annual Ambient Average Concentration Exceeded 100 micrograms per cubic meter.

K01.1 Air Quality Control Regions in the South with High Sulfur Dioxide Levels, for which the 1974-1976 Annual Average Ambient Concentrations Exceeded 100 micrograms per cubic meter.

K04.1 Nonattainment Counties for Total suspended Particulates.

K05.2 Projected 1985. Ambient sulfur Dioxide Concentrations. Interval limits in micrograms per cubic meter: (1) <.1, (2) $0.1-1.0$, (3) $1.0-3.0$, (4) $3.0-10.0$, (5) $>10.0$.

L01.1 County Land-Use Classifications based on the 1967 Conservation Needs Inventory.

L01.2 Cropland Percentages by County based on the 1967 Conservation Needs Inventory.

L02.1 Land Capability Classes I-II-III Percentages based on the 1967 Conservation Needs Inventory.

L04.1 Relative Seismic Suitability for Nuclear Facilities. 
L06.1 Soil Conservation Service Land Resource Regions.

N01.1. Counties in the South with RARE II Proposed wilderness Areas.

N02.1 Counties Containing Class I Air Quality Areas Based on the Occurrence of National Parks Greater than 5000 acres.

N03.1. Counties in the South with Existing and Proposed Wilderness Areas (RARE II).

N03.2 Counties with Existing, Endorsed; and Proposed Wilderness Areas Qualifying as Class I Air Quality Areas.

T06.1 Elevation Classifications for the South.

T07.1 Soil Order, Suborder, and Map-Unit Codes Dictionary. T09.1. Great Soil Groups Ranked within Map Units.

T10.1 Soil Map Unit Chemical Characteristics including: Base Saturation (BS), Cation Exchange Capacity $(\mathrm{CEC}), \mathrm{pH}, \mathrm{Clay}$ Content (CC), and Organic Matter $(\mathrm{OM})$.

W04.1 Bird Species Codes Dictionary.

w09.1 Endangered Species Codes Dictionary.

W10.1 Endangered Mammal Species Concentrations in the South.

W13.1 Mammal Species Codes Dictionary. 


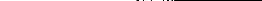




\section{AGRICULTURE (A) SECTOR OVERVIEW}

The Agriculture Sectur cuntains both crop and liviestock data for counties based on state and federal inventories. Data set A04 contains statistics for major crops for 1975 with national coverage. These data are probably the most representative county estimates because they are based on annual surveys conducted for each county. The Census of Agriculture (used for $\mathrm{AOI}$ and $\mathrm{AO} 2$ ) may have sampling errors due to survey techniques. Data for more years, more crops, and crops grown under irrigation are available on tapes: New data are added as they become avallable. 
TITLE: AOI - CROP AREAS AND YIELDS, AG LAND USE

DESCRIPTION: Major crop areas, yields for selected crops, and major farmland-use statistics were obtained from the 1969 Census of Agriculture. Hectares of land harvested and kilograms yielded were included for corn, sorghum, wheat, hay, soybeans, peanuts, cotton, and tobacco. Areas devoted to vegetables, small grains, fruit orchards, berries and small fruits, potatoes, other miscellaneous crops, and nursery and greenhouses were included so that the sum of all areas equals the total cropland in the Census. Also included are total land area, large lakes, nonharvested cropland, grazed woodlands, and ollier land statistics. Totals for irrigated and fertilized land occurring within the various categories were included with amounts of water and fertilizer used. Data do not always accurately reflect county totals: information is withheld to maintain privacy; corporate farm holdings may be reported with the headquarters county and not the county in which the crops are located; and totals may not be properly corrected for nonrespondents of the mail questionnaire.

SOURCE(S): Breen, J. T. 1972. 1969 Census of Agriculture magnetic tape file. U. S. Department of Commerce, Bureau of the Census, Agriculture Division, Washington, DC.

REFERENCE (S) : USDC 1969.

COMMENTS: Data tapes are available with approximately 500 crop and livestock types per county for 1949, 1954, 1959, 1964, and 1969. Data for North Dakota, South Dakota, Nebraska, Kansas, and the western states are not included in the data set but are available on tape.

$\operatorname{YEAR}(\mathrm{S}): \quad 1969$

GEOCOVERAGE : East

STATUS: Onl ine

NUMBER OF RECORDS: 2346

CREATED/UPDATED: Mar. 1980

COMPILER: $\quad \mathrm{R} \mathrm{J}$ Olson
TEMPORAL RESOLUTION: Annual SPATIAL RESOLUTION: County DATA SET TYPE: Single

VARIABLES PER RECORD: 42 NEW DATA: "Every 5 years

\section{VARIABLE LABEL AND UNITS OF MEASURE}

\begin{tabular}{lll}
\hline ALL_LAND & Approximate land area & ha \\
AREA 69 & Total surface area - 1969 C of Ag & ha \\
BERRY A & Berries and small fruits & ha \\
CORN_G_A & Corn for grain & ha \\
CORN_G_Y & Corn for grain yield & kg
\end{tabular}




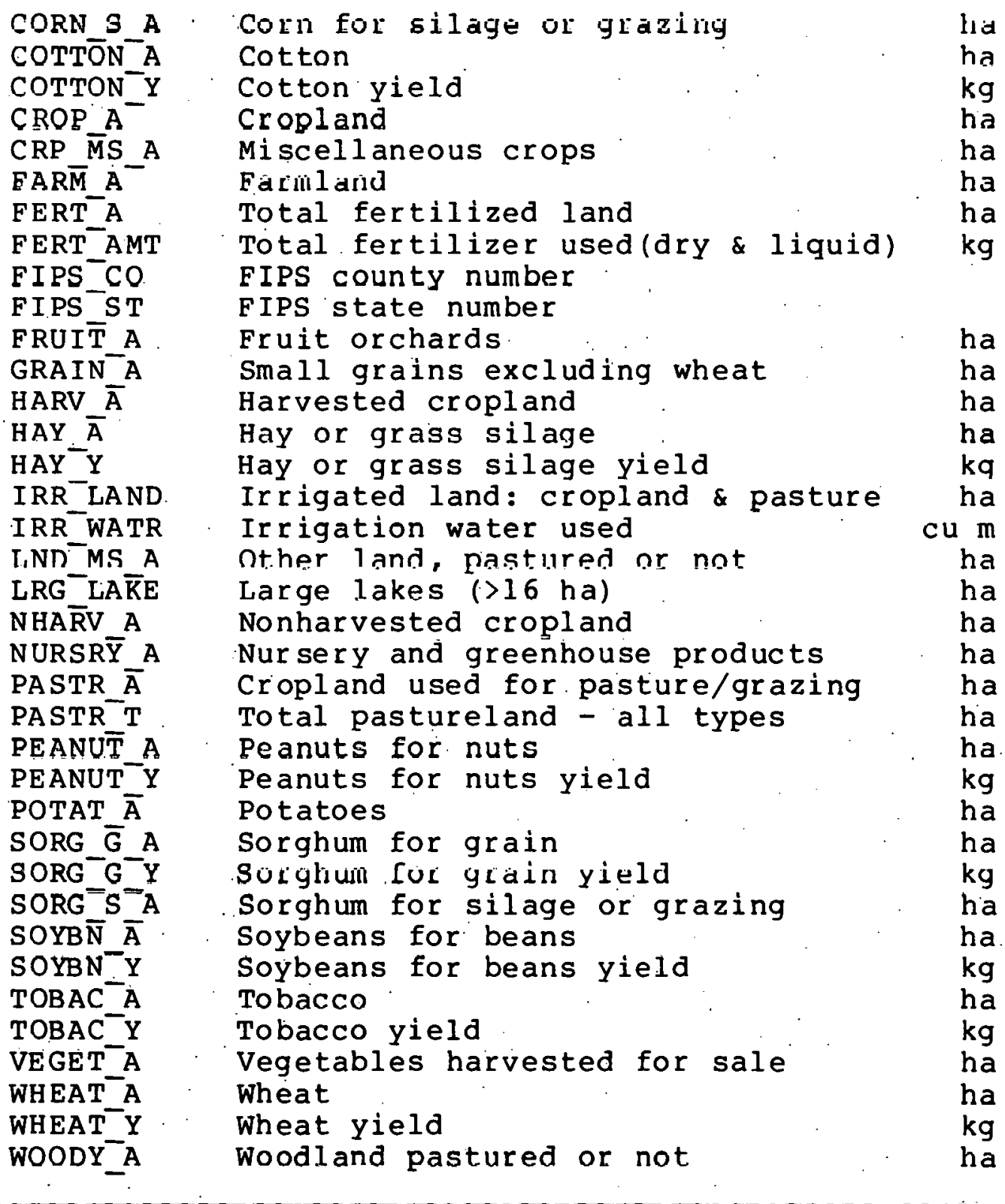


TITLE: A02 - LIVESTOCK AND POULTRY INVENTORY/SALES

DESCRIPTION: Major livestock and poultry statistics of animal inventories and numbers sold were obtained from the 1969 Census of Agriculture. Data include inventories of cattle, pigs, sheep, chickens, turkeys, ducks and geese, and horses and ponies. Counts are also included for cows that have calved and milk cows, along. with subtotals for chickens older than three months, hens and pullets, and broilers. Data have limitations because of survey and reporting methods - see A0l description.

SOURCE(S): Breen, J. T. 19.72. 1969 Census of Agriculture magnetic tape file. U. S. Department of Commerce, Bureau of the Census, Agriculture Division, Washington, DC.

REFERENCE(S) : . USDC 1969 .

COMMENTS: 'Data tapes are available with additional data for $1949,1954,1959,1964$, and 1969.

YEAR (S) : 1969

GEOCOVE RAGE : East

STATUS: Online

NUMBER OF RECORDS : 2289

CREATED/UPDATED: Mar . 1980

COMPILER: R J Olson
TEMPORAL RESOLUTION: Annual SPATIAL RESOLUTION: County DATA SET TYPE: Single VARIABLES PER RECORD: 24 NEW DATA: Every 5 years

\section{VARIABLE}

LABEL AND UNITS OF MEASURE

BROILR_I
BROILR_S
CATTLEII
CATTLE-S
CHICKN I
CHICKN S
COW_CALF
COW_MILK
COWOTHR
FIPS_CO
FIPS-ST
HENS-I
HENS-S
HORSES_I
HORSES S
PIGS_F-S
PIGS I
PIGS_S

Broiler and meat chicken inventory

Broiler and meat chicken sales

Cattle and calves inventory

Cattle and calves sales

Chickens inventory (older than 3 months)

Chickens sales (older than 3 months)

Cows that have calved

Milk cows inventory

Cows other than milk cows

FIPS county number

FIPS state number

Hens and pullets inventory

Hens and pullets sales

Horses, ponies and mules inventory

Horses, ponies and mules sales

Feeder pigs sales

Pigs inventory

Pigs sales 


$\begin{array}{ll}\text { POULT_I } & \text { Ducks, geese and other poultry inventory } \\ \text { POULTSS } & \text { Ducks, geese and other poultry sales } \\ \text { SHEEP-I } & \text { Sheep and lambs inventory } \\ \text { SHEEPSS } & \text { Sheep and lambs sales } \\ \text { TURKEY_I } & \text { Turkey inventory } \\ \text { TURKEY_S } & \text { Turkey sales }\end{array}$


TITLE: A03 - CROP AREAS AND YIELDS (SOUTHERN CROPS)

DESCRIPTION: Southern state agricultural departments provided data on harvested cropland and yields for corn, wheat, hay, soybeans, and sorghum for 1975. Data were keypunched from state reports.

SOURCE(S): Crop statistics reports for 1975 were obtained from individual states in the south and selected tables were keypunched.

$\operatorname{YEAR}(\mathrm{S}): \quad 1975$

GÉUCOVERAGE : South

STATUS: Online

NUMBER OF RECORDS : 1388

CREATED/UPDATED: Mar. 1980

COMPILER: J M Klopatek
TEMPORAL RESOLITTTON: AnnUal SPATIAL RESOLUTION: County DATA SET TYPE: Single VARIABLES PER RECORD: 12 NEW DATA: Not anticipated

\begin{tabular}{|c|c|c|}
\hline VARIABLE & LABEL AND UNITS OF MEASURE & \\
\hline CORN_G_A & Corn for grain area harvested & \\
\hline $\mathrm{CORN}^{-} \mathrm{G}^{-} \mathrm{Y}$ & Corn for grain yield & \\
\hline FIPS $\mathrm{C}^{-}$ & FIPS county number & \\
\hline FIPS_ST & FIPS state number & \\
\hline HAY $\bar{A}$ & Hay area harvested & \\
\hline $\mathrm{HAY}_{-}^{-} \mathrm{Y}$ & Hay yield & \\
\hline SORG_G_A & Sorghum for grain area harvested & \\
\hline SORG ${ }_{-}^{-}{ }^{-} \mathrm{Y}$ & Sorghum for grain yield & \\
\hline SOYB $\bar{N} \_\bar{A}$ & Soybean area harvested & \\
\hline SOYBN_Y & Soybean yield & \\
\hline WHEAT_A & Wheat area harvested & \\
\hline WHEAT_Y & Wheat yield & \\
\hline
\end{tabular}




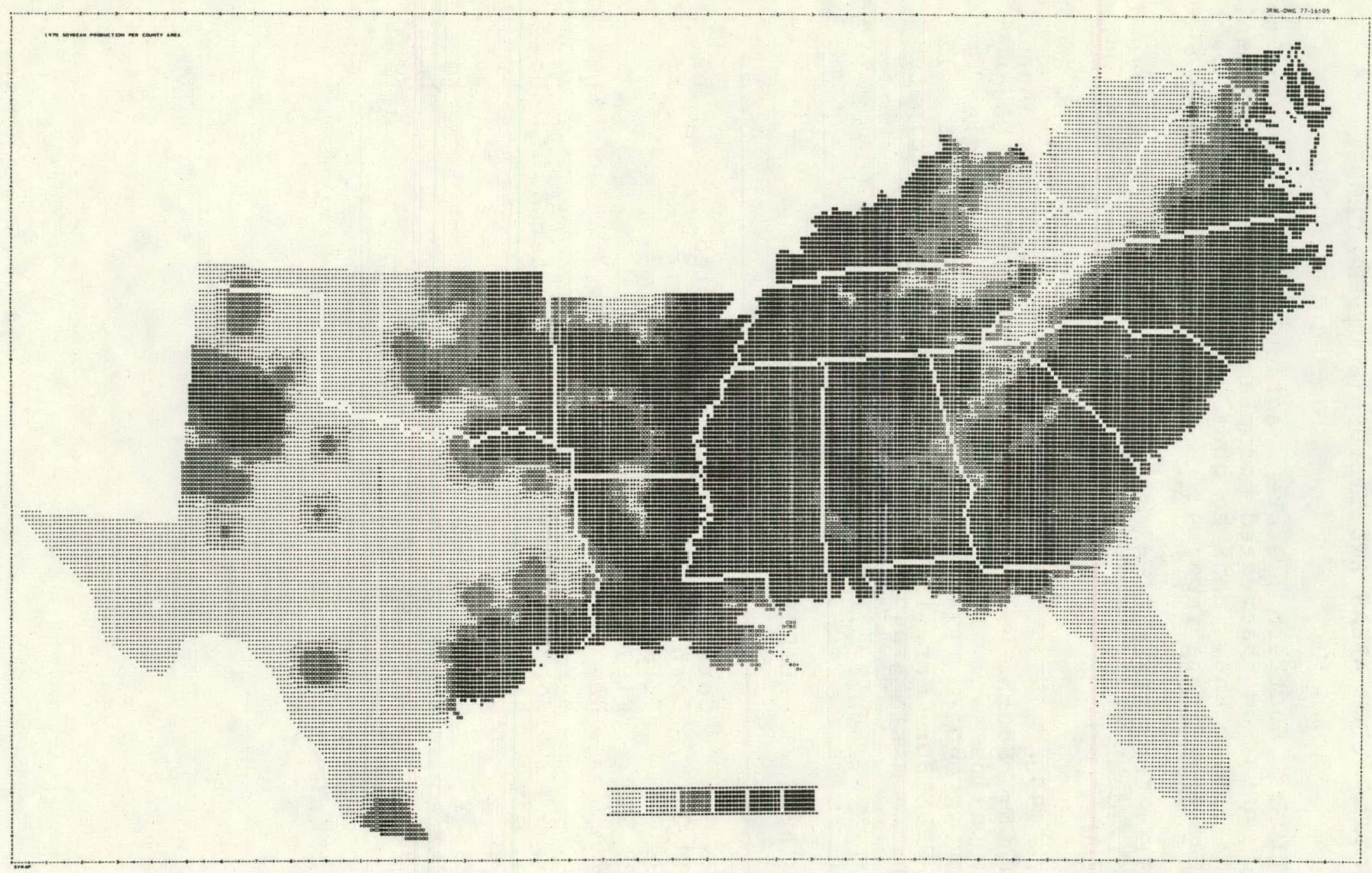

A03.1 Soybean Yield from the 1975 State Summaries Expressed as Total Production for Tozal County Area. Inzerval limits in Bushels per acre: (1) $<0.00_{-}^{-}$, (2) $0.001-0.01$, (3) $0.01-0.1$, (4) $0.1-1.0$, (5) $1.0-10.0$, (6) >10.0. 
TITLE: A04 - CROP PLANTED-HARVESTED AREAS AND YIELDS

DESCRIPTION: Statistics for land planted and harvested with associated crop yields and production were obtained from the Economics, Statistics, and Cooperative Services (ESCS), USDA, for the years 1972-1977. Data were extracted for 1975 crops of wheat, rye, rice, corn, oats, sorghum, cotton, tobacco, and peanuts crops. State statistical offices are responsible for county estimates. Data are used primarily by the Agricultural Stabilization and Conservation Service (ASCS) and Federal Crop Insurance Corporation (FCIC).

SOURCE(S): Barr, J. T. May, 1979. 1972-1977 County Crop Estimates magnetic tape. U. S. Department of Agriculture, Economics, Statistics, and Cooperatives Service, Washington, DC.

COMMENT: If crop acreages are small within a county, county values may be withheld to protect privacy; however, Crop Reporting District or state statistics on the data tape include these values in the totals. Data for 1972 through 1977 are available on a magnetic tape.

$\operatorname{YEAR}(\mathrm{S}): \quad 1975$

GEOCOVE RAGE : U. S. STATUS: Online NUMBER OF RECORDS : 13085 CREATED/UPDATED: Mar. 1980 COMPILER: C J Emerson
TEMPORAL RESOLUTION: Annual SPATIAL RESOLUTION: County DATA SET TYPE: Multiple VARIABLES PER RECORD: 8 NEW DATA: Every 10 years

\section{VARIABLE}

LABEL AND UNITS OF MEASURE

CROP
CROP HRV
CROP-PLN
CROP-PRD
CROP-YLD
FIPS-CO
FIPS-ST
YEAR

Crop name

Crop harvested area

Crop planted area

Crop production for county

ha

Crop yield, kg per area

FIPS county number

FIPS state number

1975 year of ESCS estimate 
A04.1 1975 Corn Production in Bushels.

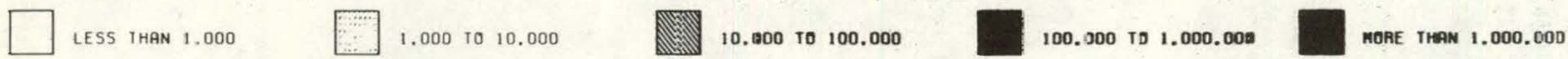

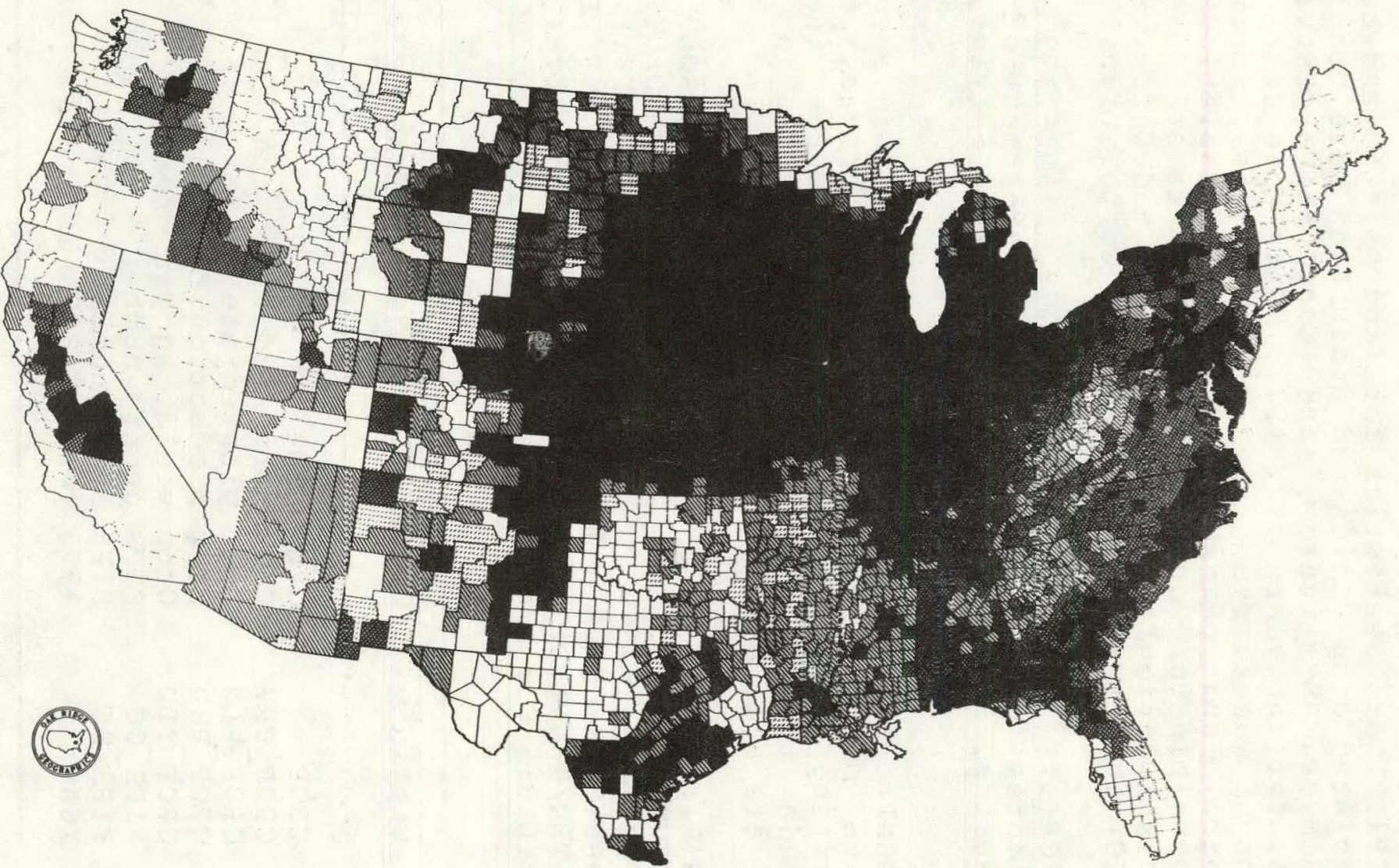

总 
TITLE: A05 - CROP REPORTING DISTRICT INDEX

DESCRIPTION: Crop Reporting Districts (CRD's) are groupings of contiguous counties within states based on homogeneous agricultural practices. They are used in summarizing crop statistics.

SOURCE(S): Barr, J. T. May, 1979. 1972-1977 County Crop Estimates magnetic tape. U. S. Department of Agriculture, Economics, Statistics, and Cooperatives Service, Washington, DC.

$\operatorname{YEAR}(S): 1975$

GEOCOVE RAGE : U. S.

STATUS: Online

NUMBER OF RECORDS : $\quad 3071$

CREATED/UPDATED: Mar. 1980

COMPILER: C J Emerson
TEM PORAL RESOLUTION: Cur rnt SPATIAL RESOLUTION: County DATA SET TYPE: Index VARIABLES PER RECORD: 3 NEW DATA: Not anticipated

\begin{tabular}{|c|c|}
\hline VARIABLE & LABEL AND UNITS OF MEASURE \\
\hline $\begin{array}{l}\text { CRD_CODE } \\
\text { FIPS_CO } \\
\text { FIPS_ST }\end{array}$ & $\begin{array}{l}\text { Crop Reporting District code } \\
\text { FIPS county number } \\
\text { FIPS state number }\end{array}$ \\
\hline
\end{tabular}


焉 


\section{BASE DATA (B) SECTOR OVERVIEW}

Basic data about the size and location of counties plus various index files are contained in the B Sector. Data set B0l defines the 3071 county units: used as the primary spatial cells in the Geoecology Data Base. Data set BolsCU defines the 79 eastern counties that have been divided into 239 subcounty units based on size and environmental characteristics. Currently, index files for Air Quality Control Regions (AQCR's) and Water Resource Council Subregions are available. The index files can be merged with other data sete by Fifs codes to aggregate counties into various regions for analysis. 
TITLE: BOI - COUNTY CODES, NAMES AND CENTROIDS

DESCRIPTION: The primary 3071 county units for the 48 conterminous states utilized in the Geoecology Data Base are defined. Included are FIPS codes, county names, land area; latitude/longitude location of the geographic centroid of each county, Vi.sual Continuity Numbers (VCN), and National County Alphabetic Numbers (NCAN). Names and land area were obtained for 1970 from the 1972 County and City Data Book (USDC 1973a). Land area includes 'census water,' defined'as lakes smaller than $16 \mathrm{ha}$ and small streams. Centroids were calculated by averaging the latitude/longitude coordinates of the county outline obtained from Department of Transportation data. The VCN and NCAN indices are unique county codes used for digitization and display programs. VCN's were assigned to counties within states so that adjacent counties have consecutive numbers (Schreiber et al. 1974). NCAN's (1 to 3069 ) were assigned sequentially to alphabetical. Iists of counties within states arranged alphabetically. Since VCN's and NCAN's were created for a special application, not all 3071 counties were assigned codes. The county mnemonic codes are unique four-character codes derived from the county name. Data set BolsCU contains similar. variables for the 79 counties in the east that have been subdivided into 239 subcounty units. It contains the additional variable SCU which is a letter designating the subcounty. unit within a county.

SOURCE(S): FIPS codes and land areas: RUSTIC, Energy Division. 1975. 1972 County and City Data Book Magnetic Tape. Oak Ridge National Laboratory, Oak Ridge, TN.

NCAN's and VCN's: Assigned by the Geoecology Project (see Schreiber et al. 1974).

County centroids: Calculated by the Geoecology Project from the coordinates of county boundaries.

REFERENCE(S): Schreiber et al 1974. USDC 1973 a.

COMMENTS: See discussion on county units and listing of 3071 units in Appendix $C$. The SAS FORMAT statement may be used to substitue state and county names for FIPS codes (see section on Special Output Formats).

$\operatorname{YEAR}(\mathrm{S}): \quad 1970$

GEOCOVE RAGE : U. S.

STATUS: Online

NUMBER OF RECORDS: 3071

CREATED/UPDATED: Mar: 1980
TEM PORAL RESOLUTION: Current SPATIAL RESOLUTION: Gounty DATA SET TYPE: Single VARIABLES PER RECORD: 11 NEW DATA: Not anticipated: 
COMPILER: $\mathrm{R}$ J Olson, $\mathrm{R}$ L Stephenson

\begin{tabular}{ll}
\hline VARIABTE, & LABEL AND UNITS OF MEASURE \\
\hline CO_AREA & Area of county exeluding >l Gha läkes \\
COCCODE & County mnemonic code \\
COUNTY & County name \\
FIPS_CO & FIPS county number \\
FIPS ST & FIPS state number \\
LATITUDE & Latitude of county centroid \\
LNGITUDE & Longitude of county centroid \\
NCAN & National County Alphabetic Number \\
NOSCU & Number of subcounty units \\
ST & State code letters \\
SVCN & State Visual Continuity Number \\
\end{tabular}




\section{B01.1 Counties of the United States with FIPS County Numbers.}

COLNTIES O= THE UNITED STATES

ORNL-DWG 78-21129 WITH FIPS COUNTY NUMBERS

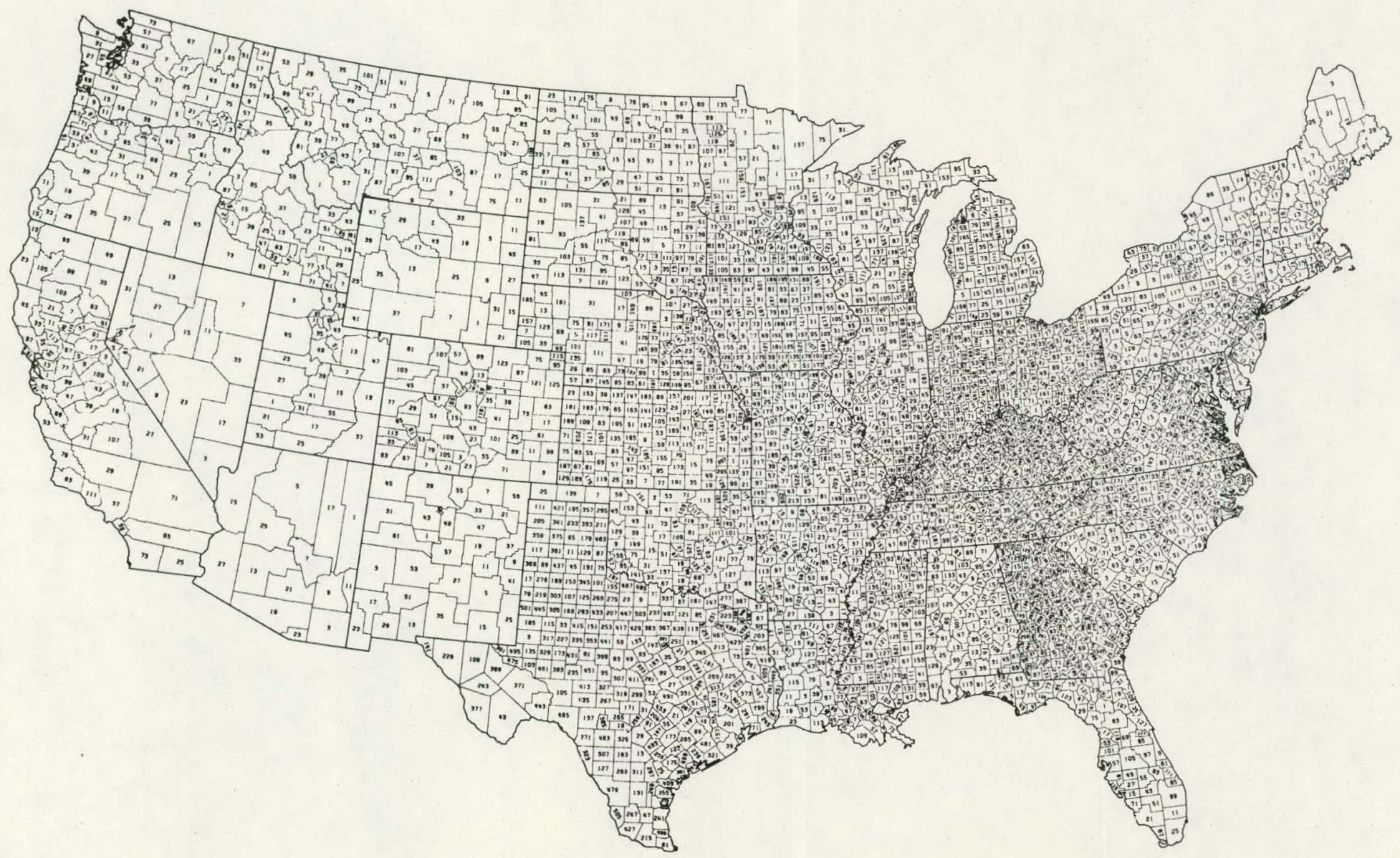


TITLE: B02 - STATE NAMES AND INDICES (EPA, BBS, NOAA)

DESCRIPTION: Various state codes and state-level regional Indices have been accumulated from several agencies as a means of facilitating conversion to FIPS codes. By merging the regional indices with other data sets, data can be aggregated by regions.

SOURCE(S): State codes were obtained from each agency.

YEAR (S) : 1970

GEOCOVE RAGE : U: S.

STATUS: ONI Ine

NUMBER OF RECORDS :

51

CREATED/UPDATED: Mar. 1980

COMPILER: $\mathrm{R} \mathrm{J}$ Olson
TEMPORAL RESOLUTION: Current SPATIAL RESOLUTION: States DATA SET TYPE: Index VARIABLES PER RECORD: 10 NEW DATA: Not anticipated

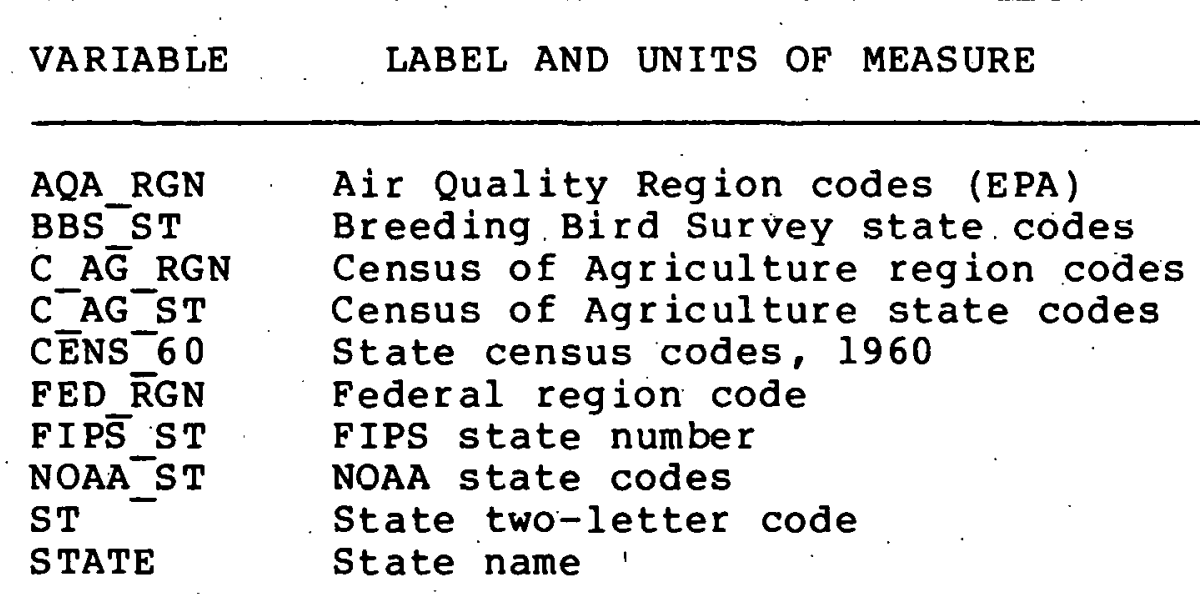


TITLE: B03 - AIR(AQCR) AND WATER(WRC-SA) INDICES

DESCRIPTION: Air and water regions are defined by naturally occurring airsheds and watersheds. These regions are approximated by Air Quality Control Regions (AQCR's) and Water Resource Council subareas (WRC-SA's) which consist of aggregations of counties. There are 247 AQCR's and 205 WRC-SA's. Air quality data are routinely provided by AQCR such as in KOl. Water supply and demand data, both actual and projected, are provided by. WRC-SA and the 10 larger water regions. Another definition of water regions (not currently included. in B03) is used for water quality data. Water quality data are available for the 327 National stream Quality Accounting Network (NASQAN) areas as in Q0l.

SOURCE(S): Wilson, D. L. 1978. AQCR and WRC-SA Computer File. Computer Sciences Division; UCCND, Oak Ridge, TN.

REFERENCE (S): AQCR'S: USEPA 1975.

WRC-SA's: Water Resources Council 1970.

$\operatorname{YEAR}(\mathrm{S}): \quad 1975$

GEOCOVE RAGE : U. S.

STATUS: Online

NUMBER OF RECORDS : $\quad 31.05$

CREATED/UPDATED: Mar. 1980.

COMPILER: $\mathrm{R}$ J Olson
TEM PORAL RESOLUTION : Cur rent SPATIAL RESOLUTION: County DATA SET TYPE: Index VARIABLES PER RECORD: 5 NEW DATA: Not anticipated

\begin{tabular}{ll}
\hline VARIABLE & LABEL AND UNITS OF MEASURE \\
\hline AQCR & Air Quality Control Region number - EPA \\
FIPS_CO & FIPS county number \\
FIPS ST & FIPS state number \\
WRCSA 75 & Water Resource Council Subareas - 1975 \\
WRCSA_76 & Water Resource Council Subareas - 1976 \\
\hline
\end{tabular}


TITLE: BO5 - REGIONAL DESIGNATIONS

DESCRIPTION: Historically, the Geoerolngy Project has accumulated data for three levels of geographic coverage. These are the southern 16 states (assigned DOE region), the 37 eastern states (containing the Eastern Deciduous Forest Biome and states that have homogeneous county sizes), and the conterminous 48 states. This file identifies the southern (S) 1388 counties, the northern (N) 1272 counties, and the western (W) 411 counties. The 2660 counties in the $S$ and $N$ regions make up the eastern level. The southern region includes Maryland, West Virginia, Kentucky, Mississippi, Oklahoma, Texas, and states to the south of these with the District of Columbia classified as a state unit. The eastern region includes North and South Dakota, Kansas, Nebraska, Oklahoma, Texas, and all states to the east.

SOURCE(S): Assigned by Geoecology Project Staff.

YEAR (S) : $\quad 1970$

GEOCOVE RAGE : U. S.

STATUS: Online

NUMBER OF RECORDS : $\quad 3071$

CREATED/UPDATED: Mar. 1980

COMPILER: M K Nungesser
TEMPORAL RESOLUTION: Cur rent SPATIAL RESOLUTION: County DATA SET TYPE: Single VARIABLES PER RECORD: 3 NEW DATA: Not anticipated

\section{3}

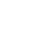


TITLE: B06 - EPA AQCR INDICES

DESCRIPTION: This data set facilitates relating EPA county codes to FIPS county codes. Work at LBL (Deane Merrill) and BNL (Carmen Benkovitz) has created updated files for all EPA county and city codes along with EPA monitoring station latitude/longitude locations.

SOURCE(S): Merrill, D. 1977. EPA County Index Computer File. Lawrence Berkeley Laboratory, Berkeley, CA:

YEAR (S) : 1975

GEOCOVE RAGE : South

STATUS: Online

NUMBER OF RECORDS : 1388

CREATED/UPDATED: Mar. 1980

COMPILER: $R$ J Olson
TEM PORAL RESOLITTTON: Current SPATIAL RESOLUTION: County DATA SET TYPE: Single VARIABLES PER RECORD: 6 NEW DATA: Not anticipated

$\begin{array}{ll}\text { AQCR } & \text { Air Quality Control Region number - EPA } \\ \text { EPA_CO } & \text { EPA county number } \\ \text { EPA-ST } & \text { EPA state number } \\ \text { FED_RGN } & \text { Federal region number } \\ \text { FIPS_CO } & \text { FIPS county number } \\ \text { FIPS_ST } & \text { FIPS state number }\end{array}$


TITLE: BO 7 - FEDERAL AND STATE LAND OWNERSHIP BY AGENCY

DESCRIPTION: The U. S. Forest service has, rompiled a county-level inventory of land managed by six federal agencies. The agencies include: U. S. Forest Servire (FS), U. S. Bureau of Land Management (BLM), U. S. Fish and Wildlife Service (FWS), U. S. Army Corps of Engineers (COE), and U. S. Bureau of Reclamation (BR). The data were obtained primarily from "payment in-lieu-of-taxes" records except for the FWS areas which were based on the Revenue Sharing Act data file. Land and water statistics are included. Also included are the areas of state natural area lands and state school lands. The natural area lands consist of a combined total area for fish and wildlife refuges, parks, and forests managed by states.

SOURCE(S): Kaplan, M. March 1980. National Land Ownership Magnetic Tape UR3653. U. S. Forest Service, Land Management Planning. Fort Collins, CO.

YEAR (S) : $\quad 1979$

GEOCOVE RAGE : U.S.

STATUS: Being Edited
TEMPORAL RESOLUTION: Current SPATIAL RESOLUTION: County DATA SET TYPE: Single 


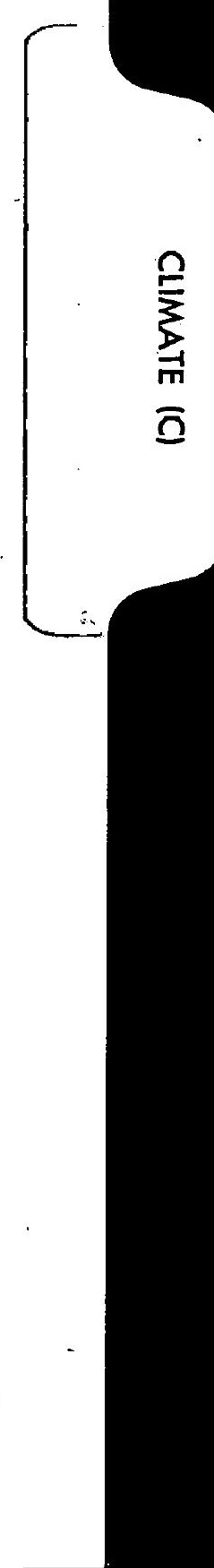


The Clillate sector contains climatic data for county-subcounty units and state Climatic Divisions. Climatic data include monthly temperature ranges and totai rainfall as well as potential evapotranspiration, moisture index, growing season and frost data, rainfall pH, and several indices. Most data were calculated from weather station data for the 30-year period 1941-1970. Additional detailed climatic data for longer periods of record are available on magnetic tapes.

Data sets C07-C10 were derived from the 1941-1970 monthly climatic norms for weather stations. Using the SYMAP program, station values were interpolated to determine county values for temperature and rainfall because there are many counties without weather stations. The algorithm to produce contour maps was used to estimate values for points on a grid using the irregularly spaced weather station data. County values were then obtained from the grid surface. Because no correction was made for elevation, caution is recommended when using data in mountainous areas. The resolution is adequate for regional. studies. The county values were then used with the Thornthwaite (1948) equations to estimate potential evapotranspiration and moisture indices. Data sets C07SCU, C08SCU, C09SCU, and ClosCU contain data for subcounty units for the 79 larger eastern counties. These. data sets are not described separately in this section as they contain the same variables as data sets C07, C08, C09, and Clo plus the variable sCU.

State Climatic Divisions (SCD's) are areas within states with similar climate. There are $353 \mathrm{SCD}$ 's in the United States defined by the National Weather Service. Most follow county boundaries, but in mountainous areas the SCD's do subdivide counties. SCD names are available in Clg and counties within each SCD are defined in Cl7. Cll-Cl6 contain monthly average temperature and rainfall norms for SCD's. The average, minimum, and maximum values were calculated for the period 1941-1970 from a file obtained from the National Climatic Center. 
TITLE: C07 - MONTHLY AVERAGE TEMPERATURES BY COUNTY

DESCRIPTION: Monthly average temperatures were estimated for the geographic centroid of county units. See climate Overview for details on the estimation procedure.

SOURCE(S): Webb, T. 1976. Climatological Magnetic Tape File. Brown University, RI.

REFERENCE(S): Webb 1976, USDC 1973d.

COMMENTS: The estimation procedure did not adjust for elevation so caution should be used with data in mountainous areas.

$\operatorname{YEAR}(\mathrm{S}): \quad 1941-1970$

GEOCOVERAGE : East

STATUS: Online

NUMBER OF RECORDS : 2660

CREATED/UPDATED: Mar. 1980

COMPILER: T Webb, III
TEMPORAL RESOLUTION: NormS SPATIAL RESOLUTION: County DATA SET TYPE: Single VARIABLES PER RECORD: 15 NEW DATA: Not anticipated

\section{VARIABLE}

LABEL AND UNITS OF MEASURE

\begin{tabular}{lll}
\hline ANN_TEMP & Annual average temperature & C degrees \\
APR_TEMP & April average temperature & C degrees \\
AUG_TEMP & August average temperature & C degrees \\
DEC-TEMP & December average temperature & C degrees \\
FEB_TEMP & February average temperature & C degrees \\
FIPS_CO & FIPS county number & \\
FIPS_ST & FIPS state number & \\
JAN_TEMP & January average temperature & C degrees \\
JUL_TEMP & July average temperature & C degrees \\
JUN_TEMP & June average temperature & C degrees \\
MAR_TEMP & March average temperature & C degrees \\
MAY_TEMP & May average temperature & C degrees \\
NOV_TEMP & November average temperature & C degrees \\
OCT_TEMP & October average temperature & C degrees \\
SEP_TEMP & September average temperature & C degrees \\
\end{tabular}




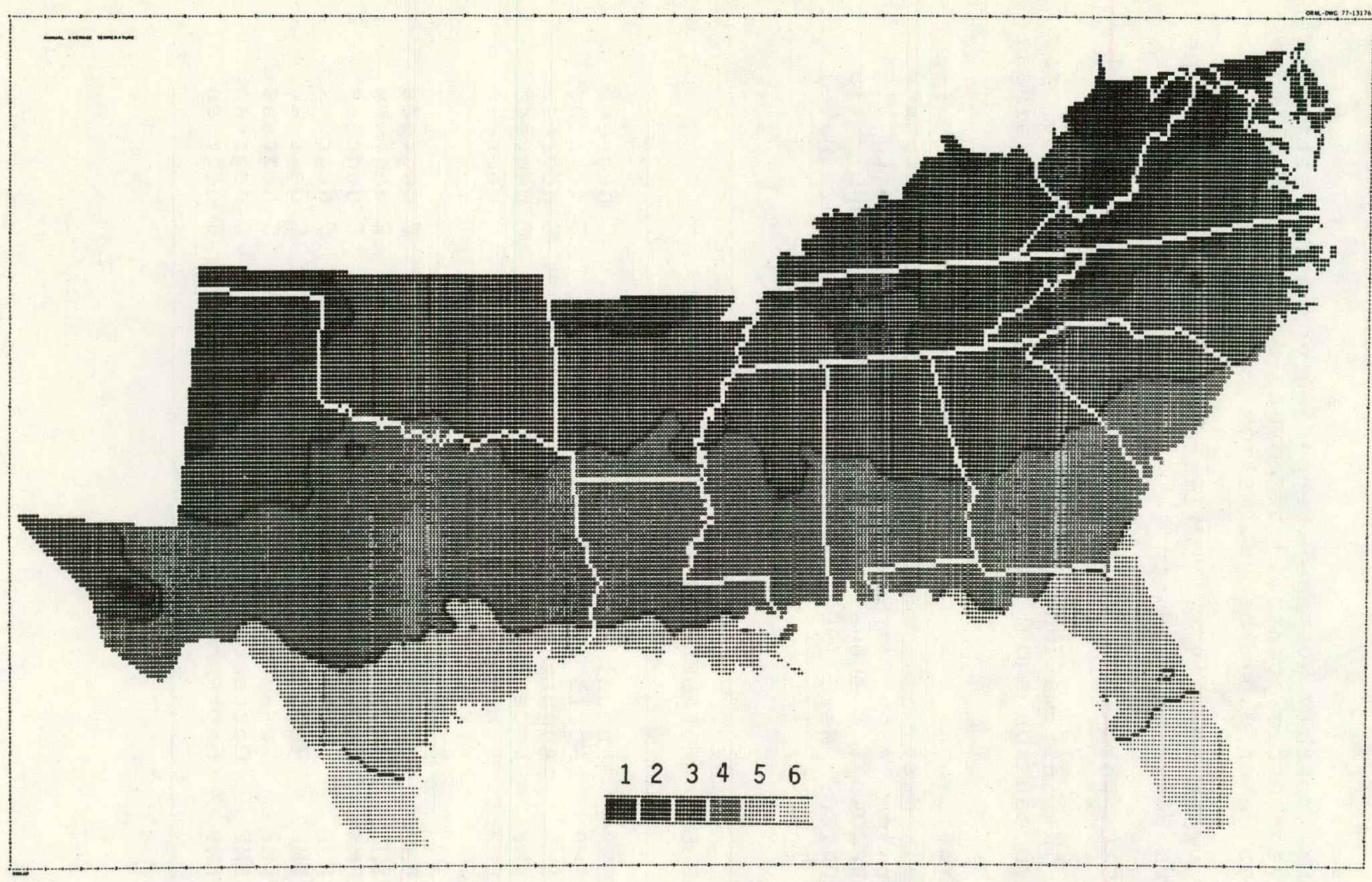

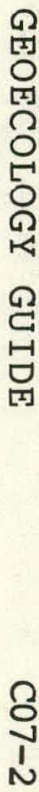

C07.1 Average Annual Temperatures Based on 30-Year Monthly Norms for the Period 1941-1970. Interval limits in degrees Fahrenheit: (1) $<54.5$, (2) $54.5-59.0$, (3) $59.0-53.5$, (4) $63.5-68.0$, (5) $68.0-72.5$, (6) $>72.5$. 
TITLE: C08 - MONTHLY AVERAGE PRECIPITATION BY COUNTY

DESCRIPTION: Monthly average rainfall totals were estimated for the geographic centroid of county units. See Climate Overview for details on the estimation procedure.

SOURCE(S): Webb, T. 1976. Climatological Magnetic Tape File. Brown University, RI.

REFERENCE(S): Webb 1976, USDC 1973d.

COMMENTS: The estimation procedure did not adjust for elevation so caution should be used with data in mountainous areas.

YEAR (S) : $\quad 1941-1970$

GEOCOVERAGE : East

STATUS: Online

NUMBER OF RECORDS : 2660

CREATED/UPDATED: Mar. 1980

COMPILER: T Webb, III
TEMPORAL RESOLUTION: NormS SPATIAL RESOLUTION: County DATA SET TYPE: Single VARIABLES PER RECORD: 15 NEW DATA: Not anticipated

$\begin{array}{lll}\text { ANN_RAIN } & \text { Annual precipitation } & \mathrm{cm} \\ \text { APR_RAIN } & \text { April precipitation } & \mathrm{cm} \\ \text { AUG_RAIN } & \text { August precipitation } & \mathrm{cm} \\ \text { DEC_RAIN } & \text { December precipitation } & \mathrm{cm} \\ \text { FEB-RAIN } & \text { February precipitation } & \mathrm{cm} \\ \text { FIPS_CO } & \text { FIPS count number } & \\ \text { FIPS_ST } & \text { FIPS state number } & \mathrm{cm} \\ \text { JAN_RAIN } & \text { January precipitation } & \mathrm{cm} \\ \text { JUL_RAIN } & \text { July precipitation } & \mathrm{cm} \\ \text { JUN_RAIN } & \text { June precipitation } & \mathrm{cm} \\ \text { MAR_RAIN } & \text { March precipitation } & \mathrm{cm} \\ \text { MAY_RAIN } & \text { May precipitation } & \mathrm{cm} \\ \text { NOV_RAIN } & \text { November precipitation } & \mathrm{cm} \\ \text { OCT_RAIN } & \text { October precipitation } & \mathrm{cm} \\ \text { SEP_RAIN } & \text { September precipitation } & \end{array}$




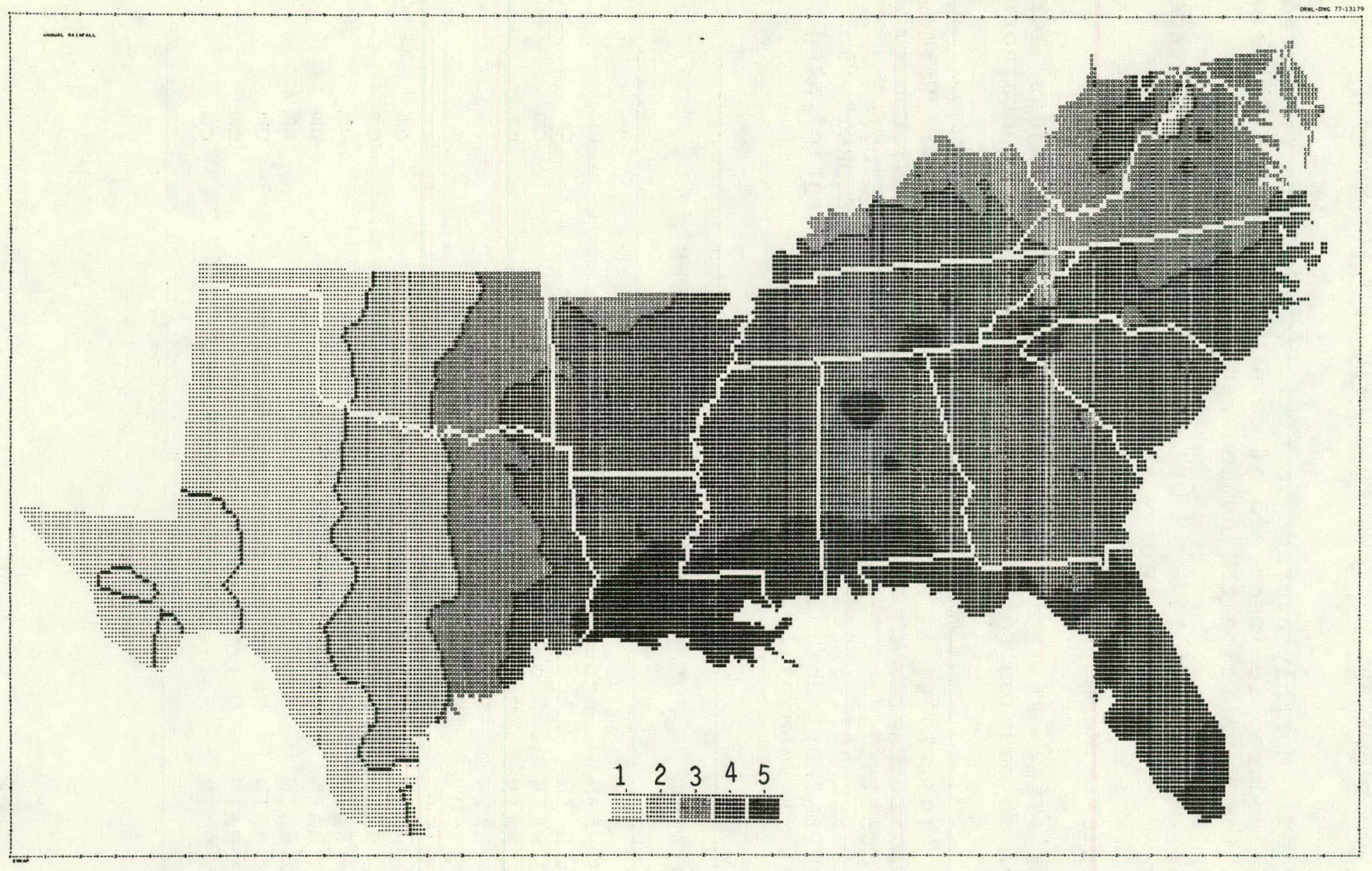

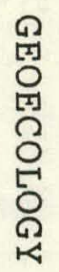

8
0
1
$N$

C08.1 Total Annual Rainfall Based on 30-Year Monthly Norms for the Period 1941-1970. Interval limits in inches: (1)<24.0, (2) $25.0-32.0$, (3) $35.0-45.0$, (4) $45.0-55.0$, (5) $>55.0$. 
TITLE: CO9 - MONTHLY POTENTIAL EVAPORATION BY COUNTY

DESCRIPTION: Monthly potential evapotranspiration (PE) values were calculated for the geographic centroid of county units. See Climate Overview for details on the data sources. Potential evapotranspiration is a calculated estimate of water loss from evaporation and plant transpiration. The Thornthwaite equation uses rainfall and average temperature with a latitudinal correction factor to calculate PE.

SOURCE(S): Webb, T. 1976. Climatological Magnetic Tape File. Brown University, RI.

REFERENCE(S): Webb 1976, Thornthwaite 1948.

COMMENTS: The estimation procedure did not adjust for elevation so caution should be used with data in mountainous areas.

YEAR(S): 1941-1970

GEOCOVERAGE : East

STATUS: Online

NUMBER OF RECORDS : 2660

CREATED/UPDATED: Mar. 1980

COMPILER: T Webb, III
TEMPORAL RESOLUTION: NOrMS SPATIAL RESOLUTION: County DATA SET TYPE: Single VARIABLES PER RECORD: 15 NEW DATA: Not anticipated

VARIABLE LABEL AND UNITS OF MEASURE

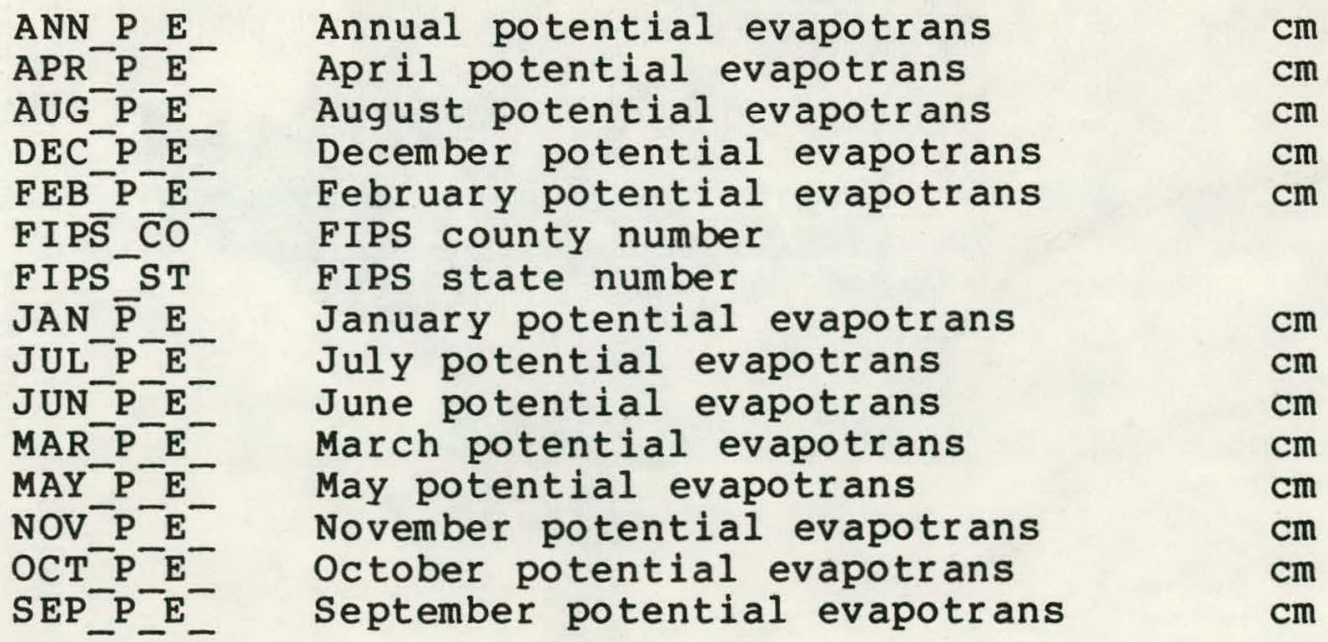




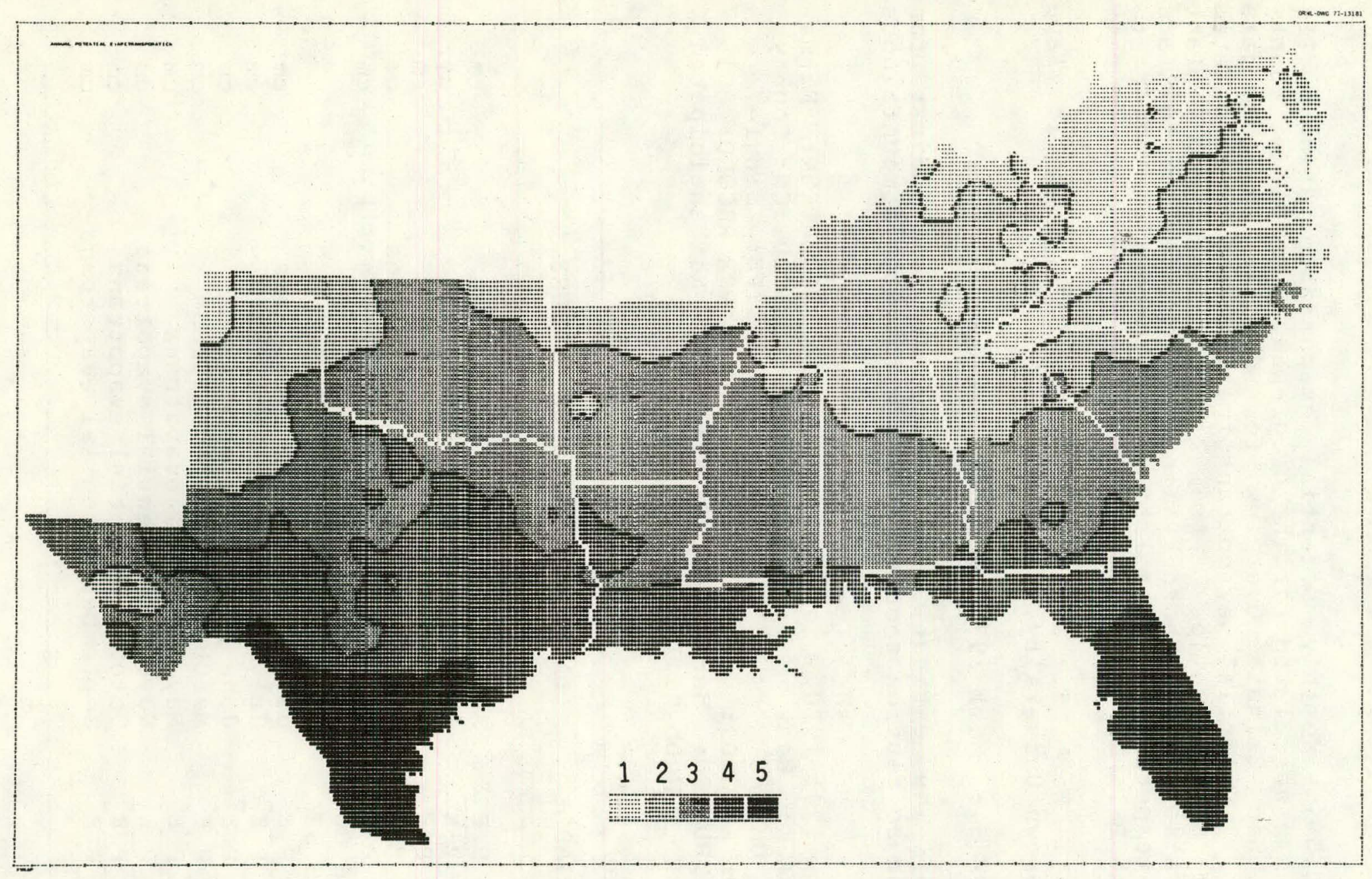

C09.1 Annual Potential Evapotranspiration Calculated from the 30-Year Monthly Temperature and ?recipitation Norms for the Period 1941-1970 Using the Thornthwaite Formulas. Inzerval limits in inches: (1) (3).0, (2) 30.0-35.0, (3) 35.0-40.0, (4) $40.0-45.0$, (5) $>45.0$. 
TITLE: CIO - MONTHLY MOISTURE INDEX BY COUNTY

DESCRIPTION: Monthly moisture index (MI) values were calculated for the geographic centroid of county units. See Climate Overview for details on the data sourccs. The moisture index is a ratio of precipitation to potential evapotranspiration (PE) with values between 1.0 and -1.0 . Positive values indicate soil moisture accumulation while negative values indicate soil moisture depletion. Because the index was initially set up to calculate annual values, individual monthly values for winter months sometimes produce nonsense values. When the PE value is small, the MI becomes unreasonably large (greater than 9999.9) and is set to 99999. When the PE value is equal to zero, MI is undefined and set to -9999. Some extremely high values for monthly MI's may still appear in the data set but may be less than 9999.9. A check for these conditions should be made when using monthly data.

SOURCE(S): Webb, T. 1976. Climatological Magnetic Tape File. Brown University, RI.

REFERENCE(S): Webb 1976, Thornthwaite 1948.

COMMENTS: The estimation procedure did not adjust for elevation so caution should be used with data in mountainous areas. When using monthly data, check for unreasonable MI values ( -9999 if the corresponding $P E$ value is zero, 99999 if the MI value is greater than 9999.9).

$\operatorname{YEAR}(\mathrm{S}): \quad 1941-1970$

GEOCOVE RAGE : East

STATUS: Online

NUMBER OF RECORDS : 2660

CREATED/UPDATED: Mar. 1980

COMPILER: T Webb, III
TEMPORAL RESOLUTION: NormS SPATIAL RESOLUTION: County DATA SET TYPE: Single VARIABLES PER RECORD: 15 NEW DATA: Not anticipated
Annual moisture index April moisture index August moisture index December moisture index February moisture index FIPS county number FIPS state number January moisture index July moisture index 


$$
\begin{array}{ll}
\text { JUN_M I- } & \text { June moisture index } \\
\text { MAR_M-I- } & \text { March moisture index } \\
\text { MAY-M-I- } & \text { May moisture index } \\
\text { NOV-M-I- } & \text { November moisture index } \\
\text { OCT-M-I- } & \text { October moisture index } \\
\text { SEP_M-I- } & \text { September moisture index }
\end{array}
$$




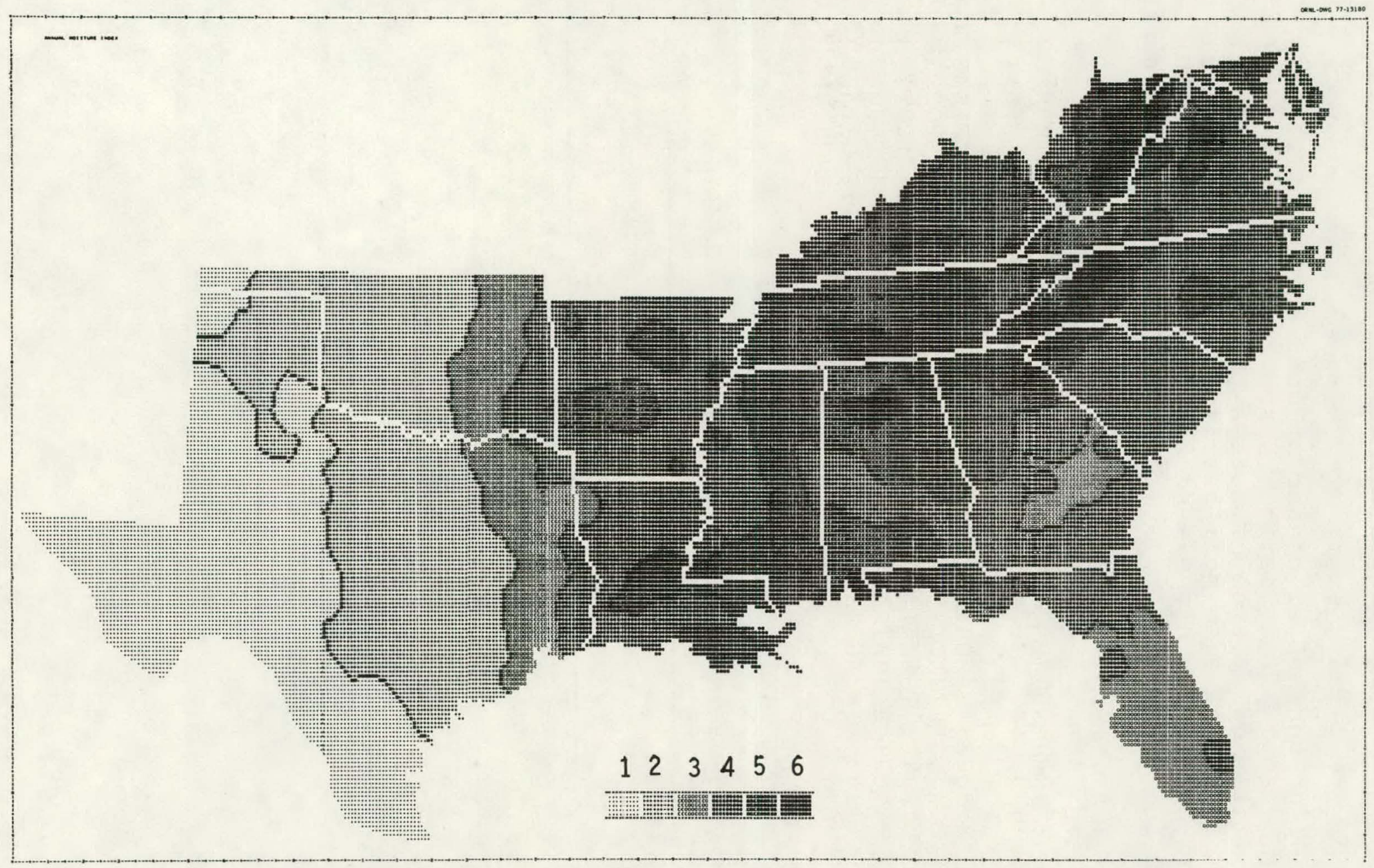

C10.1 Annual Moisture Index Calculated from 30-Year Monthly Temperature and Precipitation Norms. Interval limits: $<-40.0$, (2) $-40.0-0.0$, (3) $0.0-20.0$, (4) $20.0-40.0$, (5) $40.0-60.0,(6)>60.0$. 


\section{TITLE: Cll - MONTHLY AVERAGE TEMPERATURES BY DIVISION}

DESCRIPTION: The monthly and annual average temperatures for state Climatic vivisions (SCD's) were calculated from monthly data for the 30 -year period 1941 to 1970. See Climate. Overview for additional documentation. Data for individual years for the period 1931 to 1975 are available (Watts et al. 1980).

SOURCE(S): National Climatic Center. 1978. Monthly Temperature and Precipitation Normals for state Climatic Divisions, 1931-1976, Magnetic Tape. National Climatic Center, Asheville, NC.

REFERENCE(S): Watts et al. 1980, USDC 1973c.

YEAR (S) : $1941-1970$

GEOCOVE RAGE : U. S.

STATUS: Online

NUMBER OF RECORDS : $\quad 353$

CREATED/UPDATED: Mar . 1980

COMPILER: $R$ J Olson
TEMPORAL RESOLUTION: NOrmS SPATIAL RESOLUTION: SCD DATA SET TYPE: Single VARIABLES PER RECORD: 15 NEW DATA: Every 10 years

\begin{tabular}{|c|c|c|}
\hline 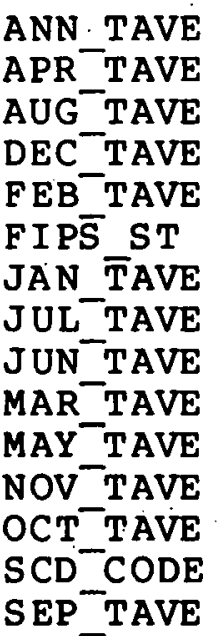 & $\begin{array}{l}\text { Annual average temperature } \\
\text { April average temperature } \\
\text { August average temperature } \\
\text { December average temperature } \\
\text { February average temperature } \\
\text { FIPS state number } \\
\text { January average temperature } \\
\text { July average temperature } \\
\text { June average temperature } \\
\text { March average temperature } \\
\text { May average temperature } \\
\text { November average temperature } \\
\text { October average temperature } \\
\text { State Climatic Division code } \\
\text { September average temperature }\end{array}$ & $\begin{array}{l}C \\
C \\
C \\
C \\
C \\
C \\
C \\
C\end{array}$ \\
\hline
\end{tabular}


Cl1.1 Monthly Temperature Ranges (Maximum, Average, Minimum) for East Tenncssee.

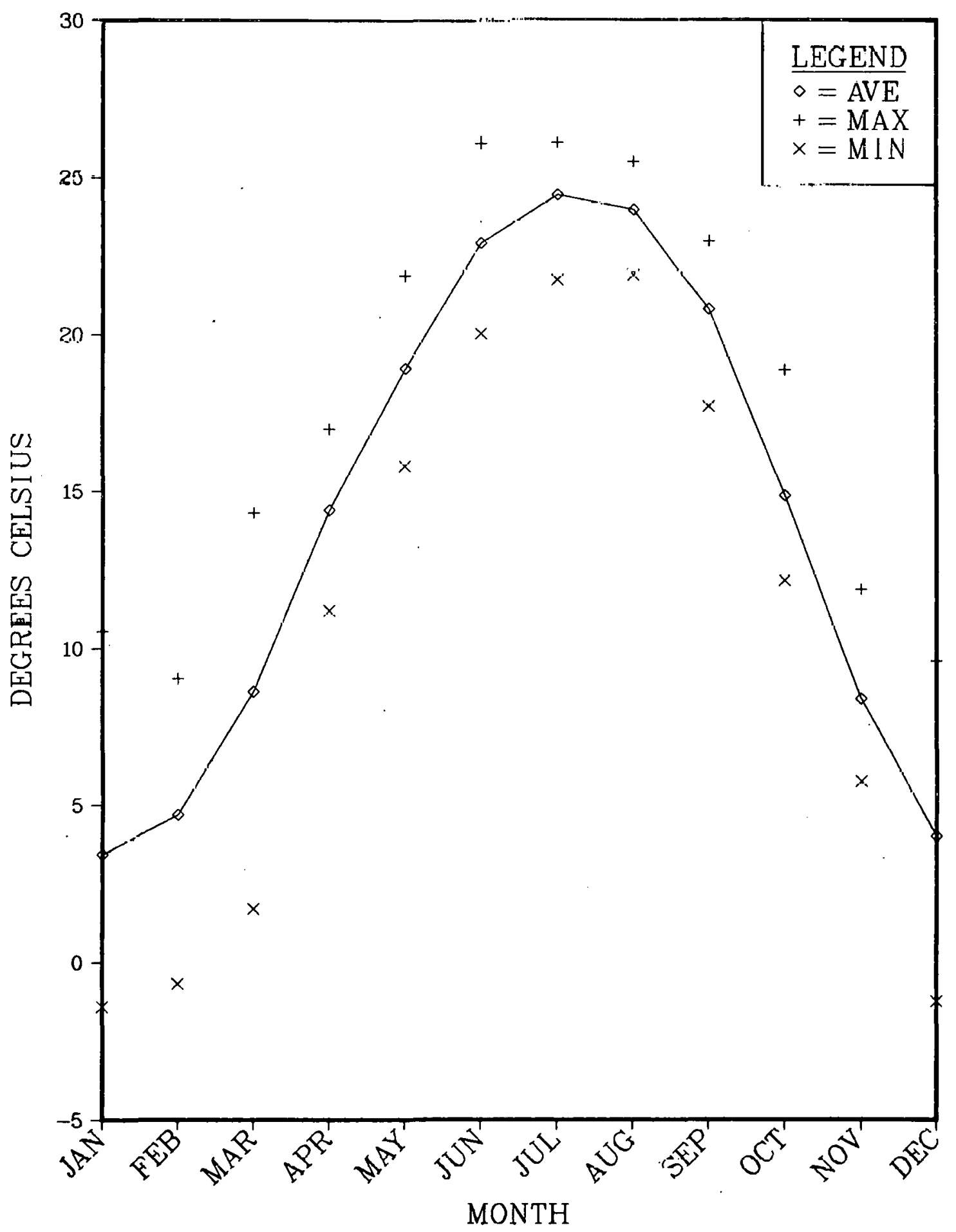


TITLE: - C12 - MONTHLY MAXIMUM TEMPERATURES BY DIVISION

DESCRIPTION: The monthly and annual maximum temperatures for State Climatic Divisions (SCD's) were calculated from monthly data for the 30-year period 1941 to 1970. See Climate Overview for additional documentation. Data for individual years for the period 1931 to 1975 are available (watts et al. 1980).

SOURCE(S): National Climatic Center. 1978. Monthly Temperature and Precipitation Normals for state Climatic Divisions, 1931-1976, Magnetic Tape. National Climatic Center, Asheville, NC.

REFERENCE (S): Watts et al. 1980, USDC $1973 \mathrm{C}$.

YEAR (S) : $\quad 1941-1970$ GEOCOVE RAGE : U. S. STATUS: Online NUMBER OF RECORDS : $\quad 353$ CREATED/UPDATED: Mar . 1980

COMPILER: $\mathrm{R} \mathrm{J}$ Olson
TEMPORAL RESOLUTION: NormS SPATIAL RESOLUTION: SCD DATA SET TYPE: Single VARIABLES PER RECORD: 15 NEW DATA : Every 10 years

VARIABLE LABEL AND UNITS OF MEASURE

\begin{tabular}{lll}
\hline ANN_TMAX & Annual maximum temperature & C degrees \\
APR_TMAX & April max imum temperature & C degrees \\
AUG TMAX & August maximum temperature & C degrees \\
DEC-TMAX & December maximum temperature & C degrees \\
FEB-TMAX & February max imum temperature & C degrees \\
FIPS ST & FIPS state number & \\
JAN_TMAX & January maximum temperature & C degrees \\
JULTTMAX & July maximum temperature & C degrees \\
JUN_TMAX & June maximum temperature & C degrees \\
MAR_TMAX & March maximum temperature & C degrees \\
MAYTTMAX & May maximum temperature & C degrees \\
NOV_TMAX & November maximum temperature & C degrees \\
OCT_TMAX & October maximum temperature & C degrees \\
SCD_CODE & State Climatic Division code & \\
SEP_TMAX & September maximum temperature & C degrees \\
\hline
\end{tabular}


TITLE: C13 - MONTHLY MINIMUM TEMPERATURES BY: DIVISION

DESCRIPTION: : The monthly and annual mimimum temperatures for State Climatic Divisions (SCD's) were calculated from monthly data for the 30-year period 1941 to 1970. See Climate Uverview tor additional documentation. Data for individual years for the period 1931 to 1975 are available. (Watts et al. 1980).

SOURCE(S): National Climatic Center. 1978. Monthly Temperature and Precipitation Normals for state Climatic Divisions, 1931-1976, Magnetic Tape. National Climatic Center, Àsheville, NC.

REFERENCE (S): Watts et al. 1980, USDC 1973c.

YEAR(S): 1941-1970 GEOCOVE RAGE : U. S. STATUS: Online. NUMBER OF RECORDS : $\quad 353$ CREATED/UPDATED: Mar: 1980 COMPILER: R J Olson
TEM PORAL RESOLUTION: NO RMS SPATIAL RESOLUTION: SCD DATA SET TYPE: Single VARIABLES PER RECORD: 15 NEW DATA: Every 10 years

\section{VARIABLE}

LABEL AND UNITS OF MEASURE

\begin{tabular}{lll}
\hline ANN TMIN & Annual minimum temperature & C degrees \\
APR_TMIN & April minimum temperature & C degrees \\
AUG TMIN & August minimum temperature & C degrees \\
DEC-TMIN & December minimum temperature & C degrees \\
FEB TMIN & February minimum temperature & C degrees \\
FIPSTS & FIPS state number & \\
JAN_TMIN & January minimum temperature & C degrees \\
JUL_TMIN & July minimum temperature & C degrees \\
JUN_TMIN & June minimum temperature & C degrees \\
MAR_TMIN & March minimum temperature & C degrees \\
MAY_TMIN & May minimum temperature & C degrees \\
NOV_TMIN & November minimum temperature & C degrees \\
OCT_TMIN & October minimum temperature & C degrees \\
SCD_CODE & State Climatic Division code & \\
SEP_TMIN & September minimum temperature & C degrees \\
& &
\end{tabular}


TITLE: CI4 - MONTHLY AVERAGE PRECIPITATION BY DIVISN

DESCRIPTION: The monthly and annual average precipitation for Statc Climatic Divisions (SCD's) was calculated from monthly data for the 30-year period 1941 to 1970. See Climate Overview for additional documentation. Data. for individual years for the period 1931 to 1975 are available (Watts et al. 1980).

SOURCE(S): National Climatic Center. 1978. Monthly Temperature and Precipitation Normals for State Climatic Divisions, 1931-1976, Magnetic Tape. Natlonal Climatic. Center, Asheville, NC.

REFERENCE(S): Watts et al. 1980, USDC 1973 C.

YEAR (S) : $\quad 1941-1970$

GEOCOVERAGE : U. S.

STATUS: Online

NUMBER OF RECORDS :

353

CREATED/UPDATED: Mar. 1980

COMPILER: $\mathrm{R} J$ Olson
TEMPORAL RESOLUTION: NOrMS SPATIAL RESOLUTION: SCD DATA SET TYPE: Single VARIABLES PER RECORD: 15 NEW DATA: Every 10 years

\section{VARIABLE LABEL AND UNITS OF MEASURE}

\begin{tabular}{lll}
\hline ANN_PAVE & Annual average precipitation & $\mathrm{cm}$ \\
APR_PAVE & April average precipitation & $\mathrm{cm}$ \\
AUG_PAVE & August average precipitation & $\mathrm{cm}$ \\
DEC-PAVE & December average precipitation & $\mathrm{cm}$ \\
FEB_PAVE & February average precipitation & $\mathrm{cm}$ \\
FIPS ST & FIPS state number & \\
JAN_PAVE & January average precipitation & $\mathrm{cm}$ \\
JUL_PAVE & July average precipitation & $\mathrm{cm}$ \\
JUN_PAVE & June average precipitation & $\mathrm{cm}$ \\
MAR_PAVE & March average precipitation & $\mathrm{cm}$ \\
MAY_PAVE & May average precipitation & $\mathrm{cm}$ \\
NOV_PAVE & November average precipitation & $\mathrm{cm}$ \\
OCT_PAVE & October average precipitation & $\mathrm{cm}$ \\
SCD_CODE & State Climatic Division code & \\
SEP_PAVE & September average precipitation & $\mathrm{cm}$ \\
\end{tabular}


C14.1 Monthly Precipitation Ranges (Maximum, Average, Minimum) for East Tennessee.

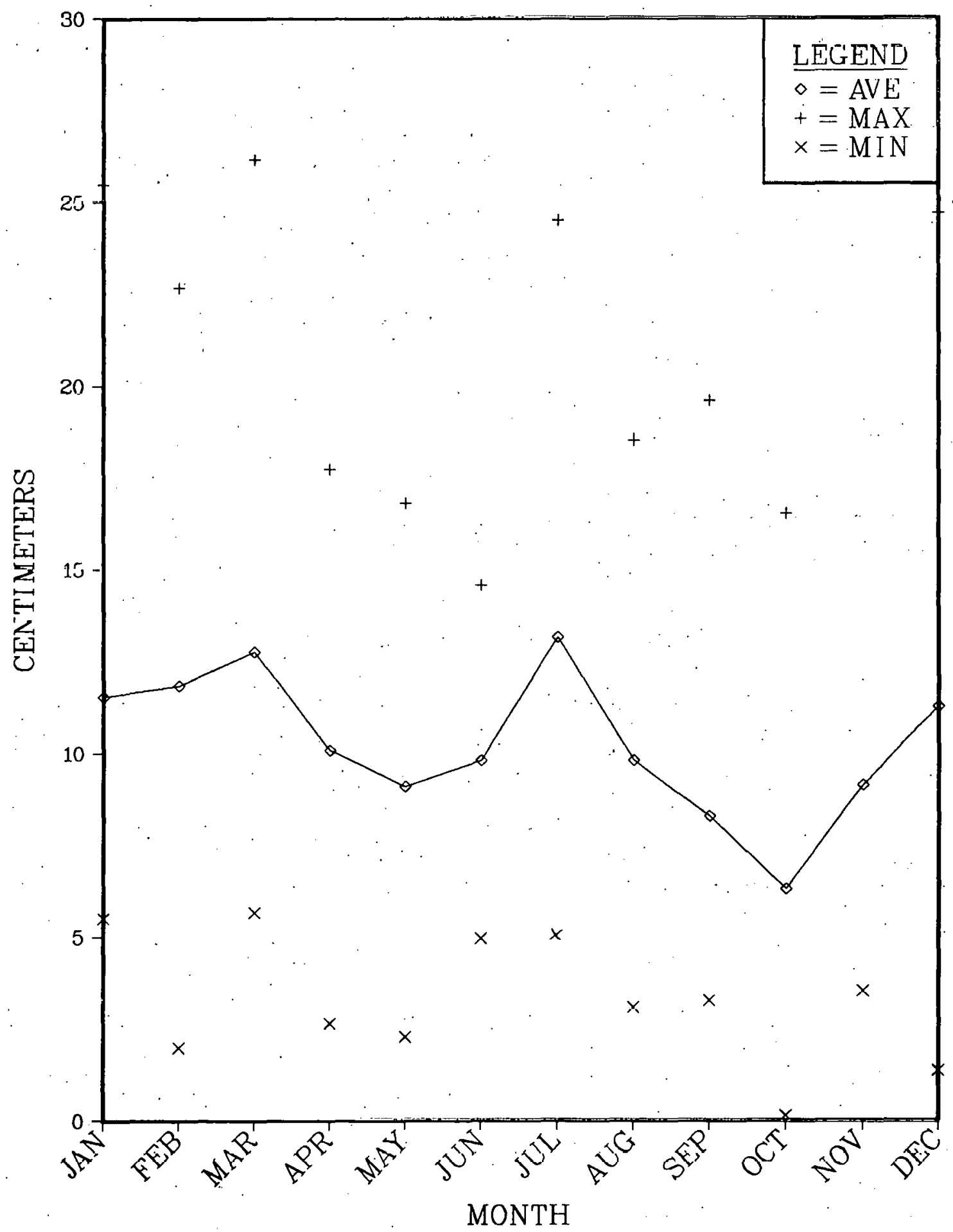


TITLE: CI5 - MONTHLY MAXIMUM PRECIPITATION BY DIVISN

DESCRIPTION: The monthly and annual maximum precipitation for State Climatic vivisions (SCD's) was calculated from monthly data for the 30-year period 1941 to 1970. See Climate Overview for additional documentation. Data for individual years for the period 1931 to 1975 are available (Watts et al. 1980).

SOURCE(S): National Climatic Center. 1978. Monthly Temperature and Precipitation Normals for state Climatic Divisions, 1931-1976, Magnetic Tape. National Climatic Center, Asheville, NC.

REFERENCE(S): Watts et al. 1980, USDC $1973 \mathrm{C}$.

YEAR(S): $\quad 1941-1970$

GEOCOVE RAGE : . U. S.

STATUS: Onl ine

NUMBER OF RECORDS : $\quad 353$

CREATED/UPDATED: Mar. 1980

COMPILER: $\quad \mathrm{R} \mathrm{J}$ Olson
TEM PORAL RESOLUTION: NO rms SPATIAL RESOLUTION: SCD DATA SET TYPE: Single VARIABLES PER RECORD: 15 NEW DATA: Every 10 years

$\begin{array}{lll}\text { ANN_PMAX } & \text { Annual maximum precipitation } & \mathrm{cm} \\ \text { APR_PMAX } & \text { April maximum precipitation } & \mathrm{cm} \\ \text { AUG_PMAX } & \text { August maximum precipitation } & \mathrm{cm} \\ \text { DEC_PMAX } & \text { December maximum precipitation } & \mathrm{cm} \\ \text { FEB_PMAX } & \text { February maximum precipitation } & \mathrm{cm} \\ \text { FIPS ST } & \text { FIPS state number } & \\ \text { JAN_PMAX } & \text { January maximum precipitation } & \mathrm{cm} \\ \text { JUL_PMAX } & \text { July maximum precipitation } & \mathrm{cm} \\ \text { JUN_PMAX } & \text { June maximum precipitation } & \mathrm{cm} \\ \text { MAR_PMAX } & \text { March maximum precipitation } & \mathrm{cm} \\ \text { MAY_PMAX } & \text { May maximum precipitation } & \mathrm{cm} \\ \text { NOV_PMAX } & \text { November maximum precipitation } & \mathrm{cm} \\ \text { OCT_PMAX } & \text { October maximum precipitation } & \mathrm{cm} \\ \text { SCD_CODE } & \text { State Climatic Division code } & \\ \text { SEP_PMAX } & \text { September maximum precipitation } & \mathrm{cm}\end{array}$


TITLE: C16 - MONTHLY MINIMUM PRECIPITATION BY DIVISN

DESCRIPTION: The monthly and annual minimum precipitation for state Climatic Divisions (SCD's) was calculated from monthly data for the 30-year period 1941 to 1970. See Climate Overview for additional documentation. Data for individual years for the period 1931 to 1975 are available (Watts et al. 1980).

SOURCE(S): National Climatic Center. 1978. Monthly Temperature and Precipitation Normals for state Climatic Divisions, 1931-1976, Magnetic Tape. National Climatic Center̃, Ashevillie, NC.

REFERENCE(S): Watts et al. 1980, USDC 1973c.

YEAR(S): $\quad 1941-1970$

GEOCOVERAGE : U. S.

STATUS: Online

NUMBER OF · RECORDS : 353

CREATED/UPDATED: Mar . 1980

COMPILER: $\quad \mathrm{R}$ J Olson
TEM PORAL RESOLUTION : Norms SPATIAL RESOLUTION: SCD DATA SET TYPE: Single VARIABLES PER RECORD: 15 NEW DATA: Every 10 years

\section{VARIABLE LABEL AND UNITS OF MEASURE}

\begin{tabular}{lll}
\hline ANN_PMIN & Annual minimum precipitation & $\mathrm{cm}$ \\
APR_PMIN & April minimum precipitation & $\mathrm{cm}$ \\
AUG_PMIN & August minimum precipitation & $\mathrm{cm}$ \\
DECPMIN & December minimum precipitation & $\mathrm{cm}$ \\
FEB-PMIN & February minimum precipitation & $\mathrm{cm}$ \\
FIPS_ST & FIPS state number & \\
JAN_PMIN & January minimum precipitation & $\mathrm{cm}$ \\
JUL_PMIN & July minimum precipitation & $\mathrm{cm}$ \\
JUN-PMIN & June minimum precipitation & $\mathrm{cm}$ \\
MAR_PMIN & March minimum precipitation & $\mathrm{cm}$ \\
MAY_PMIN & May minimum precipitation & $\mathrm{cm}$ \\
NOV_PMIN & November minimum precipitation & $\mathrm{cm}$ \\
OCT_PMIN & October minimum precipitation & $\mathrm{cm}$ \\
SCD_CODE & State Climatic Division code & \\
SEP_PMIN & September minimum precipitation & $\mathrm{cm}$ \\
& &
\end{tabular}


TITLE: CI7 - CLIMATIC DIVISION INDEX

DESCRIPTION: State Climatic Divisions (SCD's) are areas within states with similar climatic characteristics. Often the SCD's are aggregates of contiguous rounties; however, in mountainous areas, the SCD's may subdivide counties. This data set defines the counties or portions of counties within each SCD. It was created by digitizing the map of SCD's (USDC 1968, page 5.0). When a county occurred in more than one $S C D$, the proportion in each was measured with a planimeter. Individual state maps showing county 1 ines and SCD lines were used. Cl9 provides the namcs and state weighting factors (population- and area-based) for each SCD. c1l-Cl6 contain climatic data for SCD's.

SOURCE(S): USDC 1968, p 50; USDC 1977.

$\operatorname{YEAR}(\mathrm{S}): \quad 1970$

GEOCOVE RAGE : U. S.

STATUS: Online

TEMPORAL RESOLUTION: Cur rent NUMBER OF RECORDS : $\quad 3431$
CREATED/UPDATED: Mar. 1980 SPATIAL RESOLUTION: County COMPILER: M K Nungesser, $R$ M Anderson

DATA SET TYPE: Index

VARIABLES PER RECORD: 5 NEW DATA: Not anticipated

\begin{tabular}{ll}
\hline VARIABLE & LABEL AND UNITS OF MEASURE \\
\hline FIPS_CO & FIPS county number \\
FIPS_ST & FIPS state number \\
SCD_AREA & Area of county in SCD \\
SCD_CODE & State Climatic Division code \\
SCD_PART & Portion of county in SCD
\end{tabular}


TITLE: C18 - GROWING SEASON LENGTH, FIRST/LAST FROST

DESCRIPTION: The growing season is defined in terms of the last spring frost date, first fall frost date, and the length of the growing season in days. The first and last frost dates were digitized from maps in the Climatic Atlas (USDC 1968, pp 29-30) and the length calculated from the two dates.

SOURCE (S): USDC 1968, pp 29-30.

COMMENTS: The Julian dates were created such that January first is stored as 60001 and December 31 st as 60365 .

YEAR(S): 1968

GEOCOVE RAGE : East

STATUS : Online

NUMBER OF RECORDS : 2660

CREATED/UPDATED: Mar. 1980

COMPILER: L K Mann, W M Post
TEMPORAL RESOLUTION: NormS SPATIAL RESOLUTION: County DATA SET TYPE: Single VARIABLES PER RECORD: 5 NEW DATA: Not anticipated

\section{VARIABLE}

LABEL AND UNITS OF MEASURE

\section{FALF ROST \\ FIPS CO \\ FIPS $-\mathrm{ST}$ \\ GROW DAY \\ SPRF $\bar{R} O S T$}

First fall frost, Julian date

FIPS county number

FIPS state number

Growing season length in days

Last spring frost, Julian date 


\section{C18.1 Growing Season Length (days) for the Eastern United States.}

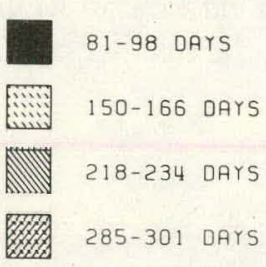

GROWING SEASON FOR THE EASTERN UNITED STATES

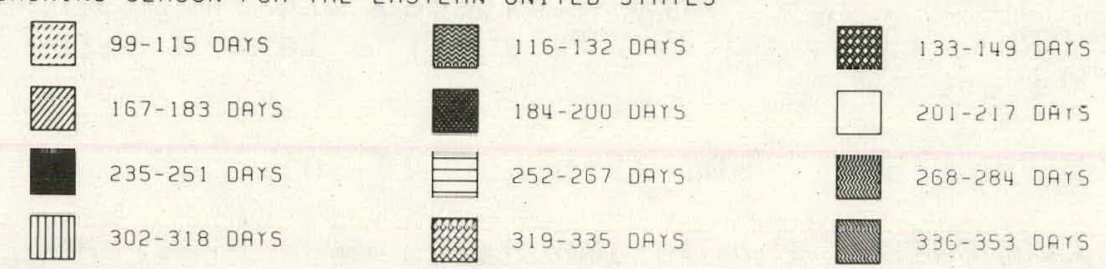

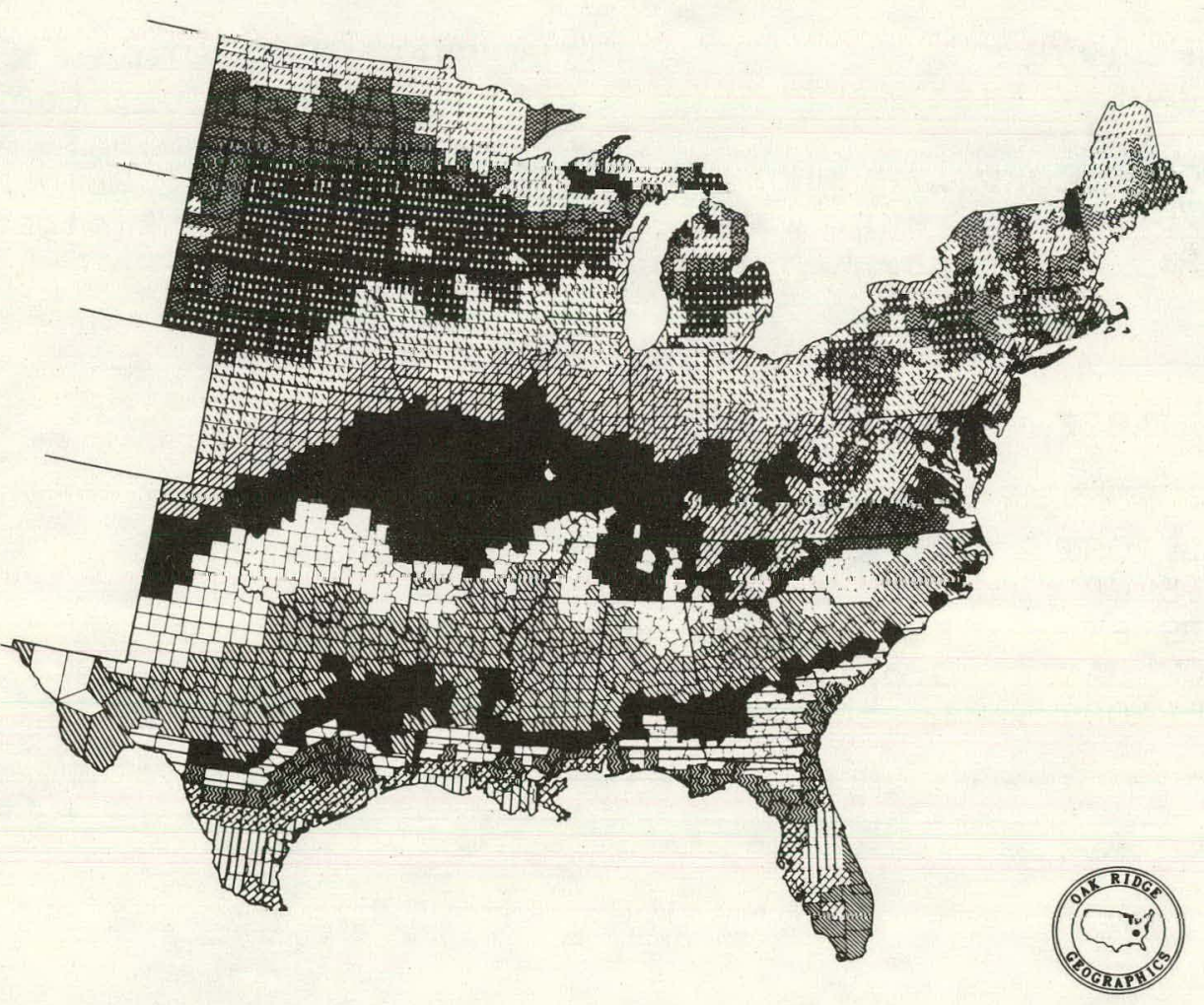


TITLE: C19 - STATE CLIMATIC DIVISION NAMES/WEIGHTS

DESCRIPTION: State Climatic Divisions (SCD's) are areas within states with similar climatic characteristics. This data set includes names and state weighting factors (population and area) for the 353 SCD's. Cll-Cl6 contain SCD climatic data and Cl7 contains definitions of counties within SCD's.

SOURCE(S): USDC 1977.

$\operatorname{YEAR}(\mathrm{S}): \quad 1975$

GEOCOVERAGE : U. S.

STATUS: Online

NUMBER OF RECORDS : $\quad 344$

CREATED/UPDATED: Mar . 1980

COMPILER: $M \mathrm{~K}$ Nungesser, $\mathrm{V}$
TEMPORAL RESOLUTION: Cur rent SPATIAL RESOLUTION: SCD DATA SET TYPE: Index VARIABLES PER RECORD: 5 NEW DATA: Not anticipated Myers

\begin{tabular}{ll}
\hline VARIABLE & LABEL AND UNITS OF MEASURE \\
\hline FIPS_ST & FIPS state number \\
SCD_A WT & Area weighted value \\
SCD_CDDE & State Climatic Division code \\
SCD_NAME & State Climatic Division name \\
SCD_P_WT & Population weighted value
\end{tabular}


TITLE: C20 - RAINFALL PH \& H-ION LOADINGS

DESCRIPTION: The problems associated with increased acidity of rainfall in the eastern United Staes are being studied to understand regional environmental impacts. The pattern of rainfall acidity for 1974 (Cogbill and Likens 1974) was digitized and combined with average annual rainfall (C08) to calculate an estimate of hydrogen-ion loading factors. The formula used was: H-ions per square meter $=$ rainfall $\mathrm{pH}$ * annual rainfall (cm) * 10 .

SOURCE(S): Cogbill and Likens 1974. C08.

REFERENCE(S): Klopatek et al. 1980a.

YEAR (S) : 1974

GEOCOVE RAGE : East

STATUS: Online

NUMBER OF RECORDS : 1572

CREATED/UPDATED: Mar. 1980

COMPILER: J M Klopatek, C S Tucker

TEMPORAL RESOLUTION: Annual SPATIAL RESOLUTION: County DATA SET TYPE: Single VARIABLES PER RECORD: NEW DATA: As available
ANN RAIN

FIPS CO

FIPS ${ }^{-}$T

H ION S

$\mathrm{R} \overline{\mathrm{A}} \mathrm{IN} \mathrm{PH}$
Annual rainfall, 1941-1970 norms, cm FIPS county number

FIPS state number

Hydrogen ion loading factor - $\mathrm{H}$ ions $/ \mathrm{m} 2$ $\mathrm{pH}$ of rainfall as of 1974 
ORNL-DWG 79-15155

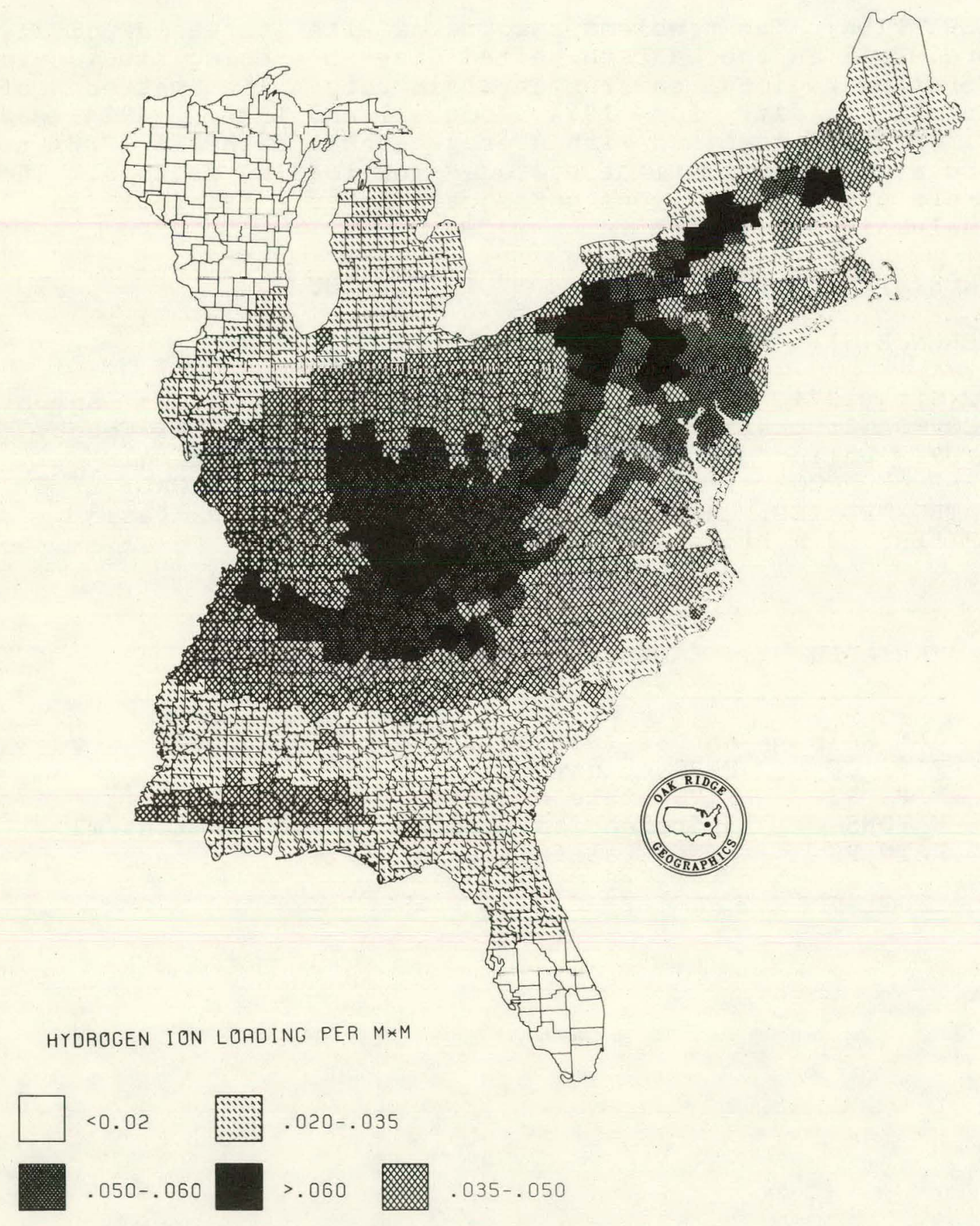

C20.1 1974 Rainfall pH for the Eastern United States. 


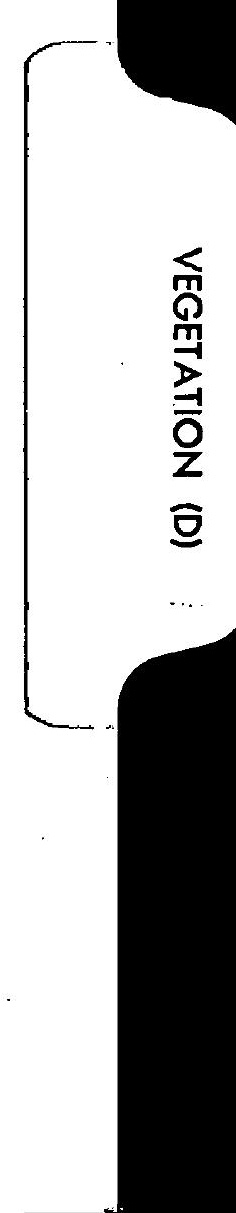




\section{VEGETATION (D) SECTOR OVERVIEW}

The Vegetation Sector is based primarily on two interrelated maps of ecoregions and potential natural vegetation. Ecoregions (Bailey 1976, Bailey 1978) represent a hierarchical landscape classification scheme based on climate, solls, and vegetation. There are 54 ecoregions at the section level in the conterminous United States. The vegetation aspect of the classification scheme is based on potential natural vegetation (Küchler 1964, USDI 1970 sheets 89 and 90). We have used Küchler's 1966 map (USDI 1970 sheet $8 y$ and $y(0)$ to define the county occurrences. However, the larger scale 1964 map (Küchler 1964) was used to help locate the vegetation boundaries. There are 106 vegetation types in the conterminous United states. The ecoregion and vegetation boundaries were aligned and the proportion of each ecoregion/vegetation combination within a county was estimated to create data set Dl0. Most other vegetation files were derived from Dlo.

The natural vegetation and ecoregion maps reflect potential climax conditions which might occur if man's impacts could be removed. Limitations of the Kuichler map have been recognized (Klopatek et al. 1979). To have the data : reflect current. conditions, the potential natural vegetation types were adjusted for current land-use practices occurring within counties. Each vegetation: type was assigned a probability of being converted by man to agriculture, pasture, or inundation. Vegetation types were then proportionally reduced within a county for these and for urban build-up changes. 
TITLE: DOI - TREE-SPECIES CODES DICTIONARY

DESCRIPTION: The dictionary of tree species includes Latin genus/species names, common names, USFS numeric codes, and ORNL mnemonic codes. The mnemonic codes consist of letters from the genus and species names selected to form unique and meaningful sequences. The algorithm for creating mnemonic codes involves deleting vowels, except the first character, followed by consonants until unique six- to eight-character codes are created. The codes are used with D02, F06 and F07.

SOURCE(S): USDA 1967

REFERENCE(S): Schreiber et al. 1974

$\operatorname{YEAR}(\mathrm{S}): 1966$

GEOCOVERAGE : U. S.

STATUS: Onl ine

NUMBER OF RECORDS :

CREATED/UPDATED: Mar. 1980

COMPILER: R R Schreiber,

TEMPORAL RESOLUTION :

SPATIAL RESOLUTION:

DATA SET TYPE: DictnrY

VARIABLES PER RECORD:

NEW DATA: Not anticipated

R L Stephenson, F G Goff

VARIABLE

LABEL AND UNITS OF MEASURE

$\begin{array}{ll}\text { TREE_DSC } & \text { Tree species common name } \\ \text { TREE-SPC } & \text { Tree genus-species scientific name } \\ \text { TREECODE } & \text { Tree species mnemonic code } \\ \text { TREE_KEY } & \text { Tree species code number }\end{array}$


TITLE: D02 - TREE SPECIES RANGES (LITTLE)

DESCRIPTION: County-level ranges of 203 tree species were digitized from Little's Atlas (1971) covering most commercially important species in the conterminous United states. The technique described by Schreiber et al. (1974) was initially used to digitize the maps and store the data. The ranges were subsequently stored in the Geoecology Data Base.

SOURCE(S): Little 1971:

REFERENCES(S): Schreiber et al. 1974.

COMMENTS: Program RANGER (Schreiber et al. 1974) provides a means to digitize and manipulate qualitative county-level data.

YEAR (S) : $\quad 1966$

GEOCOVERAGE : U. S.

STATUS: Offline

NUMBER OF RECORDS : 100,000

CREATED/UPDATED: Mar . 1980 COMPILER: R K Schreiber, R L Stephenson, F. G Goff

TEMPORAL RESOLUTION: Hist. SPATIAL RESOLUTION: County DATA SET TYPE: Multiple VARIABLES PER RECORD: 3 NEW DATA: Not anticipated
VARIABLE

LABEL AND UNITS OF MEASURE

FIPS_CO

FIPS county number

FIPS state number

Tree species mnemonic code 
TITLE: DO3 - POT. \& ADJ. VEGETATION NATIONAL STATS

DESCRIPTION: National and regional summary statistics for potential and land-use-adjusted natural vegetation were calculated from Do4. See the Vegetation Overview for additional information on vegetation data and regions. Areal extent, fraction of the total, and county occurrence frequencies are given for each vegetation type for the eastern forest region, central plains region, and western mountains region, and for the nation. Names are given for the 106 kïchler vegetation codes.

SOUTRCE (S): DO4

REFERENCE(S) : Klopatek et al. 1979.

COMMENTS: The SAS FORMAT procedure may be used to substitute vegetation names for codes (see section on Special Output Formats).

$\operatorname{YEAR}(\mathrm{S}): \quad 1966-1967$

GEOCOVE RAGE : U. S.

STATUS: Online

NUMBER OF RECORDS : 106

CREATED/UPDATED: Mar. 1980

COMPILER: $\quad \mathrm{R} \mathrm{J}$ Olson
TEMPORAL RESOLUTION: Hist. SPATIAL RESOLUTION: DATA SET TYPE: Dictnry VARIABLES PER RECORD: 26 NEW DATA: Not anticipated

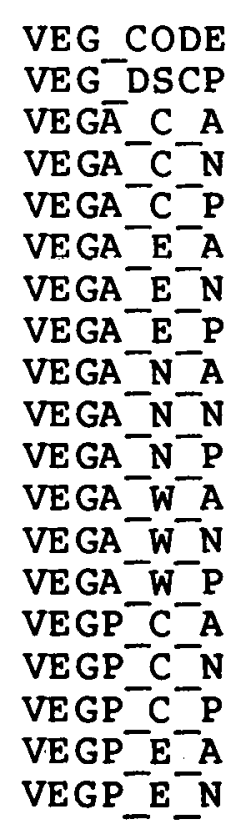

VEG_CODE

VEG DSCP

VEGĀ $C A$

VEGA $-\mathrm{C}-\mathrm{N}$

VEGA $C-P$

VEGA $E-A$

VEGA $E-N$

VEGA $E-P$

VEGA N $\mathrm{N}$

VEGA_N_N

VEGA W-A

VEGA ${ }^{-}-\mathrm{N}$

VEGA $W^{-} P$

VEGP ${ }^{-}{ }^{-} A$

VEGP ${ }^{-}-\mathrm{N}$

VEGP $\mathrm{C}^{-} \mathrm{P}$

VEGP $-\mathrm{E}$
Vegetation code, 1966 Klichler, 001-106

Vegetation description

Adj. vegetation central area

Adj. vegetation no. counties in central Fraction of adj. vegetation in central

Adj. vegetation eastern area ha

Adj. vegetation no. counties in east

Fraction of adj. vegetation in east

Adj. vegetation national area ha

Adj. vegetation national no. counties

Fraction of adj. vegetation in nation

Adj. vegetation western area ha

Adj. vegetation no. counties in west

Fraction of adj. vegetation in west

Pot. vegetation central area

Pot vegetation no. counties in central

Fraction of pot vegetation in central

Pot. vegetation eastern area

Pot. vegetation no. counties in east 
VEGP E P VEGP ${ }^{-}-A$ $\operatorname{VEGP}-\mathrm{N}^{-\mathrm{N}}$ VEGP ${ }^{-} \mathrm{P}$ VEGP ${ }^{-} A$ VEGP $W-\mathrm{N}$ VEGP ${ }^{-}-P$
Fraction of pot. vegetation in east Pot. vegetation national area ha Fot. vegetation national no. counties Fraction of pot. vegetation in nation Pot. vegetation western area Pot. vegetation no. counties in west Fraction of pot. vegetation in west 
D03.1 Potential Vegetation Percentages for the United States.

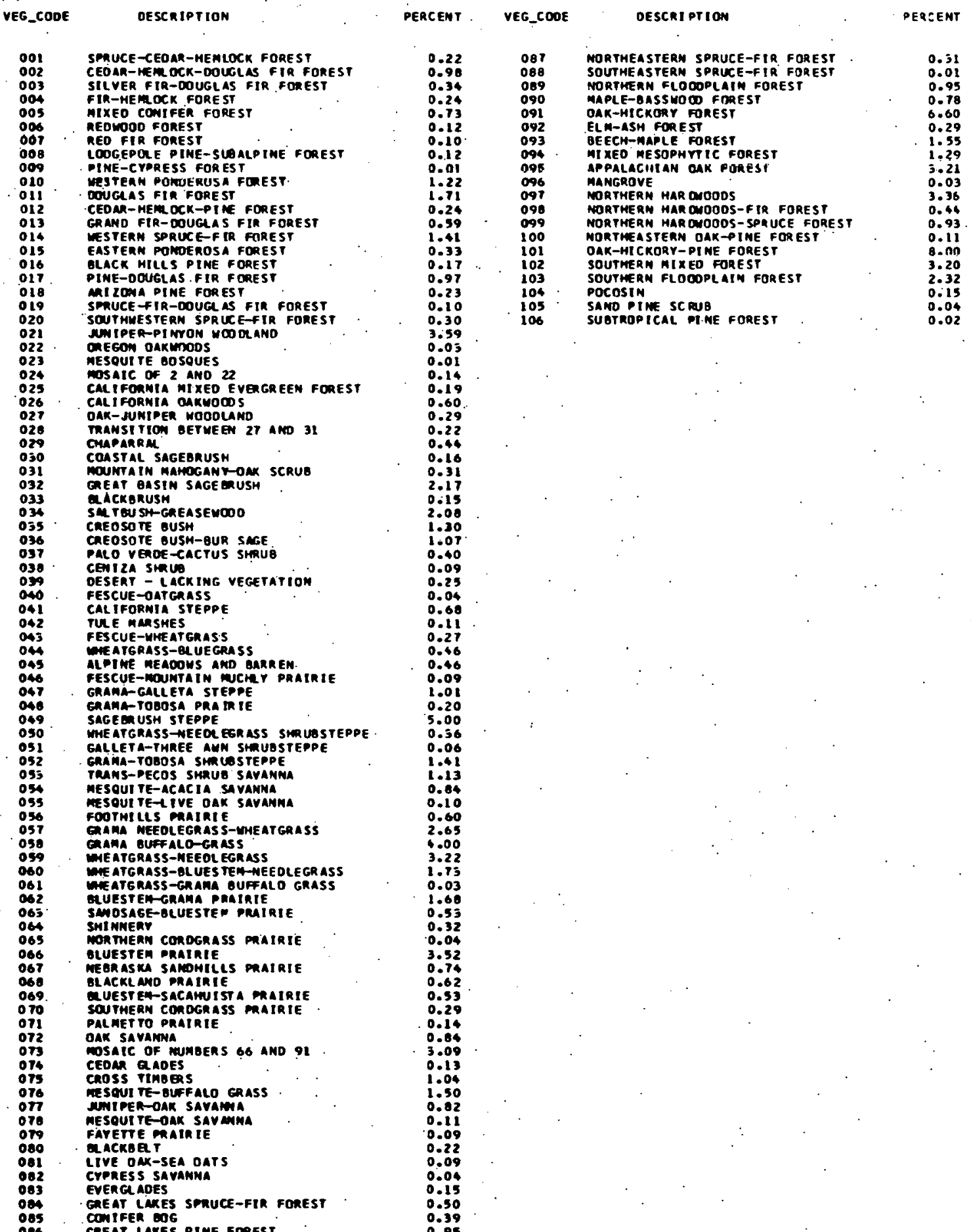


TITLE: D0 4 - POT. \& ADJ. VEGETATION

DESCRIPTION: Potential and land-use-adjusted areas of each type of natural vegetation occurring within a county were calculated from Dl0. See the Vegetation Overview for additional information on the vegetation data.

SOURCE(S) : D10.

REFERENCE(S): Klopatek et al. 1979.

$\operatorname{YEAR}(\mathrm{S}): \quad 1966-1967$

GEOCOVERAGE : U. S.

STATUS: Online

NUMBER OF RECORDS : 7227

CREATED/UPDATED: Mar. 1980

TEMPORAL RESOLUTION: Hist. SPATIAL RESOLUTION: County DATA SET TYPE: Multiple VARIABLES PER RECORD: 5 NEW DATA: Not anticipated COMPILER: C Kelsey, J M Klopatek, J L Joness

\begin{tabular}{lll} 
VARIABLE & LABEL AND UNITS OF MEASURE \\
\hline FIPS_CO & FIPS county number & \\
FIPS_ST & FIPS state number & \\
VEG_CDE & $\begin{array}{l}\text { Vegetation code, Küchler, 001-106 } \\
\text { VEGA_A }\end{array}$ & $\begin{array}{l}\text { Adjusted vegetation area } \\
\text { VEGP_A }\end{array}$ \\
\hline
\end{tabular}


D04.1 Percent Potential Vegetation Types Remaining in the Jnited States.

ORNL-OWG 70-21127

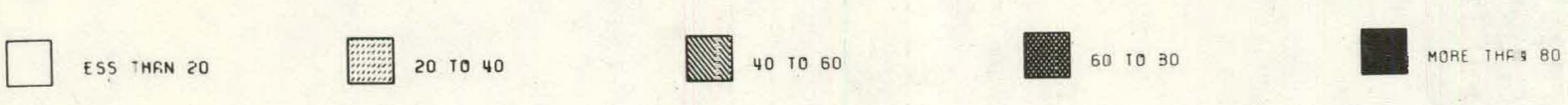

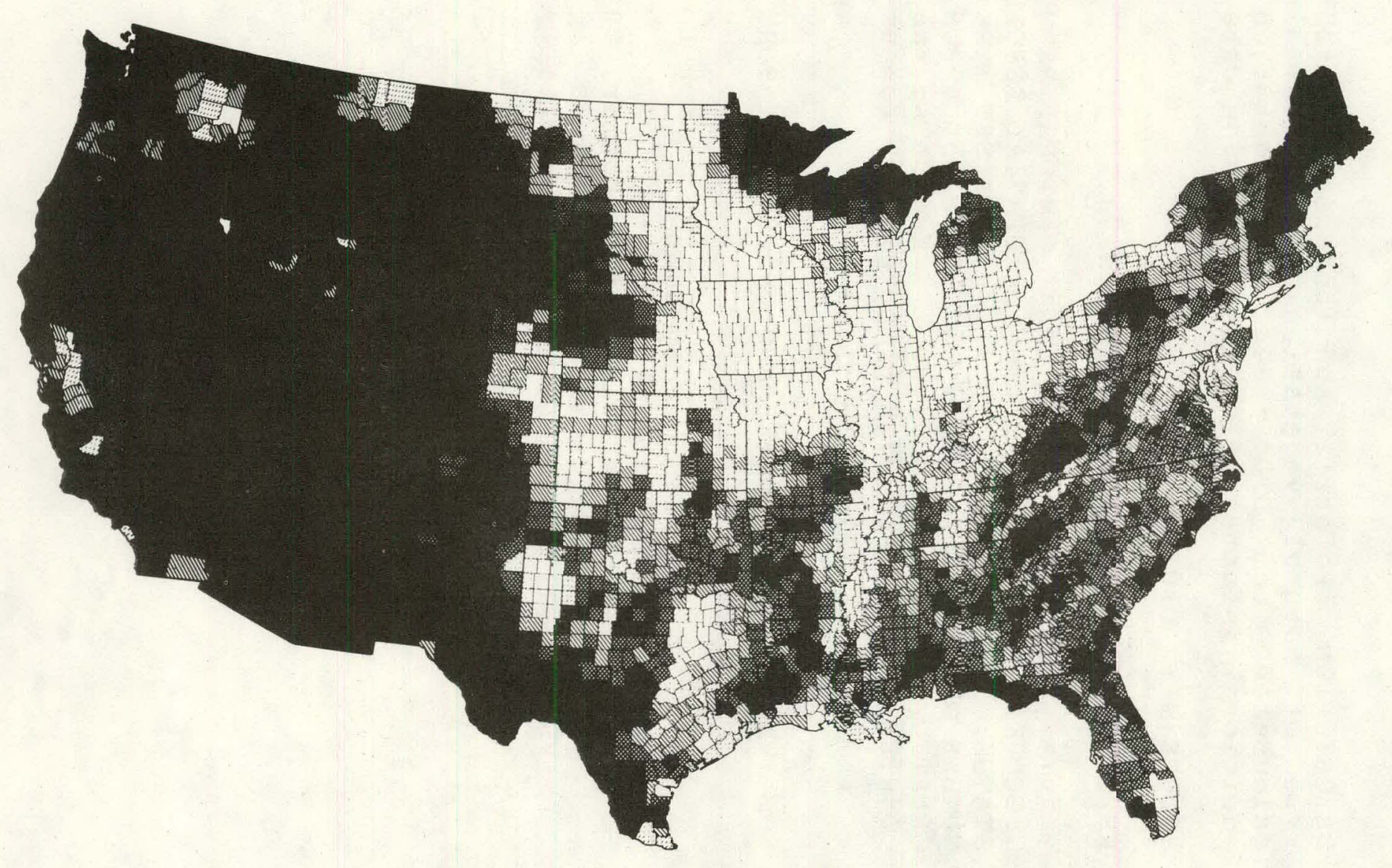

品

量 
TITLE: DO5 - VEGETATION-LAND USE CHANGE PROBABILITIES

DESCRIPTION: The algorithm to adjust potential natural vegetation for current land-use utilized conversion probabilities for each kïchler vegetation type. The probabilities consider the existing conversion of natural vegetation to cropland, pastureland, or inundation. The values contained in D05 were obtained from several sources (Klopatek et al. 1979). They were ranked 1 (high probability) to 4 (low probability).

SOURCE(S): Klopatek et al. 1979.

YEAR(S) : 1978

GEOCOVE RAGE : U. S.

STATUS: Online

NUMBER OF RECORDS : $\quad 117$

CREATED/UPDATED: Mar : 1980

COMPILER: J M Klopatek
TEMPORAL RESOLUTION: Current SPATIAL RESOLUTION:

DATA SET TYPE : Dictnry VARIABLES PER RECORD: 9

NEW DATA: Not anticipated

$\begin{array}{ll}\text { PROB_AGR } & \text { Probability of change to agriculture. } \\ \text { PROB-FOR } & \text { Probability of change to forest } \\ \text { PROB_PST. } & \text { Probability of change to pasture } \\ \text { PROB-RNG } & \text { Probability of change to range } \\ \text { PROB_WTR } & \text { Probability of being covered by water } \\ \text { PVEG-C } & \text { Vegetation code, Kúhler } 1964 \\ \text { VEG_CODE } & \text { Vegetation code, } 1966 \text { Küchler, } 001-106 \\ \text { VEG_DSCP } & \text { Vegetation description, } 1964 \text { Küchler } \\ \text { VEG_TYPE } & \text { General vegetation description - Kuichler }\end{array}$


TITLE: D06 - VEGETATION REPLACEMENT BY URBAN AREAS

DESCRIPTION: The algorithm to adjust potential natural vegetation for current land-use incorporated the replacement of vegetation types within counties by urban build-up. In the smaller eastern counties, urban build-up area was proportionally subtracted from all vegetation types occurring in a county. This data set defines vegetation types within western counties that have been urbanized. The data were obtained by overlaying a map of urban areas with Kuchler's vegetation map.

SOURCE(S): UST̄I 1970 sheets 89 and 90.

$\operatorname{YEAR}(\mathrm{S}): \quad 1978$

GEOCOVE RAGE : West

STATUS: Online

NUMBER OF RECORDS : 169

CREATED/UPDATED: Mar. 1980

COMPILER: J M Klopatek
TEMPORAL RESOLUTION: Current SPATIAL RESOLUTION: County DATA SET TYPE: Single VARIABLES PER RECORD: 3 NEW DATA: Not anticipated

\section{VARIABLE LABEL AND UNITS OF MEASURE}

\begin{tabular}{ll}
\hline FIPS_CO & FIPS county number \\
FIPS ST & FIPS state number \\
VEG_CODE & Vegetation code, Klichler, 001-106 \\
\hline
\end{tabular}


TITLE: DO7 - POT. \& ADJ. ECOREGION NATIONAL STATS

DESCRIPTION: National and regional summary statistics for potential and land-use-adjusted ecoregion areas at the section level were calculated from D08. See the Vegetation Overview for additional details on the ecoregion data. Areal extent, fraction of the total, and county occurrence Erequencies are given for each ecoregion for the Eastern Deciduous Forest region, Central Plains region, Western Mountains region, and nation. Names are also given for the 54 ecoregion section codes (Bailey 1976, Bailey 1978).

SUURCE (S) : .DO 8 .

YEAR(S) : . 1976

GEOCOVE RAGE : U. S.

STATUS: Online

NUMBER OF RECORDS:

54

CREATED/UPDATED: Mar. 1980

COMPILER: $\mathrm{R} J$ olson

TEM PORAL RESOLUTION : Hist. SPATIAL RESOLUTION:

DATA SET TYPE: Dictnry

VARIABLES PER RECORD: 10

NEW DATA: Not anticipated

\section{VARIABLE LABEL AND UNITS OF MEASURE}

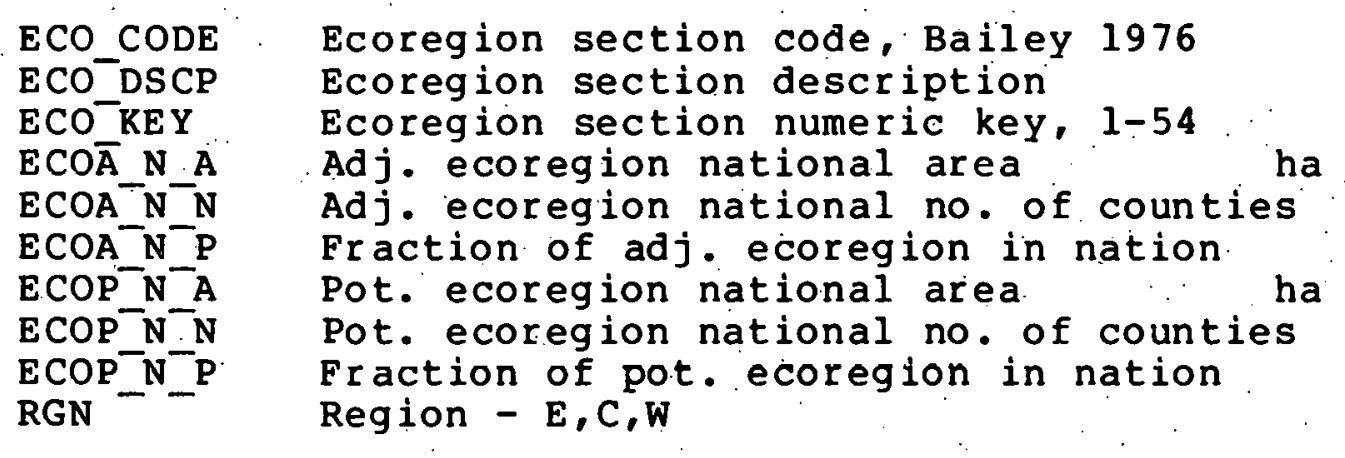


D07.1 Ecoregion Percentages for the United States.

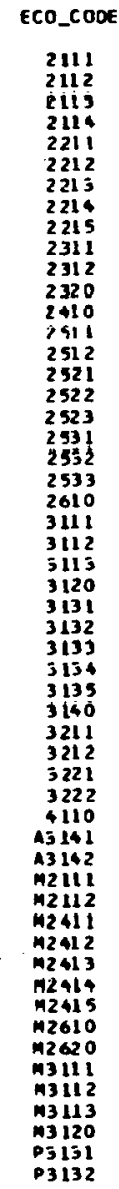

\section{DESCRIPTION}

SPRUCE-FIR FOREST

NOR THERM HAROMOODS-FIR FOREST

MOR THERH UARDUOOO 3 FORE $3 T$

NOR THEAM IHRDLDOOS-SPRUCE TOREST

MIXFN MFSNPHYTIS. FRRFST

FOAEST

MAPLE-BASSMOOD FOREST - DAK SAYAMA

APDALACHIAN OAX FOEEST

OAK-HICKOQ FOREST

OEKECH-SWEETCUH-HACHOA IA-PINE-OAK FOREST

SDUTHERN FLOJOPLATN FOREST

SNUTHEASTERN MI XED FRREST

WAK-HITKRR T-BLUES TEM PARKL AMO

oAK - bl vestem parkLamo

AESOUI TE-BUFFAL O GRASS

JUNIPER-DAK-ME SOUTTE

MESOUITE-ACACIA

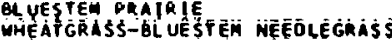

BLUESTEM-GRAYA PRAIRIE

CALIFHRNIA GRASSLAND

GRAMA-NEEOLEGRASS WHEATGRASS

WMERTGRASS-NEEDLEGRASS

GRAMA-BUFFAL O GRAS

PALOUSE GRASSLAND

SAGEBRUSH - WHEATGRASS

GAEAT BASIN SAGEBRUSH

BONNEVILLE SALTBUSH - CREASEMOOD

PONDEROSA SHR UE FOQREST

MEXICAN HIGHL ANOS SHQUB STEPPE

GRAMA - TOBOSA

PARBUSH-CREOSOTE BUSH

CREOSOTE BUSH

CREOSOTE BUSH - BLR SAGE

EVERGL AOES

MMEATGRASS - MEEOLEGRASS - SAGEBR USH

SAGEBRUSH - WHEATGRASS

DOUGL AS FIR FOREST

CEOAR - HEMLOCK - DOUGLAS FIR FORES

REOWOOD FORES

CEOAR-HEMLOCK-DOUGLAS FIR FOREST

SILVER FIR - DOUGLAS FIR FOREST

SIERRAM FOREST

CALIFORNIA CMAPPARRAL

GRAND FIR - DOUGCAS FIR FOREST

oovglas fir forest

ponoerosa pine - DOUglas fir forest

UPPER GILA MOUNTA INS FOREST

JUMIPER-PINYON WOODAND/SAGEBRUSH-SALTBUSH MOSAIT

GRAMA-GACLETA STEPDE JUNI PER P INY ON WNOL AMD MDSAIC
PERCENT

1.15

0.76

2.15

1.32
2.24
1.68
3.67

3.67

4.35
3.79

1.55

0. $\$$ Su

0.30

2.79

0.93

0.94

3.79

2. 14

0.74

3.34
3.62
4.81

0.66

0.66
3.85
1.31
1.51

0.92

0.49

0.70

1.59

1.44

0.29

0.50

1.19
0.55

0.35

1.26
0.25

0.16

0.65

0.88

1.26

1.05

0.96

3.00

1.99

1.29
1.60
2.23

1.29
1.60
2.23 
TITLE: D08 - POT. \& ADJ. ECOREGION AREAS

DESCRIPTION: Potential and land-use-adjusted areas for each ccorcgion occurring in a county were calculated from DI0. See Vegetation Overview for additional information on ecoregion data. The data were recorded at the ecoregion section level.

SOURCE (S) : DI0.

YEAR (S) : 1976

GEOCOVE RAGE : U. S.

STATUS: Online

NUMBER OF RECORDS : $\quad 4337$

CREATED/UPDATED: Mar . 1980

TEMPORAL RESOLUTION: Hist. SPATIAL RESOLUTION: County DATA SET TYPE: Multiple VARIABLES PER RECORD: 5 NEW DATA: Not anticipated COMPILER: R J Olson, J M Klopatek, J L Joness

\section{VARIABLE}

LABEL AND UNITS OF MEASURE

ECO_CODE
ECOÄA
ECOP_A
FIPS_CO
FIPS_ST

Ecoregion section code, Bailey 1976 Adjusted ecoregion area Potential ecoregion area ha FIPS county number FIPS state number 
2. Mixed mesophrtic

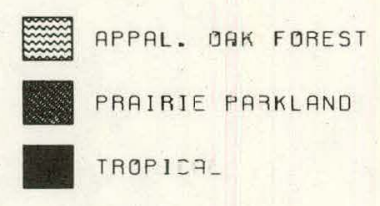

$\square$ OAK-HICKORY FOREST

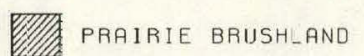

$\mathbb{W}$ SOUtheastern MiXed

篔 DESERT

TROPICA.

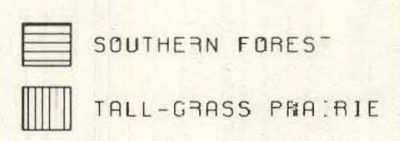

IIIII TALL-GZASS PFa:RIE

Southers f-oOdPLail

SHORT-GFASS PRAIRIE

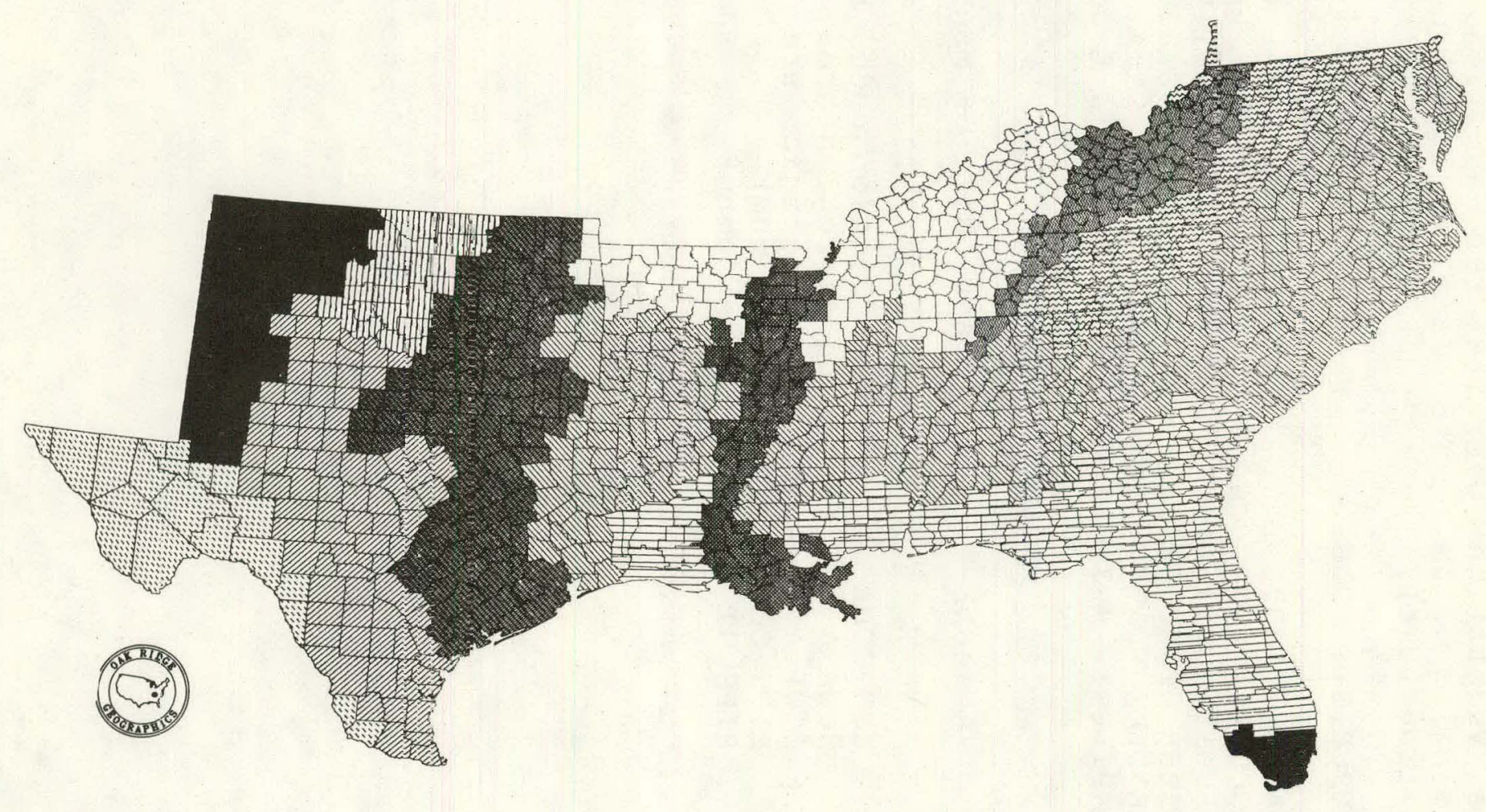

$\not$
$\infty$
1
$N$

율 
TITLE: D09-POT. \& ADJ. VEGETATION-ECOREGION STATS

DESCRIPTION: Potential and land-use-adjusted natural vegetation statistics for each ecoreglon at the section level were calculated from Dl0. See the Vegetation Overview for additional information. Statistics are given for the 387 ecoregion/vegetation combinations occurring in the conterminous United states. Areal extent, fraction of the total, and county.occurrence frequencies are included for vegetation types (Küchler 1964, USDI 1970 sheets 89 and 90) occurring in each of the 54 ecoregions (Bailey 1976, Bailey 1978). Ecoregions are keyed to their location in the Eastern Deciduous Fulest region (E), Central. Plains region (C), or Western Mountains region (W).

SOURCE (S): DI0.

$\operatorname{YEAR}(\mathrm{S}): 1978$

GEOCOVE RAGE : U. S. STATUS: Online NUMBER OF RECORDS : $\quad 387$ CREATED/UPDATED: Mar. 1980 COMPILER: $\mathrm{R} J$ Olson
TEMPORAL RESOLUTION: Hist. SPATIAL RESOLUTION: DATA SET TYPE: Dictnry VARIABLES PER RECORD: 11 NEW DATA: Not anticipated

\section{VARIABLE LABEL AND UNITS OF MEASURE}

\begin{tabular}{|c|c|}
\hline $\begin{array}{l}\text { ECO_CODE } \\
\text { ECO-KEY } \\
\text { EVEGA_A } \\
\text { EVEGA_N } \\
\text { EVEGA_P } \\
\text { EVEGP_A } \\
\text { EVEGP_N } \\
\text { EVEGP_P } \\
\text { RGN } \\
\text { VEG_CODE } \\
\text { VEG KEY }\end{array}$ & $\begin{array}{l}\text { Ecoregion section code, Bailey } 1976 \\
\text { Ecoregion section numeric key, } 1-54 \\
\text { Ecorgn/adj. veg. area } \\
\text { Ecorgn/adj. veg no. of counties } \\
\text { Fraction in ecoregion of adj. veg. type } \\
\text { Ecorgn/pot. veg. area } \\
\text { Ecorgn/pot. veg no. of counties } \\
\text { Fraction in ecoregion of pot. veg. type } \\
\text { Region - E, C, w. } \\
\text { Vegetation code, } 1966 \mathrm{Küchler,} 001-106 \\
\text { Vegetation number, } 1966 \mathrm{Küchler,} 1-106\end{array}$ \\
\hline
\end{tabular}


D09.1 Percent of Potential Vegetation Types within Ecoregions.

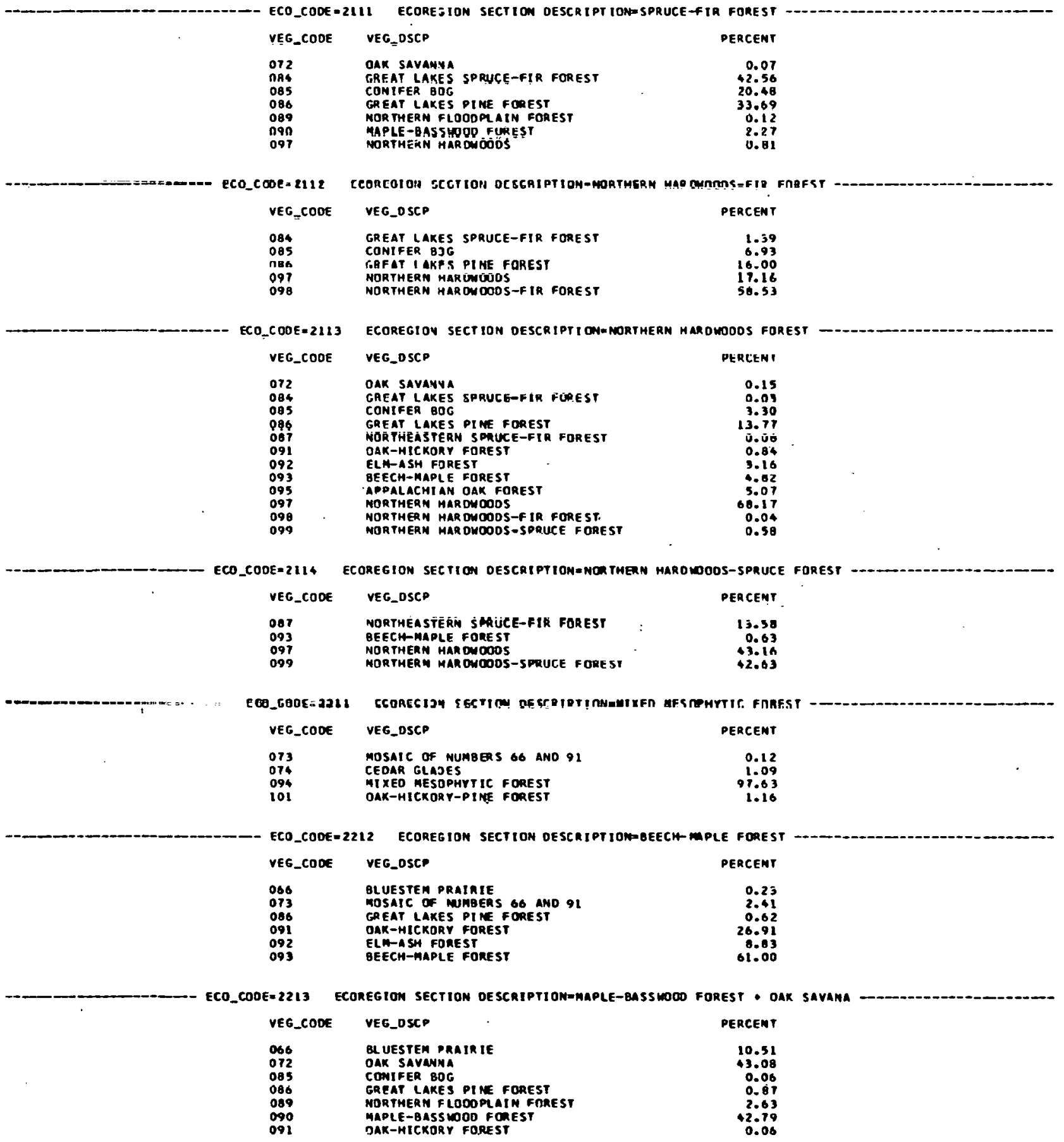


D09.1. Percent of Potential Vegetation Types within Ecoregions

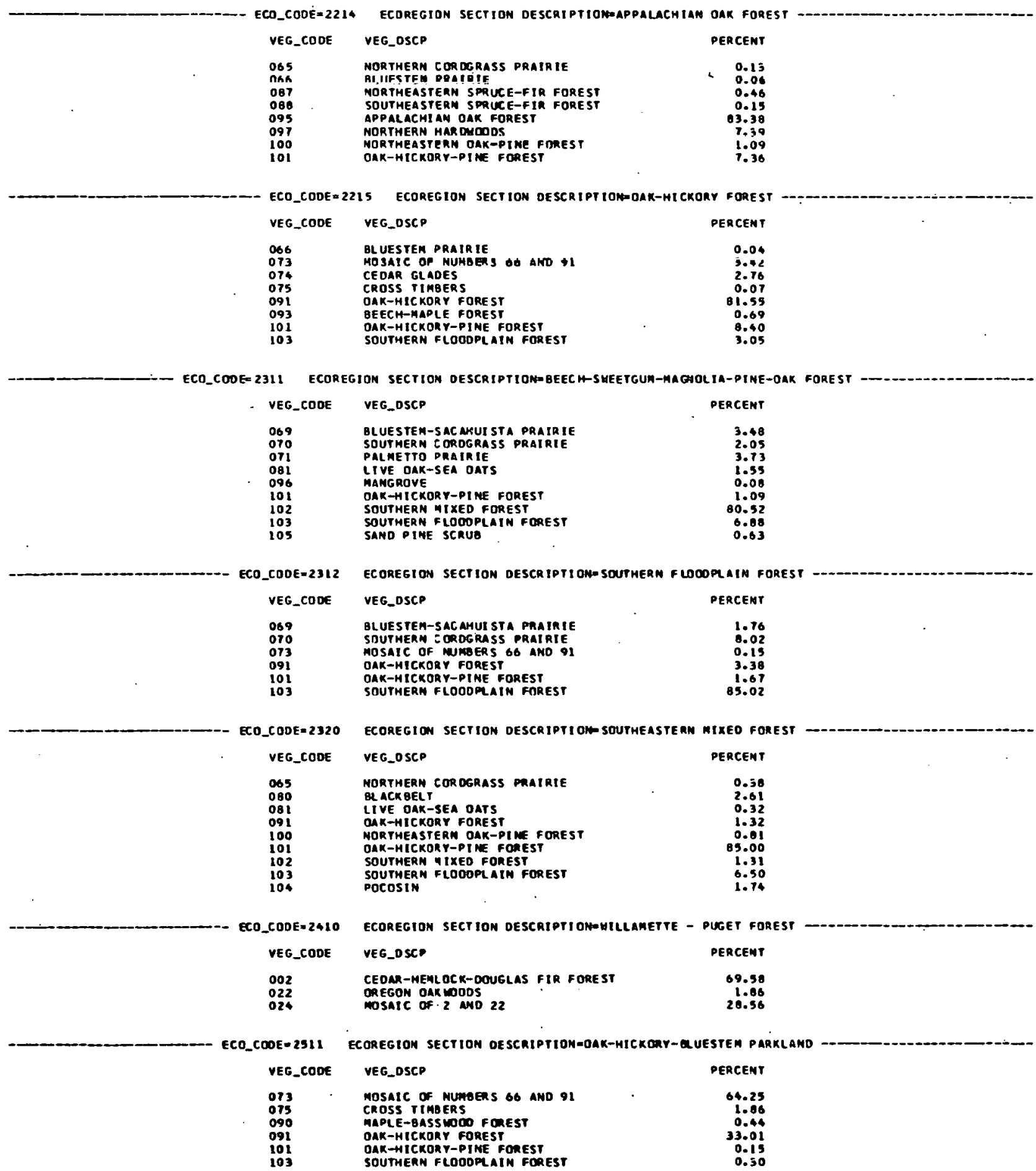




\section{D09.1. Percent of Potential Vegetation Types within Ecoregions}

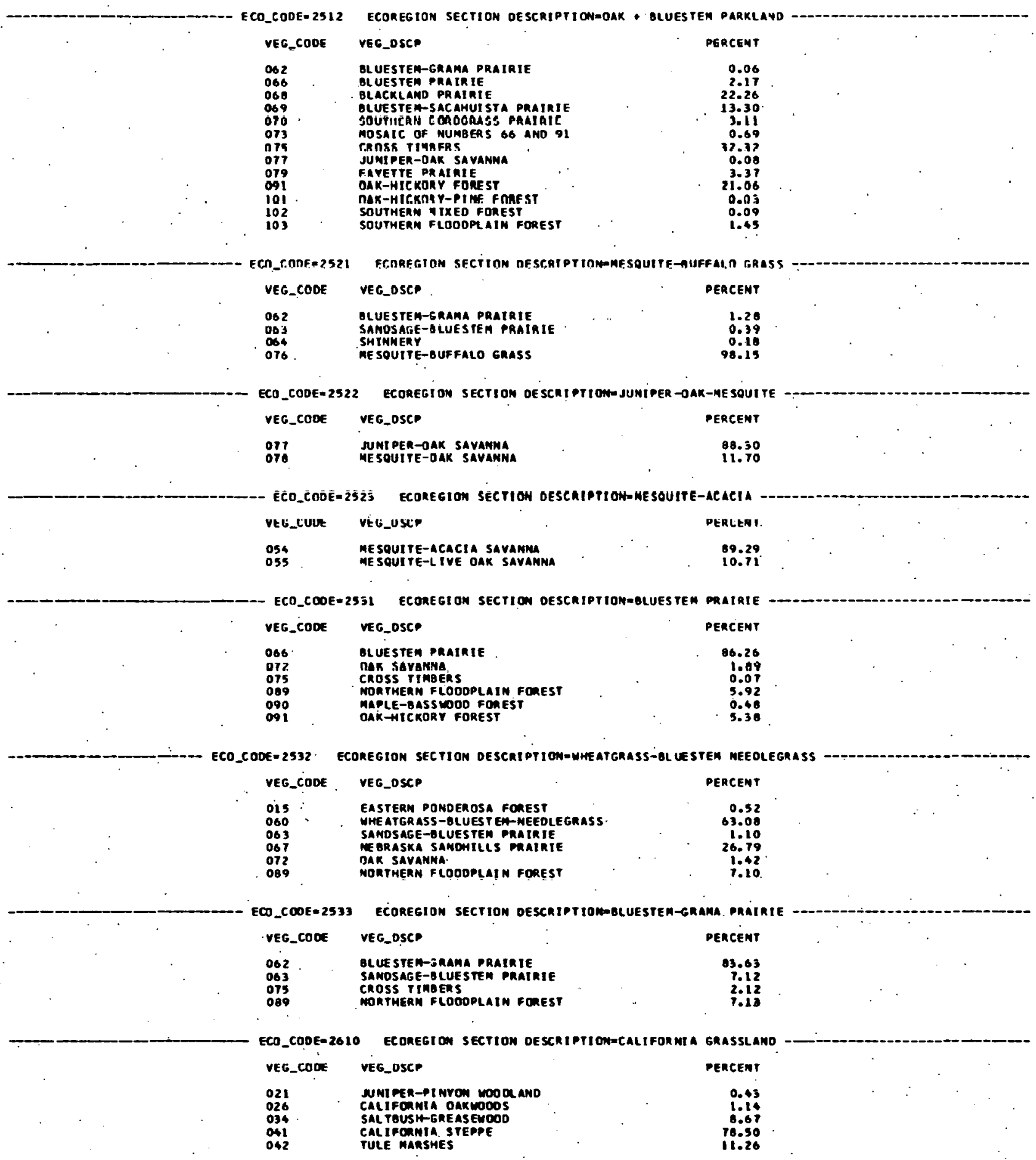


D09.1. Percent of Potential Vegetation Types within Ecoregions

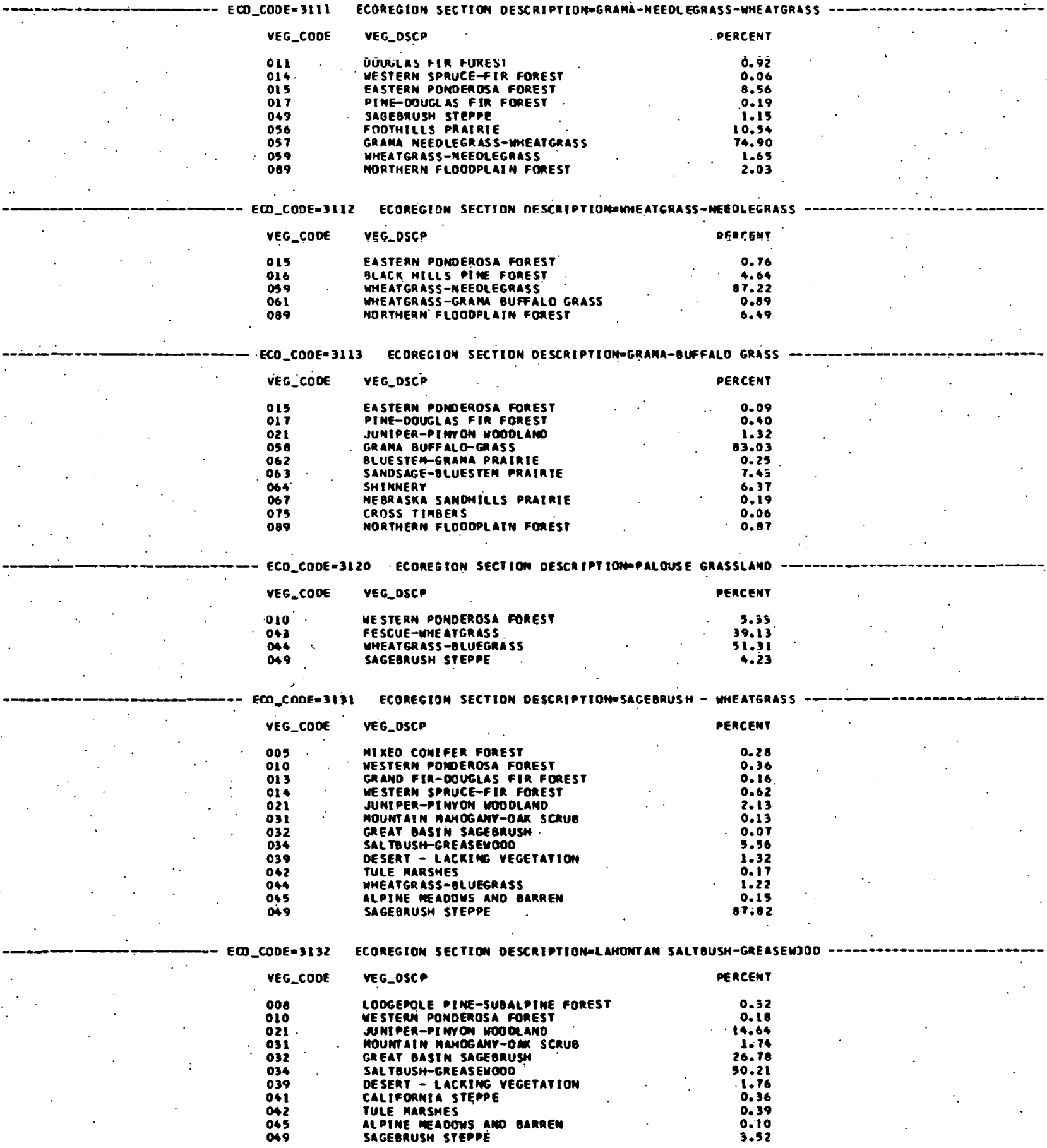


D09.1. Percent of Potential Vegetation Types within Ecoregions

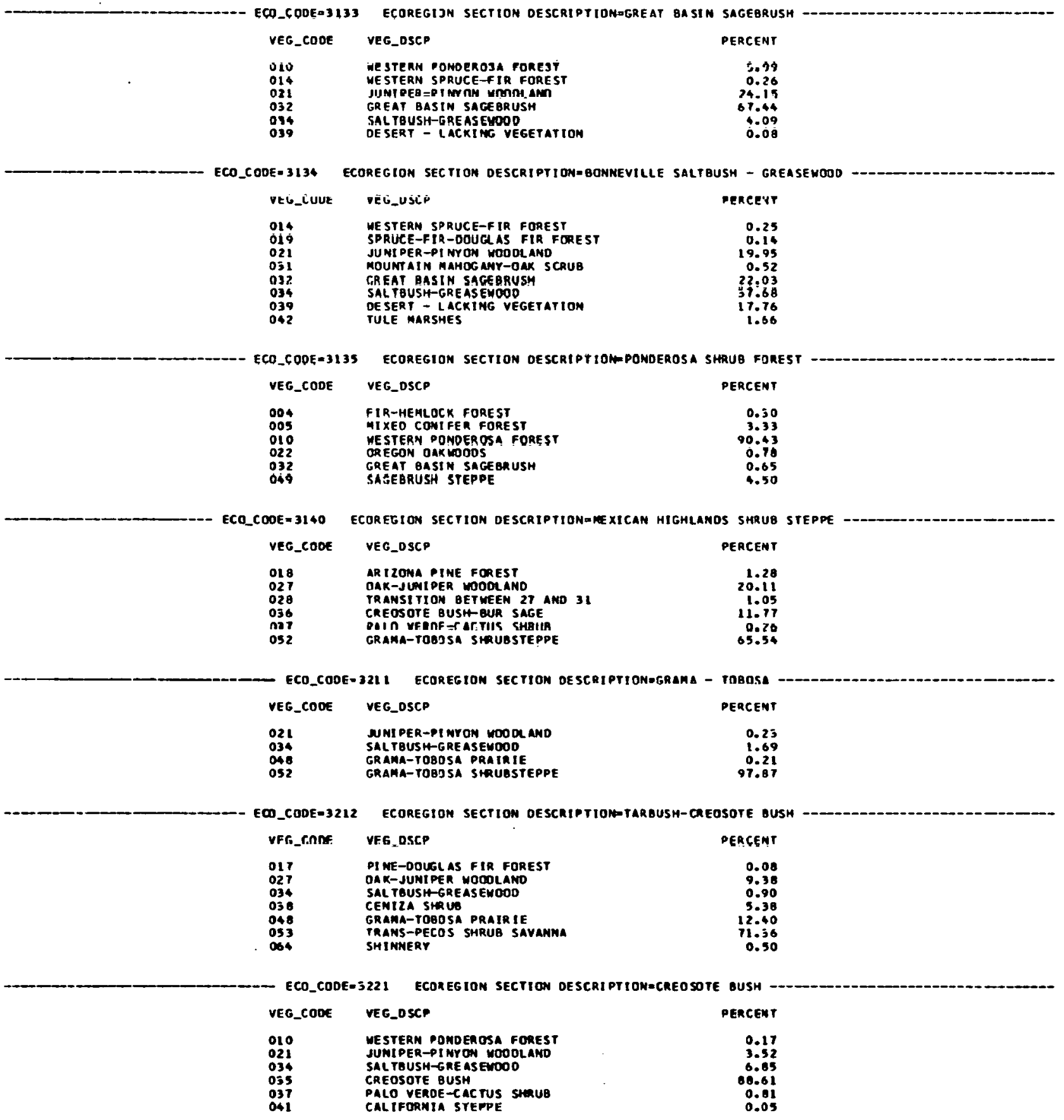




\section{D09.1. Percent of Potential Vegetation Types within Ecoregions}

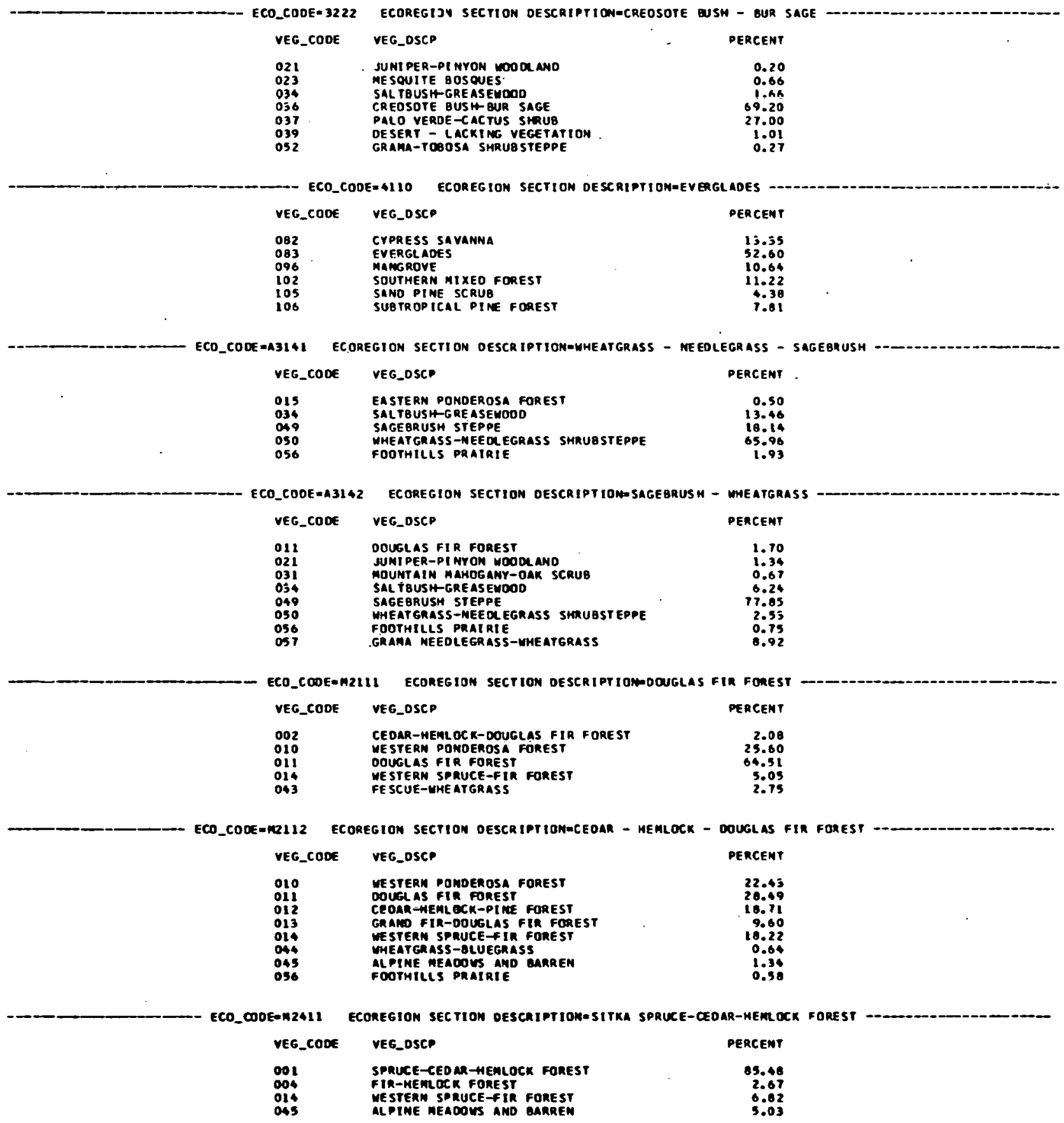


D09.1. Percent of Potential Vegetation Types within Ecoregions

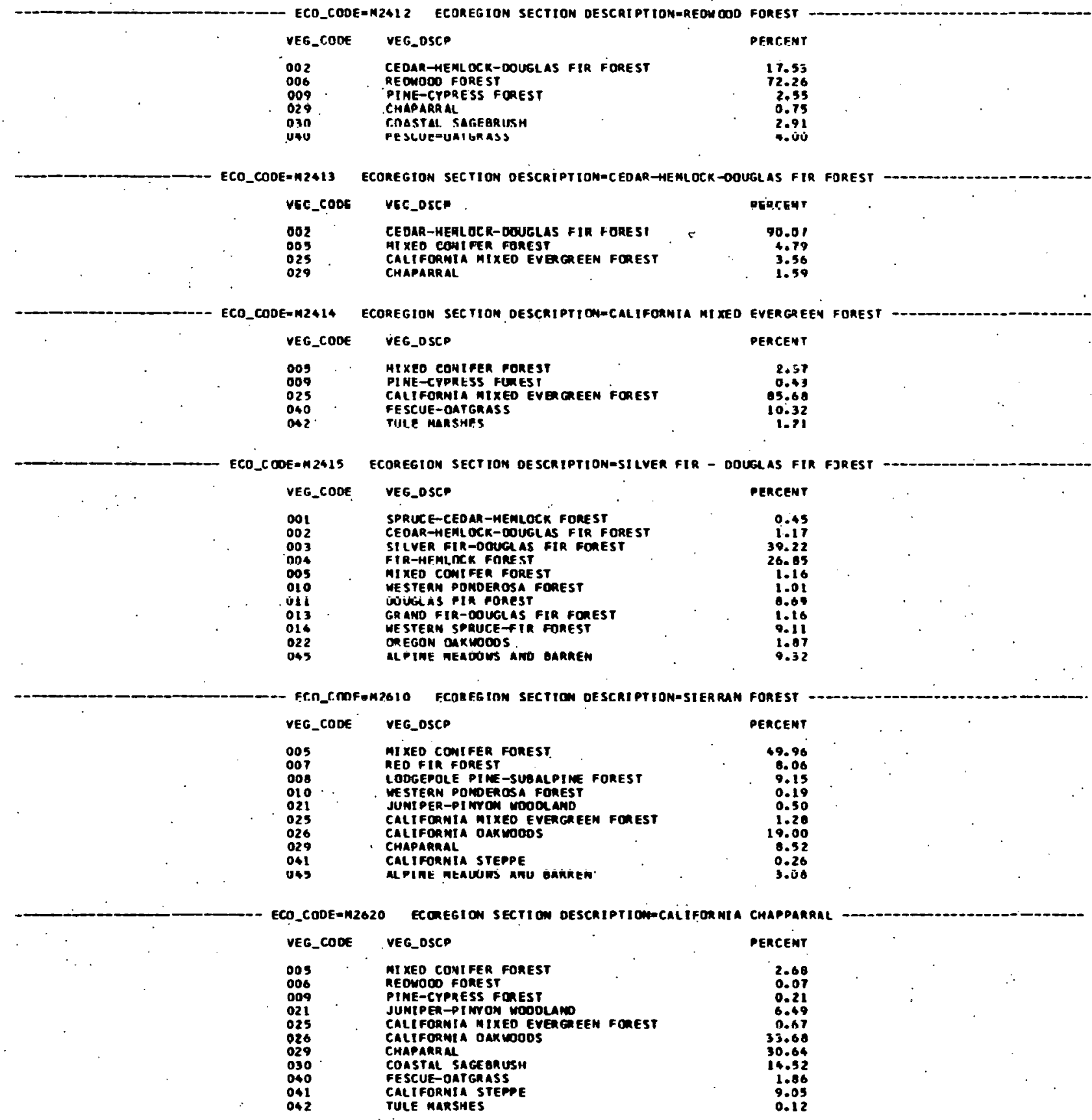


D09.1. Percent of Potential Vegetation Types within Ecoregions

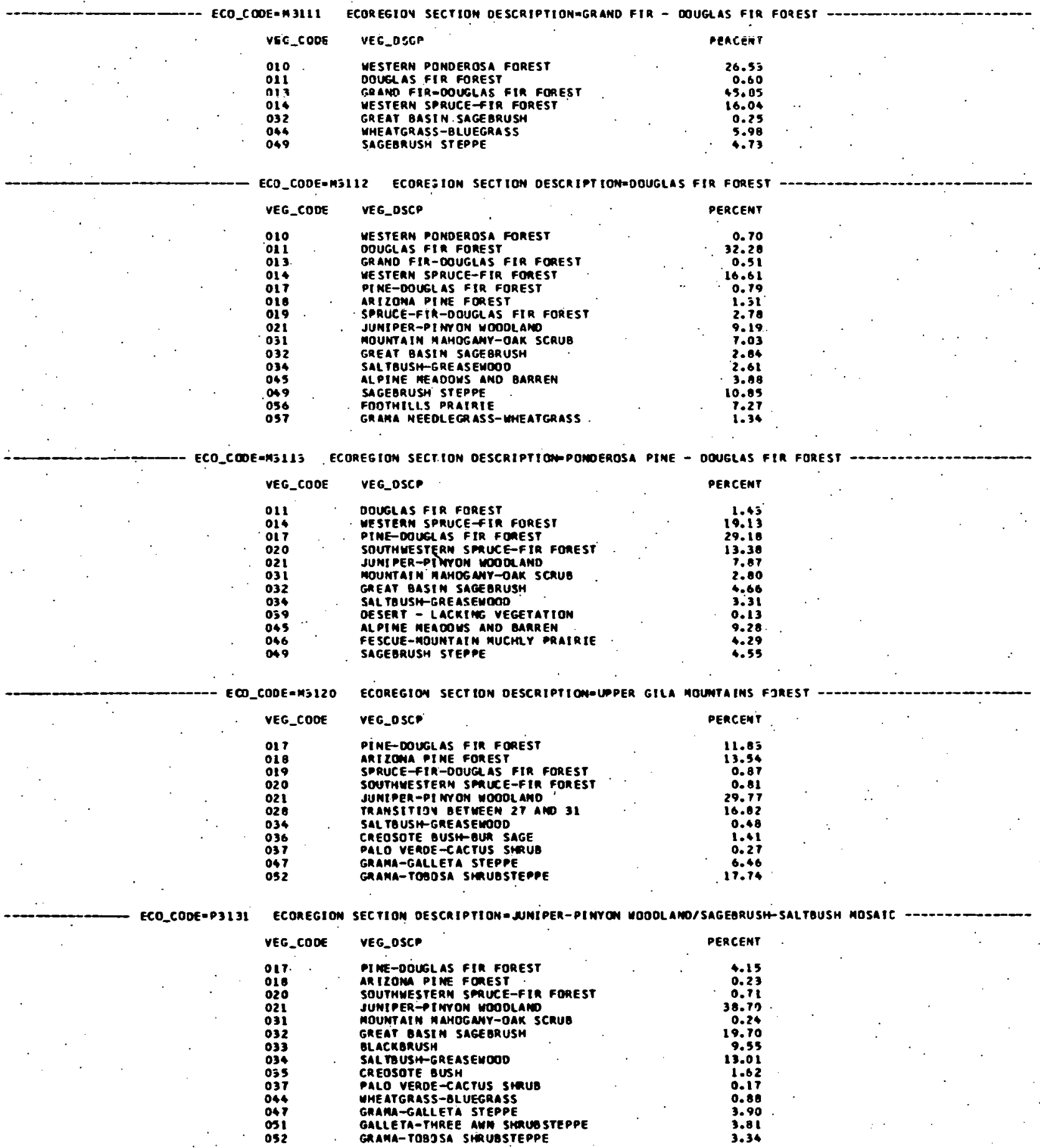


D09.1. Percent of Potential Vegetation Types within Ecoregions

VEG_oSCF

PI NE-UUWLL AS + IR RURESI

SOUTHWESTERN SPRUCE-FIR FOREST

JUNIPCA-PINYOH HODDLAMO

MOUNTATM RAHOGANY-OAK SCRUB

GREAT BASIN SAGE BQUSH

SALTRUSH-GREASEYOOO

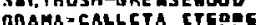

PERCENT

3.13

$0.0 \%$

2.31

3.80
38.72 
TITLE: DIO - POT. \& ADJ. VEGETATION WITHIN ECOREGIONS

DESCRIPTION: Potential and land-use-adjusted natural. vegetation areas occurring within ecoregions (section level) within county units were digitized from maps as the base data set. Sce Vegetation Overview lor additional information. The potential natural vegetation map (Kuchler 1964, USDI 1970 sheets 89 and 90) and the ecoregion map (Bailey 1976) were combined so that appropriate vegetation and ecoregion boundaries coincided. The resulting map was overlaid with county outlines and the proportion of counties in each ecoregion/vegetation type estimated. Digitizing was done with a dot grid loi the 37 eastern states and with a planimeter for the larger western states. Proportions were estimated to the nearest 10 percent for the small counties in the east, and to 0.1 percent in the west. The digitizing errors associated with individual counties are probably fairly high due to the techniques used; however, considerable effort was spent in verifying that ecoregion/vegetation types occurred in counties so recorded. Areas were calculated using the 1970 Census Bureau county I and area data (BO1).

SOURCE(S): Kuchler 1964, USDI 1970 sheets 89 and 90; Baile.y 1976 ; BOI.

$\operatorname{YEAR}(\mathrm{S}): \quad 1978$

GEOCOVERAGE : U. S.

STATUS: Online

NUMBER OF RECORDS : . 7614

CREATED/UPDATED: Mar . 1980

TEMPORAL RESOLUTION: Hist. SPATIAL RESOLUTION: County DATA SET TYPE: Multiple VARIABLES PER RECORD: 6 COMPILER: $\quad R$ J Olson, J M Klopatek, J T Kitchings

VARIABLE LABEL AND UNITS OF MEASURE

\begin{tabular}{lll}
\hline ECO_CODE & Ecoregion section code, Bailey 1976 & \\
EVEGA_A & Adjusted ecorgn/vegetation area & ha \\
EVEGP-A & Potential ecorgn/vegetation area & ha \\
FIPS_CO & FIPS county number & \\
FIPS_ST & FIPS state number & \\
VEG_CODE & Vegetation code, Klichler, 001-106 \\
\hline
\end{tabular}


TITLE: DII - ECOREGION CODES DICTIONARY

DESCRIPTION: Ecoregion codes and names are given for the province and section levels based on Bailey's (1976) map.

SOURCE(S): Bailey 1976 .

COMMENTS: The ecoregion names can be substituted for the codes by using the SAS FORMAT statement (see the section on Special Output Formats).

YEAR(S) : 1976

GEOCOVE RAGE : U. S.

STATUS: Online

NUMBER OF RECORDS :

CREATED/UPDATED: Mar. 1980

COMPILER: $R \mathrm{~J}$ Olson
TEMPORAL RESOLUTION:

SPAATIAL RESOLUTION:

DATA SET TYPE: Dictnry

VARIABLES PER RECORD: 2

NEW DATA : Not anticipated

\begin{tabular}{ll} 
VARIABLE & LABEL AND UNITS OF MEASURE \\
\hline ECO_CODE & $\begin{array}{l}\text { Ecoregion section code; Bailey } 1976 \\
\text { ECO_DSCP }\end{array}$
\end{tabular}


TITLE: DI 2 - VEGETATION WITHIN WESTERN ECOREGIONS

DESCRIPTION: The areal extent of potential natural vegetation within ecoregions, ignoring state and county boundaries, was estimated using a planimeter for the western ecoregions. These data were used in verifying the Dlo data set; however, they were not edited to agree with the Dl0 data.

SOURCE (S): Bailey 1976. Klichler 1964, USDI 1970 sheets 89 and 90 .

YEAR (S) : 1976 GEOCOVE RAGE : West STATUS: Online NUMBER OF RECORDS : CREATED/UPDATED: Mar. 1980 COMPILER: J M Klopatek, J L Joness
TIEM PURAL KESSULUTIUN: Hist. SPATIAL RESOLUTION: Ecorgn DATA SET TYPE: Multiple VARIABLES PER RECORD: 4 NEW DATA: Not anticipated

\begin{tabular}{|c|c|}
\hline $\begin{array}{l}\text { ECO CODE } \\
\text { EVE } \overline{G P} P \\
\text { PVEG } \bar{C} \\
\text { VEG } \overline{C O D E}\end{array}$ & $\begin{array}{l}\text { Ecoregion section code, Bailey } 1976 \\
\text { Vegetation within an ecoregion, percent } \\
\text { Vegetation code, Kuchler } 1964 \\
\text { Vegetation code, } 1966 \text { Küchler, } 001-106\end{array}$ \\
\hline
\end{tabular}


TItLE: DI3 - VEGETATION SENSITIVITy TO S02

DESCRIPTION: Sensitivities of potential natural vegetation (Kthchler 1964) to sulfur dioxide (502) were rated by Argonne National Laboratory (Ballou et al. 1979). Their method involved rating (sensitive, intermediate, and resistent) individual species based on tolerance to $\mathrm{SO} 2$, as reported in the literature. Vegetation communities were then classified according to the most sensitive dominant species in the association.

SOURCE(S): Ballou, S. W. 1979. Unpublished manuscript. Argonne National Laboratory, Argonne, IL.

REFERENCE(S): Ballou et al. 1979 .

COMMENTS: This data set can be combined with Dl0 to obtain the SO2 sensitivity of potential natural vegetation within counties.

$\operatorname{YEAR}(\mathrm{S}): 1979$

GEOCOVERAGE : U.S.

STATUS: Being Edited
TEMPORAL RESOLUTION: Hist. SPATIAL RESOLUTION :

DATA SET TYPE: Dictnry 
D13.1 Potential Vegetation Types with Low Tolerance to Sulfur Dioxide (Relative Sensitivity).

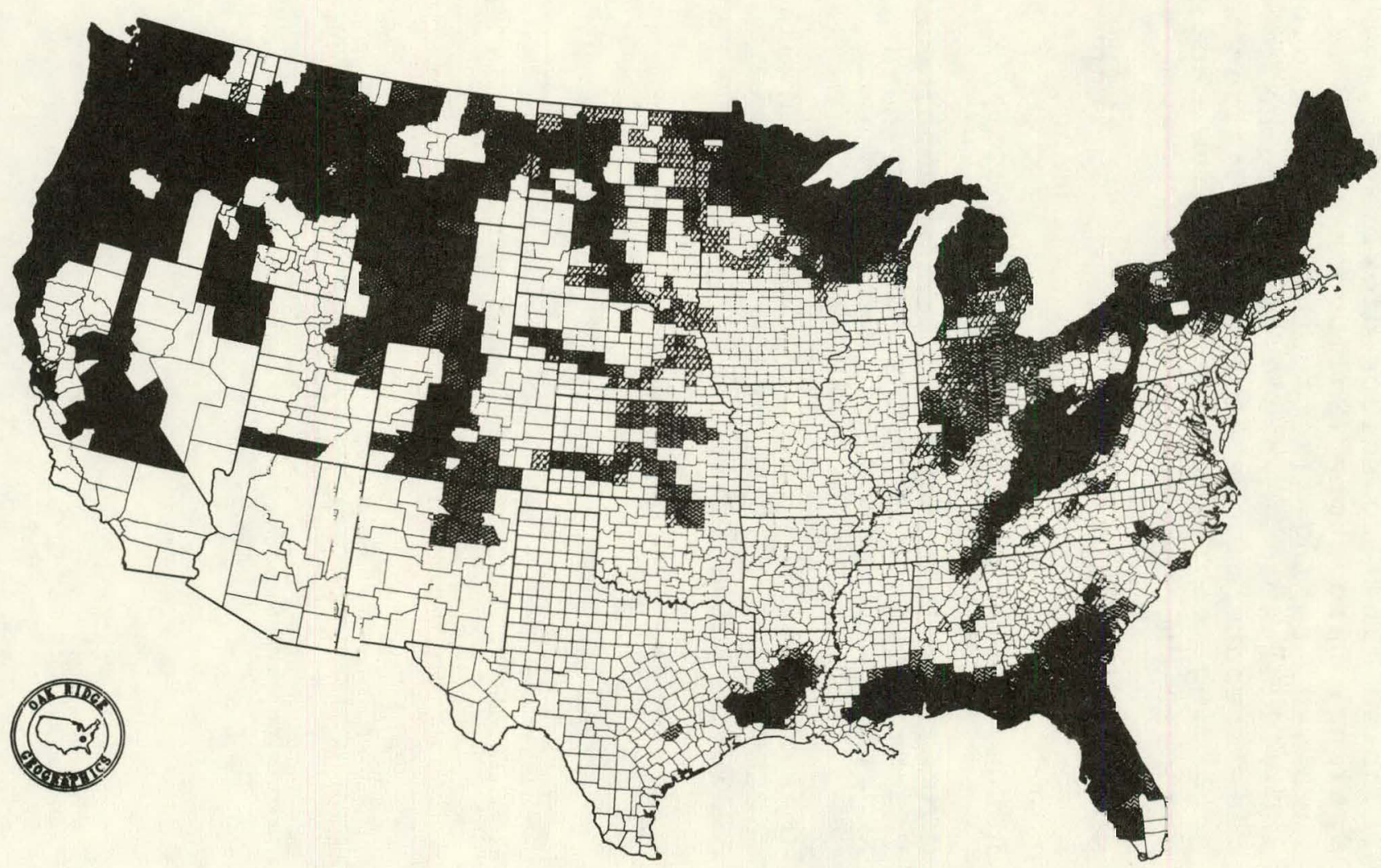




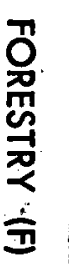




\section{FOREST (F) SECTOR OVERVIEW}

The Forest sector is based primarily on data produced by the U. S. Forest Service's Continuous Forest Inventory (CFI) program. This program conducts timber surveys on permanently established plots at approximately ten-year intervals. States are sampled on a staggered schedule. The sampling intensity is defined to produce statistical estimates within a specified level of sampling error for forest survey units. Forest survey units are aggregates of counties. County estimates have higher sampling errors and often are not published if forestland is very sparse. County-level statistics are not readily available as a national file in either printed or computer readable forms. State inventories vary in format depending on the region of the country. The list of publications used to compile data sets F0l to F07 is presented below. The compilation of county-level forestry statistics, especially species-level data in F05-F07, represents a significant effort in producing a uniform data set for the eastern United states.

SOURCE(S): F01, F02, and F03 (southern states): Bellamy and Knight 1970, Cost 1968, Cost 1975a, Cost 1975b, Earles 1967, Earles 1975, Ferguson 1964, Gansner 1968, Haines 1967, Hedlund and Earles 1969, Hedlund and Earles 1970a, Hedlund and Earles 1970b, Hedlund and Earles 1971, Knight and McClure 1967, Knight and McClure 1974, McClure 1969, McClure 1970, Snyder and Knight 1970, sternitzke and Van Sickle 1968, Welch 1968, Welch 1975, Welch and Rnight 1974.

F06 and F07 (eastern states): Delcourt et al. 1980 . 
TITLE: FOI - FOREST AREA BY MAJOR TYPES

DESCRIPTION: Forestland areas by major forest types were obtained from USFS state forest inventory publications. See Forest Overview for details on data sources. Commercial forestland is detined as land producing or capable of producing crops of industrial wood which has not been withdrawn from timber production. The sum of the major forest types equals the area of commercial forest.

SOURCE(S): USFS state forest inventory publications.

YEAR (S) : $\quad$ 1965-1977

GEOCOVE RAGE : South

STATUS : OnI ine

NUMBER OF RECORDS : $\quad 1388$

CREATED/UPDATED: Mar • 1.980

COMPILER: ' R J Olson
TEMPORAL RESOLUTION: Annual SPATIAL RESOLUTION: County DATA SET TYPE: Single VARIABLES PER RECORD: 16 NEW DATA: Every 10 years

\section{VARIABLE LABEL AND UNITS OF MEASURE}

\begin{tabular}{|c|c|c|}
\hline 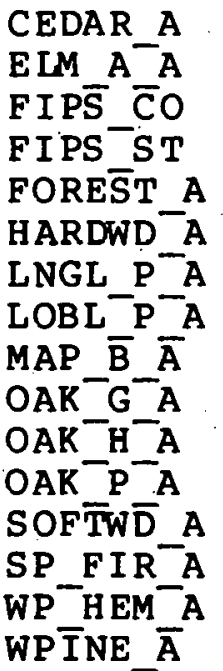 & $\begin{array}{l}\text { Cedar forest } \\
\text { Elm-ash-cottonwood forest } \\
\text { FIPS county number } \\
\text { FIPS state number } \\
\text { Forest land - commercial } \\
\text { Hardwood forest } \\
\text { Longleaf-slash pine forest } \\
\text { Loblolly-shortleaf pine forest } \\
\text { Maple-beech-birch forest. } \\
\text { Oak-gum-cypress forest } \\
\text { Oak-hlckory forest } \\
\text { Oak-pine forest } \\
\text { Softwood forest } \\
\text { Spruce-fir forest } \\
\text { White pine-hemlock forest } \\
\text { White pine forest }\end{array}$ & $\begin{array}{l}\text { ha } \\
\text { ha } \\
\text { ha } \\
\text { ha } \\
\text { ha } \\
\text { ha } \\
\text { ha } \\
\text { ha } \\
\text { ha } \\
\text { ha } \\
\text { ha } \\
\text { ha }\end{array}$ \\
\hline
\end{tabular}


TITLE: F02 - FOREST GROWING-STOCK VOLUMES

DESCRIPTION: Growing-stock volumes for commercial tree species groupings were obtained from USFS state forest inventory publications. See Forest Overview for details on data sources. Growing-stock volume is defined as net volume in live sawtimber and poletimber trees from the stump to a $1.6 \mathrm{~cm}$ top. Deductions were made for rot and other defects. Survey methods and species aggregations differ between states depending on forest conditions and the USFS forest survey region. The softwoods consist of all conifers including the southern or yellow pines and other eastern softwoods. In some states the hardwood category consists of hard and soft hardwoods. Hard hardwoods include select oaks (white and red oaks) and miscellaneous hardwoods, while the soft hardwoods include the gums.

SOURCE(S): USFS state forest inventory publications.

COMMENTS: Units of measure are thousands of cubic meters ( $k$ $m * \star 3)$.

$\operatorname{YEAR}(\mathrm{S}): \quad 1965-1977$

GEOCOVERAGE : South

STATUS : Online

NUMBER OF RECORDS : 1388

CREATED/UPDATED: Mar . 1980

COMPILER: $\mathrm{R} \mathrm{J}$ Olson
TEMPORAL RESOLUTION: Annual SPATIAL RESOLUTION: County DATA SET TYPE: Single VARIABLES PER RECORD: 12 NEW DATA: Every 10 years 2

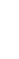

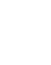




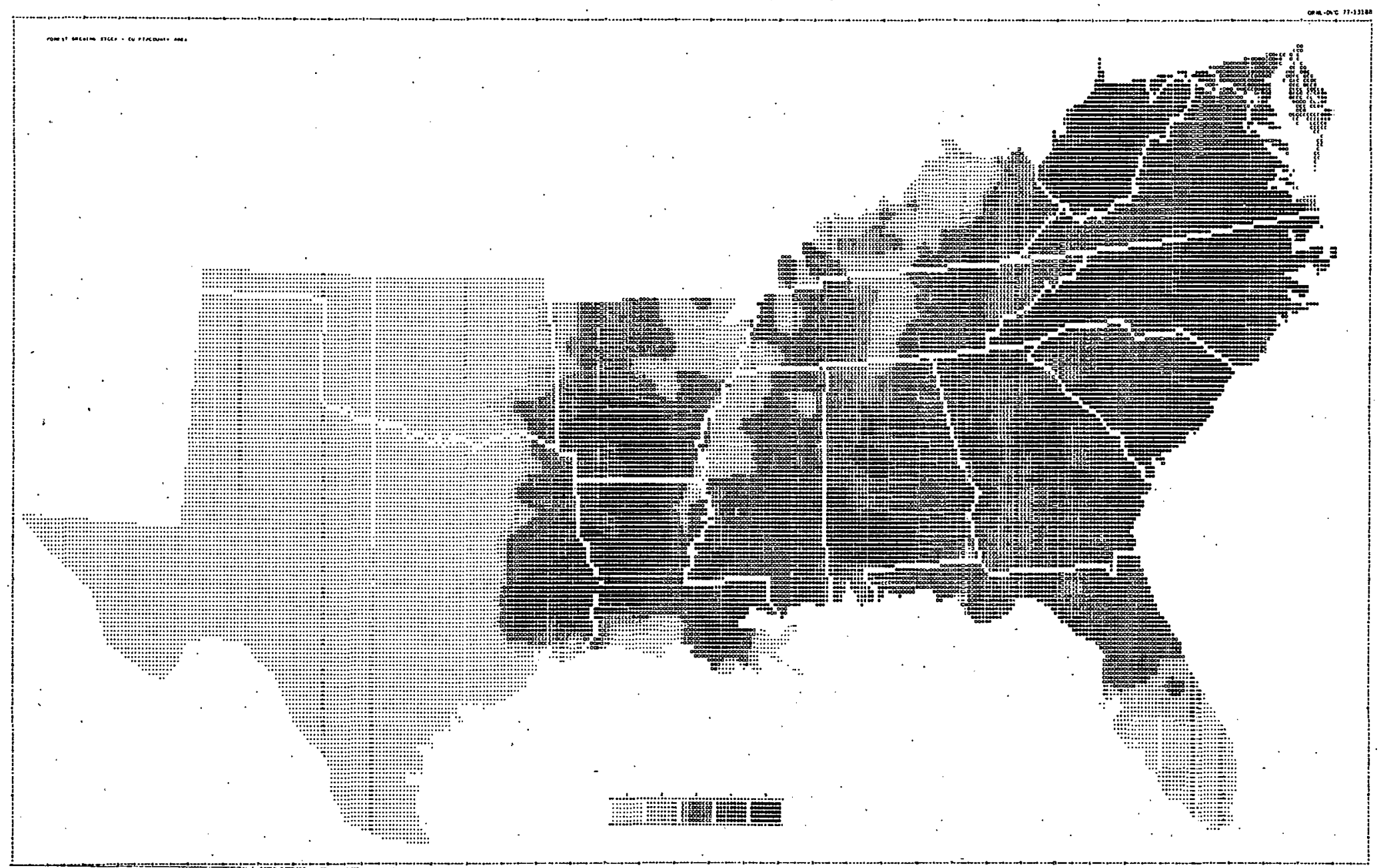

F02.1 Forest Stand Volumes based on 1963-1975 Inventories. Growing-stock volumes are expressed as net volume of trees greater than 5.0 in. dbh per total county area. Interval. limits in cubic feet per acre: (1) <100, (2) $100-250$, (3) $250-500$, (4) $500-750$, (5) $>750$. 


\section{TITLE: F03 - FOREST SAWTIMBER VOLUMES}

DESCRIPTION: Sawtimber volumes for commercial tree-species groupings were obtained from USFS state forest inventory publications. See Forest Overview for details on data sources. Sawtimber volume is an estimate of the amount of available lumber or other forest products in standing trees. Deductions are made for estimated rot and defects along with. manufacturing losses such as saw kerf and unusable slabs. Survey methods and species aggregations differ between states, depending on forest conditions and the . USFs forest survey reqion. See Fo2 for definitions of speries groupings.

SOURCE(S): USFS state forest inventory publications.

COMMENTS: Units of measure are thousands of cubic meters ( $k$ $m * \star 3)$.

$\operatorname{YEAR}(\mathrm{S}): \quad 1965-1977$

GEOCOVE RAGE : South

STATUS: Online

NUMBER OF RECORDS : $\quad 1388$

CREATED/UPDATED: Mar . 1980

COMPILER: R J Olson
TEMPORAL RESOLUTION: Annual SPATIAL RESOLUTION: County DATA SET TYPE: Single VARIABLES PER RECORD: 12 NEW DATA: Every 10 years.

\section{VARIABLE $\quad$ LABEL AND UNITS OF MEASURE}

$\begin{array}{ll}\text { ALLSPS } & \text { Sawtimber volume of all species } \\ \text { FIPS_CD } & \text { FIPS county number } \\ \text { FIPS-ST } & \text { FIPS state number } \\ \text { GUM S } & \text { Sawtimber volume of gum } \\ \text { HARD_H_S } & \text { Sawtimber volume of hard hardwoods } \\ \text { HARDSSS } & \text { Sawtimber volume of soft hardwoods } \\ \text { HARDWD_S } & \text { Sawtimber volume of all hardwoods } \\ \text { OARS } & \text { Sawtimber volume of select oaks } \\ \text { OTHR_H_S } & \text { Sawtimber volume of misc. hardwoods } \\ \text { OTHRS-S } & \text { Sawtimber volume of misc. softwoods } \\ \text { PINESS- } & \text { Sawtimber volume of southern pine } \\ \text { SOFTWD_S } & \text { Sawtimber volume of all softwoods }\end{array}$


TITLE: FO4 - FOREST SURVEY UNIT INDEX

DESCRIPTION: The Forest Service groups counties within states into forest survey units based on homogeneous forest conditions. Sampling methods and frequencies are designed to produce forest statistics with small sampling errors at the forest survey unit level. States are also grouped into regions for conducting forest inventories and other programs. This data set provides an index to these designations. The index does not include counties in the Central Plains which do not contain forestland nor does the Index include certain urbanized counties in the east.

SOURCE(S): U. S. Department of Agriculture. 1967. Forest Survey Handbook No. 436, Chap. 70. U. S. Department of Agriculture, Forest Service, Washington, DC.

YEAR (S): 1975

GEOCOVERAGE : U. S. STATUS: Online NUMBER OF RECORDS: 2842 CREATED/UPDATED: Mar. 1980 COMPILER: R J Olson
TEM PORAL RESOLUTION :

SPATIAL RESOLUTION: County DATA SET TYPE: Index VARIABLES PER RECORD: 5 NEW DATA: Not anticipated

\section{VARIABLE}

\section{LABEL AND UNITS OF MEASURE}




\section{TITLE: F05 - TREE-SPECIES CODES DICTIONARY}

DESCRIPTION: The tree-species codes dictionary for use with F06 was created from DOI with the addition of codes to accommodate aggregations of species as used by the Forest Service. See the DOl description for more information. on the coding system.

SOURCE(S): U. S. Department of Agriculture. 1967. Forest Survey Handbook, No. 436. U. S. Department of Agriculture, Forest Service, Washington, DC.

$\bar{Y} \bar{E} A R(S): \quad 1979$

GE OCOVERAGE : U. S.

STATUS : Online

$\begin{array}{ll}\text { NUMBER OF RECORDS : } & 328 \\ \text { CREATED/U PDATED: Mar } \quad & 1980\end{array}$

COMPILER: $\mathrm{R} \mathrm{J}$ Olson
TEMPORAL RESOLUTION:

SPATIAL RESOLUTION:

DATA SET TYPE: Dictnry VARIABLES PER RECORD: 3

NEW DATA: Not anticipated

\section{VARIABLE}

LABEL AND UNITS OF MEASURE

\section{TREE DSC TREE SPC TREECODE TREE_KEY}

Tree species common name

Tree genus-species scientific name

Tree species mnemonic code

Tree species code number 
F05.1 Tree Species Codes Dictionary.

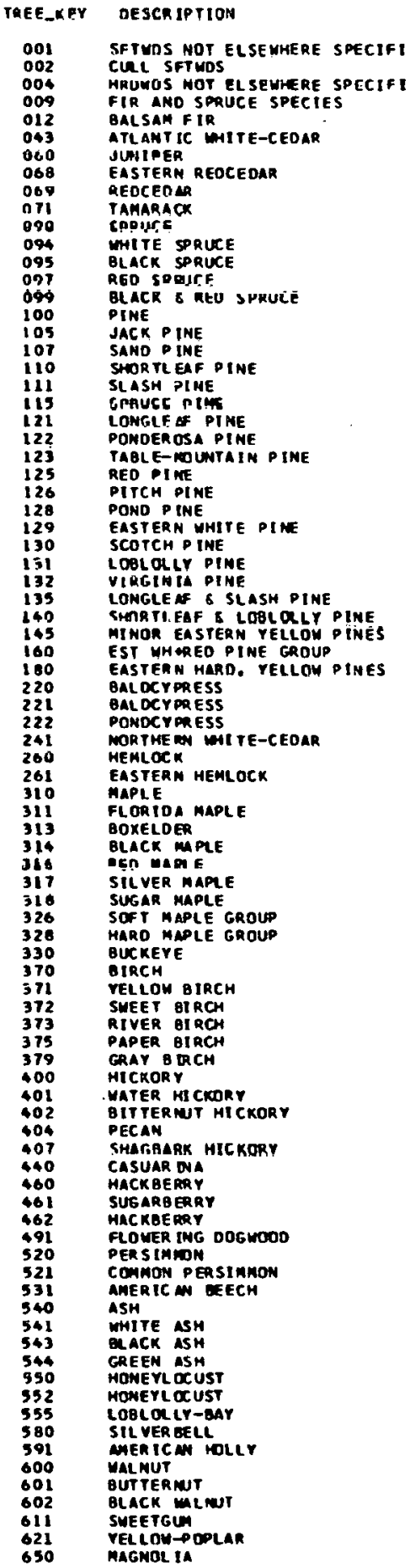

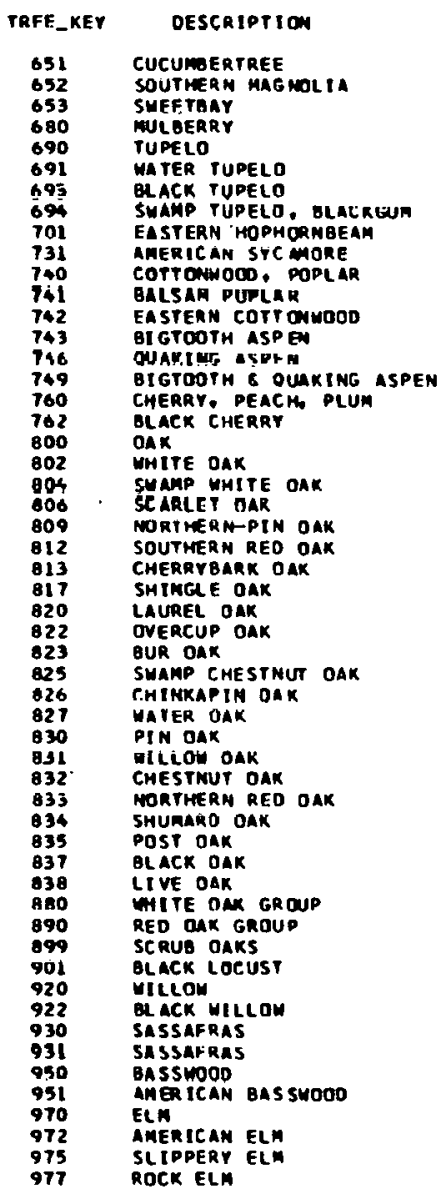


TITLE: F06 - TREE-SPECIES GROWING-STOCK VOLUMES

DESCRIPTION: Estimates of individual tree-species growing-stock volumes were obtained from USFS state furest inventory publications, unpublished tables, and data tapes (Delcourt et al. 1980). Estimates are based on the Continuous Forest Inventory (CFI) program within the USFS. See the Forest Overview for details on data sources. This compilation represents a unique and significant effort in creating a single uniform file from the various sources within the USFS. Growing-stock volume is defined as the net volume in live sawtimber and poletimber trees from stump to a $1.6 \mathrm{~cm}$ top. Deductions were made for lot and uther defects. Although most of the species are tabulated individually, when species occur at low densities they may be aggregated into genus-level groupings. Species-specific conversion factors were used to calculate biomass from the growing-stock volumes. In areas with low forest density, such as in the Corn Belt, forest statistics are presented for forest survey units.

SOURCE(S): . Delcourt H. 1979. Eastern Forest Species Data File. Environmental Sciences Division, Oak Ridge National Laboratory, Oak Ridge, TN.

REFERENCE(S): Delcourt et al. 1980 .

COMMENTS: Species may be aggregated or grouped in different combinations in different states. Data may only be available for forest survey units in some states. Forest survey units have FIPS county codes greater than 900 . See F04 for the counties within a forest survey unit.

YEAR (S) : $1965-1978$

GEOCOVE RAGE : East

STATUS: Being edited

NUMBER OF RECORDS : 29781

CREATED/UPDATED: Mar. 1980

COMPILER: H Delcourt, P Delcourt
TEMPORAL RESOLUTION: Annual SPATIAL RESOLUTION: County DATA SET TYPE: Multiple VARIABLES PER RECORD: 6 NEW DATA: Every 10 years

\section{6}

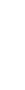


F06.1 Sensitive Tree Biomass in the South at Risk to. Higt. Levels of Sulfur Dioxide. High-level Areas are fir QLality Control

Regions in which the 1974-1976 Annual Ambiert Average

Concentration Exceeded 100 micrograms per cubic meter.

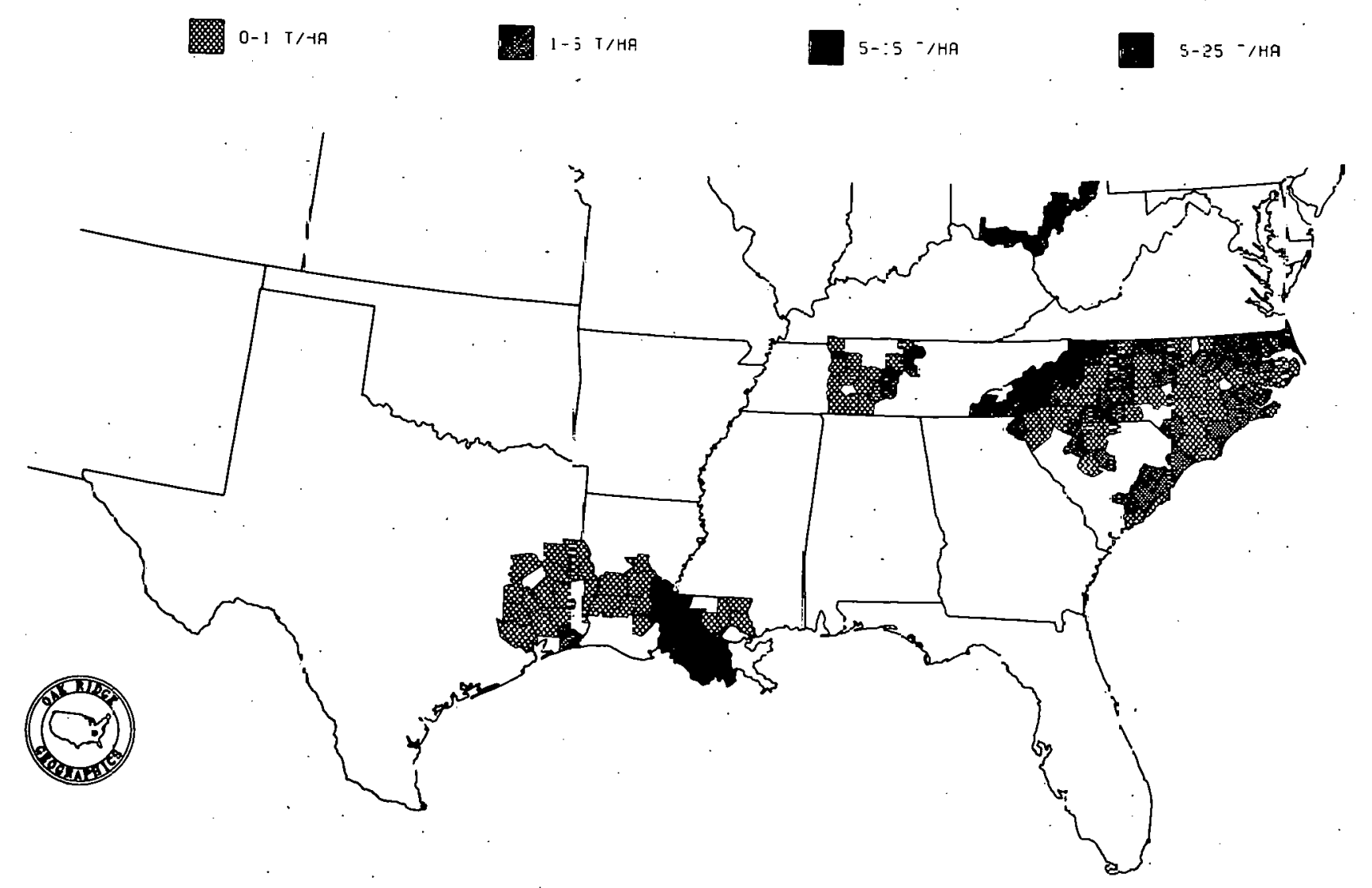

영 
TITLE: F07 - FOREST AREA \& GROWING-STOCK VOLUME

DESCRIPTION: This data set contains county or survey unit statistics compiled in connection with F06 (Delcourt et al. 1980). See the Forest Overview for details on data sources. Included are land area, forest area, and commercial forest area. The USFS 1 and area does not coincide with the BOl data primarily because water areas greater than 0.6 ha are included in $\mathrm{F} 07$ but excluded in BOl. Forestland includes areas stocked at least ten percent with forest trees or that formerly had tree cover but are not developed for nonforest use. Commercial forestland is forestland that is producing or capable of producing crops of industrial wood. USFS county codes, geographic centroid of the county or survey unit, and publication reference to the source of growing-stock data in F06 are given. The sum of the growing-stock volumes for all species in F06 and the sum of the biomass are also included.

SOURCE(S): Delcourt H. 1979. Eastern Forest Species Data File. Environmental Sciences Division, Oak Ridge National Laboratory, Oak Ridge, TN.

REFERENCE(S): Delcourt et al. 1980.

COMMENTS: Data are presented for survey units if the density of forestland is low. Forest survey unit codes are indicated by FIPS codes greater than 900. No data are included for the western portions of the Great Plains states including Texas, Oklahoma, Kansas, Nebraska, and the Dakotas. Data are included for the Canadian portions of the eastern deciduous forest.

YEAR (S) : $1965-1978$

GEOCOVE RAGE : East

STATUS: Being edited

NUMBER OF RECORDS : 1679

CREATED/UPDATED: Mar. 1980

COMPILER: $\mathrm{R}$ J Olson
TEMPORAL RESOLUTION: Annual SPATIAL RESOLUTION: County DATA SET TYPE: Single VARIABLES PER RECORD: 12 NEW. DATA : Every 10 years

\section{VARIABLE LABEL AND UNITS OF MEASURE}

FIPS CO

FIPS ST

FS $C \bar{F} A$

$\mathrm{FS}^{-} \mathrm{CO}^{-} \mathrm{A}$

FS FOR A

PUB REF
FI.PS county number

FIPS state number

Area of co. in commercial forest

Area of county based on USFS estimates

Area of county in forest

Publication reference 


$\begin{array}{ll}\text { T_S_BIO } & \text { Total stand biomass } \\ \text { T-SGGS } & \text { Total stand growing stock volume } \mathrm{m} * \star 3 / \mathrm{ha} \\ \text { USFS CO } & \text { County code - USFS } \\ \text { IISFE-IAT } & \text { Latitude of county or survey unit } \\ \text { USFS-LNG } & \text { Longitude of county or survey unit } \\ \text { USFS_ST } & \text { State code - USFS }\end{array}$


GENERAL (G) SECTOR OVERVIEW

'lhe General sector contains information un the contents of the Geoecology Data Base including data set characteristics (GOI) and labels for each of the variables within the Data Base (G02). The variables and labels were extracted from the individual sAS data set contents. These data sets were used to compile Appendices $A$ and $B$ of this report. The other data sets in the $G$ sector provide an index of supporting data tapes (G03) and of materials produced from the Geoecology Data Base. G04 is an inventory of graphs and maps that have been generated from the Data Base. 
TITLE: GO1 - DATA SET TITLES AND CHARACTERISTICS

DESCRIPTION: This data set provides general information for each of the data sets within the Geoecology Data Base. Thematic sector designation, data set title, spatial and temporal characteristics, data. set status and type, and compiler and date of compilation are included. Both the geographic coverage and spatial resolution are defined as well as the reference year(s) and temporal resolution. If a data set is an index or dictionary type, these fields will be blank. Data set type may indicate that the data set is being edited or in the planning stage. This file is updated as new data sets are added or change status. It is used to create the center section (e.g., YEAR (S) through COMPILER) of the data set descriptions in Appendix A.

SOURCE(S): Compiled from the Geoecology Data Base.

YEAR(S): Current GEOCOVE RAGE :

STATUS: Online

NUMBER OF RECORDS : 113

CREATED/UPDATED: Aug 1980

COMPILER: $\quad \mathrm{R} J$ OISON
TEM PORAL RESOLUTION :

SPATIAL RESOLUTION:

DATA SET TYPE: DictnYY

VARIABLES PER RECORD: 15

NEW DATA: as needed

\section{VARIABLE LABEL AND UNITS OF MEASURE}

$\begin{array}{ll}\text { COMPILER } & \text { Data Compiler(s) } \\ \text { DATE } & \text { Date Created/Updated } \\ \text { DSN } & \text { Data Set Number } \\ \text { GEOCOVER } & \text { Geographic Coverage } \\ \text { GEOUNIT } & \text { Spatial Resolution } \\ \text { ITEMS } & \text { Number of Variables } \\ \text { RECORDS } & \text { Number of Records } \\ \text { SECTOR } & \text { Sector Code Letter } \\ \text { STATUS } & \text { Data Set Status } \\ \text { TEMPORAL } & \text { Temporal Resolution } \\ \text { THEME } & \text { Thematic Sector Letter } \\ \text { TITLE } & \text { Data Set Title } \\ \text { TYPE } & \text { Data Set Type } \\ \text { UPDATES } & \text { Anticipated Update Interval } \\ \text { YEARS } & \text { Reference year(s) of the data }\end{array}$


TITLE: G02 - DATA SET VARIABLES AND LABELS

DESCRIPTION: Each SAS variable, label, and data set number (DSN) are included in this data set. These were extracted from the data base to generate Appendix $B$ which is an index of the 1000 variables. G02 also enables the variable names and labels to be edited to ensure uniqueness and consistency.

SOURCE(S): Compiled from the Geoecology Data Base.

YEAR(S): Current GEOCOVERAGE :

STATUS: Online

NUMBER OF RECORDS : 1500

CREATED/UPDATED: Aug 1980 COMPILER: R J Olson
TEMPORAL RESOLUTION: SPATIAL RESOLUTION: DATA SET TYPE: Dictnry VARIABLES PER RECORD: 3 NEW DATA: As Needed

\section{VARIABLE LABEL AND UNITS OF MEASURE}

DSN Data Set Number

LABEL Variable Label and Units of Measure VARIABLE Variable Name 
TITLE: G03 - SOURCE \& SUPPORTING DATA FILES (TAPES)

DESCRIPTION: The Geoecology Data Base has been created primarily from extant data. A library of source data is being accumulated in the development and expansion of the data base. This data set provides an inventory of the magnetic tapes including original source files, offline data sets (edited and stored as sAS. data sets), and back-up files.

SOURCE (S): Compiled by the Geoecology staff.

REFERENCE(S) Copenhaver and Barker 1980.

YEAR(S): Current GEOCOVE RAGE :

STATUS: Being Edited
TEM PORAL . RESOLUTION : SPATIAL RESOLUTION: DATA SET TYPE: Index 
TITLE: G04 - GEOECOLOGY-GENERATED GRAPHICS INDEX

DESCRIPTION: Many maps and graphics are generated from the Geoecology Data Base by a varicty of individuals for various project needs. We are maintaining a file of materials that have been used in publications or presentations. The index provides information on the title, source data set(s), and the ORNL drawing number, if available.

SOURCE(S): Compiled by the Geoecology Staff.

YEAR(S): Current GEOCOVE RAGE :

STATUS: Being Edited
TEMPORAL RESOLUTION: SPATIAL RESOLUTION: DATA SET TYPE: Index 
TITLE: G05 - SOURCE \& SUPPORTING MAPS

DESCRIPTION: The Geoecology Project uses many maps either to create data sets or to support the interpretation of results using the digital files. This data set provides an index to these maps and working maps that have been generated from the data base.

SOURCE(S): Compiled by the Geoecology Staff.

YEAR(S): Current GEOCOVE RAGE :

STATUS: Being Edited
TEMPORAL RESOLUTION : SPATIAL RESOLUTION:

DATA SET TYPE: Index 
1 


\section{AIR QUALITY (K) SECTOR OVERVIEW}

Ambient air quality is monitored by EPA to determine compliance with the Clean Air Act and other legislation. often monitoring stations are concentrated in industrial or urban areas. The frequency, reliability, and number of pollutants measured varies with local conditions. Air quality statistics have been compiled by Lawrence Berkeley Laboratory as part of the Population At Risk to Air Pollution (PARAP) project (Merrill 1980). These county-level statistics were estimated from the available EPA monitoring data which were screened hefore heing used. County estimates were calculated for the population centroid of the counties which had a monitoring station within $60 \mathrm{~km}$. Air emissions from projected industrial activity are calculated by the Strategic Environmental Assessment System (SEAS) model. The SEAS model is a joint DOE/EPA effort. We plan to incorporate data from SEAS on projected emissions and ambient concentrations when these data become available. The SEAS data are for AQCR's. 
TITLE: KOI - AMBIENT AIR QUALITY (SAROAD)

DESCRIPTION: Ambient air quality values for sulfur dioxide (SO2), nitrogen dioxide (NO2), and total suspended particulates (TSP) were calculated for Air Quality Control Regions (AQCR's) in the 16 southeastern states. See data sets $\mathrm{B} 03$ and $\mathrm{B} 06$ for $\mathrm{AQCR}-\mathrm{county}$ indices. Estimates were based on the EPA monitoring data collected from 1973 through 1976. Annual average concentrations were calculated for each year with arithmetic means for SO2 and NO2 and geometric means for TSP. Number of observations, minimum, maximum, and standard deviation are included for each pollutant.

SOURCE(S): EPA. 1977. SAROAD Magnetic Tape. EPA, Research Triangle Park, NC.

REFERENCE(S): Strand 1979, USEPA 1976.

COMMENTS: Units of measure are micrograms per cubic meter $(\mathrm{mcg} / \mathrm{m} 3)$. The TSP mean concentration is calculated as the geometric mean.

YEAR (S) : $\quad 1974-1976$

GEOCOVERAGE : South

STATUS: Online

NUMBER OF RECORDS : $\quad 963$

CREATED/UPDATED: Mar. 1980

COMPILER: R A Strand
TEMPORAL RESOLUTION : Annual SPATIAL RESOLUTION: AQCR DATA SET TYPE: Single VARIABLES PER RECORD: 8
VARIABLE

LABEL AND UNITS OF MEASURE

\begin{tabular}{lll}
\hline AQ_MAX & Air quality maximum value & $\mathrm{mcg} / \mathrm{m} 3$ \\
AQ_MEAN & Arith mean SO2\&NO2, geom mean TSP $\mathrm{mcg} / \mathrm{m} 3$ \\
AQ_MIN & Air quality minimum value & $\mathrm{mcg} / \mathrm{m} 3$ \\
AQ_NUM & Air quality number of observations \\
AQ_SD & Air quality standard deviation $\mathrm{mcg} / \mathrm{m} 3$ \\
AQCR & Air Quality Control Region number $-\mathrm{EPA}$ \\
POLLUTNT & Pollutant \\
YEAR & Year of data
\end{tabular}


K01.1 Air Quality Control Regions in the South with High Sulfur Dioxide Levels, for which the 1974-1976 Annual Average Ambient Concentrations Exceeded 100 micrograms per cubic meter.

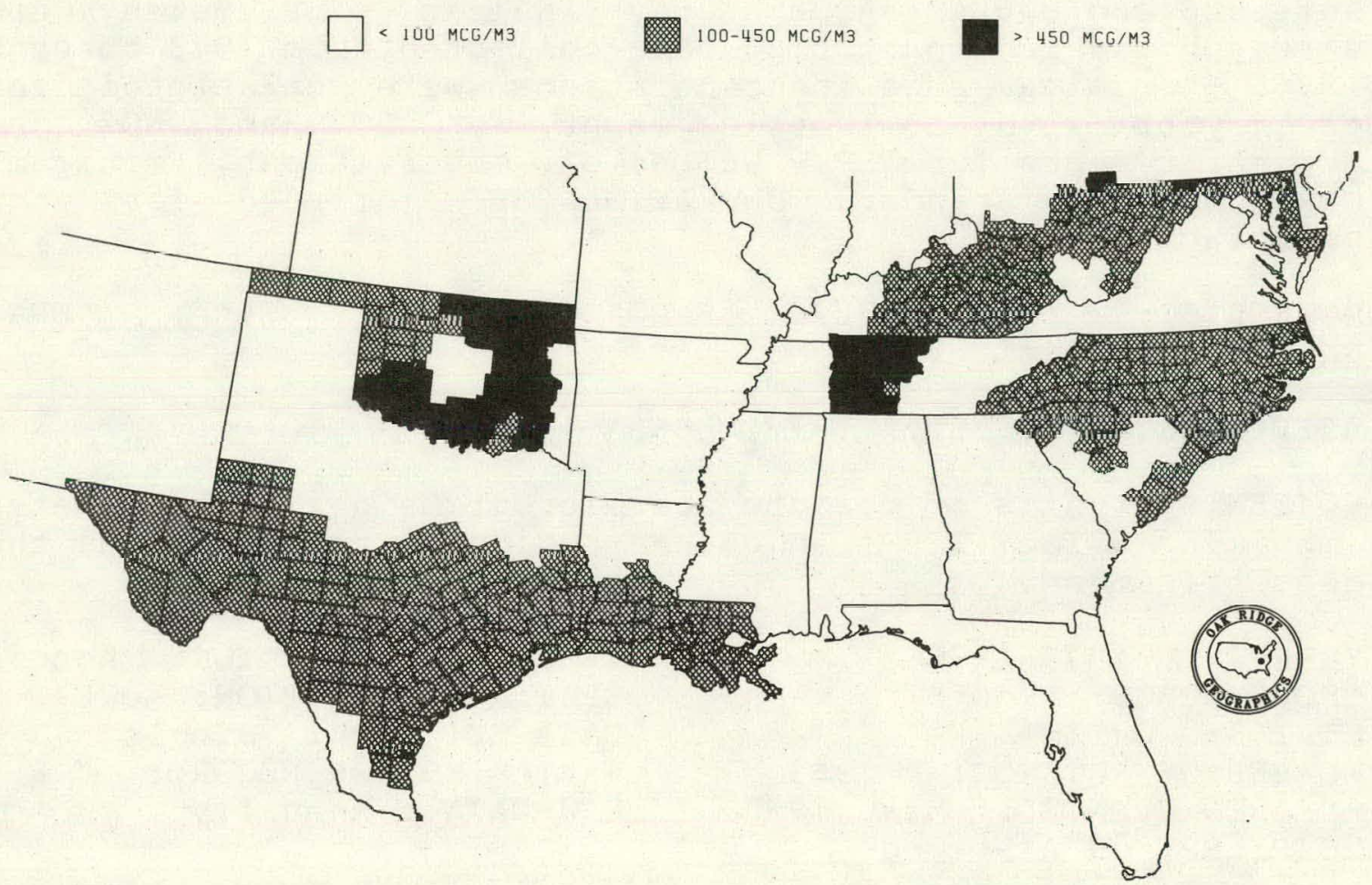


TITLE: K02 - PROJECTED EMISSIONS (SEAS)

DESCRIPTION: This data set will be compiled when the projected emission residuals become available from the DOE/EPA SEAS model.

YEAR(S): $\quad 75,85,90,2000$ GEOCOVE RAGE :' U. S. STATUS: Planned

TEMPORAL RESOLUTION: Annual SPATIAL RESOLUTION: AQCR DATA SET TYPE: Multiple. 
TITLE: K03 - PROJECTED AMBIENT SO2, TSP (SEAS)

DESCRIPTION: Data set K02 projects residuals at the AQCR level. This data set will contain ambient concentrations based on the $\mathrm{K} 02$ residuals. Contributions from adjoining AQCR's are considered through the use of a roll-back model. Data set K03 will not be available until both the SEAS and roll-back model outputs have been verified by DOE.

$\operatorname{YEAR}(\mathrm{S}): \quad 75,85,90,2000$

GEOCOVERAGE : U. S.

STATUS: Planned

TEM PORAL RESOLUTION: AnnuaI SPATIAL RESOLUTION: AQCR

DATA SET TYPE: Sinqle 
TITLE: K04 - AIR QUALITY NONATTAINMENT AREAS (EPA)

DESCRIPTION: Air quality nonattainment areas are those which have recorded a violation of the National Ambient Air Quality Standards for one of the major pollutants during a specific time. This file, from EPA, gives the status of counties as of April 23, 1979. Pollutants included are: sulfur dioxide (SO2), nitrogen oxides (NOX), total suspended particulates (TSP), carbon monoxide (CO), and photochemical oxidants (OX). Codes are included to indicate if part (P) or all (A) of the county is in violation of either the primary (1) or secondary (2) standards.

SOURCE(S): Deal, L. August, 1979. Nonattainment county card deck. EPA, Research Triangle Park, NC.

$\operatorname{YEAR}(\mathrm{S}): \quad 1979$

GEOCOVE RAGE : U. S. STATUS: Online

NUMBER OF RECORDS : $\quad 1246$

CREATED/UPDATED: Mar. 1980

COMPILER: R J Olson
TEMPORAL RESOLUTION: Annual SPATIAL RESOLUTION: County DATA SET TYPE: Single VARIABLES PER RECORD: 5 NEW DATA: Annually

$\begin{array}{ll}\text { FIPS_CO } & \text { FIPS county number } \\ \text { FIPS-ST } & \text { FIPS state number } \\ \text { NA_STD } & \text { Standard not met ( } 1=\text { primary } 2=\text { secondary) } \\ \text { NC-PART } & \text { Noncomplying part of co. (P=part } A=a l l) \\ \text { POLLUTNT } & \text { Pollutant }\end{array}$


K04.1 Nonattainment Counties for Total Suspended Particulates.

paimart, entike co Primart, part of co secondart, entire co

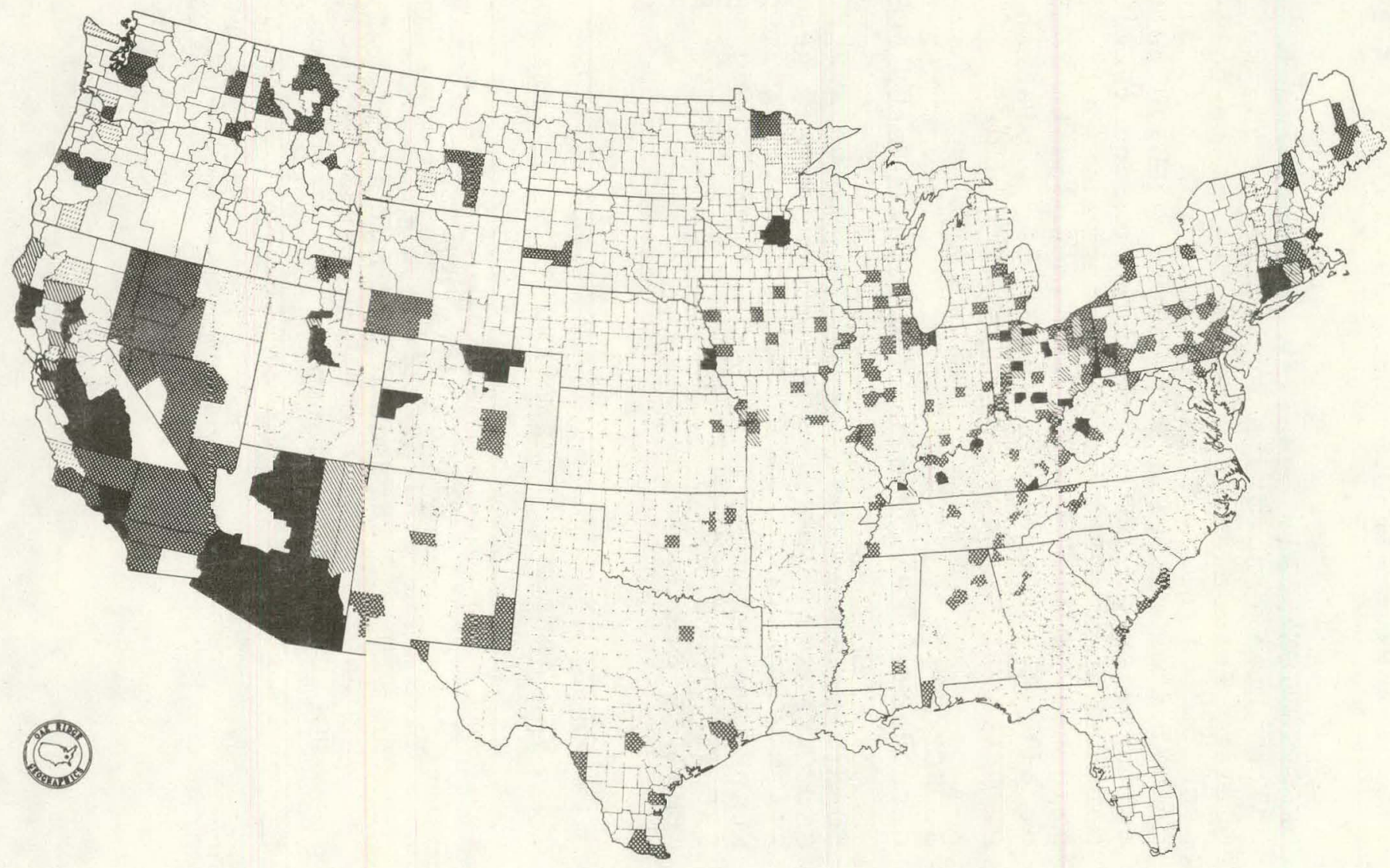


IITLE: K05 - PROJECTED AMBIENT SO2, SULFATE (NCUA)

DESCRIPTION: Ambient air quality concentrations for sulfur dioxide (SO2) and sulfate (SUL) were estimated for counties in the 16 southeastern states for 1975, 1985, and 2000 . Concentrations are given in micrograms per cubic meter $(\mathrm{mcg} / \mathrm{m} 3)$. Estimations of regional loading patterns were calculated using a long-range transport model. January climatological conditions were used because of the shallow mixing layer and high electric power demand. These conditions would produce the most severe pollution problems in most parts of the country. Emission sources for 1975, 1985, and 2000 were based on the National Coal Utilization Assessment (NCUA) power plant siting patterns. Long-range transport considered the depletion by dry deposition and washout. A sulfur dioxide to sulfate transformation rate of 5 percent per hour was used. The model utilized a rectangular grid network. The grid data were entered into the SYMAP program which fitted a surface to the estimated points. Concentration levels at the geographic centroids of counties were estimated from the SYMAP fitted surface.

SOURCE(S): Begovich, C. 1977. Data File. Computer Sciences Division, Oak Ridge, TN.

REFERENCE (S): Begovich et al. 1978, Davis 1978.

COMMENTS: Concentrations are given in micrograms per cubic meter $(\mathrm{mcg} / \mathrm{m} 3)$.

$\operatorname{YEAR}(\mathrm{S}): \quad 1975,1985,2000$

GEOCOVE RAGE : South

STATUS: Online

NUMBER OF RECORDS : 1388

CREATED/UPDATED: Mar. 1980

TEMPORAL RESOLUTION: Annual SPATIAL RESOLUTION: County DATA SET TYPE: Single VARIABLES PER RECORD: 8 COMPILER: $\mathrm{R}$ J Olson

NEW DATA: Not anticipated

\section{VARIABLE LABEL AND UNITS OF MEASURE}

$\begin{array}{ll}\text { FIPS_CO } & \text { FIPS county number } \\ \text { FIPS-ST } & \text { FIPS state number } \\ \text { SO2_1975 } & \text { Estimated SO2 ambient levels for } 1975 \\ \text { SO2_1985 } & \text { Projected SO2 ambient levels for } 1985 \\ \text { SO2_2000 } & \text { Projected SO2 ambient levels for 2000 } \\ \text { SUL_1975 } & \text { Estimated sulfate ambient levels, 1975 } \\ \text { SUL_1985 } & \text { Projected sulfate ambient levels, 1985 } \\ \text { SUL_2000 } & \text { Projected sulfate ambient levels, 2000 }\end{array}$




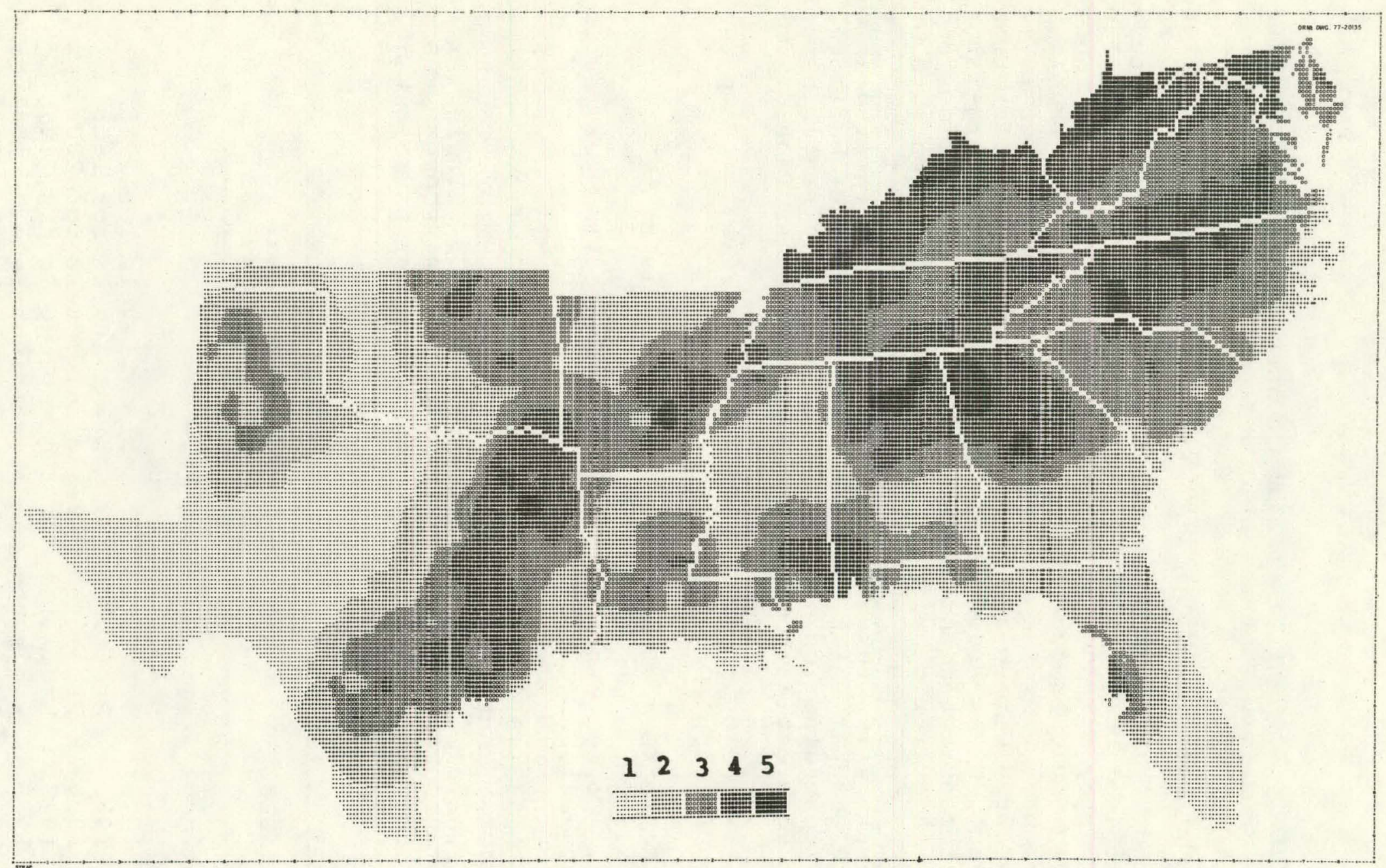

K05.2 Projected 1985 Ambient Sulfur Dioxide Concentrations. Interval

1 imits in micrograms fer cubic meter: (1) <0.1, (2) $0.1-1.0$, (3) $1.0-3.0$, (4) $3.0-10.0$, (5) $>10.0$. 
TITLE: K06- AMBIENT AIR QUALITY ESTIMATES

DESCRIPTION: Ambient air quality estimates were derived by Deane Merrill, Läwrence Berkeley Laboratory (LBL), as part of the Population at Risk to Air Pollution (PARAP) project. This file includes estimates for nine pollutants including: carbon monoxide (CO), hydrocarbons (HC), nitrogen oxides (NO2), nonmethane hydrocarbons, total oxidants, ozone (03), sulfur dioxide (SO2), total suspended particulates (TSP), and sulfates. Annual averages for the county population centroid were calculated by averaging measurements from all nearby monitoring stations for the period 1974 to 1976 . If no measurements for a pollutant were available from stations located within $60 \mathrm{~km}$ of the county centroid, the county value was not estimated. Therefore, many areas with limited monitoring data for some or all of the pollutants have no county estimates for these poliutants. Both geometric and arithmetic mean concentrations were calculated. The estimation procedure utilized a distance weighting function and smoothing parameter based on a $20 \mathrm{~km}$ distance. The choice of an appropriate weighting function is being studied by LBL.

SOURCE(S): Merrill, D. March 1980. PARAP County-level Ambient Air Quality Magnetic Tape. Lawrence Berkeley Laboratory, Berkeley,. CA.

REFERENCE(S): Merrill et al. 1978 .

COMMENTS: Averages for NO2 and $\mathrm{SO} 2$ are given based on 24-hour and hourly measurements when available. These estimates should be comparable; however, often the monitoring procedures (e.g., frequency of measurements and period of station operation) are such that the two methods produce significantly different values.

YEAR.(S) : $\quad 1974-1976$

GEOCOVE RAGE : U.S.

STATUS: Being Edited
TEMPORAL RESOLUTION: Annual SPATIAL RESOLUTION: County DATA SET TYPE: single 
齐
E 


\section{LAND (L) SECTOR OVERVIEW}

The Land Scctor includes several data sets related to land-use, land capability, and land-use restrictions. County-level land-use statistics which have national coverage are available from the 1967 Conservation Needs Inventory (USDA 1971). The CNI is both out-of-date and subject to relatively high statistical sampling errors for individual counties. The inventory is also restricted to nonfederal land. Data sets LO1, L02, L03, and L07 are based on the CNI. Land Resource Regions (LRR) (L06) are defined in terms of the agricultural practices and capabilities of a region. 
TITLE: LO1 - LAND USE (CNI DETAILED)

DESCRIPTION: Land-use statistics for 25 categories are given based on the 1967 Conservation Needs Invenlory (CNI). The CNI was conducted by the USDA to determine land use, 1 and capability, and required conservation treatment needs. Only nonfederal, nonurban land was surveyed (about 75 percent of the conterminous states and 1 percent of Alaska). It was based on field surveys using a stratified sampling scheme of individual counties. About 2 percent of the area was sampled, ranging from 1 percent to 10 percent depending on the county. A limited resurvey (state level) was conducted in 1975. The CNI data suffer fion several deficiencies but provide the only source of relatively consistent county-level land-use statistics for the nation. Problems include out-of-date estimates, high sampling errors for counties, and discrepencies in county totals. The totals for some counties differ significantly. from county area given in the 1970 Census file (BOI). We have been unable to resolve these differences. Data set L07 provides aggregated land-use statistics based on LOl, in which the values have been standardized to the 1970 county areas. The L0l data set was created by aggregating capability classes in data set L03 and merging in estimates of the noninventory categories of urban build-up, federal, and small water areas. Estimates of these areas were obtained from Iowa State University for each county.

SOURCE(S) : L03. R. Hickman. July, 1975. CNI-Noninventory Magnetic Tape. Statistical Laboratory, Iowa State University, Ames, IA.

REFERNCE (S) : USDA 1971 .

COMMENTS: The sum of the land-use areas within a county may not equal the 1970 county Census area.

YEAR (S) : 1967

GEOCOVE RAGE : U. S.

STATUS: Online

NUMBER OF RECORDS : 3071

CREATED/UPDATED: Mar. 1980

COMPILER: $\quad \mathrm{R} J$ OlsOn
TEMPORAL RESOLUTION: Annual SPATIAL RESOLUTION: County DATA SET TYPE: Single VARIABLES PER RECORD: 27 NEW DATA: As available 


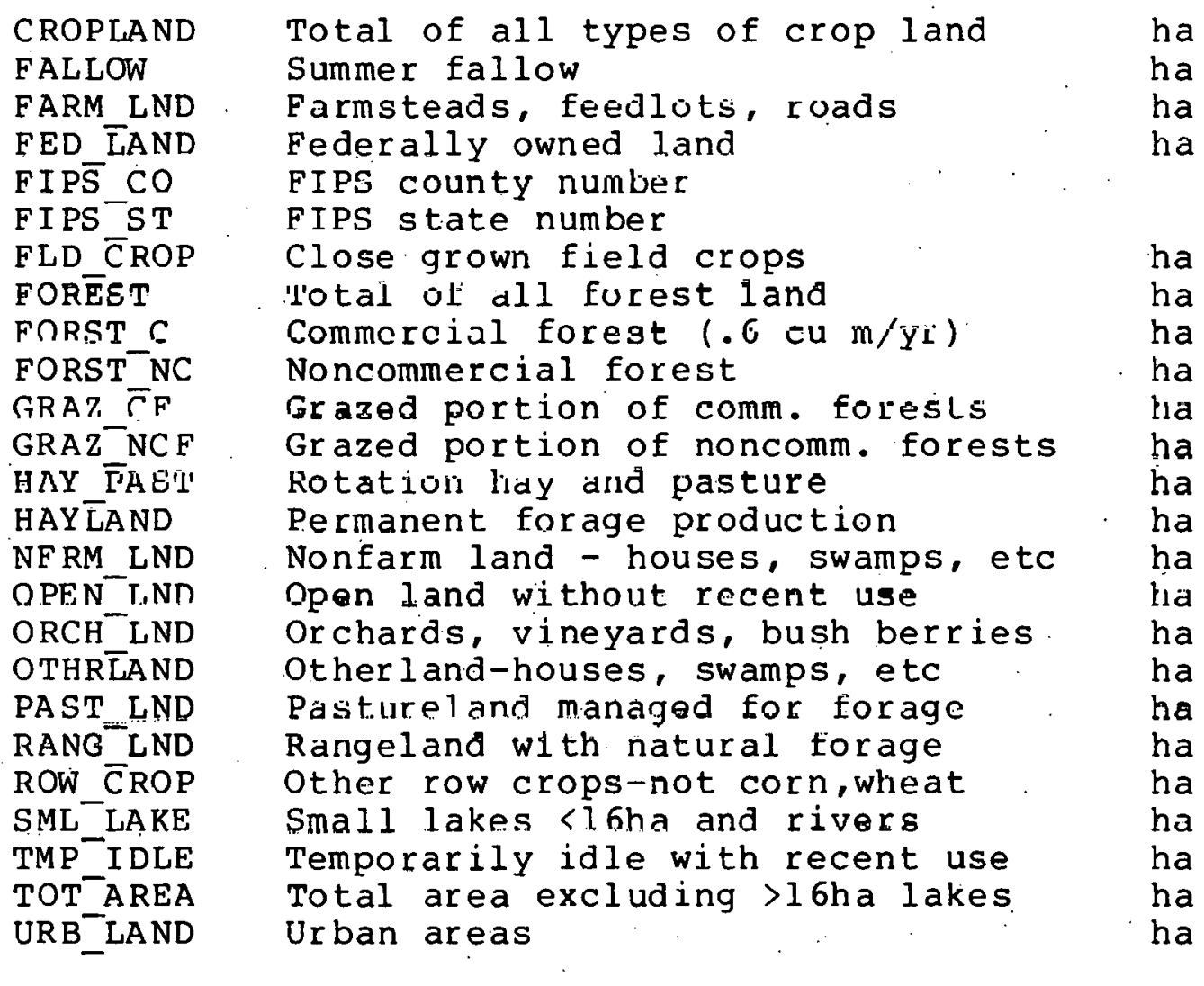


L01.1 County Land-Use Classifications based on the 1967 Conservation Needs Inventory.

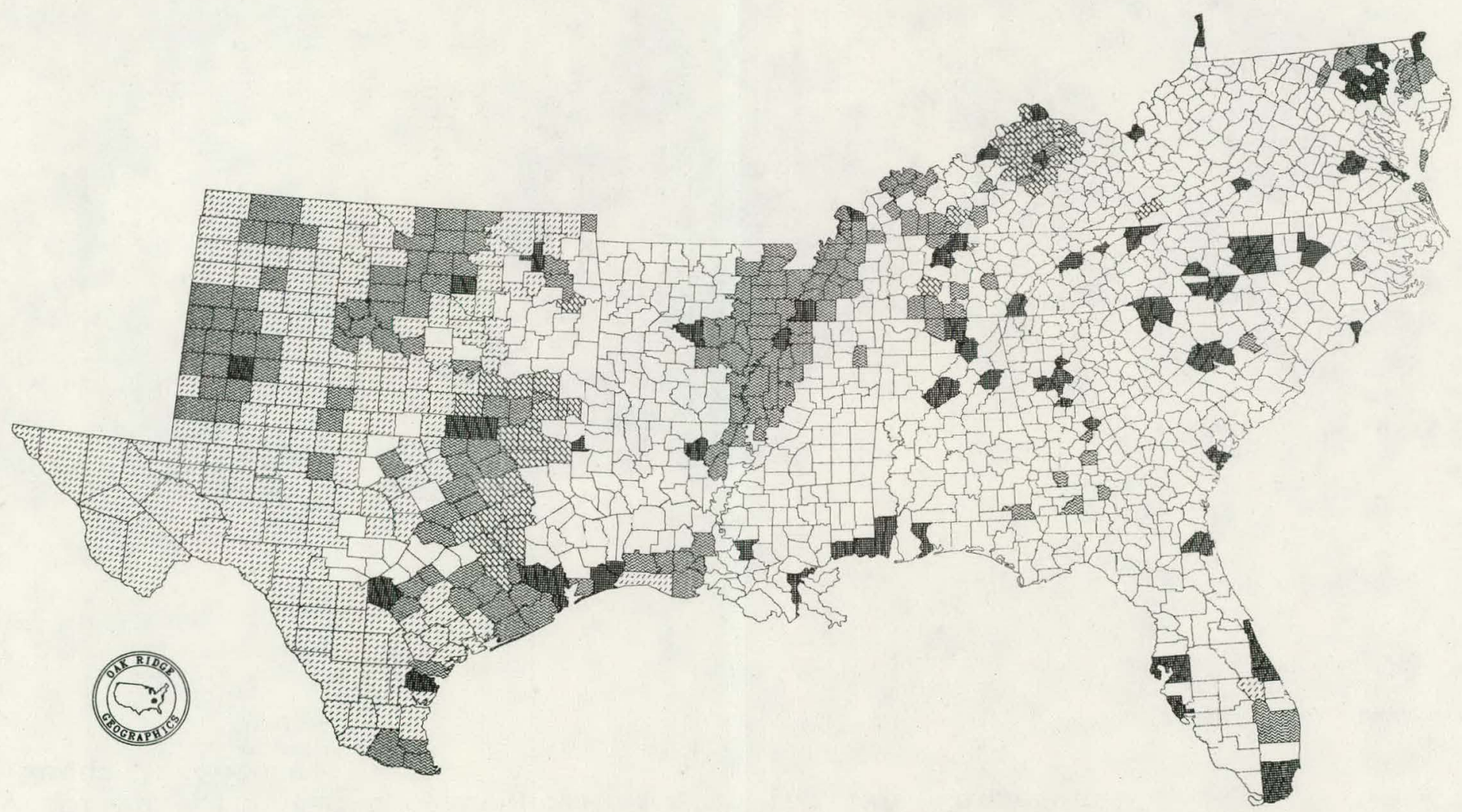

莫 
L01.2 Cropland Percentages by County based on the 1967 Zonservation Needs Inventory.

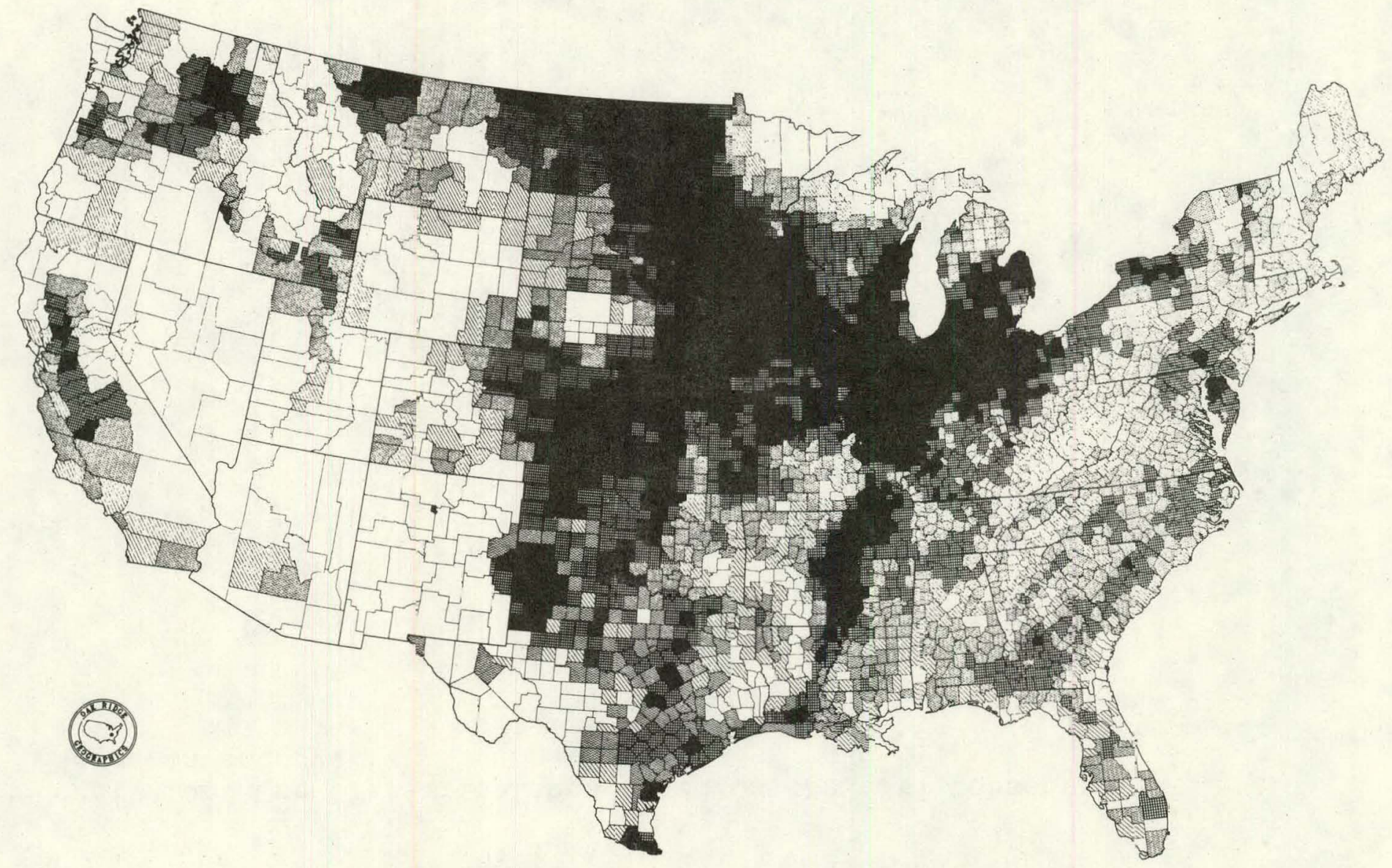


TITLE: LO2 - LAND CAPABILITY CLASSES (CNI)

DESCRIPTION: The 1967 Conservation Needs Inventory classified the land in terms of the capability of soils for agricultural uses (crops and pasture) or sustaining natural vegetation (forest and range). See L0l for a description of the CNI and limitations of the data. The Inventory did not include federal land nor urban build-up land; therefore county totals do not equal the total county area, and some counties are excluded if the entire county is federal or urban. Eight land capability classes (LCC) are included ranging from LCC-1 (few limitations restricting land use) to LCC-8 (severe limitations precluding commercial crop activities). In general, LCC-1 through LCC-4 are capable of producing cultivated crops, while LCC-5 and LCC-6 are capable of sustaining managed natural vegetation. Dominant limitations are designated as E-erosion hazard, W-excess water limitation, S-other unfavorable soil conditions such as shallowness, stoniness, salinity, low fertility, etc., and C-climatic limitation, either temperature or lack of moisture. The data set was created by aggregating land-use types in data set L03.

SOURCE (S): L03.

REFERENCE(S): USDA 1971.

COMMENTS: The $1967 \mathrm{CNI}$ does not include federal land nor urban build-up land; therefore, county totals do not equal the total county area.

$\operatorname{YEAR}(\mathrm{S}): \quad 1967$

GEOCOVERAGE : U. S.

STATUS: Online

NUMBER OF RECORDS : $\quad 3057$

CREATED/UPDATED: Mar. 1980

COMPILER: R J Olson
TEMPORAL RESOLUTION: Annual SPATIAL RESOLUTION: County DATA SET TYPE: Single VARIABLES PER RECORD: 31 NEW DATA: Not anticipated

VARIABLE

LABEL AND UNITS OF MEASURE

FIPS_CO

FIPS ${ }^{-}$T

LCC $\overline{1}$

$\mathrm{LCC}^{-} 2 \mathrm{C}$

$\mathrm{LCC}^{-} 2 \mathrm{E}$

$\mathrm{LCC}^{-} 2 \mathrm{~S}$

$\mathrm{LCC}^{-} 2 \mathrm{~W}$

$\mathrm{LCC}_{-}^{-3 \mathrm{C}}$
FIPS county number

FIPS state number

Soil with no limits ha

Soil with some limits - temp/dryness ha

Soil with some limits - erosion ha

Soil with some limits - poor soil ha

Soil with some limits - excess water ha

Soil with severe limits - temp/dryness 
LCC $3 E$

$\mathrm{LCC}^{-3 \mathrm{~S}}$

$\mathrm{LCC}^{-} 3 \mathrm{~W}$

$\mathrm{LCC}^{-} 4 \mathrm{C}$

$\mathrm{LCC}^{-} 4 \mathrm{E}$

$\mathrm{LCC}^{-} 4 \mathrm{~S}$

$\mathrm{LCC}^{-} 4 \mathrm{~W}$

$\mathrm{LCC}^{-} 5 \mathrm{C}$

$\mathrm{LCC}^{-5 \mathrm{E}}$

$\mathrm{LCC}^{-} 5 \mathrm{~S}$

$\mathrm{LCC}^{-5 \mathrm{~W}}$

$\mathrm{LCC}^{-} 6 \mathrm{C}$

$\mathrm{LCC}^{-6} 6 \mathrm{E}$

$\mathrm{LCC}^{-} 6 \mathrm{~S}$

$\mathrm{LCC}^{-} 6 \mathrm{~W}$

$\mathrm{LCC}^{-} 7 \mathrm{C}$

$\mathrm{LCC} / \mathrm{E}$

$\mathrm{LCC}^{-7} 7 \mathrm{~S}$

$\mathrm{LCCC}^{-7 \mathrm{~W}}$

$\mathrm{LCC}^{-} 8 \mathrm{C}$

$\mathrm{LCC}^{-} 8 \mathrm{E}$

$\mathrm{LCC}^{-} 8 \mathrm{~S}$

$\mathrm{LCC}^{-} 8 \mathrm{~W}$
Soil with severe limits - erosion ha

Soil with severe limits - poor soil ha

Soil with severe limits - excess water

Soil w/ very severe limits-temp/dryness

Soil w/ very severe limits-erosion ha

Soil w/ very severe limits-poor soil ha

Soil w/ very severe limits-excess water

Soil level hut wet/stoney - Lemp/dryness

Soil level but wet/stoney - erosion ha

Soil level but wet/stoney - poor soil ha

Soil level but wet/stoney - excess water

Soil for range, forest, etc - temp/dryness

Soil for range, forest, etc - erusion ha

Soil for range, forest, etc - poor soil ha

Soil for range, forest, etc - excess water

Soil for forest, wildlife - temp/dryness

Soil for forest, wildlife - erosion ha

Soil for forest, wildlife - poor soil ha

Soil for forest, wildlifc - cxcess water

Soil w/ cultivatn precluded-temp/dryness

Soil w/ cultivatn precluded-erosion ha

Soil w/ cultivatn precluded-poor soil ha Soil w/ cultivatn precluded-excess water 
L02.1 Land Capability Classes I-II-III Percentages based on the 1967 Conservation Needs Inventory.

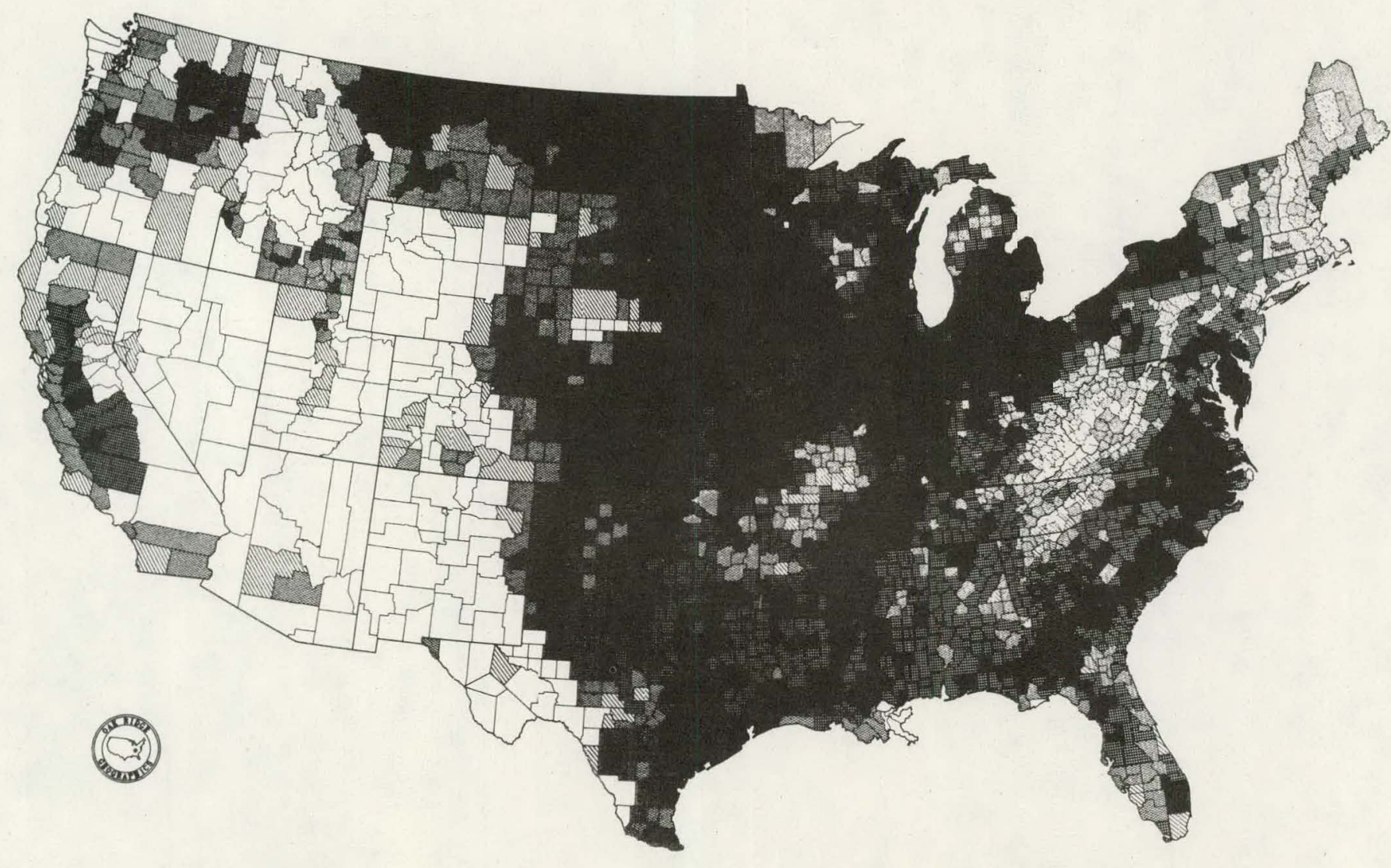


TITLE: L03 - LAND USE BY LAND CAPABILITY CLASS (CNI)

DESCRIPTION: The land-use capability class (LCC) data for each of the 22 land-use categories are maintained as an offline tape file. See data set L01 and L02 descriptions for definitions and data set problems. This file was used to produce L01 and L02.

SOURCE(S): R. Hickman. April, 1972. 1967 CNI Magnetic Tape. Statistical Laboratory, Iowa State University, Ames, IA.

REFERENCE (S) : USDA 1971 .

$\operatorname{YEAR}(\mathrm{S}): \quad 1967$

GEOCOVERAGE : U, S.

STATUS: Offline

NUMBER OF RECORDS: 37800

CREATED/UPDATED: Mar. 1980

COMPILER: $\mathrm{R} \mathrm{J}$ Olson
TEMPORAL RESOLUTION: Annua1 SPATIAL RESOLUTION : County DATA SET TYPE: Multiple VARIABLES PER RECORD: 28 NEW DATA: Not anticipated

\begin{tabular}{|c|c|}
\hline $\begin{array}{l}\text { CONS LND } \\
\text { CRN CROP }\end{array}$ & $\begin{array}{l}\text { Conservation use only } \\
\text { Corn and sorghum }\end{array}$ \\
\hline CROP̄LAND & Total of all types of crop land \\
\hline FALLOW & Summer fallow \\
\hline FARM LND & Farmsteads, feedlots, roads \\
\hline FED $\bar{L} A N D$ & Federally owned land \\
\hline FIPS_CO & FIPS county number \\
\hline FIPS_ST & FIPS state number \\
\hline FLD $\bar{C} R O P$ & Close grown field crops. \\
\hline FORĒST & Total of all forest land \\
\hline FORST_C & Commercial forest $(.6 \mathrm{cu} \mathrm{m} / \mathrm{yr})$ \\
\hline FORST_NC. & Noncommercial forest \\
\hline GRAZ_ $\bar{C} F$ & Grazed portion of comm. forests \\
\hline GRAZ-NCF & Grazed portion of noncomm. forests \\
\hline HAY_ $\bar{P} A S T$ & Rotation hay and pasture \\
\hline HAY $\bar{L} A N D$ & Permanent forage production \\
\hline LCC C CODE & Land capability ciass code \\
\hline NF R⿳亠口冋口_LND & Nonfarm land - houses, swamps, etc \\
\hline OPEN-LND & Open land without recent use \\
\hline ORCH LND & Orchards, vineyards, bush berries \\
\hline OTHRĒAND & Otherland-houses, swamps, etc \\
\hline PAST LND & Pastureland managed for forage \\
\hline RANG_LND & Rangeland with natural forage \\
\hline ROW_一̄ ROP & Other row crops-not corn, wheat \\
\hline SML_LAKE & Small lakes <16ha and rivers \\
\hline
\end{tabular}


TMP IDLE TOT AREA

URB LAND
Temporarily idle with recent use Total area excluding $>16 \mathrm{ha}$ lakes Urban areas ha

ha

ha 
TITLE: LO4 - SEISMIC RISK RATINGS

DESCRIPTION: Seismic activity was rated by the Nuclear Regulatory Commission for nuclear energy center operations. The three relative seismic suitability zones were defined in terms of difficulty in establishing seismic risk as low (1), moderate (2), or high (3). Zone 1 contains suitable sites, zone 2 would require site-specific studies, and zone 3 would be impractical for nuclear facility siting due to costs and time required for seismic studies. The ratings were based on tectonics stucture and seismologic history of the region. The proportion of each county in each category was estimated.

SOURCE(S): Wilson, D. L. 1978. Seismic Risk Data File. Computer Sciences Division, UCCNC, Oak Ridge, TN.

REFERENCE(S): USNRC 1976, Map plate 4.1.

$\operatorname{YEAR}(\mathrm{S}): 1975$

GEOCOVE RAGE : South

STATUS: Online

NUMBER OF RECORDS : 1388

CREATED/UPDATED: Mar. 1980

COMPILER: D L Wilson
TEMPORAL RESOLUTION: Cur rent SPATIAL RESOLUTION: County DATA SET TYPE: Single VARIABLES PER RECORD: 5 NEW DATA: Not anticipated

\begin{tabular}{lll}
\hline VARIABLE & LABEL AND UNITS OF MEASURE & \\
\hline FIPS_CO & FIPS county number & \\
FIPS_ST & FIPS state number & ha \\
SEISM 1A & Low seismic risk area & ha \\
SEISM-2A & Moderate seismic risk area & ha \\
SEISM_3A & High seismic risk area & \\
\hline
\end{tabular}




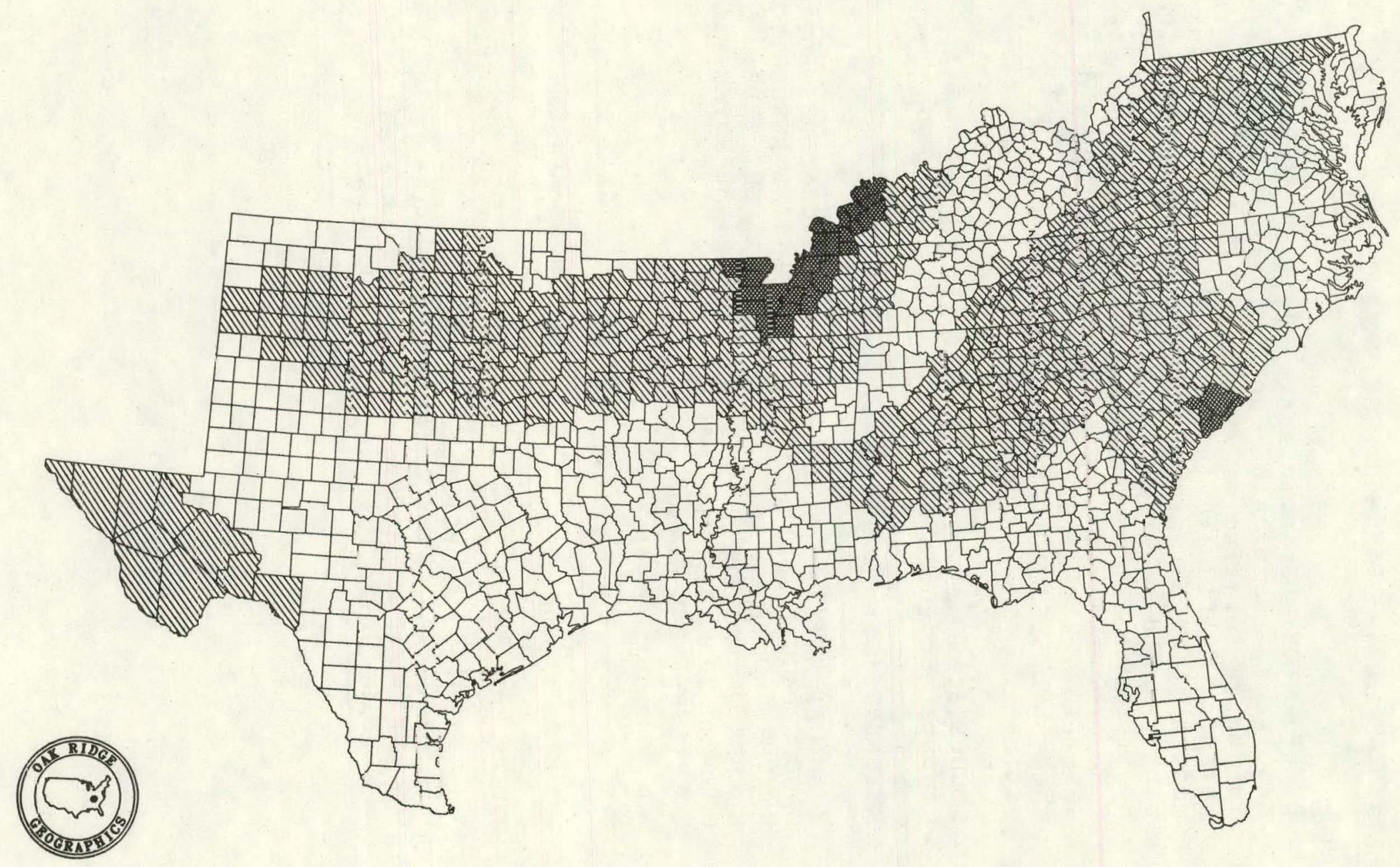


TITLE: L05 - LAND SURFACE MINING

DESCRIPTION: Areas of counties disturbed by surface mining were estimated for several types of mining activities which either do or do not require land reclamation activities. Commodities included were coal, sand and gravel, and all other. Areas needing reclamation were further subdivided into those for which reclamation is and is not required by law. Areas disturbed include land from which materials have been displaced, land upon which materials have been deposited, haul roads, and other lands whose natural state has been disturbed as a result of surface mining activities. The inventory is the fourth since 1965. The data set was created by keypunching the tables contained in the soil Conservation Service report (Holmberg 1977).

SOURCE(S): Holmberg 1977.

$\operatorname{YEAR}(\mathrm{S}): 1975$

GEOCOVERAGE : U. S.

STATUS: Online

NUMBER OF RECORDS : $\quad 3071$

CREATED/UPDATED: Mar. 1980

COMPILER: C J Emerson

TEMPORAL RESOLUTION: Annual SPATIAL RESOLUTION: County DATA SET TYPE: Single VARIABLES PER RECORD: 10 NEW DATA: As available

$\begin{array}{lll}\text { COAL_NEC } & \text { Coal mines - reclamation necessary } & \text { ha } \\ \text { COAL_RQD } & \text { Coal mines - reclam required by law } & \text { ha } \\ \text { FIPS_CO } & \text { FIPS county number } & \\ \text { FIPS-ST } & \text { FIPS state number } & \text { ha } \\ \text { LAND_DST } & \text { Total land disturbed } & \text { ha } \\ \text { LAND_NOT } & \text { Land not requiring reclamation } & \text { ha } \\ \text { OTHR_NEC } & \text { Other mines - reclamation necessary } & \\ \text { OTHR_RQD } & \text { Other mines - reclam required by law } & \text { ha } \\ \text { SAND_NEC } & \text { Sand and gravel reclam necessary } & \text { ha } \\ \text { SAND_RQD } & \text { Sand and gravel - reclam rqd by law } & \text { ha }\end{array}$


TITLE: LO6 - LAND RESOURCE REGION INDEX

DESCRIPTION: The conterminous states have been divided into 20 Land Resource Regions (LRR's) and into 156 Major Land Resource Areas (LRA's) based primarily on existing agricultural activity and physiographic conditions. The boundaries have been adjusted to counties for compilations of statistical data; however, counties within an LRA are not always contiguous. The names and characteristics of the regions are available in USDA Handbook 296 (Austin 1965). This data set was included with the 1967 CNI file. The data set also includes the Water Resource Region index code; however, data set B03 contains a more up-to-date and detailed index of Water Regions.

SOURCE(S): Hickman, R. 1972. 1967 CNI Magnetic Tape. Statistical Laboratory, Iowa State Universtiy, Ames, IA.

REFERENCE(S): Austin 1965.

$\operatorname{YEAR}(\mathrm{S}): \quad 1967$

GEOCOVE RAGE : U. S.

STATUS: Online

NUMBER OF RECORDS : $\quad 3071$

CREATED/UPDATED: Mar. 1980

COMPILER: $\mathrm{R}$ J Olson

TEMPORAL RESOLUTION: Current SPATIAL RESOLUTION: County DATA SET TYPE: Index VARIABLES PER RECORD: 5 NEW DATA: Not anticipated

$\begin{array}{ll}\text { FIPS_CO } & \text { FIPS county number } \\ \text { FIPS_ST } & \text { FIPS state number } \\ \text { LRA_CODE } & \text { SCS Land Resource Area code } \\ \text { LRR_CODE } & \text { SCS Land Resource Region code } \\ \text { WRR_CODE } & \text { SCS Water Resource Region code }\end{array}$




\section{L06.1 Soil Conservation Service Land Resource Regions.}

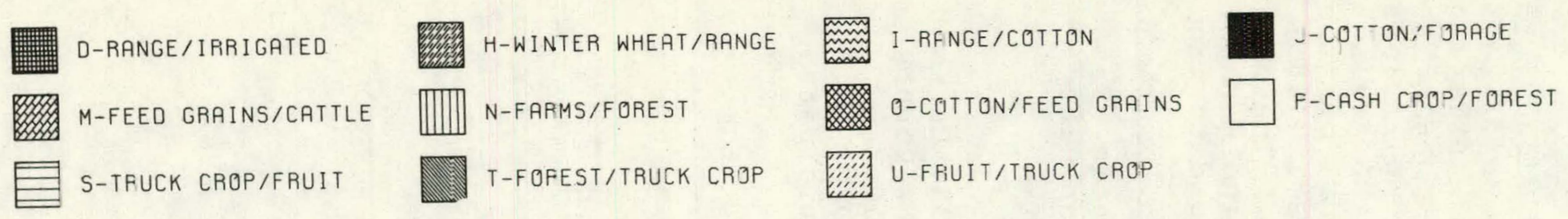

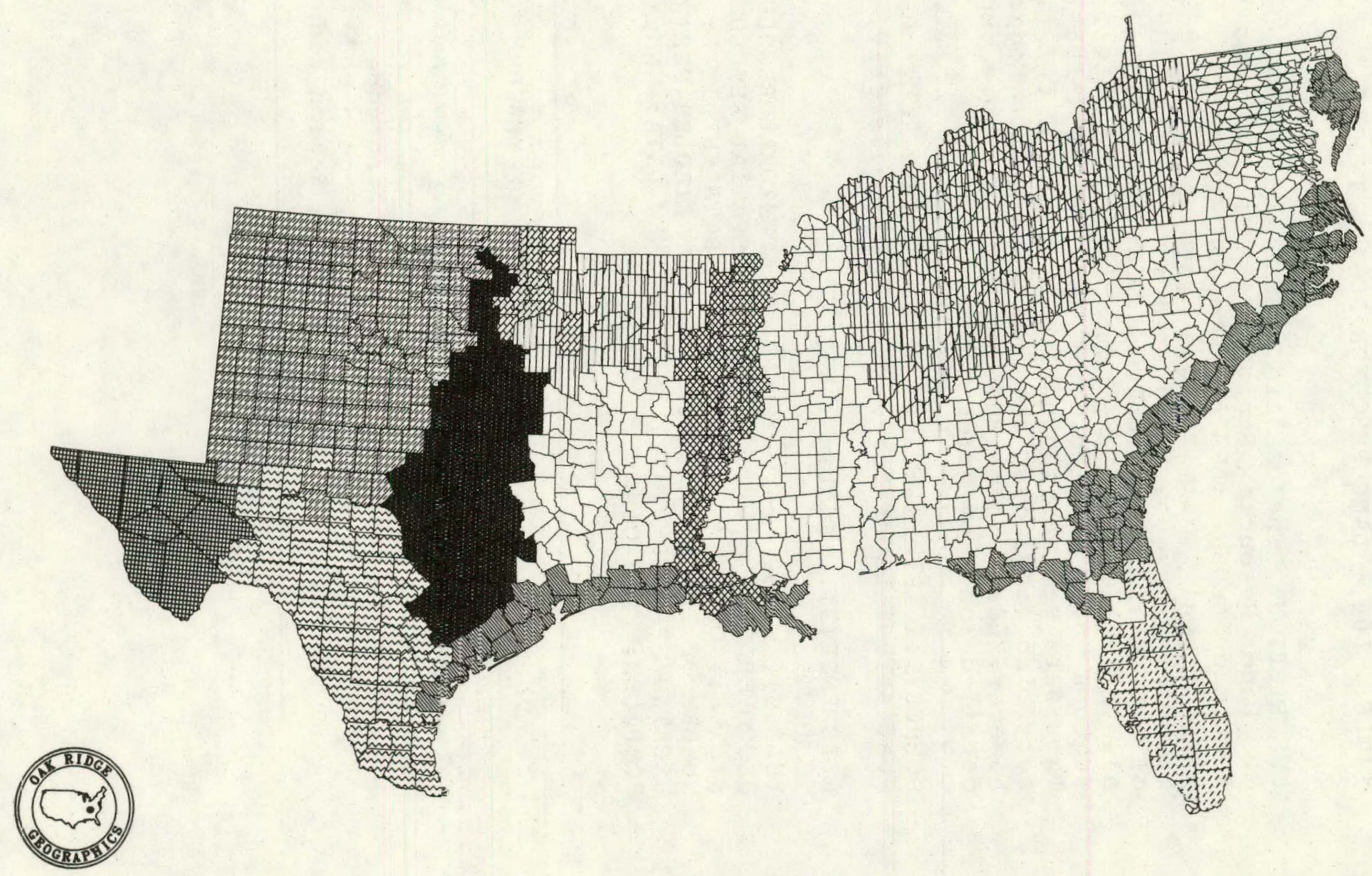


TITLE: L07 - LAND USE (CNI AGGREGATED)

DESCRIPTION: Land-use statistics were summarized from data set L01 by aggregating the land-use categories and standardizing the areas so that the county totals equal the 1970 Census county area (B01):. See L01 for a description of the 1967 Conservation Needs Inventory and the limitations of this inventory.

SOURCE (S): LOI, BOPl.

$\operatorname{YEAR}(\mathrm{S}): \quad 1967$

GEOCOVE RAGE : U. S.

STATUS: Online

NUMBER OF RECORDS : 3071

CREATED/UPDATED: Mar . 1980

COMPILER: R J Olson

TEMPORAL RESOLUTION: Annual. SPATIAL RESOLUTION: County DATA SE'l'. TYPE : Single VARIABLES PER RECORD: 11 NEW DATA: As available
VARIABLE

LABEL AND UNITS OF MEASURE

\begin{tabular}{lll}
\hline CROPLAND & Total of all types of crop land & ha \\
FED_LAND & Federally owned land & ha \\
FIPS_CO & FIPS county number & \\
FIPSET & FIPS state number & \\
FOREST & Total of all forest land & ha \\
OTHRLAND & Other land-houses, swamps, etc & ha \\
PAST_LND & Pastureland managed for forage & ha \\
RANG_LND & Rangeland with natural forage & ha \\
SML_LAKE & Small lakes <l6ha and rivers & ha \\
TOT_AREA & Total area excluding >l6ha lakes & ha \\
URB_LAND & Urban areas & ha
\end{tabular}


TITLE: L08 - LAND AREAS (RURAL, URBAN, ROADS, WATER, FED)

DESCRIPTION: Counties were inventoried by the USDA for urban, rural, water, and transportation rights-of-way areas. Transportation land included road, highway, interstate, and railroad rights-of-way areas. Roads were divided into dirt roads, gravel roads, paved roads, state highways, and interstates. $A 11$ categories were subdivided into federal and nonfederal land. This data set contains updated information which can be combined with the 1967 CNI data sets (L01, L07). Since county officials were required to verify the figures, the file is probably accurate.

SOURCE(S): Goebel, J. J. Dec. 1979. County Statistics Magnetic Tape. Statistical Laboratory, Iowa state University, Ames, IA.

$\operatorname{YEAR}(\mathrm{S}): \quad 1979$

GEOCOVE RAGE : U. S.

STATUS: Online

NUMBER OF RECORDS : 3071

CREATED/UPDATED: Mar. 1980

COMPILER: $\mathrm{R} J$ Olson
TEMPORAL RESOLUTION: Annual SPATIAL RESOLUTION: County DATA. SET TYPE: Single VARIABLES PER RECORD: 26 NEW DATA: As available

VARIABLE

LABEL AND UNITS OF MEASURE

\begin{tabular}{|c|c|}
\hline AREA_7 7 & surface \\
\hline $\begin{array}{l}\text { FEDR } \bar{L} 77 \\
\text { FIPS } \bar{C} 0\end{array}$ & $\begin{array}{l}\text { Total federal land area - } 1977 \\
\text { FIPS county number }\end{array}$ \\
\hline FI PS $-\mathrm{ST}$ & FIPS state number \\
\hline $\mathrm{H}$ IWA $\bar{Y}-\mathrm{F}$ & Highways on rural-federal \\
\hline $\mathrm{HIWAY}^{-} \mathrm{N}$ & rural-nonfederal \\
\hline INTERS_F & on rural-federal \\
\hline INTERS $^{-} \mathrm{N}$ & on rural-nonfederal \\
\hline LAND $7 \overline{7}$ & Land area - 1977 \\
\hline AIL $\bar{R} 77$ & Total railroad area -1977 \\
\hline RAI LRD $\mathrm{F}$ & Railroads on rural-federal \\
\hline AILRD_N & Railroads on rural-nonfederal \\
\hline ROAD $\mathrm{D}^{-} \mathrm{F}$ & Dirt roads on rural-federal \\
\hline$R^{\prime} A^{-} D^{-} \mathrm{N}$ & Dirt roads on rural-nonfederal \\
\hline ROAD_G_F & Gravel roads on rural-federal \\
\hline $\mathrm{ROAD}^{-} \mathrm{G}^{-} \mathrm{N}$ & Gravel roads on rural-nonfederal \\
\hline ROAD_P_F & Paved roads on rural-federal \\
\hline$R^{\prime} A_{-}^{-}-\mathrm{N}$ & Paved roads on rural-nonfederal \\
\hline ROADS $\overline{7} 7$ & Federal and state road area - 1977 \\
\hline RUR_F_77 & Rural federal land area - 1977 \\
\hline RUR ${ }^{-}-77$ & nonfederal land area - 1977 \\
\hline RURĀL $\bar{A} 77$ & Total rural land area - 1977 \\
\hline
\end{tabular}




$\begin{array}{lll}\text { URB_F_77 } & \text { Urban-federal land area }-1977 . & \text { ha } \\ \text { URBN-77 } & \text { Urban nonfederal land area-1977 } & \text { ha } \\ \text { URBAN-77 } & \text { Total urban land area }-1977 & \text { ha } \\ \text { WATER_77 } & \text { Census water area }-1977 & \text { ha }\end{array}$




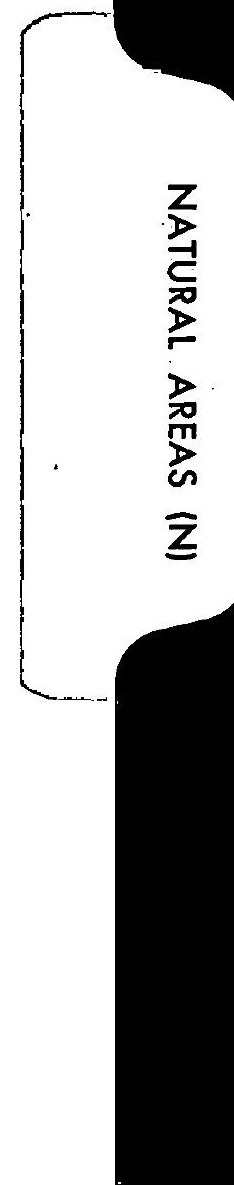


NATURAL AREAS (N) SECTOR OVERVIEW

Natural areas are defined as areas administered and protected to maintain natural ecological conditions. Included are parks, wilderness areas, national forests and rangelands, wildlife refuges, ecological preserves, and. others. We anticipate expanding this sector to include a comprehensive inventory of federal, state, and selected private natural areas. 


\section{TITLE: NOI - RARE II TRACTS}

DESCRIPTION: The USDA Forest Service initiated the Roadless Area Review and Evaluation IT (RARE II) program in 1978 to inventory existing roadless areas within the National Forests and to determine their management strategies. This data set gives code, name, size, location, 1978 status, and 1979 RARE II recommendation for each of 1910 tracts in the conterminous states. Data sets N04, N05, N06, N07, and N08 contain additional information on the RARE II tracts. These files can be merged with NOl to give complete name and location data.

SOURCE(S): Simons, P. June, Nov. and Dec. 1978. RARE II Magnetic Tape Files. U. S. Department of Agriculture, Forest Service, Washinton, DC.

REFERENCE (S) : USDA 1979.

COMMENTS: Wilderness status codes are: EX-existing, EN-endorsed, SW-wildlife refuge, ST-state area, LM-land management, and IN-inventory area.

$\operatorname{YEAR}(\mathrm{S}): \quad 1978$

GEOCOVE RAGE : U. S.

STATUS: Online

NUMBER OF RECORDS : 1910

CREATED/UPDATED: Mar. 1980

COMPILER: $\mathrm{R}$ J Olson
TEMPORAL RESOLUTION: AnnuaI SPATIAL RESOLUTION: Points DATA SET TYPE: Single VARIABLES PER RECORD: 13 NEW DATA: Not anticipated

\section{VARIABLE LABEL AND UNITS OF MEASURE}

\begin{tabular}{lll}
\hline LAT_D & Latitude of area & degree \\
LAT-M & Latitude of area & minute \\
LONG_D & Longitude of area & degree \\
LONG_M & Longitude of area & minute \\
ST & State 2 letter code & \\
USFS_RGN & USFS region code & ha \\
WLD_AREA & Wilderness gross area & ha \\
WLD_CODE & Wilderness area code number -USFS & \\
WLD_FDRL & Wilderness area federal ownership & \\
WLD_NAME & Wilderness name & \\
WLD_PLAN & Wilderness planning designation -USFS \\
WLD_RATE & Wilderness attribute rating-USFS Apr 78 \\
WLD_STAT & Wilderness status-ex, en,sw,st,lm,in & \\
\hline
\end{tabular}


N01.1 Counties in the Soutr. with RARE II Proposed Wilderness Areas.

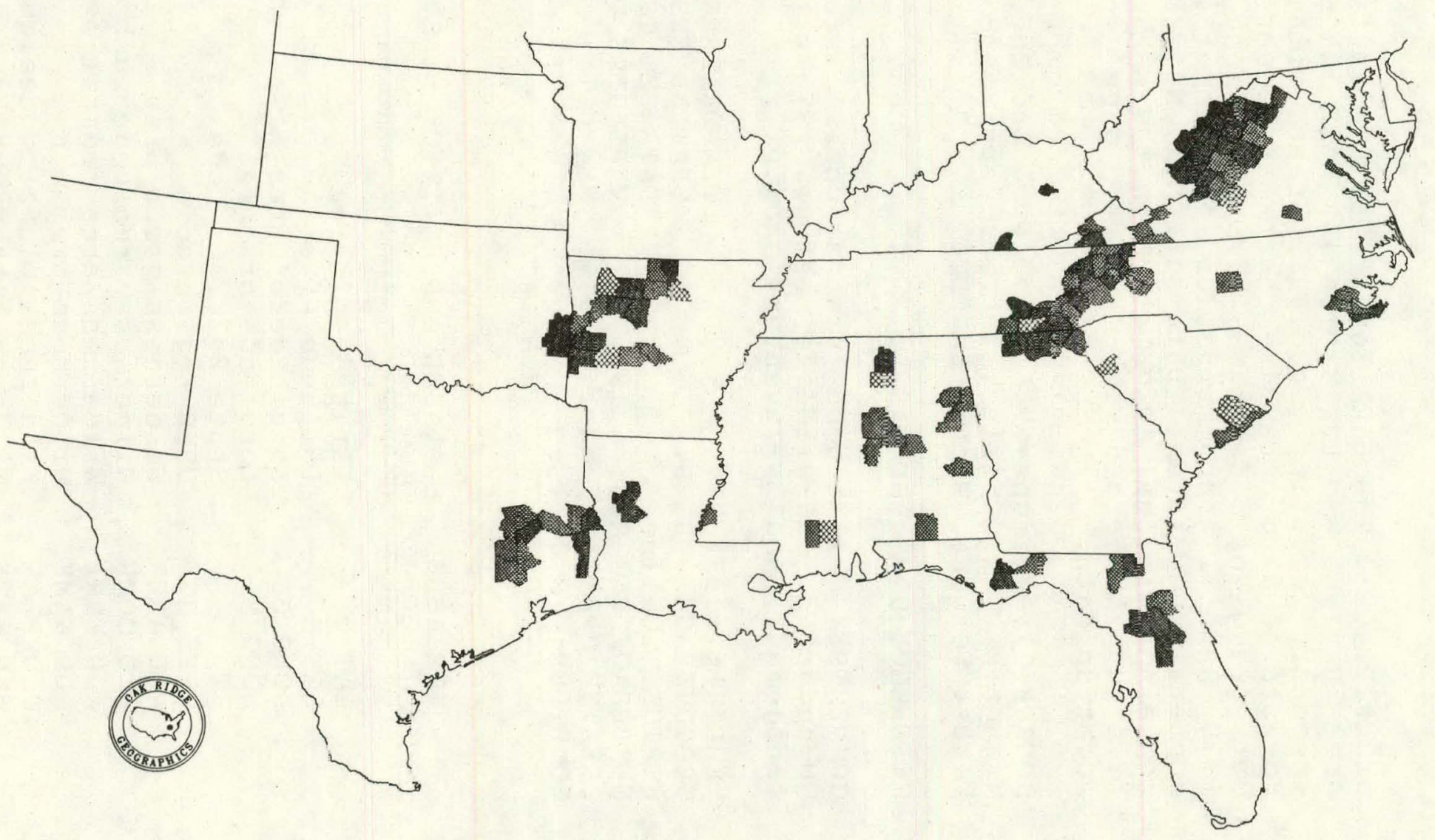


TITLE: NO2 - NATIONAL PARK SERVICE AREAS

DESCRIPTION: An inventory of the National Parks including code number, name, location, and size was obtained from the National Park Service. The file is used for accounting purposes and contains fields for bookkeeping. Occasionally a field will contain a negative number reflecting a transaction which resulted in a loss of area. Fee areas are those in which the Park Service has total interest and control (ownership). Less-than-fee areas are those for which it has limited control, such as right-of-way, easement, or scenic interest.

SOURCE(S): Ucman, F. A. June 1979. National Park Service Lands Magnetic Tape File. U. S. Department of the Interior, National Park Service, Washington, DC.

REFERENCE (S) : USDI 1975.

$\operatorname{YEAR}(\mathrm{S}): 1979$

GEOCOVE RAGE : U. S.

STATUS: Online

NUMBER OF RECORDS : $\quad 710$

CREATED/UPDATED: Mar. 1980

COMPILER: $M \mathrm{~K}$ Nungesse $r$
TEMPORAL RESOLUTION: Annual SPATIAL RESOLUTION: County DATA SET TYPE: Multiple VARIABLES PER RECORD: 11 NEW DATA: Infrequently
VARIABLE

FIPS CO

FIPS ST

PRK $\bar{A} R E A$

PRK CODE

PRK FEE

PRK LTF

PRK NAME

PRK PRV

PRK PUB

PRK SUB 1

PRK SUB 2

\section{LABEL AND UNITS OF MEASURE}

FIPS county number

FIPS state number

Park area - gross

National park identification number

Park area - fee

Park area - less than fee

ha

National park name

Park area - private

Park area - other public

Park area - fee \& less than fee

Park area - other public \& priv. ha

ha

ha

ha

ha

ha 
N02.1 Counties Containing Class I Air Quality Areas Based on the Occurrence of National Parks Greater thar. 5000 acres.

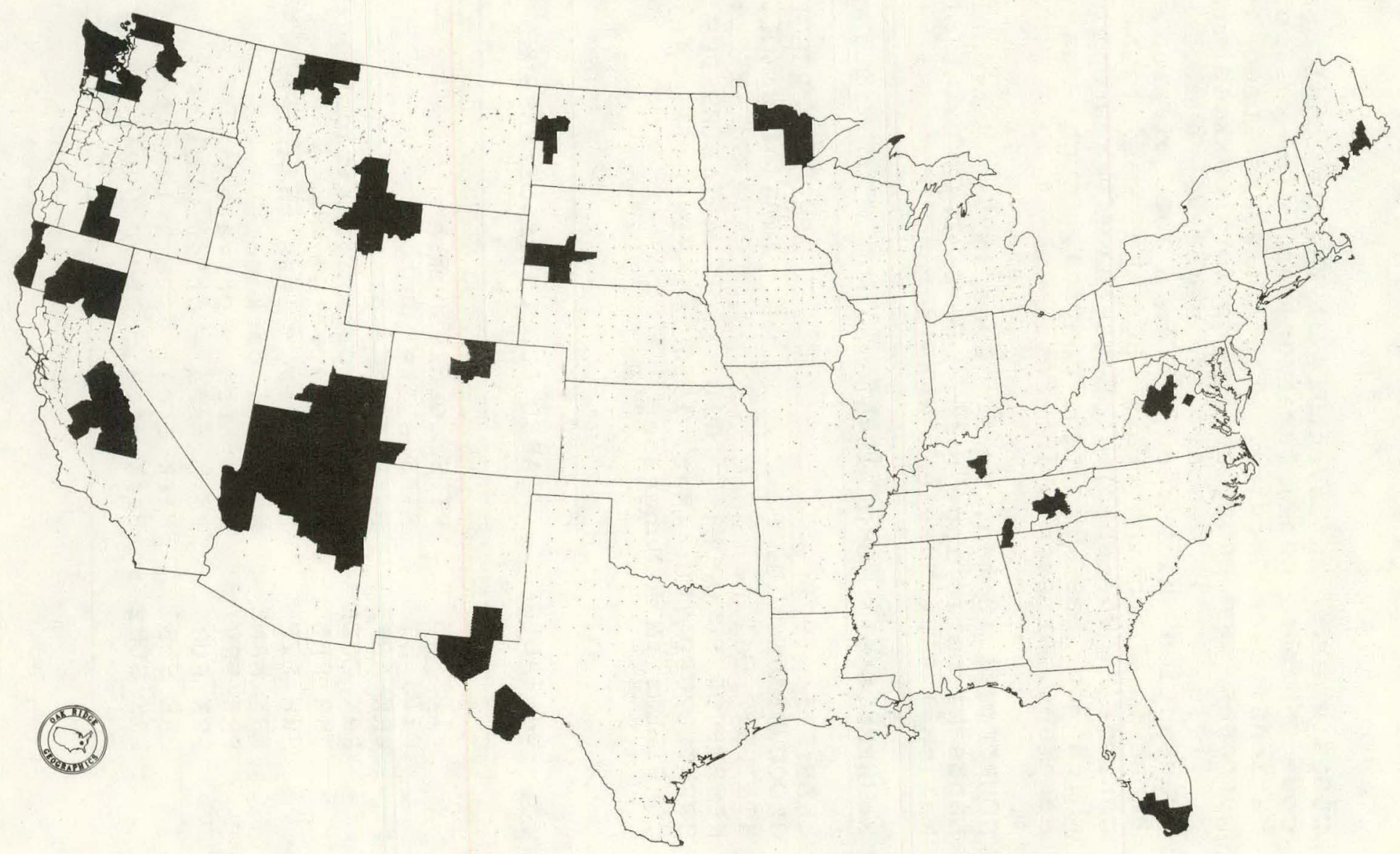


TITLE: N03 - WILDERNESS AREAS

DESCRIPTION: An inventory of existing and proposed wilderness areas was derived from the data base obtained for the RARE II project (NOI). This file excludes RARE II areas. The code designations for each tract include characters identifying the agency managing the tract. Abbreviations are NF-Forest Service; NP-National Park Service; FW-Fish and Wildlife Service; or two-character state abbreviation if it is state managed. The status codes are described under NOl.

SOURCE (S): NOI.

YEAR (S) : 1978

GEOCOVERAGE : U. S.

STATUS: Online

NUMBER OF RECORDS : 577

CREATED/UPDATED: Mar. 1980

COMPILER: R J Olson
TEMPORAL RESOLUTION : SPATIAL RESOLUTION: County DATA SET TYPE: Multiple VARIABLES PER RECORD: NEW DATA: Infrequently

\begin{tabular}{lll} 
VARIABLE & LABEL AND UNITS OF MEASURE \\
\hline FIPS_CO & FIPS county number & \\
FIPS_ST & FIPS state number & ha \\
WLD_AREA & Wilderness area - gross & ha \\
WLD_COA & Wilderness area - county portion & \\
WLD_CODE & Wilderness code number -USFS & \\
WLD_NAME & Wilderness area name & \\
WLD_STAT & Wilderness area status code \\
\hline
\end{tabular}


N03.1 Counties in the South with Existing and Proposed Wilderness Areas (RARE II).

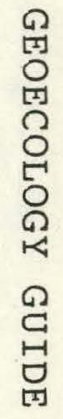

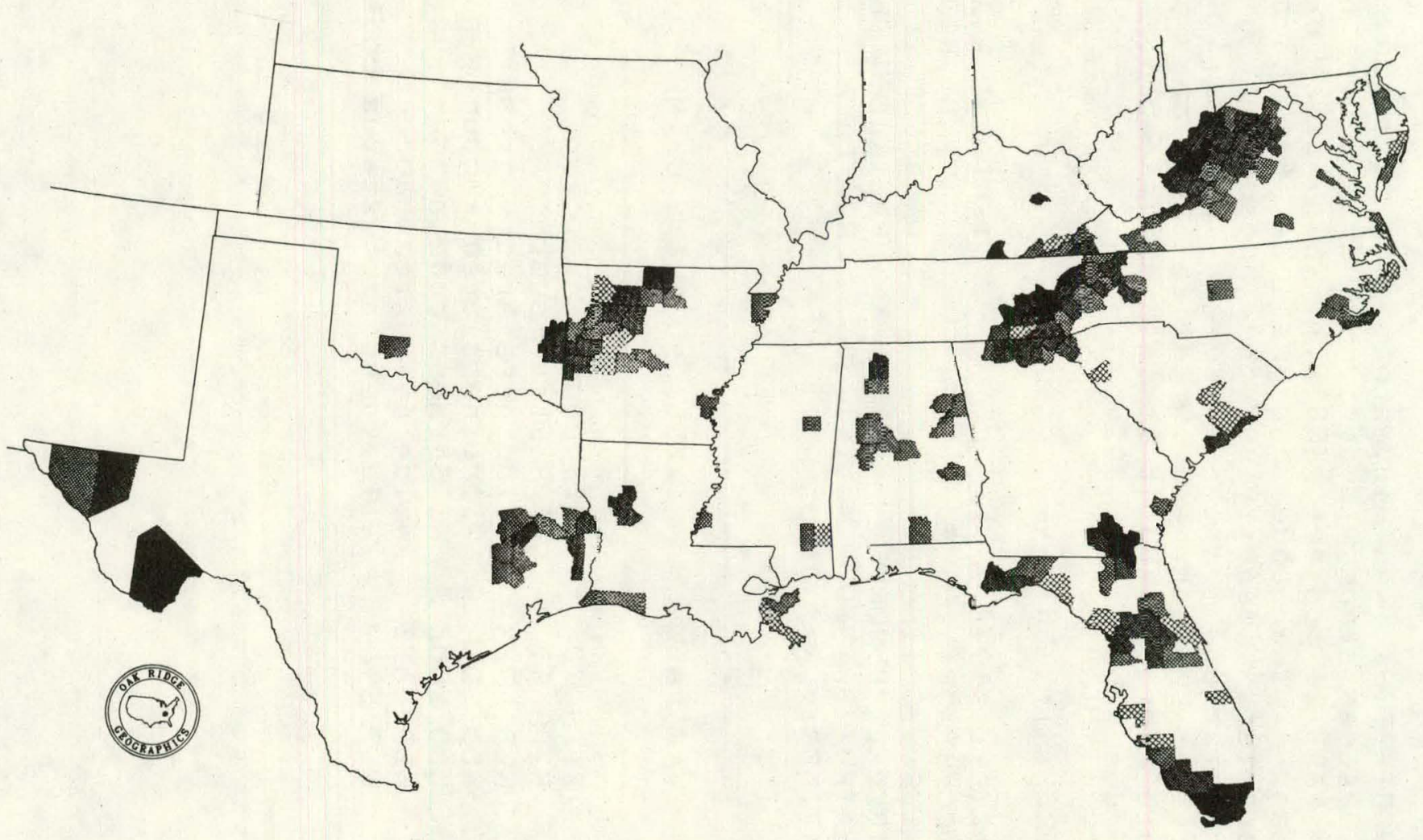

$z$
$\omega$
1
$N$

员 
N03.2 Counties with Existing, Endorsed, and Proposed Wilderness Areas Qualifying as Class I Air Quality Areas.

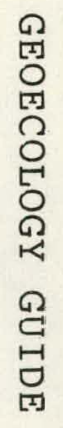

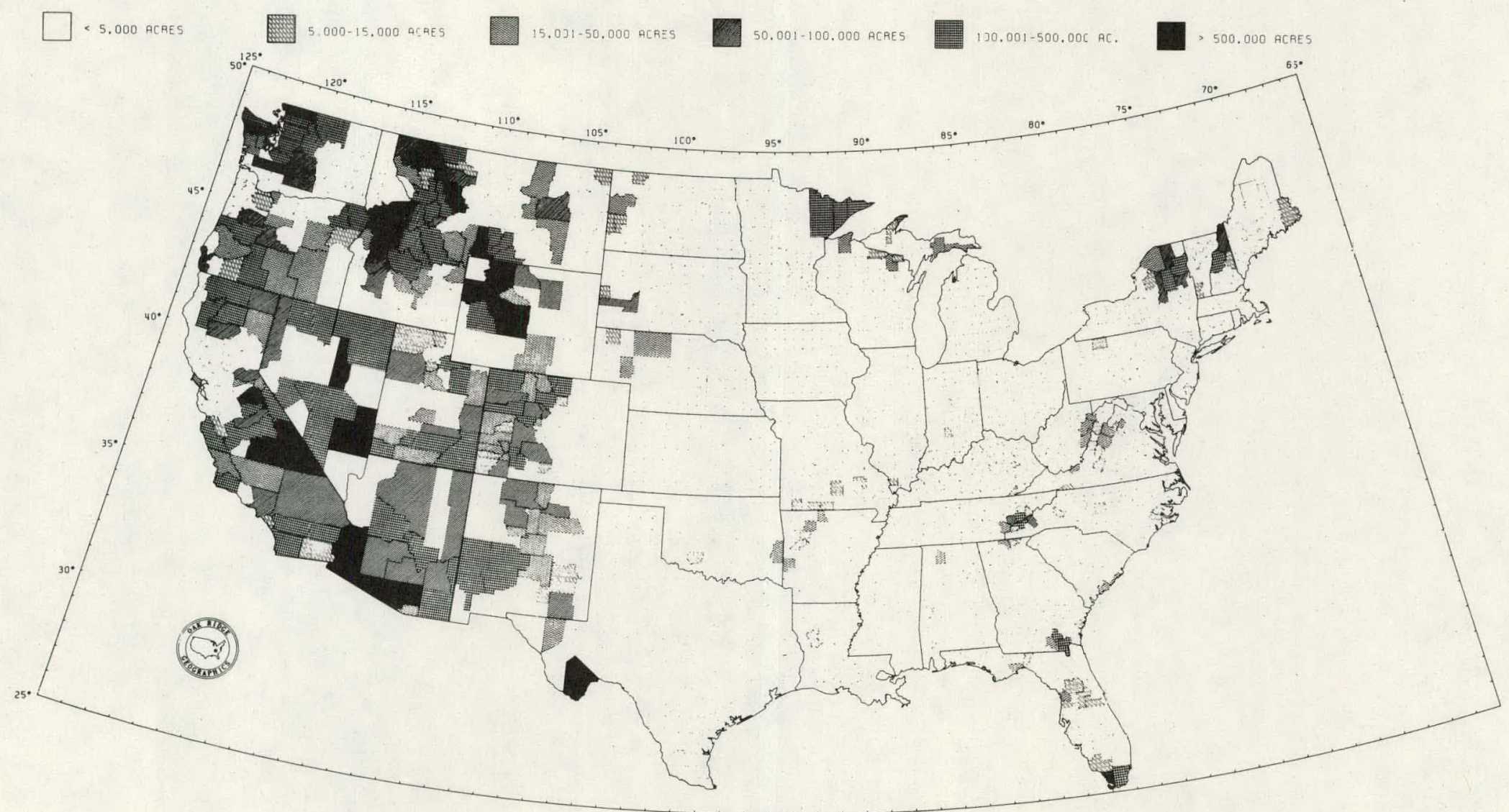

$z$
z
1
w

雚 
TITLE: N04 - RARE II TRACTS BY COUNTY

DESCRIPTION: RARE II tracts often cover parts of several counties. 'l'his file defines the area of a tract in each of the counties in which it occurs.

SOURCE(S): See N0l sources.

$\operatorname{YEAR}(\mathrm{S}): 1978$

GEOCOVE RAGE : U. S.

STATUS: Online

NUMBER OF RECORDS : 2528

CREATED/UPDA'I'EU: Mar . 1980

COMPILER: $\quad \mathrm{R} \mathrm{J}$ Olson

TEMPORAL RESOLUTION:

SPATIAL RESOLUTION: County DATA SET TYPE: Multiple VARIABLES PER RECORD: 4

NEW DATA: Not anticipated
CNTY_A

FIPS $-\mathrm{O}$

FIPS ST

WLD_CODE wilderness tract county area FIPS county number FIPS state number

Wilderness area code number -USFS 
TITLE: N05 - RARE II TRACTS BY ECOREGION \& VEG.

DESCRIPTION: RARE II tracts often cover parts of more than one ecoregion/vegetation combination. See the section on Vegetation data for a discussion of Bailey ecoregions and Kuchler potential vegetation types. This file defines the area of a tract in each of the ecoregion/vegetation types in which it occurs. The ecoregion designation was used in the ORNL analysis of the RARE II tracts. The data set was created by editing the U. S. Forest Service data (see NOI) to designate the ecoregion section-level codes in addition to the province-level ecoregion codes. The Bailey Ecoregion map and the RARE II Draft Environmental Impact statement maps were used to determine the ecoregion codes.

SOURCE(S): See N0l sources.

$\operatorname{YEAR}(\mathrm{S}): \quad 1978$

GEOCOVE RAGE : U. S.

STATUS: On 1 ine

NUMBER OF RECORDS : 2923

CREATED/UPDATED: Mar. 1980

COMPILER: R J Olson

TEMPORAL RESOLUTION:

SPATIAL RESOLUTION: Tracts DATA SET TYPE: Multiple VARIABLES PER RECORD: 4 NEW DATA: Not anticipated
VARIABLE

LABEL AND UNITS OF MEASURE

ECO CODE EVEG̈ A VEG CŌDE WLD_CODE
Ecoregion section code, Bailey 1976 Ecoregion/vegetation potential area ha Vegetation code, Kuchler 1966.

wilderness area code number -USFS 
TITLE: N06 - RARE II TRACTS ORNL RANKS

DESCRIPTION: The ecological analysis of RARE II tracts by ORNL involved ranking the attributes of vegetation, birds, mammals, and endangered and threatened species for each tract to obtain an overall ecological index (OEI). The tracts were stratified according to ecoregions for the analysis so that the OEI of tracts within ecoregions are comparable. Each attribute was evaluated at national, regional (eastern deciduous forest, central plains, and western mountains), and ecoregional scales for relative abundance. The abundance of an attribute within a tract was compared against the ecureyiui, regional, and national values. If a tract contained a proportionally large amount of a regionally and nationally rare attribute, then the tract would receive a high score for that attribute. The OEI was calculated from the sum of the four attribute values.

SOURCE(S): Calculated from several data sets.

REFERENCE (S): Klopatek et al. $1980 \mathrm{~b}$.

$\operatorname{YEAR}(\mathrm{S}): \quad 1979$

GE OCOVE RAGE : U. S.

STATUS: Online

NUMBER OF RECORDS : 2107

CREATED/UPDATED: Mar. 1980

TEMPORAL RESOLUTION :

SPATIAL RESOLUTION: Tr acts

DATA SET TYPE: Single

VARIABLES PER RECORD: 12

NEW DATA: Not anticipated COMPILER: R J Olson, K D Kumar, J T Kitchings, L K Mann, J M Klopatek

\begin{tabular}{ll} 
VARIABLE & LABEL AND UNITS OF MEASURE \\
\hline BRD_INDX & Tract score - birds \\
BRD_RANK & Tract rank - birds \\
EAT_INDX & Tract score - end. \& threat. species \\
EAT_RANK & Tract rank - end. \& threat. species \\
ECO_CODE & Ecoregion section code, Bailey 1976 \\
MAM_INDX & Tract score - mammals \\
MAM_RANK & Tract rank - mammals \\
OEI_INDX & Tract score - overall ecological index \\
OEI_RANK & Tract rank - overall ecological index \\
VEG_INDX & Tract score - vegetation \\
VEG_RANK & Tract rank - vegetation \\
WLD_CODE & Wilderness area code number -USFS
\end{tabular}




\section{TITLE: N07 - RARE II TRACTS USFS DATA}

DESCRIPTION: The Forest Service compiled characteristics of each RARE II tract whirh were published as part of the Draft Environmental Impact Statement (DEIS). These data were keypunched from the DEIS for use in the ecological analysis conducted by ORNL.

SOURCE(S): USDA 1979

YEAR(S): 1978

GEOCOVE RAGE : U. S. STATUE: Online

NUMBER OF RECORDS : 2999

CREATED/UPDATED: Mar. 1980

COMPILER: $\mathrm{R} J$ Olson
TEMPORAL RESOLUTION :

SPATIAL RESOLUTION: Tracts DATA SET TYPE: Multiple VARIABLES PER RECORD: 8 NEW DATA: Not anticipated

VARIABLE

LABEL AND UNITS OF MEASURE

$\begin{array}{ll}\text { ECO_CODE } & \text { Ecoregion province level code, Bailey } \\ \text { LND_CODE } & \text { Land surface form code, Hammond } \\ \text { SPECL_A } & \text { Special classification wilderness } \\ \text { ST } & \text { State 2 letter code } \\ \text { VEG_CODE } & \text { Vegetation code, Kuchler } 1966 \\ \text { WLD_ANML } & \text { Wilderness associated wildlife species } \\ \text { WLD_CODE } & \text { Wilderness area code number -USFS } \\ \text { WLD_RATE } & \text { Wilderness attribute rating, USFS Apr } 78\end{array}$


TITLE: NOP - RARE II TRACTS ENERGY RESOURCES

DESCRIPTION: The energy resource potential was estimated by the Department of Energy for the Forest Service, for most of the RARE II tracts. Although these estimates were provided with a minimum of field study or other verification due to time constraints, they were used in the RARE II project. Commodities evaluated include coal, oil and gas, hydroelectric, and uranium. The proportion of the tract in each of five categories was estimated. The overall evaluation consisted of selecting the highest category of the five resources that was recorded.

SOURCE(S): USDOE 1978 .

$\operatorname{YEAR}(\mathrm{S}): 1978$

GEOCOVE RAGE : U. S. STATUS: Online

NUMBER OF RECORDS : 1368

CREATED/UPDATED: Mar . 1980

COMPILER: R J.Olson
TEMPORAL RESOLUTION :

SPATIAL RESOLUTION: Tracts

DATA SET TYPE: Single VARIABLES PER RECORD: 28 NEW DATA: Not anticipated

VARIABLE

LABEL AND UNITS OF MEASURE

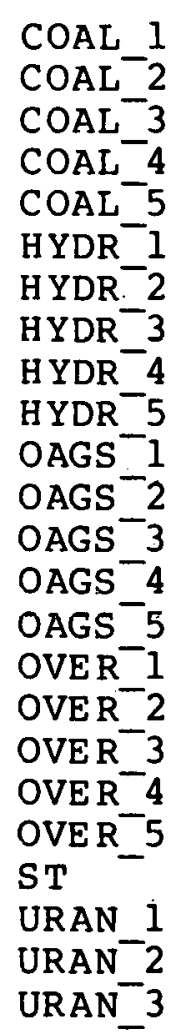

COAL 1 $\mathrm{COAL}^{-2}$ $\mathrm{COAL}^{-3}$ $\mathrm{COAL}^{-} 4$ COAL_5 HYDR- 2 HYDR 3 HYDR -4 HYDR 5 OAGS $^{-1}$ $\mathrm{OAGS}^{-2}$ OAGS 3 OAGS $^{-} 4$ OAGS 5 OVER-1 OVER 2 OVER 3 OVER_4 ST URAN 1 URAN-3
Very important coal resources Important coal resources Commercially important coal resources No commercial coal resources Indirectly significant for coal Very important hydroelectric resources Important hydroelectric resources Commercially potential hydroelectric No commercial hydroelectric resources Indirectly significant hydroelectric Very important oil and gas resources. Important oil and gas resources Commercially potential oil and gas No commercial oil and gas resources Indirectly significant oil and gas Overall - very important for energy Overall - important for energy Overall - commercial potential Overall - no commercial potential Overall - indirect significance State 2 letter code Very important uranium resources Important uranium resources Commercially potential uranium 
URAN 4

URAN 5

No commercial uranium resources

WLD CODE

Indirectly significant uranium

WLD_RMKS

wilderness area code number -USFS

Remarks on indirect energy values 
TITLE: N09 - CRITICAL NATURAL AREAS

DESCRIPTION: This data set will be created from several sources such as The Nature Conservancy and uther federal, state, and private agencies.

YEAR (S) :

GEOCOVE RAGE : U. S. STATUS : Planned
TEMPORAL RESOLUTION : SPATIAL RESOLUTION : County DATA SET TYPE: Multiple 
POPULATION (P) SECTOR 
TITLE: P01 - POPULATION BY SEX AND 5 YEAR AGE CLASSES

DESCRIPTION: The 1970 summary population counts for 5-year aye groups and for males and females are contained in data set P0l.

SOURCE(S): Loebl, A. S. 1975. 1970 Population Computer File. Energy Division, Oak Ridge National Laboratory. Oak Ridge, TN.

REFERENCE (S) : USDC 1972 .

$\operatorname{YEAR}(\mathrm{S}): \quad 1970$

GEOCOVE RAGE : U. S. STATUS: Online NUMBER OF RECORDS : $\quad 3071$ CREATED/UPDATED: Mar. 1980 COMPILER: $\mathrm{R}$ J Olson
TEMPORAL RESOLUTION: Annua 1 SPATIAL RESOLUTION: County DATA SET TYPE: Single VARIABLES PER RECORD: 41 NEW DATA: Every 10 years

VARIABLE LABEL AND UNITS OF MEASURE

$\begin{array}{ll}\text { FIPS_CO } & \text { FIPS county number } \\ \text { FIPS-ST } & \text { FIPS state number } \\ \text { F00-04 } & \text { Females between birth and } 4 \text { years of age } \\ \text { F05-09 } & \text { Females between } 5 \text { and } 9 \text { years of age } \\ \text { F10-14 } & \text { Females between } 10 \text { and } 14 \text { years of age } \\ \text { F15-19 } & \text { Females between } 15 \text { and } 19 \text { years of age } \\ \text { F20-24 } & \text { Females between } 20 \text { and } 24 \text { years of age } \\ \text { F25-29 } & \text { Females between } 25 \text { and } 29 \text { years of age } \\ \text { F30-34 } & \text { Females between } 30 \text { and } 34 \text { years of age } \\ \text { F35-39 } & \text { Females between } 35 \text { and } 39 \text { years of age } \\ \text { F40-44 } & \text { Females between } 40 \text { and } 44 \text { years of age } \\ \text { F45-49 } & \text { Females between } 45 \text { and } 49 \text { years of age } \\ \text { F50-54 } & \text { Females between } 50 \text { and } 54 \text { years of age } \\ \text { F55-59 } & \text { Females between } 55 \text { and } 59 \text { years of age } \\ \text { F60-64 } & \text { Females between } 60 \text { and } 64 \text { years of age } \\ \text { F65-69 } & \text { Females between } 65 \text { and } 69 \text { years of age } \\ \text { F70-74 } & \text { Females between } 70 \text { and } 74 \text { years of age } \\ \text { F75-79 } & \text { Feinales between } 75 \text { and } 79 \text { years of age } \\ \text { F80-84 } & \text { Females between } 80 \text { and } 84 \text { years of age } \\ \text { F85-GT } & \text { Females } 85 \text { years of age and greater } \\ \text { M00-04 } & \text { Males between birth and } 4 \text { years of age } \\ \text { M05-09 } & \text { Males between } 5 \text { and } 9 \text { years of age } \\ \text { M10-14 } & \text { Males between } 10 \text { and } 14 \text { years of age } \\ \text { M15-19 } & \text { Males between } 15 \text { and } 19 \text { years of age } \\ \text { M20-24 } & \text { Males between } 20 \text { and } 24 \text { years of age } \\ \text { M25-29 } & \text { Males between } 25 \text { and } 29 \text { years of age } \\ \text { M30-34 } & \text { Males between } 30 \text { and } 34 \text { years of age }\end{array}$


M35_39

M $40^{-} 44$

$M 45^{-} 49$

M50-54

M $55^{-59}$

$M 60^{-} 64$

M65-69

$M 70^{-74}$

$M 75^{-} 79$

$M 80^{-} 84$

$\mathrm{M} 85 \mathrm{CT}$

P $1 \overline{9} 70 \mathrm{~A}$

$\mathrm{P}-1970 \mathrm{~F}$

$\mathrm{P}^{-1} 1970 \mathrm{M}$
Males between 35 and 39 years of age

Males between 40 and 44 years of age

Males between 45 and 49 years of age

Males between 50 and 54 years of age

Males between 55 and 59 years of age

Males between 60 and 64 years of age

Males between 65 and 69 years of age

Males between 70 and 74 years of age

Males between 75 and 79 years of age

Males between 80 and 84 years of age

Males 85 years of àge and greater

1970 tontal population

1970 female population

1970 male population 
TITLE: P02 - PROJECTED POPULATION FOR 1985,2000

DESCRIPTION: Population projections for males and females. for 1985 and 2000 were estimated using the ORNL/MULTIREGION model for use in the National Coal Utilization Assessment. These county-level estimates reflect the growth associated with energy demand and supply patterns of the NCUA study.

SOURCE (S): Energy Division. 1977. National Coal Utilization. Assessment Population Projections. Energy Division, Oak Ridge National Laboratory, Oak Ridge, TN.

REFERENCE(S): Davis et al. 1978.

$\operatorname{YEAR}(\mathrm{S}): \quad 1985,2000$

GEOCOVE RAGE : South

STATUS: Online

NUMBER OF RECORDS : 1388

CREATED/UPDATED: Mar. 1980

COMPILER: R J Olson.
TEMPORAL RESOLUTION: Annual SPATIAL RESOLUTION: County DATA SET TYPE: Single VARIABLES PER RECORD: 9 NEW DATA: Not anticipated

\section{VAR IABLE}

LABEL AND UNITS OF MEASURE

$\begin{array}{ll}\text { BEA CODE } & \text { OBE economic area code } \\ \text { FIPS CO } & \text { FIPS county number } \\ \text { FIPS-ST } & \text { FIPS state number } \\ \text { P 1985A } & 1985 \text { total population } \\ \text { P-1985F } & 1985 \text { female population } \\ \text { P-1985M } & 1985 \text { male population } \\ \text { P-2000A } & 2000 \text { total population } \\ \text { P-2000F } & 2000 \text { female population } \\ \text { P_2000M } & 2000 \text { male population }\end{array}$




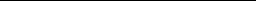




\section{WATER QUALITY (Q) SECTOR OVERVIEW}

The National Stream Quality Accounting Network (NASQAN) provides a comprehensive system of monitoring stations for 328 water basins covering. the United. States. NASQAN includes monthly values. We are developing water quality statistics from these data for inclusion in the Geoecology Data Base. 
TITLE: . Q01 - WATER QUALITY (NASQAN)

DESCRIPTION: Water quality data were obtained from the Council of Environmental Quality. They provided a copy of the National Stream Quality Accounting Network (NASQAN) data base for the period 1974-1977 as collected and compiled by the U:S. Geological Survey. The NASQAN data base consists of monthly water quality and flow readings for a set of monitoring stations. The monitoring stations were selected to be representative of each of the 328 water accounting units. Currently the file is maintained as a tape data set.

SOURCE(S): Feldman, M. 1978. NASRAN Water Quality Magnetic Tape File. Council of Environmental Quality.

$\operatorname{YEAR}(\mathrm{S}): \quad 1974-1977$

GEOCOVERAGE : . U. S.

STATUS: Being edited

NUMBER OF RECORDS :

CREATED/UPDATED: Mar. 1980

COMPILER: C.J Emerson
TEMPORAL RESOLUTION: NOrmS SPATIAL RESOLUTION: WRC-SA DATA SET TYPE: Single VARIABLES PER RECORD: 60 NEW DATA: As available 


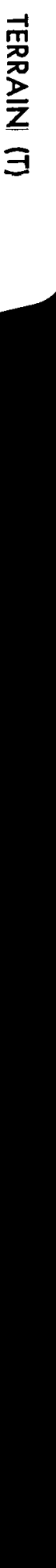




\section{TERRAIN (T) SECTOR OVERVIEW}

Various aspects of the terrain are characterized as part of the Terrain Sector. A set of National Atlas (USDI 1970) maps including land form, lithology, soils, karst terrain, glacial deposits, and elevation were digitized for counties in the eastern United States by C. A. Roswell, Jr (1977).. The proportion of counties in various terrain categories was estimated by overlaying county boundaries on the thematic maps. These files have been edited and mapped. Several, including. soils and lithology, are being expanded to cover the western United states. In addition, a map on physical regions has been digitized. Characterization data are being developed for the chemical, physical, and land-use properties of the soils file.

Data sets T01SCU, T02SCU, T03SCU, T04SCU, T05SCU, T06SCU, and TlisCU contain data for subcounty units for the 79 larger eastern counties: These data sets contain the same variables as described in this section for data sets T01, T02, etc., plus the variable SCU. 
TITLE: TOI - LAND SURFACE FORM

DESCRIPTION: Land surface form is a composite of the simple topographic variables of relief, slope inclination (profile), and slope aspect. surface form affects microclimate, drainage, and soil characteristics. Hammond (1963) produced a national map of land surface form. The bases of his classification are the proportion of area in slopes of less than eight percent (gently sloping), proportion of . such gently sloping in upland versus that in lowland, and local relief. These variables are ordinally scaled so that there is a land surface form map class for each of the 96 possible class combinations. The map was digitized by recording the proportion of each county in each 1 and surface form class. Because of the complexity of the map and large number of map classes per county, there are potential errors resulting from the digitizing process. Percentages were recorded to the nearest ten percent.

SOURCE(S): Roswell, C. A. 1976. Terrain Magnetic Tape File: University of Maryland, MD.

REFERENCE(S): Róswe11 1976, Hammond 1963.

YEAR (S) : 1964

GEOCOVE RAGE : East

STATUS : Online

NUMBER OF RECORDS : 6552

CREATED/UPDATED: Mar. 1980

COMPILER: C A Roswe11, Jr
TEMPORAL RESOLUTION: Hist. SPATIAL RESOLUTION: County DATA SET TYPE: Multiple VARIABLES PER RECORD: 7 NEW DATA: Not anticipated

\section{VARIABLE LABEL AND UNITS OF MEASURE}

$\begin{array}{ll}\text { FIPS_CO } & \text { FIPS county number } \\ \text { FIPS_ST } & \text { FIPS state number } \\ \text { LAND_S_A. } & \text { Area in land surface form code } \\ \text { LAND_S-P } & \text { Portion in land surface form code } \\ \text { LAND_S-R } & \text { Land surface local relief class code } \\ \text { LAND_S-S } & \text { Land surface gentle slope class code } \\ \text { LAND_S_T } & \text { Land surface profile type class code }\end{array}$


TITLE: T02 - BEDROCK LITHOLOGY

DESCRIPTION: Bedrock lithology affects chiefly drainage and nutrient availability. The geologic map in the National Atlas was used as the source. This map defines classes by stratigraphy rather than by lithology. Lithology can be interpreted from stratigraphy because of the correlation between age and rock type within broad regions. The map is general enough to permit rapid interpretation of lithologic information, but too broad for detailed analysis. The translation and classes are listed below. The proportion of each county in each class was digitized to the nearest ten percent.

Code Lithologic Class
1 Intrusive Igneous Rocks
2 Metamorphic Rocks
3 Consolidated Sediments
4 Unconsolidated Sediments

5 Volcanic Rocks
Geologic Map Units

Lower Tertiary, Mesozoic, Paleozoic

Precambrian (Older, Younger)

Paleozoic (Upper, Middle, Lower)

Quaternary, Tertiary (Upper, Lower), Cretaceous

Quaternary, Tertiary

SOURCE(S): Roswell, C. A. 1976. Terrain Magnetic Tape. File. University of Maryland, MD.

REFERENCE(S): Roswe 11 1976, USDI 1970 sheet Number 74 .

YEAR(S) : 1970

GEOCOVE RAGE : East

STATUS: Online

NUMBER OF RECORDS : $\quad 3414$

CREATED/UPDATED: Mar. 1980

COMPILER: C A Roswell, Jr
TEMPORAL RESOLUTION: Hist. SPATIAL RESOLUTION: CountY DATA SET TYPE: Multiple VARIABLES PER RECORD: NEW DATA: Not anticipated

\section{VARIABLE . LABEL AND UNITS OF MEASURE}

$\begin{array}{ll}\text { FIPS_CO } & \text { FIPS county number } \\ \text { FIPS_ST } & \text { FIPS state number. }\end{array}$


LITHOL_A LITHOL ${ }^{-} \mathrm{C}$ LITHOL_P
Area in bedrock lithologic class

ha

Bedrock lithologic class code

Portion in bedrock lithologic class 
TITLE: T03 - SOILS AT MAP UNIT LEVEL

DESCRIPTION: Soils data were digitized from the National Atlas soils map. The Soil Map Units are associations of Great Soils Groups according to the Seventh Approximation classification. There are 327 classes on the map with 194 occurring in the east. The map was digitized by recording the proportion of soil types. in each county to the nearest ten percent. Characteristics of the Soil Map Units are stored as separate data sets to be merged with T03 as needed. Data set T07 provides codes and names for Soil Orders, Soil. Suborders, and Soil Map Units. Data set T09 defines the occurrence and ranking. of Great Soil Groups within Soil Map Units. Data set T08 includes six ordinally scaled soil variables for Great Soil Groups. Data set Tlo defines five chemical properties of Soil Map Units.

SOURCE(S): Roswell, C. A. 1976. Terrain Magnetic Tape File. University of Maryland, MD.

REFERENCE(S): Roswe11.1976, USDI 1970 Sheet Number 86 .

YEAR (S) : . 1967

GEOCOVE RAGE : East

STATUS: Online

NUMBER OF RECORDS : 5551

CREATED/U PDATED: Mar . 1980

COMPILER: C A Roswel1, Jr
TEMPORAL RESOLUTION: Hist. SPATIAL RESOLUTION: County DATA SET TYPE: Multiple VARIABLES PER RECORD: 5 NEW DATA: Not anticipated 
TITLE: TO4 - GLACIAL GEOLOGY

DESCRIPTION: The age and nature of glacial deposits affects drainage conditions and the nutrient status of the soils develupiny un them. The sourcc for this file was the glacial map of the eastern United States. The classes are:

$\begin{array}{ll}\text { Code } & \text { Glacial Deposit } \\ 11 & \text { Wisconsin drift } \\ 12 & \text { Illinoisandrift } \\ 13 & \text { Kansan drift } \\ 14 & \text { Nebraskan drift } \\ 21 & \text { Wisconsin end moraine } \\ 22 & \text { Illinoisan end moraine } \\ 31 & \text { Ice-contact stratified drift } \\ 32 & \text { Outwash sediments } \\ 33 & \text { Lacustrine sediments } \\ 34 & \text { Marine sediments }\end{array}$

SOURCE(S): Roswell, C. A. 1976. Terrain Magnetic Tape File. University of Maryland, MD.

REFERENCE(S): Roswell 1976, Geological Society of America 1959 .

$\operatorname{YEAR}(\mathrm{S}): \quad 1970$

GEOCOVE RAGE : East

STATUS: Online

NUMBER OF RECORDS : 3250

CREATED/UPDATED: Mar. 1980

COMPILER: C A Roswell; Jr
TEMPORAL RESOLUTION: Hist: SPATIAL RESOLUTION: County DATA SET TYPE: Multiple VARIABLES PER RECORD: 5 NEW DATA: Not anticipated

\section{VARIABLE LABEL AND UNITS OF MEASURE}

\begin{tabular}{ll}
\hline FIPS_CO & FIPS county number \\
FIPS ST & FIPS state number \\
GLACL_A. & Area in glacial geology class \\
GLACL_C & Glacial geology class code \\
GLACL_F & Flag, * $=$ area is 0.001 of county
\end{tabular}


TITLE: T05 - KARST TERRAIN

DESCRIPTION: Karst terrain is often associated with extreme droughtiness or other peculiar drainage conditions, while the associated soils are generally highly basic (alkaline). The true karst is always associated. with limestone or dolomite, while particular classes of pseudokarst may be associated with: igneous rocks or unconsolidated sediments. The proportion, to the nearest ten percent, of each karst types was recorded. The eleven types are 1 isted below.

\section{LIMESTONE AND DOLOMITE}

11 Punurs and dulines on plains and valley floors; undissected uplands

12 Ponors and dolines with extensive karrenfelder on plains and valley floors

13. Doline ponds and lakes on plains

14 . Dolines and uvala on ridges and dissected uplands

15 Collapsed dolines and uvala on dissected plateaus and plains; small poljes on margin of plateaus

GYPSUM AND SALT TERRAIN

21 Dolines and ponors on plains

PS EUDOKARST

31. Sinkholes and cisterns on lava plains

32 Basins on plains of weathered lava

33 Sinkholes and basins. on gravel and sand plains. and plateaus

34 Shallow sinkholes on granite and diorite uplands

KA RRENFELDER

41. Karrenfelder outside of areas of other karst types SOURCE(S): Roswell, C. A. 1976. Terrain Magnetic Tape File. University of Maryland, MD.

REFERENCE(S): Roswel1 1976, USDI 1970 Sheet Number 77.

YEAR (S): 1970

GEOCOVE RAGE : . East

STATUS: Online

NUMBER OF RECORDS : 944

CREATED/UPDATED: Mar. 1980

COMPILER: C A Roswell, Jr
TEMPORAL RESOLUTION: Hist. SPATIAL RESOLUTION: County DATA SET TYPE: Multiple VARIABLES PER RECORD: 5 NEW DATA: Not anticipated 


\section{VARIABLE}

LABEL AND UNITS OF MEASURE

FIPS CO
FIPS ST
KARST A
KARST-C
KARST P

FIPS county number

FIPS state number

Area in karst terrain class

ha

Karst teridin class code

Fortion in karct terrain class 
TITLE: T06 - ELEVATION (BROAD CLASSES)

DESCRIPTION: Elevation has a significant influence on climatic factors, especially temperature, and indirectly affects species distributions. The source topographic map had wide contour intervals so that elevation data fall into five rather broad classes. Class limits in meters are (1) $0-150$, (2) $150-300$, (3) 300-600, (4) 600-1500, and (b) 1500-2700. An average elevation was calculated using the midpoint of each class weighted by the proportion of the county in that class.

SOURCE(S): Roswell, C. A. 1976. Terrain Magnetic Tape File. University of Maryland, MD.

REFERENCE(S) : Roswell 1976, USDI 1970 Sheet Number 59.

YEAR (S) : 1959

GEOCOVERAGE : East

STATUS: Onl ine

NUMBER OF RECORDS : 2802

CREATED/UPDATED: Mar. 1980

COMPILER: C A Roswell, Jr
TEMPORAL RESOLUTION: Hist. SPATIAL RESOLUTION: County DATA SET TYPE: Multiple VARIABLES PER RECORD: 9 NEW DATA: Not anticipated

\section{VARIABLE LABEL AND UNITS OF MEASURE}

\begin{tabular}{llr}
\hline ELEV_AVE & Average elevation & $\mathrm{m}$ \\
ELEV-1 & Area between 0 and $150 \mathrm{~m}$ & ha \\
ELEV_2 & Area between 150 and $300 \mathrm{~m}$ & ha \\
ELEV-3 & Area between 300 and $600 \mathrm{~m}$ & ha \\
ELEV_4 & Area between 600 and $1500 \mathrm{~m}$ & ha \\
ELEV_5 & Area between 1500 and $2700 \mathrm{~m}$ & ha \\
FIPS_CO & FIPS county number & \\
FIPS_ST & FIPS state number & \\
\hline
\end{tabular}


T06.l Elevation Classifications for the South.

ORNL-DWG 78-12969

$0-500 \mathrm{FT}$

济 500-1000 FT

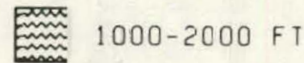

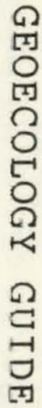

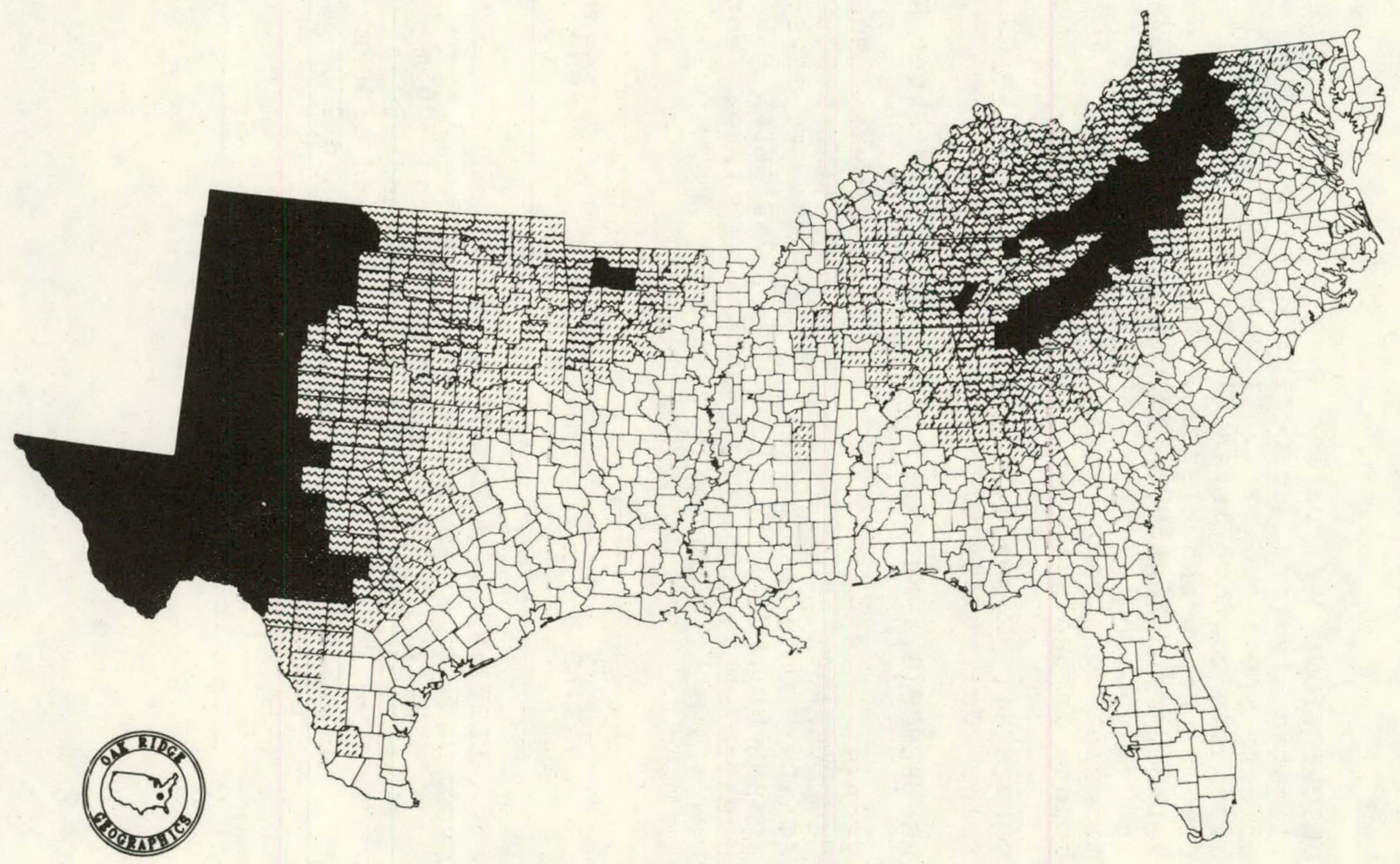


TITLE: T07 - SOIL ORDER, SUBORDER, MAP UNIT DICTIONRY

DESCRIPTION: This data set contains a dictionary of English names for the soils codes. Names are included for the nine orders, 53 suborders, and 194 map units. The dictionary includes all types occurring in the east.

SOURCE (S): Roswell 1976

$\operatorname{YEAR}(\mathrm{S}): \quad 1967$

GEOCOVE RAGE : East

STATUS: Online

NIMRER OF RFICORDS : $\quad 194$

CREATED/UPDATED: Mar. 1980

COMPILER: C A Roswell, Jr
TEMPORAL RESOLUTION: Hist. SPATIAL RESOLUTION:

DATA SET TYPE: DictnIY VARTABLES PER RECORD: 6 NEW DATA: Not anticipated

$\begin{array}{ll}\text { SOIL_M_C } & \text { Soils map unit code } \\ \text { SOIL_M-D } & \text { Soils map unit description } \\ \text { SOIL-OCC } & \text { Soils order code } \\ \text { SOIL_O-D } & \text { Soils order description } \\ \text { SOIL_S-C } & \text { Soils suborder code } \\ \text { SOIL_S_D } & \text { Soils suborder description }\end{array}$




\section{T07.1 Soil Order, Suborder, and Map-Unit Codes Dictionary.}

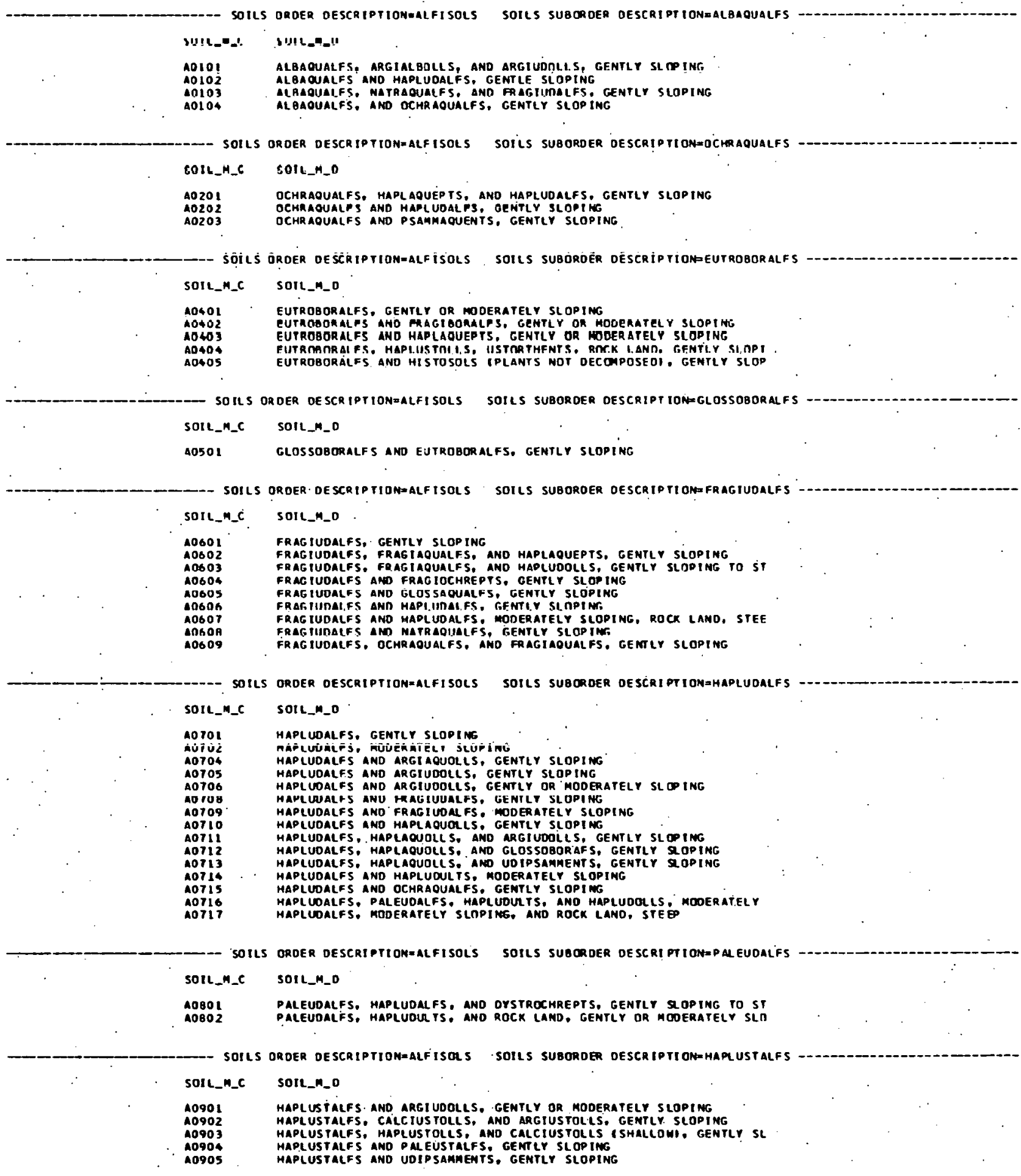




\section{T07.1 (continued)}

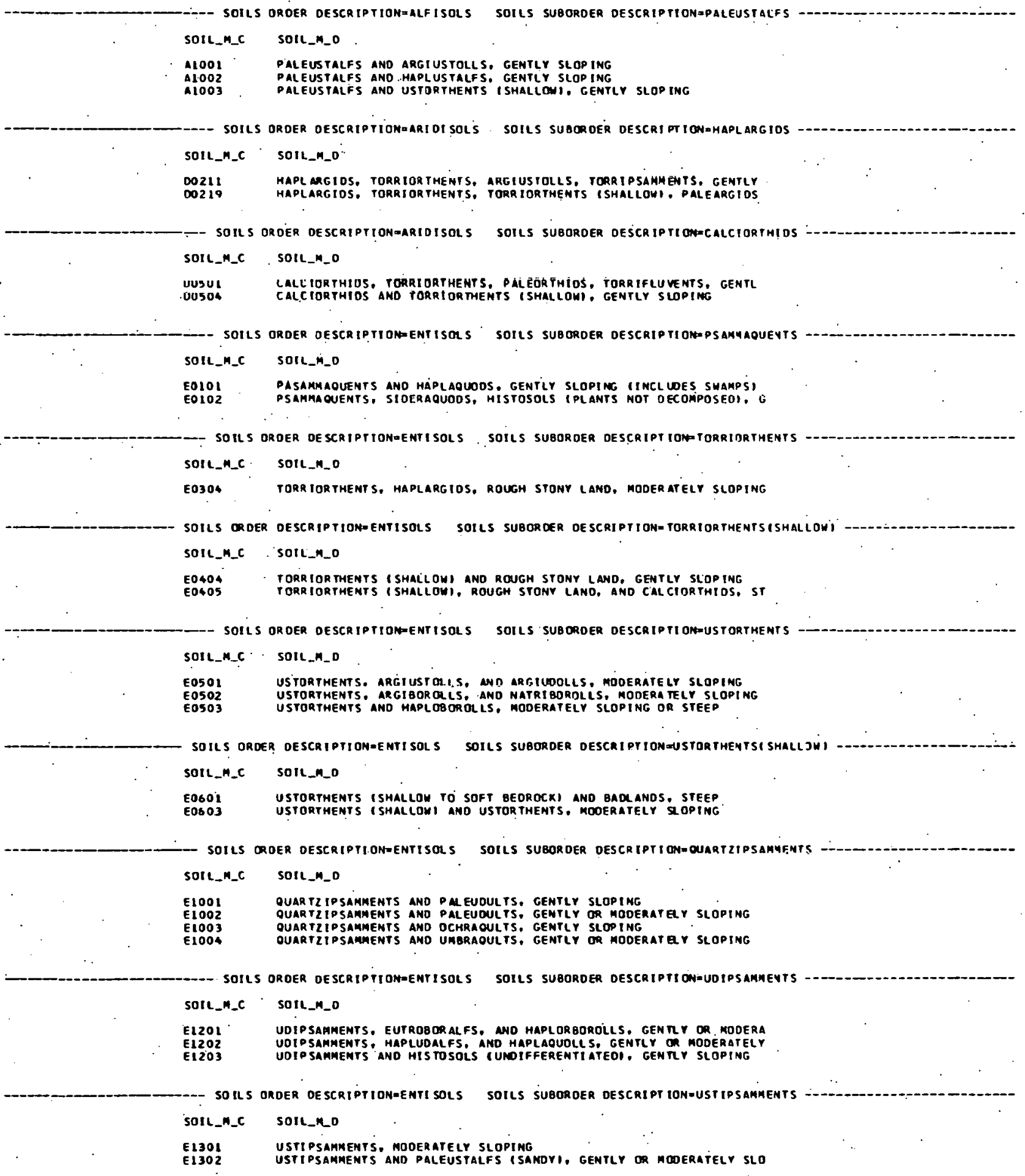




\section{T07.1 (continued)}

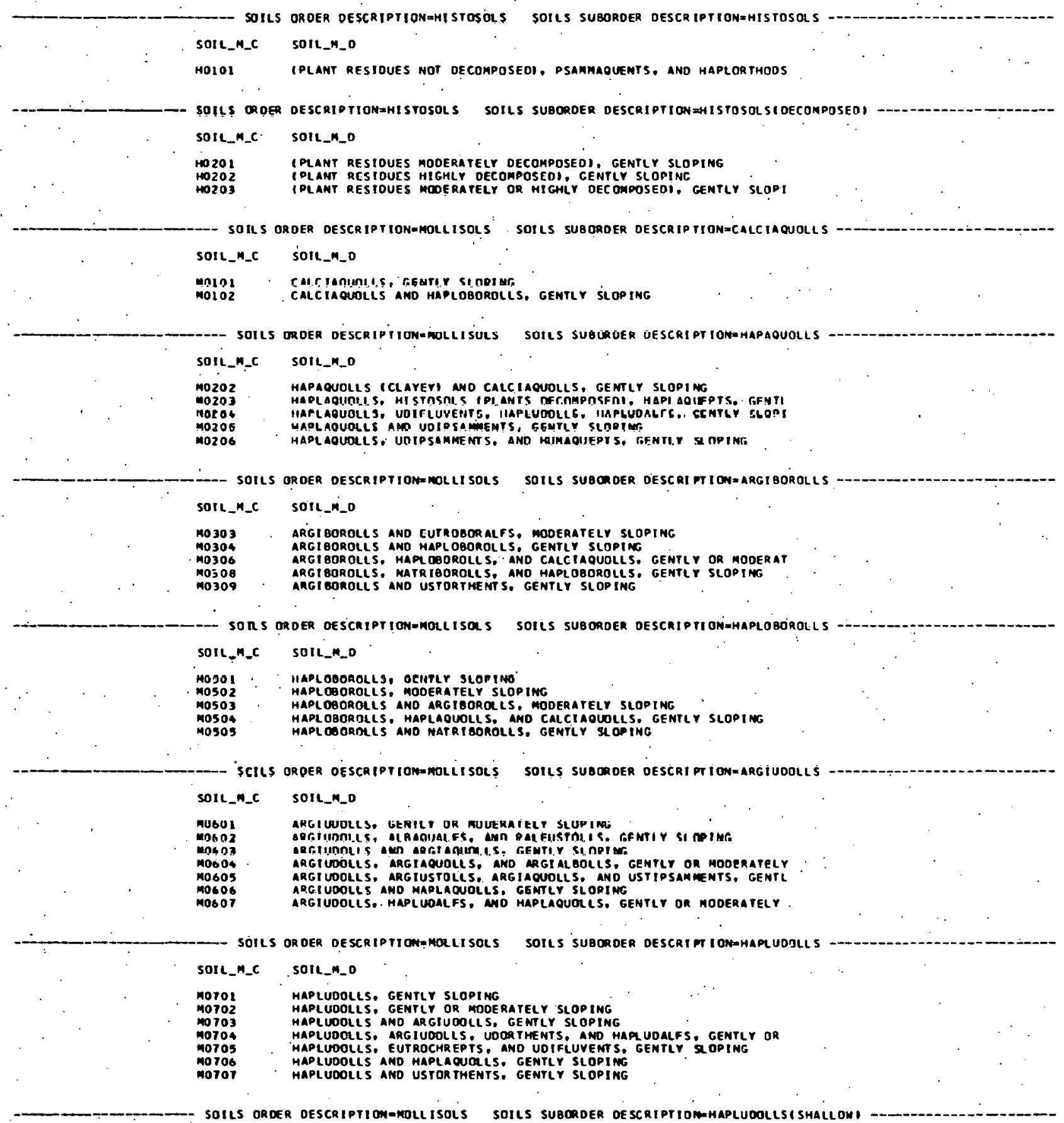

SOIL_m_C , SOIL_m_O.

mO8O1 HAPLUOOLLS (SMALLON). ARGIUSTOLLS, AND ARGIUOOLLS, GENTLY SLOP 


\section{T07.1 (continued)}

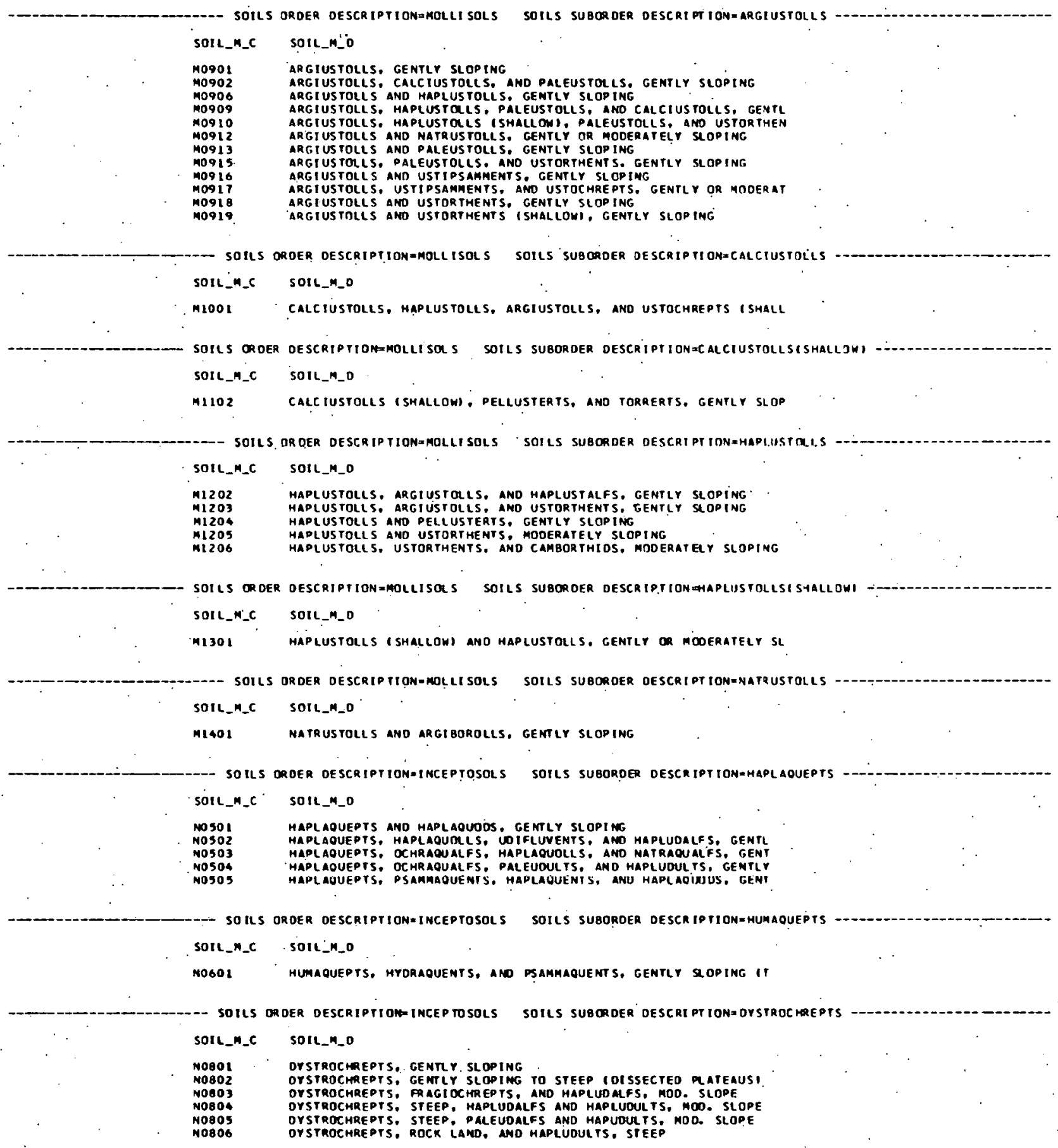




\section{T07.1 (continued)}

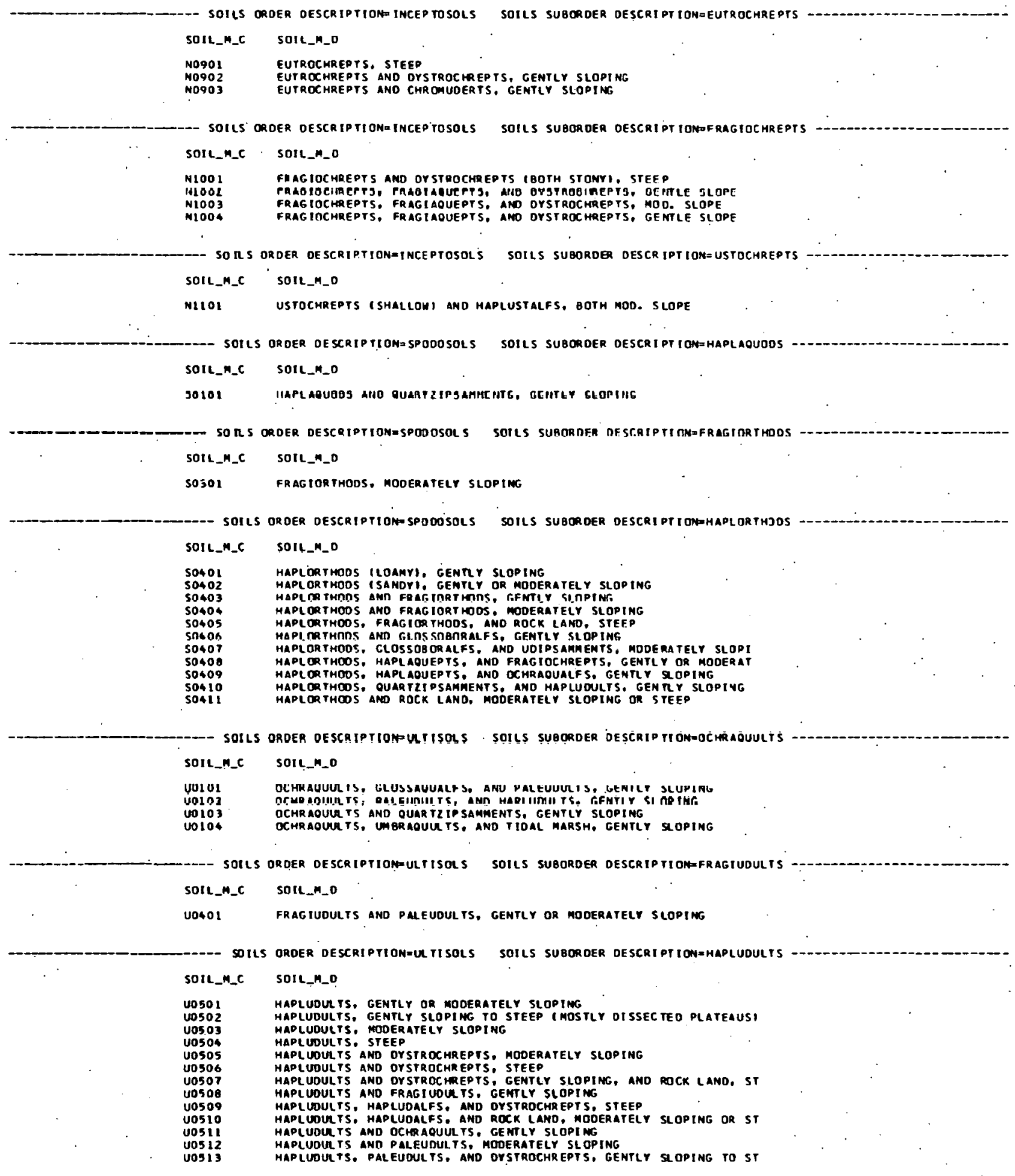




\section{T07.1 (continued)}

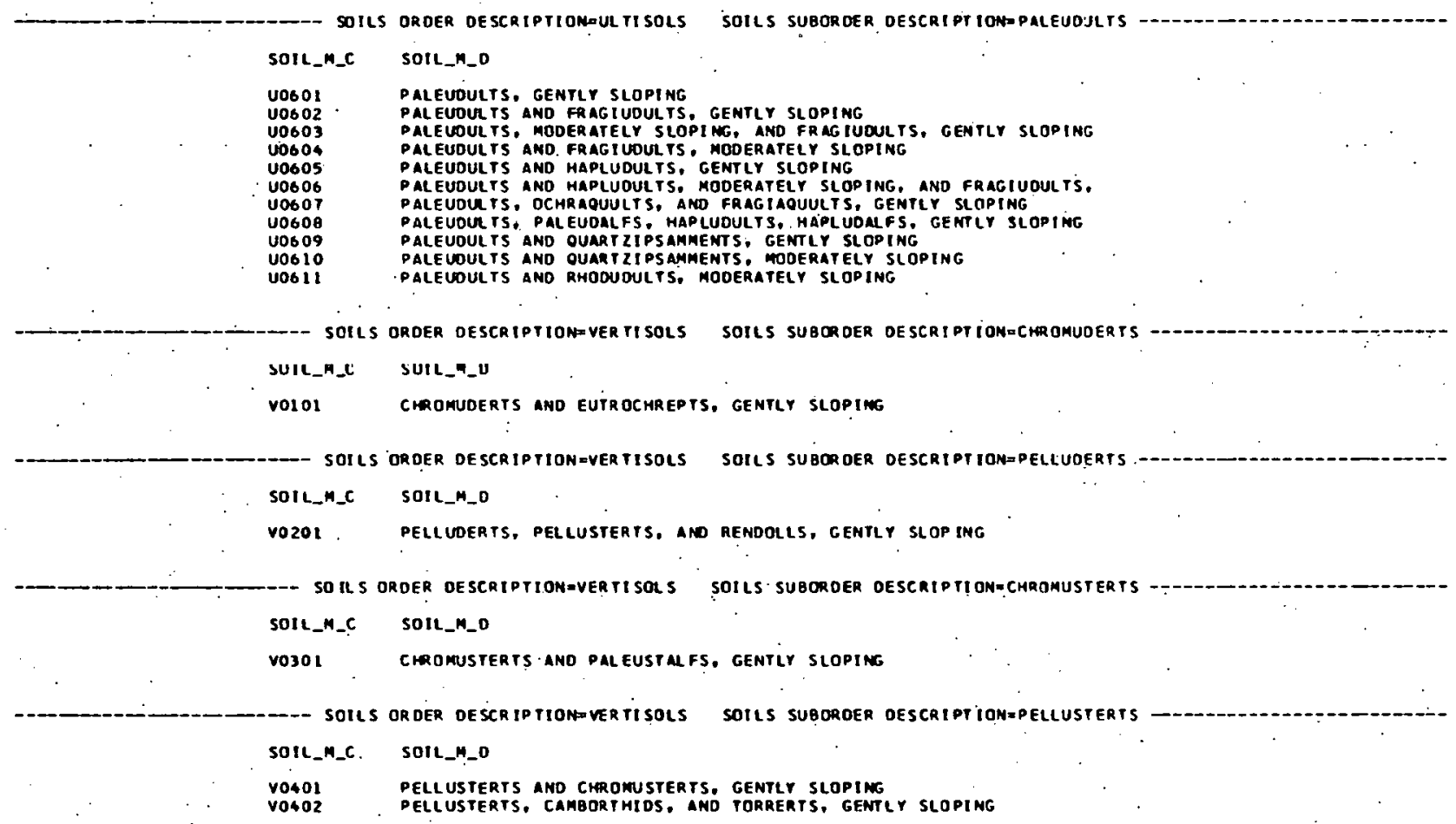




\section{TITLE: T08 - GREAT SOIL GROUPS CHARACTERISTICS}

DESCRIPTION: The Soil Map Units are associations of Great Soil Groups. This data set provides information on the average characteristics of Great Soil Groups to allow the interpretation of soils classification data in terms of ecological studies. Included are base status, moisture status, organic matter content, pans, temperature, and texture characteristics. By consulting the map legend and 1967 Supplement to the Seventh Approximation (USDA 1960, USDA 1975) of soil classification, ordinally scaled values were assigned to each soil parameter.

SOURCE(S): Roswel1, C. A. 1y\%. Terrain Magnetic Tape File. University of Maryland, MD.

REFERENCE(S): Roswe 11 1976, USDI 1970 sheet Number 86 .

$\operatorname{YEAR}(\mathrm{S}): \quad 1967$

GEOCOVE RAGE : East

STATUS: Online

NUMBER OF RECORDS :

CREATED/UPDATED: Mar. 1980

COMPILER: C A Roswell, Jr
TEMPORAL RESOLUTION: Hist. SPATIAL RESOLUTION :

DATA SET TYPE: DictnrY VARIABLES PER RECORD: 8 NEW DATA: Not anticipated

\begin{tabular}{ll} 
VARIABLE & LABEL AND UNITS OF MEA \\
\hline GSG_CODE & Great soils group cöde \\
GSG-DSCP & Great soils description \\
S_BASE_C & Soil base code \\
S_MOIS_C & Soil moisture code \\
S_ORGNCC & Soil organic matter code \\
S_PAN_C & Soil pan code \\
S_TEMP_C & Soil temperature code. \\
S_TEXT_C. & Soil texture code
\end{tabular}


TITLE: T09 - GREAT SOIL GROUPS WITHIN MAP UNITS

DESCRIPTION: The Soil Map Units are associations of Great Soil Groups. This data set defines these associations including the rank of each Great soil Group within a Soil Map Unit. This data set permits the merging of Great soil Group characteristics (T0.8) with the soils distribution data ( $\mathrm{T} 03)^{\circ}$.

SOURCE(S): Roswell, C. A. 1976. Terrain Magnetic Tape File. University of Maryland, MD.

REFERENCE(S): Roswe11.1976, USDI 1970 sheet Number 86 .

YEAR (S) : 1967

GEOCOVERAGE : East

STATUS: Online

NUMBER OF RECORDS : $\quad 459$

CREATED/UPDATED: Mar. 1980

COMPILER: $\mathrm{R} J$ Olson
TEMPORAL RESOLUTION: Hist. SPATIAL RESOLUTION:

DATA SET TYPE: DictnYY VARIABLES PER RECORD: 3

NEW DATA: Not anticipated

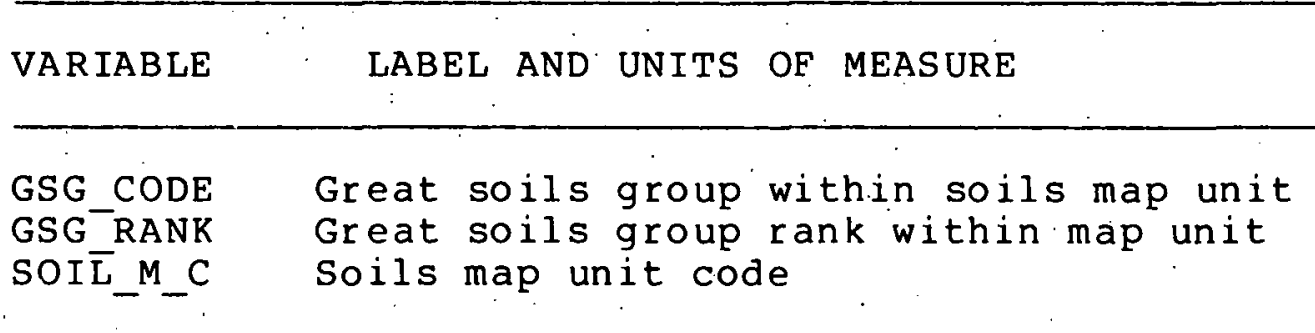


T09.1 Great Soil Groups Ranked within Map Units.

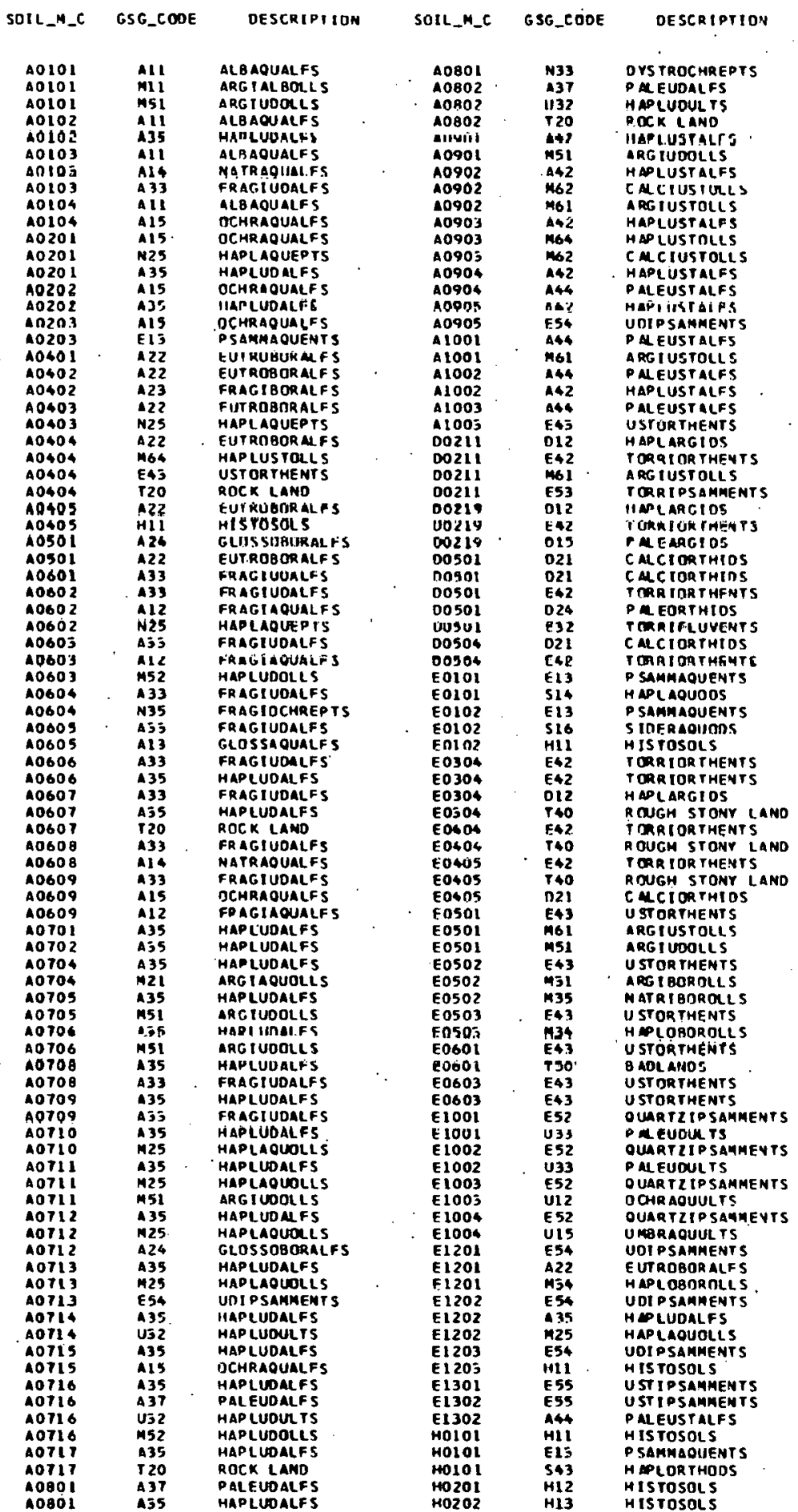


T09.1 (continued)

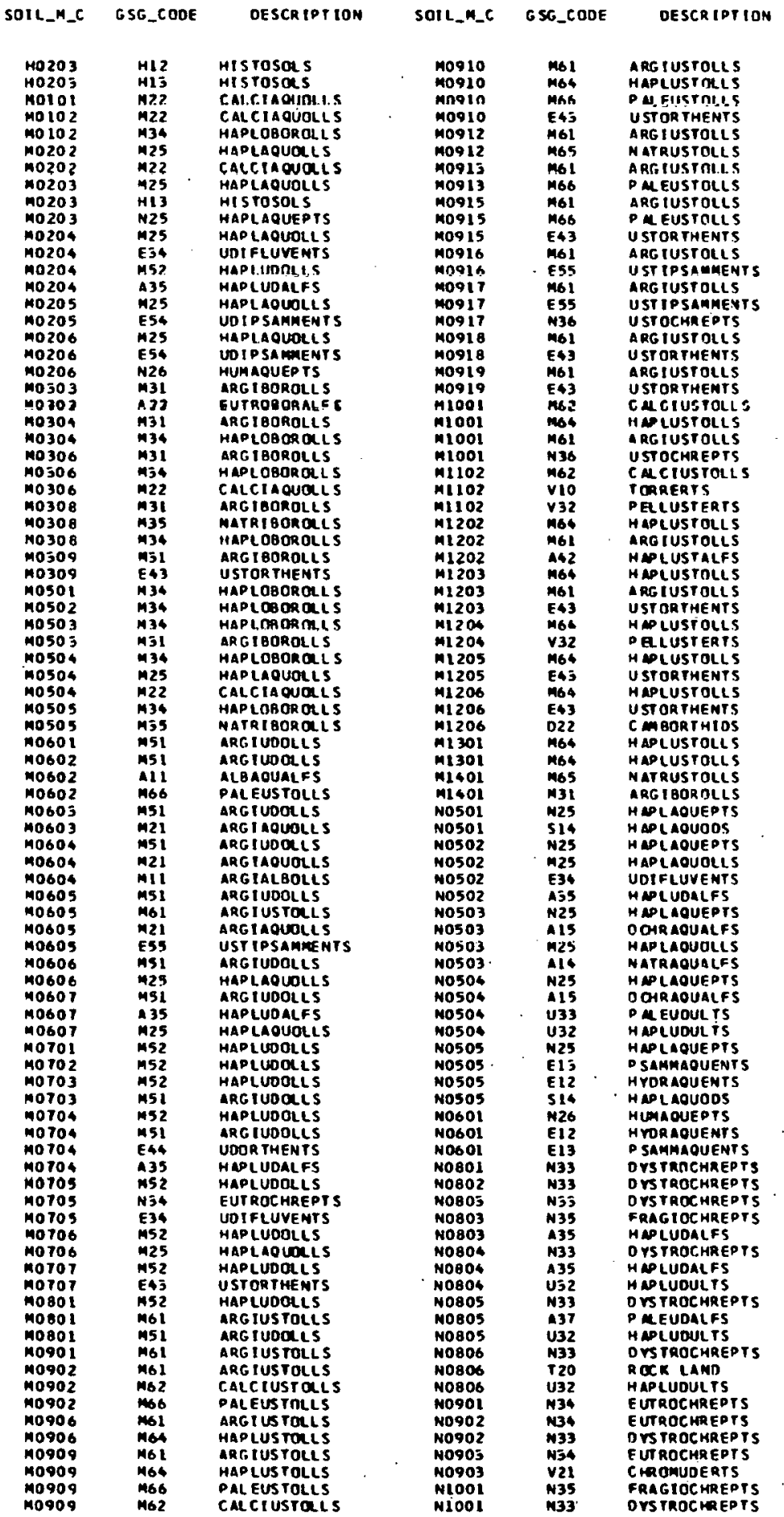


T09.1. (continued).

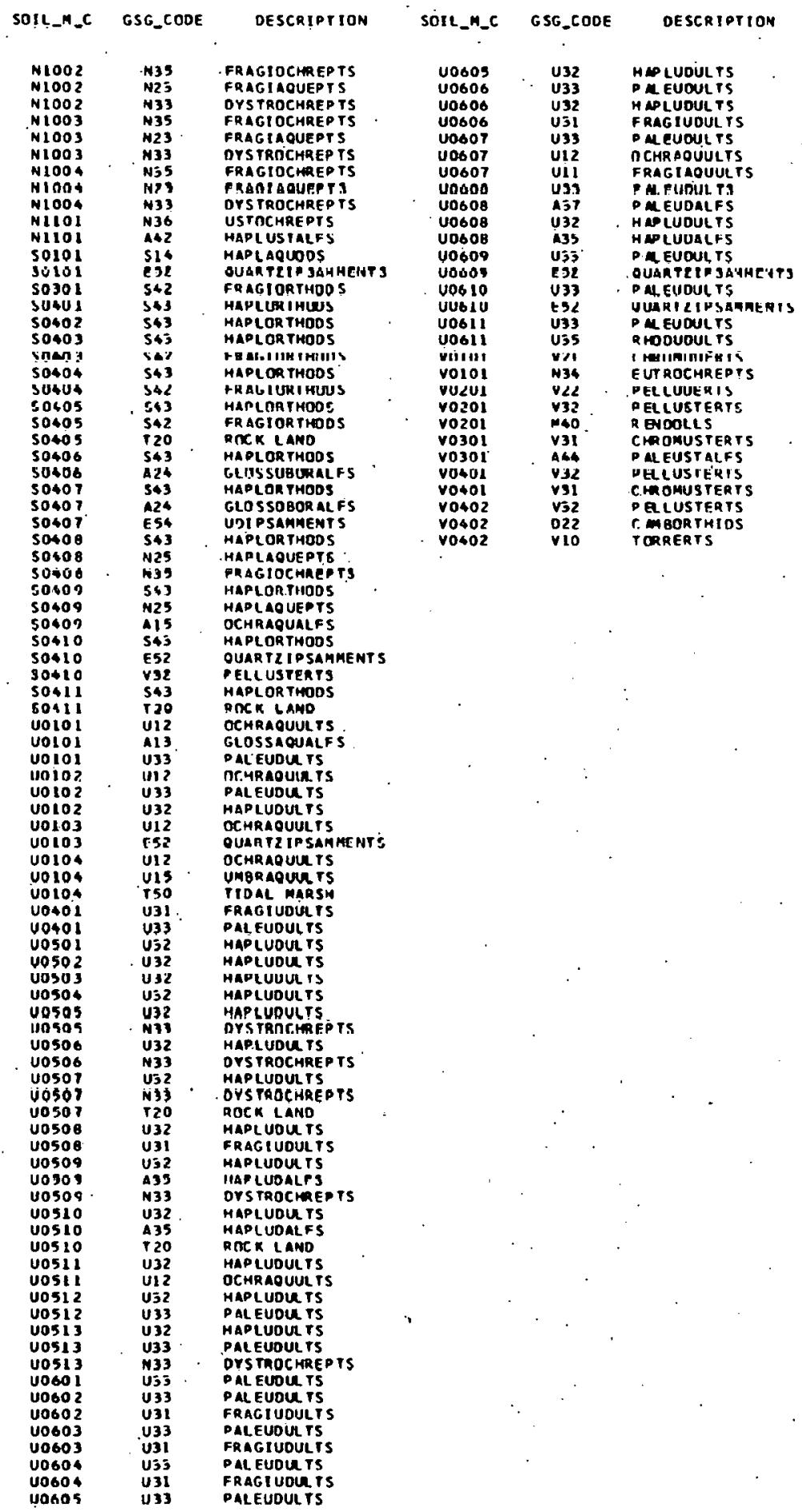


TITLE: T10 - SOIL MAP UNIT CHEMICAL CHARACTERISTICS

DESCRIPTION: The average chemical characteristics are defined for each Soil Map Unit. Values for base saturation, $\mathrm{pH}$, cation exchange capacity (CEC), soil organic matter, and clay content were obtained for the A horizon of typic soils within Soil Map Units. This values were obtained from several literature sources to represent the average conditions in the upper $20-25 \mathrm{~cm}$. If a typic soil was not described, values for an atypic but widely distributed soil were used. These data have been used to investigate impacts of acid rain on soils. In these studies the total base contents of the upper soil were estimated by multiplying base saturation by CEC.

SOURCE(S) : USDA 1975, USDA 1960, Buol et al. 1973, Hole 1976 , Hoyle 1973.

REFERENCE(S): Klopatek et al. 1980a.

YEAR(S): 1979

GEOCOVE RAGE : East

STATUS: Online

NUMBER OF RECORDS :

194

CREATED/UPDATED: Mar. 1980

COMPILER: : J M Klopatek
TEMPORAL RESOLUTION: Hist. SPATIAL RESOLUTION:

DATA SET TYPE: Dictnry

VARIABLES PER RECORD:

NEW. DATA: Not anticipated

.


T10.1 Soil Map Unit Chemical Characteristics including: Base Saturation (BS), Cation Exchange Capacity (CEC), pH, Clay Content (CC), and Organic Mattcr (OM).

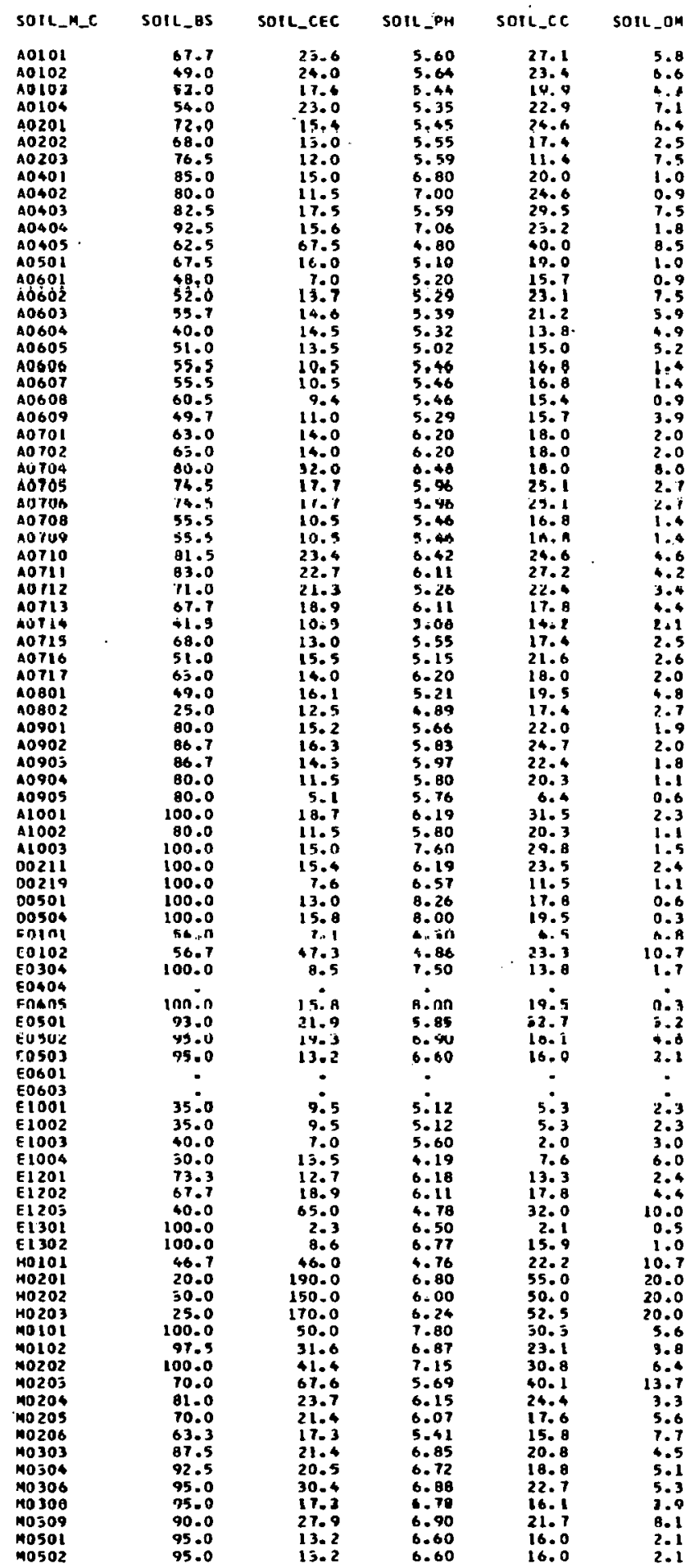


T10.1 (continued)

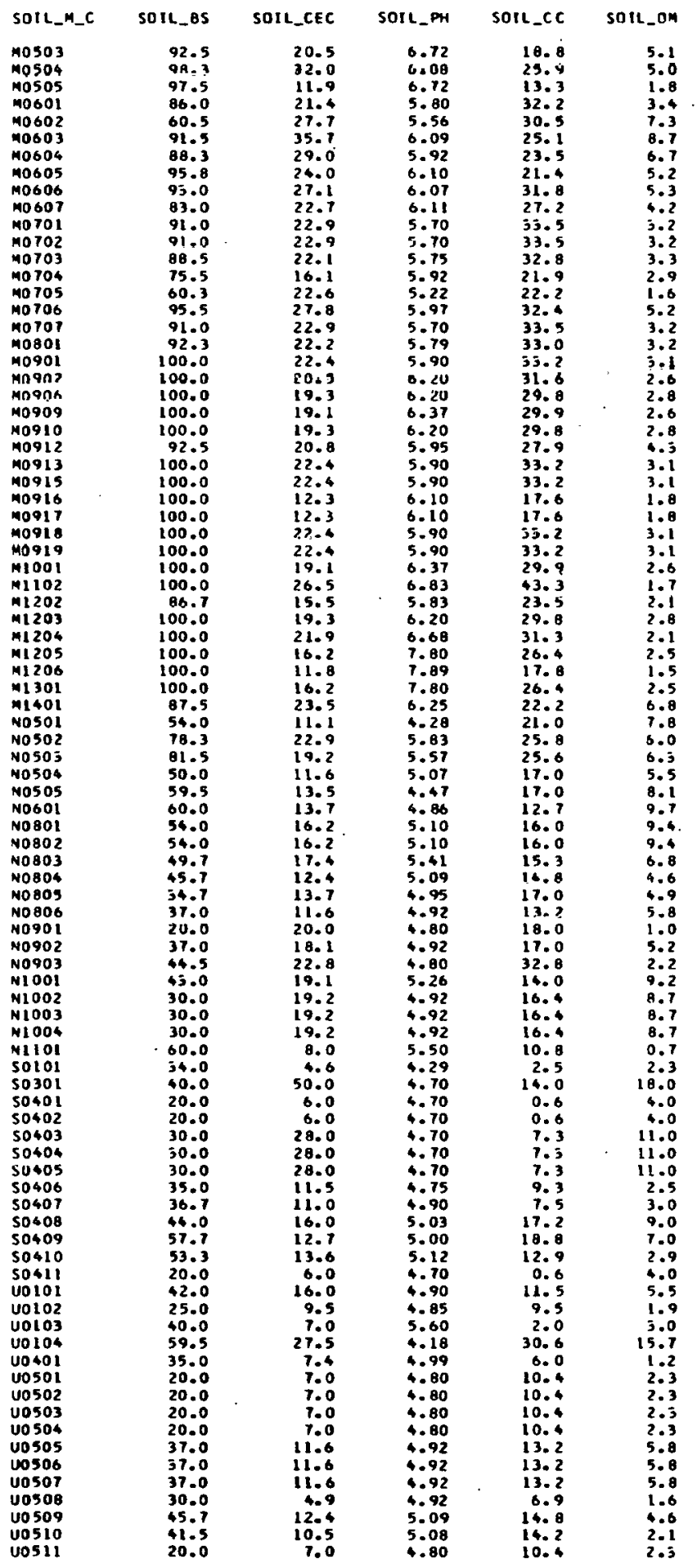


T10.1 (continued)

\begin{tabular}{|c|c|c|c|c|c|}
\hline soll__m_c & SOtL_BS & Sotl_eec & SOIL_PH & SOIL_C6 & SOIL_OA \\
\hline 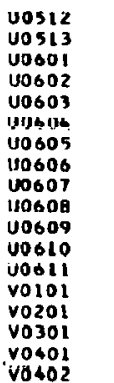 & $\begin{array}{r}23.0 \\
34.7 \\
30.0 \\
35.0 \\
35.0 \\
44.0 \\
25.0 \\
30.0 \\
25.0 \\
35.8 \\
35.0 \\
35.0 \\
41.0 \\
44.5 \\
95.0 \\
98.9 \\
99.5 \\
100.0\end{array}$ & $\begin{array}{r}9.5 \\
11: .7 \\
12.0 \\
7.4 \\
7.4 \\
7.4 \\
9.5 \\
7.3 \\
9.5 \\
12.8 \\
9.5 \\
9.5 \\
12.4 \\
22.8 \\
29.9 \\
20.1 \\
34.7 \\
22.0\end{array}$ & $\begin{array}{l}4.85 \\
4.92 \\
4.90 \\
499 . \\
499 \\
499 \\
485 \\
4.92 \\
4.00 \\
5.01 \\
5.12 \\
5.12 \\
5.15 \\
4.80 \\
5.41 \\
8.99 \\
6.00 \\
0.04\end{array}$ & $\begin{array}{r}9.5 \\
11.7 \\
8.7 \\
6.0 \\
6.0 \\
6.0 \\
9.5 \\
7.5 \\
14.2 \\
15.4 \\
5.5 \\
5.3 \\
15.4 \\
32.8 \\
43.2 \\
40.7 \\
43.9 \\
30.6\end{array}$ & $\begin{array}{l}1.9 \\
9.4 \\
1.5 \\
1.2 \\
1.2 \\
1.2 \\
1.9 \\
1.2 \\
2.2 \\
2.3 \\
2.3 \\
3.4 \\
2.2 \\
3.0 \\
2.1 \\
2.3\end{array}$ \\
\hline
\end{tabular}


TITLE: TII - UNIQUE LAND SURFACE COVER (SAND\& SWAMP)

DESCRIPTION: The land surface form map (Hammond 1959) indicates areas in which more than fifty percent of the surface is covered by sand and areas in which standing water covers more than fifty percent or covers ten to fifty percent of the surface. This data set contains the area of each county in which these conditions occur. Sands are usually droughty and infertile while standing water is the extreme case of poor drainage. These conditions either restrict the habitat or create unique habitat conditions.

SOURCE(S): Roswel1, C, A. 1976. Terrain Magnetic Tape File. University of Maryland, MD.

REFERENCE (S) : . Roswe 11 1976, Hammond 1959.

YEAR (S) : 1967

GEOCOVERAGE : East

STATUS: Online

NUMBER OF RECORDS :

CREATED/UPDATED: Mar. 1980

COMPILER: R J Olson
TEMPORAL RESOLUTION: Hist. SPATIAL RESOLUTION: County DATA SET TYPE: Single VARIABLES PER RECORD: 5 NEW DATA: Not anticipated

\section{VARIABLE}

LABEL AND UNITS OF MEASURE

FIPS CO
FIPS ST
SND 50 A
WTR_30-A
WTR_50-A

FIPS county number

FIPS state number

Area covered by sand ( $>508$ coverage) ha

Area occupied by water $(10-50 \%)$ ha

Area occupied by water $(>50 \%)$ ha 
TITLE: T12 - SOILS AVERAGE CHEMICAL CHARACTERISTICS

DESCRIPTION: The Soil Map Unit characteristics.(T10) and Soil Map Unit distribution data (T03) were combined to cstimate average soil characteristics for counties. If several Soil Map Units occurred within a county, the values were weighted according to the area of the county occupied by each type. Such an averaging procedure tends to obscure minor soil types or atypic variation. Since rocky outcrops and stony land were not included in the ratings, the county data are likely to overestimate soil properties such as the capacity to buffer acid precipitation. The orientation of this data set is regional, so local variation, which must be considered for site-speciflc studies, was not considered.

SOURCE(S): T03; T10.

REFERENCE(S): Klopatek et al. $1980 \mathrm{a}$.

COMMENTS: Soil cation exchange capacity is expressed as milli-equivalents per. $100 \mathrm{grams}$ (meq/l00g).

$\operatorname{YEAR}(\mathrm{S}): \quad 1967$

GEOCOVERAGE : East

STATUS: Online

NUMBER OF RECORDS : 2660

CREATED/UPDATED: Mar. 1980

COMPILER: J M Klopatek
TEMPORAL RESOLUTION: Hist. SPATIAL RESOLUTION: County DATA SET TYPE: Single VARIABLES PER RECORD: 7 NEW DATA: Not anticipated

LABEL AND UNITS OF MEASURE

\begin{tabular}{llr}
\hline FIPS_CO & FIPS county number & \\
FIPS_ST & FIPS state number & \\
SOIL_BS & Soil base saturation & percent \\
SOIL_CC & Soil clay content & percent \\
SOIL_CEC & Soil cation exchange capacity & meg/loog \\
SOIL_OM & Soil organic matter & percent \\
SOIL_PH & Soil pH & \\
\hline
\end{tabular}


TITLE: T13 - SOILS AT SOIL ORDER LEVEL

DESCRIPTION: The Soil Map Unit data set (T03) was aggregated to the soil order level by county to form this data set. Thus the area of counties in each of the nine Soil orders was created. This data set was mapped and used for editing the T03 file. Some of the editing was performed at Brookhaven National Laboratory by Ed Kaplan and Alicia Portas.

SOURCE (S): T03.

YEAR(S): 1967

GEOCOVEE RAGE : East

STATUS: Online

NUMBER OF RECORDS : 2660

CREATED/UPDATED: Mar. 1980

TEMPORAL RESOLUTION: Hist. SPATIAL RESOLUTION: County DATA SET TYPE: Single VARIABLES PER RECORD: 11 COMPILER: $\mathrm{R} J$ Olson

ALFI_A
ARID $\overline{\mathrm{I}} \mathrm{A}$
ENTI_A
FIPS $-\mathrm{CO}$
FIPS $-\mathrm{ST}$
HISTO $\mathrm{A}$
INCPT $-\mathrm{A}$
MOLLI_A
SPODO-A
ULTI_A
VERT $\overline{\mathrm{I}} \mathrm{A}$

Alfisol soil

Aridisol soil

Entisol soil

ha

FIPS county number

FIPS state number

Histosol soil

Inceptisol soil

ha

Mollisol soil

Spodosol soil

ha

Ultisol soil

ha

Vertisol soil

ha

hà 
TITLE: T14 - PHYSICAL REGIONS

DESCRIPTION: Land is classified by physical form. This classification differs from physiographic forms, which are geomorphological formations. Physical torms at the subdivision level provide a general view of the land, comparable to Bailey's ecoregions (Bailey 1976, Bailey 1978). There are six divisions and 35 subdivisions in the U. S. The base map for this data set is sheet 60 in the National Atlas (USDI 1970). This map was drawn by $E$. $H$. Hammond as a summary of his Land Surface Form map (Hammond 1963), which was digitized for data set Tol.

SOURCE(S): USDI 1970. Sheet 60 .

$\operatorname{YEAR}(\mathrm{S}): \quad 1970$

GEOCOVERAGE : U.S.

STATUS: Being Edited
TEMPORAL RESOLUTION: Hist. SPATIAL RESOLUTION: County DA'TA SET TYPE: Multiple 
TITLE: T15 - PHYSICAL REGIONS DICTIONARY

DESCRIPTION: Codes for E. H. Hammond's Physical Subdivisions (see T14) are tabulated at both the division and the subdivision levels. The codes consist of $a$ number and letter. The number is the division code; the letter is the subdivision code within a division. There are six divisions and 35 subdivisions in the U. S.

SOURCE(S) : USDI 1970. Sheet 60 .

$\operatorname{YEAR}(\mathrm{S}): \quad 1970$ GEOCOVE RAGE : U. S. S'IATTUS: Beiny Edited
TEMPORAL RESOLUTION : SPATIAL RESOLUTION: DATA EET TYPE: Dictnry 
The Wildlife sector includes information on birds and mammals. The distribution and abundance of birds was obtained from the Breeding Bird Survey (BBS) which is. conducted annually by the Fish and wildlife. Service: Information on the potential presence or absence of 280 mammal species by county was digitized from a variety of sources. Endangered species (animals and plants) data: were obtained from Brookhaven National Laboratory (Nagy and Calef 1979). Plans exist to incorporate additional information. which would define wildlife habitat requirements. 
TITLE: WOI - BBS ROUTES (BREEDING BIRD SURVEY)

DESCRIPTION: Since 1966, the U. S. Fish and Wildlife Service has coordinated an annual survey of birds during the breeding season (early summer). The Breeding Bird Survey (BBS) is conducted by volunteers. Routes have been established which follow roads selected to give a random sample of roadside habitats. Fifty three-minute stops are made along the $40 \mathrm{~km}$. route and the count of each species seen or heard within $0.4 \mathrm{~km}$ radius is recorded. The survey provides species composition by various habitats, relative abundance estimates, and population trends over time. This data set defines the name, number, location, type; strata code, ecoregion code, and vegetation code(s) of each route. The type code indicates if the route was not run using prescribed methods. Codes are: l=regular, 2 =experimental, $3=1$ ate finish (over 5.5 hours), 4 =check route, 5 =early start (over 15 minutes), $6=1$ ate finish (over 30 minutes), $7=\mathrm{miscellaneous,} 8=\mathrm{bad}$ weather, 9=late date, 0 =incomplete (fewer than 45 stops). Ecological strata are physiographic/ecological subdivisions used by the USF\&WS to define homogeneous regions. There are 58 strata in the United States. Each route was associated with ecoregions (Bailey 1976) by comparing: the state route maps with the ecoregion maps. Potential natural vegetation types (Kuchler $19.64)$ were also keyed to the BBS routes by comparing the BBS routes and vegetation map. When BBS routes crossed several vegetation types, the three, or fewer, most dominant types were included. This data set is used with W02 through w08 to provide route data.

SOURCE(S): Bystrak, D. 1979. BBS Super-Deck Magnetic Tape File. U. S. Fish and Wildlife Service, Laurel, MD.

REFERENCE(S): Bystrak 1979.

YEAR(S) : 1978

GEOCOVE RAGE : U. S.

STATUS: Onl ine

NUMBER OF RECORDS : 2367

CREATED/UPDATED: Mar. 1980

COMPILER: R.J Olson

TEMPORAL RESOLUTION: Annual SPATIAL RESOLUTION: Points DATA SET TYPE: IndeX VARIABLES PER RECORD: . 27 NEW DATA: . Infrequently

VARIABLE LABEL AND UNITS OF MEASURE

BBS_CMNT Comments about BBS route

BBS_LAT Latitude of start of BBS route

BBS_LONG Longitude of start of BBS route 





TITLE: W02 - BBS PHYSIOGRAPHIC STRATA DICTIONARY

DESCRIPTION: The names of the Breeding Bird Survey physiographic strata are given. The BBS strata are defined by the USF\&WS using a combination of the potential natural vegetation scheme of Kuchler. (1964) and the physiographic/land-use scheme of Fenneman (1931, 1938).

SOURCE(S): Bystrak, D. 1979. Map of BBS strata. U. S. Fish and Wildlife Service, Laurel, MD.

YEAR (S) : 1978

GEOCOVERAGE : U. S.

STATUS: Online

NUMBER OF RECORDS:

CREATED/UPDATED: Mar. 1980

COMPILER: ' $\mathrm{R} \mathrm{J}$ Olson
TEMPORAL RESOLUTION: SPATIAL RESOLUTION: DATA SET TYPE: Dictnry VARIABLES PER RECORD: 3 NEW DATA: Not anticipated

\section{VARIABLE LABEL AND UNITS OF MEASURE}

$\begin{array}{ll}\text { BBS_RT_N } & \text { BBS number of routes within a strata } \\ \text { STR_CODE } & \text { BBS strata code } \\ \text { STR_DSCP } & \text { Physiographic strata description }\end{array}$


TITLE: W03 - BBS BIRD CODES DICTIONARY

DESCRIPTION: The American Ornithologists' Union (AOU) Check-list of North American Birds (1957) identifies species with 4-digit numeric codes. This dictionary provides common names and AOU codes for each of the 700 species in the Breeding Bird Survey.

SOURCE(S): Robbins, C. 1974. AOU Bịd Species Codes Card Deck. US. Fish and Wildlife Service. Laurel, MD.

REFERENCE(S): American Ornithologists' Union 1957.

YEAR (S) :

GEOCOVE RAGE : U. S.

STATUS: On 1 ine

NUMBER OF RECORDS : $\quad 739$

CREATED/UPDATED: Mar . 1980

COMPILER: $\mathrm{R} J$ Olson
TEMPORAL RESOLUTION : SPATIAL RESOLUTION: DATA SET TYPE: Dictnry VARIABLES PER RECORD: 3 NEW DATA: Not anticipated

\section{VARIABLE LABEL AND UNITS OF MEASURE}

$\begin{array}{ll}\text { AOU_CODE } & \text { AOU bird species code number } \\ \text { AOU_SEQ } & \text { AOU sequence numbers } \\ \text { BRD_DSCP } & \text { Common bird names }\end{array}$


TITLE: W04 - BBS BIRD NATIONAL \& REGIONAL STATS

DESCRIPTION: National and regional statistics for birds were generated from the 1973-1974 average Breeding Bird Survey. (BBS) data set w08. For each species, a set of parameters were calculated for each region or the nation. The first part of the SAS variable name indicates the region, and the last character indicates the parameter. The set of parameters and their codes are: $\mathrm{N}$-count, count divided by number of routes in region; F-fraction, count divided by total count of ail species in region; and R-rank within region based on count. The bird key is an identifier which was created by assigning consecutive numbers to the 470 species that were recorded in the 1973-1974 BBS. Federally designated endangered species were deleted from this data set and treated separately in the RARE-II analysis.

SOURCE (S): W08.

YEAR (S) : $\quad$ 1973-1974 GEOCOVE RAGE : U. S. STATUS: Online NUMBER OF RECORDS : CREATED/UPDATED: Mar 1980 COMPILER: L K Mann, J T Kitchings

\section{2}

1980
TEMPORAL RESOLUTION: 'NOrmS SPATIAL RESOLUTION: Region DATA SET TYPE: Multiple VARIABLES PER RECORD: 16 NEW DATA: As available gs

\begin{tabular}{|c|c|}
\hline VARIABLE & LABEL AND UNITS OF MEASURE \\
\hline 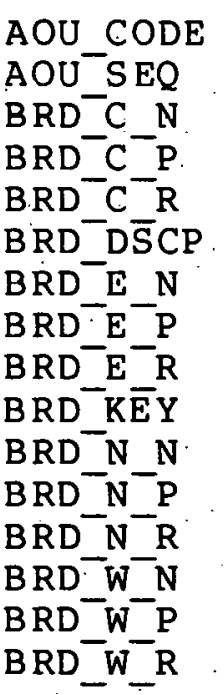 & $\begin{array}{l}\text { AOU bird species code number } \\
\text { AOU sequence numbers } \\
\text { Central aver bird count, 1973-74 } \\
\text { Fraction of central total } \\
\text { Central ranks of birds } \\
\text { Common bird names } \\
\text { Eastern aver. bird count, 1973-74 } \\
\text { Fraction of eastern total } \\
\text { Eastern ranks of birds } \\
\text { Bird key number, 1-470, RARE II subset } \\
\text { National aver. bird count, 1973-74 } \\
\text { Fraction of national total } \\
\text { National ranks of birds } \\
\text { Western aver. bird count, 1973-74 } \\
\text { Fraction of western total } \\
\text { Western ranks of birds }\end{array}$ \\
\hline
\end{tabular}


W04.1 Bird Species Codes Dictionary.

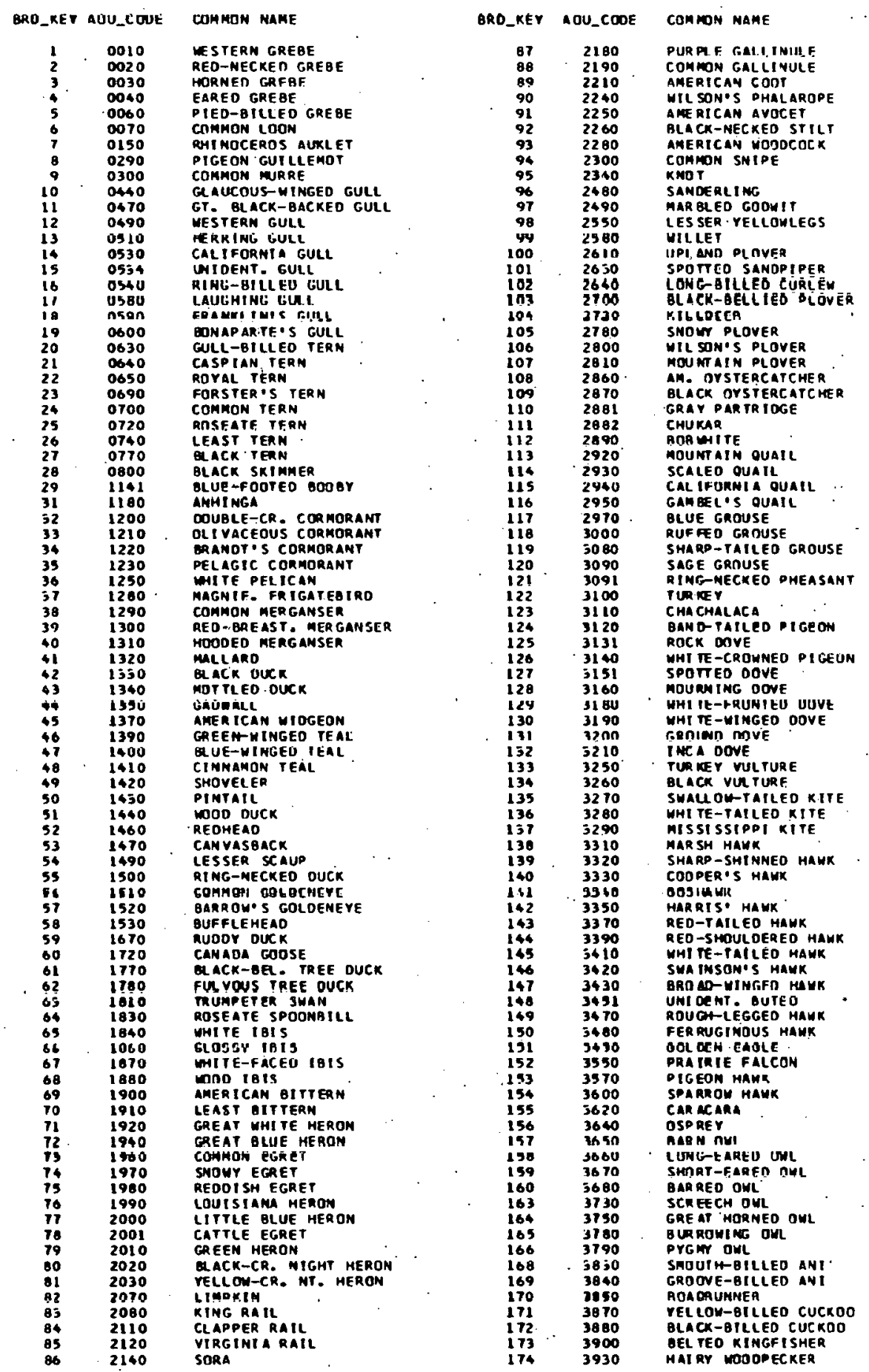


W04.1 (continued)

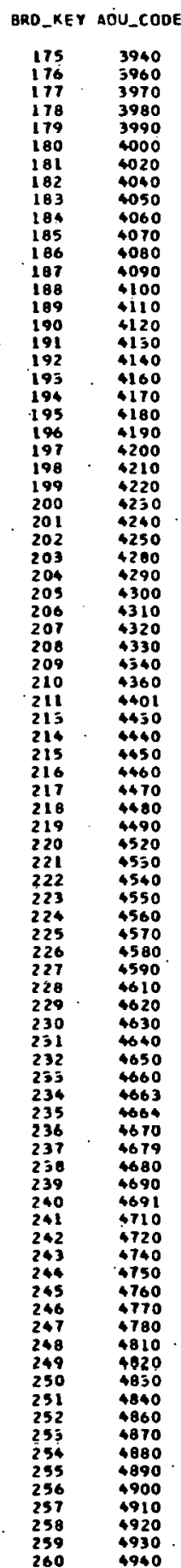

conmon mame

DOHNY MOODPECKER CADDER-BACK WODDPECKER NUTTALL 'S NOODPECKER ARI ZOMA YOODPECKER WTI TE-HEAOED WOOBPKR OLK-BACK S-TOEO WOPKR YELLOA-BEL: SAP SUCKER PILEATED WODOPECKER RED-HË $\triangle D E O$ WOODPECKER ACORN NOODPECKER RED-BELLIED WODDPECKER GOLOEN-FRONTED WODPRR GILA MODOPECKER VELLOH-SMAFTED FLICKER RED-SHAFTED FLICKER GILDED FLICKER CHUCR-MILL 'S-WI OOW
MIP-POOR-WILL POOR-WILL

PAURAGUE

COAMON NIGHTHANK
LESSER NIGHTHAYK

olack swift

CHIMNEY SHIFT

VAUX'S SWIFT

MHI TE-TMROATED SWIFT RUBY-THR. MUAMINGB IRO
GACK-CHIN MUMMINGBIRD COSTA'S HUMHING BIR ANNA 'S HUWM INGBIRD BROAD-TALL HUMM ING
RUFOUS MUAM INGS IRD RUFOUS HUMMINGSIRD CALL IOPE HUAMINGBIRD CALL IOPE HUMMINGBIRD UNI DENT. HUMM INGBIRD EASTERA KINGETRD GRAY KINGB TRD

CRAY RINGB TAD
TROPICAL KINGBIAD

TETIERM KINGBIRO

CASSIM S KIMGG

CISKADEE FIYCATCD

GTSADEE FLYCATCHER

GT. CRE STEO FLYCATCHER

WSH-THR OAT FLYCATCHER

OUI YACEOUS FL YCATCHER

EASTERH PHOEBE

SAY'S PHDEBE

Q ACK PHOEBE

OLIVE-SIDED FLYCATCMER

EASTERH WOOD DEMEE

YELER WOO DEWEE

MESTERM FLYCATCMER

ACAOIAM FLYCATC RER

TRAILL 'S FLTCATCHER

ML DER FLYCATCAER

MILLON FL YCATCHEA

ceas! revcaícrea

EMP IOONAX SP:

MUMMOND'S FLYCATCHER

DUSKY FLYCATCHER

CAAY FL VCATC HER

GeAR DESS FLYCA TCHER

MORNEO LARK

BLACK-BILLE MAGPIE

YELLOW-RILLEO MAGPIE

QUE JAY

STELLER'S JAY

SCRUB JaY

REXICAN JAY

GREEN JAY

COMHON RAVEM

WITF-MECKED RAVEN

COMHON CRO'

MORTHMESTERN CRO

FISH CRON

CLARK'

PINYON.JAY

STARLING

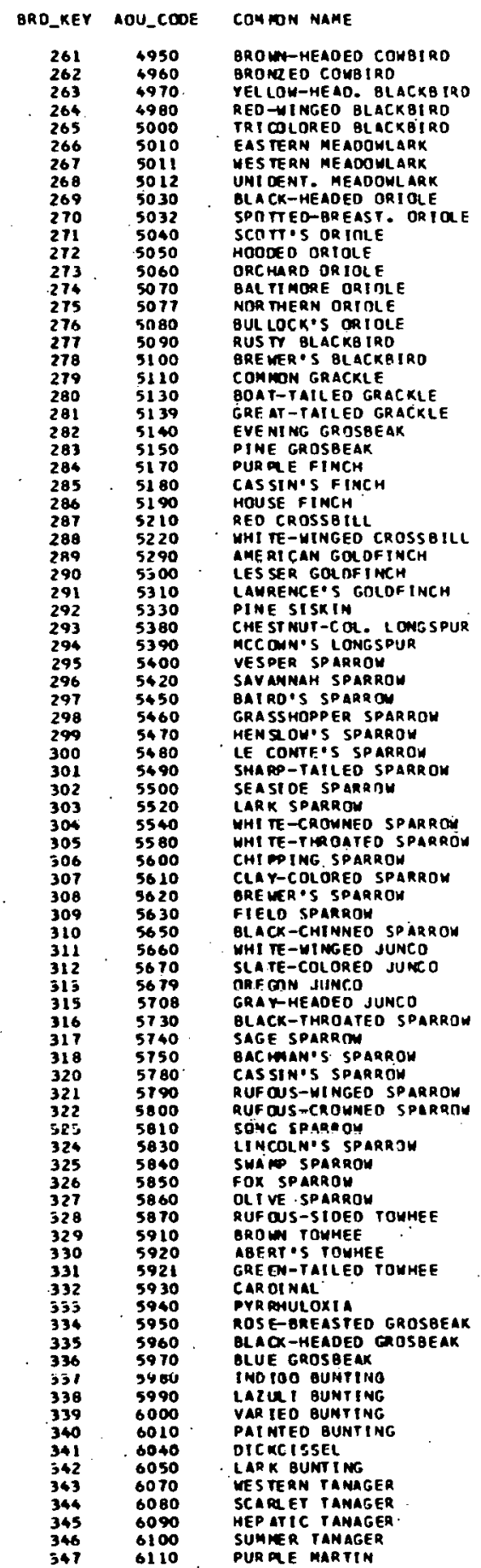


W04.1 (continued)

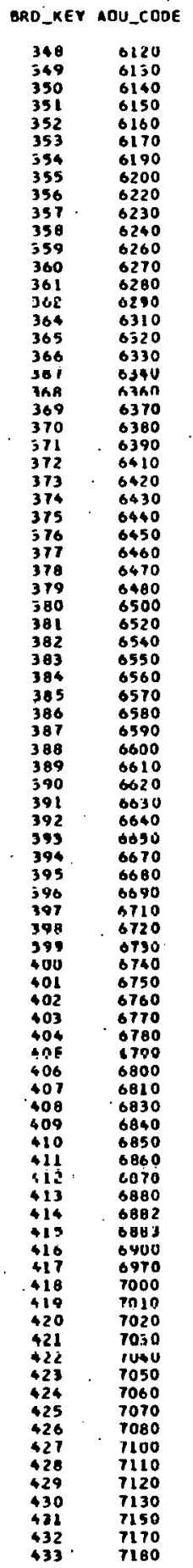

COMMON MANE

CLIFF SHALLOY

BARN SWALLOW

YIOLET-GREEN SWALLOH

VIOLE -GREEN

ROUGH-WINGEO SWALLO

CEDAR WAXWING

PHAINOPEPLA

LOGGERHEAD SHRIKE

BLACK-MHISKERED VIREO

RED-EYEO VIREO

PHILAdelPhta VIREO

MAR BL ING VIREO

YELLOW-THROATED VIREO

SOL ITAR, VIKEIS

WMITE-EYED VIREO

MTTON'S VIREO

BELL'S VIREO

GRAT VIREN

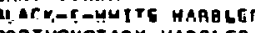

PROTHONOTARY WARBLER

SWAINSON'S WARBLER

WOAN-EATING WARBLER

COL DEN-WINGED WARBLER

GULY'S YARBLER

VIRTIMIA'S MARBLER

NASHYILLE MARRIER

ORANGE-CROINED MARBLER

TENNESSEE WARBL ER

CARULA VARBLER

CAPE MAY MARBLE

BLACK-TH BLUE WARBLER

MYRTLE YARBLER

AUDUBDN 'S WARBLER

MAGMOI. IA UARBLER

CERULEAN WARBLER

CHE STNUTI-SIOED MARBLER

BAY-BREASTED MARBLER

BLACKPOLL WAROLER

BL ACKBURNIAN WARBLER

YELLOW-THROATO WARELER

GR ACE'S WARBLER

OLALR-I WR GRAT HARBLER

BLACK-TH GREEN HARBLER

TOWNSEND'S WARB LER

HERMIT HARBLEO

DINE MARBLER

Malíté MARBLE

OVENBIRO

NORTHERN MATERTHRUSH

COUIS IANA HATER THRUSH

KEMTUCKY WARBLER

CONMECT ICUT. MARBLE

MOUAILL WARBLE WARBLER

YCGILLIVRAY

MELLOW-BREASTEO CHAT

MOODEO MARBLER

VILSON- S MARBLER

CAMAOA MARBLFR

AMER ICAN REDSTAAT

PAINTEO REOSTART

MUUSE SPAPROW

EUROPEAN TAEE SPARKOL

RED-FACEO WARBLER

WATPR PIDII

SPRAGUE 'S PIDIT

DIPPCD.

SAGE THRASHER

MUR.K IMGAION

CABSTRO

BROWN THA $\triangle$ SHER

COMG-BILLED THRA ASHER

CURVE-BILLEO THRASHER

BENDIRE 'S THRASHER

CALI FORNIA THA ASHER

LE. CONTE'S THRASHER

CRISSAL THRASHER

CACTUS WREN

MOCK WREA

CANYON WREN

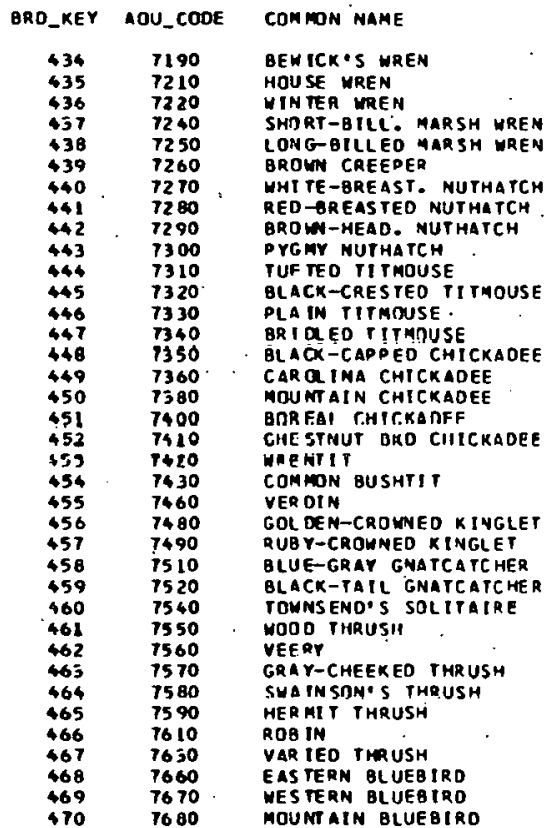


TITLE: W05 - BBS BIRD-ECOREGION STATS

DESCRIPTION: Ecoregion statistics are given for birds based on the 1973-1974 average counts from the Breeding Bird Survey data set w08. A set of parameters was calculated for each ecoregion. The last characters of the SAS name indicate the parameter. Parameters and their codes are: $\mathrm{N}$-average count, count divided by number of routes in ecoregion; P-fraction, count divided by total count of all routes in ecoregion; and TOT-total count of all species on all routes in ecoregion. Only routes that appeared entirely within an ecoregion were used to calculate w05.

SOURCE(S): W01, W08.

YEAR(S) : $1973-1974$

GEOCOVE RAGE : U. S.

STATUS: Online

NUMBER OF RECORDS :

CREATED/U PDATED: Már. 1980

COMPILER :

L K Mann, J T Kitchings

TEM PORAL RESOLUTION: NOrmS SPATIAL RESOLUTION: Ecorgn DATA SET TYPE: Multiple VARIABLES PER RECORD: 5 NEW DATA: As available

\section{VARIABLE LABEL AND UNITS OF MEASURE}

AOU CODE AOU bird species code number

EBR $\bar{D} N$

EBRD $-\mathrm{P}$

Ecoregion bird average count, 1973-74

EBRD TOT

Fraction of counts within ecoregion

ECO $\bar{C} O D E$

Ecoregion bird total, all species

Ecoregion section code, Bailey 1976 
TITLE: W06 - BBS BIRD COUNTS WITHIN STRATA

DESCRIPTION: strata statistics are given for birds based on the 1973-1974 average counts from the Breeding Bird Survey data set w08. A set of parameters was calculated for each species within each strata. The last characters of the SAS name indicate the type of parameter. Parameters and their codes are: N-average count, count divided by number of routes in strata; and TOT-number of route occurrences in the strata. Only routes that appeared entirely within a strata were used to calculate W06: The association of routes and strata was provided by Danny Bystrak of the USF\&WS including the definition of strata-cróssers.

SOURCE(S): W01, W08.

$\operatorname{YEAR}(\mathrm{S}): \quad 1973-1974$

GEOCOVE RAGE : ' U. S.

STATUS: Onl ine

NUMBER OF RECORDS: 7041

CREATED/UPDATED: Mar. 1980

COMPILER :

$\mathrm{L} K$ Mann, $\mathrm{J} T$ Kitchings
TEMPORAL RESOLUTION: NormS SPATIAL RESOLUTION: Region DATA SET TYPE: Multiple VARIABLES PER RECORD: NEW DATA: As available

$\begin{array}{ll}\text { AOU_CODE } & \text { AOU bird species code number } \\ \text { SBRD_N } & \text { BBS strata bird route occurrences } \\ \text { SBRD_TOT } & \text { BBS strata average bird count } \\ \text { STR_CODE } & \text { BBS strata code }\end{array}$


THIS PAGE

\section{WAS INTENTIONALLY LEFT BLANK}


TITLE: W08 - BBS BIRD COUNTS FOR ROUTES

DESCRIPTION: Route statistics for each species are based on the 1973-1974 average counts from the Breeding Bird survey data tapes. The average count is calculated as the total count for the two years divided by. two. All routes are included. Data set w0l provides location, type, and identifiers of strata, ecoregion, and vegetation types associated with each route.

SOURCE(S): Robbins, C. 1975. 1966-1974. BBS Magnetic Tape Files. U. S. Fish and Wildlife Service, Laurel, MD.

YEAR (S) : $\quad 1973-1974$

GEOCOVE RAGE : U. S.

STATUS: Offline

NUMBER OF RECORDS : 110613

CREATED/UPDATED: . Mar • 1980

COMPILER: R J Olson
TEMPORAL RESOLUTION: "NORMS SPATIAL RESOLUTION: Points DATA SET TYPE: Multiple VARIABLES PER RECORD: NEW DATA: As available

VARIABLE LABEL AND UNITS OF MEASURE

AOU CODE. AOU bird species code number

COUNT'T

F.IPS $S \mathrm{~T}$

Mean count based on 1973 and 19.74

BBS $\bar{R}$ T

$\mathrm{BBS}^{-} \mathrm{ST}$

FIPS state number

BBS route number within a state

BBS strata code 
TITLE: W09' - ENDANGERED SPECIES CODES DICTIONARY

DESCRIPTION: Federally designated endangered and threatened species information has been compiled by Brookhaven National Laboratory. They continually update and expand their file as new information becomes available. Thus our file, wlo, may be out-of-date. Species are identified by 3-digit numeric codes. - This data set provides English names for the codes along with species type information, e.g. mammal, bird, fish, etc. Data sets Wlo and wll contain county-level distribution data for each species. Wll has been supplemented at ORNL to include additional species and more specific species range data. Data set w09 contains the national counts (number of county occurrences) for both wlo and Wll.

SOURCE(S): Calef; C. March, 1978. 1978 ESEA Magnetic Tape File. Brookhaven National Laboratory, Upton; NY.

REFERENCE(S): Calef and Nagy 1979 .

COMMENTS: An updated file with more species, better distribution definitions, and endangered plant data is anticipated in 1980 .

$\operatorname{YEAR}(\mathrm{S}): \quad 1977$

GEOCOVE RAGE : U. S.

STATUS: Online

NUMBER OF RECORDS : 204

CREATED/UPDATED: Mar. 1980

COMPILER: C E Calef, J Nagey
TEMPORAL RESOLUTION : SPATIAL RESOLUTION : DATA SET TYPE: Dictnry VARIABLES PER RECORD: 6 NEW DATA: As available

\section{6}

\begin{tabular}{ll} 
VARIABLE & LABEL AND UNITS OF MEASURE \\
\hline EAT_CODE & Endangered species numeric code \\
EAT_DSCP & Endangered species description \\
EAT_GRP & Endangered species type group code \\
EAT_TYPE & Endangered species type description \\
EATN_BNL & Endangered species national counts-BNL \\
EATN_OR & Endangered species national counts-ORNL \\
\hline
\end{tabular}


W09.1 Fndangered Species Codes Dictionary

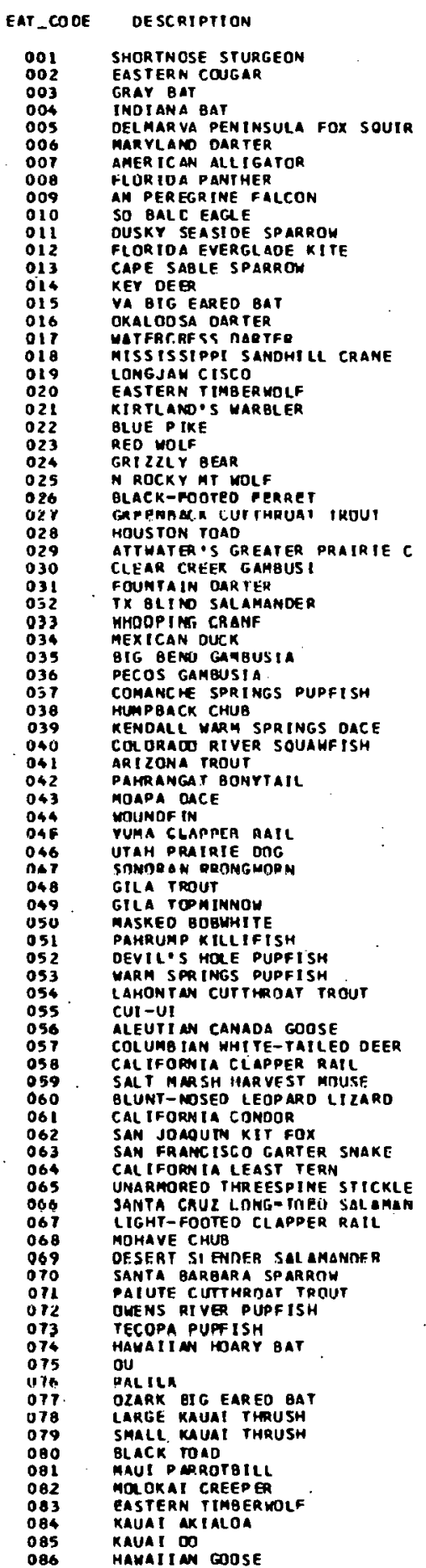

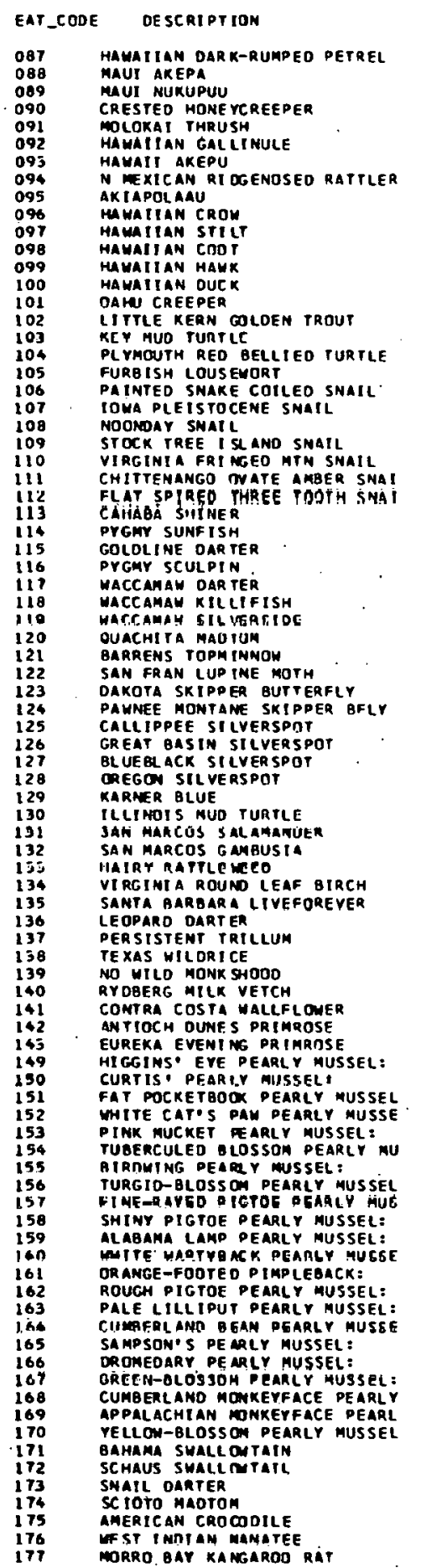


W09.1 (continued)

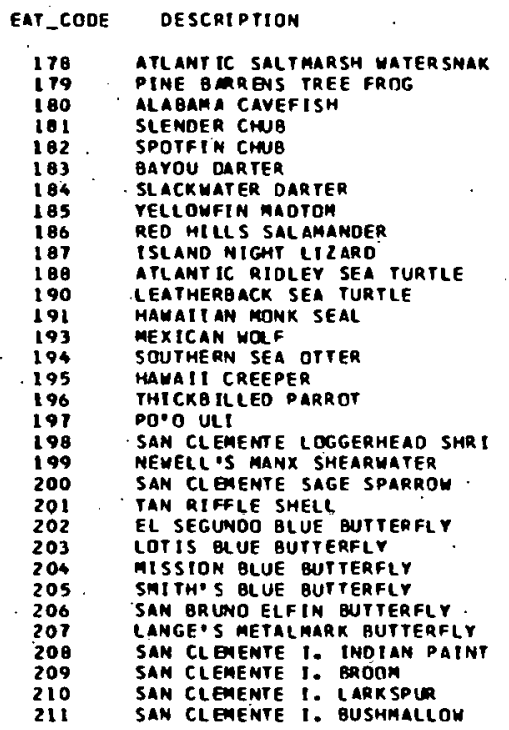

EAT_CODE DESCRIPT TON 
TITLE: WIO - ENDANGERED SPECIES (BNL FILE)

DESCRIPTION: County-level distribution data for federally designated endangered species of the United States were compiled by Brookhaven National Laboratory. Although this data set contains only the counties of historic occurrence, more recent data are available from BNL on species distribution according to four levels: designated critical habitat, present range, potential range, and historic range. See w09 for species names associated with code designations.

SOURCE(S): Calef, C. March, 1978. 1978 ESUSA Magnetic Tape File. Brookhaven National Laboratory, Upton, NY.

REFERENCE(S): Shreeve, Calef, and Nagy 1978. Calef and Nagy 1979. Nagy and Calef 1978.

$\operatorname{YEAR}(\mathrm{S}): \quad 1977$

GEOCOVERAGE : U. S.

STATUS: Online

NUMBER OF RECORDS : 6916

CREATED/UPDATED: Mar. 1980

COMPILER: C E Calef, J Nagey
TEMPORAL RESOLUTION: Hist. SPATIAL RESOLUTION: County DATA SET TYPE: Multiple VARIABLES PER RECORD:

\section{3}

NEW DATA: As available

LABEL AND UNITS OF MEASURE

EAT_CODE

FIPS $C O$

FIPS_ST
Endangered species numeric code

FIPS county number

FIPS state number 


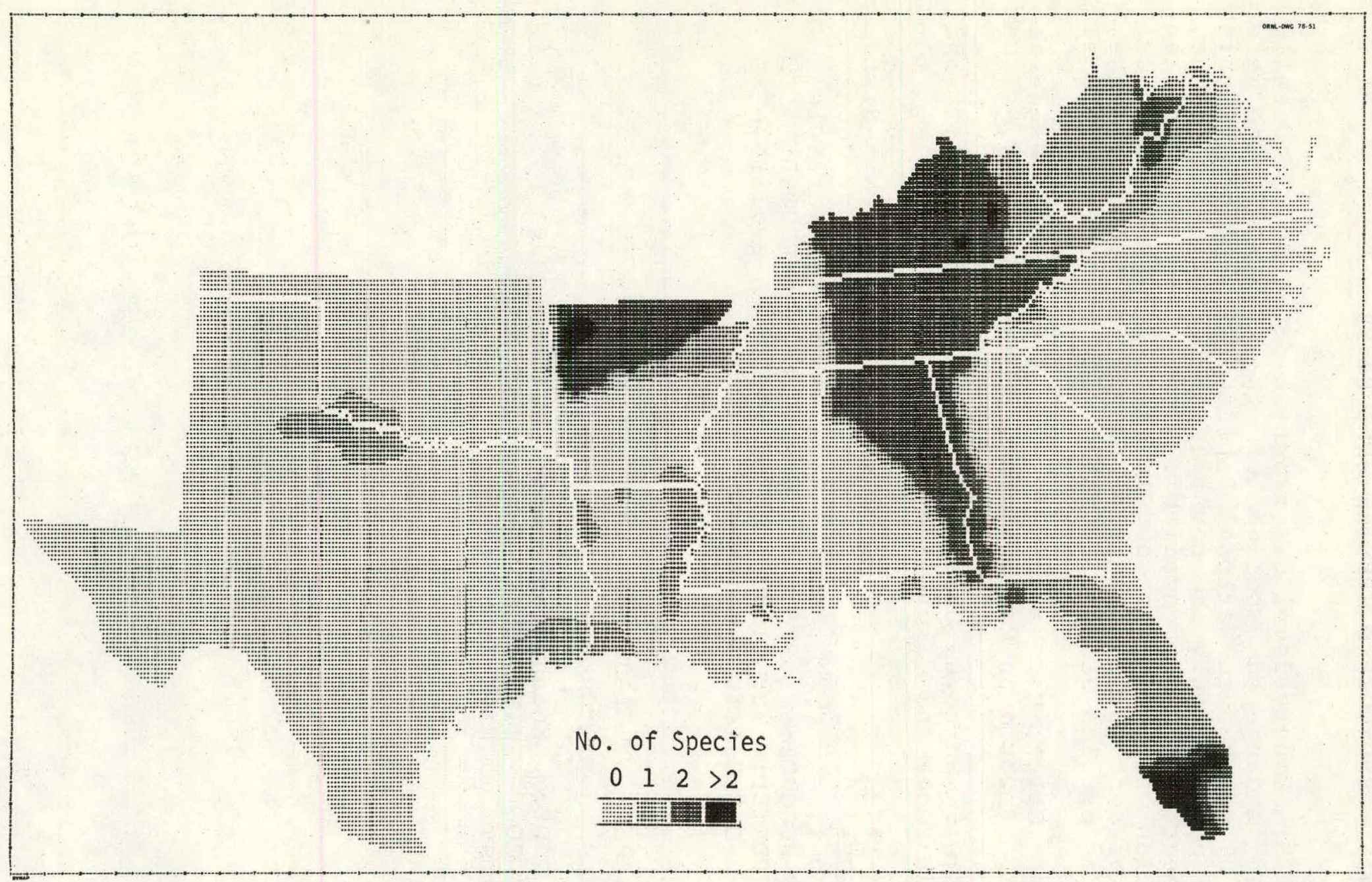

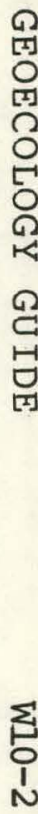

W10.1. Endangered Species Concentrations in the South. 
TITLE: WI1 - ENDANGERED SPECIES (ORNL MODIFIED)

DESCRIPTION: County-level distribution data for federally designated endangered species of the United States were compiled. by Brookhaven National Laboratory. This data set consists of file W10 which has been supplemented by ORNL. Additional state-designated endangered species have been added. Historic range, proposed or designated critical. habitat, and significant sightings information was also added for each species. Remarks were included to better describe a species occurrence in a county. See file w09 for species names.

SOURCE(S): w10. Species range data.

REFERENCE (S) : USDI 1976, USDI 1977, USDI 1978, USDI 1979, Federal Register 1977.

$\operatorname{YEAR}(S): \quad 1978$

GEOCOVERAGE : U.'S.

STATUS: Online

NUMBER OF RECORDS : 7034

CREATED/UPDATED: Mar. 1980

COMPILER: J T Kitchings, L. K Mann
TEMPORAL RESOLUTION: Hist. SPATIAL RESOLUTION: County DATA SET TYPE: Multiple VARIABLES PER RECORD: NEW DATA: As available 


\section{TITLE: WI2 - MAMMAL CODES DICTIONARY}

DESCRIPTION: County-level species range data were compiled from several sources for mammals of the United States. This data set supplies the scientific and common names for each of the 270 species. The STORER program (Schreiber et al. 1974 ) was used to digitize the species range maps. This program uses a six-character mnemonic code name to identify each species. The mnemonic name consists of the first three consonants of the genus and species names with some variations to ensure that all codes are unique (Goff et al. 1974 ).

SOURCE(S): Kitchings, J. T. 1976. Mnemonic name file. Environmental Sciences Division, Oak Ridge National Laboratory, Oak Ridge, TN.

YEAR (S) :

GEOCOVE RAGE :

STATUS: Online

NUMBER OF RECORDS: 280

CREATED/UPDATED: Mar . 1980

COMPILER: $\mathrm{J} T$ Kitchings
TEMPORAL RESOLUTION:

SPATIAL RESOLUTION:

DATA SET TYPE: DictnrY VARIABLES PER RECORD: 3

NEW DATA: Not anticipated

\section{VARIABLE LABEL AND UNITS OF MEASURE}

$\begin{array}{ll}\text { MAM_CODE } & \text { Mammal mnemonic species code } \\ \text { MAM_DSCP } & \text { Mammal common name } \\ \text { MAM_SPEC } & \text { Mammal genus-species scientific name }\end{array}$


TITLE: W13 - MAMMAL NATIONAL \& REGIONAL STATS

DESCRIPTION: National and regional statistics of county-level mammal occurrences were calculated. from data set W15. Historic species range data were compiled from published species range maps. A set of parameters was calculated for each region for each species. The first part of the SAS variable name designates the region while the last part indicates the parameter. The parameters and their codes are: N-number of county occurrences, and P-fraction of counties in a region occupied by a species. The mammal key is a sequential numeric code assigned to the 270 species in the data set.

SOURCE (S) : $\quad$ W15

YEAR (S) : 1978

GEOCOVE RAGE : U. S.

TEMPORAL RESOLUTION: Hist. STATUS: Online NUMBER OF RECORDS : $\because 270$

CREATED/UPDATED: Mar. 1980 COMPILER: J T Kitchings, L K Mann

SPATIAL RESOLUTION:

DATA SET TYPE: DictnrY

VARIABLES PER RECORD: 12

NEW DATA: Not anticipated

\begin{tabular}{|c|c|}
\hline VAR IABLE & LABEL AND UNITS OF MEASURE \\
\hline $\begin{array}{l}\text { MAM C N } \\
\text { MAM-C P } \\
\text { MAM-CODE } \\
\text { MAM-DSCP } \\
\text { MAM-E_N } \\
\text { MAMEEP } \\
\text { MAM-KEY } \\
\text { MAM N N } \\
\text { MAM_N P } \\
\text { MAM-STEC } \\
\text { MAM-W_N } \\
\text { MAM_W_P }\end{array}$ & $\begin{array}{l}\text { Central mammal county occurrences } \\
\text { Fraction of county occurrences in cent. } \\
\text { Mammal mnemonic species code } \\
\text { Mammal common name } \\
\text { Eastern mammal county occurrences } \\
\text { Fraction of county occurrences in east } \\
\text { Mammal spccics code number } \\
\text { National mammal county occurrences } \\
\text { Fraction of county occurrences in nation } \\
\text { Mammal genus-species scientific name } \\
\text { Western mammal county occurrences } \\
\text { Fraction of county occurrences in west. }\end{array}$ \\
\hline
\end{tabular}




\section{W13.l Mammal Species Codes Dictionary}

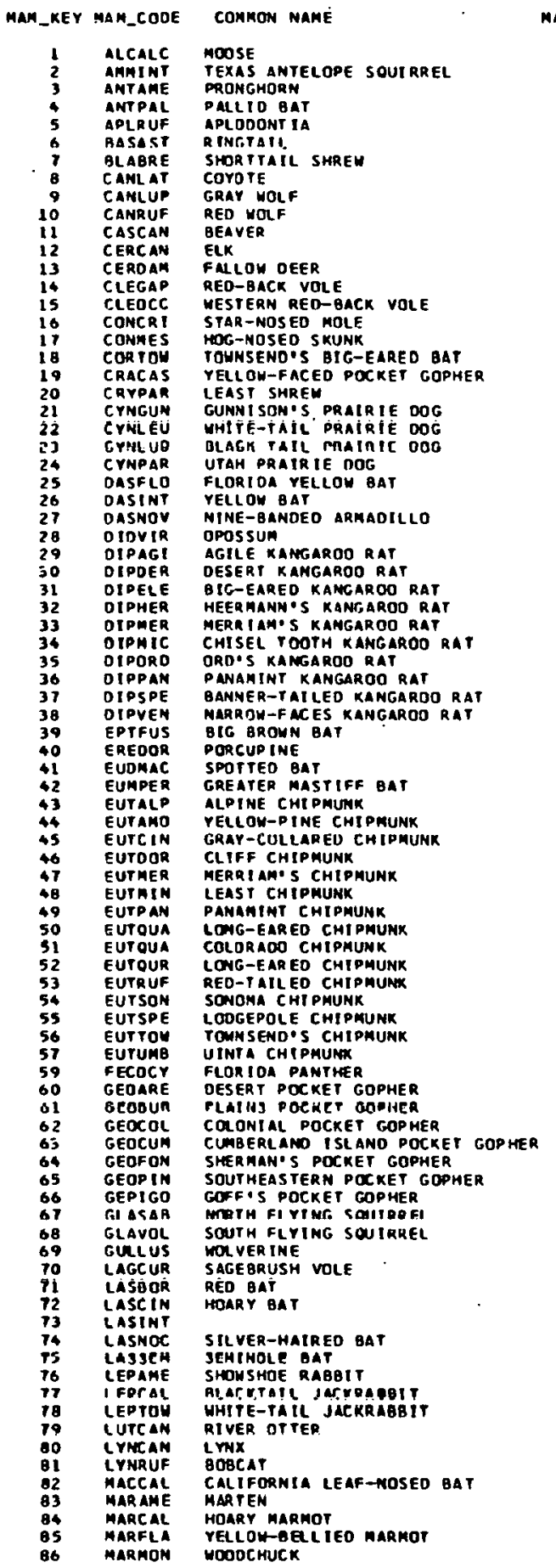

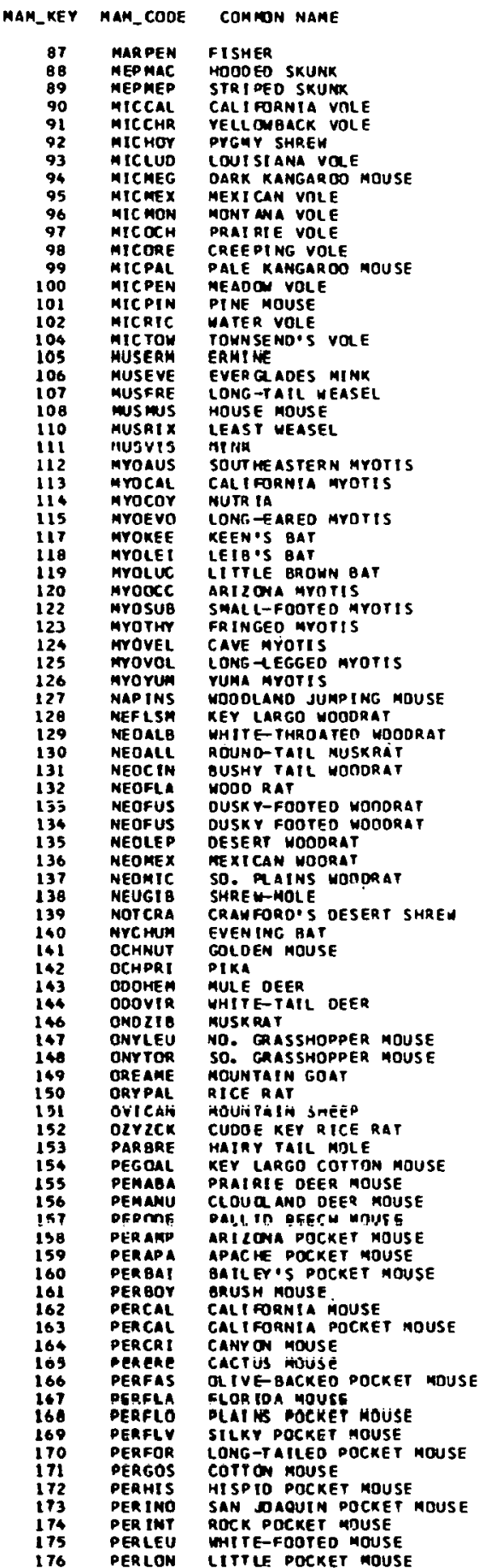


W13.1 (continued)

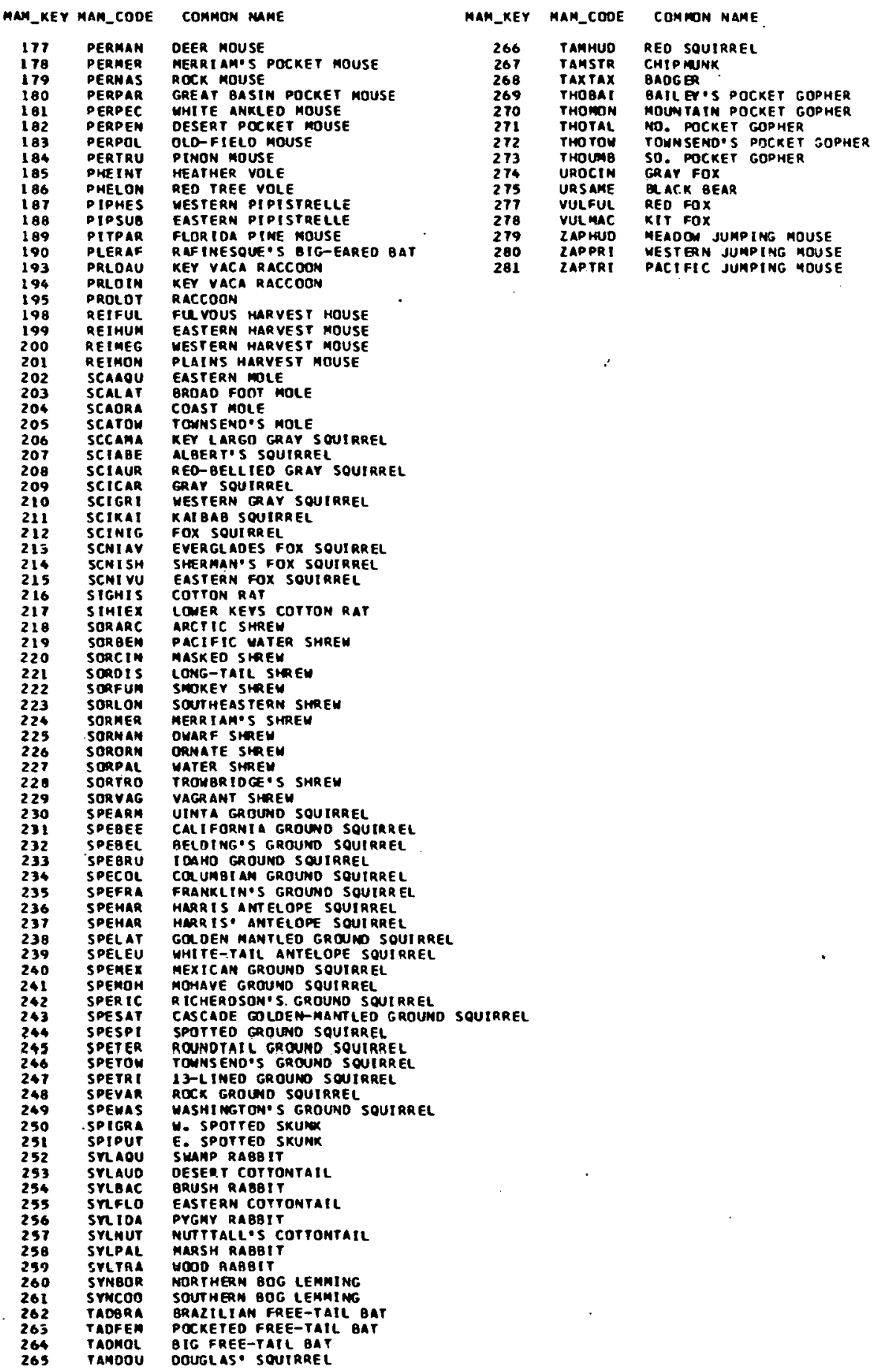


TITLE: W14 - MAMMAL-ECOREGION STATS

DESCRIPTION: Ecoregion statistiç of county-level mammal occurrences were calculated from data set Wl5. Historic species range data were compiled from published species range maps. A set of parameters.was calculated for each ecoregion. The last part of the SAS variable name indicates the parameter. The parameters included for each species in each ecoregion include: $\mathrm{N}$-number of county occurrences, and $\mathrm{P}$-fraction of counties in a region occupied by a species.

SOURCE(S): W.15

YEAR (S) : 1978

GEOCOVE RAGE : U. S.

STATUS: . Onl ine

NUMBER OF RECÓRDS : 5786

CREATED/UPDATED: Mar. 1980 .

COMPILER: J T Kitchings, L K Mann

TEMPORAL RESOLUTION: Hist. SPATIAL RESOLUTION: Ecorgn DATA SET TYPE: Multiple VARIABLES PER RECORD: 4 NEW DATA: Not anticipated

\section{VARIAB.LE}

LABEL AND UNITS OF MEASURE

ECO CODE

EMA $\bar{M} \mathrm{~N}$

EMAM-P

MAM_CODE
Ecoregion section code, Bailey 1976

Ecoregion mammal county occurrences Fraction of county occurrences by ecorgn Mammal mnemonic species code 
TITLE: WI5 - MAMMAL SPECIES RANGES

DESCRIPTION: Historic species range data for mammals of the United States were compiled from published species range maps. The STORER program (Schreiber et al. 197.4) was used to record the county-level occurrences. This program allows several shortcuts in the digitizing process based on the geographic contiguity of species ranges. The output from the STORER program was then converted to be compatible with the other Geoecology. files.

SOURCE(S): Barbour and Davis 1974. Brown 1970. Findley et al. 1975. Golley 1962. Golley 1966. Hall and. Kelson 1959. Hamilton 1943. Lowery 1974. Wyoming Game and Fish. Dept. 1977: Brown 1970 .

REFERENCE(S): Kitchings, Anderson and Olson 1976.

YEAR (S) : 1978

GEOCOVERAGE : U. S.

STATUS : Offline

NUMBER OF RECORDS : 151936

CREATED/UPDATED: Mar. 1980

COMPILER: J $\mathrm{T}$ Kitchings
TEMPORAL RESOLUTION: Hist. SPATIAL RESOLUTION: CountY DATA SET TYPE: Multiple VARIABLES PER RECORD: NEW DATA: Infrequently

VARIABLE

LABEL AND UNITS OF MEASURE

$\begin{array}{ll}\text { FIPS_CO } & \text { FIPS county number } \\ \text { FIPS ST } & \text { FIPS state number } \\ \text { MAM_CODE } & \text { Mnemonic mammals species code } \\ \text { RGN } & \text { Region }-E, C, W\end{array}$


TITLE: W16 - MAMMAL SPECIES RANGES (RARE SPECIES)

DESCRIPTION: Historic species range data for mammals of the United States were compiled from published species range maps; see the description of W15. This data set includes the endangered and threatened species contained in the W15 data set.

SOURCE (S): W15

YEAR(S): 1978

GEOCOVE RAGE : U. S.

STATUS: Online

NUMBER OF RECORDS : 4079

CREATED/UPDATED: Mar. 1980

COMPILER: J T Kitchings

TEMPORAL RESOLUTION: Hist. SPATIAL RESOLUTION: County DATA SET' 'TYPE: Multiple VARIABLES PER RECORD: NEW DATA: Infrequently

\begin{tabular}{ll} 
VARIABLE & LABEL AND UNITS OF MEASURE \\
\hline FIPS_CO & FIPS county number \\
FIPSCST & FIPS state number \\
MAM_CODE & Mnemonic mammals species code \\
RGN. & Region $-E, C, W$
\end{tabular}


APPENDIX B. INDEX OF DATA SET VARIABLES 
THIS PAGE

\section{WAS INTENTIONALLY LEFT BLANK}




\section{APPENDIX B. INDEX OF DATA SET VARIABLES}

\section{Table B.1. Index of Geoecology Data Base Variables}

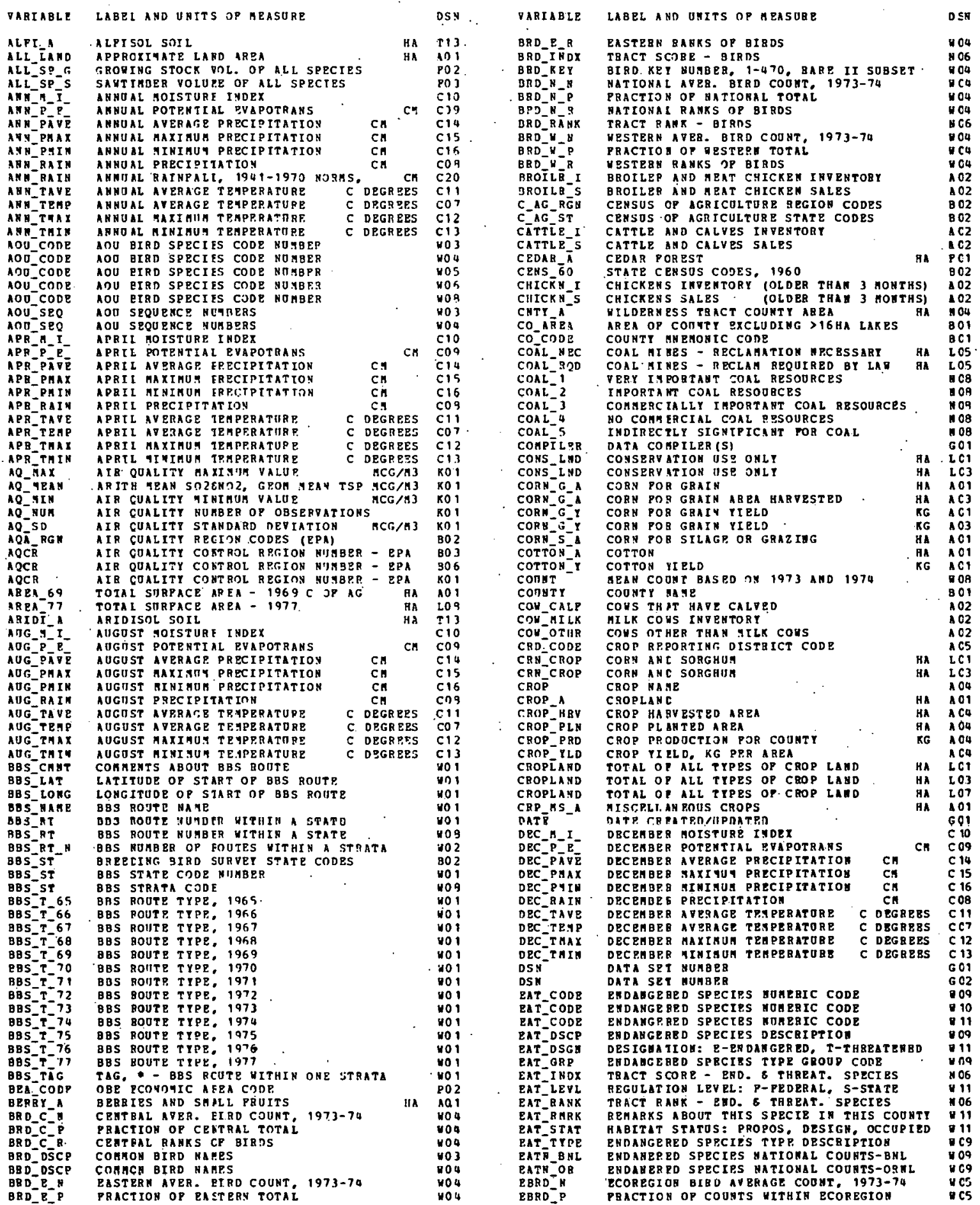




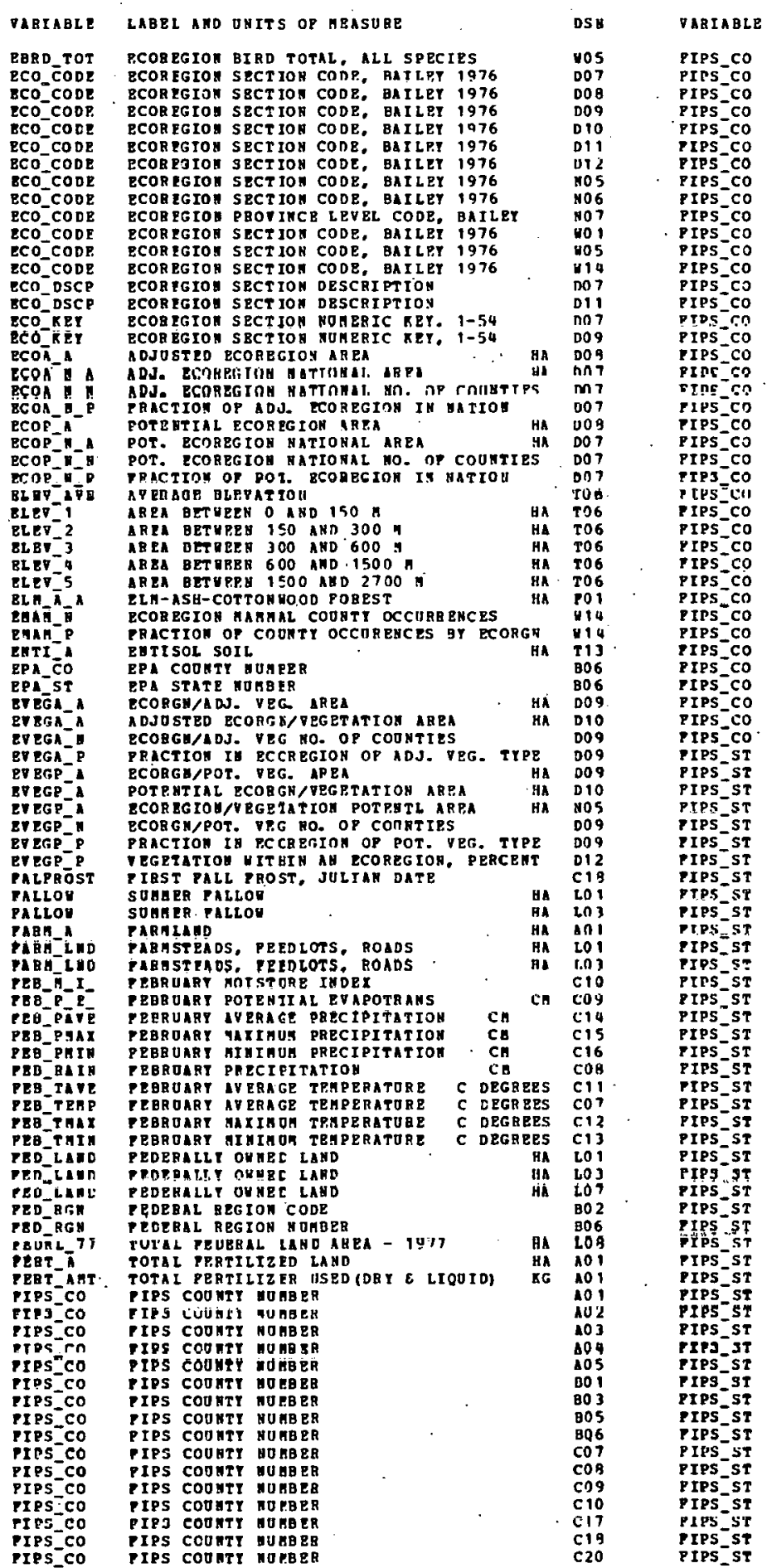

LABEL A BD OKITS OP REASORE DSI

PIPS COOHT WOHBER PIPS COOATI MUABER PIPS COOATY duABEB PIPS COUATY HOHBEa PIPS CO OIIT MONBE PIPS COOHTY MUABER TPS COOATY AOHBEB PIPS CoOAT nuABe PIPS COORT WOABER PIPS CO OBTY MUNARE PIPS COOUTY NOMBER PIPS COOHTY WUABE PIPS COOHTY HOABER PIPS covart monoes PIPs covar nusbi PLS coov Ty 1 ric coong du

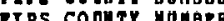
IPS coutr no PIPS co ort yone PIPS COOATY UTHER IPs courer TIPS CO OUTY MOABEB IPS COOHTY MOABE TIPS COOMTY MOMBE rips coOntr wuabe PIPS COUHTY OARB FIPS COOHTY WOABEB IIPS CnOATt BOTBEa TIPS COOATY MOAOEB PIPS COOETY MOABER PIPS CO ONTY UOABE PIPS coonty wage PIPS countr moBer TIPS COOWTY NOHBEB PIPS COOATT DOABEB
TIPS CO ONTY HOHBE PIPS STATE WOABER IPS STATE GUNBEA PIPS STATE MOAREB TPS STATE JUABEa PIPS STATE goabe Pros srare voroga IPS ST $\mathrm{T}$ gones Tios ST IPS STate JukBea TPS STITz VOMER TPS STATR URER BIPS STATR UOABE PIPS STATE GUABE YTPS STATE GURBBR IPS STATE DORBER TIPS STITE WOABE IPS STATE gOABBR PIPS STATE WOMBER PIPS STATE cOHERa PIPS STITE UUBER PIPS STATB GOAREQ FIPS ST ATE TOHBER FIPS STATE HOHERR PE3 STATE HUHBEit PIPS STITE MURBBR
PIPS STATE GOABER PIPS STATE WOABER
PIPS STATE U⿴⿱卄一一八月B PIPS STATE GOABER
PIPS STATE WOABR FIPS STATE TOEBSR PIPS STATE MOMBER FIPS STATE UOABER PIPS STATE MOABE PIPS STATE MUABEB TPS STate ninnen TPS STR IPS STATE GOBE IPS STate vonber PIPS STATE GUHBER
PIPS STATE WOARRR PIPS STATE HORBR PIPS STATE UOABER PIPS STATE NONBER FIPS ST PIPS STATR volage PIPS STATE WOHOER
PIPS STITE NOABER

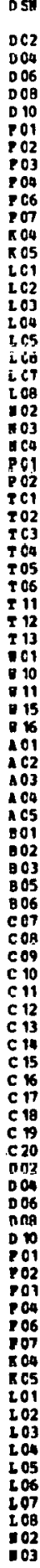


Table B.l (continued)

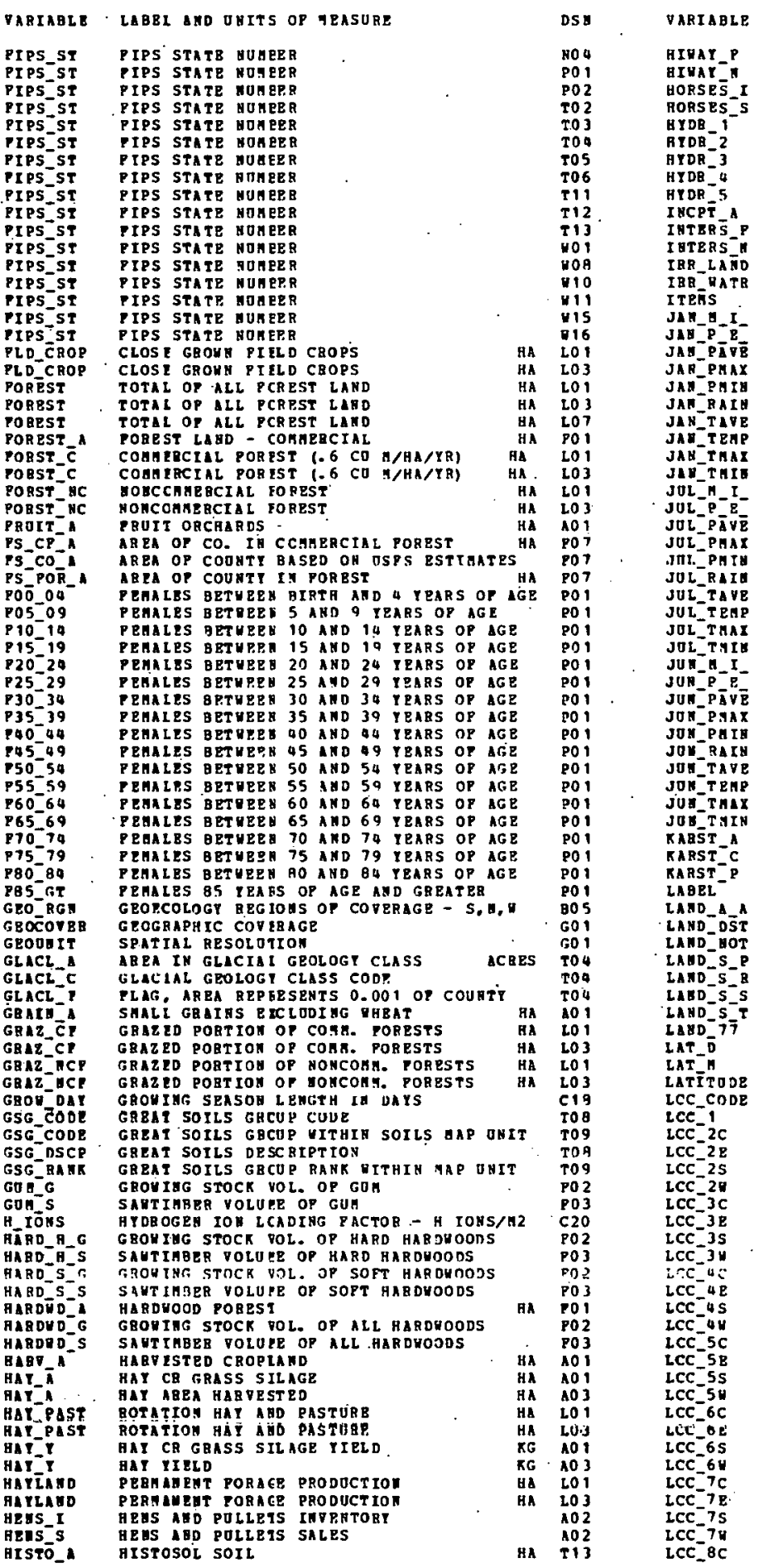

LABEL A UO UNITS OP AEASURE DSM

RIGHEAYS OH BUBAL-PEOERAL

RIGHATS OU 8OBAL-TONPEDRBAL

HORSES, POHIES IBD MULES INVEMTORT

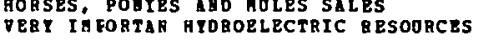

ISPORTA GT HYDROEL ECT BIC RESOOBCES

COHHECTALLT POTEUTIAL HTDROELBCTRIC

MO COHAERIAL HTDBOELECTBIC BQSOORCES

IODIRECILY SIGEIPICANT HYDROELECTRIC

INCEPTO SOL SOIL

IHTERSTATES ON BOBAL-PEDEBAL

IHTEBST AT ES OY BORAL-NOHPEDEBAL HA $\mathrm{LOg}$

IBRIGATED LABO: CROPLAGO \& PISTORE RA LOB

IBAIGATION VATEB USED

MOABER CP VARIABLES

JAHULY hOISTURE THD $2 X$

JAHOat potenTral EVAPOTRAas

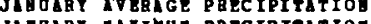

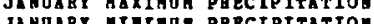

JAHOABY PBECIPITATIOH

JAMOBY GVELGE TBEPERATORE

JAROABY MAITAO TBHPEATOEE

JANOLB MIBTAOA TERPEBATURE

JULT MO ISTORE IUDET

JOLT POTEWTIAL BVAPOTBAHS

JOLY AVIRAGE PRZCIPITATION

JOLY GAXIBOS PRECIPITATION

JoLY GI aIAOH PBBCIPITATIOA

JOLT PRECIPITATIO

JOLY AV RRAGE TEMPBEATORE

JULY AVERAGE TEAPERATOBE

JULY MA IIMOA TEMPERATORE

JULE HO ISTORE INDEX

JUNE POTENTIAL EVAPOTEAIS

JUNE AV RRAGE PBECTPITATION

JUNE AAXIMUA PRBCIPITATIOS

JUNE TI HIMUN PBBCIPITATIOA

JUHR PRECIPITITIOA

JUNE AVERAGB TEAPERATORE

JONE AVERAGB TEAPERATOBB

JOBE MAXIZUA TBHPERATURE

JUBE MI UIAOY TEHPBEATURE

AREA IH KABST TBREAIB CLASS

RABST T RQRATH CLASS CODE

VARTMBLE LABEL AGD ONITS OP GEASURE

TOTAL L AMO DISTORBED

LABD DOT BBOOIRING RECLAHATION

POBTION IM LAHD STRFACE TOBA CODE

LAND SO RT UCE LOCAL RELIBP CLASS. CODB

LAHD SU BPACE GEYTLE SLOPE CLISS CODE

LATD SIIBFACE PROPILE TYPB CLASS CODE

LAND ARBA $\rightarrow 1977$

LATTTODE or $18 \mathrm{BA}$

LATITODE OF COUATY CEHTBOID

LAGD CA PaBILTYY CLAS

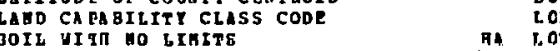

SOIL IITH SOSE LInITS - TERP/DETMBSS HA LO

SOIL WITA SOSE LIATTS - EROSIOB RA LC2

SOIL IITH SOHE LINITS - POOR SOIL FA LO2

SOIL UITH SPY

SOIL VITH SEVRRE LINITS - EROSIOA HA IC2

SOIL UITH SEVERE LIAITS - POOR SOIL HA LO2

SOIL WITH SETERE LIATTS - EXCESS WATRR LO2

JOEL A VERY SRVERE LIATTS-TEMP/ORYYESS LC2

SOIL O/ PRRT SPVERE LIAITS-EROSIOH YA LC2

SOIL M VRR SEVRRE LIAITS-POOR SOIL HA 102 SOIL / VRAT SEVRE LITITS-ExCESS VATER LO2 SOIL LE VEL BUT IET/STONEY - TEHP/DRTMBSS LO2 SOIL LEVEL BUT RET/STONEY - EBOSION HA LO2 SOIL LEVEL BOT ERT/STOHEY - POOB SOTL RA L 02 SOIL LEVRL BOT WRT/STOHET - EXCESS UATER L 02

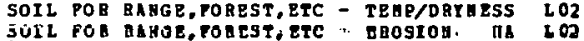

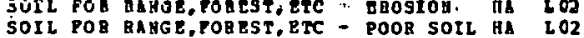
SOIL POB RABGE,POBEST, RTC - POOR SOIL HA 102 SOIL POB POREST, RILDLIPE - TERP DRYTESS 102 SOIL POR POREST, BILDLIPE - TEAP/DQYRESS 102 $\begin{array}{llll}\text { SOIL POB POREST, DILDLIPP - EROSIOR } & \text { HA } & \text { LO2 } \\ \text { SOIL POR POREST. BILDLIPE - POOB SOIL HA } & 102\end{array}$ SOIL POB POREST, RILDLIPE.- EXCESS UATEB LO2 SOIL W COLTIVATB PQBCLUDED-TEAP/DBTBESS LOZ 
Table B.1 (continued)

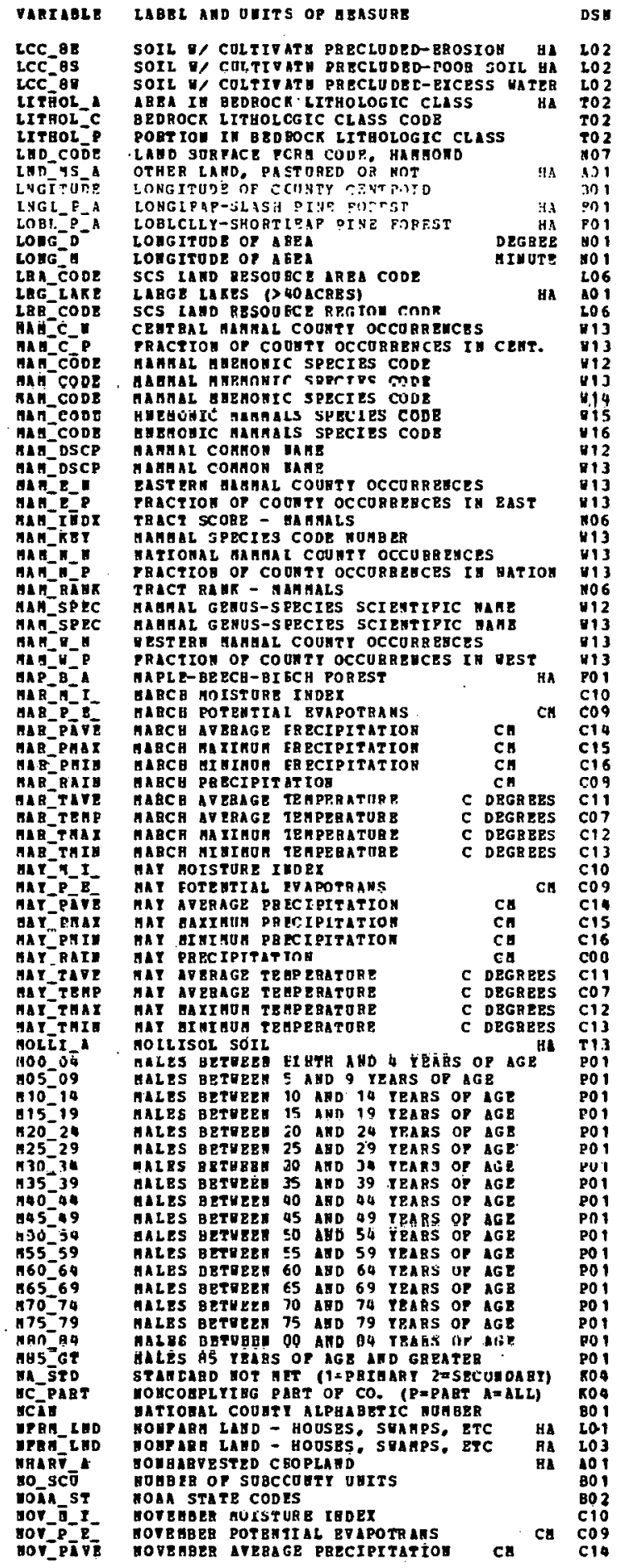

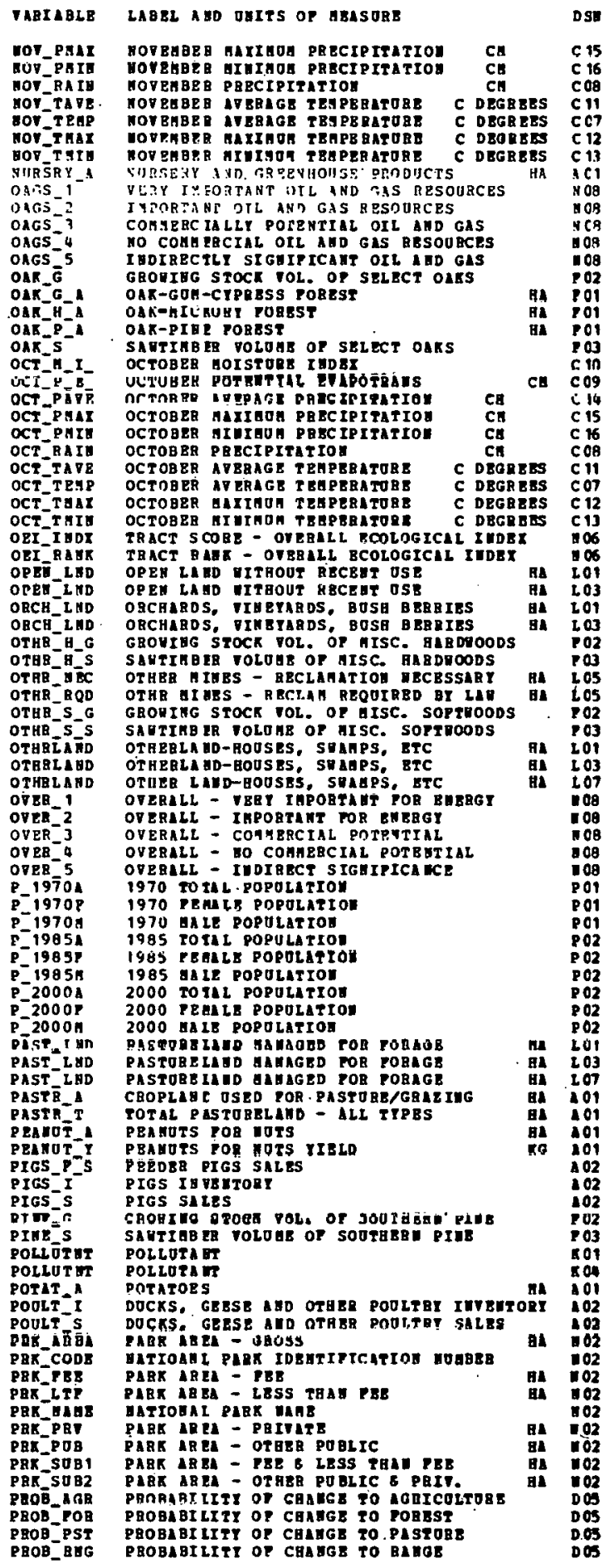


Table B.1 (continued)

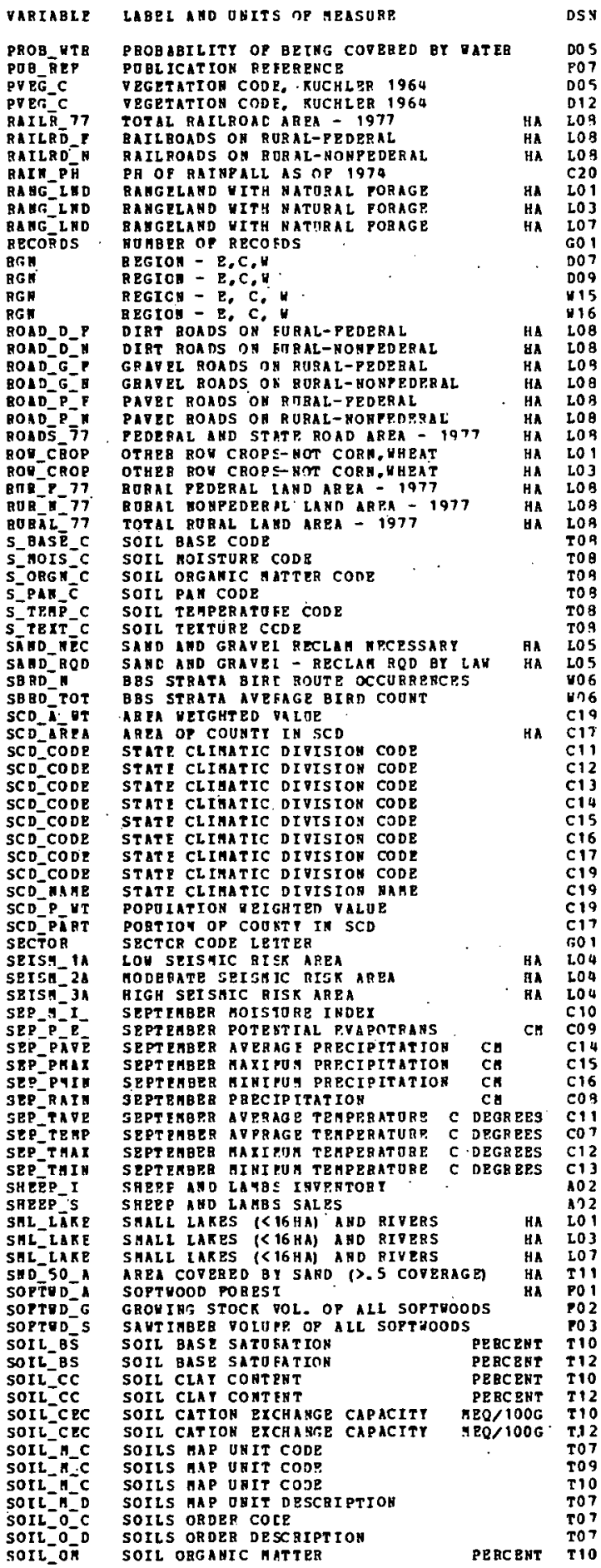

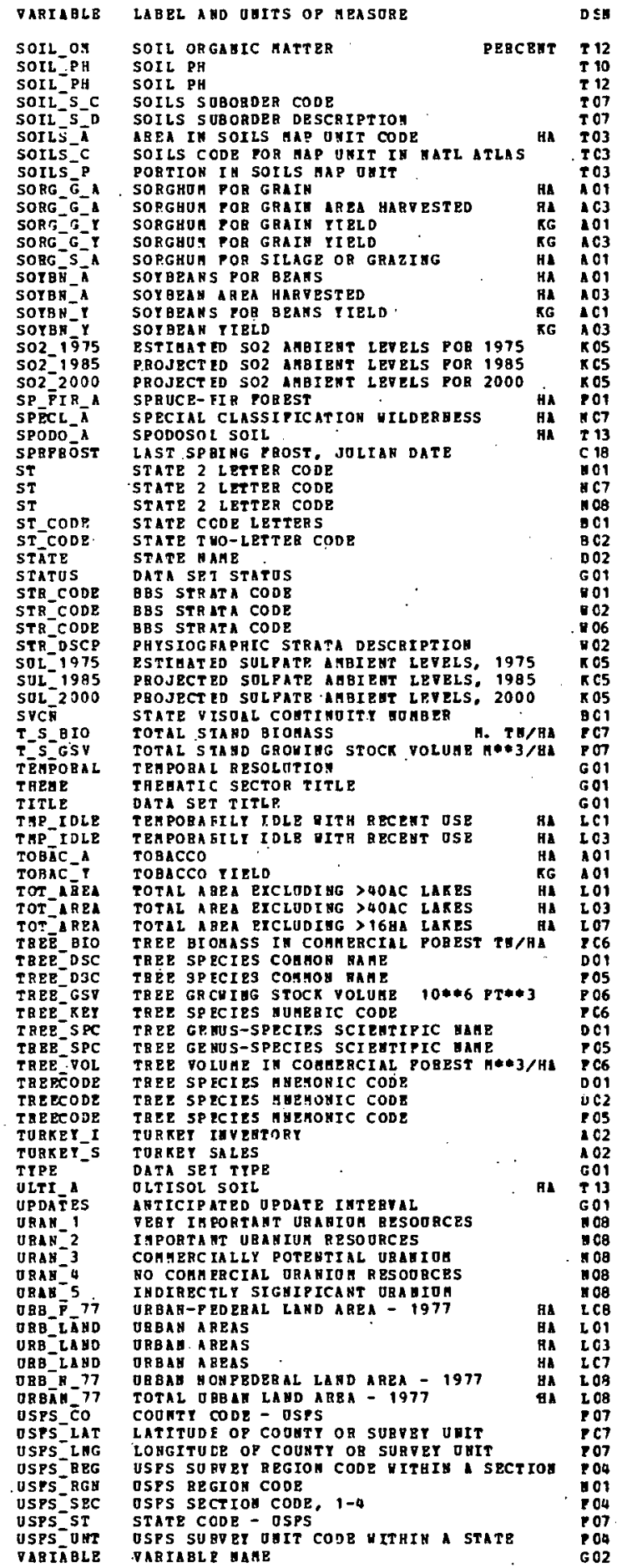




\section{Table B.I (continued)}

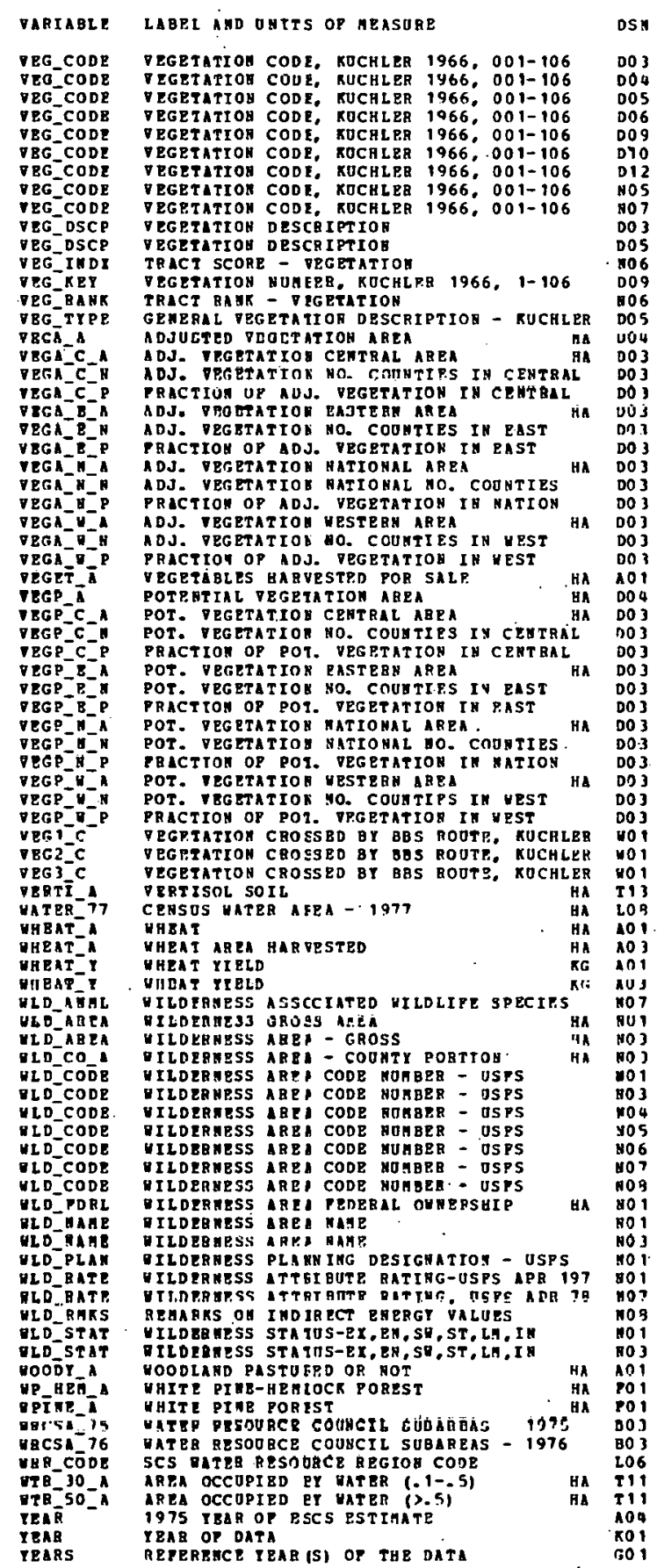


APPENDIX C. SPATIAL UNITS 
THIS PAGE

\section{WAS INTENTIONALLY LEFT BLANK}




\section{APPENDIX C. SPATIAL UNITS}

Table C.1. State areas (ha), numbers of counties, average county sizes (ha), and minimum/maximum county sizes (ha)

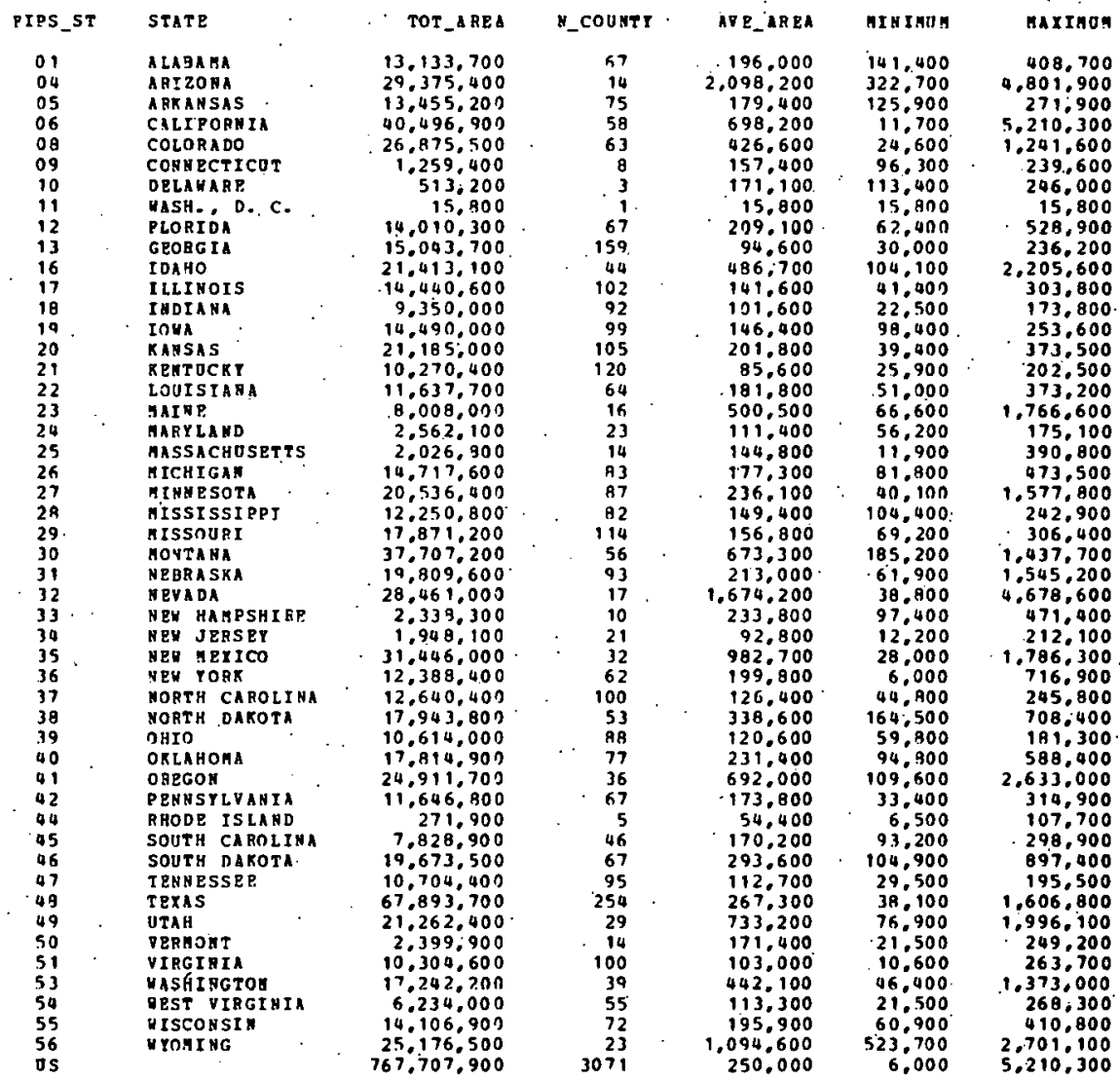


Table C.2. County unit areas (ha) and geographic centroid (degrees)

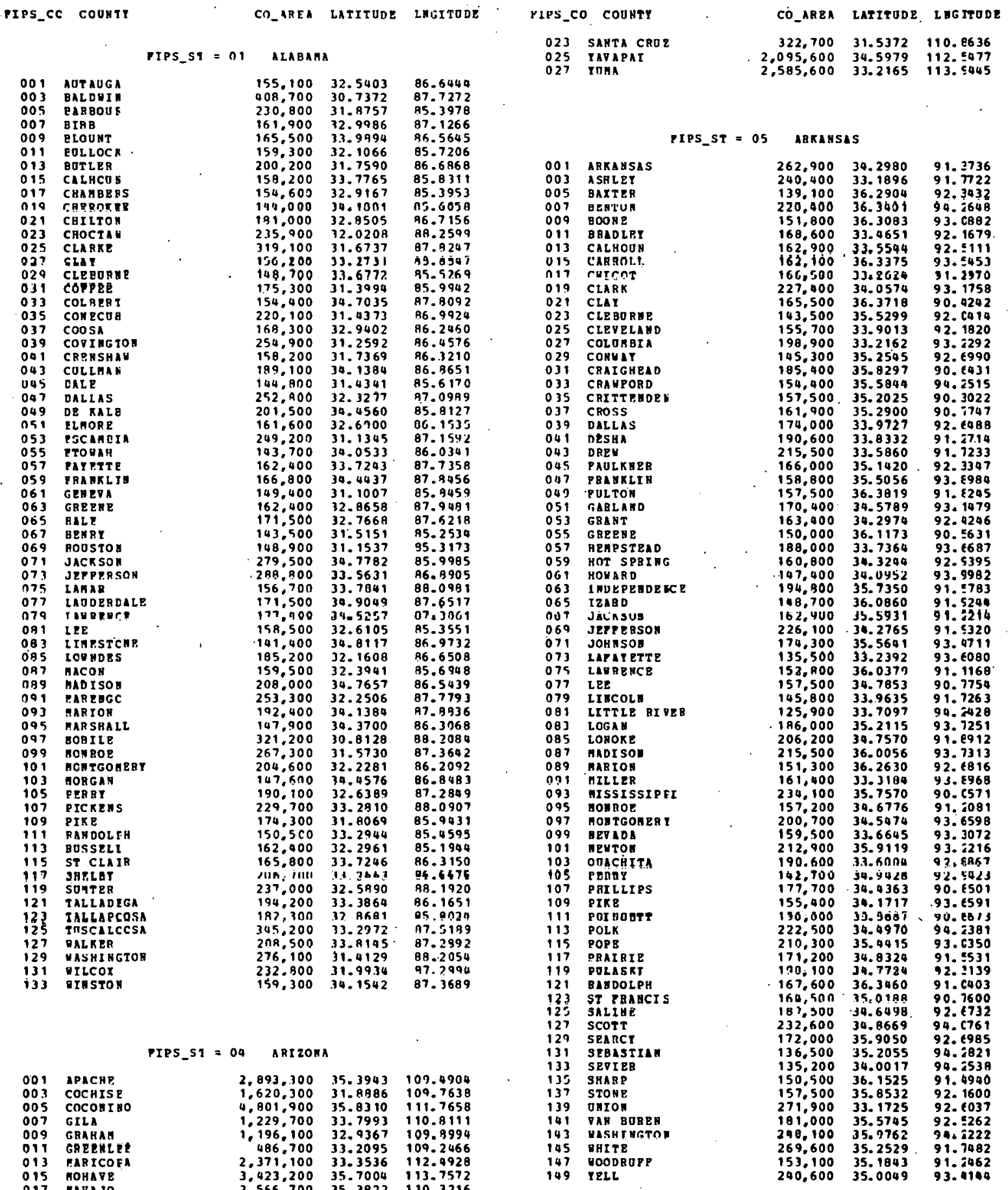


Table C.2 (continued)

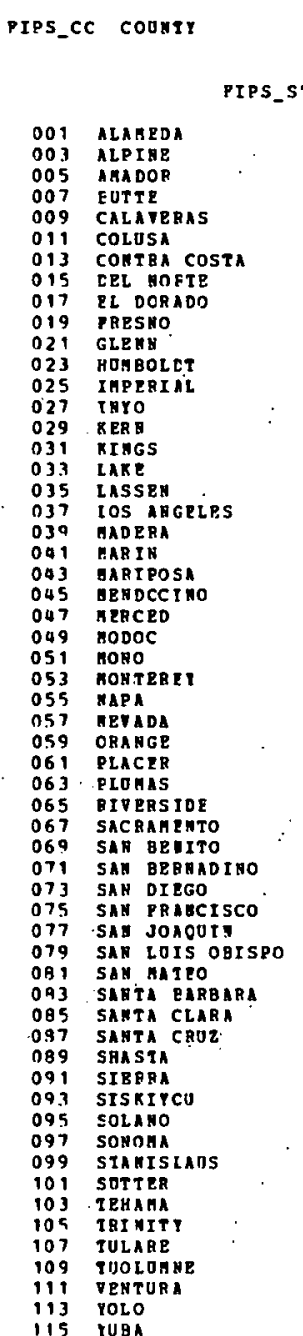

PIPS_ST $=$ OA COLCRADO

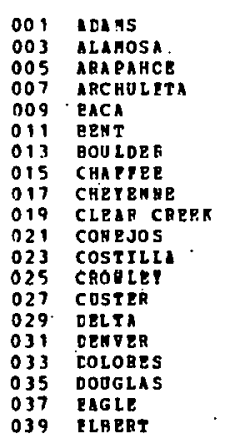

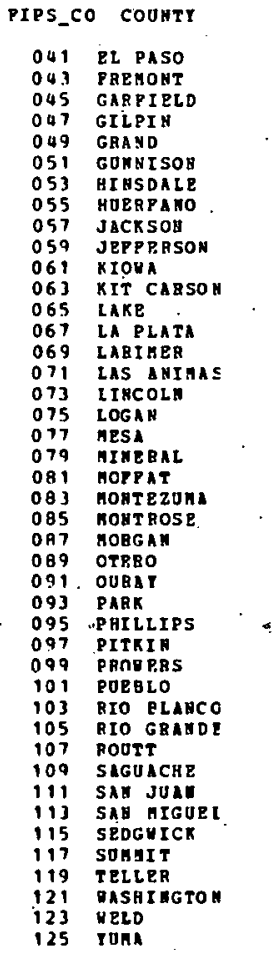

- Co_agea latitude lagitode

$558.700 \quad 39.8278$ 104. $\$ 180$

$404.300 \quad 38.4675 \quad 105.4389$

$\begin{array}{llll}776.000 & 39.5989 & 107.9084\end{array}$

$38.300,39.8608 \quad 105 . \$ 246$

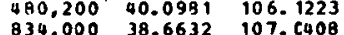

$273.000 \quad 38.6632$ 107. 3020

$\begin{array}{lll}273.000 & 37.8295 & 107 . \$ 020 \\ 407,700 & 37.6853 & 104 . \$ 603\end{array}$

$420,100 \quad 40.6677 \quad 106.2522$

$202.800 \quad 39.5922 \quad 105.3466$

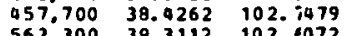

$\begin{array}{rrr}562.300 & 39.3112 & 102.6072 \\ 98.200 & 39.1930 & 106.3521\end{array}$

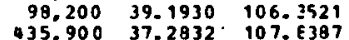

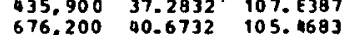

$\begin{array}{rrr}676.200 & 40.6732 & 105.4683 \\ 1.241 .600 & 37.3061 & 104.6491\end{array}$

671.60037 .3061 .104 .6491
671.60038 .9876
903.5168

$\begin{array}{lll}671.600 & 38.9876 & 103.5168 \\ 971,900 & 40.7290 & 103.1087\end{array}$

855.00039 .0183108 .4674

238.50037 .6604 106. \$288

$1.228 .400 \quad 00.6232 \quad 108.2056$

$542.300 \quad 37.3442 \quad 108.6089$

579,600 38.3979 108. 3772

$\begin{array}{lll}331.000 & 40.2722 & 103.8053 \\ 324,800 & 37.6976 & 103.7187\end{array}$

$\begin{array}{lll}324.000 & 37.8976 & 103.7187 \\ 139,900 & 38.1546 & 107.7710\end{array}$

$\begin{array}{lll}139.900 & 38.1546 & 107.7719 \\ 560.000 & 39.1187 & 105.7199\end{array}$

176.100
170.6019

$252,000 \quad 39.2130 \quad 106.5173$

$419,800 \quad 37.9496 \quad 102.3980$

$622.900 \quad 38.1670 \quad 104.5058$

605,100 39.9818 108. 14

$237.000 \quad 37.5734 \quad 106.3909$

$603.500 \quad 40.4917 \quad 106.5941$

$614.300 \quad 38.0737$ 106. 2月16

$101,300 \quad 37.7587$ 107.677

$332.300 \quad 38.0032 \quad 108.1138$

$140.900 \quad 40.8007 \quad 102.3611$

$\begin{array}{llll}156.400 & 39.6278 & 106.1223\end{array}$

$143.200 \quad 38.8809 \quad 105.1585$

$654.20039 .9748 \quad 103.1992$

$1.036,500 \quad 40.5622 \quad 104.2922$

$616,200 \quad 40.0084$

102.9236

$\begin{array}{lll}824,400 & 15.3808 & 120.3722 \\ 115,800 & 37.4370 & 122.2972\end{array}$

$708.000 \quad 34.7340 \quad 120.0123$

$336,700 \cdot 37.2305 \quad 121.6918$

$\begin{array}{lll}114.000 & 37.0657 & 121.9937 \\ 981.100 & 40.7811 & 122.0553\end{array}$

$248.100 \quad 39.5833 \quad 120.5141$

$1.621,900 \quad 41.6050 \quad 122.5626$

$213.200 \quad 38.2799 \quad 121.9215$

$415.400 \quad 3$. $5335 \quad 122.876$

39.300 39.550 120.999

$772.300 \quad 40.1381,122.2463$

$21.300 \quad 40.6724 \quad 123.246$

$1,246.300 \quad 36.2187 \quad 118.7931$

$5 \mathrm{A3}, 300 \quad 38.0294 \quad 119.9590$

$492: 500 \quad 34.4891 \quad 119.0716$

$266.300 \quad 38.6935,121.9063$

PIPS_ST = 09 conarctICUT

\begin{tabular}{|c|c|}
\hline $\begin{array}{l}001 \\
003 \\
005 \\
0007\end{array}$ & $\begin{array}{l}\text { FATBPTELD } \\
\text { AABTPOBD } \\
\text { LTTCFPIBLD } \\
\text { AIDDLPSEET }\end{array}$ \\
\hline $\begin{array}{l}009 \\
011\end{array}$ & $\begin{array}{l}\text { MEN RATEW } \\
\text { BPD LOUDO }\end{array}$ \\
\hline $\begin{array}{l}013 \\
015\end{array}$ & $\begin{array}{l}\text { TOLLAKD } \\
\text { WIUDALA }\end{array}$ \\
\hline
\end{tabular}

$\begin{array}{lll}162,100 & 41.2819 & 73.3922\end{array}$

$\begin{array}{lll}731.400 & 41.8048 & 72.7325 \\ 239.600 & 41.7962 & 73.5522\end{array}$

96,300
156.400 $1.4666 \quad 72.5339$

$\begin{array}{lll}156.400 & 1 . \$ 124 & 72 . \$ 286 \\ 172.400 & 91.4890 & 72.1003\end{array}$

$172.800 \quad 41.4890 \quad 72.1003$

$\begin{array}{lll}107.700 & 41.8575 & 72.7378 \\ 133,100 & 41.8335 & 71.5856\end{array}$

PITE_ST - 10 DELAMARE

$\begin{array}{lllll}001 & \text { KEBT } & 153,000 & 39.0894 & 75.5743 \\ 003 & \text { BEY CASTLE } & 113,000 & 39.5854 & 75.6543 \\ 005 \text { SOSSEX } & 206.000 & 38.6652 & 75.0068\end{array}$

$320.400 \quad 30.8820 \quad 104.3685$

$196,200 \quad 37.5611 \quad 105.7997$

$206.400 \quad 39.6557,104.3598$

$353.300 \quad 37.1963 \quad 107.0346$

$663.800 \quad 37.3156 \quad 102.5633$

$393.400 \quad 37.9451 \quad 103.0794$

$193.700 \quad 40.0902 \quad 105.3494$

$268.800 \quad 39.7475 \quad 106.2033$

$\begin{array}{lll}458.900 & 38.8286 & 102.6119\end{array}$

$\begin{array}{lll}102.000 & 39.6871 & 105.6467 \\ 328,400 & 37.1913 & 106.1908\end{array}$

$32 \mathrm{~A} .400 \quad 37.1913 \quad 106.1908$

$316.20037 .2769 \quad 105.4370$

$190,900 \quad 30.1043 \quad 105.3707$

$298.900 \quad 38.8472 \quad 107.975$

$24.600 \quad 39.7345 \quad 104.9750$

$265,700 \quad 37.7572 \quad 108.4989$

$218.300 \quad 39.3273 \quad 104.924$

$\begin{array}{lll}45.400 & 39.6194 & 106.6989\end{array}$

PIPS_ST $=11$ DISH...D.C.
001 VASHIGTO $15.800 \quad 38.9027 \quad 77.0369$

PIPS_ST $=12$ PIORIDL

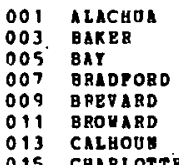

$237.200 \quad 29.6710$ $151,500 \quad 30.3240$ $193,500 \quad 30.2970$ $76,100 \quad 29.9425$ $261.800 \quad 28.1775$ 315,700
145,300 $182,10026.9036$

02. 3559 82.2009 85.6263
82.1704 82.1704
80.7574 80.7574
80.4973 80.4973
85.2139
81.8904 
Table C.2 (continued)

\begin{tabular}{|c|c|c|c|c|c|}
\hline IPS_CC & COOHTY & & CO_AREA & LATITUDE & LNGITODE \\
\hline 017 & CITRUS & & 145,000 & 29.8517 & 92.4599 \\
\hline 013 & CIAY & & 153,600 & 29.9747 & 81.9468 \\
\hline 021 & COLLIER & & 519,600 & 26.1144 & 81.3571 \\
\hline 023 & COLUABIA & & 203,100 & 30.2155 & 82.6203 \\
\hline 025 & DADE & & 528.900 & 25.6073 & 80.5991 \\
\hline 027 & CE sotC. & & 167.800 & 27.1833 & 81.8492 \\
\hline 029 & CIXIP & & 179,200 & 29.6088 & 83.1566 \\
\hline 031 & cuval & & 199,400 & 30.3167 & A 1.6561 \\
\hline 033 & ESCAMBIA & & 172,200 & 30.7212 & 87.39 B 5 \\
\hline 0.35 & PLAGLEF & & $126: 100$ & 29.4608 & 91.3150 \\
\hline 037 & PPAFKLIY & . & 178,800 & 29.9120 & 84.8001 \\
\hline 039 & GADSDEN & & 132,600 & 30.5815 & 84.6207 \\
\hline 041 & GILCHRIST & & 89,600 & 29.7242 & 82.8022 \\
\hline 043 & GLADES & & 195,000 & 26.9474 & 81.2129 \\
\hline 045 & GULP & & 146,300 & 29.9596 & 95.2480 \\
\hline 047 & HAHILTOH & & 133,100 & $30=4004$ & 02.3300 \\
\hline 049 & HARDEE & & 162,900 & 27.4912 & R1.8113 \\
\hline 251 & HEN DAY & & 307,400 & 25.5377 & 31.1717 \\
\hline 053 & HER NANDO & & 125,000 & 28.5555 & 82.4307 \\
\hline 0,5 & limaliLanos & & 290.200 & 27.3433 & AI.Jji \\
\hline 057 & HILLSBCROTGH & & 268,800 & 27.9276 & B2.30A4 \\
\hline 059 & HOL HES & & 124,800 & 30.8852 & 95.8290 \\
\hline 061 & INDIAN BIVPR & & 131,100 & 27.6826 & 80.6172 \\
\hline 063 & $\begin{array}{l}\text { JACK SON } \\
\text { D. }\end{array}$ & & 242,200 & 30.9005 & 85.2269 \\
\hline Jo5 & JEYYER SUN & & 156,700 & 30.4404 & B3. ค9ด7 \\
\hline$v_{6} \%$ & IAPAYETTE & & 142,200 & 20.3857 & 83.1923 \\
\hline 069 & LAKE & & 248,900 & 29.7484 & R1.7024 \\
\hline 071 & LEP & & 203309 & 26.5800 & 81.9033 \\
\hline 673 & I P.OF & & 173,500 & 30.4809 & 84.274 \\
\hline 075 & LEVT & & 280,500 & 20.3259 & 82.7334 \\
\hline 077 & LIBEATY & & 217,300 & 30.2484 & 84.9962 \\
\hline 079 & GADISO & & 182,100 & 30.4412 & $03.400 \mathrm{~B}$ \\
\hline 091 & HAMATPE & & 199,400 & 27.4731 & 82.3039 \\
\hline 083 & VARTON & & 414,400 & 29.2044 & 82.0561 \\
\hline 095 & MARTIN & & 144,000 & 27.0784 & B०. 3876 \\
\hline on 7 & MOH ROE & & 267900 & 25.3348 & B 1.0719 \\
\hline 059 & MASSAU & & 168,300 & $30.601 \mathrm{~B}$ & ค1. . 238 \\
\hline 091 & CKALOOSA & & 244,500 & 30.6990 & 86.5660 \\
\hline 093 & CXEECHCEEP. & & 201,200 & 27.4291 & 80.8977 \\
\hline 095 & CRAYGE & & 235,700 & 28.5013 & 81.3065 \\
\hline 097 & CSCROLA & & 340,100 & 29.0567 & 81.1499 \\
\hline 099 & FALA BEACH & & 524,000 & 26.6898 & 80.5128 \\
\hline 101 & FASCO & & 192.200 & 28.3089 & 82.3372 \\
\hline 103 & PINELLAS & & 68,600 & 27.9494 & A2.7318 \\
\hline 105 & EOL K & & 481,200 & 27.9435 & 89.6967 \\
\hline 107 & rupunn & & 201,000 & 29.6019 & A 1.7412 \\
\hline 109 & ST JOHNS & & 156,700 & 29.8945 & 81.4286 \\
\hline 111 & ST LOCIE & & 151,300 & 27.3706 & 80.4840 \\
\hline 113 & SAFTA BOSA & & 267,300 & 30.7468 & 87.0344 \\
\hline 115 & SARASOTA & & 152,000 & 27.1783 & A2. 3506 \\
\hline 117 & SEHIROLE & & 79,000 & 28.7027 & 61.2209 \\
\hline 119 & SUNTER & & 143,700 & $2 \mathrm{~A} .6922$ & \\
\hline 121 & gowntiver & & 179,700 & 30.1994 & 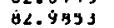 \\
\hline 123 & TAY LOR & . & 272,200 & 30.0496 & 83.6008 \\
\hline 125 & tNIOY & & 62.400 & 30.0416 & 92.3706 \\
\hline 127 & VOLOSIA & & 275.100 & 29.0524 & 81.1997 \\
\hline 129 & gaKoLLA & & 155,700 & 30.1763 & 84.4111 \\
\hline 131 & ดบ:Tก & & $277.7 n n$ & 30.6779 & 96.1720 \\
\hline 133 & WASHINGTON & & 151,500 & 30.6271 & 95.6834 \\
\hline
\end{tabular}

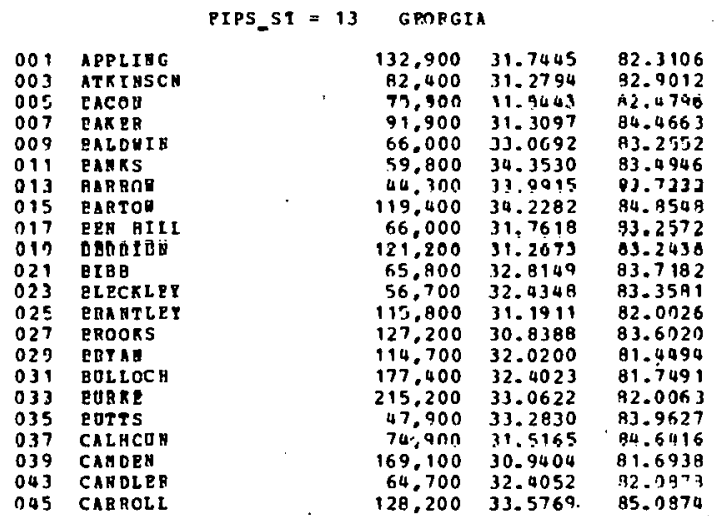

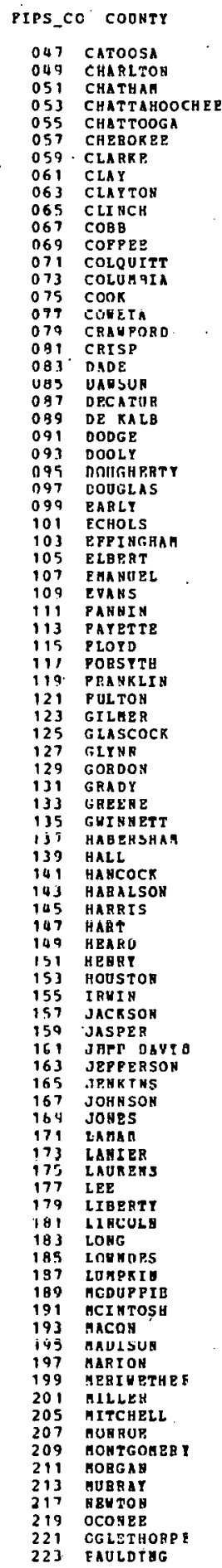


Table C.2 (continued)

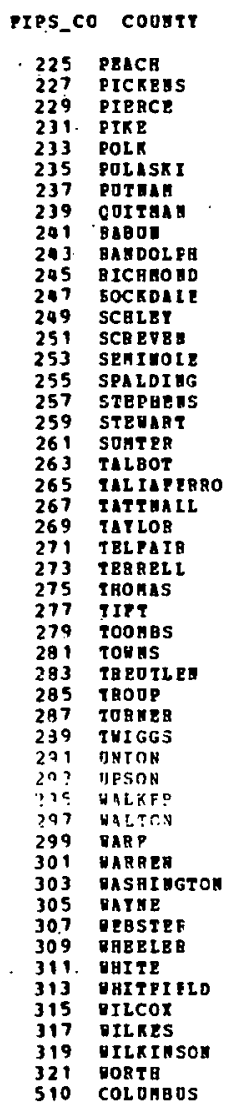

\begin{tabular}{|c|c|c|c|c|}
\hline CO_AREA & LATITODB & LUGITOOE & PIPS_CO & COOHTY \\
\hline $\begin{array}{l}39,100 \\
58,300 \\
88,600 \\
59,600 \\
80,800 \\
65,500 \\
87,800 \\
40,400 \\
95,300 \\
112,900 \\
83,700 \\
33,200 \\
42,000\end{array}$ & $\begin{array}{l}32.5749 \\
34.4555 \\
31.3552 \\
33.0806 \\
33.9973 \\
32.2284 \\
33.3222 \\
31.8554 \\
34.8788 \\
31.7523 \\
33.3603 \\
33.6498 \\
32.2553\end{array}$ & $\begin{array}{l}83.8333 \\
84.4778 \\
82.2382 \\
84.4053 \\
85.1952 \\
83.5172 \\
83.3786 \\
85.0285 \\
83.4146 \\
84.7629 \\
82.0830 \\
84.0370 \\
84.3395\end{array}$ & $\begin{array}{l}063 \\
065 \\
067 \\
069 \\
071 \\
073 \\
075 \\
077 \\
079 \\
087 \\
083 \\
085 \\
087\end{array}$ & 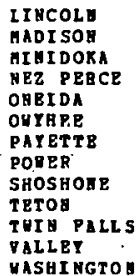 \\
\hline
\end{tabular}

$\begin{array}{rrr}92.000 & 32.2553 & 89.3395 \\ 168.600 & 32.7556 & 81.6165\end{array}$

$63.700 \quad 30.9337 \quad 84.8793$

$52.100 \quad 33.2542 \quad 84.2963$

$\begin{array}{lll}94.800 & 34.5551 & 83.2982\end{array}$

126.000 . 32.0395 84.2265

$101.000 \quad 32.6988$ 84.540

$50.500 \quad 33.5627 \quad 82.8877$

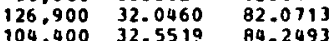

$\begin{array}{lll}104.400 & 32.5519 & 84.2493 \\ 114.000 & 31.9213 & 82.9647\end{array}$

$\begin{array}{rll}85.200 & 31.9213 & 82.9647 \\ 11.7715 & 84.4546\end{array}$

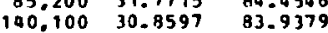

$68.900 \quad 31.4511 \quad 03.5504$

$95.300 \quad 32.1048 \quad 82.349$

$\begin{array}{lll}43.000 & 34.9075 & 83.7515 \\ 50.200 & 32.3990 & 82.5721\end{array}$

$107.500 .33 .0244 \quad 85.0370$

$75,900 \quad 31.7160 \quad$ A3.656

$94.300 \quad 32.6714 \quad 83.4525$

$70.000 \quad 34.8298 \quad 94.0749$

(6.50.) 32.7755

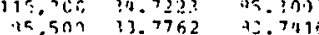

$236.200 \quad 11.0313 \quad 92.4573$

$73.600 \cdot 33.4074$ 92.6996

$\begin{array}{lll}174.600 & 32.9737 & 82.9127\end{array}$

$167,100 \quad 31.5516$

$50,500 \quad 32.0406$

$79,300 \quad 32.1115$

$62.900 \quad 34.6415$

72.800
99.200 31.7968

$121.200 \quad 33.7836$

$118.600 \quad 32.8024$

$\begin{array}{rr}150,000 & 31.5465 \\ 57,000 & 32.5045\end{array}$

91.9310

84.5739
82.7456

83.7518

84.9738

83.1711
82.7560

83.1965

83.8785
84.8787

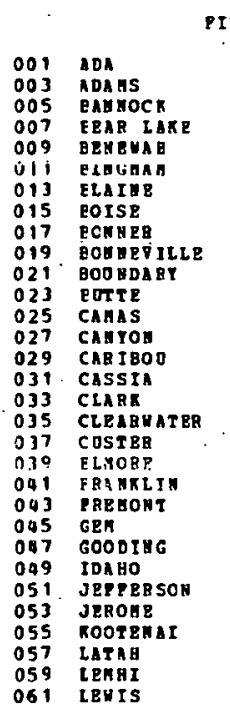

PIPS_ST $=16$ IOAnO

$270.100 \quad 43.4483 \quad 116.2366$ $355.100 \quad 44.8926 \quad 116.4439$ $\begin{array}{llll}290.600 & 42.6630 & 112.2078\end{array}$ 254,900 42.2862 111.3382 $204.100 \quad 47.2050116 .6429$ 639.800043 .2136 112.900 $494.700 \quad 43.9846$ 115.7185 $40.000 \quad 40.2900 \quad 116.5967$ 47. 33.500 4. 3570 116.4499 $579.900 \quad 03.7212 \quad 113.1691$ 273.000 43. 5551 114.8078 $40.700 \quad 43.6216 \quad 116.7065$ $152.200 \quad 02.7799 \quad 1115631$ $658.900 \quad 42.2906 \quad 113.6172$ 453.500 44. $2868 \quad 112$ $652.900 \quad 46.6629 \quad 115.6230$

$1.276 .600 \quad 44.2410 \quad 114.2732$ $789.400 \quad 43.3538 \quad 115.4645$ $172.000 \quad 42.1790 \quad 111.9199$ $482.800 \quad 44.2280 \quad 111.4970$ $143.700 \quad 44.0665 \quad 116.3823$ $\begin{array}{llll}186.500 & 42.9708 \quad 114.8172\end{array}$

$2,205.600 \quad 45.8316 \quad 115.4636$ $293,900 \quad 43.8219 \quad 112.3131$ $\begin{array}{llll}154,100 \quad 42.6933 & 114.2757\end{array}$ $323.500 .47 .6586 \quad 116.6863$ $282.300 \quad 46.8058 \quad 116.6962$

$\begin{array}{rrr}1.186 .200 & 44.9453 & 113.9257 \\ 123.300 & 46.2314 & 116.4125\end{array}$

$\begin{array}{lll}\text { CO_AREA } & \text { LATITODE } & \text { LUG TTODB } \\ 311,600 & 43.0018 & 114.1458 \\ 122,500 & 43.7795 & 111.6624 \\ 194,200 & 42.8570 & 113.9420 \\ 218,600 & 46.3195 & 116.7331 \\ 308,500 & 42.1982 & 112.5508 \\ 1979,000 & 42.5914 & 116.9768 \\ 104,100 & 44.0035 & 116.5537 \\ 366,000 & 42.6948 & 112.8420 \\ 675,700 & 47.3392 & 115.8770 \\ 118,400 & 43.7547 & 111.8203 \\ 504,300 & 42.3662 & 114.6872 \\ 952,100 & 44.7608 & 115.5620 \\ 378,700 & 44.4521 & 116.7746\end{array}$

PIPS_STT = $17 \cdot$ ILLIMOIS

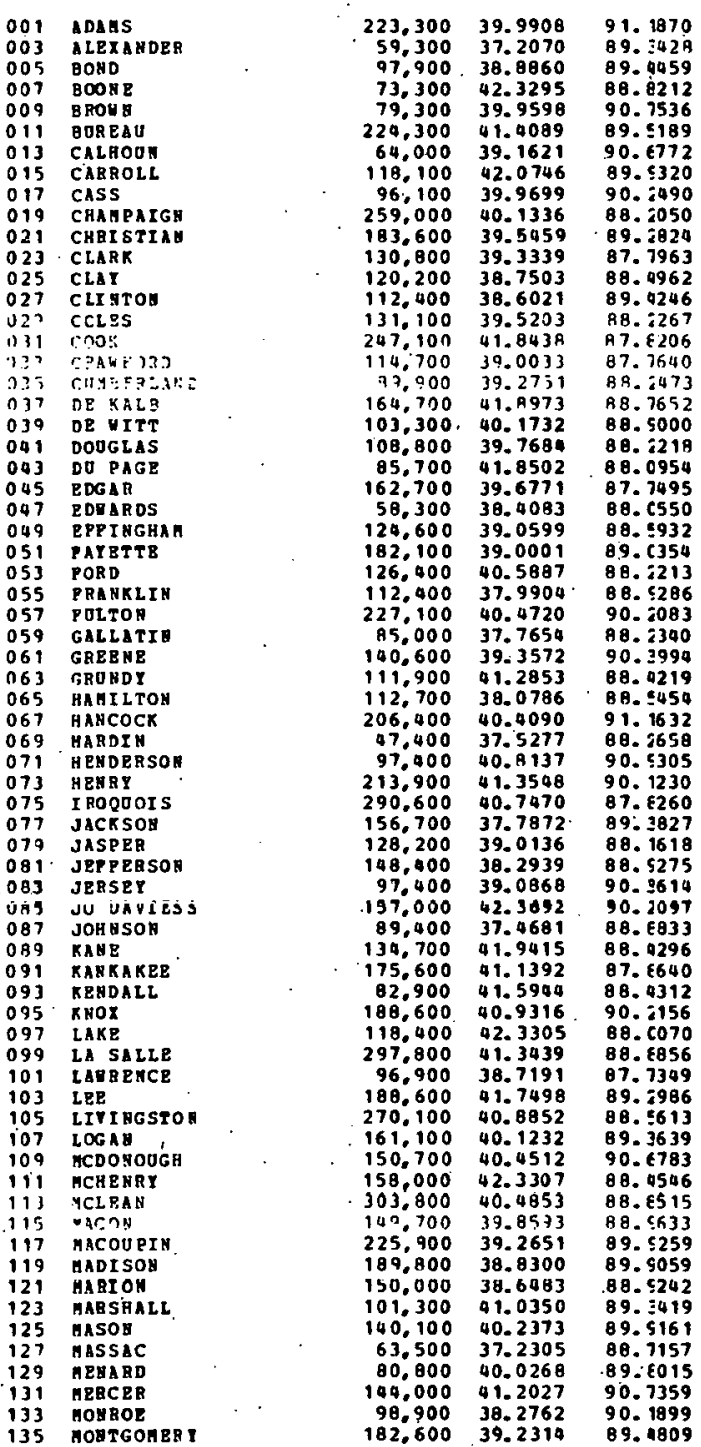


Table C.2 (continued)

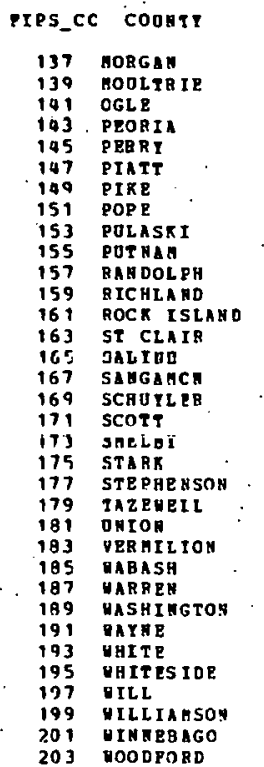

PIPS_3I - 10 I HDIAMA

\begin{tabular}{|c|c|}
\hline \multirow{2}{*}{\multicolumn{2}{|c|}{ ADA HS }} \\
\hline & \\
\hline 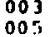 & $\begin{array}{l}\text { ALLEB } \\
\text { PART HOLCHEY }\end{array}$ \\
\hline 007 & EENTOA \\
\hline $\begin{array}{l}009 \\
011\end{array}$ & $\begin{array}{l}\text { Dinentend } \\
\text { gcone }\end{array}$ \\
\hline 313 & EROAN \\
\hline 015 & CARRCL \\
\hline & $\operatorname{CA33}$ \\
\hline 019 & CLABK \\
\hline 021 & CLAP \\
\hline & Cifllton \\
\hline 025 & CBAUPOAD \\
\hline 027 & OAVIRSS \\
\hline & CRARBOF: \\
\hline 031 & CECATIB \\
\hline 033 & CE KALE \\
\hline 0.35 & CELAYAEE \\
\hline 037 & CD80 Is \\
\hline $\begin{array}{l}039 . \\
041\end{array}$ & $\begin{array}{l}\text { ELKHART } \\
\text { FAYPTTE }\end{array}$ \\
\hline 043 & $\begin{array}{l}\text { FLOTDE } \\
\text { FLOT }\end{array}$ \\
\hline 045 & POONTAIN \\
\hline 049 & 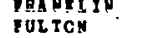 \\
\hline 051 & GIB SON \\
\hline 055 & GREEAE \\
\hline & HANTLTCH \\
\hline 059 & FABCOCK. \\
\hline & HAB RTSCE \\
\hline & BENDRICXS \\
\hline 065 & EEस 8Y \\
\hline & Liousho \\
\hline 069 & BOHTI IGTON \\
\hline 071 & JACRSOE \\
\hline & JASPER \\
\hline 075 & JAT \\
\hline 077 & JEPPRR SOR \\
\hline 079 & JEHNINGS \\
\hline OB 1 & JCก HSO ค \\
\hline 083 & KRoX \\
\hline & XOSCIUSKO \\
\hline 087 & LAGBANGE \\
\hline 099 & LAKE \\
\hline 091 & LA PORTE \\
\hline 093 & LAWRENCE \\
\hline
\end{tabular}

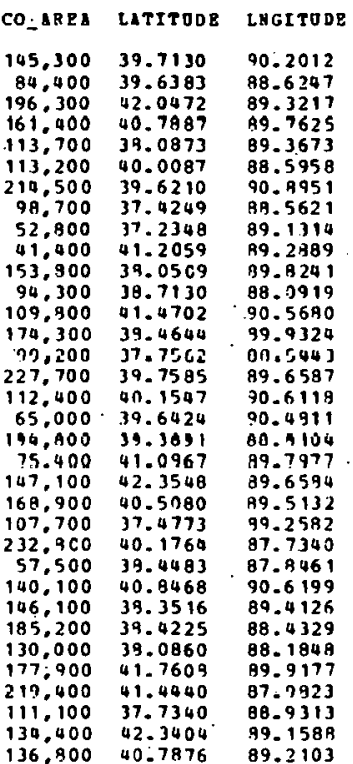

$99,400 \quad 40.7480$ $173,800 \quad 01.0994$ $104,100 \quad 39.2050$ $105.90 \mathrm{C} \quad 40.6 \mathrm{C} 15$ $43,300,40.4713$ $110.600 \quad 40.0483$ $92.600 \quad 39.196 \mathrm{~A}$ 96.900
$107.500 \quad 40.7605$ $107.500 \quad 40.7605$ $99.500 \quad 38.4829$ $94,300 \quad 39.3915$ $105,400 \quad 40.2976$ $\begin{array}{rr}80.000 & 38.2982 \\ 111.400 & 38.7055\end{array}$ 111.400
79.300
79.7055 79,300
95,900
39.3057 $94.900 \quad 41.4096$ $102.600 \quad 40.2251$ $112.100 \quad 38.3639$ $121.200 \quad 41.6 \mathrm{C} 30$ $35,700 \quad 39.6340$ $38,600 \quad 39.3198$ $102.800 \quad 40.1273$ 1192.801514 .494 $95.300 \quad 41.0483$ $129.000 \quad 38.3172$ ing, nกn an. $51.3 \mathrm{~A}$ $142,200 \quad 37.0391$ $103.900 \quad 40.0657$ $79,000 \quad 39.8129$ $124,100 \quad 38.2021$ $108,000 \quad 39.7681$ $103,600 \quad 39.9260$ $95.600 \quad 40.8332$ $134.700 \quad 39.910$ $145,60 \mathrm{C} \quad 41.021$ $100.000 \quad 40.4400$ $94.800 \quad 38.7885$ $97,600 \quad 38.9967$ 81.600
133.4842 $133.600 \quad 38.6965$

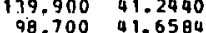
98.700
$132.900 \quad 41.6580$ $132,900 \quad 41.4216$ 157.200
$118.900 \quad 38.8400$ 05.3370 86.4614
96.2173 96.5.516 ค6ㄱำ 85.7144 87.1173 06.4687
96.4543 A6.
87.0743 87.0726
84.9932 84.9932
85.5077 ค5. 0042 85.410 86.991 85.8629 83.1951 87.2395 87.2395
$85.1 ! 664$ 86.2662 87.5841 ค5. 6610 06.9563 86.0535 85.7783 86.4992 85.4086 06. 1156 05.5022 86.0 .324
ค7. 1135 ค7. 1135 85.0160 85.4378
85.6317 $85: 6317$
86.0950 86.0950
87.4205 87.4205
85.8677 85.8677
85.4359 85.4359
87.3825 87.3825
86.7343 86.7343
86.4736
PIPS_co coutr

095 sadiso:

097 MABION
099 MABSHALL

099 MARSHA
101 MARTIY

103 MIAYT

105 HORROR
107 MONTGOBBR

109 MORGAY

111 MEHTO

1 is OHIO.

117. ORA BGB

119 ORE

123 Conay

125 PIKE

127 PCRTE
129 POSEY

ij PÜLASK

13.3 PUT NAM
135 RANDOLPH

137 BIPLEY

139 ROSH

141 ST JOSEP

143 SCOTT

145 SHELAT
147 SPEHCE?

149 STARK

151 STEOBE

155 SUITZZRLA

157 TIPPECA BOR

159 TIPTO

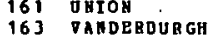

165 VERILLIOB

167 VIGO

169 gABASH

173 UARTICK

175 VASBIFGTOK

177 DAINB

103 MITtLEY $\begin{array}{rrrr}85.9947 & 179 \text { MELLS } & 95,300 & 40.7329 \\ 87.3086 & 181 . \text { HIITE } & 128,700 & 00.7440\end{array}$

CO_ABEA LATITODE LBGTTODE

$117,300 \quad 40.1330$

$89.400 \quad 38.7082 \quad 86.7975$

100,000 39.772. 86.0470

$131,300,40.0400 \quad 86.5123$

$131,300 \quad 39.4813 \quad 86.6831$

$107.000 \quad 40.9512$. 87.3976

$106.700 \quad 41.4131$ 85. 3331

$22,500 \quad 38.9504 \quad 84.5790$

$109,900 \quad 38.5418 \quad 86.0902$

$101,000 \quad 39.3178 \quad 86.2274$

$115,300 \quad 39.7704 .67 .2038$

93,500
00.0062 06.0301

$86,800 \quad 38.4004 \quad 87.2363$

$\begin{array}{ccc}110,100 & 41.4648 & 87.6647 \\ 106.700 & 38.0276 & 87.8722\end{array}$

$112,100 \quad 41.0394$. 00.t53

126.900 39.655B B.. ค.3A2

$118.400 \quad 40.1634$ Q5. (238

$114.500 \quad 39.1011 \quad 85.3748$

$105.900 \quad 39.6160$
120

$120.700 \quad 41.6214 \quad 86.2869$

50,000
10.6895 05.7432

$105,900 \quad 39.5175$ B5.7915

102,600 38.0160 B7. 11

0.000 व1. 27995

$\begin{array}{rrr}80.000 & 41.6595 & 85.0039 \\ 118.400 & 39.0951 . & 87.4192\end{array}$

$57.200 \quad 38.6277$ 85. 390

$129,500 \quad 40.3862$ 86.8850

$\begin{array}{rrr}67,600 & 40.3074 & 86.0538 \\ 43.500 & 39.6310 & 84.5340\end{array}$

$\begin{array}{lll}43.500 & 39.6310 & 64.5340 \\ 62.400 & 30.0253 & 67.5910\end{array}$

$\begin{array}{lll}62.400 & 36.0253 & 67.5919 \\ 68.100 & 39.8526 & 87.0647\end{array}$

$107,500 \quad 39.4310 \quad 87.098$

$103.100 \quad 40.8429 \quad 85.7965$

$95,300 \quad 40.3483 \quad 67.3589$

$101,300 \quad 38.0942 \quad 87.3799$

$\begin{array}{lll}133,600 & 38.6046 & 86.1001 \\ 109,900 & 39.8698 & 85.6201\end{array}$

$95,300 \quad 40.7329 \quad$ B5. 2388

$128,700 \quad 00.7440 \quad 86.8616$

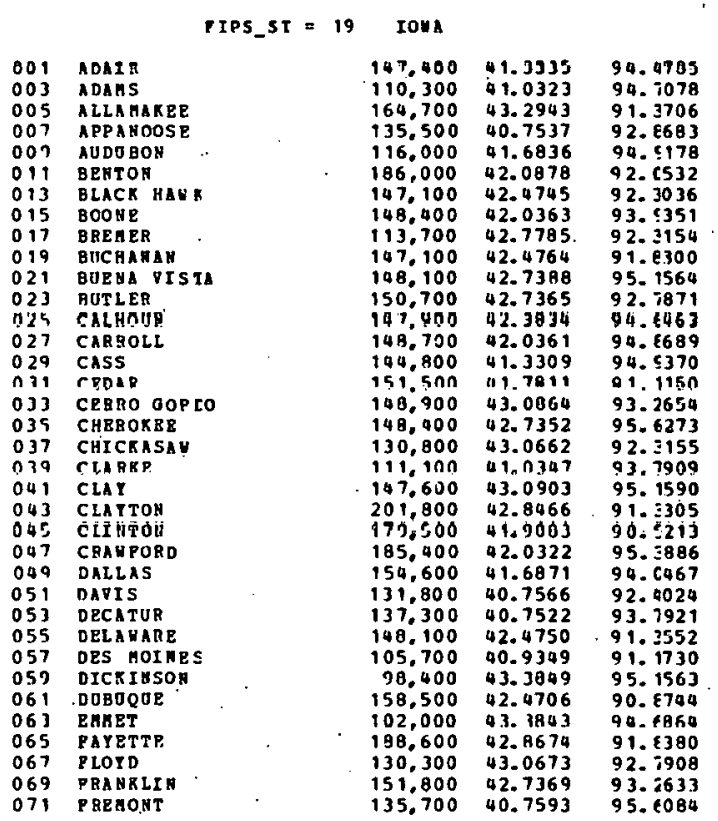


Table C.2 (continued)

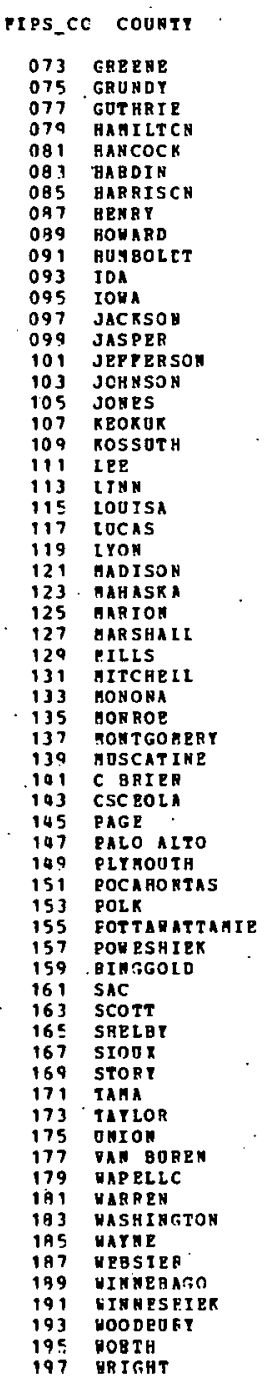

CO_AREA LATITODE LNGITUDE

$147.400 \quad 42.0379$

129,800
154,400
91.68076

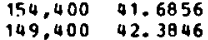

$147.600 \quad 43.0880$

$148,700 \quad 42.387$

$\begin{array}{ll}180,300 & 41.6826 \\ 114.000 & 40.9967\end{array}$

$122.000 \quad 43.364$

$112.700 \quad 42.7809$

$11.600 \quad 42.382$

$151,300 \quad 41.696$

186,800 42.1750

112.90041 .037

$160,30041.6790$

151,500 42.6790

$150,000.41 .3458$

$253.600 \quad 43.2128$

$136,500 \quad 40.66 \mathrm{C2}$

$185,700 \quad 42.0867$

$104.400 \quad 41.2300$

$152.30 \mathrm{C} .4 .380$

$146,100 \quad 41.3357$

148.10041 .3429

$48,700 \quad 42.0400$

$115,800 \quad 41.0349$

$121.000 \quad 43.3672$

$181,000 \quad 42.045$

$109.300 \quad 41.030$

$114.700 \quad 41.4012$

$148.900 \quad 43.0880$

138.600 40.7518

138.60040 .7518

$145.300 \quad 43.0916$

150.50042 .7381

$149.700 \quad 41.6862$

49.40041 .335

$52.600 \quad 41.696$

149.700 .42 .383

117.600 .42 .3833

$152,000 \quad 41.6831$

198,400 43.083

$147,100 \quad 42.035$

$186.500 \quad 42.0869$

$136.800 \quad 40.7505$

110.10041 .0332

$126.100 \quad 40.7606$

$113,200 \quad 41.0370$

$144.500 \quad 41.337$

$147.100 \quad 41.3428$

$137.800 \quad 40.7519$

$196,000 \quad 42.4270$

$103.900 \quad 43.3862$

$178.200 \quad 43.2982$

225.600 42.3814

$\begin{array}{ll}143.600 & 43.3850 \\ 149.400 & 42.7381\end{array}$
94.4001

92.7962

94.5109
93.7076

3.7.175

93.2412

95.8149

4.2063

2.0529

0.5586

93.0522

91.9350

91.1143

92.1659

94.2105

91.4660

91.4660

91.2492

93.3345

96.2056

94.0252

92.6307

92. 999

95.6169

92.79R ?

95.9599

92.8699

95.1572

91.0972

95.6265

95.5261

95.1512
90.6933

9.6933

94.6806

3.5797

95.5417

92.5199

94.2508

90.6132

90.6132

96.1707

93.4674

92.5238

94.2512

94.2512

92.4019

93.5687

9.7150

94.1921

93.7395

91.8397

96.0406

93.2649
93.7369

PtPS_ST $=20$ KAMSAS

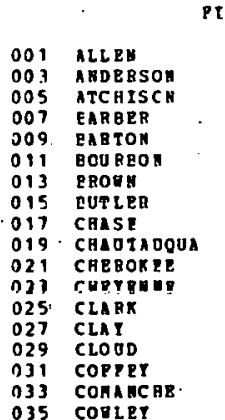

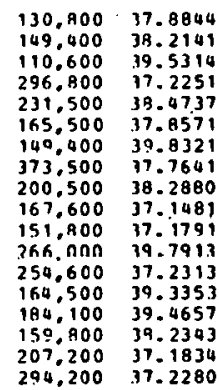

95.3150

95.3046

95.3175

98.693 .5
98.7547

90.858

94.8588
95.5719

96.9531

96.6026

96.2554

94.9623

111.7131

99.9220

99.9220
97.1662

97.1662
97.6508

95.7401

99.2849

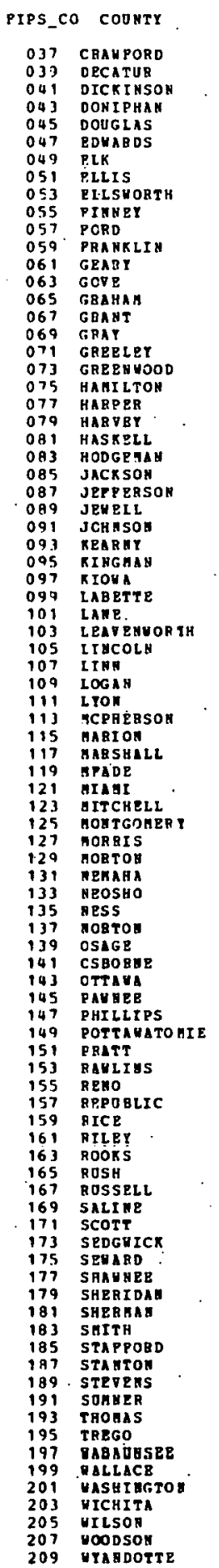

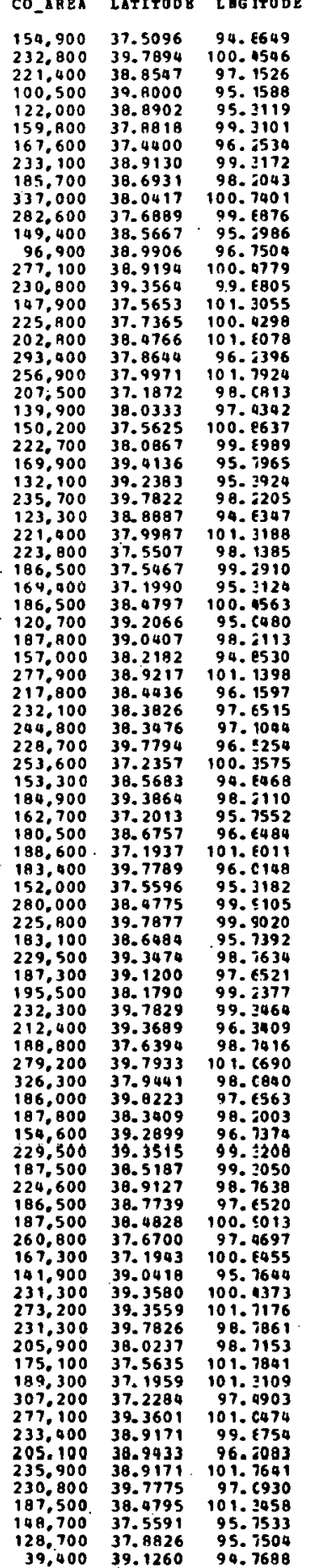


Table C.2 (continued)

\begin{tabular}{|c|c|c|c|c|c|c|c|c|c|c|c|}
\hline IPS_C & $\operatorname{COOHTY}$ & & & CO_AREA & LATITODE & LNGITUOE & PIPS_C & COUNTY & CO_ABEA & LATITHDE & L HG ITODE \\
\hline & & PIPS_SI & $=21$ & KENT OC & & & $\begin{array}{l}165 \\
171\end{array}$ & $\begin{array}{l}\text { SETCALPZ } \\
\text { AOYROE }\end{array}$ & $\begin{array}{l}76.700 \\
96.500\end{array}$ & $\begin{array}{l}36.9949 \\
36.7133\end{array}$ & $\begin{array}{l}85.0373 \\
85.7216 .\end{array}$ \\
\hline & & & & & & & $\begin{array}{l}173 \\
175\end{array}$ & $\begin{array}{l}\text { MONTGONER I } \\
\text { MORGAM }\end{array}$ & $\begin{array}{l}52,800 \\
95,600\end{array}$ & $\begin{array}{l}38.0340 \\
37.9173\end{array}$ & $\begin{array}{l}83.9074 \\
83.2517\end{array}$ \\
\hline 003 & ALLEA & & & 90,900 & $\begin{array}{l}1.0908 \\
36.7576\end{array}$ & $\begin{array}{l}83.2964 \\
86.1942\end{array}$ & 177 & $\begin{array}{l}\text { AORGAN } \\
\text { GUHLEMBRG }\end{array}$ & $\begin{array}{r}95,600 \\
124,600\end{array}$ & $\begin{array}{l}37.9173 \\
37.2134\end{array}$ & $\begin{array}{l}83.5517 \\
87.91915\end{array}$ \\
\hline & AMDERSC & & & 53.400 & 39.0014 & 84.9942 & $17 y$ & $\begin{array}{l}\text { NPISON } \\
\text { Note }\end{array}$ & 113,200 & 37.8098 & 85.4864 \\
\hline & EALLARE & & & 67.100 & 37.0740 & 89.0019 & 181 & MICHOLAS & $\begin{array}{r}52,800 \\
52,800\end{array}$ & 38.3379 & 84.6053 \\
\hline & PARREN & & & 121.200 & 36.9721 & 85.9301 & 183 & онто & 154,400 & 37.4780 & $\$ 493$ \\
\hline 013 & $\begin{array}{l}\text { eArH } \\
\text { eget }\end{array}$ & & & $\begin{array}{r}74.300 \\
95.300\end{array}$ & $\begin{array}{l}38.1530 \\
36\end{array}$ & $\begin{array}{l}83.7346 \\
8346\end{array}$ & 185 & OLDHA & 47,700 & 38.3937 & 85.4559 \\
\hline $\begin{array}{l}013 \\
015\end{array}$ & $\begin{array}{l}\text { EELL } \\
\text { EOONE }\end{array}$ & & & $\begin{array}{l}95,800 \\
64,500\end{array}$ & $\begin{array}{l}36.7270 \\
38.9640\end{array}$ & $\begin{array}{l}83.6764 \\
84.7302\end{array}$ & $\begin{array}{l}187 \\
199\end{array}$ & $\begin{array}{l}\text { OWEN } \\
\text { OUSLEY }\end{array}$ & $\begin{array}{l}90,900 \\
51.000\end{array}$ & 38.5078 & $84-\{226$ \\
\hline 017 & ROU RBD & & & 77.700 & $\begin{array}{l}38.9640 \\
38.2059\end{array}$ & 84.2105 & 191 & PPNDLETON & 72,300 & 37.4213 & 83.6780 \\
\hline 019 & goro. & & & 41.200 & 39.3637 & 92.6770 & 193 & PQRQY & 88,300 & 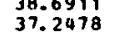 & $\begin{array}{l}84.521 \\
83.3139\end{array}$ \\
\hline 021 & EOYLE & & & 47.400 & 37.6237. & 84.9694 & 195 & PIKE & 202,500 & 37.4686 & 923 \\
\hline 023 & ERACKEN & & & 52.800 & 18.6965 & Aแ.กค7ก & 197 & PחQRL & 97,900 & 37.0316 & $03+0206$ \\
\hline $\begin{array}{l}025 \\
027\end{array}$ & BREATHITT & & & $\begin{array}{r}127,900 \\
.143\end{array}$ & 37.5265 & $\begin{array}{l}83.33157 \\
88.4353\end{array}$ & 193 & $\begin{array}{l}\text { PULASKI } \\
\end{array}$ & 169.100 & 37.1108 & 84.5610 \\
\hline $\begin{array}{l}027 \\
029\end{array}$ & $\begin{array}{l}\text { RECKISBIDGe } \\
\text { POLLITI }\end{array}$ & & & $\begin{array}{r}743.500 \\
77,700\end{array}$ & $\begin{array}{l}37.7952 \\
37.9694\end{array}$ & $\begin{array}{l}86.4753 \\
85.6977\end{array}$ & 203 & $\begin{array}{l}\text { BOBERTSOY } \\
\text { ROCKCASTLE }\end{array}$ & $\begin{array}{l}26,200 \\
80,500\end{array}$ & $\begin{array}{l}38.5160 \\
37.3670\end{array}$ & $\begin{array}{l}84.0366 \\
89.3192\end{array}$ \\
\hline ก & PATt.PR & & & $114.7 \mathrm{nn}$ & $97.21 \mathrm{Ak}$ & 86.6754 & 205 & newa $n$ & 75,100 & 30.2013 & a). 4049 \\
\hline 033 & CALONELL & & & 92.500 & 37.1420 & $87.964 ?$ & 207 & RUSSELL & 61,600 & 36.9804 & Q5: 6662 \\
\hline 035 & CALLOMAT & & & 99.500 & 36.6257 & 80.2112 & 209 & SCOTT & 73,600 & 38.2863 & 84.5820 \\
\hline 037 & CAMPBEIL & & & $\begin{array}{r}38,600 \\
50.500\end{array}$ & 38.9514 & $\begin{array}{l}84.3751 \\
889600\end{array}$ & 211 & $\begin{array}{l}\text { SHELAY } \\
\text { SSPSOY }\end{array}$ & 99,200 & 38.2071 & 85. 1994 \\
\hline $\begin{array}{l}039 \\
041\end{array}$ & $\begin{array}{l}\text { CARLISIR } \\
\text { CARROLI }\end{array}$ & & & $\begin{array}{l}50.500 \\
13,700\end{array}$ & $\begin{array}{l}36.8613 \\
38.6603\end{array}$ & $\begin{array}{l}88.96000 \\
85.1272\end{array}$ & $\begin{array}{l}213 \\
215\end{array}$ & $\begin{array}{l}\text { SIMPSOA } \\
\text { SPEACER }\end{array}$ & $\begin{array}{l}61,900 \\
50,000\end{array}$ & $\begin{array}{l}36.7414 \\
38.0285\end{array}$ & $\begin{array}{l}86.8792 \\
85.3230\end{array}$ \\
\hline 043 & CARTER & & & 102,800 & 38.3223 & 83.0340 & 217 & TAY LOQ & 71,700 & 37.3600 & 85.3361 \\
\hline 045 & CASEY & & & 112.700 & 37.3004 & 84.9 .393 & 219 & TODD & 97,400 & 36.8356 & 87.1765 \\
\hline 047 & CHR IST IAN & & & 187.900 & 36.8925 & 87.4857 & 221 & TRIGG. & 105,700 & 36.8026 & 87.8710 \\
\hline 049 & CLARK & & & 67.100 & 37.9695 & 84.1432 & 221 & TRIABLE & 37,800 & 38.6047 & B5. 3451 \\
\hline 051 & CLAY & & & 122.800 & 37.1692 & & 225 & UHIOA & 88,100 & & 87.5459 \\
\hline $\begin{array}{l}053 \\
055\end{array}$ & $\begin{array}{l}\text { CLINTON } \\
\text { CRINAPP }\end{array}$ & & & $\begin{array}{l}49.200 \\
94.507\end{array}$ & $\begin{array}{l}36.7287 \\
17.35 .32\end{array}$ & $\begin{array}{l}85-1375 \\
88.1013\end{array}$ & 227 & MARREN & 141,400 & 36.9977 & 86. 4222 \\
\hline $\begin{array}{l}355 \\
057\end{array}$ & $\begin{array}{l}\text { CRITTPNDEF } \\
\text { COTPRLA }\end{array}$ & & & $\begin{array}{l}94,507 \\
80.300\end{array}$ & 37.3532 & 8 8. 1013 & 229 & $\begin{array}{l}\text { GASHI HGTOS } \\
\end{array}$ & 79,500 & 37.7612 & 85. 1804 \\
\hline 059 & $\begin{array}{l}\text { CAVIESS } \\
\text { lave }\end{array}$ & & & $\begin{array}{l}80.300 \\
119,700\end{array}$ & $\begin{array}{l}36.7923 \\
37.7306\end{array}$ & $\begin{array}{l}85.3990 \\
97.0902\end{array}$ & 233 & $\begin{array}{l}\text { MAYNE } \\
\text { WEBSTEB }\end{array}$ & $\begin{array}{r}114,000 \\
87 ; 800\end{array}$ & $\begin{array}{r}36.8069 \\
37.5168\end{array}$ & $\begin{array}{l}84 . \varepsilon 258 \\
87.812\end{array}$ \\
\hline 061 & ED OOSCA & & & 77,200 & 37.2126 & 86.2362 & 235 & WHITLY & 118,900 & 36.7616 & $\begin{array}{l}87.882 \\
84.1471\end{array}$ \\
\hline 063 & PLETOTT. & & & 52,200 & 38.1168 & 83.0989 & 237 & NOLPE & 50,000 & 37.7409 & $\begin{array}{l}\text { D } 83.4882 \\
83.4\end{array}$ \\
\hline 065 & ESTILL & & & 67,300 & 37.6913 & 83. 9605 & 239 & W DODPORD & 50,000 & 38.0359 & $\begin{array}{l}84.7429 \\
84.29\end{array}$ \\
\hline 067 & gATETTR & & & 72,500 & 39.0399 & 84.4557 & & & & & \\
\hline $\begin{array}{l}969 \\
071\end{array}$ & FLENING & & & 90.600 & $\begin{array}{l}38.3747 \\
337.5641\end{array}$ & $\begin{array}{l}83.6839 \\
892738\end{array}$ & & & & & \\
\hline $\begin{array}{l}071 \\
073\end{array}$ & $\begin{array}{l}\text { PLOYD. } \\
\text { FAANKL IN }\end{array}$ & & & $\begin{array}{r}703.300 \\
54,600\end{array}$ & $\begin{array}{l}37.5641 \\
39.2304\end{array}$ & $\begin{array}{l}2.7368 \\
84.8786\end{array}$ & & & & & \\
\hline 075 & PULTON & & . & 52.600 & 36.5769 & 89.1229 & & PIPS_ST & $=22$ & AS & \\
\hline & $\begin{array}{l}\text { GALLATII } \\
\text { GARRABD }\end{array}$ & & & $\begin{array}{r}25,9,00 \\
61,100\end{array}$ & $\begin{array}{r}39.7469 \\
37.6408\end{array}$ & $\begin{array}{l}84.7549 \\
84.5171\end{array}$ & & ACADIA & & & \\
\hline $\begin{array}{l}079 \\
091\end{array}$ & $\begin{array}{l}\text { GARRABD } \\
\text { GRANT }\end{array}$ & & & $\begin{array}{l}61.100 \\
64.500\end{array}$ & $\begin{array}{l}77.6408 \\
38.6416\end{array}$ & $\begin{array}{l}845377 \\
84.6136\end{array}$ & $\begin{array}{l}1707 \\
0.03\end{array}$ & $\begin{array}{l}\text { ACADIA } \\
\text { ALLEY }\end{array}$ & $\begin{array}{l}171,700 \\
200500\end{array}$ & & $\begin{array}{r}92.4079 \\
92.0205\end{array}$ \\
\hline 083 & GRAVES & $\cdot$ & & 145,000 & 36.7265 & 88.5493 & 005 & A SCPNSTRN & 18,000 & 30.2042 & 90,5143 \\
\hline $\begin{array}{l}085 \\
087\end{array}$ & $\begin{array}{l}\text { GRAYSOA } \\
\text { GREP }\end{array}$ & & & $\begin{array}{r}128.500 \\
73.000\end{array}$ & $\begin{array}{l}37.0716 \\
37.2668\end{array}$ & $\begin{array}{l}86.3430 \\
8555564\end{array}$ & $\begin{array}{l}007 \\
009\end{array}$ & ASSORPTIO: & $\begin{array}{r}92,200 \\
\end{array}$ & 29.9038 & 91.0664 \\
\hline $\begin{array}{l}087 \\
039\end{array}$ & $\begin{array}{l}\text { GREER } \\
\text { GREEMOE }\end{array}$ & & & 90,900 & $\begin{array}{l}37.2668 \\
78.5505\end{array}$ & $\begin{array}{l}85.5564 \\
82.9104\end{array}$ & $\begin{array}{l}009 \\
011\end{array}$ & $\begin{array}{l}\text { AVOPELES } \\
\text { OPAOREART }\end{array}$ & $\begin{array}{l}215,500 \\
305,900\end{array}$ & $\begin{array}{l}31.0790 \\
30.6558\end{array}$ & $\begin{array}{r}92.059 \\
93.3502\end{array}$ \\
\hline 091 & Hancock & & & 48,400 & 37.8471 & 86.79 .33 & 013 & BIENVILLE & 215,500 & 32.3505 & 93.0492 \\
\hline 093 & EAEDIN & & & 159,500 & 37.7046 & 84.4121 & & gOSSIRB & & & 33.005 \\
\hline 099 & HARLAN & & & 121,500 & 36.4540 & 83.2092 & 017 & CADO & & & 93.6802 \\
\hline 097 & HARRISCN & & & $79,8 \cap n$ & 38,4397 & $94-3$ & 019. & ASIBU & & & \\
\hline 999 & FART & & & 108,8 & 37.3041 & 85.70 & 021 & CALDRELI & & & 92. \\
\hline & 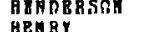 & & & 112.900 & & $\begin{array}{l}875712 \\
85.1223\end{array}$ & & Cатнаров & & $\begin{array}{l}15 \\
56\end{array}$ & נ33. 1910 \\
\hline 105 & BICXNAN & & & $\begin{array}{l}74,900 \\
63,700\end{array}$ & $\begin{array}{l}7 \mathrm{H} .0385 \\
36.6808\end{array}$ & $\begin{array}{l}\text { A5. } 1223 \\
\text { A8.9299 }\end{array}$ & $\begin{array}{l}025 \\
027\end{array}$ & $\begin{array}{l}\text { CATA HOOLA } \\
\text { CLA BOBAR }\end{array}$ & 192,2 & 31.6656 & 91.8497 \\
\hline 107 & BOPXINS & & & 143,200 & 37.3084 & 87.5 & 029 & CCHCOBDI & & $\begin{array}{l}32.8250 \\
31.4594\end{array}$ & $\begin{array}{l}922.5954 \\
99.6475\end{array}$ \\
\hline iny & JALRSUA & & & 47? ? & 37.6 & & & DE SOTO & & & \\
\hline 111 & JEPPQ & & & 97. & 38.18 & & 033 & EAST BATO\& BOUGR & & & \\
\hline 1.13 & JESSAT & & & & & & & PAST CARRCLL & & & \\
\hline 115 & JCHNS & & & 69.0 & 37.948 & & & PELICIAKa & & & \\
\hline 1.17 & КEHTOH & & & 37 & R. 9 & 84.5300 & 03 & EVA & & & 54 \\
\hline 115 & RNOTT & & & 12 & 39.36 & & 0 & PRABKLI & & & 91 \\
\hline & $\operatorname{Rad}$ & & & & & & & & & & 03.5563 \\
\hline 12 & LaAUE & & & & 37.5 & & & IBERIA & & & \\
\hline 12 & LAOREL & & & 5.500 & 37.1 & 84 & 047 & IB8R & & & \\
\hline & $\begin{array}{l}\text { LAYPERCE } \\
\text { LEE }\end{array}$ & & & 110.109 & 39.86 & $83=7$ & & 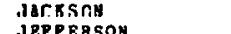 & & & \\
\hline 131 & LESLIR & & & 105.900 & $\begin{array}{l}37.5975 \\
37.0958\end{array}$ & $\begin{array}{l}83.70 \\
83.37\end{array}$ & $\begin{array}{l}037 \\
053\end{array}$ & $\begin{array}{l}\text { JEPPEASON } \\
\text { JRPPRSOR DAVIS }\end{array}$ & & & \\
\hline 133 & I tтснеs & & & 87,800 & $37.12 t 9$ & 82.844 & 055 & $\begin{array}{l}\text { JEPPERSON DAVIS } \\
\text { IAPAY ETTE }\end{array}$ & & 30.2 & 92.8069 \\
\hline 135 & IEUIS & & & 125.900 & 38.5413 & 83.368 & $05 ?$ & I APOU RCHP & & 39.57 & 80.4 \\
\hline & LIHCOL: & & & 100 & 37.4576 & 89.6 & $0 \mathrm{~s}$ & LA SALLE & & 31.6798 & 92.16 \\
\hline & IIVIBG & & & 90.5 & 37.2 & 88.3 & & Iracoly & & & \\
\hline 191 & $.208 \mathrm{AY}$ & & & 169,1 & IN.A & & & 1272 & & & \\
\hline 143 & LYo" & & & 55.9 & 37.0144 & 88.0 & or $r+r a$ & 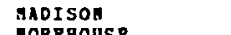 & & & \\
\hline 145 & $\begin{array}{l}\text { BCCRACREY } \\
\text { GCCRPABY }\end{array}$ & & & $\begin{array}{r}64.700 \\
108.300\end{array}$ & 37.0801 & B8.7 & $\begin{array}{l}067 \\
069\end{array}$ & $\begin{array}{l}\text { OREHOUS? } \\
\text { BORS }\end{array}$ & & & \\
\hline 189 & $\begin{array}{l}\text { RCCRRABA? } \\
\text { RCLEA }\end{array}$ & & & $\begin{array}{r}108,300 \\
66.600\end{array}$ & $\begin{array}{l}36.7454 \\
37.5289\end{array}$ & $\begin{array}{l}84.4940 \\
87.2659\end{array}$ & $\begin{array}{l}069 \\
071 .\end{array}$ & $\begin{array}{l}\text { AATCHITOC HES } \\
\text { OBLEAHS }\end{array}$ & $\begin{array}{l}334.600 \\
51,000\end{array}$ & $\begin{array}{l}31.7274 \\
30.0357\end{array}$ & $\begin{array}{l}93.6924 \\
89.9317\end{array}$ \\
\hline 151 & aADISOs & & & 115.500 & 37.7211 & 96.2760 & 073 & СОАСНITA & 165,200 & 32.4034 & 92.1605 \\
\hline 153 & Magorpia & & & 78.500 & 37.7079 & 83.0 .574 & 07 & PLAQUEAIA & 266. & 29.4 & 89.6233 \\
\hline 155. & MARIOH & & & 98.90 & 37.5 & 85.2 & 07 & COUKYE & & 30. & \\
\hline $157^{\circ}$ & MARSABLL & & & 78.50 & 36.8 & & & & & & \\
\hline 159 & MARTIM & & & 59.80 & $37-80$ & & OA 1 & IVRR & & & \\
\hline 161 & AASO: & & & 61.600 & 38.6016 & & 083 & RICHLADD & & & \\
\hline $\begin{array}{l}163 \\
165\end{array}$ & $\begin{array}{l}\text { AEADP } \\
\text { AEMIPEE }\end{array}$ & & & $\begin{array}{l}79.000 \\
54.400\end{array}$ & $\begin{array}{l}37.9849 \\
37.9482\end{array}$ & $\begin{array}{l}86.2173 \\
83.5977\end{array}$ & $\begin{array}{l}085 \\
\text { OB7 }\end{array}$ & $\begin{array}{l}\text { SABIAE } \\
\text { ST BEBABD }\end{array}$ & $2260^{\circ}$ & $\begin{array}{l}31.5702 \\
29.8968\end{array}$ & $\begin{array}{l}93.5699 \\
89.5383\end{array}$ \\
\hline 167 & AERCER & & & 65,300 & 37.8101 & 84.8761 & 089 & ST CHARLES & 76,100 & 29.8971 & 90.3621 \\
\hline
\end{tabular}


Table C.2 (continued)

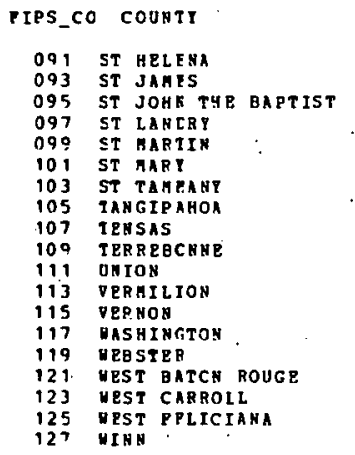

PIPS_SI $=23$ AAINE

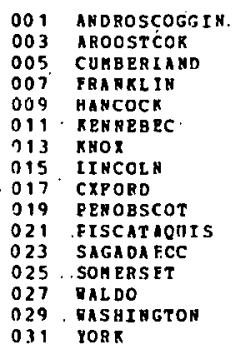

RIPS_SI $=24$ MARYLAND

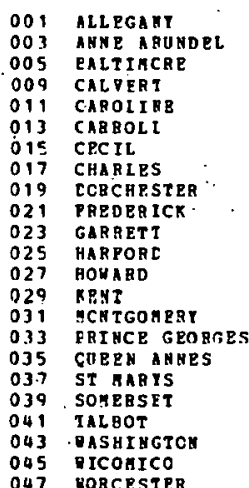

$110.900 \quad 39.6230 \cdot 78.6990$ $109.600 \quad 39.0047$ $175,100 \quad 39.4731$ 56.200
93.100
39.95320 $\begin{array}{r}93,100 \\ 119,100 \\ 39.9724 \\ \hline 39.5643\end{array}$ $\begin{array}{rr}118,100 & 39.5643 \\ 93,800 & 39.5850\end{array}$ $11 \%, 900 \quad 32.4999$ $153.800 \quad 39.4854$ $\begin{array}{rr}172.200 & 39.4775 \\ 170.700 & 39.5410\end{array}$ $\begin{array}{rr}170,700 & 39.5410 \\ 117.300 & 39.5654\end{array}$ 117,300
65,000
79.5654 $72.800 \quad 39.2583$ 125.200 39. 25.60038 .827 $96.100 \quad 39.0840$ 87.600 .38 .1232 $67.600 \quad 39.7727$ $18.900 \quad 39.612$ 98,700
$124,100 \quad 38.2249$ 76.6263 76.5879 75.2420 77.0317 75.9482 77.0441 76.0079 77.4076 79.2738 76.3272 76.0359 76.0359
77.2207 76.8643 75.9900 76.6307 5.7375 76.7938 77.8216
75.5292 75.5292
75.3459

PIPS_SI $=25$ MASSACATSRTTS

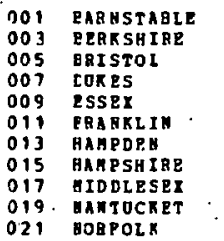

$101.800 \quad 41.7379$ $243,700 \cdot 42.3675$ $143,500 \quad 41.8051$ 26.90041 .385 $83.400 \quad 42.5832$ $160.300 \quad 42.1368$ $137,000 \quad 42.3398$ 213.70042 .4873 11.000
102.000
42.1576

70.2849 73.2057 70.6 .376 70.9627 72.5917 $72.52 \mathrm{BO}$ 72.6595 71.3929 70.05 .19
71.2253

\author{
PIPS_CC COONTY \\ 023 PLYHOUTH
025 SUPPOLK
}

CO AREA LATITODE LHGITODE

$169.400 \quad 41.9574$

$14,500 \quad 42.3107 \quad 71.1056$

$\begin{array}{lll}190,800 & 42.3521 & 71.0075\end{array}$

.075

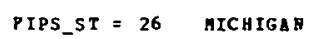

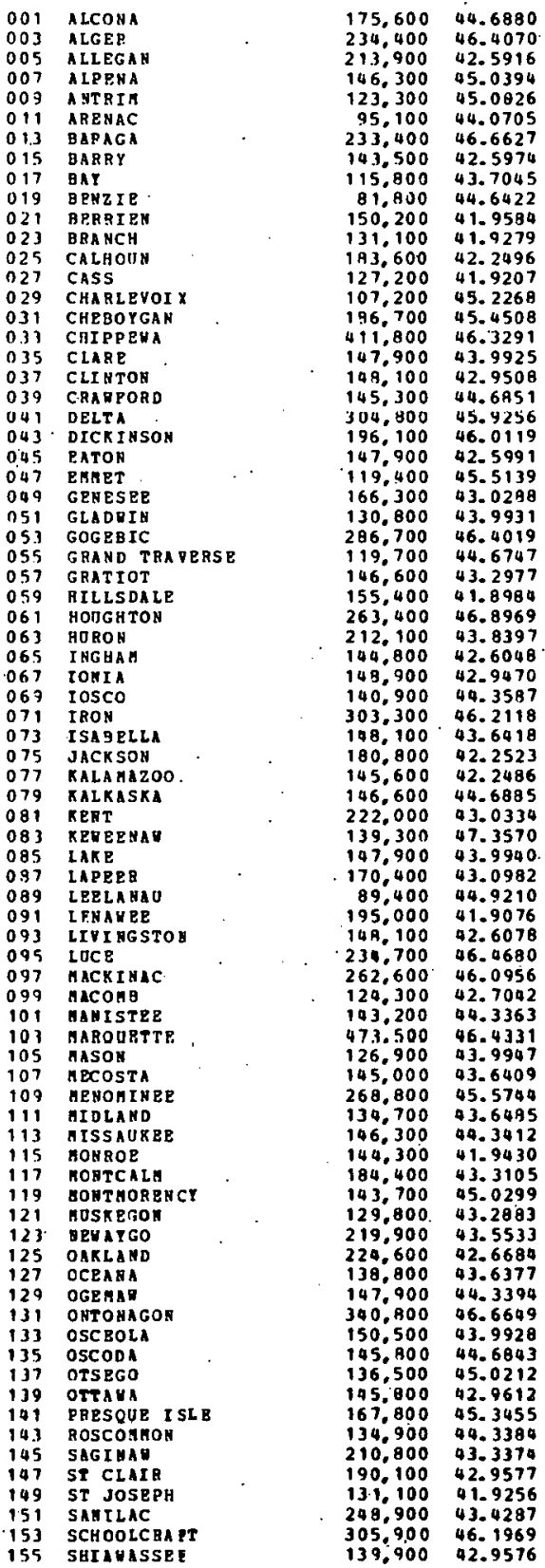

83. 5948 86.6212
85.6863 83.6287 85. $135 \mathrm{~B}$ B3. $\$ 937$ 88. 3766 85. 3144 83. 5877 86.0078 86.4201 65. 1650 85. 1047 85. 5961 85. C348 84.5044
84.7239 84.7239 89.895 84.6020 84. 6020 86.5359
87.8927 84.6398 84.6398
84.6890 B3. 7056 84. 2811 84.2811
89.6851 89.6851
85.5556 8.
Q. 2056 84.6054
84.5952 88.6858 B3. 152 84. 3706 85.6718 83. 6369 B8. 5371 Q4. 5461 84.9176 85.5286 85. CB21 85. 5076 B. 1183 85.8056
83.2229 83.2229
8.513 6.5. $\pi 13$
04.0663 B3. 5099 85. 5480 65. 1247 B6. C541. 86.
07.6468 86.2471
85.3265 85. 3265 84.3865 84.3864
B. 1835 85.5366
.83. 85. 1556 85. 1556
84. 1210 84.1214
86.1371 85.8051 85.6051
83.3844 86. 3550 84. 1216 89. $=19.4$ 84.1235 
Table C.2 (continued)

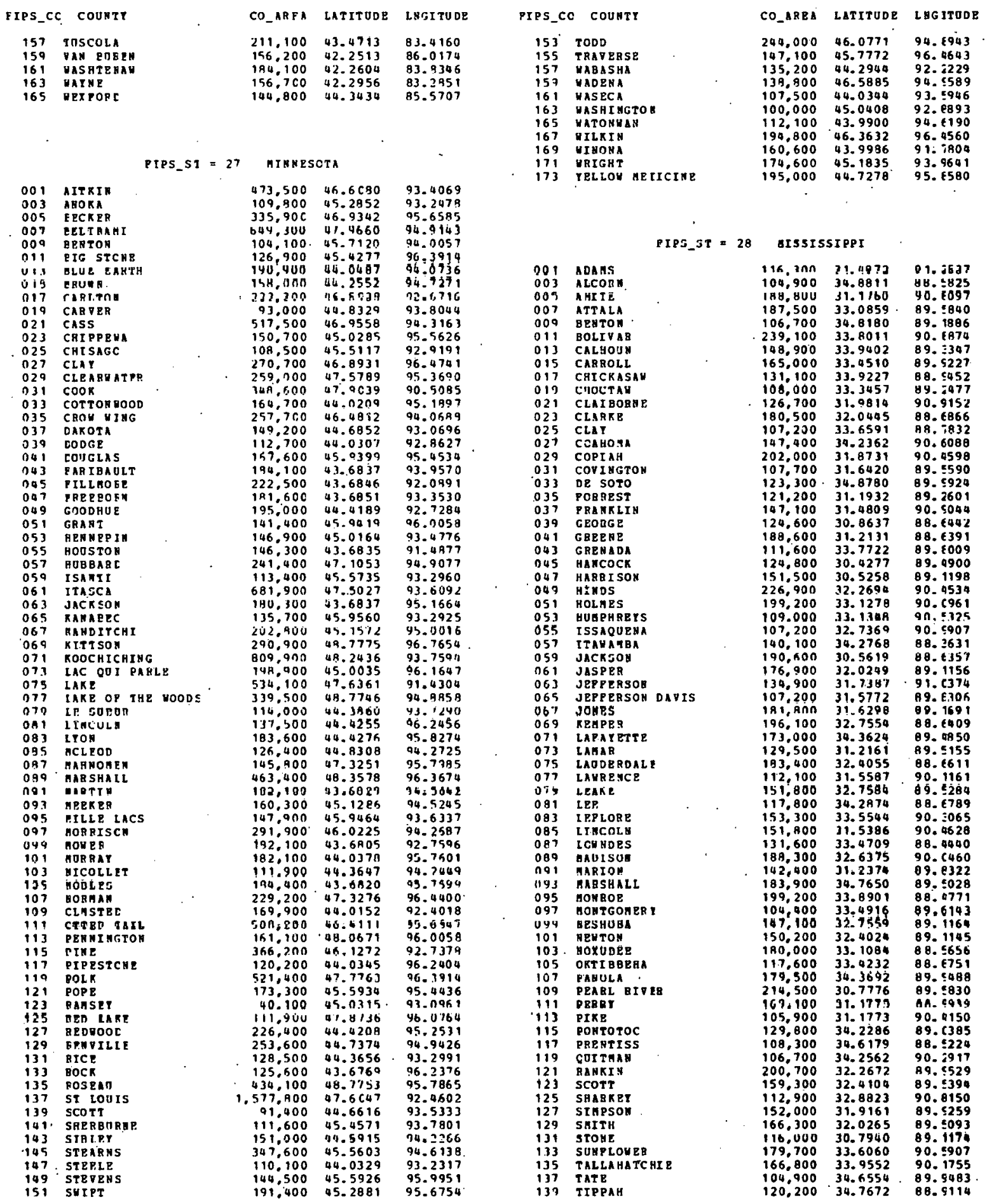


Table C.2 (continued)

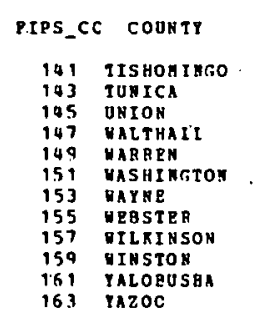

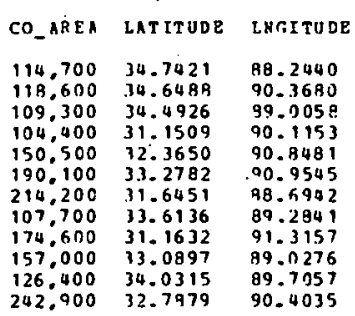

PIDS_ST $=29$ MISSAIRT

\begin{tabular}{|c|c|c|}
\hline 001 & ADAIR & \\
\hline 003 & AKDPEU & \\
\hline $\begin{array}{l}005 \\
007\end{array}$ & $\begin{array}{l}\text { ATCHISON } \\
\text { AODHIN }\end{array}$ & \\
\hline 009 & EARRY & \\
\hline 011 & EARTON & \\
\hline 013 & EATES & \\
\hline 015 & EEHTON & \\
\hline 017 & BOLLIMGER & \\
\hline 019 & EOONR & \\
\hline 021 & DOCHANAN & \\
\hline 023 & EUT LEP & \\
\hline 025 & CALDHELI & \\
\hline 027 & CALLAHAY & \\
\hline 029 & CAMOEN & \\
\hline 0.39 & CAPE GIBAR & DEAU \\
\hline 033 & CARPOLL & \\
\hline 035 & CAPTER & . \\
\hline 037 & Cass & \\
\hline 039 & CEDAR & \\
\hline 049 & CHARITC & \\
\hline 043 & CAR ISTIAS & \\
\hline 045 & CLARK & \\
\hline 047 & CLAT & \\
\hline 049 & CLIHTON & \\
\hline 051 & $\operatorname{COL} E$ & \\
\hline 053 & COOPER & \\
\hline 055 & CBAUPOAD & \\
\hline 057 & DADE & \\
\hline 059 & cablas. & \\
\hline 061 & CAVIESS & \\
\hline 063 & CE KALE & . \\
\hline 065 & DEHT & \\
\hline 067 & COUGLAS & \\
\hline 069 & CUNRLIA & \\
\hline 071 & PaA GRLIG & \\
\hline 073 & GASCOHADR & \\
\hline 075 & GEMTEY & \\
\hline 077 & GREEAP. & \\
\hline 079 & GRUNDY & \\
\hline 081 & HABRISCN & \\
\hline OA 3 & HEN RY & \\
\hline 085 & HICKORT & \\
\hline $0 \Rightarrow 7$ & BUL'? & \\
\hline OB9 & HODARD & \\
\hline 091 & คOW BLC & \\
\hline 093 & I RON & \\
\hline 099 & JACRSOR & \\
\hline 097 & JASPER & \\
\hline 099 & JEPPQPSON & \\
\hline 101 & JCH WSOS. & \\
\hline 103 & R NOX & \\
\hline 105 & LACLEDR & \\
\hline 107 & IAPAYETTE & \\
\hline 109 & IARRENCE & \\
\hline 111 & IEVIS & \\
\hline 113 & IInCOLA & \\
\hline 115 & LIEN & \\
\hline 117 & inturston & \\
\hline 119 & MCDOSA LD & \\
\hline 121 & ABCON & \\
\hline 123 & EADISON & \\
\hline 125 & MAR IRS & \\
\hline 127 & GARIOY & \\
\hline 129 & AERCPR & \\
\hline 131 & AILLER & \\
\hline 133 & MISSISSIPP & \\
\hline 135 & HOHTTEAO & \\
\hline 137. & HOH ROP. & \\
\hline
\end{tabular}

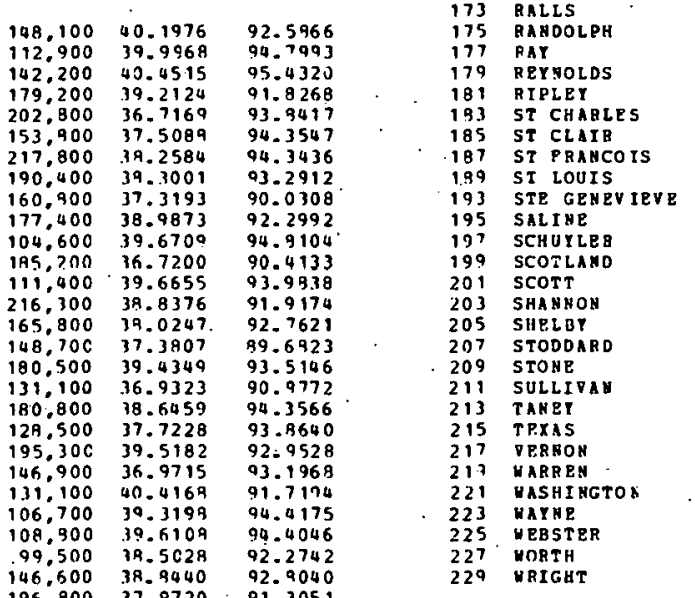

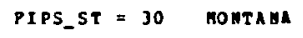

OO' BEAVERHEAC

003 BIG HOR

OOS RLAINP
007 GROADUATE

009 CABSOA

011 CARTER
013 CASCADE
015 CHODTRAO

015 CHOOTRAO

017 CUSTER

त2) Dawsก

023 DEER LODG

025 PALLON

029 PLATHEAD

031 GALLATIH
033 GARPIZLD

035 GLACIER

OJ7 GOLDEN VALLEY

039 GBANIT
041 HILL

04 1 HILL

04,3 JEPPEGSON
045 JUDITH BAST

047 LAKE

049 LEUIS AHD CLARR

$\begin{array}{ll}051 & \text { LIBEATT } \\ 053 & \text { IINCOLN }\end{array}$

O5J IINCOLN

057 MADISOA

059 MEAGHPR

061 AIMERAL

065 MUSSELSREIL

67 PABK

069 PETROLEU:
071 PHILTPS

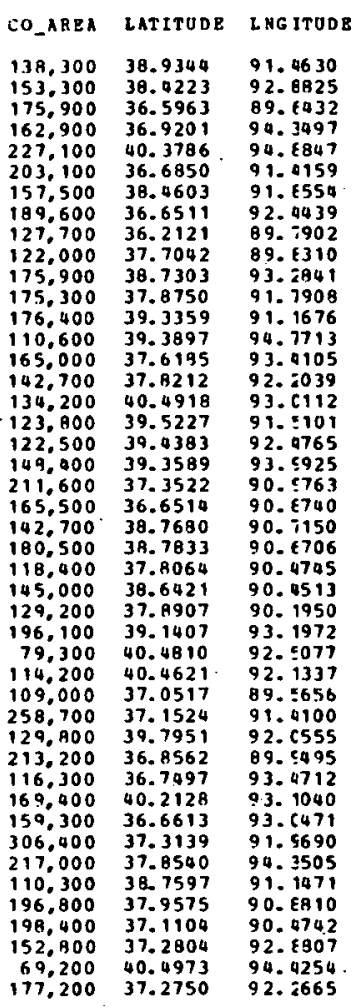
$\begin{array}{lll}1.437 .700 & 45.1294 & 112.8962 \\ 1.301,000 & 45.4228 & 107.4871\end{array}$ $1.107 .200 \quad 48.4296 \quad 108.5583$ 109.000
30.3306
5311.0934 $5.35 .100 \quad 45.2244 \quad 109.6367$ $85 \mathrm{~A}, 100 \quad 45.5197$ 104.5341 $689.200 \quad 47.3020 \quad 111.365$ $1.017 .100 \quad 47.8761 \quad 110.0278$

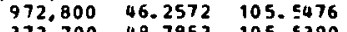
$373.700 \quad 48.7853 \quad 105 . \$ 390$ $613.800 \quad 47.2664$ 104. 5873 $191.700 \quad 46.0542 \quad 113.0636$ $422,900.46 .3362$ 104. 4102

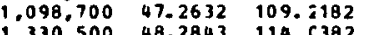
$\begin{array}{rrr}1,330,500 & 48.2843 & 114.0382 \\ 651,900 & 45.5567 & 111.1766\end{array}$ $\begin{array}{rrr}651,900 & 45.5567 & 111.1766 \\ 153.900 & 47.2826 & 106.5852\end{array}$ $\begin{array}{rrr}1.153 .400 & 47.2826 & 106.5852 \\ 767.700 & 48.6952 & 112.5999\end{array}$ $\begin{array}{lll}767.700 & 48.6952 & 112.5919 \\ 304.600 & 46.3781 & 109.1751\end{array}$ $\begin{array}{lll}304.600 & 46.3781 & 109.1751 \\ 448.800 & 46.3926 & 113.4250\end{array}$

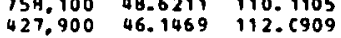
$486,900.97 .0336 \quad 110.258 .1$ $386.900 \quad 47.6397 \quad 114.0729$ 900.300 47.1145 112. 2 ค3 661.900 4.5347 115. $675.200 \quad 47.6533$ 105. 913.800 45.3037 111. 5186 316,500 47. $1413 \quad 114.5990$ $676.500 \quad 9.14130994$ $68.700 \quad 46.4947100 .595$ 749.800 45.5143 110.593 028000 47 $1190 \quad 108.045$ $\begin{array}{rrr}428.600 & 47.1198 & 108.9475 \\ 1.350 .200 & 48.2569 & 107.9754\end{array}$ $\begin{array}{lll}448.800 & 46.3926 & 113.4250 \\ 758.100 & 48.6211 & 110.1105\end{array}$ 961.900 48.5347 111. (256 
Table C.2 (continued)

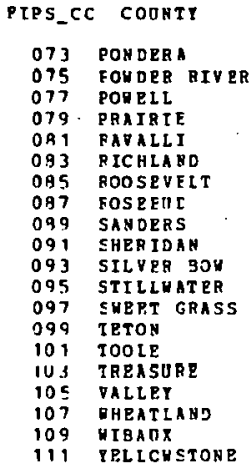

$\begin{array}{cll}\text { CO_AREA } & \text { LATITUDE } & \text { LNGTTODE } \\ 426,100 & 48,2206 & 112.2162 \\ 851.600 & 45.3981 & 105.6110 \\ 605.000 & 46.8492 & 112.9294 \\ 448,100 & 46.8644 & 105.3561 \\ 616,900 & 46.0798 & 114.1166 \\ 538.500 & 47.7884 & 104.5633 \\ 617.700 & 48.2969 & 104.9997 \\ 1.304 .600 & 46.2267 & 106.7092 \\ 719.500 & 47.6729 & 1.15 .1286 \\ 438.709 & 48.7225 & 104.5118 \\ 185.200 & 45.8939 & 112.6498 \\ 464.600 & 45.6694 & 109.3994 \\ 476.600 & 45.8144 & 109.9445 \\ 594.100 & 47.8314 & 112.2243 \\ 505.000 & 48.6549 & 111.5953 \\ 255.100 & 46.2096 & 107.2559 \\ 1.289 .300 & 48.3694 & 106.6641 \\ 367.900 & 46.4604 & 109.9468 \\ 230.500 & 46.9643 & 104.2439 \\ 694.300 & 45.9379 & 108.2701\end{array}$

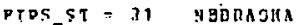

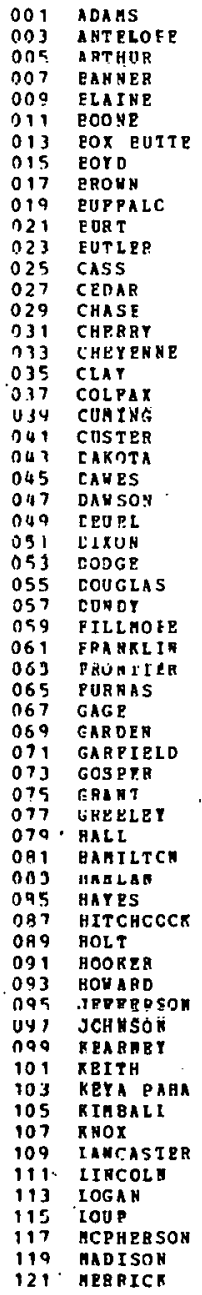

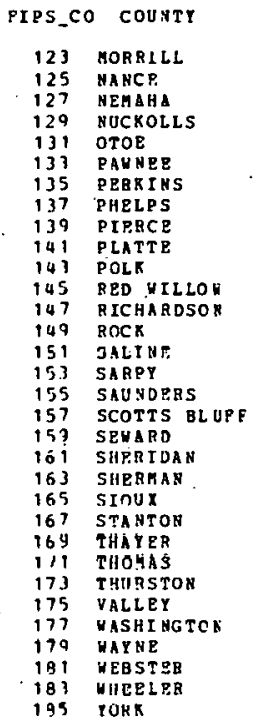

CO_AREA LATITUDE LAG JTODB

$363,100 \quad 41.7154 \quad 103.0015$

$113.700 \quad 41.3933 \quad 97.5938$

$103.600 \quad 40.3862 \quad 95.6541$

$150.000 \quad 40.1747 \quad 08.0560$

$\begin{array}{lll}160,300 & 00.6381 & 96.1350\end{array}$

$112,100 \quad 40.1289 \quad 96.2443$

$229.200 \quad 40.8509 \quad 101.6601$

$\begin{array}{lll}140.900 & 40.5102 & 99.4198\end{array}$

$148.400 \quad 42.2507 \quad 97.6004$

$111.900 \quad 41.1816 \quad 97.5729$

$177,700 \quad 40.1776 \quad 100.4721$

$142.400 \quad 0.1318 \quad 95.7187$

$261.300 \quad 42.4211 \quad 99.4536$

$148.400 \quad 40.5149 \quad 97.1421$

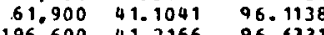

$\begin{array}{lll}196.600 & 41.2166 & 96.633\end{array}$

$\begin{array}{rrr}188.000 & 41.8549 & 103.7043 \\ 147.900 & 40.8637 & 97.8403\end{array}$

$\begin{array}{rrr}147.900 & 40.8637 & 97.1403 \\ 637.700 & 42.5065 & 102.0022\end{array}$

$\begin{array}{rrr}637.700 & 42.5065 & 102.0022 \\ 146.900 & 41.2179 & 90.5828\end{array}$

$534.300 \quad 42.4864 \quad 103.7618$

$\begin{array}{rrr}534,300 & 42.4864 & 103.7618 \\ 111, \text { KOn } & 41.9035 & 97.195 \%\end{array}$

149.400 un.1746 97.6991

$145.400 \quad 41.9156$
100.5533

$100.500 \quad 42.1449$ 96. $\$ 380$

$\begin{array}{lll}100.500 & 42.1449 & 96.8380 \\ 147.400 & 11.5647 & 98.9876\end{array}$

$100,000 \quad 41.5178 \quad 96.2157$

$114.700 \quad 12.1924 \quad 97.1125$

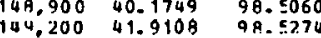

$\begin{array}{lll}144.200 & 41.9108 & 98.5270 \\ 149,400 & 40.8647 & 97.6052\end{array}$

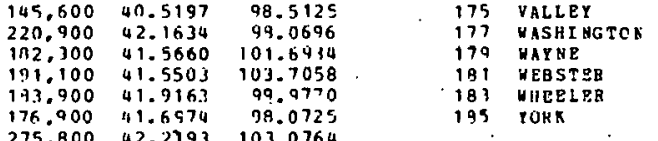

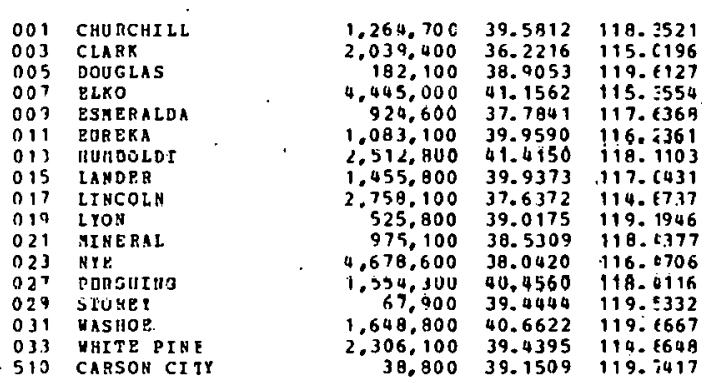

PIPS_ST $=33$ NEM HAAPSHIB

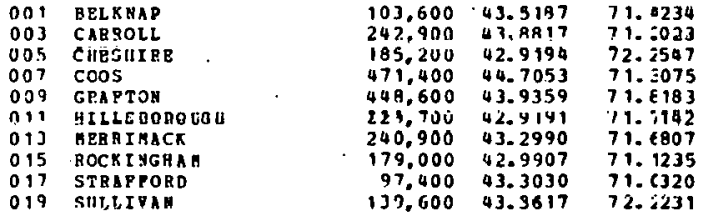

PIPS_ST $=34$ MEII JEBSET

\begin{tabular}{|c|c|c|c|c|}
\hline $\begin{array}{lll}0 & 0 & 1 \\
0 & 0 & 3 \\
0 & 0 & 5 \\
0 & 0 & 7 \\
0 & 0 & 9 \\
0 & 1 & 1 \\
0 & 1 & 3 \\
0 & 1 & 15 \\
0 & 1 & 7 \\
0 & 1 & 9\end{array}$ & 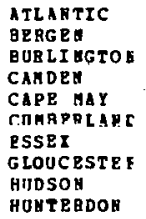 & $\begin{array}{r}167,000 \\
60,600 \\
212,100 \\
57,200 \\
69,200 \\
123,500 \\
33,700 \\
85,200 \\
12,200 \\
109,600\end{array}$ & $\begin{array}{l}39.4823 \\
40.9618 \\
39.6834 \\
39.7987 \\
39.1513 \\
39.3697 \\
40.7919 \\
39.7160 \\
40.7421 \\
40.5734\end{array}$ & $\begin{array}{l}74.6757 \\
74.6740 \\
74.6638 \\
74.5480 \\
74.6083 \\
75.1113 \\
74.2493 \\
75.1387 \\
74.6928 \\
74.5142\end{array}$ \\
\hline
\end{tabular}


Table C.2 (continued)

\begin{tabular}{|c|c|}
\hline 221 & MEBCER \\
\hline 02.3 & GIDCLESEX \\
\hline 025 & BOKYOUTH \\
\hline 027 & MORAIS \\
\hline 029 & CCEAY \\
\hline 031 & FASSAIC \\
\hline 933 & SALER \\
\hline 035 & SOMERSET \\
\hline 037 & Sossex \\
\hline 030 & ONTOA \\
\hline 041 & DARBPN \\
\hline
\end{tabular}

CO ARFA LATtTUDE LNGITHDE

$59.100 \quad 40.2863$

$80,800 \quad 40.4464$

$123.300 \quad 40.2614$

$121.200 \quad 40.8630$

166.300
$49,700 \quad 49.9151$
49.0364

$94,500 \quad 39.5923$

$79.500 \quad 40.5680$

136.500
26.700 4.1410

$93,800 \quad 40.8620$

74.6960
74.4181
74.2105
74.5572
74.2923
74.3014
75.3426
74.6230
74.5968
74.3156
75.0025

PIPS_ST $=35$ NEW MEXICO

\begin{tabular}{|c|c|}
\hline \\
\hline 00.3 & CATRON \\
\hline 105 & CHAVES \\
\hline & COLFAX \\
\hline 09 & CORAY \\
\hline 11 & DE BACA \\
\hline & DONA ABA \\
\hline & EDDY \\
\hline 17 & GRANT \\
\hline 19 & GOADALOPE \\
\hline 21. & PARDING \\
\hline & HIDALGC \\
\hline & \\
\hline 27 & IINCOLN \\
\hline $2 \mathrm{~B}$ & LOS ALAMO \\
\hline 029 & L U. A \\
\hline 031 & HCR I H L E I \\
\hline 033 & MORA \\
\hline & CTERC \\
\hline 037 & QUAY \\
\hline 039 & BIO AREIB \\
\hline 041 & BONSEVELT \\
\hline 043 & SANDOVAL \\
\hline 049 & SAH JUAN \\
\hline 04 & SAN GIGUR \\
\hline 04 & SANTA FE \\
\hline & SIERRA \\
\hline 05. & SOCORR \\
\hline 05 & 1AOS \\
\hline 05 & TORRAE \\
\hline & \\
\hline & \\
\hline
\end{tabular}

$302.900 \quad 35.0478 \quad 106.6774$ $1.796 .300 \quad 33.9118$ 108.4111 $\$ 74,900 \quad 36.5965 \quad 104.5476$

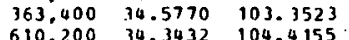
$610.200 \quad 34.3432 \quad 104.4155$ $\begin{array}{rrr}995.200 & 32.3503 & 106.3415 \\ 1.079 .300 & 32.4560 & 104.3029\end{array}$ $\begin{array}{rrr}1.079,300 & 32.4660 & 104.3029 \\ 1.029,200 & 32.7455 & 108.3969\end{array}$ $1.028 .200 \quad 32.7455 \quad 108.3969$ $\begin{array}{lll}776,500 & 34.8 .604 & 104.7994 \\ 552,700 & 35.8522 & 103.9137\end{array}$ 552.700 35.8522 103.9137 $892.900 \quad 31.9277 \quad 108.7265$ $1.258 .200 \quad 33.7522 \quad 105.4929$ $\begin{array}{rrr}258,200 & 33.7522 & 105.4929\end{array}$ $\begin{array}{rrr}28,000 & 35.8550 & 106.3199 \\ 765.900 & 32.1838 & 107.7625\end{array}$ $1.412 .600 \quad 35.5904 \quad 108.2667$ $.502 .500 \quad 36.0032$
104.0519 $1.719 .200 \quad 32.6036 \quad 105.7491$

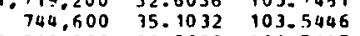
$1.513 .300 \quad 36.5025 \quad 106.7107$ $635.600 \quad 34.0227 \quad 103.4803$

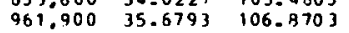
$\begin{array}{llll}1.424 .500 & 36.5083 & 108.3261\end{array}$

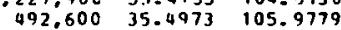
$\begin{array}{llll}1.079 .000 & 33.1297 & 107.2025\end{array}$ $1.710,200 \quad 34.0072 \quad 106.9337$ $\begin{array}{llll}584.300 & 36.5657 & 105.6416\end{array}$ 866.600 34.6306 105.8475 9RR.300 $36.4758 \quad 103.4745$ $1.575,900 \quad 33.3577 \quad 104.4566$ $1.227 .90 \mathrm{C} \quad 35.4733 \quad 104.9130$
PIPS_ST $=36$ NPW TOBK

$136.200 \quad 42.6036 \quad 73.9744$ $271,200 \quad 42.2563 \quad 78.0324$ $10.600 \quad 40.8672$ $184.900 \quad 42.1634$ 180.800 i 29198 76.5545 $290.000 \quad 42.2318 \quad 79.3705$ 107500 42.1420 233.900 42.0966 167.100 42.2514 73.6385 $130,000 \quad 42.5953-76.0550$ $373.700 \quad 42.1979 \quad 74.971$ $210.500 \quad 41.7661 \quad 73.7519$ $\begin{array}{lll}274.000 & 42.7640 & 78.7359 \\ 472.200 & 44.1161 & 73.7814\end{array}$ 433.200044 .5161 73. 7819 $129,000 \quad 43.1124 \quad 74.4275$ $129.900 \quad 42.9999 \quad 78.1991$ $169.100 \quad 42.2800 \quad 74.1320$ $949.400 \quad 43.6601 \quad 74.5035$ $371.700 \quad 43.4136 \quad 74.9718$ $335.100 \quad 44.0311 \quad 75.9174$ 1R,1nn un,fia?u 71.9553 $334.400 \quad 43.7827 \quad 75.4525$ $\begin{array}{llll}165.200 & 42.7232 & 77.7830\end{array}$ $\begin{array}{lll}171.200 & 42.9155 \quad 75.674\end{array}$ $174.800 \quad 43.1442 \quad 77.7018$ $105.700 \quad 42.9009 \quad 74.4562$ $\begin{array}{r}74.900 \quad 40.7463 \quad 73.5853 \\ \hline\end{array}$ $\begin{array}{rrr}6,000 & 40.7718 & 73.9754 \\ 137,900 & 43.1984 & 78.7369\end{array}$

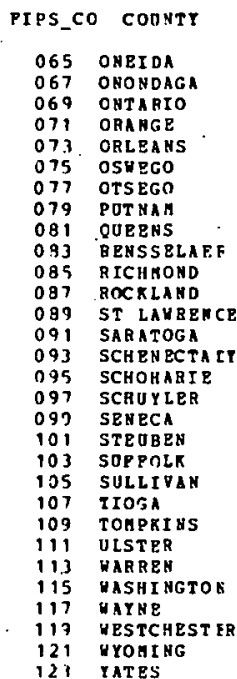

$\begin{array}{lll}127.200 & 35.2837 & 83.1912 \\ 206.400 & 35.5159 & 78.3694\end{array}$ 
Table C.2 (continued)

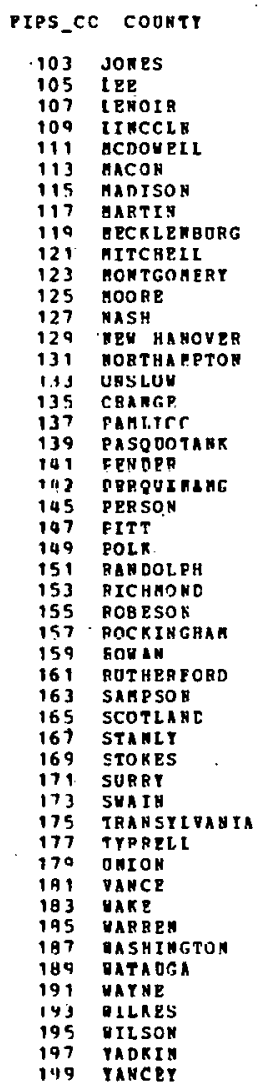

\begin{tabular}{|c|c|c|}
\hline$t$ & AtITU & \\
\hline & .0 & \\
\hline 103,600 & 35.25 & \\
\hline & & \\
\hline 112. & & \\
\hline & & \\
\hline & & \\
\hline 117.900 & & \\
\hline 137,300 & 35.2516 & \\
\hline & & \\
\hline 126.40 & & \\
\hline & & \\
\hline 140,900 & 35.95 & \\
\hline 47. & & \\
\hline & & \\
\hline 198 & & \\
\hline $\begin{array}{r}103, \\
87,\end{array}$ & & \\
\hline & & \\
\hline & & \\
\hline & & \\
\hline 103. & & \\
\hline 169. & & \\
\hline & & \\
\hline 206 & & \\
\hline & & \\
\hline 45. & & \\
\hline 400 & & \\
\hline 135, & 35. & \\
\hline & & \\
\hline & & \\
\hline & & \\
\hline 103. & & \\
\hline 118,40 & & \\
\hline 138.80 & & \\
\hline & & \\
\hline 101 & 35 & \\
\hline 165.50 & 34 & 376 \\
\hline & & \\
\hline & 35.7 & 78. \\
\hline & & \\
\hline & & 81.6 \\
\hline 144,300 & & \\
\hline & & \\
\hline & 35.7003 & \\
\hline & 35.9980 & 92,3143 \\
\hline & & \\
\hline
\end{tabular}

PIPS_ST $=39$ BORTH OAKOTA

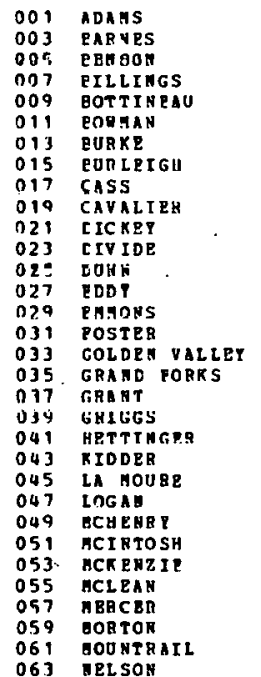

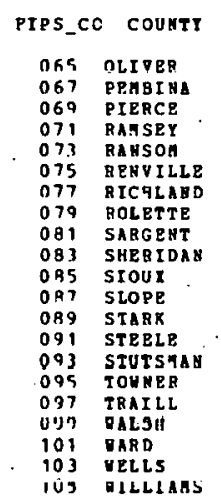

CO_AREA LATITODE LAG ITODE

$186,700 \quad 47.1163 \quad 101 . \$ 275$

$291.100 \quad 48.7700 \quad 97.5407$

$268,800 \quad 48.2503 \quad 99.5705$

$\begin{array}{rrr}323,200 & 48.2675 & 98.7219 \\ 223.000 & 46.4540 & 97.6515\end{array}$

$\begin{array}{rrr}223.000 & 46.4540 & 97.6515 \\ 229.500 & 48.7199 & 101.6577\end{array}$

$\begin{array}{rrr}229,500 & 48.7199 & 101.5577 \\ 375,300 & 46.2674 & 96.5402\end{array}$

$\begin{array}{lll}375,300 & 46.2674 & 96.5402 \\ 236.500 & 08.7747 & 99.8423\end{array}$

$220.900 \quad 46.1095 \quad 97.6240$

256.200 67.5771 100. 338

285.700 46.113. 101.033

340.300 46. 4060 103.454

340.800 46.8081 102.6545

98.900 47.4511 97.712

$270,100 \quad 48.6857 \quad 99.245$

$223.000 \quad 47.0523 \quad 97.1496$

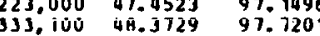

$529.000 \quad 40.3198 \quad 109.535$

$\begin{array}{rrr}529.000 & 49.2198 & 109.5354 \\ 336.400 & 4 \% .5893 & 99.6639\end{array}$

IUY RILLIABS

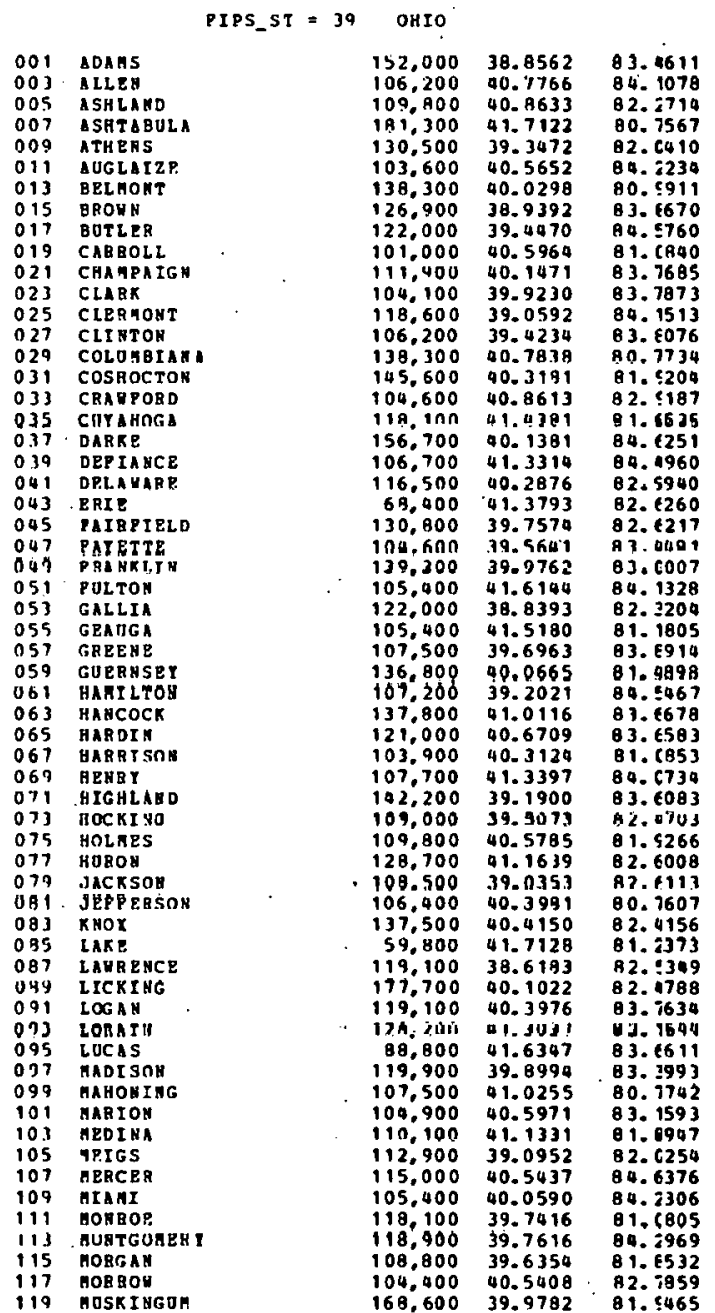


Table C.2 (continued)

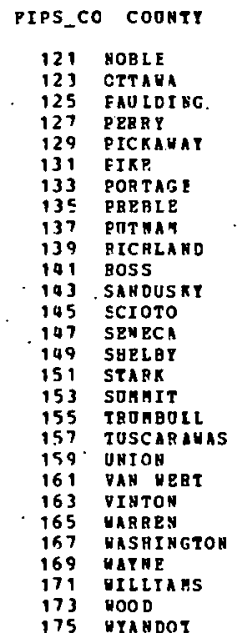

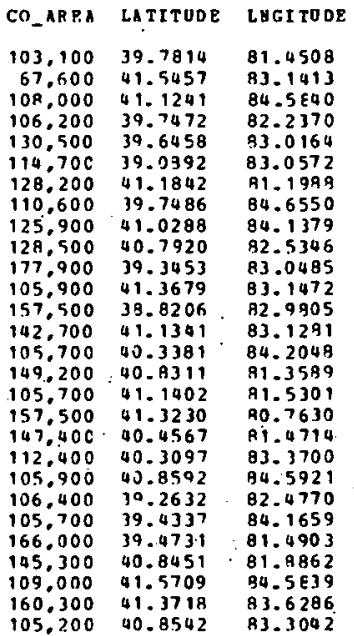

PIPS_ST $=40$ OKLAHOMA

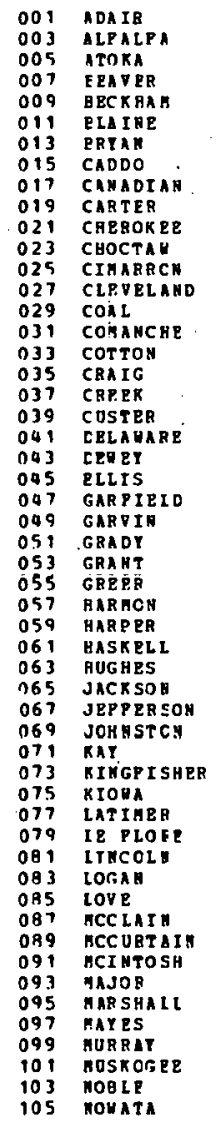

$147.600 \quad 35.9087 \quad 94.6542$ $224.800 \quad 36.7325 \quad 98.3216$ $256.700 \quad 34.3846 \quad 96.0410$ $463.600 \quad 36.7447 \quad 100.4730$ $234.900 \quad 35.2697 \quad 99.696$ $237.500 \quad 35.8696 \quad 98.4246$ $230,300 \quad 33.9652$ $329.400 \quad 35.1766 \quad 98.372$ $232.300 \quad 35.5359 \quad 97.974$ $215.000 \quad 34.2543 \quad 97.272$ 95.0106 $477,300 \quad 36.7447 \quad 102.5142$ $\begin{array}{lll}1.16 .500 & 35.2014 & 97.3287\end{array}$ $\begin{array}{lll}136.200 & 34.5947 & 96.2874\end{array}$ $\begin{array}{lll}280.800 & 34.6659 & 98.4671 \\ 168.600 & 39.2920 & 98.3579\end{array}$

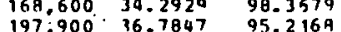
$242.400 \quad 35.9002 \quad 96.3655$ $253.800 \quad 35.6369 \cdot 989940$ $183.100 \quad 36.4323 \quad 94.8132$ $263.700 \quad 35.9865 \quad 99.0028$ $321.700 \quad 36.2072 \quad 99.7547$ $273.000 \quad 36.3709 \quad 97.7798$ $210.800 \quad 30.7112 \quad 97.3019$ $250.900 \quad 36.7946 \quad 97.7$ A5O $163,900 \quad 34.9435 \quad 49.5593$ $\begin{array}{lll}141,900 & 34.7496 & 99.9469\end{array}$ $\begin{array}{lll}141,200 & 34.7496 & 99.9469 \\ 269,600 & 36.7786 & 99.6729\end{array}$ $155,900 \quad 35.2561 \quad 95.1205$ $209.000 \quad 35.0515 \quad 96.2396$ $209.800 \quad 34.5922 \quad 99.4171$ $202,000 \quad 34.1129 \quad 97.9233$. $165,200 \quad 34.3193 \quad 96.6509$ $246.000 \quad 76.8205 \quad 97.1494$ $266.000 \quad 34.9183 \quad 99.9730$ $190,900 \quad 34.9066 \quad 95.2565$ $404.000 \quad 34.9294 \quad 94.7126$ $252.000 \quad 35.6930 \quad 96.9791$ $194.500 \quad 15.9062 \quad 97.4376$ $132.900 \quad 33.9499 \quad 97.2340$ $\begin{array}{lll}148.400 & 35.0034 & 97.4321\end{array}$ $\begin{array}{lll}466.200 & 34.1453 & 94.7943 \\ 157.500 & 35.4002 & 95.6644\end{array}$ $\begin{array}{lll}157.500 & 35.4002 & 95.6644 \\ 249.400 & 36.3116 & 99.5260\end{array}$ $\begin{array}{rrr}249.400 & 36.3116 & 99.5260 \\ 94.900 & 34.0260 & 96.7555\end{array}$ $\begin{array}{rrr}94.900 & 34.0260 & 96.7555 \\ 167.900 & 16.3320 & 95.2392\end{array}$ $\begin{array}{lll}167.900 & 16.3320 & 95 . ? 392 \\ 109.600 & 34.4987 & 97.0593\end{array}$ $\begin{array}{rrr}109.600 & 34.4987 & 97.0593 \\ 211.900 & 35.6432 & 95.3955\end{array}$ $\begin{array}{rrr}211.900 & 35.6432 & 95.3955 \\ 192.400 & 36.3865 & 97.2291\end{array}$ $201.500 \quad 34.0541 \quad 95.5468$ $283.900 \quad 35.0173 \quad 97.3901$ $234.100 \quad 35.9347 \quad 97.9355$

\begin{tabular}{|c|c|}
\hline 107 & OKPUSKEE \\
\hline 109 & OKLAHOHA \\
\hline 111 & OXnULGER. \\
\hline 113 & CSage \\
\hline 115 & OTTAWA \\
\hline 117 & PAYYEE \\
\hline 119 & PATHE \\
\hline .121 & PITTSBUAG \\
\hline 123 & PONTOTOC \\
\hline 125 & FOTTAYATOHIE \\
\hline 127 & POSUMATAHA \\
\hline 129 & ROGER AILTS \\
\hline 131 & ROGERS \\
\hline 133 & SEM I HOLE \\
\hline 135 & SEQUOYAH \\
\hline 137 & STEPHBNS \\
\hline 137 & TEXAS \\
\hline 141 & TILLAAB \\
\hline 143 & TULSA \\
\hline 145 & WAGOHER \\
\hline 147 & WASHIHGTOS \\
\hline 149 & WASHITA. \\
\hline 151 & NOODS \\
\hline & P000RARD \\
\hline
\end{tabular}

CO AREA LATITODE LOG ITUDE

$\begin{array}{llr}165,000 & 35.4654 & 96.5105 \\ 181,300 & 35.5395 & 97.4030 \\ 181,300 & 35.6569 & 95.96 .10 \\ 583,400 & 36.6343 & 96.4040 \\ 120,200 & 36.8521 & 94.8194 \\ 145,300 & 36.3190 & 96.6999 \\ 179,700 & 36.0709 & 96.5749 \\ 321,400 & 34.9494 & 95.7447 \\ 184,900 & 34.7320 & 96.6746 \\ 205,600 & 35.2019 & 96.5943 \\ 367,900 & 34.4497 & 95.5856 \\ 295,300 & 35.6932 & 99.6994 \\ 177,400 & 36.3996 & 95.6113 \\ 163,200 & 35.1699 & 96.5998 \\ 180,300 & 35.5225 & 94.7634 \\ 230,800 & 34.0971 & 97.6459 \\ 534.100 & 36.7447 & 101.9791 \\ 233,400 & 34.3761 & 98.9210 \\ 109,400 & 36.1324 & 95.5029 \\ 105,800 & 35.9861 & 95.5391 \\ 109,800 & 36.7275 & 95.9138 \\ 261,300 & 35.2922 & 98.5909 \\ 336,200 & 36.7703 & 98.6717 \\ 324,000 & 36.4174 & 99.2605\end{array}$

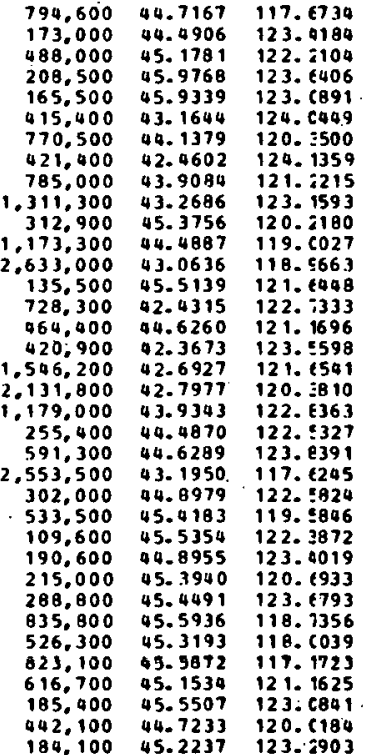

PIPS_ST = 42 PEMASTLAEIA

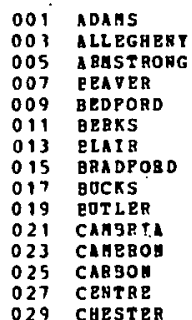

$\begin{array}{lll}136,200 & 39.8770 & 77.2181 \\ 188,600 & 40.4697 & 79.5805 \\ 168,900 & 40.8170 & 79.9651 \\ 114,000 & 40.6814 & 80.3492 \\ 263,700 & 40.0093 & 78.4891 \\ 223,300 & 40.4201 & 75.5290 \\ 137,300 & 40.4829 & 78.3499 \\ 297,300 & 41.7891 & 76.5269 . \\ 159,000 & 40.3451 & 75.1068 \\ 205,600 & 40.9102 & 79.5147 \\ 179,200 & 40.4977 & 78.7106 \\ 103,900 & 41.4327 & 78.5061 \\ 104,600 & 40.9202 & 75.7081 \\ 288,800 & 40.9227 & 77.8298 \\ 197,100 & 39.9812 & 75.7405\end{array}$


Table C.2 (continued)

\begin{tabular}{|c|c|}
\hline 0.31 & CLARIOS \\
\hline 033 & CLPARPIELD \\
\hline 035 & CLINTON \\
\hline 037 & COLUnAIA \\
\hline 739 & CQANPOAD \\
\hline 341 & CUMBEBIAKD \\
\hline 043 & CAUEH I H \\
\hline 045 & DRLAYARE \\
\hline 047 & ELR \\
\hline 049 & ERIE \\
\hline 051 & PATETTE \\
\hline 053 & FOR EST \\
\hline 055 & PQARKLIA \\
\hline 057 & PULTOH \\
\hline 059 & GREEHE \\
\hline 061 & HUNTINGOON \\
\hline 063 & IHDIANA \\
\hline 065 & JEPPEA $98 \|$ \\
\hline 067 & JUH YAT \\
\hline 069 & LACXAVARHA \\
\hline 071 & LANCASTER \\
\hline 073 & LAURENCE \\
\hline 075 & I EBAMOA \\
\hline 077 & LEHIGH \\
\hline 270 & LUZRRN \\
\hline 091 & LICOAI \\
\hline 093 & ICKEAN \\
\hline 085 & HERCER \\
\hline 097 & DIFPLIN \\
\hline 099 & EOH ROE \\
\hline $\begin{array}{l}291 \\
043\end{array}$ & $\begin{array}{l}\text { BCETGORERT } \\
\text { MOHTCHE }\end{array}$ \\
\hline 095 & HORTHA PPTOS \\
\hline 097 & NCRTHUAEEPLAND \\
\hline 099 & PQR R T \\
\hline 101 & PHILADELPHIA \\
\hline 103 & FIKE \\
\hline 105 & POTTER \\
\hline 107 & SCHOYLAILL \\
\hline 109 & SNYOER \\
\hline 111 & SOHEPSET \\
\hline 113 & SOLLIVAN \\
\hline 115 & SUSQOREANAA \\
\hline$! 17$ & $\operatorname{IIOCA}$ \\
\hline 119 & OYION \\
\hline 121 & PEHANGC \\
\hline 123 & WATREN \\
\hline 125 & MASHIHGTON \\
\hline 127 & DAYHE \\
\hline 129 & NEST MO RELA SD \\
\hline 131 & DYOHING \\
\hline 133 & YOR K \\
\hline
\end{tabular}

CO_aRE LATITUde LNGITUDE

$154.600 \quad 41.1943$

$295.000 \quad 41.0015$

$2 \mathrm{J2}, 900 \quad 41.2335$

$125.40 \mathrm{C}$
762.11 .0446

143.70040 .1690

$134.200 \quad 40.4133$

$47.700 \quad 39.9212$

209.000 a 1.0207

$207.700 \quad 33.0231$

$108,500 \quad 41.5030$

$195,300 \quad 39.9258$

112,700 .17:9260

$149,700 \quad 39.8551$

$231.800 \quad 40.4223$

$900,900 \quad 41.1237$

100.000 4.2.57

$117.600 \quad 41.4347$

245.000
95,100
40.0465

$\begin{array}{ll}95,100 & 40.9914 \\ 94,300 & 40.3685\end{array}$

94,300
00,100
00.6171

$229.500 \quad 41.1770$

$256.900 \quad 41.9067$

$173.500 \quad 41.2989$

$111.600 \quad 40.6 C 79$

$15 R, 200 \quad 41.0501$

$128.500 \quad 40.2183$

$33.700 \quad 41.0205$

$117,300 \quad 40.8428$

$142.700 \quad 40.4031$

$33.400 \quad 39.9920$
$140.400 \quad 49.3327$

$140,400 \quad 41.3327$

203.10040 .707

$84.700 \quad 40.7688$

$279,200 \quad 39.9772$

$123.800 \quad 41.4409$

$215,700 \quad 41.8219$

$276,700 \quad 41=7647$

A2.400 40.9612

$175,600 \quad 41.3923$

$234.400 \quad 41.8091$

$\begin{array}{ll}222.000 & 40.1867 \\ 191.900 & 41.6519\end{array}$

191.900
265.200 40.6519

$265,200 \quad 40.3147$

$235,400 \quad 39.9263$

79.4137
79.4779

77.6417

76.4349
90.9135

80.1135
77.2687

76.7812

75.2006

78.6456
80.0340

79.6463

79.2264
7.7185

70.1121

90.2212

79.0806

75.946

77.4079

75.5166

80. 3305

76.4537

75.5912

77.0670

79.5736

80. 2593

77.6073

75.365

76.6599
75.3107

76.7099

77.2532

75.1210
75.0503

75.0503
77.9020

76.2145

77.066

76.3247

75.9078

77.2037

77.0552

79.2766

90.2477

75.3115
79.4537

76.0294
76.7308

PIPS_ST = 44 RHODE ISLAND

$6.500 \quad 41.7133$

$44.800 \quad 41.6783$

$107.700 \quad 41.876$

Q., 100 i1 1.4807

71.2591

71.579

71.2315
71.5773

005 . NQW PORT
007 FROVIDERCE

7 i. $6,25,3$

PIPS_ST = 45 SOUTH CAROLIHA.

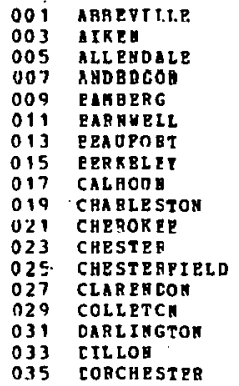

$111: 100 \quad 34.2296$

$281,500 \quad 33.5517$

$108,300 \quad 32.9949$

134,000 34.5211

$102.300 \quad 33.2168$

$\begin{array}{ll}143,200 & 33.2689 \\ 150,000 & 32.3720\end{array}$

$287,500 \quad 33.2038$

$97.600 \quad 33.6860$

$243.200 \quad 32.8399$

$102.000 \quad 35.0564$

$151,300 \quad 34.6932$

200,6100
155,100
$33.6,6727$

$271.700 \quad 32.8726$

$140,600 \quad 34.3330$

105,400
147.400
33.0767

82.4602

B1.6472

81.3575

81.0468

91.4412

80.7927

79.9483

80.7775
79.9714

B 1.6247

81. 1567

An. 1412

80.2040
80.6707

79.9498

79.3655
80.3995

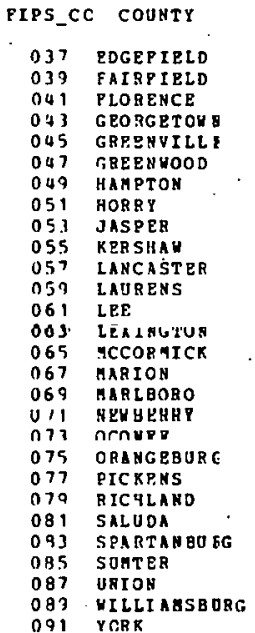

CO AREA LATITUDE LNGITUDE

$124.800 \quad 33.7799 \quad 81.9785$

180,300 34..3981 A1, 120

$208,500 \quad 34.0249 \quad 79.68$ 99

$210.300 \quad 33.4441 \quad 79.3328$

$205,100 \quad 34.8950$ B2. 711

$\begin{array}{lll}115,500 & 34.1586 & 82.1192 \\ 145,600 & 32.7789 & 81.1430\end{array}$

$299,900 \quad 33.9217 \quad 78.5869$

$169.900 \quad 32.4712 \quad 81.5364$

$202,300 \quad 34.3574 \quad 80.5854$

$130,000 \quad 34.7085 \quad 80.7063$

1 A4. $100 \quad 34.490 \mathrm{~B} \quad 82.0068$

$105.900 \quad 34.1658 \quad 80.2494$

$183.100 \quad 31.9060 \quad 81.2756$

$\begin{array}{rrr}93,200 & 33.9114 & 02.2195 \\ 126.100 & 34.0865 & 79.3497\end{array}$

$125,100 \quad 34.5958 \quad 79,665$

$164.50034 .295 i$. 1.6020

160,1900 J4.7472 03.6700

$286,500 \quad 33.4468 \quad 60.8003$

$127.400 \quad 34.8946 \quad 62.7360$

$193.700 \quad 34.0254 \quad 80.6972$

$\begin{array}{lll}118.600 & 30.0095 & 81.7261\end{array}$

$215.200 \quad 34.9400 \quad 81 . \$ 916$

$174.000 \quad 33.9139 \quad 80.3749$

$\begin{array}{lll}133,100 & 34.6918 & 81.6175 \\ 20 ? .200 & 33.6268 & 79.7202\end{array}$

$\begin{array}{rrr}207.200 & 33.6268 & 79.7202 \\ 177.200 & 34.9807 & 81.1876\end{array}$

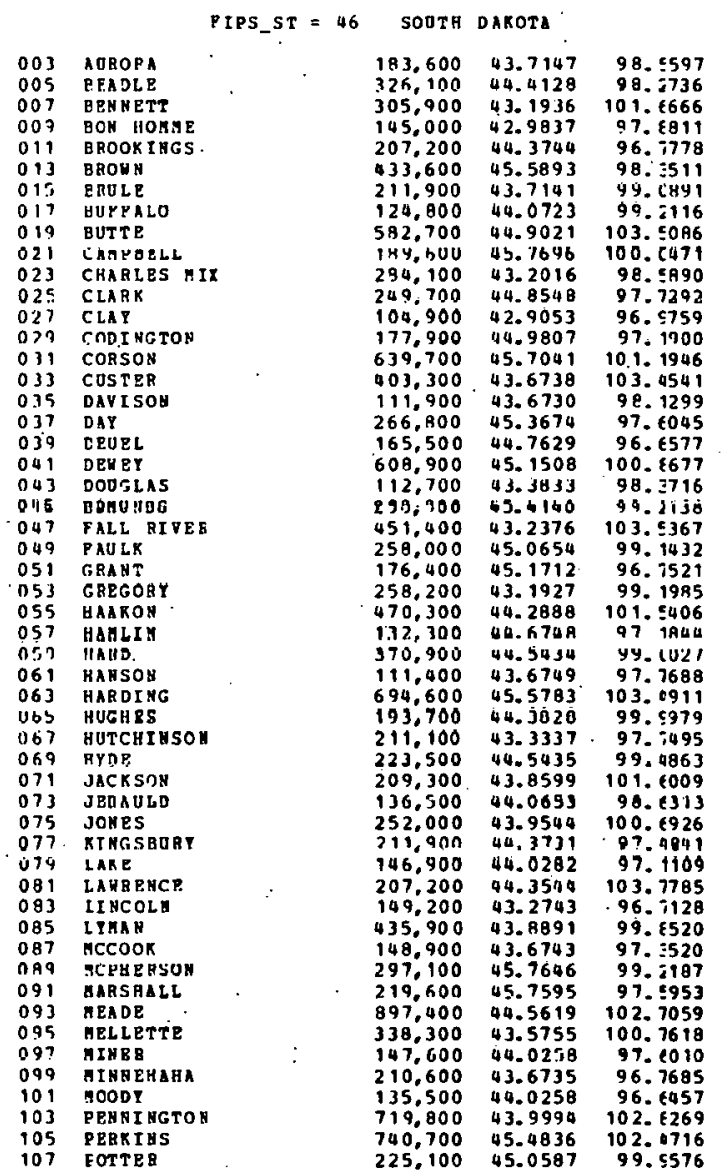


Table C.2 (continued)

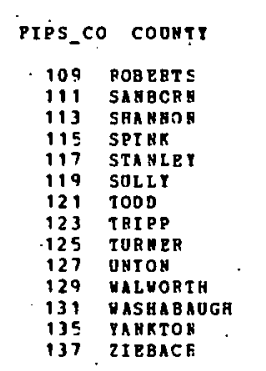

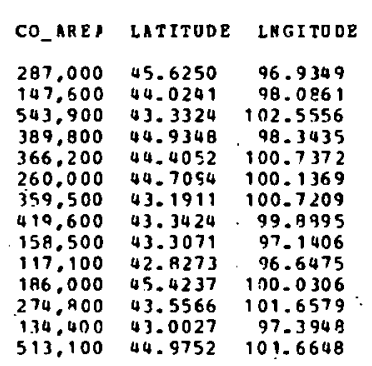

PIPS_ST $=47 \quad$ TENNESSER

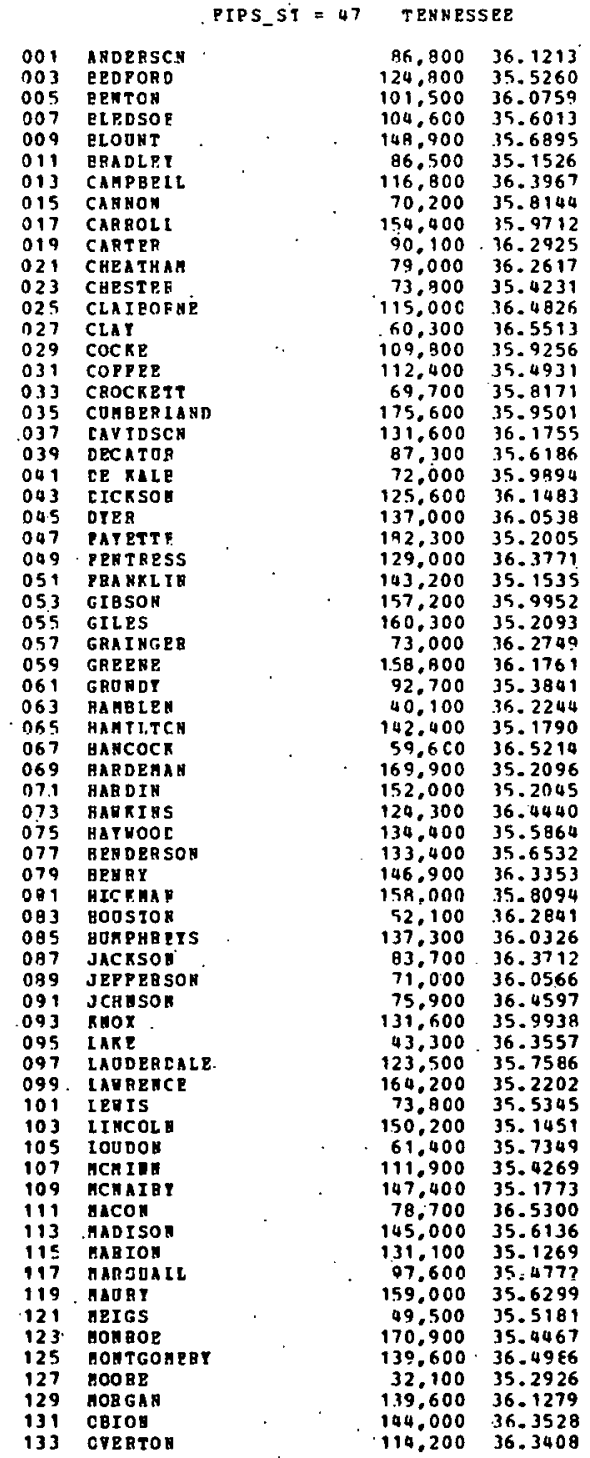

94. 1987 86. 4571 A8. 0742
B5. 2072 33.9238 84. 8629 Q4. 1452 96.0524
88.4536 $92.12 \% 4$ 87. 0932 ค9. 6176 93.6711
85.5344 85. 5344
83.1152 86.0531 89.1393 86.7796 ค8. 1131 85.9403
87.3637 A7. 3637 89.4128
99.4168 99.4168
94.9326 84.9326
86.0341 86.0341
88.9333 88.9333
97.0282 97.0282
83.4961 B2. 8461 A5. 7182
83.2377 83.2377
85.1718 85.1718
83.2121 83. 9951 88.9951
88.1926 82.9327 89. 268 म 88.3889
88.3067 88.3067
97.4818 87.7370 A5. 6734 83.4340
81.8450 81. 8450 63. 9384 89.4947
89.6236 87.3928 87.4903 86.5775 80.3144 84.6143
88.5735 86.0300 98.8344 85.6170 R6. 7619
67.0780 87.0700
84.8055 84.8055
84.2526 87. 3846 86.3556 84.6487
89.1564 89.1564
A5. 2948

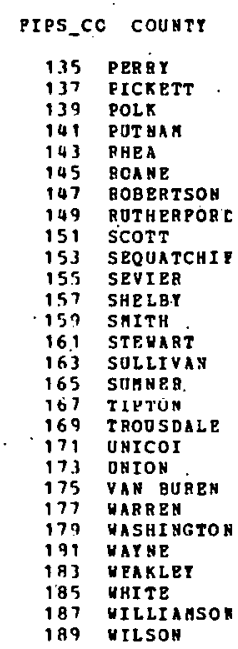

CO_AREA LATITUDE LHGITUDE

\begin{tabular}{|c|c|c|}
\hline $\begin{array}{r}106,400 \\
40,900 \\
112,400 \\
104,900 \\
90,800 \\
90,500 \\
123,300 \\
158,500 \\
140,900 \\
70,700 \\
159,600 \\
195,500 \\
83,700 \\
121,700 \\
107,000 \\
138,300 \\
119,900 \\
29,500 \\
47,900 \\
54,900 \\
65,800 \\
113,700 \\
83,700 \\
191,400 \\
149,200 \\
98,900 \\
153,600\end{array}$ & $\begin{array}{l}35.6421 \\
36.5629 \\
35.1189 \\
36.1455 \\
35.6066 \\
35.8524 \\
36.5281 \\
35.8506 \\
36.4323 \\
35.3829 \\
35.7903 \\
35.11979 \\
36.2606 \\
36.5009 \\
36.5116 \\
36.4701 \\
35.4973 \\
36.3893 \\
36.1020 \\
36.2851 \\
35.6999 \\
35.6811 \\
36.2968 \\
35.2491 \\
36.3004 \\
35.9267 \\
35.8975 \\
36.1567\end{array}$ & $\begin{array}{l}87.6642 \\
85.6687 \\
84.5286 \\
85.5554 \\
84.5281 \\
84.5138 \\
86.6720 \\
86.4050 \\
84.4954 \\
85.4202 \\
83.5213 \\
89.5841 \\
85.5571 \\
87.6357 \\
82.2032 \\
86.0537 \\
99.7386 \\
86.1494 \\
82.4430 \\
83.6313 \\
85.0489 \\
85.7656 \\
82.4970 \\
87.5913 \\
88.7245 \\
85.4617 \\
86.8951 \\
86.5919\end{array}$ \\
\hline
\end{tabular}

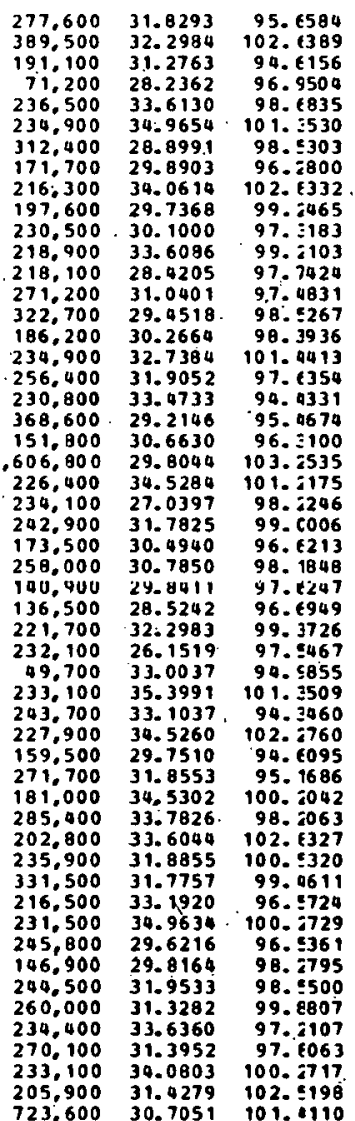


Table C.2 (continued)

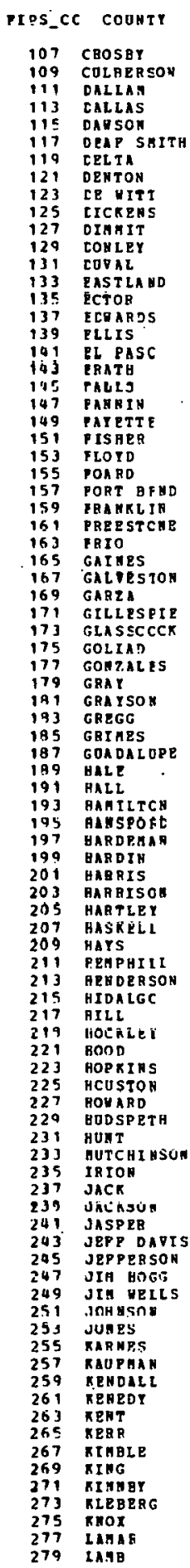

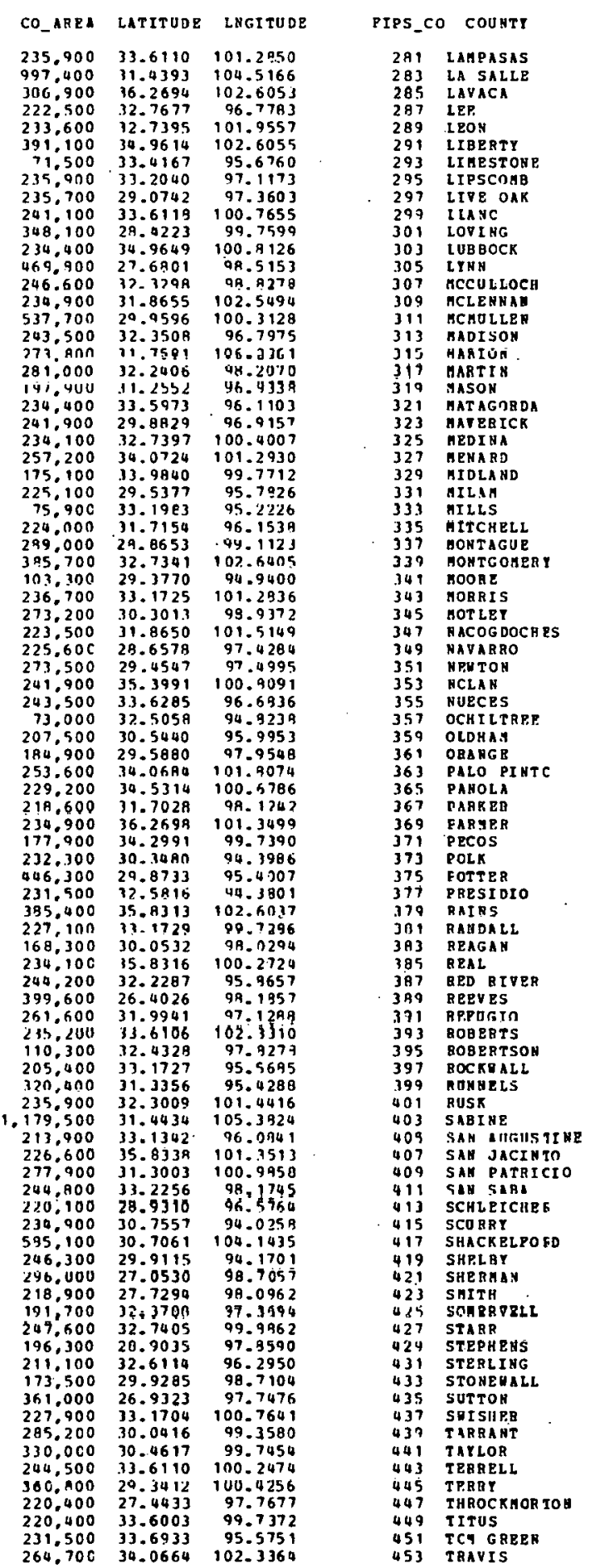

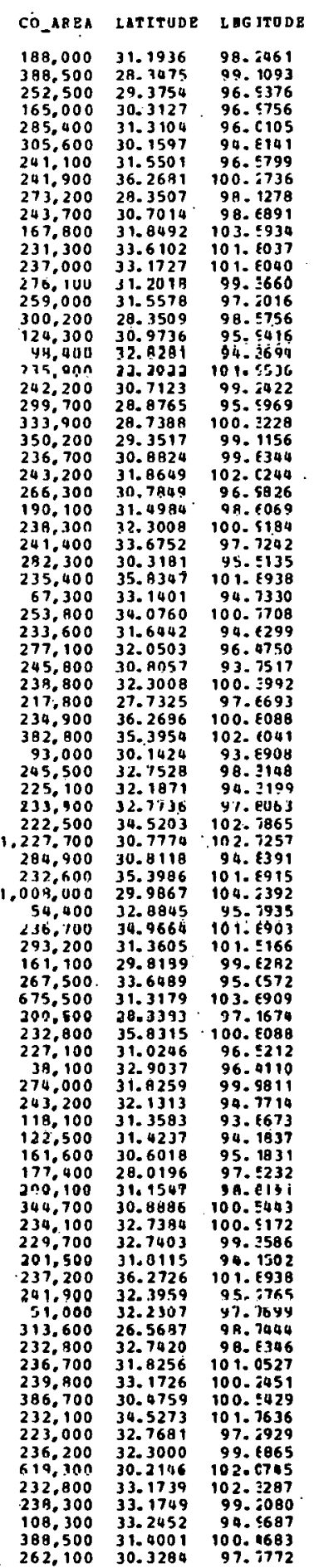


Table C.2 (continued)

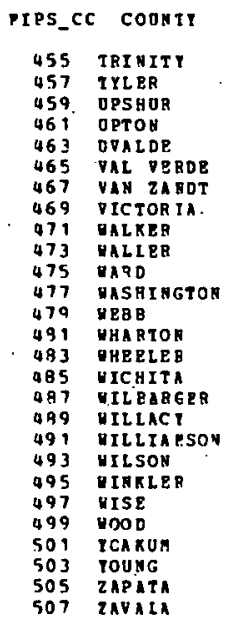

CO_AREA LATITODE LAGTTUDE

$133.100 \quad 31.1043$

$339.800 \quad 31.3590 \quad 102.9433$

$411.300 \quad 29.3484 \quad 02.0333$

$839.400 \quad 29.8757 \quad 101.1499$

$218.900 \quad 32.5944 \quad 95.9477$

$231.000 \quad 28.7904$

$204,600 \quad 30.7545$

$131.900 \quad 30.0075$

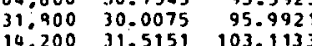

$856.300 \quad 27.7642 \quad 99.3446$

$278.700,20.2789 \quad 06.2426$

$\begin{array}{lll}236.700 & 35.3983 & 100.2711\end{array}$

$158.200 \quad 33.9898 \quad 98.7003$

$246.600 \quad 34.0797 \quad 99.2377$

153.100
285.4929 97.6959

$\begin{array}{lll}285.900 & 30.6494 & 97.6960 \\ 207.700 & 29.1787 & 98.084\end{array}$

$\begin{array}{rrr}207.700 & 29.1787 & 98.0342 \\ 229,700 & 31.8475 & 103.0699\end{array}$

$239.900 \quad 33.2120 \quad 97.657$

$196,700 \quad 32.9096 \quad 95.3338$

$\begin{array}{rrr}215.000 & 33.1678 & 102.9302 \\ 230.300 & 33.1790 & 98.6953\end{array}$

$230.300 \quad 33.1790 \quad 98.6953$

247.900
3.44 .400 27.0075

99.7622
PIPS ST $=49$ UTAH

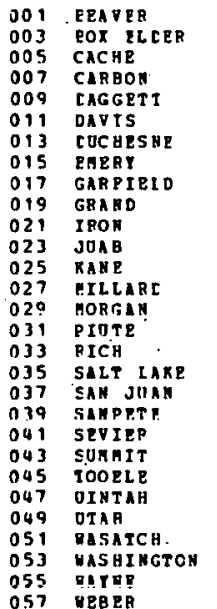

$\begin{array}{llll}669.300 & 38.3692 & 113.2333\end{array}$

$1.451 .200 \quad 41.5265 \quad 113.0942$

$304.100 \quad 41.7266 \quad 111.7527$

$382.300 \quad 30.6509 \quad 110.5918$

$176.600 \quad 40.9806 \quad 109.5125$

$76,900 \quad 40.9963 \quad 112.1188$

$\begin{array}{lll}843.000 & 40.3004 \quad 110.4346\end{array}$

$1,149.700 \quad 32.9970 \quad 110.7009$

$.335 .900 \quad 37.9587 \quad 111.4340$

$95.3 .60 \mathrm{C}$ 3R.9869 100.573

$854.700 \quad 37.8647 \quad 113.2906$

$893,700 \quad 39.7044 \quad 112.794$

.07 .00037 .2841 111.8976

156.400 39.0771 113.0978

195.200 41.0396 1.11.598

$195.300 \quad 38.1413$
265.000 112.1226

$97.000 \quad 406313,11.2534$

$1.996 .100 .37 .6246 \quad 109.7389$

$413.600 \quad 39.3804 \quad 111.5790$

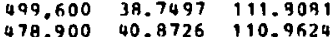

$.478 .900 \quad 40.8726$
110.9624
$1.793 .100 \quad 40.4517$
113.1289

$1.162 .100 \quad 40.1208 \quad 109.5265$

$\$ 21,600 \quad 40.1261 \quad 111.674$

608.500 40.3311

6.

150.500 41. $2707 \quad 111.992$
PIPS_ST $=50$ VERRONT

001 MDDISON

003 BETHINGTON

005 CALEDONIA

007 CRITI

009 ESSEX

013 GRAMRL IST

015 GAmoIL

017 CBANGE

OIg CRLEABS

021 guteanc

023 MISHIUGTO

027 WINDSOB

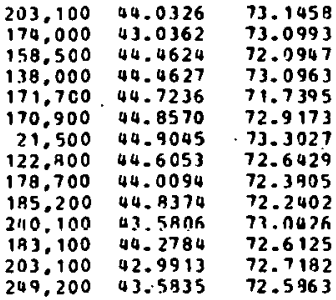

PIPS_ST $=51^{\circ}$ VIRGINIA
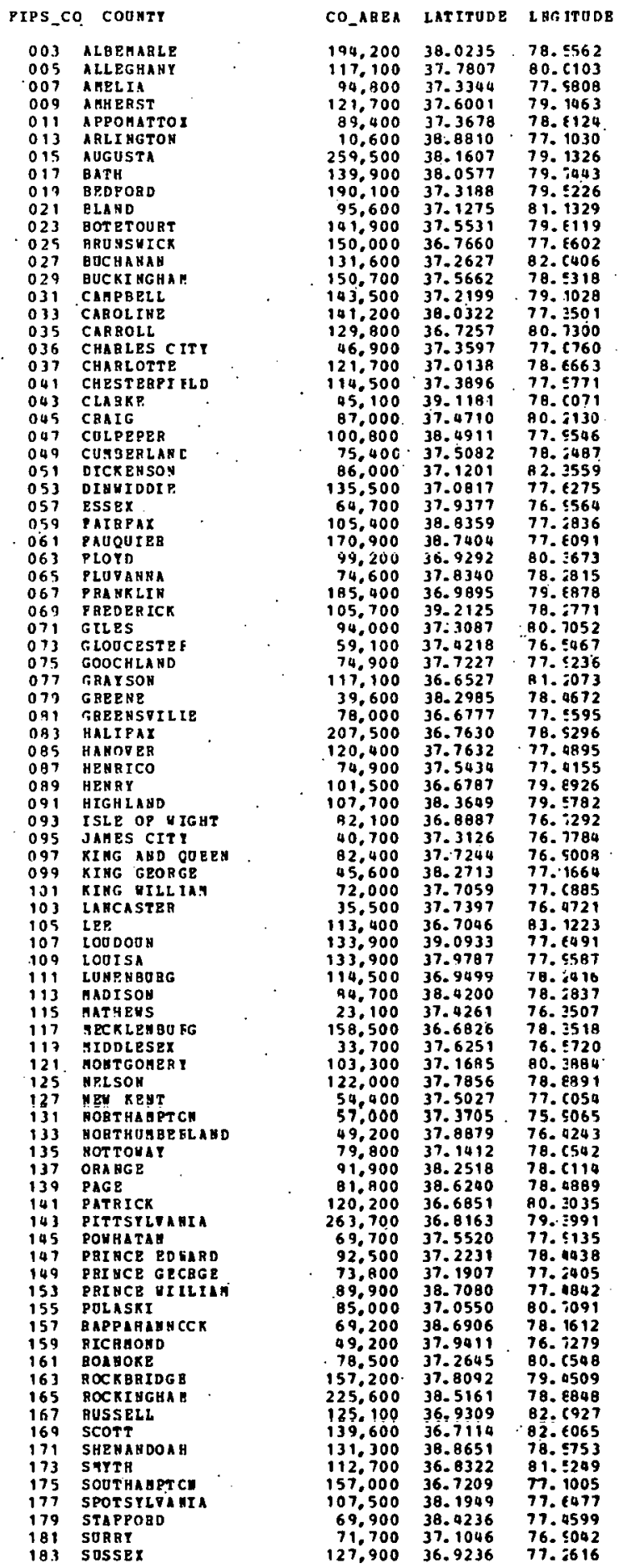

78.5562

$89.400 \quad 37.3678$

$259.500 \quad 38.1607 \quad 79.1326$

$\begin{array}{lll}39.0577 & 79.7443\end{array}$

$95,600 \quad 37.1275 \quad 81.1329$

77. 6602

$\begin{array}{lll}131.600 \quad 37.2627 & 82.1406\end{array}$

79.9318

77.350

$\begin{array}{lll}46.900 & 36.7257 & 80.7300\end{array}$

$121.700 \quad 37.0138$

$714.500 \quad 37.3896,77.5771$

87.000 37.4710 A0.3130

$00.800 \quad 38.4911 \quad 77.5546$

$\begin{array}{ll}75,400.37 .5082 & 78.3487 \\ 86,000 & \end{array}$

$\begin{array}{llll}35.500 & 37.0817 \quad 77.6275\end{array}$

.8836
.8091

79.8878

78.2771

0.7052

7.5236
1.2073

8.4672
7.5595

8. $\$ 296$

0895
.0155

-1
5782

.292

6. 5008

.1664

7. 6885

3. 1223

7.5587

.2837

. 3518

5720

8. 889

7. $\cos 4$

76. 9243

(1)

8. 4889

.$\$ 991$

. $\$ 135$

2405

. 0091

6. 7279

.6548

8. 8848

2. $(927$

8.573

7. 1005

7.4599

77.8616
001 Accomack

$123.300 \quad 37.7704 \quad 15.5312$ 
Table C.2 (continued)

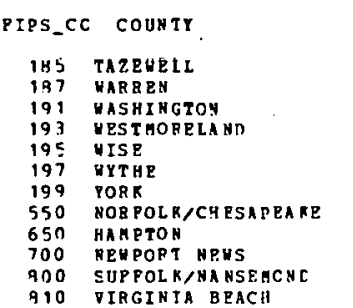

\begin{tabular}{|c|c|c|}
\hline CO_AREA & LATITUDE & LNGITRDE \\
\hline & 37.1203 & 81.5602 \\
\hline $\begin{array}{r}56,700 \\
149,700\end{array}$ & $\begin{array}{l}38.9179 \\
36.7240\end{array}$ & $\begin{array}{l}78.2128 \\
91.7544\end{array}$ \\
\hline 59.300 & 19. 1104 & 76.9322 \\
\hline 107,700 & 36.3705 & 82.5209 \\
\hline 119,100 & 16.9066 & 81.0709 \\
\hline 33.400 & .37 .2159 & 76.5371 \\
\hline 109.600 & .36 .6998 & 76.3073 \\
\hline & 37.0436 & 76.3477 \\
\hline 17,900 & .36 .9722 & 76.4168 \\
\hline 105,700 & 36.6908 & 76.6396 \\
\hline 67.100 & 36.7362 & 76.2254 \\
\hline
\end{tabular}

\begin{tabular}{|c|c|}
\hline ? 1 & AUA AS \\
\hline กก? & $\operatorname{snt} \operatorname{sit}$ \\
\hline 005 & EQNTON \\
\hline 007 & $\begin{array}{l}\text { CHELAN } \\
\text { CLALLAA }\end{array}$ \\
\hline $\begin{array}{l}609 \\
\text { bi }\end{array}$ & $\begin{array}{l}\text { CLALLAA } \\
\text { CEARK }\end{array}$ \\
\hline 013 & COLUABIA \\
\hline 015 & COWLIT2 \\
\hline 017 & covgLAs \\
\hline 019 & JERTI \\
\hline 021 & PRANKLIE \\
\hline 023 & GARPIEIC \\
\hline 025 & GRANT \\
\hline 727 & GRATS FARBOR \\
\hline 029 & ISLAHD \\
\hline 031 & JFP PPRSCN \\
\hline 033 & KING \\
\hline 335 & RITSAP \\
\hline 037 & RITTTTAS \\
\hline 039 & KLICXITAT \\
\hline 041 & I EU IS \\
\hline 043 & I I NCOL A \\
\hline 045 & MASON \\
\hline 047 & CRAHOGAH \\
\hline 049 & FAC1FLC \\
\hline 051 & PBND OREILLE \\
\hline 033 & FERLE \\
\hline 055 & SAY JUAE \\
\hline 057 & SKAGIT \\
\hline 059 & SEAHAKIA \\
\hline 061 & SNOHOAISH \\
\hline 003 & SPURABE \\
\hline & STEVRAS \\
\hline 1067 & 1 HUBSTCN \\
\hline 069 & GAHKIAROE. \\
\hline 071 & EALLA BALLA \\
\hline 073 & WHATCOE \\
\hline 075 & WHITAN \\
\hline ר> & VAR.JAB \\
\hline
\end{tabular}

PIPS_SI $=53$ AASHINGTON

\begin{tabular}{|c|c|c|c|c|}
\hline & & & & FA HDOL \\
\hline 490,500 & 46.9825 & 110.5549 & 085 & HITCHIE \\
\hline & 40.2004 & 117.1499 & 081 & $\begin{array}{l}\text { ROANE } \\
\text { SOMYERS }\end{array}$ \\
\hline $\begin{array}{r}446,000 \\
755.900\end{array}$ & $\begin{array}{r}46.2348 \\
47.8698\end{array}$ & $\begin{array}{r}119-5162 \\
120-6199\end{array}$ & $\begin{array}{l}089 \\
091\end{array}$ & $\begin{array}{l}\text { SUATERES } \\
\text { TAYLOR }\end{array}$ \\
\hline $\begin{array}{l}755,900 \\
450,01.0\end{array}$ & 48.0609 & 13.9 .9196 & 093 & THEREA \\
\hline $16 ?$, anก & 45.7607 & 132.4990 & 025 & TPLEA \\
\hline 220,900 & 46.3032 & 117.9165 & 097 & UPSHUR \\
\hline 296,300 & 46.1866 & 122.6826 & 099 & UAYNE \\
\hline 4711,200 & 47.7277 & 119.7006 & 101 & UPBSTER \\
\hline 570,300 & 18.9669 & 11 A. 5182 & 103 & WE'TZEL \\
\hline 324,500 & 46.5366 & 118.9042 & 105 & VIRT \\
\hline & 46.4298 & 117.5490 & 107 & vinoo \\
\hline & 47.1993 & 119.0567 & 109 & HYO I No \\
\hline
\end{tabular}

CO_AREA LATITUDE LNGITUDE

R0. $500 \quad 39.5120$

79.700
112.100
18.7694

$108.000 \quad 37.4025$
82.6250

$85.500 \quad 39.4110 \quad 78.5510$

$\begin{array}{lll}09.600 \quad 37.7237 & 82.1354\end{array}$

$94.500 .39 .6329 \quad 80.0375$

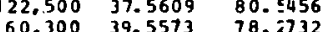

$\begin{array}{lll}60.300 & 39.5573 & 78.2732\end{array}$

66,300
27.500

$\begin{array}{rrr}27.500 & 40.1049 & 80.6246 \\ 180.000 & 38.6806 & 79.2618\end{array}$

$33.400 \quad 39.3743 \quad 81.1727$

33.400
244.3743 81.9727

$\begin{array}{lll}244,200 & 30.3329 & 80.60 \% 5 \\ 167.100 & 39.4691 & 79.6717\end{array}$

$90.100 \quad 38.5039$ 91. 5052

$156.700 \quad 37.7699 \quad$ B1. 3466

200,300 jo. 718 19. th2s

117.100 39.1A2? RI KALT

$125,900 \quad 38.7161$ A 1.3420

$\begin{array}{lll}90,600 & 37.6492 & 80.6564 \\ 45.100 & 39.3368 & 80 .(47)\end{array}$

$109.000 \quad 39.1140 \quad 79.5505$

$66.300 \quad 39.4709$ 80. E977

$\begin{array}{rrr}91,200 & 38.9046 & 80.2353 \\ 132.900 & 38.1535 & 82.0702\end{array}$

$\begin{array}{lll}132.900 & 38.1535 & 82.0202 \\ 142.700 & 38.4973 & 80.4176\end{array}$

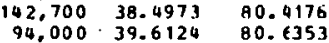

$\begin{array}{lll}94.000 & 39.6124 & 80.6353 \\ 60.900 & 39.0265 & 81.2761\end{array}$

$95.300 \quad 39.2199 \quad 81.5168$

$130,500 \quad 3 \% 6090$

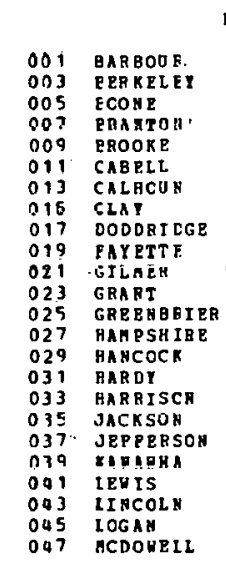

PIPS_5T - 54 WEST VIRGINIA

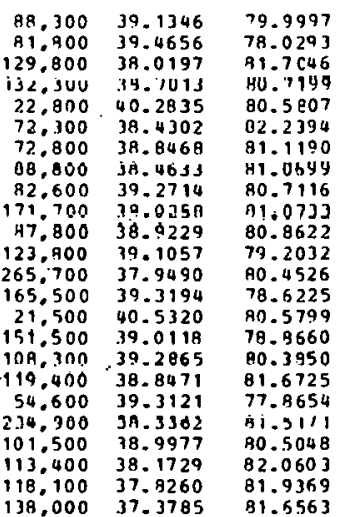

\begin{tabular}{|c|c|c|c|c|c|}
\hline & & $\mathbf{S T}=$ & WISC & 5 IF & \\
\hline $\begin{array}{llll}0 & 0 & 1 \\
0 & 0 & 3\end{array}$ & $\begin{array}{l}\text { ADAMS } \\
\text { ASHLAND }\end{array}$ & & $\begin{array}{r}167,300 \\
268,800\end{array}$ & $\begin{array}{r}43.9711 \\
46.2660\end{array}$ & $\begin{array}{l}89.7612 \\
90.6743\end{array}$ \\
\hline $\begin{array}{l}05 \\
07\end{array}$ & BARROY & & 223,800 & 45.4325 & 91.8535 \\
\hline ng & $\begin{array}{l}\text { BAYPI PI.D } \\
\text { BROY }\end{array}$ & & 378,100 & $\begin{array}{l}46.5096 \\
44.4530\end{array}$ & 88,19033 \\
\hline 11 & BUPPALO & & 184.100 & $\begin{array}{r}4.4530 \\
44.3901\end{array}$ & 91.7551 \\
\hline 11 & AHBU BTT & & 217,600 & 45.0599 & 42.9843 \\
\hline 15 & CALOAET & & 83,400 & 44.0805 & 88.2166 \\
\hline 17 & СHIPPEUA & & 263,700 & 45.0763 & 91.3768 \\
\hline 17 & CLARR & & 316.200 & 44.7380 & 90.6084 \\
\hline 21 & COLUABIA & & 201.000 & 43.4692 & 69. $\$ 347$ \\
\hline 33 & CPAHPOAD & & 147,100 & 43. 2jyu & yo. 5232 \\
\hline 25 & nANE & & 310,300 & 43.0691 & 89.0196 \\
\hline 37 & DoDr. & & 230,300 & 45.4181 & 48. 067 \\
\hline 29 & DOOR & & 127.400 & 44.9096 & A7. $: 465$ \\
\hline 13 & DOUGLAS & & 339.000 & 46.4265 & $91 . \$ 201$ \\
\hline 33 & DUNN & & 220,900 & 44.9513 & 91.5025 \\
\hline 35 & EAU CLAIRE & & 167,600 & 44.7289 & 91.2860 \\
\hline 37 & PLOREHCR & & $12 k$, inn & 45.8495 & 86.4089 \\
\hline 39 & FOHO DU I AC & - & 187,800 & 43.7536 & 88.4956 \\
\hline 041 & FOREST & & 260,800 & 45.6639 & 88.7718 \\
\hline 043 & GRANT & & 297,100 & 42.8696 & 90.6997 \\
\hline 45 & GREEN & & 151. & & 89.6074 \\
\hline 047 & GREEN LAKE & & 91,700 & 43.8 & B9. 1432 \\
\hline 043 & IOWA. & & 197,400 & 43.0 & 90.1355 \\
\hline 0.51 & IAOH & & 191.5 & 46.2 & 90.2432 \\
\hline 053 & TACKSOH & & & 44.3 & 90.8046 \\
\hline 055 & JEP ER RSOH & & 146,100 & 43.0231 & $88 . ; 766$ \\
\hline & MUNPAII & & $3 n n, 500$ & 30.9230 & 90.1051 \\
\hline 059 & R PNOSHA & & 70,400 & 42.5831 & 88. 0464 \\
\hline 061 & KEYAUNEE & & 85.500 & 44.50 & R 7,6154 \\
\hline 063 & LA CROSSE & & 116,800 & 43.91 & 91.1159 \\
\hline 065 & LAPAY YTTE & & iKf. 9 กn & 43.6609 & 90.1320 \\
\hline 061 & LANGLADE & & & 45.2624 & 89.1692 \\
\hline 069 & I INCOLN & & & & \\
\hline ודוה & 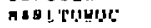 & & 152,000 & 44.1157 & 6i.t104 \\
\hline 073 & MARATHON & & 410,800 & 44.8993 & \\
\hline 075 & GAK I NETTR & & 356,900 & 45.38 & $88 .(412$ \\
\hline 077 & MARQUETTE & & 117,800 & 43. & $\$ 923$ \\
\hline 073 & HENONIMEE & & 93.2 & 45.0 & \\
\hline 079 & HILUA TKER & & 61,400 & 43.00 & 87.5650 \\
\hline 081 & MONROE & & & 43.94 & 90.6196 \\
\hline 0.33 & DCONTO & & 259.3 & 45.0 & 88. 24496 \\
\hline 085 & ONEIDA & & 289.000 & 45.70 & 89. $\$ 226$ \\
\hline & OUTAGAHIE & & & & \\
\hline 089 & CZAUKEZ & & 61,1 & 43.38 & .439 \\
\hline 091 & PEPIS & & 60,900 & 44.5917 & 92.1027 \\
\hline 093 & PIERCE & & 152,800 & 44.7266 & 92.9300 \\
\hline 095 & PCLK & & 241.100 & 45.4593 & \\
\hline & PORTAGE & & & 44.4738 & 89.0931 \\
\hline
\end{tabular}


Táble C.2 (continued)

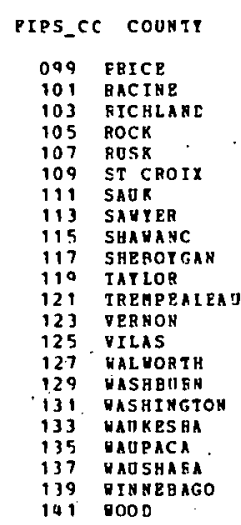

\begin{tabular}{|c|c|c|}
\hline$-A R P A$ & LATITUDE & \\
\hline & & \\
\hline & & \\
\hline & & \\
\hline & & \\
\hline & & \\
\hline & & \\
\hline & & \\
\hline & 45. & \\
\hline & & \\
\hline & 43. & \\
\hline & & \\
\hline & 44.3 & \\
\hline & & \\
\hline & & \\
\hline & 42.6 & 57 \\
\hline & & \\
\hline & 43. & \\
\hline & 43.0 & \\
\hline & & \\
\hline & 44.11 & \\
\hline & 44. & \\
\hline & 44.45 & 0.0348 \\
\hline
\end{tabular}

PIPS_ST $=56$ WYOHING

\begin{tabular}{|c|c|c|c|c|c|}
\hline & & & 00,200 & & 7222 \\
\hline & PIG HOSB & & 017. & & 9995 \\
\hline 05 & CAMP B PIL & & 231. & 44.2468 & 5391 \\
\hline & CARBON & & 47. & 41.7022 & 9246 \\
\hline 209 & CONVERSE & & & 9694 & \\
\hline 011 & CROOK & & 746 , & & 104 \\
\hline 1 & FBEHONT & & 2.39 & & \\
\hline 15 & GOSHEN & & 577 & & \\
\hline 17 & HCT SPRIMGS & & 00 & & 108 \\
\hline & JCHESON & & .0 & & \\
\hline 021 & IARANIE & & 700. & 41. & \\
\hline 023 & II $A C C L N$ & & 1.0 & & \\
\hline & AАT ROHA & & & & \\
\hline 027 & NIOBRABA & & 677 & & 104. \\
\hline 029 & FAPK & & 1,80 & & \\
\hline 03 & PLATTE. & & & & \\
\hline 03 & SHERIDAH & & 655 & 7924 & 106. \\
\hline & SUBLETTE & . & & & \\
\hline & SUERTUATE & & $.701,100$ & 41. & 108. \\
\hline 03 & TETON & & $.036,000$ & 43.7 & 110.57 \\
\hline & UINTA & & 540,300 & 49.2 & 110.5524 \\
\hline 04 & WASHAKIE & & 5,900 & 43.9095 & 107.67 \\
\hline 0 & WESTON & & 623,400 & 43.8435 & 104.5556 \\
\hline
\end{tabular}


Table C.3. Subcounty unit (SCU) areas (ha), county

areas (ha), percentages of the county, and geographic centroids (degrees) for selected eastern counties

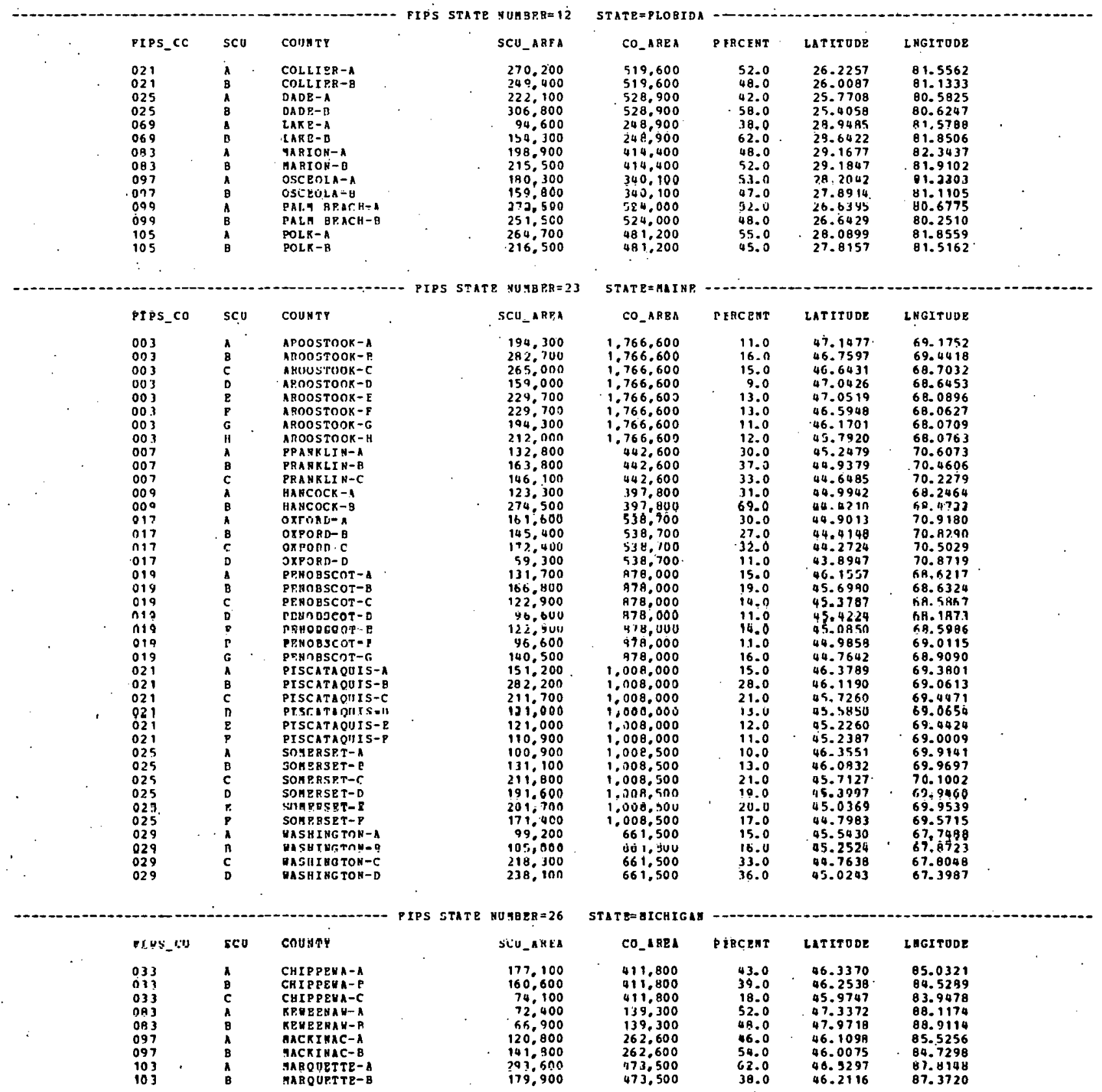


Table C. 3 (continued)

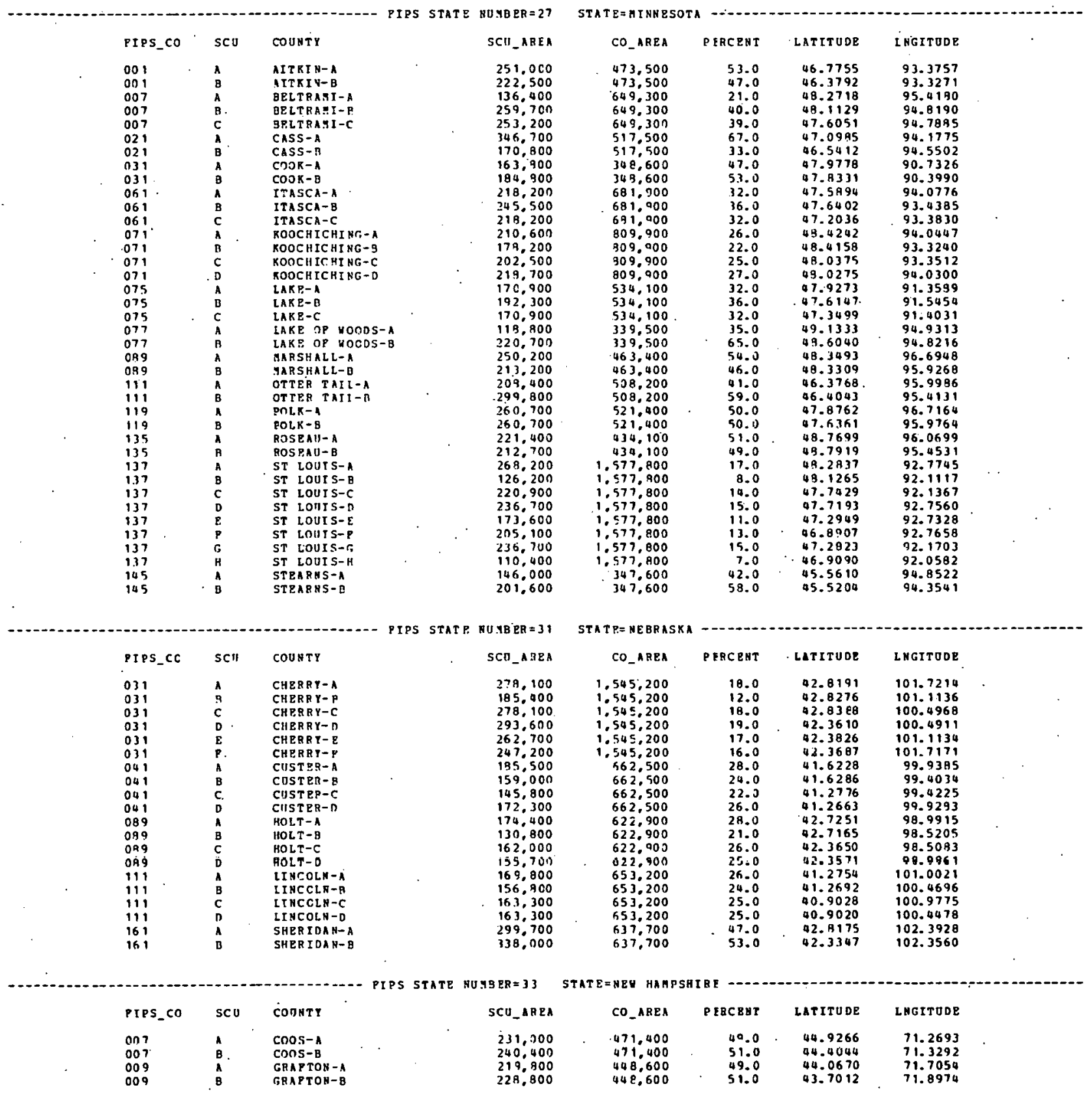


Table C.3 (continued)

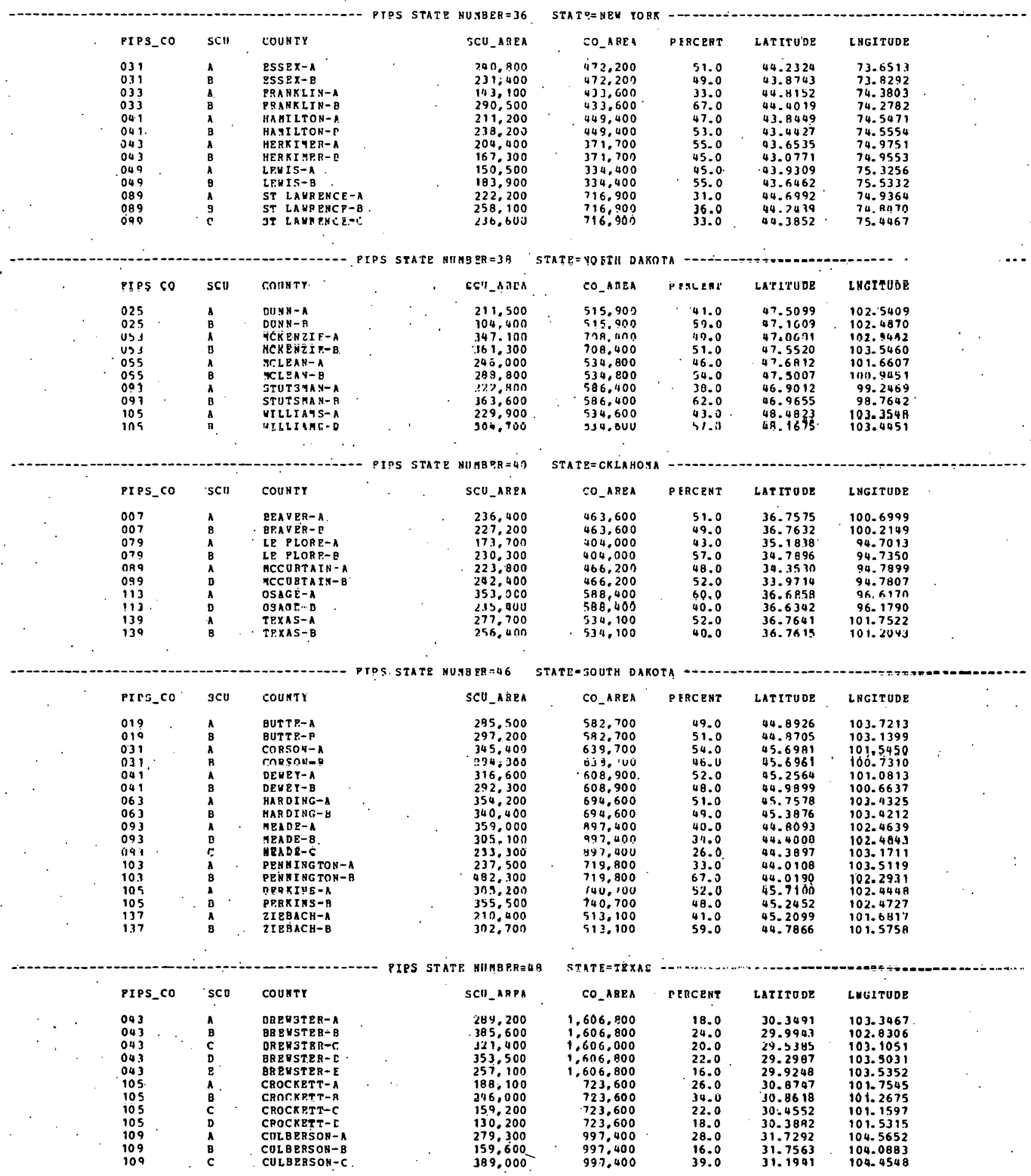




\section{Table C.3 (continued)}

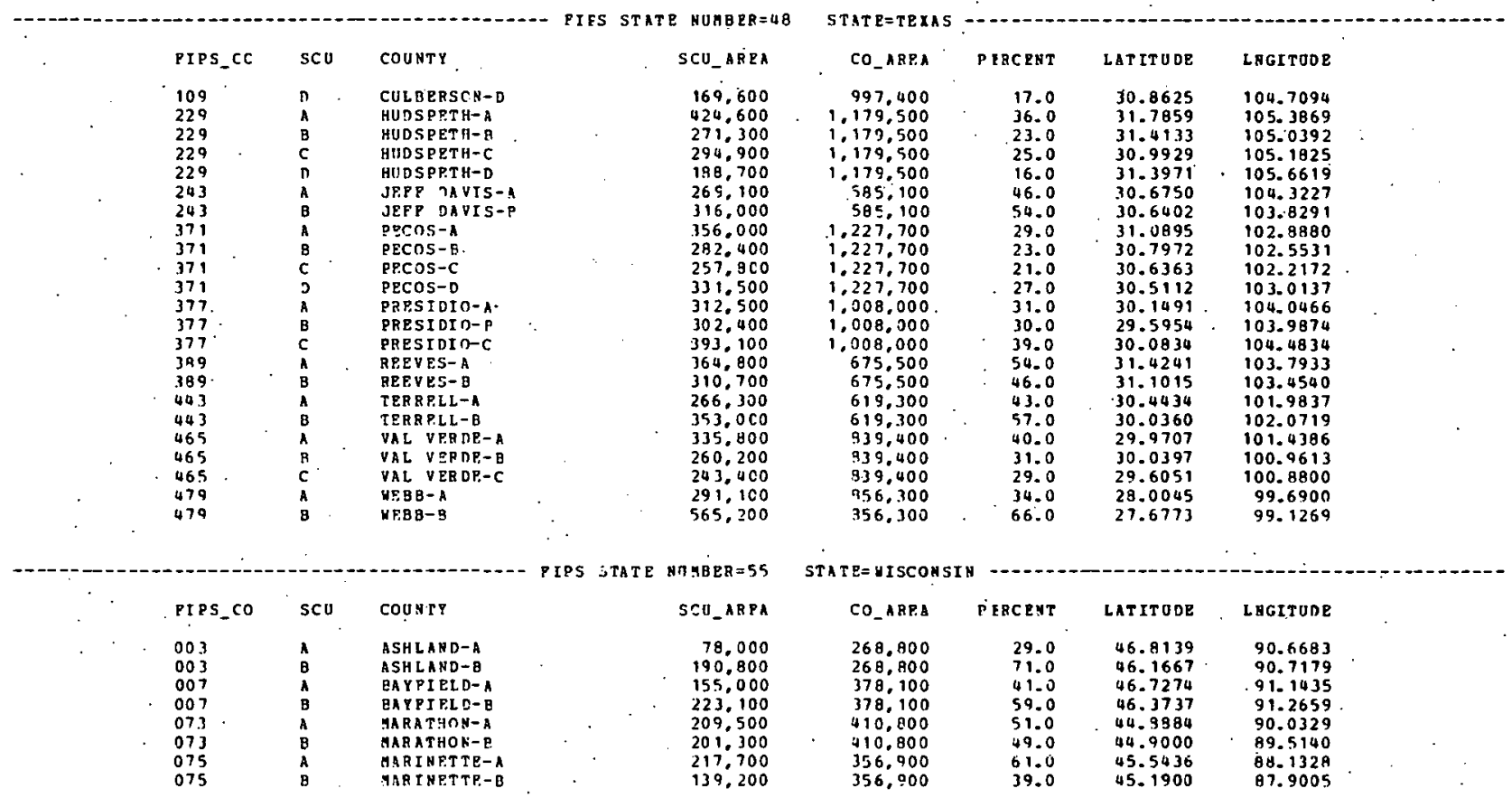


ORNL/TM-7351

\section{INTERNAL DISTRIBUTION}

1-2. S. I. Auerbach

3. C. F. Baes, III

4. R. L. Burgess

5. C. C. Coutant

6. R. B. Craig

7. J. H. Cushman

8. R. M. Cushman

9. N. H. Cutshall

10. R. M. Davis

11. H. R. Delcourt

12. J. E. Dobson

13. M. E. Dyer

14-23. C. J. Emerson

24-26. M. P. Farrel1

27. R. B. Honea

28. J. T. Kitchings

29. J. M. Klopatek

30. J. R. Krumme 1

31. K. D. Kumar

32. C. A. Little

33. R. J. Luxmoore

34. L. K. Mann

35. J. F. McBrayer

36. S. B. McLaughlin

37. N. T. Milleman

38. V. G. Myers
39. B. G. Newman

40-49. M. K. Nungesser

50. K. M. Oakes

51. J. S. 01 son

52-76. R. J. 01 son

77. D. C. Parzyck

78. M. R. Patterson

79. W. M. Post

80. J. W. Ranney

81. R. M. Reed

82. R. D. Sharp

83. A. D. Shepherd

84. D. S. Shriner

85. A. M. Solomon

86. R. H. Strand

87. C. S. Tucker

88. R. I. Van Hook

89. L. D. Voorhees

90. J. A. Watts

91-100. ESD Library

101-102. Centra1 Research Library

103-104. Laboratory Records Department

105. Laboratory Records, ORNL-RC

106. ORNL Y-12 Technical Library

107. ORNL Patent Office

\section{EXTERNAL DISTRIBUTION}

108. Stan Anderson, Nongame Section, Migratory Bird and Habitat Research Laboratory, Patuxent Wildlife Refuge, U.S. Fish and Wildlife Service, Laurel, MD 20811

109. Robert Bailey, Rocky Mounta in Experiment Station, USDA Forest. Service, 3825 Mulberry, Fort Collins, CO 80524

110. Richard Ball, Environmental Impacts Division, Office of Technology Impacts, Germantown E201, Department of Energy, Washington, DC 20545

111. Steve Ballou, Energy and Environmental Systems Division, Argonne National Laboratory, 9700 S. Cass Ave., Argonne, IL 60439

112. Carmen Benkovitz, Department of Energy and Environment, Brookhaven National Laboratory, Upton; NY 11973

113. Fred Billingsley, Jet Propulsion Laboratory, MS 198/4800 Oak Grove Dr., Pasadena, CA. 91103

114. Robert W. Brocksen, Ecological Programs, Electric Power Research Institute, P.0. Box 10412, Palo Alto, CA 94303

115. J. Buffington, Office of Biological Services, U.S. Fish and Wild ife Service, Washington, DC 20240

116. J. Thomas Callahan, Ecosystems Studies Program, National Science Foundation, Washington, DC. 20550 
117. Charles Calef, Biomedical and Environmental Assessment Division, Bidg. 475, Brookhaven National Laboratory, Upton, NY 11973

118. Peter Cavas, DIDS Program Management Office, Office of Federal Statistical Policy and Standards, Room 200, 2001 S St., NW, Washington, DC 20009

119. Gary Cohen, Regional Impacts Division, Office of Environmental Impacts, Germantown E201, Department of Energy, Washington, DC 20545

120. William J. Coppoc, Texaco, Inc., P.0. Box 509, Beacon, NY 12508

121. Theodore Crovello, Department of Biology, University of Notre Dame, Notre Dame, IN 46556

122. Charles Cushwa, Eastern Energy and Land Use Team, U.S. Fish and Wilnl ife Service, Routc 3, Box 44 Leetown, kearneysville, WV 23430

123. Roger C. Dalhman, Office of Health and Environmental Research, Department of Energy, Washington. DC 20545

124. Jack Dangermond, Environmental Systems Research Institute, 380 New York St., Redlands, CA 92373

125. Stanley N. Dav is, Head, Department of Hydrology and Water Resources, University of Arizona, Tucson, AZ 85721

126. John Ficke, Council on Environmental Quality, 722 Jackson P1., NW, Washington, DC 20006

127. Curt is Fritz, DIDS Program Management Office, Office of Federal Statistical Policy and Standards, Room 200, 2001 S Street, NW, Washington, DC 20009

128. Phyllis Fuja, Applied Math Division, Argonne National Laboratory, 9700 S. Cass Ave., Argonne, IL 60439

129. Robert M. Garrells, Department of Geological Sciences, Northwestern University, Evanston, II. 60201

130. Glenn Goff, 1305 S. Dam Rd., P.0. Bnx 301, West Branch, MI 48661

131. Loren Hall, Environmental Review Division, Office of Testing and Evaluation, Officc of Toxie Substances, Enviruminenlal Protection Agency, 401 M Street, SW, Washington, DC 20460

132. Ronnie J. Haynes, U.S. Fish and Wild life Service, Richard B. Russell Federal Bldg., 75 Spring Street, SW, Atlanta, GA 30303

133. Mark. Henriquez, B1dg. 90, 3125, 1 Cyc letron Rd., Lawrence Berkeley Laboratory, University of California, Berkeley, CA 94720

134. Thomas Hoekstra, Rocky Mountain Experiment Station, USDA Forest Service, 3825 Mulberry, Fort Collins, C0 80524

135. Peter House, Office of Technology Impacts, Department of Energy, Washington, DC 20545

136. Robert Jenk ins, The Nature Conservancy, $1800 \mathrm{~N}$. Kent St., Suite 800 , Arlington, VA 22209

137. Carter Johnson, Biology Dept. Virginia Polytechnic Institute and State University, Blacksburg, VA 24060

138. Edward Kaplan, Biomedical and Environmental Assessment Division, Bldg. 475, Brookhaven National Laboratory, Upton, NY 11973 
139. Olaf Kays, Resource Planning and Analysis Office, EGS-Mail Stop 750, National Center, Geological Survey, Reston, VA 22092

140. George H. Lauff, Director, W. K. Kellogg Biological Station, Michigan State University, Hickory Corners, MI 49060

141. Joan Lefler, Environmental Review Division, Office of Testing and Evaluation, Office of Toxic Substances, Environmental Protection Agency, 401 M Street, SW, Washington, DC 20460

142. Simon A. Levin, Section of Ecology and Systematics, Bldg. No. 6, Langmuir Laboratory, Cornell University, Ithaca, NY 14850

143. James Levenson, Energy and Environmental Systems Division, Argonne National Laboratory, 9700 S. Cass Ave., Argonne, IL 60439

144. Orie Loucks, The Institute of Ecology, Butler University, Indianapolis, IN 46208

145. Duane F. Marble, Geographic Information Systems Laboratory, State University of New York at Buffalo, Amherst, NY 14260

146. William T. Mason, Jr., Eastern Energy and Land Use Team, U.S. Fish and Wildlife Service, Route 3, Box 44 Leetown, Kearneysville, WV 25430

147-151. Ron Matheny, Regional Impacts Division, Office of Environmental Impacts, Germantown E201, Department of Energy, Washington, DC 20545

152. Helen McCammon, Office of Health and Environmental Research, Department of Energy, Germantown, MD 20767

153. Susan McCue, Ketron, Inc., 17000 N. Moore St., Rosslyn Center, Arlington, VA 22209

154. Deane Merri1l, Computer Science and Applied Math Department, 1 Cycletron Road, Lawrence Berkeley Laboratory, University of California, Berkeley, CA 94720

155. Laurance. J. Milask, Information and Scientific Applications Division, Sigma Data Computing Corp., Suite 207, 2021 K St., NW, Washington; DC 20006

156. David Moody, EGS-Mail Stop 409, Geological Survey, National Center, Reston, VA 22092

157. John Nagy, Biomedical and Environmental Assessment Division, Bldg. 475, Brookhaven National Laboratory, Upton, NY 11973

158. A. M. Neuner, Association of Systematics Collections, Museum of Natural History, University of Kansas, Lawrence, KS 66045

159. William S. Osburn, Office of Health and Environmental Research, Germantown E201, Department of Energy, Washington, DC 20545

160. Daniel Ries, Computation Dept. L-316, Lawrence Livermore Laboratory, University of California, Livermore, CA 94550

161. T. H. Ripley, Division of Forestry, Fisheries and Wildlife Development, Tennessee Valley Authority, Norr is, TN 37828

162. Paul G. Risser, Department of Botany and Microbiology, University of $0 \mathrm{k} 1$ ahoma at Norman, Norman, OK 73019

163. Charles. A. Roswe 11; Department of Geography, University of Maryland, College Park, MD 20742

164. Keith 0. Schmude, Soil Conservation Service, P.0. Bux 2890, Washington, DC 20013 
165. R. Kent Schrieber; National Power Plant Team, U.S. Fish and Wildlife Service, 2929 Plymouth Road, Ann Arbor, MI 48105

166. David Sharpe, Geography Dept., Southern Illinois University, Carbondale, IL 62901

167. Roger Shu11, Environmental Impacts Division, Office of Technical Impacts, Germantown E201, Department of Energy, Washington, DC 20545

168. Caby Smith, Science Information Division, National Park Service, Washington, DC 20240

169. Ethan T. Smith, Resource Planning and Analysis Office, EGS-Mail Stop 750, National Center, Geological Survey, Reston, VA 22092

170. Ann Stroup, MS 603, Los Alamos Scientific Laboratory, University of California, P.0. Box 1663, Los Alamos, NM. 87545

171. John Suich, Management Services Section, Savannah River Laboratory, Aiken, SC. 29801

172. Susan Sutter, Nashville Dislrict. Corps of Engineers, P.0. Box 1070, Nashville, TN 37202

173. Eric Teicholz, Laboratory for Computer Graphics and Spatial Analys is, Harvard University, 520 Gund Hall, 48 Quincy St., Cambridge, MA . 02138

174. John Thomas, Ecology Department, Box 999, Pacific Northwest Laboratories, Richland, WA 99352

175. Maurice Warner, 6652 I Bldg. 600 Area, Box 999, Pac if ic Northwest Laboratories, Richland, WA 99352

176. Richard H. Waring, Department of Forest Science, Oregon State University, Corvallis, OR 97331

177. Charles Watson, Ecology Department, Box 999, Pac if ic Northwest Laboratories, Richland, WA 99352

178. Thompson Webb, III, Department of Geological Sciences, Brown University, Providence, RI 02912

179. Helmut Wedow, Srience Applications, Inc., Jacksun Plaza, Oak Ridge, TN 37830

180. Al Wehe, Mail Drop 12, Energy Strategies Branch, U.S. Environmental Protection Agency, Research Triangle Park, NC 27711

181. William 0. Wilen. National Wetland Inventory, U.S. Fish and Wildlife Service; Suite 217, Dade Bldg., 9620 Executive Center Drive, St. Petersburg, FL 33702

182. John H. Wilson, Jr., Scient ific and Technical Information Branch, National Aeronautics and Space Administration, Reporters B1dg., Room 825, 7th and D Street NW, Washington, DC 20546

183. John Wilson, Texas Natural Resources Information System, P.0. Box 13087, Austin, TX 78711

184. Richard E. Witmer, Geography Program, EGS-Mail Stop 710, National Center, Geological Survey, Reston, VA 22092

185. Carl E. Youngmann, Cartography Laboratory, University of Washington, Geography DP-10, Seattle, WA 98195

186. Office of Assistant Manager for Energy Research and Development, DOE-ORO

187-213. Technical Information Center, Oak Ridge, TN 37830 


\title{
READER'S COMMENTS
}

\author{
Please return to: \\ Richard J. Olson \\ Bldg 1505, Environmental Sciences. Division \\ Box X, Oak Ridge National Laboratory \\ Oak Ridge, TN 37830 \\ Your name, address, and phone number:
}

Your comments or suggestions are encouraged as to the contents of this document or the Geoecology Data Base. 